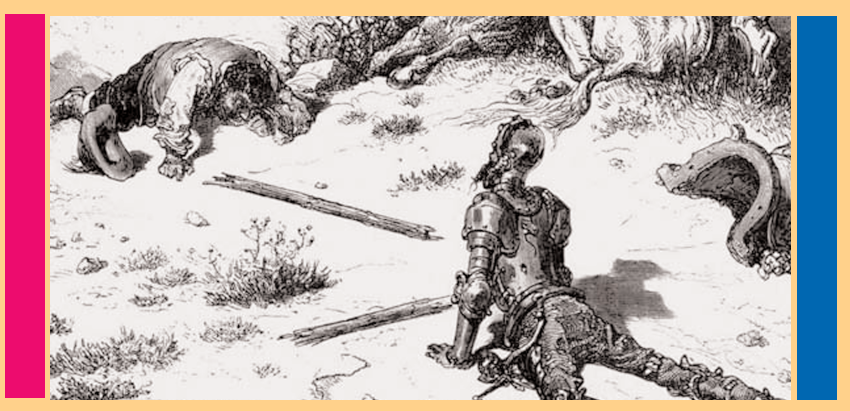

\title{
Las historias de la literatura española en la Francia del siglo XIX
}

M. ${ }^{a}$ del Rosario Álvarez Rubio

\section{pers}

Prensas Universitarias de Zaragoza 

LAS HISTORIAS DE LA LITERATURA ESPAÑOLA EN LA FRANCIA DEL SIGLO XIX 



\section{LAS HISTORIAS DE LA LITERATURA ESPAÑOLA EN LA FRANCIA DEL SIGLO XIX}

M. 'del Rosario Álvarez Rubio 


\section{FICHA CATALOGRÁFICA}

\section{ÁLVAREZ RUBIO, M.a del Rosario}

Las historias de la literatura española en la Francia del siglo XIX / M. a del Rosario Álvarez Rubio. — Zaragoza : Prensas Universitarias de Zaragoza, 2007 398 p.; $22 \mathrm{~cm}$. - (Humanidades ; 63)

ISBN 978-84-7733-949-6

1. Literatura español-Historia y crítica. 2. Crítica literaria-Francia-S. XIX. I. Universidad de Zaragoza. II. Título. III. Serie: Humanidades (Prensas Universitarias de Zaragoza) ; 63

$$
\text { 821.134.2:821.133.1.09«18» }
$$

No está permitida la reproducción total o parcial de este libro, ni su tratamiento informático, ni la transmisión de ninguna forma o por cualquier medio, ya sea electrónico, mecánico, por fotocopia, por registro u otros métodos, ni su préstamo, alquiler o cualquier forma de cesión de uso del ejemplar, sin el permiso previo y por escrito de los titulares del Copyright.

(C) M. ${ }^{a}$ del Rosario Álvarez Rubio

(C) De la presente edición, Prensas Universitarias de Zaragoza

1. ${ }^{\text {a }}$ edición, 2007

Ilustración de la cubierta: José Luis Cano

Colección Humanidades, n. ${ }^{\circ} 63$

Director de la colección: José Ángel Blesa Lalinde

Prensas Universitarias de Zaragoza. Edificio de Ciencias Geológicas, c/ Pedro Cerbuna, 12 50009 Zaragoza, España. Tel.: 976761 330. Fax: 976761063

puz@unizar.es http://puz.unizar.es

Prensas Universitarias de Zaragoza es la editorial de la Universidad de Zaragoza, que edita e imprime libros desde su fundación en 1542.

Impreso en España

Imprime: Línea 2015

D.L.: Z-3699-2007 


\section{PRÓLOGO}

Una de las mayores satisfacciones que un profesor universitario puede tener es la de seguir de cerca la trayectoria de ciertos alumnos suyos que, con el paso del tiempo, acaban convirtiéndose en queridos y admirados colegas. Conozco a la Dra. María del Rosario Álvarez Rubio desde el curso en que inició los estudios de Filología Hispánica en nuestra Facultad de Filología de la Universidad de Oviedo; en la asignatura que yo impartía obtuvo, tras un excepcional examen, la máxima calificación. Volvi a encontrarla como alumna en cuarto y quinto curso de dicha licenciatura, y de nuevo obtuvo en ambos casos la máxima calificación. Ahora sus excelentes resultados tenian un mérito añadido: María del Rosario Álvarez Rubio simultaneaba los estudios de Filología Hispánica con los de Filología Francesa, especialidad esta en la que también obtenía magnificas calificaciones. Ya licenciada, se inscribió en los cursos de doctorado de los Departamentos de Filología Española y de Filología Francesa de la Universidad de Oviedo y en los de lengua, literatura y civilización francesa de la Universidad de Pau, efectuando sus correspondientes trabajos de investigación —uno de ellos, dirigido por el autor de estas líneasbajo una doble y simultánea linea temática: las relaciones culturales entre España y Francia y la presencia de la literatura en la prensa (cultural y de información general). Además, con su tesis de licenciatura (La imagen de España en la «Revue des Deux Mondes»: Artículos críticos sobre la literatura española (1833-1894), dirigida por la Dra. Carmen Fernández Sánchez, profesora titular de Filología Francesa) obtiene el correspondiente Premio Extraordinario de la citada licenciatura.

Aludo con cierto detalle a la trayectoria académica previa a la tesis doctoral de María del Rosario Álvarez Rubio porque dicho trabajo de investigación viene a representar la conjunción de sus conocimientos en aquellas dos 
licenciaturas: titulada La literatura española en la prensa cultural francesa del siglo XIX: La Revue des Deux Mondes y la Revue de Paris, fue redactada minuciosamente a lo largo de varios años, de nuevo bajo la tenaz y exigente dirección de la ya citada Dra. Carmen Fernández Sánchez. Junto con los queridos y admirados colegas los profesores L. Romero Tobar, J. R. Aymes, J. M. ${ }^{a}$ Fernández Cardo y Dalia Alvarez Molina, tuve la satisfacción de formar parte del tribunal que juzgó dicho documentadisimo trabajo académico. Como se le indicó por varios integrantes del tribunal, dicha tesis era, en realidad, dos tesis o, al menos, dos libros. El primero, el que podia derivarse del amplio capitulo "Historias de la literatura española en Francia: Estudios, antologias, manuales, artículos diversos (1810-1900)", es el que, con las lógicas modificaciones, tengo ahora la satisfacción de prologar. El segundo libro, o sea, la segunda parte de la tesis, esperemos que no tarde en ver la luz. Digamos también que dicha tesis doctoral motivó que su autora obtuviera el Premio Extraordinario de Doctorado de Filología Francesa de la Universidad de Oviedo.

El presente volumen creo demuestra con rotundidad que la excelente doble formación académica de la Dra. Álvarez Rubio la capacitó para llevar a cabo una difícil y extensa tarea de documentación y comentario de la actitud y juicio de los distintos tipos de hispanistas franceses acerca de la literatura española a lo largo del complejo siglo XIX, un siglo que arranca con el Romanticismo, pasa por el Realismo y el Naturalismo y finaliza en un Realismo espiritualista que abre las puertas a un todavía más complejo y denso fin de siglo. Un siglo de una enorme complejidad política y cultural en Francia y en España, en el que el Romanticismo impulsa los diversos nacionalismos europeos, el posterior positivismo cientifico encarna una evidente fe en el progreso humano a la vez que se plantean las relaciones entre ciencia y religión, entre confesionalismo y libertad religiosa, y ofrece, en su segunda mitad, la confrontación crítica entre la cultura del norte y la cultura latina, todo lo cual tiene su honda repercusión en todos los órdenes de la vida de ambos países y, por tanto, en su literatura y en la valoración que, en este caso, Francia hace de la literatura española.

Estamos ante un libro denso, sin digresiones innecesarias, repleto de información acerca no solo del conocimiento y valoración que los hispanistas franceses tienen de la literatura española, sino también, ¿inevitablemente?, de lo que los franceses piensan de si mismos y de su propia literatura, ya que con frecuencia parten del supuesto explícito de que el canon estético, el punto de referencia para valorar lo que escriben sus vecinos europeos, es la literatura que 
ellos cultivaron o cultivan. Pero a lo largo de ese recorrido que minuciosamente expone la autora de modo diacrónico en cada capitulo, también podremos ver cuánto deben estos al Prerromanticismo y al Romanticismo alemanes, claros ejemplos de rebelión nacionalista alemana contra el galocentrismo del siglo XVIII y de enaltecimiento de un Calderón antitesis del clasicismo, o, en general, qué grado de deuda tienen con los criticos e historiadores no franceses que escribieron sobre la literatura española, desde los alemanes Schlegel y Bouterwek, el suizo Sismondi o el español exiliado Juan María Maury hasta el norteamericano Ticknor. Puede apreciarse también como en la segunda mitad del siglo XIX se empieza a prestar atención a la literatura española contemporánea, dando lugar en algún caso a valoraciones hoy incomprensibles por desmesuradas (el Hubbard republicano, anticlerical y partidario del compromiso social del escritor, que llega a decir que Campoamor es un artista digno de Dante y Milton, pero que también formula sensatas objeciones al Zorrilla poeta y autor del Tenorio).

Lógicamente, no solo encontraremos las inevitables valoraciones criticas - a veces, fluctuantes - acerca de los grandes titulos como el Quijote, el Lazarillo, La Celestina o el romancero, o de los grandes autores como Garcilaso, Herrera, Lope, Calderón, Góngora o Quevedo, sino también los juicios sobre las figuras de segundo orden, cuando no las típicas de los trabajos eruditos.

Al hilo de la exposición de las ideas criticas difundidas en Francia acerca de la literatura española, la autora nos informa frecuentemente, sobre todo en nota, de las traducciones que alli se hacen de las obras literarias españolas, ya en versiones completas, ya en antologias, ofreciéndonos asi unos datos complementarios muy útiles para conocer mejor la recepción de nuestra literatura en el país vecino: por ejemplo, el Poema de Mio Cid se traduce en 1858, a pesar de que ya habia recibido notables elogios años antes. Hablando de notas, digamos que, a veces, tienen tal cantidad de información que, muy posiblemente, podrian ser el origen de un futuro trabajo académico.

Un aspecto del presente estudio que me parece muy interesante es la incorporación de algunas fuentes documentales periodisticas, las de la prensa cultural parisina, de notable difusión entre los lectores, posiblemente más abundantes y más variados que los de los libros. Tal ocurre con los pasajes dedicados a difundir las ideas que sobre la literatura española sostienen algunas personalidades no vinculadas al habitual ámbito erudito o docente de los hispanistas franceses: es el caso del escritor Prosper Merimée —quien, además de ser 
temprano defensor de Calderón, elogia más a Guillén de Castro que a Corneille-y el del murciano exiliado Juan Florán, quien, limitándose -y no por voluntad propia - al ámbito de la literatura medieval española, lleva a cabo una defensa de los valores artísticos del romancero, de Berceo, de Juan Ruiz y del Poema de Mio Cid.

También podemos ver que se plantean a lo largo de todo el siglo XIX cuestiones como el origen de la "nacionalidad española", acudiendo algunos de los críticos a la época hispanorromana, con Séneca y Lucano como referentes, a la vez que surgen, para aceptarlos o rechazarlos, los tópicos del exotismo hispánico. En un sentido opuesto, las literaturas españolas en lengua no castellana - ya medievales, ya del Romanticismo en adelante- están prácticamente ausentes de las informaciones y valoraciones de los criticos franceses, situación nada sorprendente dado que se produce en el país por antonomasia jacobino. En otro orden de cosas, comprendo las lógicas limitaciones de espacio que tiene siempre una publicación académica, pero pienso que quizá habría sido útil incorporar un pequeño apéndice documental con algunos textos criticos relevantes que hayan tenido una limitada difusión en España, reproduciéndolos ya en la lengua original, ya en traducción castellana, opción esta última más adecuada, dado el bajo nivel actual de conocimiento de la lengua francesa en España.

De todo lo que muy sintéticamente he resumido pero también de mucho más — traducciones previas o simultáneas a los textos de los criticos estudiados, antologías, etc. - nos da cumplida cuenta la Dra. Álvarez Rubio, con un lenguaje elegante y contenido - quizá en exceso- en la formulación de sus opiniones sobre los criterios ajenos, y con un tono sosegado y acumulativo, que se adecua perfectamente al cometido de poner al alcance del lector interesado una abundante, casi exhaustiva información acerca de ese complejo entramado cultural e ideológico que fueron las relaciones literarias entre Francia y España a lo largo del siglo XIX. Un lector interesado, desde el campo de la Filología Francesa o desde el ámbito de la Literatura Española contemporánea, como es el caso del autor de estas lineas prologales, tiene que agradecer profundamente al Dr. Romero Tobar que haya impulsado la edición de este libro y, sobre todo, a la Dra. Álvarez Rubio que haya escrito tan útil y tan completo estudio académico sobre uno de los aspectos críticos más relevantes acerca de las relaciones literarias —y más que sociales - entre España y Francia en el siglo XIX.

Antonio FERNÁNDEZ INSUELA Universidad de Oviedo 


\section{PRELIMINARES}

En el apretado panorama liminar a su Histoire de la littérature contemporaine en Espagne 1 titulado "Coup d'œil sur la littérature espagnole, depuis la formation de la langue jusqu'à la révolution de 1808», el republicano Gustave Hubbard se hacía esta reflexión sobre el cometido y alcance de una historia de la literatura: "Qu'est-ce que l'histoire d'une littérature? Biographie des auteurs? Mise en relief des chefs-d'œuvre? Tableau de toutes les formes, styles, genres qu'une nationalité a adoptés pour revêtir l'expression de sa pensée? Encore quelque chose de plus» (p. 2). Tal sucesión de definiciones parciales que desgajan los aspectos habitualmente tratados por sus predecesores en esta disciplina entonces ya consolidada — noticias biográficas, selección de las obras modélicas, repertorio genérico cultivado por la nacionalidad literaria - preludia la reivindicación de un examen global que integre la literatura en el conjunto de las demás ramas de su cultura («il faut qu'une synthèse hardie les embrasse d'un seul et même coup d'œil»). Su propuesta, fundada en el análisis sociológico ${ }^{2}$ difundido por Sismondi y la polémica ideológica — más destacada por la postura disidente del crítico respecto a posicionamientos más conservadores de otros estudiosos contemporáneos-, ejemplifica varias de las principales tendencias dominantes en el discurso francés sobre la historia de la literatura española, subsumido en el arraigado estudio de la civilización más que en un análisis plenamente filológico que se impondrá en el último tercio del XIX. Sin embargo, no

1 París, Charpentier et Cie, Libraires-Éditeurs, 1876.

2 "C'est la combinaison de tous les élémens sociaux qu’il faut apprécier, si l'on veut arriver au but de toute science, à la prévision de l'avenir» (p. 3). 
es menos cierto que su enfoque, influenciado por las ideas de Taine sobre el ascendiente de la raza y el medio, ${ }^{3}$ entronca con orientaciones precursoras de los ilustrados españoles, que ya repararon en la relación entre las letras y las instituciones políticas, y legaron una aspiración totalizadora que inscribía el fenómeno literario en la historia de la cultura. Un año antes de las apóstrofes de Hubbard, el catedrático de literatura extranjera de la Universidad de Clermont-Ferrand, Eugène Baret — responsable de la primera historia autónoma de la literatura española de autoría francesa-, al enjuiciar la magna obra de José Amador de los Ríos ${ }^{4}$ subrayaba su primacía y prelación en propósito y método entre sus compatriotas, relegando a un ingrato olvido la monumental historia comparada del padre Andrés, antaño prestigiosa en el extranjero. Su mermado recuento de trabajos antecesores, ${ }^{5}$ a los que no reconocía la condición de historias por sus criterios recopiladores así como por su anchurosa concepción semántica de la literatura, distinguía así entre acopio documental y estudios fundados en una concepción unificadora. Y, sin embargo, aunque no están encaminados abiertamente a una indagación teórica, como ha mostrado I. Urzainqui, ${ }^{6}$ los prolíficos trabajos de resurrección, criba y selección valorativa del caudal

3 «il faut qu' elle [la historia de la literatura] se dégage des simples vues du biographe, du bibliophile et du grammairien, pour nous faire saisir toute une face de l'esprit humain; il faut qu'elle nous démontre un caractère spécial résultant du développement d'une race sur un territoire et dans un milieu donnés: il faut, en un mot, qu'elle nous fasse pénétrer dans la vie morale d'une société» (p. 2).

4 Observations sur l'Histoire de la Littérature Espagnole de M. Amador de los Ríos, París, Librairie Pedone-Lauriel, Success. de Durand, 1875.

5 «Plus d'un effort a été tenté, plus d'un travail entrepris pour sauver de l'oubli la mémoire des hommes dont le talent avait illustré la patrie. Toutefois, malgré l'étendue et l'importance des recherches, on ne peut qualifier d'histoire de la littérature les Bibliothèques latines de Nicolas Antonio, la Biblioteca hispana-rabbinica de Rodríguez de Castro, les histoires partielles de Ximeno, de Fuster, de Felice de la Tassa. Ce sont de précieux matériaux pour l'histoire de la littérature, ce n'est pas un monument. Stimulés par l'esprit libéral qui anima le règne de Charles III, les frères Mohedano, du tiers ordre des Augustins, entreprirent une histoire générale de la littérature espagnole, sur le modèle de notre histoire littéraire des Benédictins de Saint-Maur; mais ces écrivains courageux embrassaient dans leur plan l'histoire des lettres et celle des sciences. [...] À partir de cette tentative avortée, on voit encore des essais partiels d'histoire littéraire, comme l'estimable travail de Sempere sur les écrivains du règne de Charles III, mais l'idée même d'un travail d'ensemble parut abandonnée dans les scandales énervants du règne de Charles IV [...]» (art. cit., pp. 5-6).

6 I. Urzainqui, "Hacia una teoría de la historia literaria en el siglo XVIII: competencias del historiador", en L. Romero Tobar (ed.), Historia literaria/Historia de la literatura, Prensas Universitarias de Zaragoza, 2004, pp. 209-236. 
histórico y literario que llevan a cabo los eruditos españoles desde el XVIII en sus noticias bio-bibliográficas, en sus monografías y luego en sus historias reflejan las tendencias estético-literarias y epistemológicas contemporáneas del resto de Europa y proporcionan con rigor abundoso material que cimentará los estudios posteriores.

Así pues, la disciplina que toma como objeto de estudio la literatura española se difunde en Francia en ese fructífero gozne de entresiglos. Ni poéticas ni retóricas — pese a que este ejercicio impregnó las lecciones francesas hasta la especialización finisecular-, estos discursos participan de una concepción orgánica común en la que reconocen su genealogía genérica con sus directrices, fuentes, comunidad de contenidos, enfoques y principales valoraciones. De origen o destino principalmente académicos, la mayor parte de estos trabajos - perfilados sobre el horizonte cultural alemán en su acercamiento a las literaturas nacionales extranjerascompiten trabajosamente a lo largo del siglo con los estudios clásicos y franceses primero y, aún al amparo de consideraciones geopolíticas y comerciales, con los anglicistas y germanistas después, para lograr su propio espacio en el circuito universitario desde su institucionalización en el seno de las cátedras de literatura extranjera ${ }^{7}$ hasta el asentamiento del hispanismo a finales del XIX. ${ }^{8}$ Anteriores a esta etapa final de especialización, los autores estudiados pertenecen a las dos generaciones principales de hispanisants, ${ }^{9}$ eruditos, hombres de letras de diversa condición profesional y generalistas de finales de siglo, salidos de la École Normale Supérieure en

7 M. Espagne, Le paradigme de l'étranger. Les chaires de littérature étrangère au XIXe siècle, París, Les Éditions du Cerf, 1993.

8 Las obras de los especialistas del hispanismo, cuajadas en los primerísimos años del XX —estudios y ediciones críticas de eruditos de la envergadura de un Morel-Fatio o los de Ernest Mérimée como su Précis de la littérature espagnole (París, Garnier, 1908), el contingente de colaboradores del Bulletin Hispanique, o la traducción de la historia del hispanista Fitzmaurice-Kelly (Littérature espagnole en la traducción de Henry-D. Davray, 1904), entre los más conocidos- y cuyo magisterio en las facultades de letras tutela a finales del XIX un creciente número de tesis doctorales, quedan fuera de nuestro estudio en este corte cronológico.

9 Véanse, por ejemplo, A. Niño (Cultura y diplomacia. Los hispanistas franceses y España. 1875-1931, Madrid, CSIC/Casa de Velázquez/Société des Hispanistes Français, 1988) y uno de sus referentes, E. Escalier (Hispanistes français érudits de 1830 à 1875. (De Viardot à Th. de Puymaigre), mémoire pour le Diplôme d'Études Supérieures, París, Institut d'Études Hispaniques). 
numerosos casos, que colaboran a menudo en la prensa periódica divulgando junto a las traducciones el acervo cultural español ante el lectorado francés. En su mayor parte, estos críticos incardinan paulatinamente su labor difusora en el marco de las teorías schlegelianas, sin cejar en la defensa del panteón nacional francés y su legado como justo medio estético y encrucijada cultural de Europa. Si los primeros estudios españoles del XVIII se regían en parte por su cotejo con el canon difundido de Francia y de los clásicos, en el XIX sus vecinos insertarán su propia literatura en el desarrollo del comparatismo. En guardia contra los ataques a la férula estética francesa - por ejemplo, de un Schlegel o un Wolf en sus comentarios a la traducción española de un Bouterwek más templado, y frente a un Ticknor cuya historia nacionalista no deja de ser aún respetuosa hacia los grandes modelos del clasicismo francés-, un nacionalismo combativo subyace a menudo en sus análisis reivindicando la imitatio clásica como sello distintivo.

El discurso expositivo y evaluador de este discurso histórico en la centuria decimonónica, adoptado por las historias fundacionales extranjeras, tempranamente traducidas al francés, o por las más tardías de autoría francesa, es observado asimismo en otros textos, anejos y concurrentes, tales como ensayos, cursos universitarios, manuales divulgativos, antologías, discursos inaugurales, memorias académicas, monografías, prólogos de traducciones o artículos de la prensa cultural. Si algunos de ellos ensanchan en distinta medida la materia de estudio haciendo variar su percepción en el curso del siglo, la mayoría reproduce, las más de las veces, la vigencia de sus conceptos principales, periodización básica y canon fundamental de autores, en un proceso de readaptación alentado desde Alemania, vanguardia de la reforma universitaria del siglo. A través del análisis de un acotado conjunto de textos representativos las páginas que siguen no aspiran a un examen exhaustivo, sino más bien a ofrecer una primera aproximación al panorama general que presenta el estudio de la historia de la literatura española en Francia a lo largo del siglo XIX. El enfoque diacrónico y fundamentalmente descriptivo que hemos aplicado a la revisión del corpus elegido de entre ese copioso arsenal de diverso alcance ayuda a aprehender las orientaciones ideológicas y estéticas dominantes, las periodizaciones en vigor y las informaciones retenidas en las que los investigadores franceses inscriben sus variaciones o asentimientos, transmitidos en gran parte al siglo XX. Nuestra selección comprende principalmente tra- 
ducciones de historias de la literatura de reconocido magisterio, ensayos que abarcan la literatura española en su diacronía, disertaciones académicas y estudios que participan del discurso narrativo y del catálogo antológico, así como producciones francesas en este género a partir de la segunda mitad del siglo, manuales generales dirigidos a un público estudiantil o mundano, y diversos florilegios. Aunque hemos incluido varios resúmenes de cursos dictados en las cátedras de París y publicados en prensa, junto a algunos artículos ejemplificadores previos a ese período de institucionalización, hemos postergado el diálogo de las historias con otras aportaciones francesas, fuentes de consulta para los estudiosos, como las colecciones periódicas de carácter cultural y las monografías — dedicadas primero al Siglo de Oro, luego a la Edad Media y posteriormente a la producción contemporánea-, limitándonos a alusiones contextuales.

Los principales jalones de nuestro examen diacrónico, organizado según el orden de las ediciones ante el lectorado francés, se asientan entre ambas orillas cronológicas de la centuria, desde un consultado ensayo, editado en 1810 pero informado por la herencia ilustrada en una fase de mayor flexibilidad del neoclasicismo, hasta las colecciones generales de fines de siglo, predecesoras inmediatas de las historias editadas por los hispanistas cuyo magisterio se prolonga en el XX. Como preámbulo a este recorrido, un panorama general sobre los juicios que suscita la literatura española — principalmente divulgada en traducciones y por diversos canales culturales - durante el período previo a la aparición de las primeras historias y a lo largo de su devenir decimonónico, junto a una introducción a las pautas y el contexto en que se incardinan las contribuciones francesas, preceden a la revisión de los textos escogidos. Los distintos tramos en la evolución de este dilatado episodio de la institucionalización progresiva de dicha literatura y su canon en el siglo XIX francés ${ }^{10}$ se inician en esas primeras décadas con el análisis del ensayo arriba mencionado - comedida apertura tras los pasos de Linguet y de esporádicas publica-

10 Tanto en la exposición de las historias y ensayos como en las antologías estudiadas, aun respetando la clasificación cronológica y genérica de sus autores, se ha procurado también ordenar los contenidos subrayando sus preferencias, que reflejen sus posibles enfoques y valoraciones respectivos. Los títulos de las traducciones al francés se conservarán cuando ofrezcan alguna variante de relevancia. Por último, la bibliografía final comprenderá una selección fundamental de entre los títulos consultados. 
ciones periódicas favorables-, y los cursos académicos fundadores de Bouterwek, Schlegel y el muy leído Sismondi. La difusión del hispanismo alemán del XVIII se irradia al resto de Europa desde sedes como la prestigiosa Universidad de Gotinga, avanzada de la investigación filológica e influyente no solo en el proyecto colectivo de Eichhorn en el que participa Bouterwek, sino también en la trayectoria de Schlegel o en la de un joven Ticknor. ${ }^{11}$ Heredero de los redescubrimientos del humanismo alemán, Bouterwek, autor de la primera historia de la literatura española autónomamente concebida, marca senderos desbrozados por los eruditos del XVIII español a la luz de las orientaciones del nuevo centro dispensador del canon. El amplio espacio dedicado a este historiador sobre los otros autores examinados se justifica por su impronta en la organización de la materia, el afinamiento de conceptos y los enjuiciamientos posteriores de historias, ensayos, memorias, antologías y discursos didácticos. Su ascendiente en la andadura de las principales obras historiográficas de los estudiosos europeos y americanos acerca de la literatura española — como los críticos franceses en los que nos detendremos, o alemanes como el reputado Schack, españoles como Gil y Zárate ${ }^{12}$ o el nacionalista Amador de los Ríos, por ejemplo, o el americano Ticknor - lo convierte en irrefutable piedra de toque a lo largo del XIX pese a la irrupción de la monumental historia de este último, vertida al francés por Magnabal después de la traducción española de Gayangos y Vedia. Sin embargo, en esta primera aproximación al repertorio francés de los estudios hispanisants, en lugar del análisis pormenorizado de la importante historia de Ticknor —inflexión en estos estudios influenciada por su predecesor alemán-, hemos decidido recoger en su momento cronológico algunos testimonios de su recepción en Francia — por ejemplo, la reticente reseña de Mérimée-. La infrecuencia de esta última acogida por otro entendido y experimentado conocedor de la cultura española ilustra por contraste el renombre de que gozó el estudioso americano — aunque sus reseñadores franceses no suelen demorarse en análisis más pormenorizados-, al punto de ser incorpora-

11 F. Meregalli, "George Ticknor y España», en A. Sotelo Vázquez (coord.) y M. C. Carbonell (ed.), Homenaje al profesor Antonio Vilanova, Barcelona, Universidad de Barcelona, 1989, vol. II, pp. 413-426.

12 J.-C. Mainer, "La invención de la literatura española», en J. M. a Enguita y J.-C. Mainer (eds.), Literaturas regionales en España, Zaragoza, Institución "Fernando el Católico», 1994, p. 34. 
do a las citas de autoridad de los manuales franceses y a la suma de referencias reconocidas de sus bibliografías. Asimismo, si bien nos atendremos a un orden cronológico como hilo conductor, a fin de hacer resaltar las filiaciones entre los textos y su recepción en Francia hemos alterado esta clasificación al abordar la traducción de las lecciones vienesas de Schlegel, atendiendo a las deudas recíprocas con el primer historiador y a su consulta referencial por Sismondi —su precedente cronológico en su conocidísima edición parisina-. De esta manera, más que un examen detenido de sus ya conocidas premisas estéticas, observaremos principalmente en este caso sus reflexiones sobre el teatro español con el objeto de encuadrarlas en el contexto general de los estudios franceses sobre la literatura del sur de los Pirineos.

La creciente envergadura de estudios parciales en artículos y reseñas publicados en la prensa cultural, más alerta ante las novedades contemporáneas que las historias literarias - $-\mathrm{y}$ origen en ocasiones de estudios impresos en volumen, como, por ejemplo, el de Viardot de 1835 que también analizaremos-, explica la pertinencia de la inclusión de algunas aportaciones puntuales de relevancia. De igual modo, el afianzamiento de las primeras cátedras universitarias de lenguas y literaturas extranjeras en los años treinta y cuarenta - en un período de asentamiento y difusión de las bases de los primeros estudios y de ahondamiento en parámetros como el comparatismo de fuerte impronta nacionalista francesa o la historia de la civilización - justifica asimismo una cala sucinta en varios extractos periodísticos de cursos magistrales dictados en París, así como en diversos manuales auxiliares de estas décadas. Tras la incursión comparatista de Puibusque en 1843, la traducción francesa de la historia de Ticknor y el eco de la voluminosa de Amador de los Ríos, estudiosos franceses de distinta experiencia y cometido — como Baret, cuya historia más mediocre y restringida examinaremos, así como la discutida de Hubbard, volcada en su contemporaneidad - afrontan aisladamente su estudio autónomo en la segunda mitad del XIX precediendo a su inclusión en las historias generales europeas de las últimas décadas del siglo, en las que asimismo nos detendremos. En último lugar, de entre la amplia variedad de antologías -otro género crítico-histórico que confluye con los discursos anteriores - hemos seleccionado algunas de ellas, a fin de observar detenidamente la galería de modelos estilísticos y ejemplares más difundidos en Francia del canon español. Concebidos unos para un lectorado francés 
medianamente culto y curioso durante una primera etapa de auge de lo hispánico en la primera mitad del siglo, alguno en el seno de las academias de provincias, cuando empieza a decaer el interés por la literatura vecina, y los más en el marco de la enseñanza, estos florilegios, escogidos en cortes diacrónicos, permiten apreciar sus márgenes más acusados a lo largo del XIX, antes de ofrecer finalmente una breve recapitulación de las principales conclusiones generales.

Esta presentación somera del estudio que viene a continuación - desarrollado a partir de un capítulo de la tesis doctoral La literatura española en la prensa cultural francesa del siglo XIX: La Revue des Deux Mondes y la Revue de Paris, defendida en el Departamento de Filología Anglogermánica y Francesa de la Universidad de Oviedo- no podría terminarse sin mostrar su deuda con aquellas personas que han contribuido a que este vea la luz: sobre todo a los profesores de mi facultad Dña. Carmen Fernández Sánchez, directora de la tesis, por su confianza, disponibilidad y buenos consejos, D. Antonio Fernández Insuela del Departamento de Filología Española, por su gran deferencia al haber aceptado prologar este trabajo, y Dña. Flor Bango de la Campa, siempre servicial; y, en el Departamento de Filología de la Universidad de Zaragoza, al equipo de investigación ${ }^{13}$ que con tanta amabilidad me ha acogido, y en particular a su director, D. Leonardo Romero Tobar, a quien le expreso muy especialmente mi profundo agradecimiento por su enorme generosidad y su paciencia impagable.

13 Constituido en 2000, actualmente está formado por los profesores de la Universidad de Zaragoza Jesús Rubio, Ángeles Ezama, Enrique Serrano, Daniel Mesa, Rosa Pellicer y Dolores Royo; los profesores Rafael Alarcón (de la Universidad de Jaén), Pilar Vega y Fermín de los Reyes (de la Universidad Complutense); y los becarios Marta Marina, Antonio Martín, Elisa Martínez y Soraya Sádaba. 


\section{LA LITERATURA ESPAÑOLA EN FRANCIA: ENTRE LA REHABILITACIÓN Y EL PREJUICIO}

Entre las declaraciones más reiteradas a lo largo del siglo XIX por los estudiosos extranjeros y por los susceptibles escritores españoles, atentos a la valoración de su literatura nacional más allá de sus fronteras, se encuentra la fundada queja por el escaso conocimiento que el público foráneo, en especial el francés, tiene de la literatura española. Esta arraigada atención a Francia, centro indiscutible del clasicismo oficial del siglo XVIII y eje vertebrador de la Ilustración, está firmemente cimentada en el duradero prestigio que su cultura continúa irradiando en Europa en la centuria siguiente. No en vano ostentaba aún, pese a las tensiones entre la emulación y el rechazo que provoca en las literaturas - sobre todo limítrofes - que la admiran, el papel de mediadora cultural, de polinizadora, en suma, y asimismo, gracias a ese indudable ascendiente, el de fuente principal de las traducciones de todo género que se editan por entonces en España. ${ }^{14}$

Dentro de esa rebeldía contra el modelo clasicista francés cabe situar, como un grito de manumisión en nombre de las literaturas fronterizas, el

14 Así lo demuestra el examen de las bibliotecas madrileñas por J. A. Martínez Martín (Lecturas y lectores en la España isabelina (1833-1868), Editorial de la Universidad Complutense de Madrid, 1986, 2 vols.). Las referencias bibliográficas se extienden a todos los géneros, no solo los especializados como historia o economía política, sino también desde principios de siglo otros muy demandados por su gran consumo como el teatro y la novela, en los que a menudo los traductores o adaptadores enmascaraban sus propias obras para facilitar su venta o burlar la censura. 
ataque del crítico alemán August Wilhelm von Schlegel. En la traducción francesa de 1814 de sus lecciones públicas sobre el género teatral, Cours de littérature dramatique, denuncia de nuevo la incuria que padecían las traducciones de las obras españolas en Francia, férreamente renuente esta a principios del XIX a aceptar otras estéticas no sancionadas por su normativa. De este modo, la selección — de por sí parcial— de obras españolas del teatro áureo era vertida de manera parca y mutiladora en las ediciones francesas - a pesar de la ventaja difusora que esta mediación llevaba implícita-, y luego divulgada por el resto de Europa, donde las deficiencias se repiten. ${ }^{15}$ La inquina de Schlegel contra la hegemonía del clasicismo francés había llevado al autor a extender su crítica no solo a los exponentes de la decadencia postclásica, sino también a todo el período con sus más ilustres representantes. El crítico alemán no deja de señalar la deuda con el teatro español de los dramaturgos franceses del siglo XVII y aún del XVIII, a los que acusa con fruición de saqueadores de galas ajenas, tomadas impunemente del rico botín de la dramaturgia española. Esta vívida imagen de despojamiento se suma a otros cargos que inciden en diversos aspectos también recordados por críticos posteriores, como, por ejemplo, la infidelidad de estas traducciones de traducciones, que diluyen la belleza y armonía de los versos en perífrasis de pasajes indiscriminados, escogidos por el acicate de la intriga argumental y a expensas de la riqueza de las obras originales.

No obstante, si el desigual conocimiento de esta literatura y su historia, más receptivo al prestigioso pasado — como confirmaba Eugenio de Ochoa ${ }^{16}$

15 «On n’a guère en France d'autre idée du théâtre espagnol que celle qu'en donnent les traductions de Linguet. Ces mêmes traductions ont été mises en allemand, et on y a joint quelques pièces tirées immédiatement des originaux, mais qui ne sont pas très supérieures aux autres. Les traducteurs n'ont choisi que des comédies d'intrigue, ils ont délayé les vers dans de la prose (car toutes les pièces espagnoles sont versifiées, à l'exception de quelques entremeses, saynètes et des comédies très modernes); ils n'ont donné de plusieurs pièces, que des extraits imparfaits, et se sont fait un mérite de les avoir dépouillées de leurs plus brillants ornements» (A. W. von Schlegel, Cours de littérature dramatique, París, Lacroix, Verboeckhoven et Cie Éditeurs, Librairie Internationale, 1865, p. 343).

16 «je me propose de constater dans cette lettre la véritable part de l'Espagne dans le mouvement intellectuel qui s'opère en Europe. [...] Il est aussi malheureusement trop vrai que l'on ne sait pas en France, je dirai même en Europe, si nous avons ou non, aujourd'hui, une littérature. De ce qu'on n'en sait rien ou à peu près, on conclut pour la négative, et, je ne crains pas de le dire, on se trompe» ("La littérature espagnole au XIX siècle», Revue de Paris, t. Xx, 1840, p. 36). 
al vindicar en plenos años cuarenta el mérito de la producción contemporánea en la evolución cultural general-, distaba de ser plenamente satisfactorio entre el lectorado francés, no ocurría así entre los investigadores. Conceptos consagrados por la teoría romántica como el espíritu particular de cada época y cada nación, la afirmación de la relatividad ejemplar de los modelos, la simbiosis entre géneros, la apoteosis del subjetivismo y del valor de la imaginación, y, en consecuencia, la progresiva aunque demorada ampliación del canon de obras maestras modelan la perspectiva con que el siglo XIX aborda las diversas literaturas. A mediados de la centuria, el crítico germanista Saint-René Taillandier, en su reseña ${ }^{17}$ de los trabajos recientes en este ámbito, da fe del creciente y firme entusiasmo que despierta la cultura española desde las historias de principios de siglo entre los estudiosos y lectores cultivados («partout chez les lettrés un retour inattendu de sympathie et de respect pour les monuments intellectuels de son pays [España]»). A fines de siglo, cuando las circunstancias que dirigen la orientación de los estudios siguen de cerca el ritmo intelectual de los países del Norte, el ilustre catedrático Ferdinand Brunetière, ${ }^{18}$ atento a la marcha de las literaturas ajenas, constata de nuevo con cierta resignación el abandono o la indiferencia mayoritaria que inspira en Francia la evolución literaria española cuya única fama recae en Cervantes, Calderón y Lope, junto al Quijote, el Romancero del Cid, por el drama corneliano, y gracias a Lesage el Lazarillo y el Guzmán.

17 «La littérature espagnole et ses historiens modernes», Revue des Deux Mondes, t. VIII, 15-X-1854, pp. 278-317.

18 «Entre les grandes littératures de l'Europe moderne, il y en a peu, sans doute, qui soient plus riches, mais surtout plus originales que la littérature espagnole, et cependant, il n'y en a guère qui nous soient moins connues. [...] Et, en effet, joignons au nom de Cervantes les noms de Calderon et de Lope de Vega; joignons à Don Quichotte le Romancero $d u$ Cid, à cause de Corneille, et le Lazarille de Tormes ou le Guzman d'Alfarache, à cause de Le Sage, c'est à peu près tout ce que nous savons aujourd'hui de la littérature espagnole; et ceux-là passent presque pour des érudits qui connaissent le nom de Quevedo, par exemple, ou celui de George de Montemayor: je ne dis pas qui ont lu leurs œuvres» («Revue littéraire. L'influence de l'Espagne dans la littérature française», Revue des Deux Mondes, t. CIV, 1-III-1891, pp. 215-216). 
El legado secular del exotismo hispánico, ${ }^{19}$ corriente subterránea que resurge de cuando en cuando en la cultura francesa, y la fluencia ahora más constante de la investigación filológica y crítica coinciden en el tiempo, y en numerosas ocasiones se interpenetran en el curso del siglo. A pesar de ello - y a veces por sus efectos recíprocos-, tras la boga de las «espagnolades» de fines de siglo o la celebración de las exposiciones universales, y cercano a la inminente fundación de las primeras asociaciones e instituciones del hispanismo colegiado que cobrarán radical importancia años más tarde, ${ }^{20}$ Boris de Tannenberg ${ }^{21}$ encarecía en el prólogo de su estudio de 1889 sobre los poetas del siglo XIX en lengua castellana ${ }^{22}$ tanto de la Península -Quintana, Rivas, Espronceda, Zorrilla, Campoamor, Bécquer, Núñez de Arce, y finalmente Manuel del Palacio, Valera y Menéndez Pelayo- como de las naciones hispanoamericanas - Olmedo, Andrés

19 D.-H. Pageaux, «Une constante culturelle: l'exotisme hispanique en France», en R. Antonioli (ed.), Exotisme et création, Lyon, Hermes, 1985, pp. 107-119, o también sus artículos «Un aspect des relations culturelles entre la France et la Péninsule Ibérique», en F. Lafarga (ed.), Imágenes de Francia en las letras hispánicas, Barcelona, PPU, 1989; y "Recherches sur l'espagnolade en France (1870-1914). Éléments d'une bibliographie», Récifs, n. ${ }^{\circ}$ 8, 1986, pp. 123-137; o R. Toumson, «L’exotisme. Problématiques de la représentation de l'autre et de l'ailleurs», en Mélanges Simon Jeune, Burdeos, Société des Bibliophiles de Guyenne, 1990, pp. 433-450; o también M. Boixareu y R. Lefere (eds.), La Historia de España en la Literatura Francesa. Una fascinación..., Madrid, Castalia, 2002.

20 Véase A. Niño, ob. cit.

21 Este estudioso ruso-alemán (1864-1914) de lengua y formación francesa, colaborador de diversas publicaciones como, por ejemplo, el periódico literario L'Espagne, o el conservador Journal des Débats, para el que redactó diversos artículos críticos y sus Silhouettes contemporaines —así, de Ganivet, "maître de la jeune Espagne», entre otros-, abordó el análisis de la literatura española, particularmente de la decimonónica, a varios de cuyos más destacados representantes trató en París — como Campoamor-o entrevistó en España para su documentación, y se carteó con reputados hispanistas españoles y también hispanoamericanos como el colombiano Rufino José Cuervo, con quien le unió una respetuosa amistad (véase M. G. Romero (ed.), Epistolario de Rufino José Cuervo con Alfred Morel-Fatio, Gaston Paris y otros hispanistas de lengua francesa, Bogotá, Instituto Caro y Cuervo, 1987).

22 La Poésie castillane contemporaine (Espagne et Amérique), París, Librairie Académique Didier, Perrin et Cie, libraires-éditeurs, 1889. Dedicado a Castelar — quien lo proveyó de cartas de presentación para sus visitas de dos años antes a los escritores estudiados como, por ejemplo, un hospitalario Zorrilla, entonces reducido a una mezquina pensión que compensaba con la publicación de sus memorias en El Imparcial-, este era el primer tomo de una proyectada trilogía sobre la literatura española consagrada a sus poetas, novelistas y dramaturgos. Incluía un apéndice final con nombres como Tassara, Campillo, Alcalá Galiano, Velarde, Ferrari, Selgas o Ruiz Aguilera. 
Bello, Gutiérrez González, Batres, Heredia y Andrade- el interés de su literatura contemporánea a ambos lados del Atlántico, presentando pródigamente textos y citas para que el lector juzgara por sí mismo. Años más tarde, el crítico recoge en L'Espagne littéraire ${ }^{23}$ otra serie de estudios sobre sus eximios maestros tras la Septembrina, escogidos por una común militancia católica — no exenta de matices - y su representatividad de un genuino y atemporal carácter español, ${ }^{24}$ en el género teatral, novelístico y crítico. Como otros estudiosos que ya acostumbran entonces a entrevistar en su hogar, biblioteca o despacho a los autores extranjeros reseñados para sus relatos de viajes, semblanzas o trabajos literarios, Tannenberg acude a su vez al encuentro de un venerable Tamayo y Baus, secretario perpetuo de la Academia Española y director de la Biblioteca Nacional; o de un Pere$\mathrm{da},{ }^{25}$ alabado pintor de las costumbres de provincias, cuyo acendrado conservadurismo contrastaría con la postura ideológica de un Galdós ${ }^{26}$ nombrado, por su parte, "héritier des grands picaresques» (ob. cit., p. 188); esboza a grandes rasgos el perfil de una culta e inquieta E. Pardo Bazán; ${ }^{27}$

23 París, A. Picard et fils, cuya edición de 1903 hemos consultado.

24 Tannenberg se propone ofrecer una idea más justa de «l'Espagne vraie», alejada de la popularizada por las convenciones románticas, a través de eximios escritores que encarnan «sous des formes diverses, le sentiment traditionaliste, la fidélité à l'Espagne d'autrefois» (p. xvi).

25 Tras reconocer su importancia dentro del realismo contemporáneo, y señalar también préstamos ulteriores tomados del naturalismo francés, Tannenberg inserta sus cuadros de costumbres en la tradición española desde Cervantes y Quevedo hasta Larra, Mesonero, Estébanez Calderón o Fernán Caballero — cuya sinceridad sin embozos en la cruda pintura de las pasiones populares antepone elogiosamente a su censurada tendencia a las prédicas morales, frente a un Trueba que goza, a su juicio, de una reputación usurpada- De entre sus obras, atentas al ritmo de la vida campesina y de provincias, se detiene, por ejemplo, en sus Scènes montagnardes (Escenas montañesas), Pedro Sánchez, Don Gonzalo González de la Gonzalera, El Sabor de la tierruca, La Puchera, Peñas arriba, o Sotileza, traducida primero en la Revue des Deux Mondes por Jacques Porcher, y luego editada en volumen por Hachette en 1899.

26 Menos afín a este, también aplaudido novelista de las costumbres madrileñas, Tannenberg personifica en él «toutes les aspirations un peu confuses de l'Espagne nouvelle» (ob. cit., p. 211).

27 Como silhouette publicada inicialmente en el Journal des Débats, este breve examen no desarrolla como en los artículos anteriores un demorado análisis selectivo en la producción general de esta prolífica autora, de cuyas principales obras - como su autobiografía, novelas, ensayos, colecciones de cuentos y relatos o biografías - levanta acta el crítico. Tannenberg traza sucintamente su evolución ideológica desde un carlismo acérrimo, que 
y se extiende largo y tendido en la talla intelectual de un muy admirado anfitrión Menéndez Pelayo, cuyas lecciones en la Universidad Central de Madrid también había escuchado en su juventud. Discípulo de Milà i Fontanals, erudito medievalista y culto esteticista a cuya influencia duradera sobre el historiador suma Tannenberg la de su amigo Juan Valera — lector selecto y juicioso, y elegante y delicado poeta—, ${ }^{28}$ Menéndez Pelayo, crítico humanista armado de una vasta erudición y dotado de un fino sentido literario, ${ }^{29}$ se yergue para su reseñador sobre A. de los Ríos como el verdadero y cumplido iniciador del estudio moderno de la historia de la

coexiste con un inesperado apostolado del naturalismo — con La Question palpitante, trasladada al francés bajo el título Le Naturalisme (París, E. Giraud, 1886) por Albert Savine, conocido traductor de varias obras de autores españoles como J. Verdaguer, N. Oller, Valera, Trueba o Galdós-, hasta su compromiso con las reformas más avanzadas. Su gran estatura intelectual y su activa colaboración periodística en favor de L'Espagne nouvelle — tanto desde su inagotable provisión de artículos y reseñas para su revista mensual Teatro Crítico, como impulsando nuevas colecciones del relieve de La España Moderna-, la convierten en autoridad referencial para los estudiosos de la actualidad literaria española. Cualidades estas por las que Tannenberg anima a la autora, tentada en su momento de escribir una historia de la literatura española, a cumplir su proyecto.

28 En su estudio de 1898 Tannenberg lo había elogiado no solo como poeta culto por su gracia y exquisito gusto - a pesar de cierto rebuscamiento formal y de su escasa imaginación-, sino también como traductor, aún incomprendido por la mayoría del público español por su sutileza, y cuyo ingenioso y refinado talento se encubre a veces bajo un aire de improvisación ligera. El crítico había esbozado con notable sagacidad su retrato: «Je le considère comme un de ces humanistes de la Renaissance, qui avaient à un si haut degré le sentiment des choses antiques, admirateurs très païens de la forme; et je vois aussi en lui un philosophe, un sceptique grand seigneur du siècle dernier, très audacieux et très moqueur; et j'ajouterai enfin qu'on ne peut le lire sans retrouver dans ses écrits l'influence des mystiques du seizième siècle, qu'il a beaucoup étudiés comme modèles de prose castillane et d'analyse psychologique» (ob. cit., p. 210).

29 Sobre este concepto revitalizado desde Alemania en la obra de Voigt (1859) con el sentido amplio de intelectual atento a la educación humana como formación integral, y la interpretación cristiana y sincrética del humanismo renacentista español por Menéndez Pelayo, véanse, por ejemplo, las reflexiones de A. Blecua («El concepto de Siglo de Oro», en L. Romero Tobar (ed.), Historia literaria/Historia de la literatura, 2004, especialmente pp. 130-136). La conjunción de sus dotes críticas, su capacidad de estudio, su vasta erudición en la literatura española y sus conocimientos de las extranjeras lo singularizan para Tannenberg entre los principales investigadores europeos de la época: «M. Menéndez y Pelayo est, en effet, une des personnalités littéraires les plus originales et les plus curieuses de ce temps, et je ne crois pas qu'il y ait aujourd'hui en France — ni même en Danemarkun critique joignant à l'érudition la mieux informée sur tout ce qui touche à la littérature et à l'histoire de son pays un goût plus délicat et plus compréhensif, une culture plus vaste et plus vraiment européenne» (ob. cit., p. 88). 


\section{literatura y el pensamiento españoles. ${ }^{30}$ Empeñado en la rehabilitación de la España histórica y literaria, indisolublemente ligada al catolicismo a su}

30 Tras haberlo abordado en 1898 como poeta neo-clásico de destacables versos blancos, apasionado de la Antigüedad y de Horacio, Tannenberg acomete ahora su ingente producción como crítico de la historia literaria española. Si bien señala varios errores menores en sus argumentos, y sus propias correcciones a la intemperancia de lenguaje por la vehemencia de las discusiones de sus obras de juventud, también subraya la envergadura de su propósito, encaminado a la glorificación nacional a través de sus escritores, hombres de ciencia y pensadores, rescatados de nuevo en ediciones, antologías y estudios de historia literaria. De este modo, no solo se recupera la tradición literaria a la que se acepta que el país se mostró fiel aun bajo la influencia francesa, sino también la filosófica, estudiada asimismo por G. Laverde o L. Vidart. Tannenberg se muestra de acuerdo con el crítico santanderino en sus críticas a los krausistas, contra los que este había hecho sus primeras armas en pro del tradicionalismo español. Así, se reprocha a Sanz del Río - y a sus seguidores Fernando de Castro, Azcárate y, antes de su abandono, a Revilla y Salmerón - la introducción en España de la filosofía alemana a través de un subalterno como Krause, en lugar de seguir a Kant o Leibniz, Hegel, Schelling o Schopenhauer, y cuyo arraigo el reseñador explica acudiendo a la tradición estoica española («La morale krausiste, avec son austérité unie à un vague mysticisme, leur présentait sous une forme nouvelle cet idéal stoïcien, auquel depuis Sénèque ils restèrent toujours fidèles. Pourquoi faut-il que, par une malechance singulière, l'Espagne, que son passé prédestinait à bien comprendre l'impératif catégorique de Kant, n'ait connu la pensée allemande que par un de ses plus médiocres représentants?», p. 112). No obstante, en su repaso a las principales ideas del reseñado, Tannenberg también mantiene sus reservas ante las argumentaciones del crítico respecto al alcance y perniciosidad de la influencia inquisitorial — asunto aún candente en las revisiones de su pasado histórico por los intelectuales españoles de aquellas décadas - y que, pese a la documentación puntual del santanderino, sigue juzgando nefasta a la larga por su vigilancia de las conciencias. Sin embargo, frente a la afirmación de Núñez de Arce en su discurso de recepción a la Academia recogido en su Miscelánea Literaria (Barcelona, 1886), concede que no fue la única causa de la decadencia intelectual a partir del XVII. Habiendo leído también a Cánovas en su Bosquejo, además de mencionar la despoblación por las guerras, la colonización americana y la abundancia de profesiones religiosas, invoca el argumento de Valera, conocido enemigo de generalidades simplistas y del liberalismo declamatorio, en su respuesta a Núñez de Arce (Disertaciones y juicios literarios, Madrid, 1878, p. 123), que apuntaba al carácter mismo de la nación — como Chasles, en parte, en sus cursos y artículos a partir de los años treinta-, y al orgullo exasperado, ignorancia desdeñosa e intolerancia de las clases populares más que de sus dirigentes. Pese al disentimiento de R. Altamira (Psicología del pueblo español, Madrid, 1902, p. 67), recordado por el reseñador en nota, en que señalaba la admiración del español por lo extranjero y su denigración de lo propio, en materia tan compleja y vidriosa Tannenberg insiste en que los españoles del XVI fueron tan orgullosos de su nacionalidad como los del XIX. Por otro lado, también retoma las principales observaciones de Menéndez Pelayo sobre la historia de la filosofía y asimismo de la ciencia - para cuyo cultivo no habrían sido las aptitudes, sino el espíritu científico lo que habría faltado- y su vindicación de los méritos españoles desde las contribuciones de marinos, geógrafos, naturalistas y técnicos, hasta Hervás y Panduro, tan alabado por Müller, y otros españoles también homenajeados por Humboldt, o un Ramón y Cajal, su único científico contemporáneo de reputación internacional, según anota el comentarista. 
entender - que tampoco se pliega rigurosamente a las directrices del neocatolicismo vigente-, el estudioso santanderino pretende, como su precursor, caracterizar el genio español tal como aparece en su literatura, sin llegar, no obstante, a formular como Taine una definición evidente, disgregada en cambio en indicaciones dispersas por sus escritos. ${ }^{31}$ Coincidiendo con Brunetière en el pertinaz desconocimiento de esta cultura entre el lectorado extranjero - a excepción de un asentado Quijote cuya estima convive con juicios vagos y contradictorios sobre sus poetas, su teatro y sus místicos-, e invocando la idea veterana de seleccionar entre la abundancia las cúspides de la historia literaria, Tannenberg justifica la necesidad de difundir la ingente labor de eminentes personalidades de rango europeo como Menéndez Pelayo, que por aquel entonces, a la inversa que sus colegas franceses, había orillado la abierta militancia ideológica inicial por los absorbentes estudios literarios. ${ }^{32}$

En una centuria convulsa de transformaciones radicales, el panorama que tales ejemplos permiten atisbar sobre la recepción de esta literatura constituida en un nuevo campo de conocimiento por explorar, su paulatina y sesgada penetración en las diversas clases sociales a través de los gabinetes de lectura y, primordialmente, de la enseñanza — secundaria y universitaria-, así como la imagen que preside su nombre en recreaciones de diversos géneros — desde la tragedia a obras de consumo popular como el exitoso melodrama y los vaudevilles, o de la lírica al panfleto encomiástico o las composiciones de circunstancias- aún refleja una serie de prejuicios vigentes a lo largo de esa centuria, de los que solo en parte se irá despojando la opinión pública vecina, gracias en cierta medida a los frutos posteriores del naciente hispanismo francés. ${ }^{33}$

31 Por ejemplo, la herencia hispanorromana, la energía moral, la inspiración idealista caballeresca y el misticismo, la capacidad de aprehender el carácter de cada tiempo y lugar, o el gusto por la burla, la ironía o el humour, cuya analogía con el inglés repiten varios críticos franceses.

32 "Tandis qu'en France nos meilleurs critiques, un Lemaître, un Brunetière, lassés de la pure littérature, se sont tournés vers l'action politique ou l'apostolat, l'auteur de la Science espagnole et des Hétérodoxes se confine de plus en plus dans les recherches d'histoire littéraire. Il étudie l'evolution des idées esthétiques en Espagne et ailleurs, fait une $A n-$ thologie des poètes espagnols, multiplie les éditions et les préfaces, élève un monument grandiose à la mémoire de Lope de Vega» (ob. cit., p. 97).

33 Sobre las complejas relaciones culturales, políticas e ideológicas entre ambos países en el XIX véanse, por ejemplo, la síntesis general de Ch. Abbadie-Maumejean y 


\subsection{Apertura del canon occidental}

Dentro de un movimiento de apertura hacia las culturas extranjeras y de un proceso de redefinición del canon de la literatura francesa, ${ }^{34}$ la boga romántica de lo español produce a lo largo de esas décadas un profuso caudal ${ }^{35}$ de obras literarias, eruditas, o de circunstancias sobre España, así como memorias de los combatientes bonapartistas, traducciones, impresiones de viajes, cartas geográficas, resúmenes históricos de enseñanza libe-

E. Cobos Castro («Les relations franco-espagnoles au XIX ${ }^{\mathrm{e}}$ siècle», Estudios de Investigación Franco-Española, n. ${ }^{\circ}$ 9, 1993, pp. 41-55), el estudio de H. Juretschke (España ante Francia, Madrid, Fe, 1940), Niño (ob. cit.) y especialmente las valiosas visiones de conjunto dedicadas a la segunda mitad de siglo y su etapa finisecular por P. Aubert («Linfluence idéologique et politique de la France en Espagne de la fin du XIXe siècle à la Première Guerre Mondiale (1875-1918)», pp. 57-102) y É. Témime («France et Espagne dans la seconde moitié du XIX siècle: le déclin d'une influence», pp. 247-264), editadas ambas en España, Francia y la Comunidad Europea, J.-P. Étienvre y J. R. Urquijo (eds.), Madrid, Casa de Velázquez/CSIC, 1989.

34 Como se afirma en la introducción de la Bibliographie des traductions françaises (1810-1840). Répertoires par disciplines, Lovaina, Presses Universitaires de Louvain, 1995, p. ix: «L'époque romantique redéfinit les frontières de sa culture lettrée; elle donne à voir un échange complexe entre les zones littéraire et religieuse, historique, scientifique, philosophique et autres. Mais elle renouvelle également ses contacts avec l'étranger, au point qu'il convient de s'interroger sur la fonction intermédiaire des traductions, celles-ci facilitant peut-être l'échange interdisciplinaire au sein même du système culturel français».

35 Como muestra de esta dilatada bibliografía véanse, por ejemplo, L.-F. Hoffmann (Romantique Espagne. L'image de l'Espagne en France entre 1800 et 1850, París, PUF, Princeton University, 1961), Margaret Rees (French Authors on Spain. 1800-1850. A checklist, Londres, Grant \& Cutler, 1977), L. Miard («Images d'Espagne en France (1820-1880). (Flâneries bibliographiques)», Interférences, n. ${ }^{\circ}$ 6, en.-jun. 1977, pp. 9-145), o L. Trénard ("Images mythiques d'Espagne sous la Restauration», Revue des Sciences Humaines, n. ${ }^{\circ}$ 107, jul.-sept. 1962, pp. 367-422); repertorios bibliográficos decimonónicos como los fundamentales del bibliófilo J.-M. Quérard (La France Littéraire, ou dictionnaire bibliographique des savants, historiens et gens de lettres de la France..., París, Firmin Didot père et fils (Firmin Didot frères), 1827-39; La littérature française contemporaine, 1827-1849, París, Daguin, 1840-57), continuados por Bourquelot y Maury (La Littérature française contemporaine, 1842-57); o del librero O. Lorenz (Catalogue général de la Librairie Française pendant 25 ans (1840-1865), París, chez O. Lorenz, 1867 (Estrasburgo, Imprimerie de Veuve BergerLevrault)); o también catálogos de traducciones como el de K. Van Bragt (Bibliographie des traductions françaises (1810-1840). Répertoires par disciplines. Avec la collaboration de Lieven D’hulst et de José Lambert. Lovaina, Presses Universitaires de Louvain, 1995) o el más acotado de M. Horn-Monval (Répertoire bibliographique des traductions et adaptations françaises du théâtre étranger du XV siècle à nos jours, París, CNRS, 1958-67, t. IV, 1961). 
ral, ${ }^{36}$ folletos polémicos, artículos periodísticos o lecciones académicas pronto impartidas en las recién estrenadas cátedras de literaturas meridionales. En esa aproximación a la tierra y las gentes españolas exaltadas por los recientes acontecimientos históricos, más que una valoración crítica profunda y pertinente de España subyace principalmente un fondo común de prejuicios transmitidos por los libros de viajes ${ }^{37}$ al que se suman las nuevas preocupaciones estéticas y políticas. La nueva interpretación del paisaje, ${ }^{38}$ vía de penetración de la sensibilidad romántica desde finales del XVIII, las exposiciones de colecciones pictóricas como las galerías privadas de Aguado y del general Soult, o la de Luis Felipe en el Louvre, ${ }^{39}$ o las reformulaciones estéticas que en contados casos observan la realidad del peculiar caso español contribuyen a moldear una imagen de la cultura española a la que también recurrirán la mayoría de los reportajes, relatos, cuentos, novelas —editadas bajo los, a menudo, sedicentes marbetes de histoire, anecdote o nouvelle espagnole, o como pretendidas traducciones-, poemas, estudios, sainetes, piezas teatrales y reseñas insertas en los feuilletons literarios y dramáticos de la prensa así como las historias literarias.

A fines de la Restauración y bajo el régimen de Julio, durante la edad dorada del teatro, la cultura española se convierte, por obra del pujante gusto por el exotismo y de las empresas traductoras, en el cañamazo de numerosas composiciones de jóvenes autores. La intensa efervescencia del teatro a principios de la centuria, uno de los géneros literarios de mayor impronta social por sus implicaciones ideológicas y pedagógicas, se mani-

36 Género lanzado en 1821 con gran éxito por F. Bodin - director después de la colección de Résumés historiques editados por Lecointe y Durey-, y acogido por los liberales como propagador de la "diffusion des lumières".

37 Véase el repertorio bibliográfico de J. Rubio y E. Ortas («Informe: El viaje romántico por España», El Gnomo. Boletín de Estudios Becquerianos, n. ${ }^{\circ} 3$, 1994, pp. 163-211) y el estudio de É. Témime (Voyages et voyageurs français en Espagne au milieu du XIX siècle, Aix, 1973), además del imprescindible volumen de R. Foulché-Delbosc, Bibliographie des voyages en Espagne et en Portugal, Madrid, Julio Ollero Editor, 1991.

38 Véase, por ejemplo, E. Ortas Durand y las fundamentaciones teóricas y estéticas de los textos analizados además de la copiosa y útil bibliografía (Viajeros ante el paisaje aragonés (1759-1850), Zaragoza, Institución «Fernando el Católico», 1999).

39 Sobre la difusión del arte español véanse también, por ejemplo, V. Bozal (Imagen de Goya, Barcelona, Lumen, 1983); P. Guinard (Dauzats et Blanchard, peintres de l'Espagne romantique, Burdeos, Casa de Velázquez/Université de Bordeaux, Féret \& fils, 1967); o I. H. Lipschutz (La pintura española y los románticos franceses, Madrid, Taurus, 1988). 
fiesta en el número de salas, de hojas periódicas, anuarios, agendas de teatro, almanaques y revistas especializadas de la época, ${ }^{40}$ y en una floreciente edición teatral. ${ }^{41}$ Con el bagaje de las aportaciones de la crítica, la introducción de nuevos subgéneros como el histórico o la comedia lacrimosa (comédie larmoyante), los adelantos en escenografía, vestuario, técnica y dirección actoral logrados principalmente desde la década de $1760,{ }^{42}$ el teatro conoce una gran eclosión de fórmulas dramáticas — desde la consagrada tragedia, la comedia y, en menor medida, el teatro histórico al vaudeville, obras de crítica social o de partidismo político, proverbes, las aventuras del celebérrimo Macaire, opéras-comiques, piezas de gran espectáculo, o el melodrama, decisivo en la conformación del drama romántico-—. ${ }^{43}$

40 Véanse, además del indispensable E. Hatin (Bibliographie historique et critique de la Presse périodique française, ou Catalogue systématique et raisonné de tous les écrits périodiques de quelque valeur publiées ou ayant circulé en France depuis l'origine du Journal jusqu'à nos jours, avec extraits, notes historiques, critiques et morales, indication des prix que les principaux journaux ont atteints dans les ventes publiques, etc., précédé d'un Essai historique et statistique sur la naissance et les progrès de la presse périodique dans les deux mondes par...., París, Librairie de Firmin-Didot frères, fils et Cie, imprimeurs de l'Institut, 1866), P. Berthier ( $\mathrm{La}$ Presse littéraire et dramatique au début de la Monarchie de Juillet (1830-1836), Presses Universitaires du Septentrion, 1997, 4 vols.), la documentación depositada en la colección Rondel, y un sinnúmero de repertorios bibliográficos de la producción teatral de la época entre los que citamos, por ejemplo, N. Brazier (Chroniques des petites théâtres de Paris, 1837, reimpreso con anotaciones y variantes en 1883 por G. d'Heylli (E.-A. Poinsot)), M. Albert (Les Théatres des boulevards (1789-1848), París, 1902), G. Douay (Répertoire général de toutes les pièces représentées sur les théatres de Paris, hasta el año 1911, Ms. Bibliothèque de l'Arsenal), Ch. B. Wicks (The Parisian Stage: Alphabetical Indexes of Plays and Authors (1800-1815), (1816-1830), (1830-1850), University of Alabama Press, t. 1-3, 1950, 1953, 1961), o también A. Joannidès (La Comédie Française de 1680 à 1900. Dictionnaire Général des pièces et des auteurs avec une préface de Jules Claretie, Nueva York, Burt Franklin, 1901; o su otro estudio La Comédie Française de 1680 à 1920; tableau de représentations par auteurs et par pièces, París, Plon-Nourrit, 1921).

41 O. Krakovitch, «Le théâtre sous la Restauration et la monarchie de Juillet: lecture et spectacle», en A. Vaillant (dir.), Mesure(s) du livre, París, Bibliothèque Nationale, 1992, pp. $147-164$.

42 P. Peyronnet, La Mise en scène au XVIII siècle, París, A.-G. Nizet, 1974.

43 Véanse D. O. Evans, Les Problèmes d'actualité au théâtre à l'époque romantique, París, 1923; S. L. England, «Bibliographie des pièces de théâtre parues en France de 1815 à 1848 avec indication des pièces ayant un caractère social ou une tendance sociale», Revue d'Histoire Littéraire, 1934-35; P. Gerbod, "La scène parisienne et sa représentation de l'histoire nationale dans la première moitié du XIX siècle», Revue historique, t. 266, n. ${ }^{\circ} 1,1981$, pp. 3-30; M.-H. Jones, Le Théâtre National en France de 1800 à 1830, París, Klincksieck, 1975. 
En ese arco temporal de tensiones ideológicas y de lucha por una estética, dentro de esa variedad de moldes se representan, en los teatros populares principalmente, obras dramáticas de varia calidad —óperas, vaudevilles, ballets, actuaciones musicales y giras de bailarines y artistas españoles, melodramas y dramas románticos-, abiertas a los modelos literarios extranjeros y cuyas licencias con la historia y fallos compositivos son a menudo censurados en la prensa cultural francesa. En estas piezas, lejanamente inspiradas en el romancero, el teatro áureo o el sainete recuperados en las traducciones contemporáneas de la literatura española, como también en su épica y en ciertos pasajes celebrados de su Edad Media, asoman desde el último tercio del XVIII ${ }^{44}$ y principios de la centuria siguiente personajes del romancero y las crónicas como Pelayo, Sancho II el Fuerte, su vasallo el Cid, doña Urraca, señora de Zamora, o Pedro el Cruel, indisociablemente ligado, como un episodio más, a las vicisitudes de la guerra de los Cien Años, así como modelos literarios. ${ }^{45} \mathrm{Si}$ los vaudevilles y los melodramas, por ejemplo, reflejan los conflictos ideológicos y sociales franceses bajo un disfraz español, ${ }^{46}$ muchas composiciones responden a las revelaciones personales y vigorosas del mito en grandes autores como un Stendhal, un Mérimée — adelantado recreador del universo dramático áureo desde su

44 Véase también Cl. D. Brenner (Plays in the French Language (1700-1789). A bibliographical list, Berkeley, California, 1947) y en especial las minuciosas entradas bibliográficas de Quérard (ob. cit.).

45 En el contexto de los últimos momentos de la pugna por la renovación estética se suceden los estrenos de obras construidas sobre el mito español como La Fille du Cid de Casimir Delavigne, a partir del Romancero, la fracasada Le Cid d'Andalousie (1825) de Lebrun, fundada en L'Étoile de Séville atribuida entonces a Lope, la tumultuosa representación en el Théâtre Français de La Reine d'Espagne (1831) de Latouche, o los dramas emblemáticos de Victor Hugo, por citar algunas de las más resonantes de su época.

46 L. Metayer («L'Espagne et les Espagnols dans les mélodrames parisiens (18301848)», Recherches et études comparatives ibérofrançaises, n. ${ }^{\circ}$ 5, 1983, pp. 46-62) ha estudiado la utilización ideológica de cierta imagen de España en los melodramas parisinos representados ante un público popular durante el régimen de Julio. Según el autor, «la finalité de ces pièces espagnoles n'est pas d'éclairer le public sur ce qu'est l'Espagne réelle. Il s'agit d'œuvres militantes écrites par des auteurs préoccupés par la politique intérieure française» (p. 59). Esa propaganda indirecta y adversa giraba en torno al poder de la Iglesia española representada por la Inquisición y por un clero reaccionario, fanático y rijoso. Constituía, así, una advertencia al entorno del rey, al gobierno y a las masas populares de los peligros que entrañaba una situación análoga en Francia. Metayer concluye: «ce répertoire a sans doute contribué à renforcer des préjugés que la propagande impériale avait déjà commencé à diffuser dans le peuple». 
Théâtre de Clara Gazul editado en 1825-, un Balzac e incluso un Gautier y un Hugo. En consonancia con esta revisión, España también atrae como tierra de fortuna, negocios y hazañas donde verter la energía represada en la ecléctica e intrincada sociedad de los notables del régimen de Julio, aunque los viajeros no dejan de observar, pese a todo, una realidad en metamorfosis que, a su vez, en un complejo juego de refracción, proyecta al extranjero su propia imagen de sí misma, corrigiendo o reforzando el enfoque ajeno y ahondando también sus reflexiones autocríticas. Nuevo eslabón en la transmisión secular de la materia española, esta efervescencia cultural en la que se desarrollan los primeros estudios franceses hereda el bagaje dieciochesco sobre la literatura vecina, cuyas vicisitudes de recepción en los aledaños de las fechas en que se inicia la andadura de las historias de su literatura en Francia trazaremos en líneas generales.

\subsection{Redescubrimientos de la literatura española}

Entre las valoraciones vigentes en el umbral del siglo XIX sobre la cultura española y su literatura aún tenían predicamento aquellas que ponían en tela de juicio la utilidad de su estudio y reforzaban las dudas sobre sus aportaciones a la civilización europea, tan debatidas estas a lo largo del XVIII ${ }^{47}$ y cuyos ecos aún se hacen oír a comienzos del siglo siguiente. Así pues, entre los factores a los que se suele achacar ese desinterés, cuando no abierto desdén, cabe destacar, por ejemplo, la impronta teórica de la doctrina clásica, que sigue midiendo también en España la calidad literaria, el peso de diversos lugares comunes que confluyen con otras nociones en boga sobre el carácter nacional, o también la tradición histórica de la atracción francesa por Italia, la tierra del clasicismo. Sin embargo, en la segun-

47 La boutade frívola de Montesquieu (Lettres persanes) que levantó tantas suspicacias en España - como, por ejemplo, la temprana respuesta de un joven Cadalso (Defensa de la nación española contra la carta LXXVIII de Montesquieu. Edición, prólogo y notas de G. Mercadier, Univ. de Toulouse, France-Ibérie Recherche, 1970) mucho antes de sus reflexiones en las Cartas marruecas - o la borrascosa polémica suscitada por el artículo categórico de Masson de Morvilliers en 1784 (véase W. Floeck, "L'article "Espagne" de Masson de Morvilliers dans "L'Encyclopédie Méthodique" et sa versión espagnole par Julián de Velasco", Estudios de Investigación Franco-Española, n. ${ }^{\circ} 3$, 1990, pp. 103-124, quien remite a la bibliografía sobre las circunstancias y efectos de la polémica, y aborda el texto original, una traducción española y sus variantes). 
da mitad del XVIII ya se rastrean numerosos indicios de una gran curiosidad por las letras españolas que, en ocasiones, llega a apelar abiertamente a la rehabilitación de su estima en Francia. Si bien colecciones como L'Europe Savante (1718-1729) ${ }^{48}$ de principios de siglo ignoran la cultura española, esta va haciéndose un hueco en varias publicaciones a lo largo del siglo, desde el Journal Étranger (1754-1762), la Gazette Littéraire de l'Europe (1764-1766), ${ }^{49}$ ambos de Suard y el abate Arnaud, o la importante L'Année littéraire (1754-1790). ${ }^{50}$ Mientras que la segunda, en la que colabora Voltaire, mediocremente atraído por esta cultura, muestra menos interés y aprecio, en cambio sus predecesoras ofrecen diversos exponentes de la actualidad literaria española. ${ }^{51}$ Sin embargo, puede decirse que a menudo las referencias a esta literatura, generalmente considerada desde una óptica común de indiferencia o de descrédito por los enciclopedistas y sus refutadores, son también instrumentalizadas por antienciclopedistas como Fréron, cabeza del diario europeo, como un ariete en la polémica.

En ese contexto —estudiado exhaustivamente por Daniel-Henri Pageaux — ${ }^{52}$ de lento reconocimiento y utilización de las cualidades de esta literatura del sur de sus fronteras en el curso del XVIII, destaca la tentativa - prometedora pero malograda por su aparición temprana- de Nicolas Bricaire de La Dixmerie (1731-1791), ${ }^{53}$ dedicada exclusivamente

48 L. Belozubov, L'Europe Savante (1718-20), París, A. G. Nizet, 1968.

49 R. Pageard, "L'Espagne dans le Journal Etranger (1754-62) et la Gazette Littéraire de l'Europe (1764-66)", Revue de Littérature Comparée, jul.-sept. 1959, pp. 376-400.

50 P. Van Tieghem, L'Année Littéraire (1754-1790) comme intermédiaire en France des littératures étrangères, París, F. Rieder \& Cie, Éditeurs, 1917.

51 Por ejemplo, la primera inserta romances, correspondencias, estudios y discursos académicos de historiadores, eruditos, escritores y políticos ilustrados desde Mayans, Montiano, Feijoo, Luzán o Nasarre a Campomanes, Iriarte o Isla, y también concede espacio a representantes del Siglo de Oro con extractos traducidos por Coste d'Arnobat de Pérez de Montalbán, María de Zayas, o la presencia de Cervantes, Quevedo, y de romances del Romancero general de 1604, así como reflexiones sobre obras dramáticas como El ricohombre de Alcalá de Moreto, contribuciones significativas en estos años.

52 L'Espagne devant la conscience française au XVIII siècle. 1715-1789, s.l., s.n., 1975, 2 vols.

53 Dieciocho años después del elogio fúnebre que los correligionarios masones de La Dixmerie leyeron en sesión pública en la Société Nationale des Neufs-Sœurs - logia a la que también pertenecieron Franklin y Voltaire-, el prologuista de la selección editada en 1810 es requerido por un amigo para trazar un nuevo elogio preliminar. En él refiere la activa participación del escritor en la vida literaria y en la prensa de su tiempo: sustituto de 
a la cultura española. En 1774, poco después de la afamada empresa traductora de Linguet, dio a la estampa su miscelánea bajo forma epistolar, L'Espagne littéraire, politique et commerçante, ${ }^{54}$ una de cuyas aspiraciones

Marmontel en el Mercure por largo tiempo, donde publicó diversos cuentos, además de en la Bibliothèque des romans; impulsor durante dos años de otra publicación periódica como L'Avant coureur, y colaborador de L'Observateur littéraire. Entre las fuentes complementarias, aparte de discursos y memorias, este reseñador anónimo evalúa sumariamente varios relatos de viajes accesibles entonces al público: los más alabados por su completitud son el Tableau de l'Espagne moderne... de Bourgoing, y su otro Nouveau Voyage en Espagne, fait en 1777 et 1778, publicado entonces anónimamente en Londres (por Esmly en el Strand, y en París de venta en Théophile Barrois, 1782, 2 vols.), al que critica, sin embargo, por su escritura descuidada; así como el Voyage pittoresque et historique de l'Espagne de Laborde (1806, t. I, 1820); por su información sobre las bellas artes en España encarece otros textos también de verdaderos viajeros como el Voyage d'Espagne fait l'année 1755... del padre Caimo, cuya traducción francesa por el P. Livoy (1772) juzga incorrecta, el Viaje de España (1772-1794) de Antonio Ponz, el Voyage de France, d'Espagne, de Portugal, et d'Italie de M. de Silhouette (1770) durante tres meses de 1729, y las cartas descriptivas de Baretti (Voyage de Londres à Gênes par l'Angleterre, le Portugal, l'Espagne et la France), traducidas en torno a los años finales de la década de 1770, aunque mezclan lo sacro y lo profano; más desacreditado le parece por su impostura y poca importancia el Voyage de Figaro en Espagne del marqués de Langle (1784), muy reeditado, junto a otros verídicos pero de menor calidad en su información: el Voyage (1730) del P. Labat en 1705, que critica por su poca fiabilidad y fantasía, así como los poco fidedignos Annales d'Espagne et de Portugal de un supuesto Âlvarez de Colmenar, a quien se le atribuían Les Délices de l'Espagne (1707; 1715) basadas en el relato de Mme d'Aulnoy, o también las aventuras amorosas de las Lettres d'une dame Anglaise à une de ses amies, à Paris, de agradable lectura pero ajenas a las costumbres y usos de España. Para más información básica sobre las ediciones, véase Foulché-Delbosc, ob. cit. Entre las obras de La Dixmerie se citan asimismo sus Contes philosophiques et moraux (1765) y Les Deux Âges du goût et du génie, sous Louis XIV et Louis XV, donde argumentaba la superioridad del Siglo de las Luces sobre la centuria precedente. (Véase también Le Grand Larousse du XIX siècle, 1870, t. 6, p. 989).

54 De periodicidad mensual, su primer número vio la luz en enero de 1774 . Se proyectaba la publicación de 5 vols. en $12 .^{\circ}$ por año, de los que se llegaron a imprimir 4 vols. en total. Los interesados en abonarse debían acudir a M. Wild (rue Grenier Saint-Lazare) y a Lacombe en París. Su primer título rezaba Espagne littéraire, politique et commerçante, ou Journal Espagnol \& Portugais, dans lequel on rend un compte périodique de la littérature, des poësies, des théatres, de l'histoire, des sciences exactes \& spéculatives; des arts, de l'industrie, de l'agriculture, du commerce, de la navigation, des établissemens, des mines, des inventions \& du génie de ces deux Nations envisagées sous ses différens aspects. Fue editada de nuevo durante las campańas napoleónicas en la Península, como Lettres sur l'Espagne, ou Essai sur les mours, les usages et la littérature de ce royaume par feu La Dixmerie. Précédé d'un Éloge de l'auteur et suivi d'un Précis sur les formes judiciaires de l'Inquisition, par C.P. [Michel de Cubières-Palmézeaux] Augmenté d'une anecdote espagnole [Les Époux amans] et de pièces fugitives, par Mme Fanny de Beauharnais..., París, Librairie économique, 1810, 2 vols. 
habría sido la de servir de curso de literatura española ${ }^{55}$ gracias a la participación de sabios y estudiosos llamados a colaborar a la mayor gloria de su patria. A manera de desagravio de los prejuicios que pesaban sobre su rica cultura, La Dixmerie reclamaba la utilidad de su conocimiento para los franceses,${ }^{56}$ reivindicaba sus aportaciones independizándolas incluso de la prestigiosa Italia ${ }^{57}$ y proponía un ambicioso plan de rehabilitación justificado por el florecimiento científico y literario bajo el patronazgo de Carlos III, dando cabida en sus páginas a todos los géneros y saberes. ${ }^{58} \mathrm{De}$ esta manera, además de composiciones literarias y estudios de costumbres, historia, ciencias y administración general, se extractan artículos y memorias de las academias y fundaciones, se insertan relatos de viajes, pasajes de compendios como la Bibliotheca Arabico-Hispana Escuarialensis de Casiri (Madrid, 1760-1770), de historias literarias como la de los Mohedano, o de antologías como el Parnaso español de Sedano ${ }^{59}$ que publicitan un caudal de textos ilustrando la abundancia de grandes nombres en todos los ámbitos. La redacción procura asimismo destacar fragmentos de comedias que, como un mentís a sus detractores, demuestran su respeto a las reglas del arte, y de igual modo guarda las distancias respecto a autores de esté-

55 «Nous desirons, \& peut-être nos lecteurs le desirent-ils comme nous, que notre ouvrage devienne, indépendamment de ses autres objets, un cours de littérature espagnole \& portugaise» (t. I, p. 13).

56 "Une seule mine nous restait à exploiter, \& il est surprenant que jusqu'ici on ait négligé d'y puiser, \& d'ajouter à tant de trésors acquis, ceux qui peuvent nous enrichir encore. Cette mine presque inconnue jusqu'à nos jours, c'est la Littérature Espagnole; elle étoit bien digne cependant de fixer nos regards \& d'intéresser notre curiosité» (t. I, p. 2).

57 "On vante encore les services que l'Italie a rendu à l'Europe littéraire: elle devint l'asyle des beaux Arts chassés de la Grèce, leur ancienne patrie; mais avant cette époque si glorieuse pour les Italiens, les Espagnols cultivoient ces mêmes arts inconnus chez tant d'autres peuples de la terre, \& oubliés en Italie même» (t. I, p. 2).

58 En su prospecto La Dixmerie declaraba su decisión de apartarse de toda crítica ofensiva y anunciaba la exhaustividad de sus contenidos, aprovisionados en las memorias de las academias españolas y portuguesas, y también en todo tipo de escritos ajenos a esos cuerpos, para mostrar los progresos de los conocimientos y el gusto entre sus vecinos del Sur. El enciclopedismo de temas abordados comprendía un anchuroso y heterogéneo campo de contenidos: «Littérature agréable \& légère, poësies, théâtres, romans, histoire, sciences exactes \& spéculatives, beaux-arts, industrie, agriculture, commerce, navigation, établissemens de toute spèce; en un mot, tout ce qui constitue l'Espagne, sous ces différens aspects, est du ressort de notre entreprise, et sera constamment l'objet de nos recherches» (t. I, pp. 12-13).

59 Parnaso español: colección de poesías escogidas de los más célebres poetas castellanos, Madrid, Joaquín Ibarra y Antonio de Sancha, 1768-78, 9 vols. 
tica tan distante como por ejemplo Quevedo ${ }^{60}$ aún apreciado en la España del XVIII pese a críticas — después más ponderadas- del sector reformista. ${ }^{61}$

Así pues, al calor del cosmopolitismo dieciochesco — difundido después ampliamente por el ascendiente europeo de Rousseau ${ }^{62}$ - y de los deseos de renovación de la literatura francesa que reclaman una mayor información de los avances de las literaturas vecinas, la recepción de la cultura española va venciendo paulatinamente resistencias desde la morosa inclusión de noticias, reseñas y traducciones en la prensa periódica a partir de mediados de la centuria, y se le franquea la entrada a los artículos bibliográficos de diccionarios como el clasicista Dictionnaire

60 Aparte de alguna sátira y un poema suyo (stance), correspondiente a la canción "Oh tú, que, inadvertido, peregrinas», que el redactor titula «La Solitude» (Lettre LVI, p. 197 "O toi! Qui d'un pas chancellant essaies d'atteindre le sommet»), se insertan pasajes traducidos de su novela picaresca El buscón (Lettre LII, pp. 159-169) —entonces conocido en las traducciones francesas como Le Fin Matois, aunque a su juicio su verdadero título debería ser L'Habile Escroc-, por el éxito y prestigio como autor clásico de que goza este autor en España («tour à tour, et souvent à la fois dans un même ouvrage, théologien, philosophe, moraliste, politique, satirique») y por el interés que aún puede despertar su lectura. Sin embargo, el redactor disiente del entusiasmo de sus compatriotas («Placé audessus de tout ce que l'Europe a produit de mieux en ce genre [écrits légers], sans même excepter l'Italie, qui, pourtant, avait déjà produit l'Arioste») y prefiere otras producciones suyas («je dirai plus, c'est que Quévedo exagère lui-même tout ce qu'il veut peindre; qu'en général ses tableaux sont trop chargés; qu'il est quelquefois moins gai que bouffon, moins saillant que burlesque, moins piquant que cynique. Ce qui lui sied le mieux est le ton grave, et surtout le ton grondeur», p. 156). Asimismo, considera la traducción francesa de 1665 en Lyon —a la que se le añadió un opúsculo traducido por La Geneste titulado Lettres du chevalier de l'Epargne (consejos dirigidos a quien desee saber conservar su dinero) que contenía noticias históricas y políticas - superior a la italiana y la flamenca.

61 La Geneste (Le Coureur, París, 1633 y 1644) inauguró la serie de adaptaciones y reescrituras de esta novela al francés que contó con diversos títulos como Le Coureur de nuit, ou l'Aventurier nocturne de Raclot (Ámsterdam y París, 1713), Le Fin matois, ou Histoire du grand Taquin: Lettres du chevalier de l'Épargne de Rétif de la Bretonne y d'Hermilly (Madrid, París, Costard, 1776), edición de la que según Quérard (ob. cit.) quinientos ejemplares llevaron por título, en deuda con los originales españoles (El Buscón, o El gran tacaño del XVIII), L'Aventurier Buscon, ou Histoire du grand Taquin, suivie des Lettres du chevalier de l'Épargne. Finalmente se alude a otra edición de fines del XVIII, Vida del Buscón ou la Vie du Chercheur, seguida de un Traité sur la nature de l'homme con notas históricas de Ch.-F.-M. Mersan (Lyon, 1793).

62 Véanse Ch. Dédéyan (Le Cosmopolitisme européen sous la Révolution et l'Empire, París, Société d'Édition d'Enseignement Supérieur, 1976) o J. Texte (J. J. Rousseau et les origines du cosmopolitisme littéraire, París, 1909). 
$d u$ Théatre, editado durante el Imperio, a colecciones relevantes como Les Archives Littéraires de l'Europe (1804-1808), ${ }^{63}$ de Vanderbourg y De Gérando, precursores del germanismo de Mme de Staël, o a importantes publicaciones como el Journal Général de la Littérature Étrangère. ${ }^{64}$ Editado este por los responsables del Journal Général de la Littérature de France, ofrece una selección —expurgada de toda alusión política en los años de censura napoleónica- de lo más granado y representativo del panorama europeo ${ }^{65}$ a través de "un répertoire raisonné des ouvrages les plus intéressans de la littérature étrangère», cuya finalidad («former, pour ainsi dire, un tableau où l'on puisse saisir d'un coup d'œil l'état général des sciences et de la littérature de chaque nation») será asimismo contemplada en manuales y compendios franceses de la centuria posterior. De este modo, la frecuencia de alusiones a la cultura española, dispuestas al compás de la actualidad literaria y de la pervivencia de la fama de los modelos del Siglo de Oro y su revitalización por los eruditos españoles del XVIII, irá creciendo en las disertaciones, publicaciones periódicas, ensayos y primeros estudios de su literatura en la Francia del XIX, ganados por la investigación historicista y la exaltación de la nacionalidad.

63 R. Mortier, Les "Archives littéraires de l'Europe» (1804-1808) et le cosmopolitisme littéraire sous le premier Empire, Bruselas, Palais des Académies, 1957, especialmente pp. 197-203.

64 Ou Indicateur bibliographique et raisonné des Livres nouveaux en tous genres, Cartes géographiques, Gravures et CEuvres de Musique qui paraissent dans les divers pays étrangers à la France, classés par ordre des matières, avec la notice des objets traités par les sociétés savantes et des prix qui y ont été proposés, les nouvelles découvertes et inventions, la nécrologie des Écrivains et Artistes célèbres de l'Europe, des nouvelles littéraires et bibliographiques, etc., etc. Citamos por el primer volumen (primera parte, meses de vendimiario a ventoso del año IX (1801), París, chez Treuttel et Würtz et Estrasburgo, chez les mêmes librairies).

65 Inserta desde sus primeros números títulos de la actualidad editorial española: por ejemplo, la edición de 1797-98 del Quijote por Pellicer, obras diversas de Pedro de Montengón — sus Odas, traducciones de ocho salmos y de los cánticos de Hababuc, Moisés e Isaías, su poema épico El Rodrigo- - estudios de historia literaria y sobre todo trabajos eruditos como la Biblioteca española de Sempere y Guarinos, o la Historia crítica de España y de la cultura española de Masdeu, traducciones de los clásicos latinos como la de Azara, memorias de la Academia de la Historia, discursos oficiales, informes sobre la administración, comercio e industria españoles. 


\subsection{Las traducciones en la revalorización de la literatura española}

En el sistema de selección, transmisión y promoción de los autores ocupan también un lugar destacado las traducciones, ediciones y posteriormente antologías como puertas de entrada al canon paulatinamente afianzado por el circuito de los estudios universitarios y la prensa periódica, que se apoyan mutuamente y entrecruzan sus argumentos. ${ }^{66}$ Como han dejado bien sentado Delisle o Lefevere entre otros, ${ }^{67}$ entre las funciones de la traducción se cuenta la difusión no solo de un género y sus reescrituras, sino también de una poética y una ideología, al adaptar el texto modelo a un sistema de recepción que arrastra consigo e impone una imagen de esa obra e incluso a menudo, por extensión, de su cultura. Desde este punto de vista práctico y primordial, uno de los problemas más importantes a los que se enfrentan los estudiosos extranjeros de la literatura española en el XIX es la dificultad de acceder a los textos originales, vertidos en su mayoría en adaptaciones, versiones y traducciones más o menos fieles. Con todo, ha de constatarse, sin lugar a dudas, la radical importancia de estos trasvases de lenguas — aún más, de estéticas y usos sociales_, que se manifiesta en las adaptaciones, mutilaciones, troncamientos o desfiguraciones de las obras originales españolas no solo en Francia, ${ }^{68}$ sino también en el proceso de esa doble dirección de influencias. La primacía de este criterio adaptador es

66 Véase L. Romero Tobar, «Las Historias de la literatura y la fabricación del canon», en Cànon literari: ordre i subversió. Edició a cura de Jaume Pont i Josep M. Sala-Valldaura, Lérida, Institut d'Estudis Ilerdencs y Fundació Pública de la Diputació de Lleida, 1998, pp. 47-64; y también su artículo "Regulaciones del canon en el siglo XIX», incluido en La literatura en su historia, Madrid, Arco Libros, 2006, pp. 99-107.

67 J. Delisle y J. Woodsworth (eds. y dirs.), Translators through History, Ámsterdam y Filadelfia, John Benjamins, 1995; o A. Lefevere (Translation/History/Culture. A sourcebook, Londres y Nueva York, Routledge, 1992; Traducción, reescritura y la manipulación del canon literario, Salamanca, Colegio de España, 1997). Véase también, por ejemplo, H. Van Hoof (Histoire de la traduction en Occident. France, Grande-Bretagne, Allemagne, Russie, Pays-Bas, París, Duculot, 1991) para un panorama muy general de su historia en Europa. Además del recorrido de J. F. Ruiz Casanova (Aproximación a una historia de la traducción en España, Madrid, Cátedra, 2000), es de gran utilidad la colección de estudios editados por F. Lafarga y L. Pejenaute (Historia de la traducción en España, Salamanca, Ambos Mundos, 2004).

68 Desde mediados del XVIII y especialmente en el curso del XIX se va ampliando el elenco de traductores franceses de obras españolas. Pageaux se ha referido a los principales que se acercan en la centuria dieciochesca a la literatura española. Horn-Monval ha aludido a las generaciones de traductores del siglo posterior, de entre los que destacan por 
defendida por la mayoría de críticos franceses del Setecientos, desde luego, y aún de principios del siglo siguiente. Sin embargo, la práctica traductora conoce un replanteamiento de sus bases conceptuales especialmente en la segunda mitad del XVIII en Francia, sobre todo por lo que respecta a las novelas, en su mayoría importadas de Inglaterra, y que constituyen un enjundioso mercado editorial. Esta fuerte demanda alienta la aparición de empresas con procedimientos industriales y provoca una división de pareceres respecto a los principios que rigen la traducción. Frente a la minoría que defiende el respeto a la literalidad escrupulosa - Turgot o SaintSimon, por ejemplo-, dominan los que abogan por una interpretación libre del texto, procedente a veces de estéticas diferentes, sometiéndolo al molde francés y ajustándolo, según la capacidad del traductor, a este nuevo lecho de Procusto, por mor de cierta idea del gusto francés, la elegancia de su elocutio y las expectativas estéticas prestigiadas por la doctrina clasicista defendida por la Academia, en las que han sido educados traductores y lectorado - Prévost, Fresnais, d'Alembert, o en menor grado Le Tourneur-. La evaluación habitualmente asumida contempla la transmisión del sentido general de la obra, acomodándolo al gusto del público, e impulsando su divulgación, aun a costa de la desnaturalización inevitable del texto original. No obstante, se irá imponiendo progresivamente una perspectiva más rigurosa y reflexiva sobre este quehacer, al menos en teoría, que, pese a todo, no superará de modo notable hasta la década de 1860 las prácticas de las denostadas «belles infidèles» de siglos precedentes, a la búsqueda de la belleza de estilo y de la amenidad. El buen gusto como criterio mayor aún pauta de modo más o menos subterráneo esta operación mediadora, que procedía, sin embargo, en gran parte mediante los mismos métodos descuidados tan repudiados de viva voz pero ejercidos con similar constancia aún bien entrado el XIX. ${ }^{69}$ Tres son los géneros en particular que los france-

sus repercusiones en el estudio y difusión de las obras traducidas Damas-Hinard, La Beaumelle, Esménard, Germond de Lavigne, A. de Latour, H. Lucas, E. Baret, Cl. Rochet, L. Rouanet o A. Royer - a los que habría que añadir, por ejemplo, otros nombres como J.-G. Magnabal-, además de un creciente contingente de adaptadores más o menos conocidos que en su mayoría no siempre suscitan la aquiescencia de los escritores españoles traducidos.

69 A este propósito véanse, por ejemplo, G. Mounin (Les Belles Infidèles, París, Cahiers du Sud, 1955) y también el recordatorio de J. Lambert, «La traduction en France à l'époque romantique, à propos d'un article récent [de J. A. Béreaud]", Revue d'Histoire Littéraire de la France, 1975, pp. 396-412. 
ses asimilan a la producción española, el teatro, la novela y los romances, a imagen de un mundo caballeresco, cuya ética y estética barroca triunfan antes de diluirse o escamotearse con la férrea y duradera imposición del clasicismo desde la segunda mitad del XVII. Y estos son — pues sus colecciones poéticas fueron menos difundidas en el extranjero, como recuerda Tannenberg al señalar la escasa deuda de la poesía moderna con la influencia española- los que concitarán también una atención privilegiada en los estudios y recreaciones decimonónicos sobre esta literatura y abrirán nuevas vías $^{70}$ de renovación poética en Francia desde fines de la centuria precedente.

\subsubsection{El teatro}

Los dos proyectos traductores ${ }^{71}$ en el siglo XVIII de más relevancia y mayores consecuencias fueron la antología de Du Perron de Caste$\mathrm{ra}^{72}$ en 1738 , cuyo discurso preliminar sobre la inferioridad de la tragedia española suscitó las réplicas de $\mathrm{Nasarre}^{73}$ y de Montiano y Lu-

70 Cabe señalar asimismo que, ya entrado el siglo XIX, cuando los estudios de literaturas extranjeras se hallan más asentados y los grandes autores reconocidos cuentan con varias versiones, la empresa traductora se ve impelida a rescatar y promover autores menos conocidos que no siempre despiertan el favor de los críticos.

71 Entre los numerosos traductores de este siglo señalados por Horn-Monval (ob. cit.) y sobre todo por Pageaux (ob. cit.), es bien conocida la fama de Lesage, en particular por su Gil Blas de Santillana, y también como adaptador de novelas picarescas y de piezas teatrales españolas (Théâtre espagnol, ou les meilleures comédies des plus fameux auteurs espagnols, París, J.-Ch. Rémy, 1700, y ediciones posteriores); y asimismo de Calderón (Cela va de mal en pis (o D. César Urbin), de Rojas Zorrilla (La trahison cherche le châtiment, Le Trầtre puni), y de Lope (Garder et se garder o Don Félix de Mendoce, Il n'y a point d'ami, Le Point d'honneur, en Recueil des pièces mises au théatre françois par M. ..., París, J. Barois fils, 1739).

72 Extraits de plusieurs pièces de théâtre espagnol; avec des réflexions, et la traduction des endroits les plus remarquables, París, chez Vve Pissot, 1738, 2 t. Comprendía principalmente extractos de obras lopescas: L'Amitié récompensée (La amistad pagada), Les Castelvines et les Monteses (Castelvines y Monteses), Les Plaisanteries de Matico (Los donaires de Matico), Urson et Valentin (Ursón y Valentín), Les Mariés d'Hornachuelos (Los novios de Hornachuelos), Le Pythagore moderne (El nuevo Pitágoras), Le Roi Wamba (Vida y muerte del rey Wamba), La Pauvreté de Renaud de Montauban (Las pobrezas de Reinaldo); y pasajes de dos entremeses: Le Père trompé (El padre engañado) y Le Triomphe de la vertu (El triunfo de la virtud).

73 Comedias y entremeses de Miguel de Cervantes [...] con una disertación o prólogo sobre las comedias de España..., Madrid, 1749, 2 vols. 
yando, ${ }^{74}$ y las adaptaciones de Linguet $^{75}$ en 1768 (Théâtre espagnol, París, de Hansy, 4 vols en $12 .^{\circ}$ ) que difundieron quince comedias y cinco entremeses (intermèdes). ${ }^{76}$ La propuesta de Linguet - contemporánea de las reescrituras de Shakespeare por Le Tourneur y Ducis, y de las demandas de renacimiento teatral de $\mathrm{Mercier}^{77}$ —, con mayor calado que la de Du Perron, se atenía también a un repertorio de obras escogidas y arregladas al gusto francés. Su recopilación comprendía piezas de diversos ingenios españoles del Siglo de Oro ${ }^{78}$ de entre los que sobresalía la selección calderoniana. ${ }^{79}$ En el prólogo el antólogo justificaba su iniciativa por la importancia, mayor que para cualquier otra nación, de este teatro en la literatura francesa, y ofrecía ese repertorio como un modelo inspirador - una de las constantes en la atención francesa hacia las literaturas ajenas- a fin de renovar su fatigada escena. ${ }^{80}$

74 Discurso sobre las tragedias españolas, acompañado de sus dos tragedias Virginia y Ataúlfo (Madrid, 1750-53).

75 Devérité (Quérard, ob. cit., t. III, p. 544) trata de Linguet (Reims, 1736-París, 1794), inmerso en las polémicas del mundo literario del XVIII, en varios escritos (Notice pour servir à l'histoire de la vie et des écrits de S. N. H. Linguet, nouvelle édition corrigée et augmentée, 1782 (1. ${ }^{a}$ ed., 1781), o los folletos de 1790 «Qu'est-ce que Linguet?» y "Qu' estce que ce train-là, pour servir de suite à Qu'est-ce que Linguet».

76 Horn-Monval, ob. cit. Los entremeses elegidos fueron Intermède des Melons et de la femme têtue (E. del Melonar y la respondona), Les Beignets (E. de los buñuelos), I. du Malade imaginaire (E. de Juan Rana Comilón), I. de la Relique (E. de la reliquia), I. de l'Écolier magicien (E. de la Cueva de Salamanca). Los entremeses barrocos serán objeto de una nueva traducción en 1897 (Intermèdes espagnols du XVII) a cargo de Léo Rouanet.

77 Nouvel Essai sur l'Art dramatique y Examen de la Tragédie Française (1773-78). Mercier indica pronto nuevas vías como la recreación de la historia nacional y contemporánea, o los modelos extranjeros como Shakespeare, Calderón, Lope, Schiller.

78 De Lope tomó tres comedias: La Constance à l'épreuve (La esclava de su galán), Le Précepteur supposé (El dómine Lucas), Les Vapeurs ou la Fille délicate (Los melindres de Belisa; otras tres de Moreto: La Chose impossible (No puede ser guardar una mujer), La Ressemblance (El parecido en la corte) y L'occasion fait le larron (La ocasión hace al ladrón); una de Solís: Le Fou incommode (Un bobo hace ciento), otra de Bances Candamo: La Fidélité difficile (El duelo contra su dama) y una más de Matos Fragoso: Le Sage dans sa retraite (El sabio en su retiro y villano en su rincón, Juan Labrador).

79 Il y a du mieux (Mejor está que estaba), Le Viol puni (El alcalde de Zalamea), La Cloison (El escondido y la tapada), Se défier des apparences (Nunca lo peor es cierto), La Journée difficile (Los empeños de seis horas) — que se le atribuía entonces_- y On ne badine point avec l'amour (No hay burlas con el amor).

80 Algunos autores de la época escribieron piezas menores inspiradas en temas y situaciones de su selección calderoniana. Por ejemplo, Collot d'Herbois hizo representar en 1779 la comedia Le Paysan magistrat, de cinco actos en prosa, basada en El alcalde de Zala- 
En su momento la acogida en Francia a esta empresa traductora no fue, en general, del todo hostil, como demuestran las reseñas francesas recopiladas en la Bibliographie Parisienne ${ }^{81}$ que coinciden, en su mayoría, en celebrar la utilidad y la oportunidad de la colección impresa - destinada principalmente a la lectura y no a la representación — para servir de acicate creativo. ${ }^{82}$ Bien es verdad que las censuras de rigor - licen-

mea — una de las obras calderonianas más adaptadas en Francia-, editada en 1780 dentro de la colección de sus obras dramáticas, y registrada como adaptación en 1790; o A. J. Dumaniant con Beaucoup de bruit pour rien, comedia en tres actos en prosa, estrenada en 1793. Quérard (ob. cit., t. III, p. 71) menciona otra comedia en tres actos en verso libre, "mêlés d'ariettes» (Isabelle et Fernand, ou L'Alcade de Zalaméa, París, Prault, Brunet, 1784) de Faur, que adapta el drama de honor al molde de la comedia sentimental. Véase también K. van Bragt (ob. cit.). Brenner (ob. cit., entrada 5922) apunta otro drama del conde de Dufort de Cheverny, L'Alcalde de Zalamea en cinco actos en prosa, representado en casa del autor (Madrid y París, Robin, 1778), adaptado de la obra calderoniana. Sobre la acogida dispensada en Francia y el resto de Europa a Calderón véanse también A. M. Martín («Ensayo bibliográfico sobre las ediciones, traducciones y estudios de Calderón de la Barca, en Francia», Bulletin Hispanique, n. ${ }^{\circ} 32-33$, t. XVIII, pp. 53-100); M. Franzbach (El teatro de Calderón en Europa, Madrid, Fundación Universitaria Española, 1982); o J. Fradejas Lebrero (Calderón en Europa, Madrid, Aula de Cultura, n. ${ }^{\circ}$ 14, 1991). Entre la copiosa bibliografía sobre las implicaciones de su obra en su contexto histórico, analizada desde diversos flancos, artístico, filosófico, jurídico, social, retórico, literario, espectacular, cultural en suma, y su recepción en Occidente, remitimos al vasto estudio de A. Regalado (Calderón. Los orígenes de la modernidad en la España del Siglo de Oro, Barcelona, Destino, 1995, 2 vols.).

81 Elaborada, según consta en el privilegio de impresión, por Dellepierre de NeuveÉglise, su título completo es «Bibliographie Parisienne, / ou / Catalogue d'ouvrages / De Sciences, de Littérature, et de tout ce qui concerne les Beaux Arts, tels que la Musique, la Gravure, etc. imprimés ou vendus à Paris. / Avec / les Jugements qui en ont été portés dans les Écrits périodiques, ensemble l'énoncé des Édits, Arrêts et Déclarations du Roi, etc. etc. etc. etc. / Par une Société de Gens de Lettres. / Année 1770 / Dissociata locis concordia pace ligavit. Ovide, Metam. L.I. / Tome Premier / À Paris, / Chez Desnos, Libraire, Ingénieur-Géographe du Roi de Dannemark, rue S. Jacques, au Globe. / Avec Approbation \& Privilège du Roi». Las citas extraídas figuran entre las páginas 148-151.

82 Si bien el Journal des Beaux Arts (septiembre, t. 3, p. 317) se limita a consignar la publicación recomendando su lectura a las nuevas generaciones, y el Mercure de Fran$c e$ se extiende en encarecimientos generales («Les Espagnols trouveront dans cette traduction l'hommage qu'ils ont droit d'attendre de notre reconnaissance. Le traducteur rend un grand service aux jeunes Auteurs auxquels il procure un champ vaste pour recueillir de riches moissons. Ce Théâtre mérite d'être placé à la suite du Théâtre des Grecs du P. Brumoi \& du Théâtre Anglois de M. de la Place», abril, t. I, pp. 75-82); por su parte, los Affiches ("Annonces et Avis divers», octubre de 1770, n. ${ }^{\circ} 43$, p. 172, col. I), tras haber escatimado en un primer momento las deudas del teatro francés con el español del XVII frente al prestigio de los italianos y desde luego de los antiguos clásicos, y aun echando en falta el género trágico — ausencia que se achaca, bien a la selección del 
cias morales, inverosimilitudes, desaliño y cierto forzamiento en los desenlaces, la complicación extrema de sus tramas, que tachan como sus herederos decimonónicos de "romans dialogués», y su hibridismo genérico, distante del modelo teatral canónico ${ }^{83}$-, aun templadas, sin embargo, por el reconocimiento en diversos pasajes de una belleza poética, en ocasiones deslumbrante, de caracteres admirables, situaciones cómicas y escenas logradas, ${ }^{84}$ concuerdan con la imperiosa necesidad de adaptar las obras extranjeras a la idiosincrasia francesa y a la estética clásica dominante, sometida asimismo a la presión del decoro y las normas sobre el género dramático en razón de su carácter público. Con todo, ya afloran comentarios más receptivos de un clasicismo menos rígido como la aprobación a la finalidad de esta selección representativa de modelos aprovechables en los Affiches o el Journal Encyclopédique, que echa de menos un repertorio más amplio y dedica mayores alabanzas también a la materia seleccionada - los entremeses, más ingeniosos que las farsas francesas, y alguna de las obras de Calderón (Se défier des apparences) ${ }^{85}$

traductor, bien a la mezcla de géneros en el teatro español-, vuelve sobre sus pasos y aplaude los beneficios de esta tentativa a fin de dar una selección representativa de las mejores obras españolas y su carácter nacional («L'objet de M. Linguet n’étoit point de donner un Recueil volumineux des Comédies Espagnoles, qui nous seroit sans doute inutile; mais de faire un choix des meilleures, tant pour faire connoître en France le génie national de nos voisins en ce genre, que pour nous présenter des modèles, non à copier servilement, froidement, ou à défigurer comme a fait Scarron; mais propres à nous faire penser, à exciter l'imagination de nos stériles Dramatiques, qui n'inventent rien, \& qui ne font plus que se traîner, tous sur les pas les uns des autres, dans un cercle étroit, audelà duquel il ne voyent rien. M. Linguet n'a point ici mêlé de Tragédies Espagnoles, parce qu'il n'en reconnoît presque point, ou qu'elles sont trop peu distinguées des autres Drames», noviembre, n. ${ }^{\circ} 45$, col. I, p. 180).

83 «M. Linguet ne manque point de talents nécessaires pour faire une bonne Traduction; c'est un Théâtre à traduire, qui lui a manqué; des Romans dialogués ne sont pas un Théâtre» (La Porte-Feuille Hebdomadaire, noviembre, t. 3, n. ${ }^{\circ} 45$, p. 294).

84 "Il n'y a point de Comédie dans ce nouveau Recueil, qui n’offre des beautés, \& même des étincelles de génie; mais la scène française n'en supporteroit pas une seule sans beaucoup de changements \& de corrections. Les intrigues en sont, en général, trop compliquées, les mœurs peu décentes, les événements souvent invraisemblables, les denouëments toujours précipités. On y trouve de beaux caractères, des situations comiques, des traits intéressants, des scènes heureuses. Divisées en journées, elles forment de vrais Romans ou des Contes mis en action» (ib., col. I, n. ${ }^{\circ}$ 6, p. 47).

85 «La Pièce de Don Pedro de Calderon de la Barca, qui a pour titre \& pour but se défier des apparences, est conduite avec beaucoup d'art, \& quoique Comédie d'intrigue, les caractères en sont très-bons et bien soutenus» (ib., julio, t. 5, parte I, pp. 68 y 82). 
por su regularidad, maestría en el plan y desarrollo de los caracteres, y de Moreto (La Chose impossible), ${ }^{86}$ no tanto ciertamente por el planteamiento de su intriga como por su comicidad y por cierta comunidad de tratamiento con el canonizado Molière.

Veinte años más tarde, La Harpe (1739-1803), abanderado de un neoclasicismo militante, nombra en su Lycée, ou Cours de littérature ancienne et moderne (París, chez H. Agasse, an VII [1799]) ${ }^{87}$ a varios autores españoles, siempre relegados a menciones accesorias: Cervantes; los dramaturgos barrocos, subordinados a su papel de proveedores de la materia teatral —Lopez (sic) de Vega, Calderón, Diamante, recordado por Voltaire, Guillén de Castro, Roxas (Rojas Zorrilla), fuente de la tragedia Venceslas de Rotrou-; y un único contemporáneo, el ilustrado Olavide, famoso reo de la Inquisición aludido en el poema de Roucher Les Mois. Detractor del antienciclopedista Fréron y rendido admirador de Voltaire, el académico La Harpe se erige en portavoz del gusto, el ideal absoluto de belleza, la religión y la moral en estos discursos, fruto del curso público pronunciado en 1797 tras su conversión por su terrible experiencia revolucionaria. La autoridad de esta obra normativa cuya periodización asume la visión clasicista — que muestra, por otra parte, los primeros signos de especificidad literaria- ${ }^{88}$ y preconiza la universalidad de un inmutable canon clásico se prolonga a principios de siglo hasta la imposición definitiva del relativismo romántico en textos diversos, como, por ejemplo, antologías francesas de modelos retóricos o manuales de

86 «On a pu reconnoître dans la Pièce intitulée La chose impossible de Don Augustin Moret [sic], moins habile que Lopès de Vega \& Calderon dans l'art d'intriguer sa fable, mais non moins comique ni moins gaie, quelques traits de l'École des Femmes, \& mème de l'École des Maris de Molière. Mais quelle différence pour la conduite \& la manière?" (ib., parte 2, pp. 221, 222, 236). Con todo, la comedia de Antonio de Solís, autor cuya obra histórica y dramática es igualmente apreciada en el siglo XIX, plantea más reparos por su intrincada acción frente a la sencillez de la pieza de Matos Fragoso.

87 El ejemplar consultado, perteneciente en origen a la biblioteca del conde de Toreno, data de 1834 (Lycée ou Cours de littérature ancienne et moderne, París, Didier, 2 vols.).

88 Como indica en el prefacio, «mais c'est bien ici, je crois, la première fois, soit en France, soit même en Europe, qu'on offre au public une histoire raisonnée de tous les arts de l'esprit et de l'imagination, depuis Homère jusqu'à nos jours qui n'exclut que les sciences exactes et les sciences physiques». Los géneros que admite en su revisión abarcan la poesía, la elocuencia, la historia, la filosofía y la «littérature mêlée». 
educación. ${ }^{89}$ En la primera parte La Harpe se demora en los maestros de la Antigüedad con ejemplos modélicos de autores bíblicos, griegos y latinos, en torno a los grandes hitos concentrados en la época de un gran gobernante, que sellan el relevo cultural desde los antiguos hasta el esplendor francés del XVII. De este modo, en lugar de un decurso histórico evolutivo el recorrido se limita a los jalones de los sucesivos renacimientos desde el siglo de Pericles y la edad de oro del primer emperador romano hasta, silenciada la denigrada Edad Media, el tiempo de los Médicis italianos y de los franceses Francisco I y su sucesor Borbón - Luis XIV, que da nombre a su siglo, sancionado por Voltaire como la época cumbre que entronca con la excelencia del siglo de Augusto-, y finalmente la contemporaneidad francesa del XVIII.

No obstante, el género dramático en España, insumiso a las normas clásicas, también habría logrado a veces felices resultados. Las breves explicaciones de Laharpe repiten argumentos consabidos en torno a un exotismo más o menos doméstico de un Oriente cercano ${ }^{90}$ y a la condición híbrida del drama español como novela dialogada. ${ }^{91}$ Si bien reconoce que en la Francia del XVII la comedia conservó hasta Molière la hinchazón retórica española y la afectación italiana, subraya la mejora de sus modelos gracias al estilo, elocución y disposición de la retórica francesa. Ambos autores representativos, Lope y Calderón, poseen una rica capacidad inventiva,

89 Le Lycée es una de las fuentes confesas - junto a ponderados estudios como el Traité des études de Rollin, el Cours de Le Batteux, o Trois siècles de la littérature française ou Tableau de l'esprit de nos écrivains depuis François I (Ámsterdam, París, 1772) - del exitoso Cours de littérature ancienne et moderne à l'usage des jeunes demoiselles de la condesa Joséphine de Beaufort-d'Hautpoul, que extracta de ellos pasajes enteros (2. ${ }^{a}$ edición, revisada y aumentada con un volumen más dedicado a la literatura extranjera. París, Bossange et Masson; Londres, Bossange et M. et Leblanc, 1815). Este manual de educación social de las jóvenes de la aristocracia y la alta burguesía, limitado a principios básicos contenidos en el decoro de su sexo, se incardina en la prestigiosa tradición del salón y la conversación francesa que constituyó un triunfo de los Modernos como formadora del gusto de los jóvenes bajo la iniciativa de nobles egerias. (A este respecto véase Marc Fumaroli, "La conversation", en Trois institutions littéraires, París, Gallimard, 1994, pp. 111-210).

90 "L'Espagne, qui tenoit des Maures sa galanterie chevaleresque, ses tournois, ses poésies, son tour oriental et ses romances, eut alors son Lope de Véga, et depuis son Caldéron, qui montrèrent de l'élévation, de la fécondité, et un génie théâtral».

91 «La comédie [...] d'Espagne, n'étoit qu'une espèce de roman dialogué, une suite d'incidens sans vraisemblance et sans décence; elle n'étoit que ce qu'on appelle encore aujourd'hui imbroglio, et régna aussi jusqu'à Molière». 
dominio de la retórica, prodigalidad y cierto genio teatral. Pese a que sus incontables dramas se hallan despojados de las enseñanzas del arte y del sentido común (bon sens), «il y a des situations, des effets, des caractères même» de los que carecieron los mejores trágicos franceses contemporáneos de estos autores, anteriores a Corneille y Racine — naturalmente, la verdadera cima del arte para La Harpe- - Aun siendo Lope más aludido, La Harpe no omite ciertos parabienes hacia Calderón al referir (tomo I, p. 430) que, si bien su poesía dramática no tiene una forma regular ni bien ajustada, a veces alcanza cotas de calidad elevadas. Tempranamente coteja a ambos dramaturgos con el redescubierto Shakespeare, parangón entre representantes de dos teatros nacionales llamado a sucederse en el siglo posterior. Si el dramaturgo inglés comparte con los primeros las mismas bellezas y defectos, los sobrepasa a su juicio en talento natural («quelquefois élevé jusqu’au sublime des pensées, à l'éloquence des passions fortes, à l'énergie des caractères tragiques»), ${ }^{92}$ preferencia anglófila que perdura en Mme de Staël, los redactores del prestigioso Le Globe y numerosos estudiosos y docentes de literaturas extranjeras, más avezados en la inglesa que en la española durante buena parte del XIX.

Además de difundir las obras foráneas, desde principios de este siglo la creciente actividad traductora sigue proponiendo, sin renunciar en el fondo al viejo criterio dieciochesco del gusto y la amenidad — aparte de la diversa competencia lingüística de sus traductores_,,${ }^{93}$ nuevos cauces

92 De cualquier modo, pese a sus destellos de genio, don cuya precedencia sobre el gusto y los principios concede el crítico conforme a predecesores como Boileau, Shakespeare no constituye para La Harpe un representante del arte universal, sino que se circunscribe exclusivamente a los prejuicios de su nación. De este modo, epítome de un sistema rebelde a las reglas, solo puede ofrecer a ojos del crítico francés escasos pasajes cuya calidad, aun siendo superior a menudo a la de su siglo, sea digna de la atemporalidad de las tragedias francesas.

93 Aún en la segunda mitad de siglo, no son infrecuentes las quejas de los escritores españoles contemporáneos a las licencias de la mayor parte de sus adaptadores franceses. Por ejemplo, las protestas de Fernán Caballero en sus cartas a su amigo A. de Latour (A. Morel-Fatio, "Fernán Caballero d'après sa correspondance avec Antoine de Latour", Bulletin Hispanique, t. III, 1901, pp. 252-294) o el humor resignado de Valera en su correspondencia (por ejemplo, Epistolario de Valera y Menéndez Pelayo 1877-1905, Madrid, Espasa-Calpe, 1946. Citamos por las referencias señaladas por R. Pageard, «Pepita Jiménez en France», Bulletin Hispanique, en.-jun. 1961, pp. 28-37). Para una consulta más detallada del parecer del último escritor sobre estos aspectos véase también el t. III de entre los hasta ahora publicados de su Correspondencia, ed. de L. Romero Tobar, Á. Ezama Gil, E. Serrano Asenjo, Madrid, Castalia, 2002-2005. 
literarios adaptables a la práctica literaria francesa entonces en proceso de renovación. Inmersos en un floreciente mercado abierto a esas novedades y sustentado en una clase burguesa estable, hombres de letras profesionales, excombatientes, periodistas o abogados se vuelcan en la traslación de las obras y autores que las historias literarias comienzan a sancionar, e introducen otros menos frecuentados. Si bien la tendencia mayoritaria en esta centuria respecto al teatro español prefirió una difusión encaminada a la lectura, hubo alguna iniciativa minoritaria - no siempre con felices críticas_- ${ }^{94}$ para su representación en las tablas, como las adaptaciones en verso de la dramaturgia áurea, estrenadas en el París de los años cuarenta por Hippolyte Lucas, ${ }^{95}$ un antiguo asiduo al Cénacle del Arsenal y colaborador de Le Globe. Sus versiones de Lope, ${ }^{96}$

94 Por ejemplo, la «Revue dramatique» de la Revue de Paris (19-XI-1844) firmada por M. Y., que deploraba la moda de traducciones y pastiches que entran a saco en cualquier período, se mostró parca y circunspecta ante su Tisserand de Ségovie por su osadía al medirse con los grandes autores de las literaturas extranjeras («Nous croyons, pour notre part, que M. Lucas est vis-à-vis d'Alarcon un peu dans la même situation que Ducis est vis-à-vis de Shakespeare»).

95 Lucas recogió en volumen varios de estos dramas, piezas en un acto y óperas en colaboración, publicadas primero en las colecciones teatrales de la época. Su edición Théâtre espagnol (París, M. Lévy, 1851) comprendía L'Hameçon de Phénice de Lope, Le Médecin de son honneur de Calderón, Le Tisserand de Ségovie alarconiano, Diable ou femme tomado de La dama duende calderoniana - comedia en un acto en verso estrenada en el Théâtre Français el 12-XII-1846 y publicada en el Journal du dimanche (1846 y 1847)—, Le Collier du roi (García del Castañar) de Rojas Zorrilla — adaptación propiciada por la gira de la compañía de Juan Lombía en 1847-, Rachel ou la belle juive, La Jeunesse du Cid a partir de Guillén de Castro — comedia con música de Bazzoni, representada en el Odeón el 8-IX-1849- Asimismo, recopiló varias obras inspiradas en el ciclo cidiano en su libro Documents relatifs à l'histoire du Cid (París, Alvares, 1860). Su comedia Celui qui honore son père se basa en la obra El honrador de su padre, de Diamante, autor que le suministra la materia de su Cid, impresa en 1846 en el feuilleton del Moniteur (números 16, 20, 25 y 30, de enero de 1846) y editada el mismo año (París, Boulé).

96 El anzuelo de Fenisa, tan apreciada en el XVIII y en el XIX — por ejemplo, era muy elogiada por Lista (Lecciones de Literatura Española, Madrid, Imprenta de Nicolás Arias, 1836) y fue difundida principalmente gracias a la refundición de Trigueros_-, dio lugar a L'Hameçon de Phénice, comedia en un acto estrenada en el Théâtre Français el 11-V-1843; La Estrella de Sevilla, que entonces se le atribuía, propició una ópera en cuatro actos con música de Balfe, L'Étoile de Séville, estrenada en la Opéra. Académie Royale de Musique, el 15-XII-1845 y publicada el mismo año (París, Vve Jonas); asimismo, La judía de Toledo, junto al romancero y Diamante, se amalgaman en Rachel ou la Belle Juive, drama histórico en tres actos en verso, estrenado en el Odéon el 17-II-1849 y publicada el mismo año (París, M. Lévy), y El castigo sin venganza inspiró su drama inédito en tres actos, publicado póstumamente por su hijo Léo Lucas en 1896 (Vannes, Libr. Lajolye). 
Calderón, Alarcón, ${ }^{97}$ Rojas Zorrilla, Guillén de Castro y Diamante pagaron tributo, no obstante, a la arraigada tradición clasicista francesa. ${ }^{98}$ Aun cuando se vertieron al francés ciertas obras de dramaturgos españoles de fines del XVIII - Moratín sobre todo-y esporádicamente de la contemporaneidad decimonónica - Martínez de la Rosa y Gorostiza principalmente, alguna obra aislada de Quintana, Bretón, Gutiérrez Alba y Ramón de Navarrete, Rodríguez Rubí, Zorrilla, Echegaray, por ejemplo, o un apreciado Tamayo y Baus a fines de siglo-, fue el teatro barroco el que despertó un mayor interés a lo largo de esta centuria. ${ }^{99}$ Entre las ediciones célebres de mayor difusión en el siglo XIX destaca la Collection des chefs-d'euvre des théatres étrangers (París, Ladvocat, 18221827), ${ }^{100}$ de cuyos veinticinco volúmenes, cinco están dedicados a autores españoles. ${ }^{101}$ Asimismo son de destacar también el Répertoire des théâtres étrangers (París, Brissot-Thivards, 1822), el segundo volumen del

97 Representado en el Théâtre-Français el 4 de noviembre de 1844 Le Tisserand de Ségovie, drama en tres actos y en verso, fue editado en la colección dramática La France dramatique au dix-neuvième siècle, choix de pièces modernes, París, C. Tresse, éditeur de la France Dramatique, Perrin, libraire, 1845. En la hoja final se inserta, sin indicar la fuente, un pasaje elogioso de un periódico que contrasta con las críticas de otras reseñas.

98 Esta actitud comprometida entre la tradición francesa y el modelo español se manifiesta especialmente en su versión del Collier $d u$ roi, a partir de la tan valorada en el Romanticismo Del rey abajo ninguno, o García del Castañar de Rojas Zorrilla. Su adaptación escénica en tres actos conserva los caracteres principales, situaciones audaces y cierta mezcla de tonos, comicidad y dramatismo en su reivindicación del género tragicómico, acatando, no obstante, tras las innovaciones románticas las tres reglas estructurales del teatro clásico francés. Véase M. ${ }^{a}$ R. Álvarez Rubio ( Reescrituras del teatro clásico español representadas en la Francia del siglo XIX: Le Collier du Roi de Hippolyte Lucas», en Actas del XIII Congreso Internacional Intertexto y Polifonia de la Asociación de Profesores de Francés de la Universidad Española (APFUE), Oviedo).

99 Véanse principalmente los estudios citados de Horn-Monval y Bragt, así como de Vauchelle-Haquet, Les ouvrages en langue espagnole publiés en France entre 1814 et 1833 (présentation et catalogue). Préface de Gérard Dufour, Aix-en-Provence, Publications de l'Université de Provence, 1985; y Les ouvrages en langue espagnole publiés en France: au temps de la première guerre carliste 1834-1840 (présentation et catalogue), Aix-en-Provence, Publications de l'Université de Provence, 2003.

100 El ambicioso título continuaba enumerando las literaturas de origen: allemand, anglais, chinois, espagnol, hollandais, indien, italien, polonais, portugais, russe, suédois, traduits en français. Hubo reediciones en 1827 (París, Rapilly), una selección en 1829 (Théatre espagnol (Choix de pièces) Chefs d'ceuvre des théatres étrangers, París, Dufey) y en la segunda mitad del siglo.

101 Torres Naharro, Guillén de Castro, Lope y Calderón por Labeaumelle, Cervantes por Esménard, y Moratín por R.-Th. Chatelain. 
Théâtre européen. Nouvelle collection des chefs-d'euvre des théatres allemand, anglais, espagnol, italien (París, É. Guérin, 1835), dirigido por Amédée Pichot, la antología de Damas-Hinard Chefs-d'eeuvre du théâtre espagnol ${ }^{102}$ en la década siguiente, o en la segunda mitad de siglo —al margen de las versiones de piezas sueltas de los principales autores-, las selecciones, por ejemplo, de Alphonse Royer, ${ }^{103}$ de Antoine de Latour, ${ }^{104}$ de Eugène Baret, ${ }^{105}$ de Charles Habeneck, ${ }^{106}$ de A. Fée, ${ }^{107}$ de Germonde de Lavigne, ${ }^{108}$ de Léo Rouanet, ${ }^{109}$ de L. Dubois y F. Oroz, ${ }^{110}$ o de Clément Rochel. ${ }^{111}$

102 París, Ch. Gosselin, 1841-44. A partir de 1850 (Charpentier) contó con nuevas ediciones en los años posteriores (1861-62, 1869 y 1881). En los dos volúmenes dedicados en 1842 a Lope rompe una lanza en su favor sobre un Calderón traducido en tres de los volúmenes de la colección. El Grand Larousse Universel du XIX siècle, pese a ciertas discrepancias respecto a la biografía del dramaturgo, recurre a su prefacio en su artículo sobre Lope de Vega, además de al censo de Cayetano Alberto de la Barrera (Catálogo bibliográfico y biográfico del teatro antiguo español, Madrid, 1860), y, tras reconocer como la mejor edición de sus obras autentificadas la de Rivadeneyra, alaba la traducción de DamasHinard de sus mejores comedias junto a la selección de la Bibliothèque étrangère DramardBaudry, y el estudio de Ernest Lafond (Étude sur Lope de Vega, 1859), que también trasladó alguna al francés entre sus numerosos análisis.

103 Théatre de M. Cervantes, París, chez Michel Lévy, 1862, a partir de la edición de Nasarre (1749), basado en la de Villarroel (1615); de Tirso (Théâtre de Tirso de Molina, traduit pour la première fois de l'espagnol en français par .... París, Michel Lévy, 1863); y de Alarcón (Théâtre d'Alarcón, traduit pour la première fois..., París, Michel Lévy, 1865).

104 Euvres dramatiques de Calderon, París, Didier, 1871-73.

105 Euvres dramatiques de Lopez [sic] de Vega, ouvrage couronné par l'Académie française, París, Didier, 1869-70.

106 Chefs-d'cuvre du théâtre espagnol, París, Hetzel; Claye, 1862 y 1867.

107 Études sur l'ancien théâtre espagnol, París, Libr. Firmin-Didot fr., fils et Cie, 1873.

108 La Comédie espagnole (París, 1883), que comprende pasos y entremeses.

109 Drames religieux de Calderon (Les Cheveux d'Absalon, La Vierge du Sagrario, Le Purgatoire de St. Patrice), traduits et annotés, París, 1898. Este estudioso de la literatura española y su cultura recopiló abundante documentación de sus bibliotecas en sus viajes a España, que publicó posteriormente en diversos trabajos en colaboración —como Le théâtre espagnol con Morel-Fatio en 1900- o solo, en torno a los dramas calderonianos, la edición de piezas teatrales del XVI de la Biblioteca Nacional de Madrid, desde composiciones religiosas, clasificadas en bíblicas, hagiográficas y alegóricas, a coloquios, imitaciones a lo divino y farsas - por ejemplo, su Colección de autos, farsas y coloquios del siglo XVI (Barcelona y Madrid, Biblioteca Hispánica, 1901)_, o canciones populares, sin tampoco desatender a algunos contemporáneos como Ganivet, abordado también en la Revue Hispanique (1898).

110 Pièces choisies du Théâtre espagnol, París, Garnier, 1899.

111 Rayando ya el siglo XX, Les Chefs-d'ouvre du théâtre espagnol ancien et moderne, París, Garnier, s.f. 


\subsubsection{La novela}

Desde el siglo XVII la literatura española también encarnaba la exaltación caballeresca y la galantería amorosa, y comenzaba a ser considerada el feudo privilegiado de la imaginación, una de las facultades bien valoradas en el Siglo de las Luces antes de su exaltación romántica. Mantendrán su prestigio y evocación inspiradora hasta entrado el XIX producciones del Siglo de Oro frecuentadas por el lectorado, como la novela de caballerías y el género de aventuras bajo el patronazgo del Amadis emblemático - Le Beau Ténébreux tan apreciado desde el XVI en la versión de Herbery des Essarts, sustituida en la estima general por el exitoso pastiche del conde de Tressan en el XVIII-; el Quijote en sus diversas traducciones, ${ }^{112}$ entre las que destaca la muy difundida de Filleau de Saint-Martin, desbancada decididamente en la década de 1840 por la de Viardot, preeminente aun tras la de Biart de 1877; la narrativa morisca ${ }^{113}$ de las Guerras civiles de Granada (1595) de Ginés Pérez de Hita, que a su vez había insertado diversos romances; o la picaresca —entonces llamada novela de costumbres (mours) o del gusto picaresco según el marbete español más reiterado en las historias $\mathrm{y}$ estudios franceses-. Incluida esta entre los «romans comiques» ${ }^{114}$

112 Sobre su recepción en Francia véanse especialmente M. Bardon ("Don Quichotte» en France au XVII et au XVIII siècle. 1605-1815, París, Librairie ancienne Honoré Champion, 1931. Reedición en Ginebra, Slatkine, 1974); M. H. Neumann («Cervantes in Frankreich (1592-1910)», Revue Hispanique, LXXVIII, 1930, pp. 1-309) o también E. J. Crooks ("Translations of Cervantes into French", en Cervantes across the centuries, Nueva York, 1947).

113 Véanse, por ejemplo, Cazenave, "Le roman hispano-mauresque en France», Revue Littéraire Comparée, V, 1925, pp. 594-640; M. A. Chaplyn, Le roman mauresque en France, de Zayde au Dernier Abencérage, Nemours, 1928.

114 Véase A. A. Parker, Los picaros en la literatura. La novela picaresca en España y Europa (1599-1753), Madrid, Gredos, 1971. Bajo este anchuroso marbete, del que no diferenciarían cumplidamente las «novelas picarescas» hasta finales de la década de 1840, se abarcaban las obras de asunto realista o satírico que, por esa condición, eran asignadas a la comedia de acuerdo con la convención genérica dominante. Descritas décadas antes como cuadros costumbristas y documento del estado político y social de su tiempo («expression pittoresque de son [de la España de la época] état politique et social»), aún en las últimas décadas del XIX alguno de los manuales de historia literaria española de redacción francesa seguiría catalogando el Lazarillo como «roman comique», frente al uso de los marbetes ya plenamente sancionados como "genre picaresque» o "roman picaresque». Véase también P. Verdevoye («La novela picaresca en Francia», Clavileño, sept.-oct. 1955, pp. 30 y pássim) y sobre todo la revisión de Romero Tobar sobre la acogida de la novela picaresca en las historias literarias (art. cit., 1998). 
ampliamente demandados — pese al desdén de los enciclopedistas, que solo aceptaban las prestigiadas L'Astrée de Urfé y La Princesse de Clèves de Mme de Lafayette-, su inventario se vería sometido a recreaciones como las admiradas reformulaciones burguesas de Lesage, adaptaciones progresivas e incluso mutilaciones como en el caso paradigmático de su fundadora el Lazarillo de Tormes, antes de la traducción restituidora de Viardot. ${ }^{115}$

La aceptación pública del nuevo género en vías de reconocimiento teórico ${ }^{116}$ alimenta desde el XVIII bajo el lema del utile dulci la proliferación de colecciones y «bibliotecas» de novelas, ${ }^{117}$ como la célebre, longeva

115 Antes de la celebrada traducción de Viardot, era conocida la edición de las Aventures et espiègleries de Lazarille de Tormes, écrites par lui-même (trad. J.-A. de Charmes, G. de Bocker, ed. 1817, París, Saintin). Sobre la historia editorial de la obra y su transmisión textual véanse R. Guise («La fortune de Lazarille de Tormès en France, au XIX siècle», Revue de Littérature Comparée, t. XXXIX, 1965, pp. 337-357) y A. Rumeau («Les éditions romantiques et Hurtado de Mendoza (1810-1842)», en Mélanges à la mémoire de Jean Sarrailh, París, CRIEH, 1966, pp. 301-311). La prelación de esta novela en el género fue generalmente admitida pese al disentimiento de Germond de Lavigne, que defendió erróneamente la Histoire de don Pablo de Ségovie (París, Claude Warée, 1843) de Quevedo, que tradujo, como pionera y ejemplo sobresaliente de la novela picaresca, contra el silencio de Viardot en su pormenorizado estudio y traducción del Lazarillo («Lettre à M. Louis Viardot [...]», La France littéraire, 1843, pp. 146-152). Valorada principalmente por la representatividad nacional de sus tipos — de modo que diversos pasajes como el episodio celebérrimo del escudero encarnará una de las caras del mito español junto con el Caballero de la Triste Figura en el imaginario francés-, varios críticos, como, por ejemplo, Rendu en sus Leçons espagnoles de 1830, gustan de los contrastes, pero rastrean asimismo en la denuncia satírica de los defectos de la sociedad española la trascendencia genérica de los vicios humanos.

116 A pesar de su floreciente cultivo y provechosa venta desde hacía más de dos siglos, en su trabajoso y polémico proceso de afianzamiento genérico como una clase diferente de la epopeya y de la tragedia, y aún no dotada de una poética, el ingreso oficial de la novela en la Academia Francesa se retrasaría hasta finales del XIX.

117 Valgan como ejemplo el éxito de De l'usage des romans (Ámsterdam, 1734) del abate Lenglet Dufresnoy, primer ensayo de bibliografía-nomenclatura exclusivamente dedicada a la novela, y modelo inspirador de Paulmy sobre todo por su clasificación temática; la Bibliothèque d'un homme de goût (1772) del abate Chaudon, otro listado bibliográfico no especializado en novelas, que no citaba entre los extranjeros más que a Cervantes, Richardson y Fielding; y la Bibliothèque de campagne ou amusement de l'esprit et du cour (1761), que publicaba relatos completos y también abrazaba otros géneros excediendo las fronteras de la novela. Véase R. Poirier, La Bibliothèque Universelle des Romans. Rédacteurs, Textes, Public, Ginebra, Droz, 1976. 
e influyente Bibliothèque Universelle des Romans ${ }^{118}$ —fundamental venero de traducciones-, fundada por el bibliófilo A.-R. de Voyer, marqués de Paulmy d'Argenson (1775-1778), cuya amplia cultura y gusto clásico favoreció una notable presencia de variados y genuinos títulos españoles, frente a su continuador J. F. Bastide (1779-1789), más atento al reclamo publicitario. Concebida como una enciclopedia del género basada en la selección de extractos o «miniaturas» analizados y acompañados de notas, presenta en su prólogo — redactado por Paulmy, su primer director junto al conde de Tressan - un panorama de la novela europea de acuerdo con las inclinaciones lingüísticas adecuadas al nuevo género y la teoría de los climas, en el que prevalece la española conforme a los argumentos de Lenglet de Dufresnoy, que ya había atribuido su preeminencia a la influencia de la literatura oriental, el clima y la rigidez de sus costumbres. ${ }^{19}$

Esta genealogía editorial se perpetúa fructuosamente a lo largo del XIX en consultadas colecciones especializadas que suelen adelantar resúmenes y extractos de títulos en el mercado, elegidos en nombre de la moral familiar y social, como los catálogos de los libreros A. $\operatorname{Marc}^{120}$ y A. N. Pigoreau ${ }^{121}$

118 Poirier, ib. Utilizaremos por mayor comodidad las siglas $B U R$. La colección fue publicada por el librero Jacques Lacombe y, tras el cambio de director, por Panckoucke. Al contrario que Bastide, escritor profesional más afanado por lograr el éxito financiero de la colección, que prefirió a los ingleses y los alemanes contemporáneos, Paulmy mostró su predilección por las novelas españolas, italianas y orientales. Entre los representantes novelísticos españoles, incluyó elogiadas miniaturas de novelas del XVI y del XVII en las diversas categorías desde las de caballerías, pastoriles, picarescas o moriscas hasta obras de Diego de San Pedro, Cervantes, María de Zayas, o, por ejemplo, también de Santa Teresa, entre otros.

119 Esa primacía española se vincula al grado de civilización de su sociedad, entregada a la imaginación, sometida a los dictados de su región climática y a un estado menos evolucionado, y en el que transparenta la alusión al popular género de la novela de caballerías, que gozaba de numerosos representantes editoriales en Francia («une nation naturellement fière mais très courageuse, galante et voluptueuse et disposée à la jalousie, qui habite un climat brûlant dont l'ardeur donne plus d'activité à ses qualités estimables et plus de force à ses passions [...] une pareille nation paraît faite pour fournir au genre romanesque plus de héros et d'auteurs qu'aucune autre»).

120 Dictionnaire des romans anciens et modernes (1819).

121 Su exitosa colección Petite Bibliographie biographico-romancière ou dictionnaire des romanciers, tant anciens que modernes tant nationaux qu'étrangers, avec un mot sur chacun d'eux, et la notice des romans qu'ils ont donnés, soit comme auteurs, soit comme traducteurs. Précédé du catalogue des meilleurs romans publiés depuis plusieurs années (Pigoreau, 18211828. Reimpresa en 1968, Ginebra, Slatkine) dio lugar a varios suplementos. 
—que, en la aglomeración de tomitos en $12 .^{\circ}$ de novelas sentimentales, históricas, aleccionadoras, romans noirs, memorias de guerra, relatos fantásticos y de aparecidos, pastiches diversos y libros de viajes, registra diversos ejemplares deudores de un gusto conservador, arraigado desde el siglo XVII, por los subgéneros tradicionalmente ligados al acervo español—; ;22 o la escrupulosa Revue des Romans ${ }^{123}$ de Girault de Saint-Fargeau, que en sus 1100 análisis ${ }^{124}$ solo da cabida a cuatro autores españoles, el ineludible Cervantes, ${ }^{125}$

122 Por ejemplo, en su selección de ediciones principalmente decimonónicas Pigoreau se inclina por la novela de caballerías - la versión del Amadís de Tressan o la traducción de Caylus de 1775, apreciada por los bibliófilos por su rareza, de la Histoire du vaillant chevalier Tirant le Blanc-; ofrece una notable representación cervantina encabezada por su Quijote en las traducciones del elogiado Florian — conocido por su versión de La Galatea y su adaptación de las novelas ejemplares, escogidas también por Coste (Nouvelles imitées de Michel Cervantes, et autres auteurs espagnols) reeditado en 1802- y de Bouchon Dubournial (1807), responsable asimismo de la traducción del Persiles (Persilès et Sigismonde, ou les Pèlerins du nord), y en su estela adaptaciones, ficciones y reescrituras en otros géneros; se rinde a la fama del género picaresco tamizado principalmente por las versiones burguesas del insoslayable Lesage - su Histoire de Gil Blas de Santillane en su edición de 1819, su Histoire de Gusman d'Alfarache, imité de Mateo Alemán en una de 1787, su imprescindible Diable boiteux, augmenté des Entretiens sérieux et comiques des Cheminées de Madrid, et suivi des Béquilles du Diable boiteux en otra de 1820, el Bachelier de Salamanque, ou mémoires de don Chérubin de la Ronda y la Histoire d'Estévanille de Gonzalez, surnommé le garçon de bonne humeur, en otra de 1792_, junto a las Aventures et espiègleries de Lazarille de Tormes atribuido a Hurtado de Mendoza, de quien cita también su Histoire de la guerre contre les Maures de Grenade; y como un eco de la pervivencia bucólica del XVIII consigna colecciones como la Bibliothèque pastorale, contenant les chefs-d'ouvre des meilleurs poëtes pastoraux, anciens et modernes; recueil essentiellement utile aux persones qui veulent jouir de la campagne (1813).

123 E. Girault de Saint-Fargeau, Revue des Romans. Recueil d'analyses raisonnées des productions remarquables des plus célèbres romanciers français et étrangers, París, 1839, 2 vols. Reimpreso en 1968 (Ginebra, Slatkine).

124 Este afán enciclopédico o bibliográfico lleva al autor a incluir un interesante «Essai de Bibliographie Spéciale des Romans» que ilustra el enorme interés por el género desde el siglo XVIII.

125 El diccionario bibliográfico de Quérard, fuente de enjuiciamientos para Saint-Fargeau, inventaría sus principales traducciones antes de la irrupción triunfante de Viardot (1836). Precursoras de la celebérrima de Filleau de Saint-Martin et Challes (Histoire de l'admirable Don Quichotte de la Manche, París, M. Clousier, 1713-22), suelen mencionarse la mediocre de Rosset, la de César Oudin, más buscada por anticuarios y coleccionistas, y la de Saint-Hyacinthe (1677-79). Pese a su languidez, la preeminencia exitosa hasta bien entrado el XIX de la de Filleau - quizá por inercia editorial, o mantenimiento de las normas y del concepto de clasicismo como valor nacional y estético según declara Quérard, dando indirectamente la razón al antólogo Juan Maury cuando reprochaba el excesivo sometimiento al lecho de Procusto del clasicismo francés - se impone sobre la muy reimpresa versión póstuma de Florian (París, impr. Didot, an VII, 1799), ya denostada como la más infiel pero no por ello menos frecuentada y popular, como demuestra el aprecio de Pigoreau por su amenidad y estilo elegante, o incluso 


\begin{abstract}
Avellaneda, ${ }^{126}$ Quevedo, ${ }^{127}$ y un solo nombre contemporáneo, Trueba y Cossío, cuyas novelas históricas escritas en inglés e inspiradas en el pasado medieval y el Siglo de Oro españoles eran entonces traducidas en Francia.
\end{abstract}

la reproducción en ambos bibliógrafos de las impresiones más comprensivas del académico Chénier frente a la reacción posterior de Viardot. Entre otras ediciones que atestiguan la asiduidad francesa dieciochesca de la novela, se citan asimismo la fallida y menos recurrente revisión de d'Hermilly (París, Cailleau, 1777) que abrevió el original con la sanción prestigiosa de la Academia en una de sus ediciones (París, Plassan, 1825), o la más completa, fiel y sencilla de Bouchon-Dubournial, editada de nuevo en 1807 - y aumentada en la de 1822 (París, Méquignon-Marvis) con el itinerario del héroe por el coronel Bory de Saint-Vincent, geógrafo, naturalista y literato miembro de diversas academias-, que, no obstante, incurre en negligencias como la omisión de El curioso impertinente — publicado por separado bajo el título de Le Mari trop curieux - y fracasa a juicio de Quérard en la traducción de las poesías insertas. Sin embargo, en la jerarquía estimativa de ambos bibliógrafos el primer lugar lo ocupa la de Delaulnaye, elegante y fiel, acompañada de un mapa de los viajes de su protagonista en su hermosa edición parisina (Th. Desoer, 1821) y con notas y viñetas de T. Johannot en el primer tomo de la de 1836. Publicaciones y reediciones todas ellas, en suma, que conviven en ese período con otras traducciones anónimas recogidas en otras colecciones así como taraceas de varias versiones como la de F.-P. Brotonne, Histoire de Don Quijote de la Manche, traduite sur le texte original et d'après les traductions comparées de Oudinet, Rosset, Filleau de Saint-Martin, Florian, Bouchon-Dubournial et Delaunay (1837), antes de la versión de Viardot, que las irá oscureciendo progresivamente ante el lectorado francés. Sobre la recepción e interpretaciones principales del Quijote véase A. Close, La concepción romántica del Quijote, Barcelona, Crítica, 2005, y también L. Romero Tobar, «El Quijote de románticos y realistas", en La literatura en su historia, Madrid, Arco Libros, 2006, pp. 243-262.

126 A la sombra del Quijote se sitúa la novela de Avellaneda (Tarragona, 1614), que durante un tiempo había sido considerada superior a su modelo desde la traducción de Lesage (Nouvelles aventures de l'admirable Don Quichotte de la Manche, París, Veuve Barbin, 1704, editada posteriormente en 1705, 1716, 1741 - y a la que Quérard alude bajo el título Suite nouvelle et véritable de l'Histoire et des Aventures de l'incomparable Don Quichotte de la Manche, et donnée comme une traduction d'un manuscrit espagnol de Cid-Hamet Benegely, París, 1722, 1726, 1741-). Saint-Fargeau —que lo confunde con un novelista inglés - asume el juicio negativo de sus contemporáneos sobre esta obra como una deleznable continuación de la novela cervantina, y le censura la repetición de peripecias similares y su manera de narrar ("c'est une plate caricature d'un chef-d'œuvre d'imagination et de style», p. 30). De igual modo pensará Mérimée en 1877 —cuando dispone ya de las elucubraciones de Benjumea sobre el autor - al afirmar la calidad superior de la adaptación de Lesage, quien abrevió y modificó el original hasta hacerlo legible, sin mentar tampoco la más reciente versión de Germond de Lavigne desde el XVIII (París, Didier, 1853).

127 Entre los grandes modelos del XVII más reconocidos en antologías, diccionarios, estudios e historias, la excelencia de Quevedo, bien conocido por sus contemporáneos franceses, como constató Cioranescu (Le masque et le visage. Du baroque au classicisme français, Ginebra, Droz, 1983), es habitualmente reconocida, pese a la ambigüedad que suscita en los historiadores y críticos atentos a la observancia de las normas y recelosos del gusto distante del barroco. Principalmente valorado como autor jocoso en el XIX -lectura limitada que Ochoa se había propuesto corregir ofreciendo en una de sus antologías un repertorio más variado de la completitud genérica de su producción-, había 
Como este recopilador que privilegia en su selección —además de la exaltación romántica del Quijote ${ }^{128}$ y de la consideración, a su vera, por las novelas ejemplares, ${ }^{129}$ reconocida naturalización de la novella italiana en

atraído la atención de diversos traductores franceses desde el XVIII como La Geneste, D’Hermilly o Rétif de la Bretonne hasta Germond de Lavigne, a cuya versión del Buscón (1843) ya nos hemos referido. Saint-Fargeau, como Quérard — quien le demuestra una alta consideración al punto de emparejarlo con Cervantes («l'un des littérateurs les plus féconds et les plus spirituels, et le seul que l'on puisse comparer à Cervantes, quoiqu'il ne l'ait point égalé» (ob. cit., t. VII, 1835, pp. 401-402) y refiere otras ediciones de principios de los años veinte de sus Obras jocosas (Lyon, Cormon y Blanc)—, también repara en las Visiones de 1812, entre las que alaba la calidad del Songe des crânes en el "genre grotesque».

128 Como la generalidad entonces de la crítica, Saint-Fargeau aprecia más la segunda parte de la novela - en la que destaca la entrevista del protagonista en el capítulo 72 con don Álvaro de Tarfe, tomado de la novela de Avellaneda- por el ahondamiento en el carácter de personajes como Sancho, atraído a la esfera ideal de su amo, y la incorporación de otros nuevos como el escéptico bachiller Carrasco, o don Diego, el más sensato después del escudero; por la inclusión de deliciosos episodios como el de las bodas de Camacho - uno de los predilectos de las recreaciones literarias y las antologías hasta mediados del XIX-; y por un mayor realismo que trasciende la parodia del género caballeresco. A partir de la traducción de Bouchon-Dubournial, Girault recomienda vivamente a sus lectores la obra cervantina — pilar de la novela española en el extranjero y modelo inimitable de ese género-, en que la imaginación va al paso de la razón, y la sátira al de la buena crítica, por su respeto al decoro y la moralidad ajenos a la escabrosidad de sus precursores Petronio o Apuleyo. Es más, ya la proclama «la plus salutaire révolution en Espagne» no solo por su completitud literaria, sino también como una suerte de compendio quintaesenciado de los valores de la cultura española, una summa divertida y seria de «tout le génie espagnol, toute la finesse espagnole, toute la philosophie sérieuse de l'Espagne». El compilador ensalza la vivacidad, finura y verdad con que el autor consigue hacer revivir un mundo lejano para los lectores, alaba su dominio en el encadenamiento de peripecias, cuadros de costumbres, historias intercaladas, preceptos y retratos, y elogia la igualdad de ánimo de sus protagonistas, cuyos caracteres se complementan. Sin embargo, Girault no hace hincapié en las situaciones humorísticas tan celebradas en las primeras recepciones de la obra, ni en su anacronismo ya en el siglo XVII, sino en el daño que sufre el personaje acosado por la sociedad y la crueldad de la vida, hasta convertirse en una "pauvre âme généreuse qui se perd dans le positif de la vie! Pauvre poëte sans asile que personne ne peut comprendre!». Héroe investido de una misión, filósofo poético, poeta cuerdo, español de viejo abolengo, noble como el célebre Bayard, «le chevalier sans peur et sans reproche» del medievo francés exaltado en su teatro histórico del XVIII, don Quijote encarnaría asimismo en la lectura de Girault genuinas cualidades burguesas como honestidad, sencillez y probidad.

129 Aunque eran conocidas las recreaciones cervantinas de Florian de las Nouvelles nouvelles (París, impr. Didot l'aîné, 1784) con Léocadie (La fuerza de la sangre) y Le Dialogue des Chiens (El coloquio de los perros), la traducción de Bouchon-Dubournial (Nouvelles choisies..., París, Panckoucke, 1825, que formaba parte de la colección Traduction des chefs-d'ceuvre classiques étrangers) y la de Viardot de 1838, Saint-Fargeau reseña las tra- 
las historias literarias, y por el Persiles ${ }^{130}$ - los aspectos pintorescos, la comicidad y la sátira, y los juegos de contrastes en los trágicos sucesos tomados de la historia de España, asimismo durante décadas los antólogos y redactores de manuales y estudios suelen apreciar no solo los subgéneros bien conocidos desde el XVI, sino también las obras del XVII y sus romans de mours accesibles en las traducciones de Viardot o Lavigne, y como único relevo cervantino la novela satírica del padre Isla — de estima declinante en el curso de la centuria-. A este repertorio heredado de la tradición se irán añadiendo paulatinamente las composiciones contemporáneas de una Fernán Caballero bastante traducida tras la primicia difusora de Latour desde Le Correspondant en 1857, y a notable distancia en su difusión popular francesa Trueba, Valera, Pérez Galdós o Pereda, así como se incluirán en sus inventarios a folletinistas como, por ejemplo, Pérez Escrich, a autoras como Pilar Sinués entre otras, o a una Pardo Bazán presente en extractos de manuales escolares y en monografías de fines de siglo.

\subsubsection{El romancero}

El romancero, uno de los pilares fundamentales de la reivindicación de la originalidad literaria española, cuya mención no silencian los antólogos e historiadores del XIX, imbuidos de las teorías del Volksgeist, también

ducciones de las novelas breves cervantinas a partir de la edición de 1808 basada en la traducción de Petitot. El colector distingue entre su variedad temática aquellas que pretenden conmover al lector (Léocadie, L'Amant généreux, L'Espagnole anglaise, o Constance) de aquellas otras que se proponen divertir con la pintura cómica de las flaquezas humanas (Rinconet et Cortadille, Le Licencié Vidriera, Le Dialogue des deux chiens de Mahude, etc.). De todas ellas, satisfaciendo el deseo de pintoresquismo de su lectorado, prefiere Le Licencié Vidriera por su variedad de caracteres y costumbres, L'Amant généreux — pese a su acumulación de acontecimientos excesivamente novelescos- por sus evocaciones de los turcos, "peuples rebelles à toute civilisation", y Les Deux Chiens, de la que destaca la comicidad de la conversación entre el poeta, el matemático, el químico y el proyectista.

130 La querencia de Cervantes por esta novela bizantina no halla eco entre los críticos franceses del XIX. A través de la conocida traducción de Bouchon-Dubournial (Persilès et Sigismonde ou les Pèlerins du Nord) mencionada en varias ediciones (1809 y 1822), SaintFargeau esgrime los habituales reproches - como una selvática proliferación de episodios que ensombrecen la historia central, o la impaciencia que suscita en el lector decimonónico la reserva del amor platónico de los protagonistas, reducidos a oyentes de historias ajenas-, elogiando, con todo, episodios dignos de su autor como los de Martín Banedo y Ruperta o la historia de Isabel de Castrucho, ya anotados por Sismondi. 
reanuda una tradición «hispanista» fluctuante pero ininterrumpida. ${ }^{131}$ Pese al descrédito en que había caído ante los ilustrados por la difusión de romances de guapos y jaques, de tremendos y morbosos crímenes a través de los pliegos de cordel, la vitalidad del género — permeable a vejámenes, disputas, sátiras, fábulas y cantos amorosos- propició un notable cultivo dieciochesco. ${ }^{132}$ Sin embargo, es a raíz del estallido nacionalista cuando, según Dérozier, ${ }^{133}$ se impulsa vigorosamente la revalorización de esta poesía que a fines del XVII y a lo largo del XVIII no habría expresado su potencial popular y colectivo. Aun así, atisbos de una conciencia de nacionalidad literaria están ya presentes en contribuciones importantes en la divulgación y promoción del género - tras su defensa pionera por Sarmiento o por valedores como Meléndez Valdés entre otros- como un influyente y adelantado Quintana, ${ }^{134}$ secundado principalmente en el XIX por la edición de Böhl ${ }^{135}$ — menos difundida aunque conocida por los estudiosos-, o las selecciones del antólogo Juan Maury ${ }^{136}$ u Ochoa, ${ }^{137}$ y en especial de Durán, ${ }^{138}$ abanderado del nacionalismo militante, cuya crucial declaración sienta las bases del relevo de la investigación alemana — retomado por Milà i Fontanals y sus teorías sobre los orígenes del género a partir de las epopeyas primitivas, y la escuela de Menéndez Pidal— ${ }^{139}$ y fundamenta el

131 Sobre la moda del gusto por los romances en Francia, véase, por ejemplo, H. Tronchon, «Romanceros préromantiques», en Romantisme et Préromantisme, París, 1930, pp. 243-244; y a propósito de su convergencia con el desarrollo del género «troubadour» $\mathrm{H}$. Jacoubert, Le Genre troubadour et les origines françaises du romantisme, París, Société d'édition les «Belles-Lettres», 1928.

132 F. Aguilar Piñal, Romancero popular del siglo XVIII, Madrid, CSIC, 1972.

133 A. Dérozier, "Le duc de Rivas et la résurgence du romancero", Les Langues Néolatines, n. ${ }^{\circ}$ 68, 1974, pp. 24-50.

134 En el tomo XVI de la Colección de poetas castellanos de Ramón Fernández (1796), a su cargo, incluía diversas clasificaciones temáticas romancísticas.

135 Floresta de Rimas Antiguas Castellanas, Hamburgo, 1821-25.

136 L'Espagne poétique, París, P. Mongie, 1826-27, 2 vols.

137 Tesoro de los Romanceros y Cancioneros españoles, París, Baudry, 1838.

138 Su Colección de romances castellanos anteriores al siglo XVIII (1828-32) fue completada más tarde por su Romancero general, o Colección de Romances castellanos anteriores al siglo XVIII, recogidos, ordenados, clasificados, y anotados por don Agustín Durán (Madrid, 1849-51, 2 vols.), recopilación de romances clásicos extraídos de series de los Siglos de Oro.

139 Por ejemplo, las ediciones de Milà i Fontanals, como sus Cantos populares españoles (París, 1884), y, tras los pasos de Juan Menéndez Pidal (como su Poesía popular [de Asturias], Madrid, Hijos de J. A. García, 1855), las de sobra conocidas investigaciones de Ramón Menéndez Pidal, traducido también por E. Mérimée, atento también a la divulgación de los estudios romancísticos. 
uso ideológico del vigoroso romance en la segunda mitad del siglo como portavoz de los intereses de una clase media aliada con los grupos de poder, y cuya puesta en práctica más celebrada y mejor lograda son los Romances históricos (1841) de Rivas. ${ }^{140}$

Paralelamente a su revigorización española y a la moda del genre troubadour, la duradera $B U R$ se convierte en la impulsora francesa del auge del romancero en Europa gracias a las adaptaciones del ciclo cidiano ${ }^{141}$ por Couchu, ${ }^{142}$ origen de las versiones de Herder y de Creuzé de Lesser (1814 y 1823). ${ }^{143}$ La recopilación romancística comienza con meritorios trabajos eruditos de varios filólogos alemanes —Grimm, Diez, Depping y más tarde Wolf_- a la que suceden las traducciones de ingleses - como Rodd, Bowring o Lockhart-o italianos. ${ }^{144}$ En cambio, el rezago francés en la

140 Véase L. Romero Tobar, Panorama crítico del romanticismo español, Madrid, Castalia, 1994, pp. 199-202.

141 Véase F. Ramos Ortega («La fortuna del Cid en el romanticismo francés», Revista de Literatura, n. ${ }^{\circ} 43,1981$, pp. 31-58) y sobre todo el estudio de P. Bénichou ("Romancero español y romanticismo francés», en Hispanic Studies in honor of Joseph H. Silverman, Newark, Juan de la Cuesta, 1988, pp. 77-108). Además de Creuzé de Lesser y Herder, contó con otra edición en 1830 por Regnard (Romances du Cid), o la versión de Rénal en 1842, cuya calidad y fiabilidad fue puesta en entredicho por Damas-Hinard.

142 Responsable también de un fragmento, inserto en el volumen de diciembre de 1779, de la novela de caballerías el Libro del esforzado caballero conde Partinuples que fue emperador de Constantinopla, Alcalá de Henares, 1593 (Poirier, ob. cit.).

143 Le Cid; romances espagnoles imitées en romances françaises, París, Delaunay, 1814. Quérard (ob. cit., t. II, 1828, p. 337) menciona una nueva edición bajo el título Les Romances $d u$ Cid, imitées de l'espagnol en vers français, París, Delaunay, 1823.

144 Grimm publica su Silva de varios romances viejos sacada en su mayor parte del Cancionero de Amberes (Viena, 1815); F. Diez, su Altspanischen Romanzen (1818); G. B. Depping, su Sammlung der besten alten spanischen historischen, Ritter- und maurischen Romanzen; mit Einleitung und Anmerkungen (Altenburg y Leipzig, Brockhaus, 1817), que fue traducida por V. Salvá (Londres, 1825) y editada y anotada por Alcalá Galiano (Romancero Castellano, o Colección de antiguos romances populares de los españoles, recopilado por $G$. $B$. Depping, 1844). De esta colección dice Quérard que se publicó una edición más correcta pero menos completa en Londres en 1825 titulada Colección de los más célebres romances españoles antiguos, por $G$. B. Depping; ahora considerablemente enmendado, por un Español refugiado, 2 vols. en 12 . $^{\circ}$ Señala asimismo que este editor solo reproduce 224 romances de los 300 que comprendía el compendio, además de suprimir los romances moriscos. Otra más fue editada en Hamburgo bajo el título Recueil d'anciennes poésies espagnoles (1821-25). F. Wolf publica en 1837 una Floresta de rimas castellanas y varios artículos sobre la historia del romancero con Hoffmann (Primavera y flor de romances, Berlín, 1856). Entre los ingleses, antes de la difusión de Southey de la Chronique du Cid (Londres, 1808) en vísperas de 
recopilación romancística impone la consulta de las selecciones extranjeras editadas. Durante algún tiempo la única colección al alcance de su lectorado y venero para artistas ${ }^{145}$ sería la de Abel Hugo, ${ }^{146}$ que presentó el ciclo del rey Rodrigo y la pérdida de España - y cuyo prólogo recogió sus lecciones literarias dictadas en su curso de literatura española de 1821 para la Société des Bonnes-Lettres—. ${ }^{147}$ En las décadas siguientes la nómina se amplía con la apertura a otras temáticas y $\operatorname{ciclos}^{148}$ difundidos por las his-

la guerra de la Independencia, Th. Rodd dio a la imprenta su Ancient Ballads from the Civil Wars of Granada, and the twelve peers of France (Londres, 1801); así como era también conocida la selección de Lockhardt Ancient Spanish ballads (Londres, 1838, 1842). En el ámbito italiano se puede citar, por ejemplo, el Romancero del Cid, traduzione dallo spagnuolo di Pietro Monti (Milán, 1838), juzgada por Damas-Hinard la más completa, cuyo autor también entregaría a la imprenta sus Romanze storiche e moresche e Poesie scelte spagnuole, tradotte in versi italiani (Milán, 1850).

145 De entre las recreaciones de diversa fortuna de la época descollaba entonces el Romancero de Rodrigue (Rodrigue, dernier Roi des Goths) de Émile Deschamps (Études françaises et étrangères, París, U. Canel, 1828); en 1829 (París, A. Levavasseur) se publica la $4 .^{a}$ edición, corregida y aumentada con ocho nuevas piezas). Sus imitaciones, a pesar de ciertas reminiscencias dieciochescas, constituían a ojos de Blaze («Poètes et romanciers de la France. Sur Émile et Antoine Deschamps», Revue des Deux Mondes, 15-VIII-1841) su mejor obra, donde recrea el espíritu de ese ciclo romancístico con mejor fortuna incluso que las Orientales de Hugo, y la de mayor influencia sobre la poesía contemporánea («Du reste, si l’on s’en souvient, l'œuvre de M. Émile Deschamps ne laissa point d'exercer une action puissante sur la poésie contemporaine, et nous croyons ne pas nous tromper en disant que c'est de là, de cette imitation du Romancero, que sont sortis la plupart des contes et des poèmes à la manière espagnole publiés vers cette époque» (p. 553). Véanse también G. Lanson («Émile Deschamps et le Romancero. Étude sur l'invention de la couleur locale dans la poésie romantique», Revue d'Histoire littéraire de la France, t. VI, $6{ }^{\circ}$ año, pp. 1-20) y, sobre su obra y su significación en su época, H. Girard (Un bourgeois dilettante à l'époque romantique: Emile Deschamps, París, Champion, 1921).

146 Tras la edición parisina de 1821 del Romancero e historia del rey de España don Rodrigo, postrero de los godos, en lenguaje antiguo, recopilado por ..., A. Hugo publicó al año siguiente su traducción francesa Romances historiques, traduites de l'espagnol... (París, Pellicier, 1822). Como señalaba G. París ("La "romance mauresque” des Orientales», Revue d'Histoire littéraire de la France, t. VI, 1899, pp. 333-342), en la recopilación de Abel Hugo - cuya fuente principal y no siempre confesa habría sido el Romancero general de 1604 se daba cabida también a nueve poemas pertenecientes al ciclo de los siete infantes de Lara. De ellos, cuatro pertenecen a antiguos romances que serían incluidos en la Primavera y flor de romances de Wolf y Hoffmann; los otros cinco son versificaciones de la Crónica general o composiciones más modernas.

147 M. Espagne, ob. cit., p. 160.

148 La división de Durán en ocho clases, según la época en razón del estilo y el estado de la lengua, suscitó la aprobación de críticos como, por ejemplo, Baret, que retoma en 
torias literarias, antologías, artículos periodísticos y nuevas ediciones, entre las que destaca por el aprecio general entre sus compatriotas —además de otras posteriores bien valoradas como, por ejemplo, las de Denis o el estudioso Puymaigre - la traducción en 1844 de Damas-Hinard, ${ }^{149}$ que ratifican la asentada consagración del género como poesía nacional, popular y original, y la excepcionalidad en Europa de su precoz recolección.

1863 la clasificación ya habitual en romances caballerescos, históricos o heroicos y moriscos como sus ramas temáticas principales, completados con los de la Antigüedad clásica y los mitológicos — considerados de peor calidad-, los pastoriles, los líricos y los que, a falta de otra etiqueta, llama romances de costumbres (o de "mœurs»), así como recoge los principales ciclos desde el de los siete infantes de Lara, el del rey Rodrigo, el cidiano, el de Bernardo del Carpio, Fernán González o el carolingio con los doce pares.

149 Romancero général ou recueil des chants populaires de l'Espagne. Romances historiques, chevaleresques et moresques. Traduction complète, avec une introduction et des notes (París, Charpentier, Libraire-Editeur, 1844, 2 t.). Damas-Hinard agrupa por siglos y reinados los romances históricos medievales - cuyo origen liga a la guerra de reconquista desde Asturias-, a los que suma otros líricos, diversos, caballerescos y moriscos, relegando en cambio los del romancero nuevo, que tacha de frías y artificiales imitaciones. Contraviniendo la opinión general arraigada hasta no mucho antes, rechaza el ascendiente árabe sobre la poesía haciendo resaltar la influencia cristiana, a la que atribuye, en la línea de Bouterwek, el asentamiento de las instituciones caballerescas y el nuevo estatus femenino («j) oserai soutenir que de tous les peuples de l'Europe, celui qui, pour la poésie, a le moins emprunté aux Arabes, c'est le peuple espagnol», p. xxiii). El traductor recurre principalmente al Cancionero de Romances (Amberes, 1555), consultado en su momento por Bouterwek, la Silva de varios Romances (Barcelona, 1611), el Tesoro escondido de todos los más famosos Romances (Barcelona, 1626), el Romancero general (1604) y con menos frecuencia el de Sepúlveda, además de acudir a las ediciones de Durán y Depping. Asimismo, entre otros estudios contemporáneos se pueden mencionar los del historiador Rosseeuw Saint-Hilaire (Étude sur l'origine de la langue et des romances espagnols de 1838) o de Adalbert Séller (Stuttgart, 1840) y traducciones como las arriba aludidas de F. Denis (Romancero español) o la de Puymaigre (Petit romancero: choix de vieux chants espagnols, traduits et annotés par ..., París, Librairie de la Société Bibliographique, 1878). 



\section{CONTRIBUCIONES A LA HISTORIA DE LA LITERATURA ESPAÑOLA EN FRANCIA: ESTUDIOS, HISTORIAS, CURSOS MAGISTRALES, ARTÍCULOS, MANUALES, ANTOLOGÍAS}

Entre la beligerante acusación de Schlegel a comienzos del XIX contra el imperialismo estético francés, y la constatación por el catedrático Ferdinand Brunetière de la inercia común de su lectorado respecto a la literatura española o - ante la categórica sentencia de Taine en su introducción a su Histoire de la Littérature Anglaise - la defensa en los años de entresiglos de su vitalidad contemporánea por Tannenberg, se consolidan, no obstante, diversas transformaciones estéticas, conceptuales e ideológicas de gran trascendencia, empezando por el asentamiento del restringido concepto de literatura — limitada ${ }^{150}$ progresivamente desde el último tercio del XVIII a

150 Entre los numerosos estudios cabe mencionar a R. Escarpit («La definición del término literatura», en Hacia una sociología del hecho literario, Madrid, Edicusa, 1974, pp. 257-272; también "Histoire de l'histoire de la Littérature», en Histoire des littératures, París, Encyclopédie de la Pléiade, Gallimard, t. III, 1962), O. Tacca (La historia literaria, Madrid, Gredos, 1968); R. Queneau (Histoire des littératures, París, Encyclopédie de la Pléiade, Gallimard, 1962, t. II, «Préface»); V. Aguiar (Teoría de la literatura, Madrid, Gredos, 1986); así como, sobre las reflexiones que suscitan sus problemas teóricos, las disertaciones incluidas en el volumen colectivo editado por L. Romero Tobar (Historia literaria/Historia de la literatura, 2004); además del conocido trabajo de G. Díaz-Plaja («Esquema historiográfico de la Literatura española», en Historia general de las literaturas hispánicas, Barcelona, Barnes, t. I, 1949), ha de citarse asimismo, entre otros estudios, particularmente respecto al período cercano a su institucionalización, a I. Urzainqui ( El concepto de historia literaria en el siglo XVIII», en Homenaje a Álvaro Galmés de Fuentes, Madrid/Oviedo, Gredos/Universidad de Oviedo, t. III, 1987, pp. 565-589). 
las Belles-Lettres (buenas o bellas letras) — y, por ende, de su historia como disciplina científica. En la trabajosa elaboración del constructo llamado «historia de la literatura» en España entran, asimismo, como la crítica ha dejado bien demostrado, ${ }^{151}$ diversos componentes estéticos e ideológicos como la asunción del modelo filosófico de las ciencias humanas, ${ }^{152}$ las difundidas teorías schlegelianas ${ }^{153}$ o la idea de nacionalidad inspirada en Herder, proyectada en la construcción de un concepto e imagen de nación, propia y ajena, y extendida a través de la formación académica. A estos aspectos — los más habitualmente tratados en la aproximación crítica y erudita a las historias de la literatura, como ha señalado Romero Tobar-154

151 Por ejemplo, aparte de la veterana introducción de H. Juretschke (Vida, obra y pensamiento de Alberto Lista, Madrid, CSIC, Escuela de Historia Moderna, 1951), y sobre todo del útil estudio panorámico de P. Sainz Rodríguez (Historia de la crítica literaria en España, Madrid, Taurus, 1989), véanse especialmente los artículos de J.-C. Mainer («De historiografía literaria española: el fundamento liberal», en S. Castillo, C. Forcadell, M. ${ }^{a}$ C. GarcíaNieto, y J. S. Pérez Garzón (coords.), Estudios sobre Historia de España. Homenaje a Manuel Tuñón de Lara, Madrid, Universidad Internacional Menéndez Pelayo, 1981, vol. II, pp. 439472; y "La invención de la literatura española», 1994, pp. 23-49), así como la síntesis de R. de la Fuente en su "Introducción» a La historia de la literatura y la crítica, Salamanca, Colegio de España, 1999, por él coordinada, o el estudio de M. Ramos Corrada (La formación del concepto de historia de la literatura nacional española. Las aportaciones de Pedro J. Pidal y Antonio Gil de Zárate, Oviedo, Departamento de Filología Española, 2000).

152 Véase M. Garrido Palazón, La filosofía de las Bellas Letras y la Historia literaria en España (1777-1844), Almería, 1992.

153 Desde las aportaciones documentales de A. Peers (Historia del movimiento romántico español, Madrid, Gredos, 1973, 2 vols.), dentro del haz de enjuiciamientos y directrices críticas, algunos estudiosos como V. Llorens o Shaw han llamado "reacción antirromántica» (véanse, por ejemplo, D. L. Shaw, «La reacción antirromántica en España», en D. T. Gies (ed.), El romanticismo, Madrid, Taurus, 1989, pp. 242-251; V. Llorens, "La reacción antirromántica», en El Romanticismo español, Madrid, 1979, pp. 535-539; o H. Juretschke, «La reacción contra el Romanticismo liberal», en Origen doctrinal y génesis del romanticismo español, Madrid, 1954, cap. 4) a esta postura hegemónica que otros, como Ph. W. Silver (Rutinan y restitución: reinterpretación del romanticismo en España, Madrid, Cátedra, 1996), vinculan a la admisión de un Romanticismo liberal conservador ligado al proyecto de centralismo político, mientras que D. Flitter (Teoría y crítica del romanticismo español, Cambridge University Press, 1995), a partir del análisis de los principales juicios teóricos y críticos de la época, considera más bien el triunfo de su variante conservadora, el Romanticismo histórico, que arraigó en la crítica literaria española de los años treinta y cuarenta y mantuvo largamente su vigencia.

154 Véanse sobre todo su panorama «La Historia de la Literatura española en el XIX (materiales para su estudio)", El Gnomo, n. ${ }^{\circ}$ 5, 1996, pp. 151-183, guía referencial de documentación; su artículo "Algunas consideraciones del canon literario durante el siglo XIX", Ínsula, n. ${ }^{\circ}$ 600, dic. 1996, pp. 14-16; así como sus consideraciones en tanto historiador de la literatura en torno a las propuestas, hasta la actualidad, de presentación en diacronía de esta materia ( La historia literaria, toda problemas", en Historia literaria/Historia de la literatura..., pp. 67-85), recopiladas también en La literatura en su historia, ob. cit., pp. 19-35. 
cabe añadir además la atención que se ha venido dispensando a la retórica - en tanto marco conceptual y discursivo en el que primero surge la reflexión sobre los modelos y el concepto de canon ejemplar-, ${ }^{155}$ a sus mecanismos de organización, selección y disposición de la materia así como a la indagación en las nociones historiográficas que desarrolla y propaga la disciplina. ${ }^{156}$ En convergencia con estos fundamentos, el estudio de la literatura española en Francia se incardina asimismo en el seno de otras corrientes de gran pujanza como el historicismo, el valor de las expresiones literarias y artísticas como reflejo del grado de civilización - y en tanto búsqueda del marco social idóneo para la moderna expresión cultural—; ${ }^{157}$ la consiguiente relativización —al menos aparente- de los cánones, el nacimiento del comparatismo, la revitalización de conceptos estéticos a finales del XVIII como la apología definitiva de la originalidad ${ }^{158}$ y de acepciones privilegiadas de longevos criterios de enjuiciamiento ético-literario como el genio, el entusiasmo, lo pintoresco, la imaginación creadora, o el auge de lo sublime de larga tradición tan influyente desde Burke; ${ }^{159}$ la vigencia de la inveterada teoría de los climas aplicada al análisis de las diferencias entre naciones - convertida pronto en un lugar común a partir de su consagración por la autoridad de Dubos, Montesquieu en L'Esprit des lois y Buffon

155 Véase, sobre todo, J. M. ${ }^{a}$ Pozuelo Yvancos y R. M. ${ }^{a}$ Aradra Sánchez, Teoría del canon y literatura española, Madrid, Cátedra, 2000.

156 El equipo dirigido por L. Romero Tobar y subvencionado por el Ministerio de Ciencia y Tecnología dentro del Plan Nacional de Investigación Científica, Desarrollo e Innovación Tecnológica ( ${ }^{\circ}{ }^{\circ}$ de referencia: BFF2002-03401) está llevando a cabo la elaboración de un diccionario de términos historiográficos. Sus colaboradores proceden de diversos centros universitarios: los profesores de la Universidad de Zaragoza Jesús Rubio, Ángeles Ezama, Enrique Serrano y Daniel Mesa; los profesores Rafael Alarcón (de la Universidad de Jaén), Pilar Vega y Fermín de los Reyes (de la Universidad Complutense) y Rosario Álvarez (de la Universidad de Oviedo); y los becarios Marta Marina, Antonio Martín, Elisa Martínez y Soraya Sádaba.

157 La influencia de las instituciones sociales en la literatura, apuntada por De Maistre, se difundió ampliamente a partir de presupuestos contrarios a este último, desde el círculo de Coppet, como, por ejemplo, la aplicación de De Barante a su Tableau de la littérature française au XVIII siècle (1809).

158 R. Mortier (L’originalité. Une nouvelle catégorie esthétique au Siècle des Lumières, Ginebra, Droz, 1982) ha analizado el surgimiento de este nuevo valor en el XVIII y su transformación positiva a comienzos del XIX, contemporánea de los primeros juicios que sobre la literatura española vamos a abordar.

159 A. Becq, Genèse de l'esthétique française moderne. De la Raison classique à l'Imagination créatrice. 1680-1814, París, Albin Michel, 1994. 
en su Histoire naturelle, y del definitivo impulso de Mme de Staël en De la littérature considérée dans ses rapports avec les institutions sociales (1810)_; la autoridad a principios del XIX de Voltaire ${ }^{160}$ y Marmontel (Éléments de littérature, 1786), secundados también por el influyente Cours de Littérature de La Harpe, y la impronta clasicista de críticos e historiadores franceses - sancionada por las directrices cohesionadoras de la Academia Francesa en torno a las lecciones de los grandes modelos del panteón francés consagrados como valores universales-, que subyace a la lenta asimilación del romanticismo schlegeliano. Por esos cauces heterogéneos discurre con renovado impulso entre el lectorado francés la difusión de las culturas ajenas como contrapunto a la propia, cuyas vías de transmisión conocidas - los salones, los viajes, las correspondencias, las traducciones o el desarrollo de la prensa periódica, entre otras - se ven reforzadas por la paulatina institucionalización de su estudio. No obstante, la fundación de las cátedras de literaturas y lenguas extranjeras por la ordenanza oficial dictada en 1838 por el ministro Salvandy — primer intento de creación de una ciencia de lo extranjero- no se orienta tanto como base para un análisis erudito y filológico, sino en función del reparto utilitarista de áreas y especificidades culturales, según apunta M. Espagne. ${ }^{161}$ Esta oficialización propicia asimismo la investigación y revalorización de su pasado y, frecuentemente, por reacción especular, su reafirmación nacionalista a través del exaltado protagonismo de una Francia cosmopolita y conquistadora, abanderada del progreso civilizador, en la estela de la proclama de Guizot sobre la condición histórica de su país como encrucijada geopolítica y cultural de Europa.

Difundida por los contertulios de Coppet, la capital importancia del factor histórico-social e incluso político sobre el fenómeno literario impregna indeleblemente el enfoque de los estudios franceses y su recepción de los extranjeros. Agotadas las propuestas del postclasicismo, en crisis el modelo socio-político del Antiguo Régimen, atacados los dioses tute-

160 Traducido no solo como referente literario, sino también por su significación ideológica dentro de las motivaciones y parámetros de la situación española, ejerció también gran influencia a este lado de los Pirineos desde la segunda mitad del XVIII. Véase F. Lafarga, Voltaire en España (1734-1835), Edicions de la Universitat de Barcelona, 1982.

161 "Dans la tension entre une recherche des origines linguistiques et littéraires des peuples voisins et un effort pour les plier au moule du classicisme français se joue la construction idéologique de la notion de peuple et de nation européenne» (M. Espagne, ob. cit., p. 17). 
lares del panteón francés, el comparatismo cultural en Francia, a la vez que dilata las fronteras del canon europeo, fomenta la búsqueda de su propia afirmación como literatura nacional reivindicando la sociabilidad francesa y, bajo la égida de la Academia, la imitatio re-creadora y original a imagen de la abeja clásica. Esta fragmentación de la moderna República de las Letras en literaturas septentrionales —representadas por anglosajones y alemanes, encarnación estos de la otredad para el imaginario francés del XIX, como señala Espagne- - y meridionales de estirpe latina, ${ }^{162}$ de entre las que la italiana ${ }^{163}$ parece recibir una más cálida acogida que la española — asimilada en el ámbito peninsular hasta principios del XIX a la portuguesa en algunos autores_-, ${ }^{164}$ sigue vertebrando fructuosamente la elabo-

162 Desde la reivindicación europea de la literatura provenzal medieval por Fauriel —y, a través de él, de la mediación francesa - como canal de expresión del genio moderno, numerosos compatriotas suyos van cediendo a lo largo del XIX en su defensa de la primacía latina frente al germanismo emergente y la alianza de las naciones del norte de Europa. Esta pugna latente, que cruza el siglo y convive con los postulados ecuménicos de Ranke a mediados de siglo en pro de una fusión paneuropea cuyos primeros frutos se reconocen en la comunidad intelectual del continente, se irá inclinando, tras precursores como los catedráticos de los años cuarenta, a favor de las pujantes culturas septentrionales, como constata finalmente Tannenberg («Nous ne croyons plus à la supériorité si longtemps incontestée du génie latin, et notre curiosité est plutôt éveillée par les littératures du Nord, slaves et germaniques, si originales, si différentes de la nôtre, et où nous espérons trouver une autre conception de la vie, quelques-uns peut-être un évangile nouveau», ob. cit., 1903, pp. viii-ix).

163 En L'Homme du midi et l'homme du nord del suizo Charles-Victor de Bonstetten, otro de los asiduos de Coppet, el país representante de las regiones meridionales es Italia, aureolada de un veterano prestigio. Su autor concede la palma a las civilizaciones del Norte - tendencia progresivamente generalizada entre los estudiosos e historiadores franceses, salvo voluntariosas vindicaciones aisladas como la de Baret (1863), afín al régimen bonapartista- y señala que las divergencias entre las razas, pueblos, regiones y culturas latina y germánica se deben ante todo al clima, que se refleja en las diversas ramas de la civilización desde la agricultura, las relaciones del hombre con la naturaleza y su explotación hasta la moral, la educación, la vivencia de la religión, del amor y la intelectualidad, como la literatura y las artes. Esta obra alcanzó bastante popularidad, como reflejan su temprana traducción al alemán (1825) y alguna refutación, mientras que la traducción inglesa fue más tardía (1864). Según M.-L. Herking (Charles-Victor de Bonstetten (1745-1832). Sa vie, ses œuvres, Lausana, Imprimerie La Concorde, 1921), la obra habría sido terminada en 1812, pero no sería hasta 1824 cuando se publicaría en francés, para ser reeditada en 1826 .

164 Si bien cabe señalar dentro de los estudios extranjeros en la Francia del XIX la progresiva disgregación de estas literaturas en la extrema frontera meridional europea, la ligazón peninsular entre las dos nacionalidades literarias por su contigüidad geográfica y afinidades históricas queda de manifiesto en diversos ejemplos de las primeras décadas: así, el 
ración de opúsculos, manuales e historias literarias a lo largo de la centuria. Bajo la influencia de la nueva potencia intelectual alemana - exportadora de las teorías de la nacionalidad, la búsqueda de los orígenes y de los modernos métodos filológicos e historicistas aplicados al análisis de las literaturas nacionales ${ }^{165}$ —, el estudio de la literatura española - limítrofe y ex-céntrica, periódicamente soslayada, innegablemente influyente en el pasado y paradigma de enraizamiento popular - adquiere indirectamente el valor de piedra de toque para acotar, afirmar y salvaguardar las cualidades identitarias de la literatura francesa, durante un período de canonización de sus propios modelos clásicos. A su vez, sustentada en su preeminencia geopolítica e irradiación cultural, la vieja aspiración francesa a mantener su primacía como eje catalizador europeo no será ajena a la fundación de los organismos hispano-franceses del XX en un esfuerzo por equilibrar las fuerzas en litigio en el continente.

Los orígenes del hispanismo se remontan a las investigaciones de los sabios españoles del siglo XVIII que sentaron las bases de la historia litera-

primer ensayo francés sobre la historia de la literatura española (1810), aunque consciente de la diferencia entre ambas, trata brevemente de los autores portugueses anteriores al XVI aludiendo a una unidad cultural en la Península - herencia asimismo de los esfuerzos de integración y atención a la pluralidad por parte de los eruditos y estudiosos del XVIII, como recalcó Ávarez Barrientos ( «Nación e historia literaria a mediados del siglo XVIII en España", en L. Romero Tobar (ed.), Historia literaria/Historia de la literatura, 2004, pp. 101114)_; o también, por citar algunos más, los vindicativos estudios del español exiliado Álvaro Agustín de Liaño (Répertoire portatif de l'Histoire et de la Littérature des nations espagnole et portugaise, Berlin, Nauck, 1818, o sus Observaciones y noticias curiosas sobre la literatura castellana y portuguesa, continuación en español de la anterior, y editada en Aquisgrán y Leipzig, 1829-30). La disposición de la obra prometida por su autor comprendía en conjunto cinco partes, en las que se ofrecerían distintos extractos y documentos fidedignos ilustrativos de la historia general de ambas naciones, así como la de su literatura, su religión y sus supersticiones en sus respectivas provincias, colonias y administraciones, acompañados de notas biográficas de sus hombres célebres y de sus escritores, una bibliografía y una crestomatía variada de los diversos géneros.

165 Para un panorama más preciso de la evolución epistemológica de la historiografía véanse M. Garrido Palazón, "La evolución de la historiografía literaria románica», 1994, pp. 85-119; M. Werner, "À propos de l'évolution historique des philologies modernes. L'exemple de la philologie romane en Allemagne et en France», en M. Espagne y M. Werner (eds.), Philologies. I. Contribution à L'histoire des disciplines littéraires en France et en Allemagne au XIX siècle, París, Éditions de la Maison des Sciences de l'homme, 1990, pp. 159186; y en especial el estudio de F. Baasner sobre la historia de la historiografía española, Literaturgeschichtsschreibung in Spanien von den Anfängen bis 1868, Fráncfort del Meno, M. Vittorio Klostermann (Analecta Romanica, n. ${ }^{\circ}$ 55), 1995. 
ria española concebida nítidamente como ciencia a fines de ese siglo. ${ }^{166} \mathrm{La}$ labor ingente de estos eruditos en su tierra natal y en el exilio, como es el caso de los jesuitas expulsos, constituye el pilar fundamental — tanto en concepción organicista como en determinados criterios, periodizaciones, teorías y ciertas revaloraciones autoriales y genéricas también exportadas al extranjero- en el que se afianzan los pasos del hispanismo alemán, el más constante, riguroso y entusiasta de entonces, en la vanguardia cultural de la época, y, tras sus huellas, el resto de estudiosos europeos. Paralelamente a la reorganización del Estado, los estudiosos españoles — encabezados por un Mayans de prestigio europeo y animados por la defensa patriótica de los valores culturales españoles ${ }^{167}$ — van reestructurando el "canon roto» heredado, en expresión de Mainer. ${ }^{168}$ Tras las diversas etapas de recrudescencia en las tensiones ideológico-estéticas — que reactivan asimismo oposiciones añejas como genuino/foráneo, a la que se superpone la pareja culto/popular, ${ }^{169}$ reactualizadas en la crítica decimonónica en torno al concepto evanescente de espíritu nacional—, se dará paso a otra de consenso, en palabras de Checa, ${ }^{170}$ que sobrevive en la centuria siguiente bajo sus propias tensiones como un canon mixto ${ }^{171}$ cuyo eclecticismo crítico,

166 Véase particularmente el estudio de conjunto de J. Álvarez Barrientos y A. Mestre, «Orígenes de la Historia de la literatura española», en G. Carnero (coord.), Historia de la literatura española. Siglo XVIII (1), Madrid, Espasa-Calpe, 1995, pp. 108-136.

167 Véase, por ejemplo, Álvarez Barrientos, art. cit., en Historia literaria/Historia de la literatura..., 2004.

168 "La invención de la literatura española», art. cit., p. 25.

169 J. M. ${ }^{a}$ Pozuelo Yvancos, "Popular/culto, genuino/foráneo. Canon y teatro nacional español», en J. G. Maestro (ed.), Theatralia III. Tragedia, Comedia y Canon, Universidad de Vigo, 2000, pp. 235-260.

170 J. Checa Beltrán, «En busca del canon perdido: el siglo XVIII», Studi Ispanici, 2002, pp. 95-115. A partir de los años ochenta las dos corrientes, la conservadora y nacionalista y la crítica, filosófica y rupturista, ya firmemente definidas, constituyen las bases de la revisión transmitida a sus sucesores. Así concluye el autor: "gracias al mayoritario acuerdo en torno a una poética común se perfiló un canon integrador, donde cabía lo barroco, lo medieval y lo popular, y además no faltaba la saludable discusión sobre la canonicidad de autores contemporáneos y sobre la oportunidad de una literatura "comprometida". Esta fue la base que propició la historia nacional de la literatura diseñada en los años siguientes» (p. 115).

171 Refiriéndose a la perspicacia con que Larra anticipó los derroteros por donde se encauzará el ambiente cultural de décadas posteriores, Mainer apunta: "por un lado, impulsó la elaboración de un canon de literatura utilitario y amplio, menos dictado por la hegemonía de las obras de imaginación que por la presencia de aquellos textos reveladores 
partícipe del discurso político, el estudio histórico y la creación artística, le garantiza un notable arraigo.

A fines del XVIII los estudios disponibles en Francia para trazar la historia de las literaturas nacionales aún se subsumían en los anchurosos límites de la erudición enciclopédica — de difícil acceso para la mayoría de lectores profanos (les gens du monde)—, que comprendía Bibliotecas, diccionarios biográficos, colecciones de memorias y disertaciones presentadas en las diversas academias, y los sólidos y áridos trabajos eruditos de los benedictinos de Saint-Maur (Histoire littéraire de la France, París, chez Osmont, 1733-1763), vasto ejemplo sistematizador — continuado por el Institut de France- cuyos esfuerzos solo llegaron a mediados del XII. Con el correr del tiempo, el listado bibliográfico de los manuales e historias editados en Francia, acrecentado conforme avanzaban los estudios, no solo alberga entre sus fuentes los principales hitos de la erudición del XVIII - prolífico en voluminosas historias literarias y compendios, cuyo cultivo es el más ensalzado de ese período por los historiadores del XIX-, pertenecientes a diversas fases de las enconadas polémicas entre sí y con franceses e italianos — como Quadrio, Tiraboschi, Bettinelli o el aún citado Signorelli-: desde las reediciones de la enciclopedia de Nicolás Antonio o la labor ingente de Mayans ${ }^{172}$ hasta el período finisecular con la obra del gran educador Sarmiento, la ambiciosa historia de los hermanos Rodríguez Mohedano, ${ }^{173}$ la inexcusable Storia d'ogni letteratura del jesuita Juan

de la substancia histórica del país; por otro, instaló en el centro de ese canon una visión crítica y hasta negativa de buena parte de ese pasado y subrayó la difícil coincidencia de la época de la tiranía y del fanatismo con la época de los más admirados frutos del arte nacional» (art. cit., p. 36).

172 Tras las bibliografías nacionales de García Matamoros Pro adserenda hispanorum eruditione de 1553 (reeditada en 1736 y 1769), Escoto o Taxandro, citados en repertorios como Lefranc, pervive la autoridad erudita de la Bibliotheca hispana vetus (Roma, 1672) y la Bibliotheca hispana nova (Roma, 1696) de Nicolás Antonio - la primera, reeditada en 1788 con notas de Bayer y la segunda entre 1783 y 1788 - ; J. Rodríguez de Castro (Biblioteca española, Madrid, 1781-86), Bernardo de Iriarte (Catálogo de los manuscritos griegos, Madrid, 1769), las obras de Mayans y Siscar, además de los mencionados J. A. Álvarez y Baena, J. B. de Rossi, Viera y Clavijo, Lapagna y alguna inclusión de Forner.

173 De propósito totalizador y exhaustivo - y forzosamente inconclusa-, su Historia literaria de España desde su primera población hasta nuestros días; origen, progresos, decadencia y restauración de la Literatura española... Madrid, Imprenta de Antonio Pérez de Soto, $1766-91$. 
Andrés ${ }^{174}$-monumento intelectual español, consagrado como libro de texto de la efímera y adelantada cátedra de San Isidro de 1786-, la disertación de Sempere y Guarinos, ${ }^{175}$ la apologética nacionalista de Lampillas, ${ }^{176}$ o el importante Capmany; ${ }^{177}$ también allega ensayos como el atribuido a Malmontais (1810) — aún recordado en la segunda mitad de siglo-, las nuevas historias de Bouterwek y Sismondi, relevadas por Ticknor; antologías, artículos y estudios de la emigración española y de los afincados en el reino, desde la colección de Ramón Fernández a Quintana, Mendíbil, Maury, Marchena u Ochoa, o la empresa divulgadora de la Biblioteca de Autores Españoles, ${ }^{178}$ hasta las enriquecedoras notas filológicas y eruditas de los traductores de Bouterwek, Cortina y Hugalde y Mollinedo - que conforman una historia complementaria-, la labor de Böhl de Faber o Durán, o las también citadas notas en apéndice del Arte

174 Dell'origine, progressi e stato attuale d'ogni letteratura, Parma, Stamperia Reale, 1782 y 1799, 7 vols. Traducido por su hermano Carlos bajo el título Origen, progresos y estado actual de toda la literatura, Madrid, Antonio de Sancha, 10 vols., 1784-1806.

175 Ensayo de una biblioteca de los mejores escritores del reinado de Carlos III, Madrid, Imprenta Real, 1785-89.

176 Saggio storico apologetico della Letteratura Spagnola contro le pregiudicate opinioni di alcuni moderni scrittori italiani, Génova, Felipe Repetto, 1778-81; Ensayo histórico-apologético de la Literatura Española contra las opiniones preocupadas de algunos escritores modernos italianos, traducido por Josefa Amar y Borbón, Zaragoza, 1782-84; Madrid, Gabriel de Sancha, 1783.

177 Su Filosofía de la elocuencia y sobre todo su Teatro histórico-crítico de la elocuencia española (Madrid, Sancha, 1786-1794), importante antología esta última, muy recurrente en las bibliografías de los estudiosos franceses, que aborda, como contrapunto a la colección de Sedano, la prosa de pensamiento española desde el punto de vista del estilo modélico de los siglos XVI y XVII.

178 Por ejemplo, la Colección de Ramón Fernández en su edición de 1804; las analectas de Quintana (Poesias selectas castellanas, Madrid, 1807, 1829-39; Parnaso español, selección desde la época de Juan II hasta mediados del XVIII, o su Tesoro del Parnaso español); la antología escolar de P. de Mendíbil y M. Silvela (Biblioteca Selecta de Literatura Española, o modelos de Elocuencia y Poesía, tomados de los escritores más célebres desde el siglo XIV hasta nuestros dias, y que pueden servir de lecciones prácticas a los que se dedican al conocimiento y estudio de esta lengua, Burdeos, Imp. de Lawalle Joven y Sobrino, 1819, 4 vols.); las de Maury, Andrés Muriel o Marchena (Lecciones de Filosofia Moral y Elocuencia, o Colección de los trozos más selectos de Poesía. Historia, Religión y Filosofia Moral y Politica de los mejores autores castellanos. Puestas en orden por Don Jose Marchena. Antecede un Discurso preliminar acerca de la Historia Literaria de España y de la relacion de sus Vicisitudes con las Vicisitudes Politicas, Burdeos, P. Beaume, 1820); además de la infatigable labor editora de Ochoa. A propósito de la investigación del exilio inglés véase también V. Llorens, Liberales y románticos. Una emigración española en Inglaterra (1823-1834), Madrid, Castalia, 1979. 
poética (1827) de Martínez de la Rosa, hasta Amador de los Ríos y Menéndez Pelayo; incorpora diccionarios, compendios biográficos y gramáticas; ${ }^{179} \mathrm{y}$, atendiendo al lectorado interesado, acude asimismo a observaciones registradas en libros de viajes — como los más frecuentados del diplomático Bourgoing y de Laborde, ya citados, de Quinet o de Blanqui secundariamente, y de ingleses tan difundidos como Ford, entre otros, junto a reediciones de contemporáneos del esplendor político español—, ${ }^{180}$ y a traducciones de las obras españolas como la colección de Ladvocat, recurrente aún a finales de siglo y acompañada de nuevas contribuciones. Este fondo bibliográfico que comprendía asimismo las principales obras recientes de investigación sobre su historia ${ }^{181}$ y su literatura, procedentes de las diversas áreas europeas, se vuelve accesible gracias a su difusión no solo en la prensa periódica, ${ }^{182}$ sino también en sus tra-

179 Fruto del trabajo filológico auspiciado por la Academia Española y de su labor reeditora de textos clásicos, españoles y grecolatinos, se señalan las ediciones de la Gramática de Nebrija, A. Morales, B. de Aldrete (Del origen y principio del romance), junto con aportaciones más recientes como las de Chalumeau de Verneuil y Núñez de Taboada, cuyo diccionario es nombrado junto a los de Sobrino, Gattel, Capmany y Hamonière.

180 Antes de la mención esporádica de Blanqui (Voyage à Madrid, París, DoudeyDupré, 1826) son más frecuentadas las citas de Ford (Handbook for Travellers in Spain and Readers at Home, Londres, Murray, 1845) o Quinet (Mes vacances en Espagne, París, Chamerot, 1843), cuyos juicios y documentación son más tenidos en cuenta que la comprensión estética del paisaje y el patrimonio artístico y vital del importante Voyage en Espagne de Gautier, generalmente orillado. En ocasiones también se invocan otros relatos de viajeros extranjeros del XVII como el muy reeditado de Mme d'Aulnoy, Relation du voyage d'Espagne (1691), aún reimpreso en fecha tan tardía como 1874, antes de la edición crítica de Foulché-Delbosc.

181 Por ejemplo, junto a las Recherches sur l'Histoire politique et littéraire de l'Espagne pendant le moyen âge (Leiden, 1849) de R.-P.-A. Dozy, los estudios históricos de W. H. Prescott sobre el descubrimiento de América y la conquista de sus principales imperios indígenas, o los reinados de los primeros Habsburgo Carlos I y Felipe II, y en especial su History of the reign of Ferdinand and Isabella the Catholic of Spain (1838), traducida más tarde al francés (Histoire du règne de Ferdinand et d'Isabelle, traduite de l'anglais par G. Renson, París, Firmin-Didot frères, fils et Cie, 1861-62); L'Espagne depuis le règne de Philippe II, jusqu’à l'avènement des Bourbons (París, L. Hachette, 1844), versión bastante leída de una de las numerosas obras de Ch. Weiss sobre ese período; o la Histoire des Mores Mudejares et des Morisques ou des Arabes d'Espagne sous la domination chrétienne (París, G.-A. Dentu, 1846) del conde A. de Circourt.

182 En particular, las receptivas revistas culturales Le Globe, la Revue de Paris o la prestigiosa y longeva Revue des Deux Mondes, abiertas al mundo académico, además de otras como, por ejemplo, la veterana Revue Britannique, el Journal des Débats o el Correspondant, que dan cabida con cierta regularidad a los reseñadores de la cultura española. 
ducciones francesas, más frecuentes en la primera mitad del XIX, que ceden su prelación editora ante el adelantamiento significativo de Vedia y Gayangos, y posteriores relevos españoles, si bien más tardíos, en la traslación de estudios alemanes primordiales. ${ }^{183}$ La condición libresca de este vasto repertorio, completado con la correspondencia entre eruditos y bibliófilos, ${ }^{184}$ se impone en el acercamiento a la literatura española entre los historiadores y estudiosos extranjeros de gran parte del siglo. Alejados del dinamismo contemporáneo de la vida cultural española — como el erudito Bouterwek, que consulta la rica biblioteca universitaria de Gotinga, o el cosmopolita Sismondi, que prefiere otras rutas más prestigiosas al igual que Ticknor, un brahman de Boston cuya breve estancia en 1818 dejó poca mella en su experiencia personal y que se aprovisionaba en los fondos suministrados por sus contactos con Gayangos-, frente a la mayor cercanía de periodistas, reseñadores y exiliados franceses examinados e interesados en su estudio - en contacto en mayor o menor medida con sus círculos sociales, políticos y literarios-, los investigadores regularizarán gradualmente sus esporádicas estancias convirtiendo la visita del país en una marca de especialización, institucionalizada finalmente con las misiones pedagógicas y científicas de la III República.

183 No obstante, si bien los hispanisants franceses no desconocen los principales títulos contemporáneos de los estudiosos españoles en su lengua original, la mayor parte de estas obras citadas en sus bibliografías —al igual que otros trabajos conocidos como el influyente Some account of the lives and writings of Lope Félix de Vega Carpio and Guillén de Castro (Londres, 1806) de lord Holland- no suelen ser traducidas: así, ni el Arte poética de Martínez de la Rosa, ni los textos de Lista, ni las monografías de Durán o de Gayangos, ni el manual de Gil y Zárate (1842) mencionado en ocasiones a través de su edición parisina de 1853, o la historia de Amador de los Ríos — varios de cuyos estudios históricos sí fueron trasladados al francés como también, en cambio, las obras filosóficas de los más difundidos Donoso Cortés y Balmes-. Asimismo, tampoco la autoridad de consultadas aportaciones alemanas como, por ejemplo, los Studien zur Geschichte der spanischen und portugiesischen Nationalliteratur (Berlín, A. Asher \& Co., 1859) de F. J. Wolf o el estudio fundamental de Schack - y en menor medida el Manual de Lemcke o las consideraciones de Schmidt sobre Calderón, o de Grillparzer sobre Lope, entre otros-, suscita, tras Schlegel, traducciones francesas.

184 Los estudiosos franceses, críticos y reseñadores de la prensa cultural y eruditos hispanisants, van trenzando progresivamente una red de relaciones con sus colegas españoles que no solo incumbe al cursus honorum de reconocimientos oficiales e ingresos en academias: por ejemplo, en la segunda mitad de siglo cabe citar las correspondencias del catedrático Baret con Milà i Fontanals, o de Morel-Fatio con Menéndez Pelayo (véase Epistolario de Morel-Fatio y Menéndez Pelayo. Prólogo y notas por Enrique Sánchez Reyes, Santander, CSIC, Sociedad de M. Pelayo, 1953). 
Si bien los estudiosos que publican en Francia sobre la literatura española pertenecen a sucesivas promociones generacionales de diversa formación y contexto profesional - bibliotecarios, historiadores, hombres de letras, economistas, polígrafos, profesionales de la enseñanza, abogados-, el marco preferente en el que surgen los trabajos sobre su historia literaria acostumbra a ser erudito o universitario, y, por tanto, orientado primordialmente a la docencia, ya incardinada en un largo proceso de secularización dentro de un vasto y lento programa alfabetizador. A pesar de la implantación de las cátedras de literaturas extranjeras en la década de los años treinta, la indefinición de esta disciplina desde los cursos magistrales de principios de siglo condiciona su desarrollo académico hasta el nacimiento corporativista del hispanismo francés a finales de la centuria. ${ }^{185}$ Esta escasa profesionalización explica asimismo la rivalidad desigual del estudio del español — refugiado en gran parte en las escuelas de comercio sobre todo de las regiones del sur, y relegado en la enseñanza secundaria y universitaria hasta un lento movimiento de expansión finisecular— ${ }^{186} \mathrm{con}$

185 Entre los mecanismos claves que los estudiosos con cierta especialización ponen en práctica para la institucionalización definitiva de su disciplina —en jalones como Burdeos, Toulouse, Montpellier, Lyon, Rennes y París-, constan la organización de sus propios circuitos de contactos con las instancias ministeriales, por una parte, y con sus colegas por el conducto de memorias, monografías y tesis doctorales; la implantación de las agregaciones; la congregación de grupos de estudiantes y la fundación de asociaciones como la Société franco-ibérique de 1879, sustituida por la Société académique franco-hispano-portugaise de Toulouse, que, al favorecer intercambios económicos y culturales, propiciaron al fin la fundación de la primera cátedra, ocupada por Ernest Mérimée, en Toulouse en 1886; a su impulso, los necesarios medios de expresión canalizadores de estos estudios como La Revue Hispanique (1894) y el Bulletin Hispanique (1899), destinado a recoger trabajos y estudios sobre historia y literatura españolas, portuguesa y catalana, y más tarde, Les Langes Néolatines (1906), desgajamiento del anterior, para propagar la enseñanza del español; y gracias a estas pujantes corporaciones se ponen en marcha los cursos de verano en Burgos para afianzar la presencia cultural francesa en España. Véanse Espagne, ob. cit., Niño, ob. cit. y Prost, L'enseignement en France, 1800-1967, París, Librairie A. Colin, 1968.

186 El avezado traductor y funcionario de Instrucción Pública J. G. Magnabal, designado por su superior, el entonces ministro Jules Ferry, para representar a las instancias oficiales francesas durante los fastos calderonianos, trazaba grosso modo en su discurso de 1881, publicado en francés y en español (Aperçu sur l'étude classique des lettres espagnoles en France, Madrid, Imprenta de Aribau y Cía.), el plano de los estudios españoles en la enseñanza francesa reseñando sucintamente el repertorio de orientaciones, trabajos, traducciones y memorias. Así, instaurado en las escuelas primarias y normales de las zonas fronterizas, afianzado en las escuelas de comercio y politécnicas, el español se va expandiendo con las cátedras de institutos en Toulouse, Burdeos y París, acogido en un plan de estudios que 
otras lenguas relativamente privilegiadas como el inglés o el alemán e incluso las lenguas clásicas. Como ha estudiado M. Espagne, la actividad de los docentes de literaturas extranjeras, de formación predominantemente generalista, se inscribe en circunstancias socio-históricas, administrativas y culturales que afectan a su promoción profesional dentro de estrategias de medro universitario, al perfil de su auditorio - heterogéneo, medianamente culto y mundano- y a su metodología, que experimentará una lenta bifurcación entre los conocimientos popularizados y la especialización erudita en el transcurso del XIX. ${ }^{187}$ Afinadas en el ejercicio de las conferencias ${ }^{188}$ y de las reuniones educadoras de las clases rectoras en política, economía y círculos intelectuales, que comienzan a afianzarse en la Restauración y logran su apogeo en el régimen de Julio, las lecciones públicas también conservan en sus comienzos vestigios del prestigioso salón francés en vías de transformación en el seno de la nueva sociedad decimonónica, y en los que la brillantez retórica de los oradores es tanto o más apreciada que los conceptos; asimismo, este discurso se entrecruza con la ideología en exposiciones del género de la elocuencia — tan fortalecido desde la época de la Revolución- ante un público estudiantil contestatario en períodos tumultuosos. ${ }^{189}$ Ante esta diversidad de hábitos, dedicaciones y rigor — según las afinidades e iniciativas personales de estudiosos no siempre incardinados en el cauce universitario-, que subraya el irregular desenvolvimiento de esta disciplina, debemos hablar, como señala Antonio

recorre el mapa francés: desde los orígenes y la Edad Media de su cultura, abordados en los centros de Nancy, Douai, Burdeos y Aix; el Siglo de Oro, en Aix y Poitiers; el XVIII, en Caen y Dijon; así como cursos temáticos en torno a los "romans picaresques», al Quijote, también implantado como libro de texto, o a la analogía comparatista de su dramaturgia con obras maestras del teatro extranjero en Clermont, Douai, Rennes, Nancy, Toulouse y Burdeos.

187 Véanse sobre la situación M. Espagne, ob. cit.; P. Gerbod, La condition universitaire en France au XIXe siècle, París, PUF, 1965; A. Prost, ob. cit.; o también Th. Zeldin, Histoire des passions françaises (1848-1945). Orgueil et intelligence, París, CNRL, t. II, 1978.

188 Véase A. Martin-Fugier, "La formation des élites: les "Conférences" sous la Restauration et la monarchie de Juillet", Revue d'Histoire Moderne et Contemporaine, abr.-jun. 1989, pp. 211-244.

189 Sobre la configuración del mundo estudiantil véase J.-Cl. Caron, Générations romantiques: les étudiants de Paris et le Quartier Latin (1814-1851), París, Armand Colin, 1991. 
Niño, ${ }^{190}$ al menos hasta mediados de siglo, de hispanisants antes que de hispanistas, pues estos autores no formaban parte de ninguna institución constituida para el estudio de la literatura del sur de los Pirineos, por cierto una de las últimas en ser reconocida estatutariamente. Habrá que esperar a los últimos veinte años del XIX para que la puesta al día de los métodos filológicos alemanes en la École Pratique des Hautes Études se imponga definitivamente con una mayor especialización disciplinar.

La autoridad de las primeras historias tutela los estudios posteriores y los resúmenes destinados a la enseñanza, mientras que, por el contrario, las reticencias e innovaciones surgen principalmente de otros ámbitos como la prensa cultural y de nuevas investigaciones eruditas. Pese a refutaciones puntuales, diversos juicios asentados por Bouterwek - el historiador que, antes de Ticknor, pasaba por el más completo entre los extranjeros y que marca la pauta durante buena parte del siglo-, y en menor medida por Sismondi, son largo tiempo repetidos en varias historias y manuales franceses, y a ellos se añadirá la exhaustiva historia del americano — aplaudida en general como la excelente del XIX, auxiliada en bibliografía y notas por Julius, Wolf y por estudiosos españoles como Gayangos o Böhl一, que se adelanta a la monumental de Amador de los Ríos. Sin embargo, cuando a fines del XIX Tannenberg levanta acta de los estudios de los últimos veinte años en España sobre su literatura, ${ }^{191}$ sigue reclamando a los españoles una historia que trascienda la recopilación bibliográfica de los meritorios modelos precedentes y enfoque su materia con los valores del humanismo. Halla tal competencia en dos españoles ya prestigiosos, la Pardo Bazán, dotada de la capacidad y entrega necesarias para llevar a cabo el proyecto

190 El ejemplo más veterano, según afirma Niño (ob. cit., p. 3), aparece en un artículo de Morel-Fatio («Revue Historique. Espagne», Bulletin historique, XIX, 1-IV-1879, p. 167). Véanse también E. Escalier (ob. cit.) y Aubrun («Hispaniste, hispanisant, hispanisme, etc.», Les Langues Néolatines, n. ${ }^{\circ}$ 170-171, sept.-dic. 1964, pp. 3-11) sobre la historia del término. Aún en su edición de 1903 Tannenberg sigue usando el término hispanisant frente al nuevo, aún no incontestablemente generalizado.

191 Pendiente aún la edición textual de sus grandes escritores, tras reconvenirles por su fraseología banal, hipérbole encomiástica y suspicacia nacionalista, Tannenberg juzga olvidables la mayor parte de los trabajos críticos españoles, exceptuando sumariamente en una evaluación retrospectiva, aparte de la formidable producción de Menéndez Pelayo, las introducciones y notas («excellentes quoique un peu vieillies») de Quintana a su antología, algunas páginas sugerentes de Durán, varios artículos de Revilla y de Valera — sobre todo su discurso sobre el Quijote - la historia anecdótica, según afirma, del marqués del Valmar sobre la lírica del XVIII, el libro de Milà i Fontanals sobre la Poésie hérö̈co-populaire, «estimé par tous 
que acarició en su día, ${ }^{192}$ y sobre todo su admirado Menéndez Pelayo, ${ }^{193}$ versado en diversas literaturas ${ }^{194}$ — y más capacitado que Ticknor y que Amador de los Ríos por su síntesis entre erudición y crítica, sentido artístico y juicio crítico-, y al que, sin embargo, disuadió la envergadura de la obligada reorganización de la materia. ${ }^{195}$

les romanistes comme un chef-d'œuvre de science et de méthode», junto a los valiosos trabajos de Menéndez Pidal o de Cotarelo sobre el XVIII, discípulos de su reseñado (ob. cit., 1903, pp. 153-154).

192 Así lo indica el crítico: «Ce livre nécessaire, nul n’est mieux préparé qu'elle à l'écrire; nul ne réunit si bien toutes les qualités requises. Le sujet est un des plus beaux qu'on puisse rêver, et il n'en est guère d'aussi neuf. L'ouvrage de Ticknor, que l'on n'a pas surpassé, ne nous satisfait plus. Le Manuel de Fitz-Maurice Kelly n'est qu'un bon manuel. Mme Pardo saurait nous donner une histoire pittoresque, et vivante, sans abus d'érudition indigeste, à la française, de cette riche et originale littérature encore si peu étudiée et si mal comprise» (ob. cit., 1903, p. 309).

193 «Si la littérature espagnole n'a pas été l’objet d'une enquête aussi approfondie que les autres littératures modernes, on voit qu'elle n'en a pas moins suscité des travaux d'érudition parmi lesquels il en est de premier ordre. Ce qui lui a manqué le plus, c'est un vrai critique, joignant à un vaste savoir le goût des idées générales, le sens littéraire le plus exercé et le talent de l'exposition; elle a enfin trouvé en M. Menéndez y Pelayo ce large esprit et ce gran écrivain» (ob. cit., 1903, p. 155).

194 Además de su antología en torno a la evolución de la lírica en España — cuyos penetrantes análisis sobre el arcipreste de Hita, Jorge Manrique o incluso el romancero alaba-, Tannenberg elogia particularmente su singular e inconclusa Histoire des Idées esthétiques en Espagne, en especial sus dos últimos volúmenes, como culmen de su itinerario profesional, por su disposición equilibrada de la materia, su claridad expositiva y la finura de su sentido crítico. En este vasto recorrido por la estética occidental y su influencia en España, desde los griegos hasta Taine, el reseñador destaca entre sus logros, por ejemplo, su demostración del papel innegable de España en el Renacimiento clásico - con la profunda influencia de la viva reacción platónica contra el peripatetismo aristotélico, tan intensa como en Italia; o los sagaces comentarios de escritores y críticos del XVI y XVII sobre Aristóteles y Horacio-; recoge sus matizaciones sobre el ascendiente francés en el XVIII español y su ratificación de la pervivencia de una tradición nacional ininterrumpida que adaptó las aportaciones foráneas, o bien hizo apología de la fórmula teatral propia, restando así alcance a la iniciativa atribuida habitualmente al movimiento romántico divulgado desde Alemania y Francia; y subraya la atención dispensada a los místicos, en la que el autor desistió de ahondar.

195 Tannenberg llega a fantasear con lo que hubiera sido su obra y fama de haber trabajado en Francia en circunstancias más favorables, con un público fiel ya ganado, una casa editorial idónea como Hachette, pudiendo dedicarse a la crítica como Taine o Sainte-Beuve y delegando en otros la recopilación bibliográfica y la revisión de textos. Sobre esta base sólida, hubiera podido presentar más publicaciones de cuidado estilo a la manera francesa, más clara que los eruditos y profundos trabajos alemanes, superiores, no obstante, en calidad crítica. Y, sin embargo, hubo de replegarse a pesar de todo, midiendo sus fuerzas: «Au lieu d'une histoire générale de la littérature espagnole, il préféra ne nous en donner que quelques chapitres. L'évolution des théories littéraires, celle de la poésie lyrique, le théâtre et en particulier l'œuvre de Lope de Vega fixèrent spécialement son attention» (ob. cit., 1903, p. 161). 
La conciencia de este género como narrativa cronológica, sintética y evaluativa que abarcaba por épocas el origen de su literatura, progresos y decadencia y sus causas, en torno a una idea matriz organizadora de la documentación, ya está presente a partir de la labor de Mayans, en estudiosos como Trigueros, que sienta las bases de la historia de la literatura, ${ }^{196}$ los Mohedano o el fundamental padre Andrés. Desde los cursos académicos y las disertaciones comparatistas hasta las colecciones de los generalistas finiseculares, autores como Bouterwek, Ticknor, o Amador de los Ríos en España, asumen declaradamente ese título ${ }^{197}$ conforme a esa concepción global, que, no obstante, los diferentes críticos franceses siguen reclamando a lo largo del siglo. Prueba asimismo del abandono de la condición de poéticas bajo las que se presentaban los análisis literarios, los términos más utilizados para referirse a sus discursos históricos — coadyuvantes o convergentes en las historias - varían a principios de siglo, desde ensayos o catálogos (essai, revue) hasta cursos o cuadros panorámicos (esquisse o tableau, profusamente utilizado en la crítica literaria desde el XVIII con el ejemplo ilustre de Diderot, por ejemplo), que junto a la prudencia de los primeros marbetes revelan su intención de presentar un panorama general de la literatura en su devenir, y muestran en otros casos una relación veterana con las técnicas pictóricas que algunos críticos subrayan en su dis-

196 «Historia literaria se llama la narración y examen de la aplicación y de los progresos del entendimiento humano desde el principio hasta nuestros días. Esta narración abraza igualmente la Historia de las Letras y de los Literatos, que la de los subsidios y obstáculos de aquella: es por lo mismo un estudio accesorio a todos los estudios y a cada uno de ellos; y un utilísimo adorno y auxilio exterior, que no siendo la erudición misma, es un engalamiento de la erudición; y [...] por lo tanto, aunque no hace digno del nombre de sabio al que nada más sabe, $[\ldots]$ pone en estado de ser más docto al que entiende bien una facultad» («Discurso sobre el estudio metódico de la Historia Literaria para servir de introducción a los primeros exercicios públicos de ella», Madrid, Benito Cano, 1790, en J. Simón Díaz, Historia del Colegio Imperial de Madrid, III, Madrid, CSIC, 1959, p. 271).

197 En su introducción de 1844 a su reeditadísima Histoire de la littérature française Nisard distinguía entre "historia literaria» (histoire littéraire) como cuadro de la vida literaria, e "historia de la literatura" (histoire de la littérature) - diferencia no observada en la traducción de Bouterwek, que recurre alternadamente a ambos marbetescomo objeto determinable de estudio, catálogo de reflexión con valor artístico y estético. Véase Clément Moisan, Qu'est-ce que l'histoire littéraire?, París, PUF, 1987, p. 68, citado también en Palazón, art. cit.; y Romero Tobar, art. cit., en Historia literaria..., 2004. 
curso específico, conforme a los descubrimientos de los valores pictóricos de la llamada más tarde escuela española. ${ }^{198}$

La temprana definición de Mayans sobre el cometido del género ${ }^{199}$ halla eco en gran parte de los críticos franceses del XIX, que no renuncian tampoco a la difundida valoración de la literatura como expresión moral de una nación, pues el enjuiciamiento sancionador de la literatura, dictado por un canon estético de gran impronta clásica, constituye un rasgo no derogado por estos estudiosos. Los criterios rectores seleccionados en las historias sobre la literatura española —en las que se transparenta la vieja y difusa demarcación del buen siglo y de los buenos autores - suelen atender a los valores del buen estilo conforme a la retórica clásica y a la influencia ejercida por sus grandes autores, cuyas obras se analizan incorporando ejemplos y notas biográficas, para explicar sus mejores logros y a menudo utilizarlos como documentos de su época histórica. Durante gran parte del

198 La exposición pública de la colección pictórica de Luis Felipe en el Louvre (1838), reunida gracias a la expedición del barón Taylor acompañado de Dauzats y de Blanchard durante la primera guerra carlista aprovechando la desorganización del país, la ingenuidad o venalidad, constituye un hito en la difusión del arte español en Francia, ya apreciado por los generales napoleónicos. Asimismo, el descubrimiento de los Caprichos de Goya se difunde en los cenáculos románticos e impregna el imaginario de escritores, pintores y grabadores, estrechando vínculos entre las diferentes artes creativas y el programa totalizador de estos autores a la hora de aprehender la realidad, así como las caricaturas políticas de la época. I. H. Lipschutz (ob. cit.), por ejemplo, ha estudiado su influencia y la de otros pintores españoles apreciados entonces como Murillo, Zurbarán, Ribera o Velázquez. Ejemplo de la generalización progresiva en estos discursos de las vinculaciones entre distintas artes, Tannenberg recurre en su Espagne littéraire (p. xi) al viejo topos del ingenium sobre el ars, aplicado a la creación literaria española emparejando a dos grandes mitos de su cultura, Velázquez y Cervantes, paradigma este de nuevo, pese a la interpretación reivindicativa de Chasles, de genio ignorante de su propia calidad por su Quijote («ce livre-type de la littérature espagnole, écrit à la diable par un grand génie qui s'ignore, démontre avec évidence la supériorité de l'inconscient sur sa réflexion dans l'obscur travail de l'imagination créatrice», p. xiii).

199 Recuérdese la claridad de la definición normativa de Mayans sobre la historia literaria -inserta entre los "razonamientos distintos de la oración persuasiva» en su Rhetórica de 1757-, que se mantiene sobre todo a principios del XIX en el enfoque de los estudiosos franceses: "La historia literaria refiere cuáles son los libros buenos y cuáles los malos, su método, estilo y uso; los genios e ingenios de sus autores; los medios de promover sus adelantamientos o de impedirlos; los principios y progresos de las sectas eruditas; las Universidades literarias, las Academias y Sociedades de varias Ciencias y el estado de la Literatura en ellas, y el adelantamiento o descuido de las naciones en cada género de Ciencia» (Retórica, 2. a ed., Valencia, por José y Tomás de Orga, 1786, II, p. 501). 
siglo sobreviven asimismo con notable fuerza las construcciones teóricas neoclásicas en arraigadas premisas estéticas que, aunque relativizadas, se consideran universales como lo bello, la apelación a la razón y la primacía del buen gusto dictado desde el centro cultural francés — cuyo modelo de las belles-lettres será sustituido finalmente por el historicismo filológicoy que, en cuanto control racional de la inspiración, con las paulatinas penetraciones del Romanticismo, se refuerza con el concepto revalorizado del genio, como han señalado Sebold o Martínez Torrón. ${ }^{200}$ Por otro lado, siendo la literatura uno de los factores definitorios del carácter de un pueblo, el panorama de la civilización europea se podría trazar a partir del estudio de los productos literarios de sus diversas naciones. Este ideal de una cultura colectiva — presente desde principios del XIX en compendios conformados como una summa enciclopédica de historias de literaturas nacionales desgajadas, y reforzado con la enseñanza de las literaturas extranjeras en torno a grandes temas emblemáticos - se conjuga a su vez con una añorada primacía cultural francesa en Europa que aún prevalece en las colecciones nacionalistas de la III República.

A la luz de la nacionalidad, los historiadores de cada diacronía literaria, además de trazar una sumaria digresión sobre su métrica, suelen resumir las investigaciones empezadas por los ilustrados ${ }^{201}$ sobre los orígenes de su lengua dominante - forjada junto a las costumbres y el carácter patrio por los diversos pueblos agrupados en el solar hispano-, ${ }^{202}$ sobre la pluralidad lingüística peninsular y sus respectivas regiones de influencia

200 Por ejemplo, R. P. Sebold («Romanticismo y Barroco», en Trayectoria del romanticismo español, Barcelona, Crítica, 1983, pp. 43-73) o D. Martínez Torrón (Ideología y literatura en Alberto Lista, Sevilla, Alfar, 1993).

201 El recurrente Sarmiento, entre otros eruditos, consideraba el español o castellano como una lengua romance, y ya trazó los diversos dominios lingüísticos de los dialectos en uso así como, por ejemplo, las zonas de influencia del provenzal y el gallego, y la expansión del castellano sobre el resto de lenguas peninsulares, además de un catálogo de términos de origen árabe, también mentado por los estudiosos.

202 Las fuentes más frecuentadas al tratar de la lengua española — progresivamente admitida por unanimidad como descendiente del latín- son Mayans y Siscar, Sarmiento, Aldrete, Hervás o Erro y Aspiroz, nómina que se va ampliando relativamente a partir de las apuntaciones de Humboldt, por ejemplo — mencionado en especial por sus disquisiciones sobre el vasco, referencia principal entonces sobre esta lengua junto a la gramática de Larramendi-, en los resúmenes preliminares de las historias y disertaciones. 
histórica, registrando ocasionalmente a principios de siglo sus manifestaciones literarias periféricas. Con el asentamiento de las teorías herderianas ${ }^{203}$ se insiste en la antigua identificación entre el carácter nacional, sustentado en el pueblo, y su lengua y literatura respectivas — consagradas a su vez por su período de esplendor pasado- retomando asimismo el mito del "génie de la langue» ${ }^{204}$ de tan larga vigencia. De este modo, la calidad estilística —investida de perfección clásica y a la vez de la pureza, claridad y naturalidad atribuidas a una rica lengua romance en expansión- que, en contra del cultismo artificioso de los epígonos gongoristas, promocionó entre los reformadores del XVIII a los humanistas y escritores del XVI, y aun a los buenos autores del polémico XVII, como modelos elocutivos, se mantiene duraderamente en vigor como criterio de compromiso entre los valores clásicos y la recopilación del acervo popular. De igual manera, se generalizan las introducciones históricas previas a la revisión, catalogación y enjuiciamiento de obras y autores, cuya contextualización, deudora de axiomas liberales de la historiografía contemporánea, incide en rasgos identitarios como la independencia del ser español. Los cortes históricos en los que suelen detenerse, cada vez más detallados — que en ocasiones postulan un alcance supratemporal—, ${ }^{205}$ son en sustancia los mismos,

203 No obstante, los críticos franceses más aferrados a las concepciones clásicas - como Sismondi o la traductora de Bouterwek e incluso Puibusque (1843) — siguen teniendo en mucho la sanción de la Academia respecto al modelo de buen gusto representado por la "partie la plus saine de la cour». Si bien se van imponendo las tesis de Herder, que promueve una transmisión de sentido inverso, emanada del acervo popular, a este haz de ideas se suman otros topoi como la ligazón añeja entre linaje nobiliario y cultivo de las letras, que convive con los argumentos del carácter noble innato de esta lengua.

204 La conformación de cada Estado respondería, pues, a una irresistible tendencia natural, propia de su idiosincrasia, que transparentaría en su lengua. La caracterización del español - cuyo desarrollo culmina en la etapa de esplendor, en que por fin alcanza su decoro y gravedad distintivos - obedece a una serie de topoi desgajados del ser nacional: fruto del choque de las culturas más ricas de Europa y de Oriente, que le confieren sus cualidades de sonoridad, gravedad y majestad elocutiva — heredada del Norte-, y de apasionamiento, pomposidad e incluso jactancia procedentes del legado árabe en el tono y en la sintaxis, su naturaleza contrastaría, por ejemplo, a ojos de los críticos con la aptitud de la lengua francesa para la expresión universal de la filosofía y la ciencia.

205 A este propósito, conviene hacer notar que son numerosos los que hacen arrancar los rasgos nacionales más allá de las fronteras temporales prescritas, es decir, apuntan la existencia de ciertas tendencias naturales entre los autóctonos de la Península, ya desde los autores hispanorromanos - Séneca y Lucano sobre todo- hacia el retoricismo, la hinchazón y el galimatías en el discurso. Por ejemplo, desde el prologuista de Bouterwek, que 
investidos de significación cultural y política como forja de la nacionalidad: desde las invasiones bárbaras, la penetración de los visigodos, la dominación árabe y la lenta expansión de los reinos cristianos hasta su elevación a gran potencia, ${ }^{206}$ el declive y la guerra de la Independencia.

Las tendencias fundamentales que se prolongan hasta fines de siglo en los discursos franceses sobre la literatura española parecen guiarse, pues, por varias perspectivas predominantes: como ejemplo aleccionador para la meditación política o para la reivindicación de una teoría estética como la romántica, o para el ataque solapado contra otra como el realismo o - aunque no tanto en las historias consultadas como en monografías y ciertas publicaciones periódicas de prestigio— ${ }^{207}$ contra el naturalismo.

las observaba tanto en poesía como en elocuencia y solo consideraba ejemplares en hermandad crítica a Quintiliano, maestro de retóricos y pedagogos, y a Cervantes, su equiparable en un salto de siglos, este argumento es ratificado décadas más tarde por Bougeault, que reconoce, junto al atribuido énfasis asiático, el arte de estos escritores formados en el estudio de los grandes modelos (ob. cit., p. 265).

206 Si bien la mayoría de críticos censura la ambición de Carlos V por una monarquía universal y su avidez de tesoros y conquistas, y condena el ejercicio de poder de sus sucesores, como resume Bougeault a fines de siglo («Après avoir pressuré les peuples par de lourds impôts, épuisé les trésors de l'Amérique, sacrifié la fleur de ses populations dans de longues et cruelles guerres d'ambition, expulsé les Mores industrieux et paisibles, elle [España] tomba dans une sorte de marasme, de décadence politique et intellectuelle dont elle n'a pu se relever jusqu'à nos jours", ob. cit., p. 304), desde principios del XIX la opinión general suele bifurcarse en los periódicos debates sobre la significación histórica española, entre los que extienden la responsabilidad en mayor o menor medida a sus súbditos por su excesivo orgullo y un receloso misoneísmo, y los que los exculpan como sufridas víctimas de sus gobiernos autoritarios. Por ejemplo, frente a las reticencias de Sismondi, Schlegel absuelve al pueblo de las demasías y la corrupción de sus gobernantes. Al igual que en Europa su fulminante expansión lo habría obligado a ceder su libertad y doblegarse ante la política tiránica de Felipe II, atrayéndose injustamente el odio de las demás naciones; de igual modo, el alemán lo redime de sus cuentas con las provincias ultramarinas vindicando sus hazañas en tierras americanas («Des traits isolés de cruauté et d'avarice ont souillé la gloire de l'héroïsme le plus réfléchi, mais la nation ne fut pas atteinte par la corruption. Nulle part l'esprit chevaleresque n'a survécu, autant qu'en Espagne, à l'existence politique des chevaliers, et longtemps encore après que les fautes de Philippe II eurent diminué le bonheur ainsi que l'influence politique de son pays, cet esprit anima la littérature espagnole, et en marqua l'époque la plus florissante de son sceau particulier»).

207 Por ejemplo, en 1903 Tannenberg ensalza la resistencia de la literatura española, sana y viril en conjunto, a los excesos de un naturalismo descarnado y sensual — pese a los ensayos de jóvenes autores que no precisa-. Al invocar la oportunidad inspiradora del conocimiento de esa desconocida literatura fronteriza para revigorizar la creación francesa, asoman en sus valoraciones viejas líneas maestras de más de un siglo de antigüedad en las 
Esta instrumentalización ideológica o estética deja entrever en ocasiones cierta vehemencia combativa que se infiltra en los juicios de valor que llegan hasta las colecciones finiseculares. El enfoque filosófico de historia de la civilización en el que se subsume el estudio de la literatura como una parte de la cultura global, ${ }^{208}$ deudor del modelo filosófico sensualista de la "ciencia del hombre», predomina en los discursos franceses sobre la historia de esta literatura. En la primera mitad de la centuria España aparece ante todo como un modelo negativo, la advertencia ejemplar de una experiencia fallida, sometida a la evaluación del filósofo y del estadista evocados por Stapfer, introductor de Bouterwek en Francia: ${ }^{209}$ el primero

relaciones literarias franco-españolas: si bien la España contemporánea no aporta ideas nuevas, sino "sensations littéraires précieuses et inattendues», se promueve la selección de «œuvres fortes et originales» — cualidades infrecuentes entre los franceses, cuya cuidadosa técnica contrasta sobre todo con la espontaneidad inventiva de los españoles-, y cuya moralidad se alaba, como se hiciera a fines del XVIII y principios del XIX, frente a las inglesas contemporáneas.

208 Esta perspectiva también rige, por ejemplo, el referido Répertoire portatif de Liaño, cuyo prólogo expone el plan de esta compilación ilustrada bajo el patrocinio de la verdad, la razón, la imparcialidad y la utilidad («je ne perds jamais de vue les grands intérêts de la société, ceux du cœur humain, la religion, l'équité, la morale, et dans un recueil où certains lecteurs croiront trouver l'esprit des siècles superstitieux et barbares, tout sera consacré à la cause vraiment sainte de la raison et de ses progrès»). Contrario a la superstición como a la irreligiosidad, partidario del trono y defensor de Ureña, Quiroga y Almodóvar frente a otros más radicales y ultramontanos, admirador de Martínez Marina y de los Ocios de espanoles emigrados, varias de cuyas teorías insertas lamenta, este historiador y crítico, entonces agregado de la Biblioteca Real de Berlín - para la que procuró hacer acopio de documentos como, por ejemplo, los manuscritos de la Inquisición que le había dejado su amigo el canónigo Llorente- , dirige su obra al colectivo erudito de «'Europe savante». En su proyecto de 1820 (p. v) de presentar una gran «Bibliothèque espagnole et portugaise» de sus respectivas literaturas, desglosa partes de un proyectado plan heterogéneo — definido como colección miscelánea que no hemos logrado encontrar-, comprendiendo no solo un ensayo preliminar, materiales extractos de libros españoles, memorias para la historia de las reinas de ambos países y estudios sobre antigüedades y numismática, sino además una tercera parte dedicada a noticias sobre escritores, documentos para el estudio de la historia de ambas naciones, y finalmente una cronología histórica hasta la muerte de Carlos III y del príncipe del Brasil.

209 «L'homme qui, dans l'histoire littéraire d'une nation, aime surtout à observer la réaction qu'ont exercée mutuellement les uns sur les autres les événemens et les lettres, l'état politique et la direction des études, les entreprises sociales et la culture de l'esprit, les mœurs et les lumières, trouvera dans celle d'Espagne une marche concordante de phénomènes moraux et littéraires, qu'il chercherait vainement ailleurs, des points de vue aussi lumineux que féconds en applications instructives, et, presqu’à chaque page, des problèmes plus intéressans à méditer que difficiles à résoudre. On peut dire que nulle part le littéra- 
podría observar la oposición en materia de gusto de su literatura a los principios de las autoridades grecolatinas, modelos estéticos y guías intelectuales, y el segundo reflexionar acerca del daño irremisible de los sistemas de administración despóticos sobre el progreso moral, industrial y cultural de una nación. Esta interrelación entre organismos de poder, ideología y literatura cobra un declarado protagonismo en los estudios posteriores, dispuesta en torno a los polos de progreso y reacción, compensando relativamente esa primera negatividad con la inserción de los votos por una prometida regeneración literaria y estatal - ya explícitos en el cierre esperanzador $^{210}$ de Luis José Velázquez en sus Orígenes de la Poesía Española (Málaga, Aguilar, 1754)—. Para encabezar este relevo — paulatinamente diferido por la crítica del XIX- se invoca desde el XVIII ${ }^{211}$ una voz poética y crítica —e incluso más tarde declaradamente ideológica— que, a imagen de Molière o también de Voltaire, guíe a partir de buenos ejemplos los derroteros de la dramaturgia, primero, y, paulatinamente en el curso de la centuria siguiente, del resto de géneros literarios. Si en sus análisis retrospectivos los estudiosos franceses hacen resaltar, por ejemplo, la singularidad aislada de Juan Ruiz en su tiempo, van desestimando la influencia de un desorientado Mena o un Santillana, suelen reconocer la excelencia de Garcilaso y sobre todo de Fray Luis, o proclaman el buen juicio de un Cervantes desoído frente a la influencia arrolladora de un Lope y el ascendiente desestabilizador de Góngora, la ambivalencia de Quevedo, el buen

teur philosophe ne verra une contre-épreuve plus évidente des principes que les Grecs ont proclamés et suivis en matière de goût, ni l'homme d'état des leçons plus frappantes de vérité sur le mal irréparable que les systèmes d'administration, fondés sur l'égoïsme et sur la défiance, font non-seulement à l'industrie et au bien-être des nations, mais encore à leurs facultés morales et aux arts mêmes qui embellissent la vie et en allègent les peines. Nulle part la providence n'a écrit en caractères plus lisibles, que la crainte des lumières éteint le flambeau de la raison et de la vérité; que le rétrécissement de l'esprit amène celui du cœur; qu'il paralyse les caractères les plus vigoureux, et qu'il tarit les sources les plus abondantes des talens et du génie» (Histoire de la littérature espagnole, traduite de l'allemand de M. Bouterwek, professeur à l'université de Gottingue, par le traducteur des lettres de Jean de Muller (Mme de Streck, avec une préface par M. Stapfer, d'après Barbier), París, chez Renard, Pauline, frères Michaud, t. I, 1812, pp. 7-8).

210 Como cierre de su ensayo ya encarecía los esfuerzos de las instituciones culturales como la Real Academia Española, «de cuyo zelo puede la nacion esperar, que la Poesia Castellana bolverá a ponerse sobre el buen pie, en que estuvo en su siglo de oro» (ob. cit., p. 174).

211 «Quando la Nacion logre un genio tan superior como el de este gran Comico [Molière], podrá esperar, que se restablesca la Comedia Española» (Velázquez, ob. cit., p. 118). 
sentido de Luzán luego condenado como yerro, el magisterio de Moratín, o la autoridad de un Quintana y de un Martínez de la Rosa aún más respetado por los críticos vecinos - hasta mediados de siglo-, la literatura española contemporánea aún aguardaría a juicio general un influyente representante de su nacionalidad y buenos modelos, adecuado a las necesidades de su momento histórico y que ejerciera verdadero ascendiente sobre sus compatriotas.

También la periodización vigente en el siglo XIX de la literatura española así como la primera parcelación en tres sectas poéticas corruptoras del buen gusto ${ }^{212} \mathrm{e}$ incluso algunas jerarquizaciones de autores se remontan a esa obra pionera de 1754 , concebida como respuesta a la crítica entablada en el campo de la literatura francesa, fundamentada en discernimientos e inventarios de su contertulio Luzán, y transmitida con relativas variaciones al resto de estudiosos europeos por medio, principalmente, de la traducción abundantemente anotada del erudito alemán J.-A. Dieze (17291785). ${ }^{213}$ Las etapas acotadas por el estudioso español responden a una concepción organicista dispuesta de acuerdo con una división cronológico-política por siglos y reinados, en que se discriminan estilos y escuelas y se difunde la etiqueta de Siglo de Oro. ${ }^{214}$ Las edades del hombre, sus ciclos

212 Este inventario, que será retenido y ampliado por los críticos posteriores, abarcaba «en la poesía dramática con Virués, Lope de Vega, Pérez de Montalvan, a quienes siguieron, refinando mas el mal gusto, D. Pedro Calderon, D. Agustin de Salazar, D. Francisco Candamo, D. Antonio de Zamora y otros, que adelantaron este desorden hasta introducir en el dramma una cierta altura de estilo, que aun no seria tolerable en la Epopeya, ni en la Poesia Ditirambica» (p. 68); los conceptistas en la lírica casi los mismos; los cultos (Gongora y tras sus pasos, Villamediana, Francisco Manuel, Fr. Hortensio F. Paravicino, Félix de Arteaga y otros).

213 Don Luis Joseph Velázquez. Geschichte der spanischen Dichtkunst, aus dem Spanischen übersetzt und mit Anmerkungen erläuter, von Johann Andreas Dieze, Gotinga, V. Bossiegel, 1769. Véase J. J. A. Bertrand, «Figures d'hispanologues: Dieze, Bouterwek», Bulletin Hispanique, n. ${ }^{\circ} 24,1922$, pp. 343-360.

214 Luzán formula por primera vez en su Poética el término «edad de oro», que acuña definitivamente Mayans en 1737 y difunde Velázquez con gran fortuna. Véanse F. López, «Comment l'Espagne inventa le Siècle d'Or», en Hommage des Hispanistes Français à Noël Salomon, Barcelona, Laia, 1979, pp. 517-576; J. M. Rozas, «Siglo de Oro: historia de un concepto, la acuñación de un término", en Estudios sobre el Siglo de Oro. Homenaje al profesor Francisco Ynduráin, Madrid, Editora Nacional, 1984, pp. 413-428; A. Blecua, art. cit., 2004; F. Baasner, «Una época clásica controvertida. La polémica sobre el Siglo de Oro en la historiografía literaria española de los siglos XVIII y XIX», Revista de Literatura, LX, n. ${ }^{\circ} 119,1998$, pp. 57-78; así como la destacada bibliografía aconsejada por este último (nota 4, p. 58). 
vitales — infancia, madurez o plenitud, y decadencia - se ven traspuestas de esta manera a la evolución de una lengua y su literatura, a imagen de las Vidas de Vasari. ${ }^{215}$ Si bien se abrazan las grandes épocas, las divisiones más atendidas en las historias extranjeras en Francia desde la traducción de Bouterwek y el ensayo de Malmontais suelen respetar la sucesión por siglos. Aquellos que seguirán despertando un mayor interés continúan siendo los consagrados como período de esplendor - la franja temporal que liga los siglos XVI y XVII, conteniendo tempranamente ya en germen indicios de decadencia-, la investigación medieval y el protagonismo creciente de la contemporaneidad decimonónica, que desbanca el prestigio de los ilustrados vigente aún en la primera mitad del siglo y el de la creación del período finisecular en ligazón con los maestros prestigiados del patrimonio nacional.

Las fuentes irrenunciables a las que acuden los estudiosos de la literatura española a lo largo del siglo XIX al tratar del origen y progreso de la literatura española en la Edad Media proceden originariamente del caudal erudito y difusor español, ${ }^{216}$ a las que recurren también los estudiosos del

215 J. Schlosser, La literatura artística, presentación y adiciones por A. Bonet Correa, Madrid, Cátedra, 1976.

216 Además del opúsculo de Velázquez, las obras póstumas de Sarmiento (Memorias para la historia de la poesía y poetas españoles, Madrid, Ibarra, 1775), la fundamental Colección de poesías castellanas anteriores al siglo XV del P. Tomás Antonio Sánchez (Madrid, Sancha, 1779-90) con introducción, notas y un glosario final, —reeditada por Ochoa (Nueva edición, hecha bajo la dirección de D. Eugenio de Ochoa. Con notas al pie de las páginas, una introducción y un vocabulario de voces anticuadas, y aumentada con un suplemento que contiene tres poemas nuevamente descubiertos, París, Baudry, Librería Europea, 1842) con las aportaciones de Pedro José Pidal (El Libro de Apolonio, Vida de Santa María Egipcíaca y la Adoración de los Santos Reyes) y por Florencio Janer en la colección de Rivadeneyra (Madrid, BAE, XX, 1864) —, se suelen citar otros estudios como las muy frecuentadas analectas de Quintana (Tesoro del Parnaso Español, 1. a ed. 1808, o Poesías selectas desde el tiempo de Juan de Mena hasta nuestros días, completada con otra dedicada a la poesía del XVIII en 1830), junto a otras suyas menos mentadas como su De Musa épica (1833), además de aportaciones documentales desde las conocidas recopilaciones romancísticas y cancioneros hasta estudios de renombre - legatarios del vigor del medievalismo español del XVIII básico, como recuerda A. Gómez Moreno («Historia y canon de la literatura española medieval: 20 años de evolución y cambios», en Historia literaria..., 2004, pp. 161-175)—, como el bastante consultado de Amador de los Ríos (Euvres du marquis de Santillane, Madrid, 1852) o los estudios de Milà i Fontanals (por ejemplo, De los trovadores en España, Barcelona, 1861) o de Pascual de Gayangos sobre las novelas de caballerías (como Del Palmerín de Inglaterra y su verdadero autor, Madrid, 1862) y sus ediciones en la BAE (Madrid, 1857). 
comparatismo impulsado en Francia por Fauriel, Villemain o J.-J. Ampè$\mathrm{re},{ }^{217} \mathrm{e}$ investigadores alemanes en diversos ámbitos romanistas, germanistas u orientalistas. ${ }^{218}$ Aun ajustando la expresión escuela al magisterio de determinados autores como cabezas visibles de movimientos o tendencias, el repertorio básico de autores y obras que va incrementándose de acuerdo con una visión autorcéntrica — sin atender a agrupaciones más sólidas como las escuelas poéticas medievales reconocidas hoy en día por la crítica como el mester de clerecía, por ejemplo- se reparte también en siglos y géneros. Asimismo, se considera que, como su lengua y su literatura, el carácter nacional ha sido modelado por tres grandes influencias - realzadas unas más que otras, según la orientación del crítico - tras la romanización y la invasión de los pueblos del Norte - y cuya literatura medieval hispano-latina, recuperada por Cerdá, sería enaltecida por Amador de los Ríos y atendida por Menéndez Pelayo, por ejemplo—: la árabe en la Edad Media, la italiana en el Renacimiento y la francesa dominante desde la Francia del clasicismo. El reconocimiento de la impronta oriental, sobre todo, estaba llamado a una notable difusión, propiciada por las corrientes

217 Sus estudios aparecen editados durante los años del impulso de las cátedras universitarias de culturas extranjeras: así, la reeditada primera parte de las lecciones de AbelFrançois Villemain dictadas en la Sorbona, Cours de littérature française. Tableau de la littérature du moyen âge en France, en Italie, en Espagne et en Angleterre (1830) y complementadas por la edición de las dedicadas al Tableau de la littérature au XVIII siècle; la Histoire de la littérature française au moyen âge, comparée aux littératures étrangères (París, J. Tessier, 1841) de Jean-Jacques Ampère; o las monografías del legitimista Th.-J. Boudet, conde de Puymaigre - miembro de numerosas academias de provincias, entre cuyas investigaciones sobre la literatura española figuran trabajos sobre el folklore, la historia, las gestas épicas, exámenes de autores medievales aún no traducidos así como reseñas, por ejemplo, sobre colecciones romancísticas judeoespañolas-, tales como Les vieux auteurs castillans jusquà la fin du XIV siècle (París-Metz, Rousseau-Pallez, 1861-62) —en dos tomos que comprendían los hitos de rigor: poemas y crónicas sobre el Cid, el Apolonio, Berceo, Lorenzo de Segura, entonces dado como autor del Libro de Alexandre, y Alfonso X en el primero; y Juan Manuel, el arcipreste de Hita y diversos escritores, además del Amadis, Ayala, los romances históricos, carolingios y caballerescos en el segundo-, cuya segunda edición, al parecer inacabada, apareció bajo el título de Histoire de l'ancienne littérature espagnole (París, A. Savine, 1888 y 1890, 2 t.); y particularmente La Cour littéraire de don Juan II, roi de Castille (París, Lib. A. Franck, 1873, 2 vols.), que le valió la entrada en la Real Academia de la Historia y Bellas Letras de Barcelona.

218 Así, por ejemplo, los recurrentes estudios de Clarus (Darstellung der spanischen Literatur im Mittelalter, Maguncia, 1846, 2 vols.), Dozy (ob. cit., 1849) o, por ejemplo, A. Ebert (Histoire générale de la littérature au moyen âge en Occident, París, E. Leroux, 188389, 3 vols.), traducido del alemán por J. Aymeric y J. Condamin. 
de exotismo que resurgen en la historia francesa. ${ }^{219}$ Desde el eminente Casiri con su bibliografía, el reivindicativo Lampillas en su apologética de 1782 y el padre Andrés ${ }^{220}$ — que proclamó a toda Europa las aportaciones de la cultura árabe al origen de la literatura moderna, su influjo en la poesía trovadoresca y en la ciencia europea desde la Escuela de Traductores de Toledo- , un aún no tan denostado José Antonio Conde en su obra póstuma $^{221}$ y la escuela decimonónica de arabistas españoles y extranjeros, la curiosidad erudita por el pasado musulmán español ${ }^{222}$ se propagaría gradualmente alentando a su vez investigaciones filológicas e históricas más profundas.

219 La aureola exótica de la civilización musulmana mantenida a lo largo del XVII era de nuevo perceptible, por ejemplo, en la moda de los romances moriscos, cuya estela llega hasta el último exponente de calidad del XIX, el Abencérage de Chateaubriand. Los críticos decimonónicos, fascinados por su propia visión de la Edad Media, quedan subyugados, como Sismondi, por la imagen literaria del Oriente ultrapirenaico. No obstante, Schlegel también había subrayado, ante el olvido contemporáneo, el papel de la Península como salvaguarda de la cristiandad frente a la amenaza musulmana al sur de Europa y la gesta histórica de la Reconquista — otro de los motivos historiográficos insistentes y avivados por los sucesos recientes de la guerra de la Independencia- como barbacana europea.

220 Véanse C. Valcárcel, "Juan Andrés y la literatura española: la tesis árabe y la polémica sobre el Barroco», en P. Aullón de Haro, J. García Gabaldón y S. Navarro Pastor (eds.), Juan Andrés y la teoría comparatista, Valencia, Biblioteca Valenciana, 2002, pp. 245265; y el examen sobre Lampillas de A. Blecua, art. cit., 2004, pp. 120-123.

221 Historia de la dominación de los árabes en España, sacada de varios manuscritos y memorias arábigas (1820-21).

222 Difundida por los eruditos ilustrados, la influencia de esta civilización en la Península se convierte en un topos crítico seminal cuya sombra cubre no solo las obras de creación, sino también las teorías literarias y las ideas sobre el ser nacional. Las investigaciones lingüísticas y culturales del XVIII, continuadas por los estudiosos decimonónicos, confluyen, en el seno de las complejas polémicas entre reformistas y apologistas, con afirmaciones de autores como García de la Huerta a favor de la conservación del carácter genuinamente oriental de la literatura española, que a su vez hallarán eco en el siglo posterior con una imagen de España como implantación de Oriente en los extremos meridionales del continente europeo. Esta filiación, paralela a la tendencia nacional ya apuntada en los hispanorromanos, incumbe asimismo a su estilo y a su gusto por la hipérbole y la sutileza, transmitidos incluso hasta el XVII. Habiendo reconocido el papel mediador de la cultura árabe medieval entre la Antigüedad y Occidente, en las primeras historias se recogen teorías que atribuían a la influencia árabe el origen de los romances, de la novela o de sus modelos antiguos, e incluso la recuperación del teatro, así como una impronta significativa en las primeras producciones españolas como, por ejemplo, el cantar de gesta, que serían reivindicadas décadas más tarde para la influencia francesa. Emancipada después la literatura provenzal de semejante grado de dependencia del ascendiente árabe, para otros críticos e historiadores aquella se convierte en la cuna de la literatura moderna. Aunque en 
En el período siguiente la crítica va incorporando lentamente a la periodización general la nueva categorización de Renacimiento ${ }^{223}$ - difundida por Michelet (1855) y Burckhardt (1860) y referida a una cronología más acotada—, que coexistirá aún hasta fines de siglo con el valor remitente de renovación literaria, más ambiguo y extensible a cualquier época — por ejemplo, la incorporación de la cultura clásica a través de los árabes, hasta el renacer del XIX contemporáneo-, en tanto retorno periódico a la excelencia de los buenos ejemplos. En cambio, se adopta tempranamente, aunque no de manera hegemónica, el marbete de «Siglo de Oro» acuñado en el siglo XVIII («siècle» o «âge d'or») y que concurre con otros de mayor frecuencia, regidos por la cronología, el criterio dinástico o de titulares de reinados y de etapas, ${ }^{224}$ para referirse a una franja difusa paulatinamente lastrada estética e ideológicamente — cuyos avatares ha resumido Blecua en su artículo ya citado- y de compleja e incómoda parcelación. Encarnado en el XVI desde Luzán, Mayans o Velázquez, progresivamente va dilatando sus márgenes fluctuantes hasta comprender una parte del XVII con sus diversas escuelas genéricas, en pugna con la corrupción cultista que se generaliza en la segunda mitad del XVII. Esta tensión dialéctica entre las premisas clásicas,

nombre de la nacionalidad raigal de origen se sigue reconociendo sobre su poesía popular ese ascendiente oriental distintivo ("probablement parce que ses premières productions furent des romances et des romans écrits en langue romane; c'est cette poésie qui fut d'abord celle des Provençaux, qui passa de la Provence en Italie, où elle fut élevée par Pétrarque à toute la perfection dont elle était susceptible, et qui, née elle-même en Espagne, s’y modifia seulement par la teinte d'orientalisme que lui donnèrent les Arabes, et demeura, sous ce nouveau caractère, la poésie vraiment nationale des Espagnols», Bouterwek, ob. cit., pp. 47-48), el espíritu de la caballería que moldea la nueva poesía romántica —y con ella el culto a la dama, la posterior institución de la caballería y el desarrollo de la imaginación y de nuevos códigos amorosos, como es sabido, gracias a la convivencia con los pueblos conquistados y la expansión del cristianismo, en cuyo papel determinante frente a la cultura pagana clásica ya había reparado el P. Andrés - se atribuye ya en Bouterwek a un origen germánico.

223 Véase, por ejemplo, W. K. Ferguson, La Renaissance dans la pensée historique, París, Payot, 1950.

224 Entre la variedad de marbetes que dan testimonio de la indefinición de este período aparece con frecuencia abrumadora también en los manuales e historias publicados en Francia la clasificación neutral por siglos, y tras ella etiquetas como «époque» o "siècle des trois Philippes», presente en Bouterwek y transmitida a sus sucesores al menos hasta los años cuarenta; "siècle de Charles-Quint» al menos hasta 1830, u otros que privilegian determinados autores como «siècle de Cervantès», además de alguna analogía con el "grand siècle» francés. 
concebidas como universales, y la divergente propuesta barroca española, ya polémica en su tiempo, revela la dificultad de discernir lo original y lo clásico que se refleja asimismo en las clasificaciones de las historias y estudios decimonónicos en Francia. Encrucijada de conflictos estéticos e ideológicos que condicionan su revisión de la aportación española, condenándola o vindicándola conforme a cada posicionamiento, este período arrastra controversias de hondo calado desde el propio XVI, reavivadas en el XVIII - como ha expuesto Baasner en su importante artículo-, a las que se añade durante gran parte del XIX cierta hostilidad por su asimilación con el despotismo y la decadencia política hasta su incorporación progresiva a la periodización de la literatura española. Esta incomprensión hacia la poética del Barroco ${ }^{225}$ — término prácticamente ausente así como su concepto historiográfico introducido por Burckhardt (1855), Carducci (1860), que lo aplica a la historia literaria, y Nietzsche, Wölfflin o Spengler a las artes-, identificada, a grandes rasgos y no sin fisuras, con la invasión del mal gusto a lo largo del XVII tras ciertos indicios premonitorios en el siglo anterior, permite, no obstante, una valoración favorable de determinados aspectos y estilos de los principales autores de esa estética, especialmente en los metros cortos - recreaciones de los populares del Volksgeist - y en la ejemplificación paradigmática del caso conflictivo de su dramaturgia.

La exaltación del teatro calderoniano por el Romanticismo alemán incitó a una mayor investigación sobre el teatro del Siglo de Oro como testimonio de las costumbres de la época, como expresión herderiana de la originalidad nacional, y como ejemplo de arte no sometido, aparentemente, a las reglas. Tras Schlegel y Bouterwek, sobre todo, se transmite vigorosamente en Francia la caracterización de la dramaturgia española como un teatro nacional y original que encarna los valores de la religión, el honor, el entusiasmo, las pasiones violentas y el heroísmo caballeresco. Es un reflejo de sus creencias, un arte expresivo y vital, exuberante en imaginación y excesivo sin reflexión. Esta concepción del teatro como reflejo del vivir y sentir nacionales, recogida en España en el importante discurso

225 Así lo condensa Mainer: «el caso español se caracteriza por la persistencia de un canon literario mixto (a menudo mucho más ideológico que literario, lo que coincide poco con la tendencia general europea después de 1800) y por el escaso acuerdo de la literatura española consigo misma: vale decir, por la activa presencia de la idea de que parte sustancial de la propia tradición es un camino erróneo» (art. cit., p. 24). 
de Durán (1828), ${ }^{226}$ es asumida mayoritariamente en los estudios franceses, que irán introduciendo regularmente documentación relativa a los aspectos materiales del teatro, las condiciones sociológicas de su público y las circunstancias y espacios de la representación. Sin embargo, esta dramaturgia ya había empezado a ser revalorizada con cautela en el siglo XVIII en refundiciones o «arreglos» de las piezas más afines a las directrices neoclási$\operatorname{cas}^{227}$ — de lo que había dado fe, por ejemplo, el informe encomendado a Bernardo Iriarte-, o a las demandas de un público ávido de enredos, lances y adaptaciones de los modelos caballerescos, sobre todo de la comedia calderoniana, a los plebeyos. ${ }^{228}$ La infatigable labor de las refundiciones ${ }^{229}$ — de raigambre veterana desde el XVII—, ${ }^{230}$ más frecuente y concurrida que la escenificación de las obras originales, servía de aprendizaje de las técnicas teatrales, y constituía un oficio bien remunerado y también un trabajo serio de adaptación y reorganización de la materia dramática a las nuevas estéticas, primero neoclásicas, y a los cambios sociales e ideológicos, con su exaltación nacionalista de ciertos valores antiguos. Sus recursos formales, que desempeñaron un papel fundamental en la gestación del drama romántico, serán utilizados por las próximas generaciones literarias. ${ }^{231}$

226 Discurso sobre el influjo que ha tenido la critica moderna en la decadencia del teatro antiguo español y sobre el motivo con que debe ser considerado para juzgar convenientemente su mérito popular (Madrid, Impr. Ortega y Cía., 1828). Edición e introducción de D. L. Shaw, Exeter, University of Exeter, 1973.

227 I. Urzainqui, De nuevo sobre Calderón en la crítica española del siglo XVIII (en su tercer centenario), Oviedo, Universidad de Oviedo-Cátedra Feijoo, Anejos del BOCES. XVIII, 2, 1984.

228 R. Andioc, Teatro y sociedad en el Madrid del siglo XVIII, Madrid, Castalia, 1987.

229 N. B. Adams, «Siglo de Oro plays in Madrid, 1820-50», Hispanic Review, vol. 4, 1936 , pp. 342-357. A la cabeza de los autores seleccionados se situaba Tirso, hegemónico hasta los años treinta con 541 representaciones, seguido de Lope con 458, Calderón con 275, Moreto con 273, Rojas Zorrilla con 182, Cañizares, Belmonte Bermúdez, Zamora, Ruiz de Alarcón..., autores todos ellos de los que tratará Viel-Castel en sus artículos publicados en la Revue des Deux Mondes (15-III, 1-V, 15-VII, 1-XI-1840 y 1-II-1841). De 1840 a 1849 se muta el orden a favor de Lope, Moreto, Calderón, Tirso y Rojas Zorrilla. Véase también A. M. Coe, Catálogo bibliográfico y crítico de las comedias anunciadas en los periódicos de Madrid desde 1661 hasta 1819, Baltimore, The Johns Hopkins University Press, 1935.

230 Véase, por ejemplo, A. L. Mackenzie, La escuela de Calderón: estudio e investigación, Liverpool, Liverpool University Press, 1993.

231 Véase sobre la radical importancia de las refundiciones Caldera, o, por ejemplo, D. T. Gies, "Notas sobre Grimaldi y el "furor de refundir" en Madrid (1820-1833)», Cua- 
El teatro del Siglo de Oro, que tanto españoles como franceses llaman antiguo («ancien théâtre», "vieux théâtre») — por oposición a las producciones modernas - y nacional — marbete de reafirmación triunfante $^{232}$ junto a "comedia nacional española», heredados de la crítica dieciochesca, y en comedida concurrencia posterior con el de "clásico» ${ }^{233}$ desempeña un papel crucial en las controversias ideológicas del momento, avivadas en el XVIII, en la definición del papel de la crítica y en el dificultoso encauzamiento de los nuevos modelos literarios, a través de estudios, cursos públicos, artículos, ediciones y folletos. ${ }^{234}$ Se suceden ya desde las dos primeras décadas del siglo los estudios aclimatando las propuestas schlegelianas sobre todo tras la primera penetración del alemán españolizado y converso Böhl de Faber, de tendencia reaccionaria durante la llamada querella calderoniana, y modelo condenado al fracaso en su formulación, hasta la aprobación de Lista, uno de los más tempranos y firmes impulsores de la revisión y rehabilitación del teatro del Siglo de Oro desde presupuestos neoclásicos, como afirma Martínez Torrón, y del discurso de Durán, liberal conservador, que van asentando la variante tradicional o conservadora del Romanticismo y en el que se transparentan asimismo readaptaciones de las controversias del XVIII, antes de sus reformulaciones por Amador de los Ríos, como ha expuesto Pozuelo Yvancos en su artículo ya referido.

dernos de Teatro Clásico, n. ${ }^{\circ}$ 5, 1990, pp. 11-124. E. Caldera y A. Calderone, «El teatro en el siglo XIX (1808-1844)", en J. M. ${ }^{a}$ Díez Borque (dir.), Historia del teatro en España, Madrid, Taurus, 1988, vol. II, pp. 377-624.

232 Véase Pozuelo, art. cit.; y, a propósito del Resumen histórico de Gil de Zárate, R. Senabre, "La creación de un mito cultural: el teatro nacional español», en Túa Blesa (ed.), Mitos, Zaragoza, Anexos de Tropelías, 1998, vol. I, pp. 90-94.

233 En su edición de L'Espagne littéraire de 1903 Tannenberg en una mirada retrospectiva a propósito del incierto carácter nacional del teatro contemporáneo, sobre lo que no osa pronunciarse, utiliza ese marbete («Les Espagnols eurent-ils au dix-neuvième siècle un théâtre national, qui rappelle au moins, s’il ne l'égale pas, leur grand théâtre classique et puisse faire fortune hors d'Espagne?», p. 1).

234 Véanse, por ejemplo, los importantes y clarificadores estudios de M. ${ }^{\mathrm{a}} \mathrm{J}$. Rodríguez Sánchez de León, La crítica dramática en España (1789-1833), Madrid, Instituto de la Lengua Española, 1999, o su artículo «El teatro español del Siglo de Oro y la preceptiva poética del siglo XIX», Cuadernos de Teatro Clásico, n. ${ }^{\circ}$ 5, 1990, pp. 77-98; J. Escobar, "El teatro del Siglo de Oro en la controversia ideológica entre españoles castizos y críticos. Larra frente a Durán», Cuadernos de Teatro Clásico, n. ${ }^{\circ}$ 5, 1990, pp. 155-170; Flitter, ob. cit., entre otros. 
A partir de un corpus de estudios básicos y antologías del XVIII ${ }^{235}$ ampliado a lo largo del XIX en España y en el extranjero, ${ }^{236}$ los estudiosos van haciendo acopio del patrimonio dramático español a fin de analizarlo y difundirlo entre el lectorado: desde las ediciones de Ortega junto a los paulatinos trabajos editoriales de los españoles en la Península $^{237}$ — como la temprana avanzadilla del romanticismo schlegeliano de Böhl, las compilaciones de Durán, los textos de Lista, las ediciones de Rivadeneyra, las contribuciones de Hartzenbusch en la colección de Boix y de Mesonero Romanos en el Semanario Pintoresco Español 238 además de sus ediciones posteriores, ${ }^{239}$ o los artículos en la prensa cultural española de la segunda mitad de siglo sobre el teatro prelopesco, que testimonian el interés renovado por los orígenes del teatro y sus primeros autores, fundamentalmente tras el acopio documental de Moratín ${ }^{240}$

235 Desde García de la Huerta o, por ejemplo, Villanueva (Teatro español) o la edición neoclásica del teatro cervantino por Nasarre (ob. cit.), habitualmente mencionados.

236 Por ejemplo, desde las aportaciones del hispanismo alemán de Dieze y Tieck y sus traducciones cervantinas y calderonianas hasta el estudio de radical importancia de Schack, o la reivindicación de Lope y Guillén por lord Holland, o los estudios, artículos y cursos de Chasles sobre Calderón y Alarcón, muy leídos y elogiados por los estudiosos franceses en el curso del siglo.

237 Entre las ediciones peninsulares cabe citar títulos como la antología escolar de Lista (Colección de trozos escogidos de los mejores hablistas castellanos, en verso y prosa, libro de texto en 1821), la Colección general de 1826-34, censurada por Durán, Gorostiza y García Suelto, Comedias escogidas de Calderón (1826-33), Talía española o Colección de dramas del antiguo teatro español de A. Durán (1834), la poco difundida de Böhl, el Tesoro del teatro español de Ochoa (1838), o Hartzenbusch, Teatro escogido de Fray G. Téllez (1839-42), como signo de una creciente tarea editorial que se complementa además con revisiones en las publicaciones periódicas.

238 «Rápida ojeada sobre la historia del teatro español», 1842, pp. 364, 372, 380, 388 y 397. J. Álvarez Barrientos («Ramón de Mesonero Romanos y el teatro clásico español», Insula, n. ${ }^{\circ} 574$, octubre de 1994 , p. 28) señala el amplio proceso de relectura ideológica de los clásicos que se realiza en estos años en España para afianzar el nacionalismo español frente a la visión extranjera: "Mesonero, como otros literatos que pudieron ejercer control sobre la vida cultural del país y moldearla, dotó a la idea de nacionalización cultural de instrumentos ideológicos que la afianzaron mediante sus discursos sobre el teatro clásico nacional y con sus biografías de comediógrafos, pero también proporcionando textos que pudieran avalar y ejemplificar esa visión de la historia literaria, según la cual la esencia de lo español se encuentra en el teatro clásico».

239 Así sus Dramáticos contemporáneos de Lope de Vega (Madrid, 1857-58) y Dramáticos posteriores a Lope de Vega (Madrid, Rivadeneyra, 1858-69).

240 Además de trabajos también consultados como el de Casiano Pellicer (Tratado histórico sobre el origen y progresos de las comedias y del histrionismo en España, Madrid, 1804), basado en las Memorias cronológicas sobre el origen de la representación de Comedias en Espa- 
y en el exilio, ${ }^{241}$ o en estancia voluntaria, como Ochoa, ${ }^{242}$ al otro lado de los Pirineos. En Francia también se reeditan las traducciones - a menudo reescrituras de las obras referenciales_ por Labeaumelle y Esménard o Damas-Hinard, a las que van sumándose otras más de Chasles, Lafond, Baret o Latour, entre otros, hasta finales de siglo; se publican nuevos trabajos en volumen y en prensa que asientan las bases de estudio para los investigadores, a la vez que ponen de manera accesible un creciente repertorio de poetas y dramaturgos españoles —incrementado posteriormente con entremeses, prólogos y loas, y piezas propias de la representación barroca-, al alcance del gran público, no iniciado en esta lengua.

Los historiadores de la literatura española se refieren a los diversos tramos aún imperfectos en ese camino hacia la cumbre del XVII con el advenimiento triunfal de Lope, desde las églogas de Juan del Encina cuyo lenguaje limado y estilo elevado se ponen de relieve, las licenciosas comedias

$\tilde{n} a$, por J. A. de Armona, duque de Híjar, corregidor de Madrid (1785), es fuente referencial la documentación reunida por Moratín en su Catálogo histórico y crítico de piezas dramáticas incluido en sus Orígenes del Teatro español (1825, reeditado en París por Ochoa (Baudry en 1838)), tenida en cuenta por Lista (Lecciones de Literatura Española, Madrid, Nicolás Arias, 1836, y Ensayos literarios y críticos, 1844). Además de la selección del Teatro español anterior a Lope de Vega (Hamburgo, 1832) y del muy mentado curso de Charles Magnin editado bajo el título Les Origines du théâtre en Europe (1838), este período recibe también la atención de otros autores en las décadas siguientes como Gallardo, Gayangos, Fernández Guerra, Hartzenbusch, Zarco del Valle, Sancho Rayón o Juan Colón y Colón, y críticos como, por ejemplo, Cañete.

241 Entre las ediciones de los exiliados en Inglaterra, pueden citarse, por ejemplo, P. Mendíbil (Revista del antiguo teatro español o selección de piezas dramáticas desde el tiempo de Lope de Vega hasta el de Cañizares, Londres, 1826) o Ángel Anaya (El Teatro Español o Colección de dramas escogidos de Lope de Vega, Calderón de la Barca, Moreto, Rojas, Solis, Moratín y otros célebres escritores, precedida de una breve noticia de la escena española y de los autores que la han ilustrado, Londres, 1817-21).

242 Los cinco tomos dedicados al Tesoro del Teatro Español (París, Baudry, 1838) comprendían en el primero el estudio de Moratín Orígenes del Teatro español además de una selección de piezas dramáticas anteriores a Lope; el segundo, Teatro escogido de Lope junto con un resumen biográfico del autor y un examen de sus obras; el tercero estaba dedicado a Calderón, el cuarto a Tirso, Mira de Amescua, Montalbán, Guevara, Moreto, Rojas, Alarcón y Matos Fragoso (1838); y el quinto, además de recoger obras de Diamante, La Hoz, Belmonte, Felipe IV (a quien, entre otros, se atribuía El diablo predicador), Leiva, Cubillo, Figueroa, Zárate, Candamo y Solís, se iba adentrando en el tiempo más reciente con Zamora, Cañizares, Jovellanos, Huerta, Ramón de la Cruz, Cienfuegos, Moratín, Quintana, Martínez de la Rosa, Gorostiza y Bretón de los Herreros. 
de Torres Naharro, que contienen en germen el molde lopesco y un estilo natural - a las que añaden las piezas de Gil Vicente, que juzgan un ensayo aunque meritorio-, las imitaciones eruditas de los trágicos y cómicos griegos y latinos, hasta las farsas, los pasos y entremeses de Lope de Rueda, de sabor nacional. Junto a Juan del Encina, este último y Torres Naharro formarán, a juicio de los españoles y de la crítica de la época, la tríada fundadora. ${ }^{243}$ El historicismo y la relativización del gusto, sancionada por la crítica romántica, rigen, pues, las reflexiones acerca de los avatares de la apreciación de este teatro en Europa. Sus grandes nombres, Lope de Vega $^{244}$ — cuyo canon fijará definitivamente para la posteridad del siglo XX el estudio fundamental de A. F. von Schack - ${ }^{245}$ y Calderón, entronizado por la crítica alemana, van siendo aceptados conforme a la diversidad estética de genios nacionales, y valorados como materia dramatúrgica no desdeñable por los más respetados autores franceses. No obstante, los críticos franceses, aferrados a veteranos argumentos de raigambre clasicista, suelen rebatir la primacía que — tras la apertura comedida de Holland o Maury y antes de la vindicación posterior de Menéndez Pelayo- Schack le atribuye a Lope como fundador del teatro nacional sobre las otras escenas europeas, y le reprochan en ocasiones la carencia de un verdadero drama histórico, unidad cohesionadora y una cosmovisión semejante a la summa cervantina. Pese a la ya aceptada diversidad de los dramaturgos del XVII en

243 Así perduran a principios del XX en estudios, traducciones y antologías como las anotadas de H. Mérimée y E. Vauthier Le Théatre espagnol (1925), que incluía a Encina, Torres Naharro, Lope de Rueda y Lope de Vega.

244 Aunque bastante editado, Lope conoce diversos avatares en la crítica francesa desde las selecciones del XVIII y principios del XIX, hasta convertirse en uno de los temas centrales de las lecciones universitarias francesas de la centuria. Sobre su recepción general en el canon español véase E. Santo-Tomás, La creación del "Fénix». Recepción crítica y formación canónica del teatro de Lope de Vega, Madrid, Gredos, 2000, así como, por ejemplo, F. B. Pedraza Jiménez, «La formación del canon dramático de Lope», Insula, n. ${ }^{\circ} 658$, octubre de 2001, pp. 29-33.

245 Citado por los estudiosos franceses en su lengua original (Geschichte der dramatischen Literatur und Kunst in Spanien, Berlín, 1845-46, 3 vols.), sería traducido al español en 1885 por Eduardo de Mier bajo el título Historia de la literatura y del arte dramático en España (Madrid, Imprenta y Fundición de M. Tello, 1885-87, 5 vols.). Pese a su importancia crítica, aún Tannenberg (ob. cit., 1903, p. 148), que describe a su autor como poeta e influyente diletante, mentor y mecenas, y meritorio estudioso por su reafirmación de la importancia de Lope y sus atisbos de la calidad de Tirso, juzga su reputación un tanto hinchada y reprocha a su obra su falta de contención imparcial y su sequedad de estilo entrecortada por vehementes ditirambos. 
las principales historias y resúmenes, el reconocimiento de su calidad debe contender trabajosamente con las resistencias remanentes de estudiosos como un reticente Morel-Fatio, según recuerda Tannenberg, que, pese a sólidos argumentos favorables precedentes, insisten en rebajar su belleza formal y verdad humana a un valor documental. Por otra parte, también incide en sus apreciaciones la persistencia de enjuiciamientos que subrayaban en detrimento de la elocutio, que concede una mayor atención a la estructura y disposición, un mayor cultivo retórico de la inventio - que acentúa la importancia de la imaginación - que se sigue achacando a los autores del XIX. ${ }^{246}$ La producción contemporánea — prometedor relevo en tanto retorno al carácter genuino español en sus diversos géneros, y cuyo balance final no parece tan afortunado en todos los estudios retrospectivos - no será analizada con detenimiento por los estudiosos franceses hasta el último tercio de la centuria, tras las halagüeñas observaciones de las primeras historias en torno al gozne de entresiglos.

Productos institucionales difundidos en colegios, sociedades culturales, institutos oficiales y centros universitarios, las historias literarias están íntimamente ligadas a los principales cauces retóricos vigentes acatados por la tradición —elocuencia y poesía- y suelen privilegiar como eje ordenador en el decurso cronológico la división genérica - fundamental red suprahistórica de múltiples nudos jerarquizados—, ${ }^{247}$ que no discrimina a la novela frente a géneros veteranos más prestigiosos, $\mathrm{y}$ acoge anchurosamente hasta fines de siglo las diversas manifestaciones del fenómeno literario. En tanto revisión y reformulación del pasado durante la conformación paralela de ambos Estados modernos, estos discursos históricos comportan determinadas implicaciones ideológicas que persiguen la modelación ejemplar de un canon nacional dirigido a las nuevas generaciones. La mutabilidad y multiplicidad inherentes a este

246 Aún repetía Tannenberg (ob. cit., 1903, p. 2) que era raro encontrar en el repertorio moderno español obras de calidad capaces de imponerse al público extranjero por otras cualidades distintas de «une versification brillante, une intrigue ingénieuse, un dialogue vif et savoureux, un certain don d'observation exacte, mais superficielle», características atribuidas al drama áureo.

247 Véase C. Guillén, ob. cit., así como sus sugerentes y ricos artículos sobre la emergencia de las literaturas nacionales compilados en Múltiples moradas. Ensayo de Literatura Comparada, Barcelona, Tusquets, 1998. Para más información sobre las vías de estudio actuales véase la recopilación de trabajos al cuidado de A. Gnisci, Introducción a la literatura comparada, Barcelona, Crítica, 2002. 
concepto, ${ }^{248}$ como ratifican las oposiciones abstractas — como las recurrentes innovador/tradicional o céntrico/periférico, entre otras- surgidas de las teorías de los polisistemas de Even-Zohar, invocan un corpus dinámico y abierto a actualizaciones, desvíos, olvidos y nuevos ingresos. Los términos que, en los textos consultados, contornean difusamente sus acepciones aparecen aureolados de un prestigio clásico que los entronca con la venerada fuente modélica: el antiguo "parnaso» de Sedano, que evoca en Sánchez, Quintana, Bouterwek o Maury la arriscada cumbre apolínea de la estima, convive con las ocurrencias de "panteón» o «museo", y del pronto preeminente "monumento literario» cuya aplicación a las obras del pasado impone un distanciamiento historicista que, a excepción de diversas declaraciones de estudiosos españoles en la prensa, las preconiza como reliquias o documentos de estudio más que como modelos inspiradores de la creatividad contemporánea. Los nombres conocidos por el público francés y ligados a los cauces de los géneros más apreciados entonces, que sobreviven de los años de educación a lo largo del siglo - vulgarizados en lecturas, de oídas en numerosos casos, a través de ediciones con mejor o peor fortuna y calidad, o en grabados y recreaciones teatrales y literarias-, conforman en general a fines del XIX una reserva reducida y prácticamente incólume de géneros arraigados. De este palimpsesto surge una imagen original de la nacionalidad literaria española que consagra perdurablemente una serie de valores proclamados por el Romanticismo a la vez que consolida la ya inveterada ${ }^{249}$

248 Sobre las funciones, conceptos y teoría del canon véanse, por ejemplo, la compilación de trabajos de E. Sullá, El canon literario, Madrid, Arco Libros, 1998, especialmente las reflexiones de W. Mignolo, «Los cánones y (más allá de) las fronteras culturales (o ¿de quién es el canon del que hablamos?)»; la edición de J. Pont y J. M. Sala-Valldaura, Cànon literari: ordre i subversió, 1998; y particularmente J. M. Pozuelo Yvancos y R. M. ${ }^{a}$ Aradra Sánchez, ob. cit., 2000.

249 Además de numerosas ediciones modernas a finales del XVIII y del variado repertorio de recreaciones de temática española en dicha centuria, la recepción de esta literatura había confluido en Francia con una incipiente atención hacia la Edad Media: corrientes nostálgicas de la galantería y las justas moriscas de las publicaciones del siglo anterior convergen en el mundo medieval de caballerías evocado por el Quijote — bajo diversas perspectivas y tonos_- Pérez de Hita, o el Amadis, junto con pastiches del género troubadour impulsado por Tressan, o las ediciones populares de romans de chevalerie y sus selecciones cultas en la $B U R$, coetáneas del desprecio ilustrado por su credulidad y rudeza, y paralelas a la investigación erudita de su historia e instituciones por La Curne de Sainte-Palaye (Mémoires sur l'ancienne chevalerie, considérée comme un établissement politique et militaire, 
como transmisora privilegiada y genuina del ideal caballeresco, ${ }^{250} \mathrm{y}$, por otro lado, como encarnación del realismo cómico y satírico, impregnado, no obstante, de cierto idealismo, de sus novelas picarescas, en especial el Lazarillo. Tras la intensa labor editora en el primer cuarto de siglo por las prensas francesas - en español y moderadamente en francésdel patrimonio vecino, fundamentalmente desde el XVI hasta los tiempos actuales - poetas, místicos, moralistas, historiadores, novelistas, predicadores, dramaturgos, fabulistas o polemistas-, y las traducciones intermitentes de los autores españoles, la memoria colectiva retiene un conjunto representativo, resumido lapidariamente por Brunetière y Tannenberg y amoldado a nuevas interpretaciones —en muchos casos superpuestas a esa pertinaz visión-, antes del afianzamiento oficial de los trabajos eruditos del hispanismo francés. Si bien es cierto que las aportaciones eruditas acrecientan el repertorio de obras y autores, alguno de los manuales universitarios de fines de siglo mantiene en pie la premisa de Villemain de los años treinta que preconizaba desde el mirador del XIX el único estudio de las cumbres modélicas — aun contextualizadas convenientemente en las circunstancias socio-políticas y culturales-. Mientras la Edad Media afianza su presencia desde el primer estudio que hemos seleccionado, ampliando relativamente su inventario, son el llamado Siglo de Oro, esa franja variable desde el XVI hasta parte del XVII, y la etapa subsiguiente, juzgada de decadencia política y corrupción literaria, las privilegiadas en las historias y manuales por encima del siglo XVIII — cuyo período final suele ser acogido con mayor entusiasmo a principios de siglo que en los decenios siguientes - y en parte también del contemporáneo siglo XIX, abordado por los estudiosos franceses a

1759-81) o Millot con su Histoire littéraire des troubadours — precursores de Raynouard y Fauriel, continuados por Cousin, Guizot, Thierry, Michelet o Tocqueville—; asimismo, el linaje de novelas picarescas es transmitido principalmente por las reescrituras, reeditadas aún en el XIX, de Lesage, mediador junto con Linguet y sus sucesores del XIX en la difusión francesa del teatro áureo, además de autores también conocidos en el XVII como Quevedo, los místicos y las historias de Mariana o Solís, por ejemplo, cuyas evocaciones impresionantes y pintorescas despertarán de nuevo el interés de los estudiosos y antólogos del XIX, como muestran, por ejemplo, los diccionarios bibliográficos.

250 Sobre las diversas facetas de la visión de la Edad Media en el XIX, especialmente en su segunda mitad, tras los precedentes de la centuria anterior, véase J. R. Dakyns, The Middle Ages in French Literature. 1851-1900, Oxford University Press, 1973. 
medida que avanza la centuria. A fin de trazar la ruta de las querencias, resistencias o desaprobaciones que suscitan los hitos más recurrentes en la importación del canon vecino en vías de institucionalización, ${ }^{251}$ observaremos el discurrir de las principales historias, disertaciones, antologías y manuales de la literatura española editados en la Francia del XIX antes del florecimiento del hispanismo.

\subsection{Primeras décadas del siglo XIX}

Si bien las labores de propaganda bonapartista y las circunstancias políticas propiciaron un relativo y utilitario conocimiento de su aliada transpirenaica en reediciones de relatos de viajes y escritos polémicos - redactados en la centuria anterior o en el gozne de entresiglos-, es principalmente en el período final del régimen cuando comienza la difusión de las historias de la literatura española gracias a la traducción de los principales estudios, divulgados desde el nuevo centro cultural que le disputa su preeminencia y dilata el canon aceptado. Precedida por la historia de la literatura italiana de P. L. Ginguené ${ }^{52}$ el año anterior, y poco tiempo antes por la traslación francesa de diversos extractos de su volumen dedicado a la inglesa, la historia de Bouterwek inaugura, junto a un ensayo francés de 1810 y los cursos contemporáneos de Schlegel y de Sismondi, los trabajos sobre esta literatura en Francia a lo largo del XIX. En su progresión desde el primer ensayo analizado - anclado en una postura clasicista contemporizadora - hasta la asunción de las teorías schlegelianas, estos se apoyan unánimemente en la erudición ilustrada española y en su documentación, canon, periodización —en especial el estudio de Velázquez de 1754, al que acceden por una vía independiente y paralela el estudio francés referido y Bouterwek-, e incluso ciertas valoraciones, tamizadas tanto por un neoclasicismo más flexible como por el romanticismo schlegeliano. Inmersos en este período de redescubrimiento cosmopolita, aunque en sus acercamientos a las literaturas nacionales modernas estos críticos pierden la pers-

251 Sobre el canon español en los siglos XVIII y XIX, véase particularmente R. M. ${ }^{a}$ Aradra, De la retórica a la teoría de la literatura (siglos XVIII y XIX), Universidad de Murcia, Servicio de Publicaciones, 1997.

252 Histoire littéraire de l'Italie (1811-18, 9 vols.), continuada por F. Salfi. 
pectiva comparatista global del P. Andrés al yuxtaponerlas, también apelan con más decisión a la subjetividad como criterio de enjuiciamiento, sin por ello sacrificar el buen gusto. ${ }^{253} \mathrm{La}$ receptividad de los primeros textos hacia la literatura española reconoce en primer lugar la calidad de los poetas clásicos vecinos, seguidores de las reglas atemporales a través de los prestigiosos modelos grecolatinos - fuente común, primigenia e irrenunciable de alemanes y franceses - y de los modernos de la Italia humanista; y asimismo — especialmente en la incursión pionera de 1810 — el valor de la traducción como acicate para el conocimiento, la renovación genérica y el afinamiento y enriquecimiento de la lengua. No obstante, gracias a la difusión del Volksgeist herderiano divulgado desde Alemania, se va aceptando progresivamente su nacionalidad literaria, popular, singular y original, al igual que -otro hallazgo sancionado por el XIX- comienza a observarse el color local de las costumbres reflejadas en sus obras.

En estos años de controversias y transformaciones culturales en que las reticencias clasicistas ante la penetración filosófica y metodológica alemana se manifiestan en la cautela de los prólogos introductores de las nuevas corrientes y en sus esfuerzos por conservar la herencia enciclopedista y clásica superando el anquilosamiento postclasicista, los primeros estudios y traducciones de las historias sobre la literatura vecina se incardinan paulatinamente en el discurso de la filosofía de la civilización. Desde una perspectiva liberal dominante, reflexionan sobre las causas de su decadencia, atribuidas fundamentalmente a la represión política y religiosa que, en su período de mayor expansión y de esplendor literario, corrompieron su sociedad y expresiones culturales como el gusto. No obstante, los estudiosos franceses - e incluso Schlegel, en su inquina antienciclopedistaextreman con fortuna la denuncia más temperada de Bouterwek de la incidencia de los factores político-ideológicos. Por otro lado, la revisión de los reajustes del XVIII por recuperarse del estancamiento precedente demuestra - pese a los recelos de Schlegel, que lo tachan de extranjerizante e imitador y se impondrán en las décadas posteriores - el prestigio de esa centuria, especialmente en su fase de regeneración a partir de Carlos III. De

253 Por ejemplo, no solo Schlegel lo ejerce en sus revisiones estéticas o Sismondi lo anuncia declaradamente en su curso mundano, sino que también el estudio divulgador de 1810 señala la ósmosis del traductor con el autor al que traduce, y el kantiano Bouterwek invoca la empatía del lector al abordar la obra de fray Luis de León. 
igual modo, la dependencia coyuntural de las circunstancias diplomáticas del XIX favorece desde el incipiente ensayo francés el injerto de las inextricables interrelaciones entre literatura y política coetáneas, que marcarán las historias y estudios de los hispanisants franceses en su apreciación de la cultura fronteriza. Tras la culminación de sus modelos propios, y para justificar la utilidad del conocimiento de las literaturas extranjeras en el estadio presente de su cultura, suena la hora reflexiva de la revisión de otros sistemas literarios y estéticos, como anuncian Sismondi y Stapfer -editor de la traducción de Bouterwek-, relevados por los comparatistas franceses, dando acogida a una originalidad foránea que, aun así, no alcanzará a juicio de estos las cotas de los grandes nombres del clasicismo francés.

\subsubsection{Un precursor de entresiglos}

El primer estudio al que nos vamos a referir, dedicado exclusivamente a la literatura española y consultado por los eruditos franceses, es el Essai sur la littérature espagnole, supuestamente anónimo, editado por J. B. Lecouteulx de Canteleu ${ }^{254}$ pero atribuido generalmente a un tal Malmontais. ${ }^{255}$ Publicado en el París imperial de 1810, al calor de las directrices

254 Jean-Barthélemy Lecouteulx de Canteleu (Normandía, 1749-París, 1818), partidario de los girondinos y dedicado a las finanzas y la administración, se apartó de la política durante la etapa de terror revolucionario hasta que el favor de Bonaparte lo promovió a diversos cargos y honores. Véase Grand Larousse Universel du XIX siècle français, París, 1873, t. X, p. 304. L. Perdices Blas (Pablo de Olavide (1725-1803). El ilustrado, Madrid, Editorial Complutense, 1993) apunta su relación en Francia con Olavide tras la atemorizante experiencia de este como paciente de la Inquisición.

255 Aunque la obra (París, Charles Barrois, 1810) no presenta el nombre de su autor, y ni Stapfer, el editor de la traducción francesa de la historia de Bouterwek (1812), ni Puibusque (1843) dan su nombre, Jarry en su Atlas (1831) añade el de Malmontet o Malmontais, como también sostienen Quérard (ob. cit.) y É. Lefranc (1843) hasta Demogeot (1880), a excepción de Baret (1875), que le concede más importancia a Lecouteulx en la redacción: «En 1810, au moment où le roi Joseph venait de monter sur le trône de Philippe II, un Français croyait devoir apprendre au public, en un mince volume in- $8 .^{\circ}$, que l'Espagne possédait une littérature dont plusieurs écrivains n'étaient pas à dédaigner, et il offrait à l'appui de son dire d'élégantes traductions de Garcilaso, de Louis de Grenade et du P. Isla. M. Lecoulteux avait lu ces écrivains et connaissait parfaitement l'espagnol, ce qu'on ne saurait affirmer de M. de Sismondi, qui accorde à l'Espagne un coin de son tableau de la littérature du midi de l'Europe, en traitant son sujet beaucoup moins d'après l'étude des textes que d'après les appréciations, et surtout les traductions des écrivains allemands» ("Observations...", art. cit., p. 6). En el siglo siguiente, Díaz-Plaja (El estudio de la literatura..., p. 138, 
reformistas promovidas en la corte josefina durante la guerra de la Independencia, y guiado por un propósito de difusión ilustrada de los valores de esta literatura, el ensayo presenta un talante clasicista receptivo y conciliador en sus apreciaciones. Su intención es ofrecer, ante todo, no una poética al uso, sino un panorama histórico de la literatura española. Su carácter auxiliar para el estudio de la historia literaria vecina se compadece, no obstante, con un planteamiento dirigista a fin de orientar y asentar los juicios sobre ella de los interesados en el aprendizaje de esta lengua. ${ }^{256}$ Coincidiendo en el tiempo con las reediciones, propiciadas por la intervención bonapartista, de relatos de viajes por la Península o de misceláneas como las prematuras Lettres d'Espagne de 1774, el examen global de Malmontais - aceptemos la atribución - sugiere, a su vez, un palimpsesto de préstamos y redacciones de épocas diversas. ${ }^{257}$ En su esfuerzo por despejar

nota 38) y Romero Tobar («La historia de la literatura española en el siglo XIX...», art. cit., p. 162, nota 26) mantienen asimismo la atribución mayormente aceptada. Martínez Torrón (ob. cit., pp. 243-245) podría arrojar indirectamente cierta luz sobre su autoría al referirse a la temprana reseña por Lista en la Gaceta de Sevilla en 1811 de un libro titulado Ensayo sobre la literatura española ("que han dado a luz los redactores de los archivos literarios sobre la literatura del norte») y cuyas líneas generales, presentadas por Martínez Torrón a través de las apostillas de Lista a la obra, parecen coincidir con algunas de las argumentaciones y contenidos del texto que comentamos. M. Moreno Alonso subraya como objetivo de la obra, sin referirse a su autoría, la enseñanza de la lengua española («El libro, publicado en 1810, lo que se proponía fundamentalmente era hacer familiar a los franceses la lengua española», La generación española de 1808, Madrid, Alianza Editorial, 1989, p. 34).

256 "comme mon intention n'est pas de faire une poétique mais seulement un tableau historique et rapide de la littérature espagnole, je me renfermerai dans mon plan et ne ferai que ranger les écrivains suivant l'ordre des époques auxquelles ils ont appartenu. J'essayerai seulement de faire connoître par quelques citations et par de courtes analyses, le caractère de leur talent, afin de diriger le goût et de fixer les idées de ceux qui se livreront à l'étude de leur langue» (p. 71).

257 Impreso en 1810 con un voto final de esperanza por la dinastía josefina en España, ciertos aspectos adelantan, no obstante, su composición. Los párrafos finales dejan entrever en el texto un injerto sobre una obra empezada tiempo atrás, tal vez unos veinte o treinta años antes si damos fe a las declaraciones del autor dispersas por la obra. Por ejemplo, el autor se refiere a la edición (1779-90) de T. A. Sánchez como si, pese a tener noticias de ella, esta aún estuviera en vías de publicación: «un auteur moderne, le père Tommaso-Antonio Sanchez, dans le prospectus d'un ouvrage où il comptoit rassembler ceux des poètes castillans antérieurs au quinzième siècle, annonce que sa collection sera composée des morceaux suivans dont j'ai indiqué la plus grande partie: le Poëme du Cid Campeador, les poëmes de Gonzalo Berceo, la Vie de S. Ildefonse écrite par le bénéficié d’Ubeda; les poésies de Juan Ruys archiprêtre de Hita, du Juif D. Santo, de Pedro Lopez de Ayala, de Juan Manuel auteur du comte Lucanor; l'histoire du comte Fernan Gonzalez; des vers de 
los prejuicios de sus conciudadanos hacia los valores culturales españoles, el autor se dirige no solo al erudito sino también al lector profano, los "Amateurs des Belles-Lettres», para darles a conocer «l'origine et progrès de la poésie nationale en Espagne», y cuya riqueza encarece ${ }^{258}$ como ya hiciera La Dixmerie en su prospecto. Si condena vehementemente en numerosas ocasiones la represión ejercida por el poder monárquico e inquisitorial al haber retrasado la propagación de las luces, fomentado la superstición y ahogado en gran medida las iniciativas de progreso y el desarrollo de las ciencias, ${ }^{259}$ en contrapartida, expone a la revisión pública las obras del pasado y del presente para dar testimonio de las excelencias de esta literatura —en su moderno sentido más acotado—, ${ }^{260}$ que posee

Pedro Gomez, avec quelques autres poëmes rares qu'il cherchoit encore» (p. 57). Como es sabido, el bibliotecario Sánchez dio a la luz pública sus cuatro tomos en 1779 (t. I), 1780 (t. II), 1782 (t. III) y 1790 (t. IV). En 1842 Ochoa apuntaba en la «Advertencia» que encabezaba su edición de la obra (ob. cit., pp. vii-viii): «cuando la empezó [Sánchez] ni aun tenia noticia de las obras que luego publicó en ella, como se ve por sus notas». Pero, a su vez, Malmontais tiene conocimiento de la actualidad literaria de Iriarte, García de la Huerta, Moratín, Ramón de la Cruz, Meléndez Valdés, Montengón, o los dramas sentimentales de Valladares, por lo que el arco temporal de redacciones, de creer esa cita anterior, oscilaría entre finales de los años setenta y los años próximos a su publicación en París.

258 «La littérature espagnole est une mine féconde, peu connue et peu exploitée encore qui leur promet une foule de jouissances nouvelles. On sera étonné peut-être de trouver autant de productions marquées au coin du bon goût, dans une langue assez généralement regardée comme vouée à l'emphase et à l'hyperbole. Son malheur est d'avoir été jugée sur ses Cotin, ses Voiture et ses Scuderi. Si je suis assez heureux pour éveiller l'intérêt du public en sa faveur, il me sera facile de dissiper ces préventions établies par l'ignorance plutôt que par la mauvaise foi» (pp. 188-189).

259 En sus apostillas ideológicas Malmontais repara en la vigilancia inquisitorial padecida por el padre Mariana y en las persecuciones políticas de grandes personalidades como, por ejemplo, un Villena presentado como debelador del oscurantismo, un fray Luis de León o un Quevedo observados como modelos al proyectar sobre ellos una visión liberal que destaca su compromiso con los intereses de su nación. La audacia, independencia y libertad de expresión de Feijoo, protegidas por la corte, son doblemente destacadas al hallarse reunidas explícitamente en un monje español, ensalzado como adalid de la razón. Asimismo detecta en diversas obras literarias críticas a sus gobiernos y censura la parcialidad trastamarista del canciller Ayala, a la vez que atribuye la verdadera crónica petrista a Juan de Castro.

260 En ese sentido cabe interpretar la justificación del autor al incluir a Feijoo por su maestría estilística, buen gusto y adecuación del tono a la temática de sus discursos y la libertad de su pensamiento, pese a la heterogeneidad de su erudición, que sobrepasa el campo puramente literario; así como sus comentarios a propósito del afamado poema didáctico de Céspedes sobre la pintura («Appliquer le langage de l'imagination à un sujet qui l'exclut formellement, c'est à la fois un outrage pour la science et pour la poésie, c'est l'ignorance absolue des égards que l'on doit à l'une et à l'autre», p. 143). 
también «des ouvrages classiques dans presque tous les genres» (p. 2), tanto en verso como en prosa. La incitación patriótica de Velázquez en su discurso académico de $1754^{261}$ a conservar la memoria de los poetas antiguos y modernos de mérito, examinados por los entendidos y no decididos por el vulgo, ${ }^{262}$ halla eco en la disponibilidad de Malmontais - asimismo receloso del juicio popular— ${ }^{263}$ para demostrar las afinidades del

261 Origenes de la poesía castellana por D. Luis Joseph Velázquez, Caballero del Orden de Santiago, de la Academia Real de la Historia, y de la de las Inscripciones, Medallas, y Bellas Letras de París, Málaga, Oficina de Francisco Martínez de Aguilar, 1754 (2. edición, 1797). Obra dedicada a Fernando de Silva Álvarez de Toledo, duque de Huéscar, director entonces de la Real Academia Española. Su discurso había sido tratado ya en el Journal Étranger en febrero de 1755 (véase R. Pageard, art. cit., 1959). Sobre su redacción y recepción véase también $\mathrm{Ph}$. Deacon, "La historia interna de los Origenes de la poesía castellana de Luis Joseph Velázquez», BOCES. XVIII, 1978, n. ${ }^{\circ}$ 6, pp. 65-82. Las citas de Velázquez que se incluirán proceden de la primera edición.

262 Velázquez alaba enormemente la preparación de la antología que dejó interrumpida el malogrado Nasarre, relevado por Cerdá y López de Sedano, [Parnaso Español.] Colección de las Poesías Castellanas, y que no vería la luz hasta 1768 ( «Será conocido el merito de muchos Poetas nuestros, de que casi no havia memoria; y los Estrangeros verán la injusticia, con que han juzgado del talento Poetico de una Nacion, cuyos verdaderos sentimientos en materia de literatura no se deben buscar en medio del vulgo, casi siempre corrompido, sino en los Escritos de los hombres Sabios, que conservan siempre el buen gusto, y el honor, que es debido a las Letras; y que se desentienden á vezes de los desordenes, con que se pervierte la buena economia de ellas, quando ven que aman la dolencia, los mismos de cuya curacion se trata", pp. 141-142).

263 Malmontais marca sus distancias respecto a la abigarrada realidad teatral española de más éxito: si disculpa la preferencia popular por las representaciones de entonces de las comedias de capa y espada calderonianas - cuyas refundiciones, compuestas en torno a los años ochenta, no subirán a escena hasta los primeros años del XIX-, sentencia la incompatibilidad del buen gusto con otros espectáculos híbridos como las piezas de magia y de santos (los autos sacramentales habían sido suprimidos en 1765), los sainetes o el teatro sentimental de finales de siglo: «le genre régulier dans toute espèce de drame, n'obtient auprès des Espagnols qu'un succès d'estime. Leur enthousiasme est exclusivement réservé pour les auteurs fidèles à l'esprit de la vieille école, pour Calderon surtout qui est demeuré en possession de leur plaire. Si leur admiration se bornoit encore à des pièces qu'ils appellent de capa y espada qui sont des peintures brillantes de leurs anciennes mœurs, on trouveroit tout naturel que la prévention nationale l'emportât un peu sur le bon goût en littérature, et que les Espagnols fussent très-sensibles à ces tableaux pompeux et animés des passions comme des vertus qui leur étoient propres, des ridicules même qui n’en étoient que l'excès. Mais le sentiment qui les dirige alors perd un peu de son prestige, quand on songe que les transports qu'il excite, redoublent à la représentation des Autos sacramentales, ou des parades de Ramon de la Cruz, ou des mélodrames de Villadarez [Antonio Valladares de Sotomayor], enfin devant des pièces telles que le Vinaigrier de Madrid [El vinatero de Madrid, 1784], les Vivandières illustres [Las vivanderas ilustres, 1792], le Diable prédicateur, 
canon español en proceso de elaboración con el modelo estético heredero del neoaristotelismo italiano irradiado desde Francia. Al tanto de la prodigalidad de sus historias literarias, ${ }^{264}$ habiendo frecuentado, según afirma, sus principales bibliotecas en busca de documentos, tratado con sus conservadores y consultado las ediciones exhumadoras del patrimonio cultural español — principalmente el opúsculo de Velázquez, el primer tomo de las obras póstumas del padre Sarmiento, el Ensayo de una biblioteca de traductores españoles de Pellicer (1778), tal vez también la colección de Sánchez-, ${ }^{265}$ el autor francés ofrece un recorrido cronológico comentado por las escuelas, estilos y autores dignos de mención, acompañado de abundantes pasajes traducidos, en bastantes ocasiones paralelos a los textos originales. ${ }^{266}$

etc. Au surplus, l'expérience de tous les peuples prouve qu'on les captive plutôt en frappant fort qu'en frappant juste. C'est une observation dont Molière a quelquefois usé avec discernement, et dont les charlatans dramatiques ont toujours étrangement abusé» (pp. 170171).

264 Las voluminosas de los Mohedano, el padre Andrés, Lampillas o Sempere, dignas de gran estima, entre otras muchas.

265 Además de sus consultas en la Biblioteca del Escorial, asegura haber acudido a la Biblioteca Real de Madrid, la de Toledo y la Biblioteca Imperial de Francia. Junto a las fuentes citadas, compartidas por los estudios principales en los que se documenta - cancioneros, traducciones, antologías y bibliografías como la Bibliotheca Hispana de Nicolás Antonio-, menciona asimismo fuentes indispensables sobre la influencia árabe en las artes y las ciencias (el Dictionnaire oriental de Herbelot, la Bibliotheca Arabico-Hispana Escurialensis de Casiri), los estudios de Aldrete sobre la lengua, colecciones poéticas valencianas y aragonesas - como el Parnaso aragonés de Juan Francisco Andrés de Uztarroz (1652) o el Aganipe de los Cisnes aragoneses celebrados en el clarin de la fama-, así como la ingente labor editorial de Mayans, una de las fuentes primordiales de sus noticias biográficas. Para familiarizar a su público con la cultura vecina remite también a informaciones puntuales del reeditado Tableau de l'Espagne moderne de Bourgoing.

266 Como complemento, Malmontais llegó a proyectar una antología de copiosos extractos en prosa, elegidos por su belleza elocutiva y la originalidad de sus conceptos, para que divulgaran un juicio atinado de sus avances paralelos a los de la poesía ("On verra que la prose a suivi constamment dans ses révolutions la fortune de la poésie, s'élevant par degrés, comme elle, à un goût pur, et déclinant de même sous l'influence de l'école d'Italie, après s'être soutenue pendant plus d'un siècle dans un état stationnaire de gloire et de perfection, sous les règnes de Charles V, Philippe II et Philippe III. C'est alors que l'on vit la teinte de l'esprit politique du temps se communiquer aux écrits de tous les genres, et leur donner ce caractère noble et viril dont furent empreintes toutes les entreprises de ce siècle», p. 190). Aunque no hemos encontrado constancia alguna de su publicación definitiva, Malmontais enumera en su selección el código legislativo de San Fernando, terminado por su sucesor; ejemplos sacados de los romanciers y de los cronistas de los siglos XIV y XV, y de los monjes Castillo, Yepes y Sigüenza, en los que aprecia destellos de buen gusto e ingenio inspirados en modelos clásicos como Tito Livio, Tácito y Plutarco; Luis de León, Luis de 
La disertación polémica y evaluativa de Velázquez, contemporánea del período de readaptación al modelo clasicista europeo más que de vindicación declarada de las propuestas españolas divergentes de la preceptiva, le sirve de cañamazo a Malmontais — junto a las aportaciones de Sarmientopara urdir un discurso en el que conjuga la paráfrasis con la amplificación y el resumen de contenidos. De esta fuente toma su periodización, partes sustanciales y criterios de organización de la materia ${ }^{267}$ — varios de cuyos pasajes traduce casi literalmente- desde su indagación en los orígenes y los hitos más señalados en su devenir; así como sus valoraciones sobre el teatro, sacadas a su vez por el español de las autoridades de la Academia del Buen Gusto en las que delegó el enjuiciamiento de materia tan delicada. ${ }^{268}$ Sin embargo,

Granada, Juan de la Cruz, Santa Teresa, Estella y Rivadeneyra, como modelos de elocuencia sagrada y moral contemplativa; historiadores como Mendoza, Mariana o Zurita; tratadistas políticos como Saavedra Fajardo, caracterizado por la «tournure ingénieuse de la pensée», o Baltasar Gracián, destacable por su honda capacidad de observación; ensayistas como Huarte por su dialéctica audaz («déliée des anciens») u Oliva Nantes por la modernidad de las hipótesis fisiológicas; así como ejemplos representativos del género novelístico.

267 Su tabla de contenidos abraza cuatro grandes partes que comprenden en primer lugar las fuentes y el carácter de las poesías que influyen en la castellana - la de los españoles primitivos, la latina, la arábiga, la provenzal o lemosina, la portuguesa, la gallega y la vascuence-; en segundo lugar, el origen, progreso y edades de la poesía castellana hasta la actualidad del autor; seguidamente, tras una breve introducción histórica a la métrica y la rima, el análisis histórico de las especies genéricas de la poesía castellana - la dramática (tragedia y comedia), la épica y la lírica (égloga, oda, elegía, idilio, epigrama, poema didáctico y poesía jocosa) - con una numerosa relación de nombres; por último, un artículo conclusivo que aborda diversos asuntos heterogéneos vinculados a la poesía, su historia, sus colecciones, escolios, poéticas y traducciones. En sus siete capítulos — desde el primero, "Origine et progrès de la poésie nationale en Castille»; los cuatro dedicados a las épocas respectivas; hasta el consagrado al teatro español y la monografía final «Sur la Bibliothèque de l'Escurial, les traductions des classiques grecs, latins et italiens, les Commentateurs et les Prosateurs espagnols»—, Malmontais refuerza el orden cronológico, y a partir de la crucial tercera época adopta un criterio autorcéntrico en su examen de los principales géneros con numerosos ejemplos traducidos.

268 Velázquez difunde las opiniones de sus compañeros de la tertulia de la marquesa de Sarriá, que Malmontais va a retomar: la Poética de Luzán (1737), de la que copia numerosos pasajes entrecomillados; la Disertación sobre la comedia Española que precede a las Comedias de Cervantes en la 2. ${ }^{a}$ ed. (Madrid, 1749) de Nasarre; el Discurso sobre las tragedias españolas y el Discurso II sobre las tragedias españolas (Madrid, 1750 y 1753) de su mentor y corrector, el académico Montiano. En su viaje por España junto a su dibujante en busca de documentos originales para la elaboración de una historia de España (Deacon, art. cit.), Velázquez se trasladó a diversas bibliotecas reales, conventuales y eclesiales, a cuyos fondos consultados se refiere con pormenor en su estudio. Sus intensas pesquisas se vieron completadas asimismo por el recurso a la erudición de Nicolás Antonio, Mayans o Pellicer, así como a artículos de la prensa de su tiempo como, por ejemplo, el Diario de los Literatos, o la traducción del padre Isla en el Año Cristiano. 
el crítico francés se emancipa de su referente en ciertas alteraciones estructurales en el orden de los contenidos favoreciendo una disposición cronológica del asunto principal; en la inclusión de extractos ejemplificadores, comedidas incursiones en otros géneros y añadidos documentales y biográficos que ensanchan puntualmente el canon y los límites cronológicos; en consideraciones políticas — como la abierta censura a la Inquisición y al coartamiento de las libertades, publicada cuando en España ya se había abolido por primera vez el Santo Tribunal-y reflexiones cuajadas a fines de siglo como la asunción del carácter nacional de la lengua y la poesía — adjetivadas indistintamente como españolas o castellanas-, oficializado en la asociación de las coronas castellana y aragonesa, o la contextualización de su evolución literaria dentro de los cauces europeos a través de apuntes comparatistas. ${ }^{269}$ La periodización en edades ligadas a siglos y reinados de la historia orgánica de Velázquez queda asimismo explicitada por Malmontais de manera más regular. Las cuatro edades del modelo se corresponden con las cuatro épocas de Malmontais: la primera comprende tres siglos, desde la datación en el siglo XIII de los primeros documentos descubiertos, hasta el reinado de Juan II; la segunda arranca del siglo XV hasta el advenimiento de Carlos V; la tercera abraza de principios del siglo XVI al reinado de Felipe IV a mediados de la centuria siguiente, en la que aún se cuenta con buenos autores pese a la alteración temprana del buen gusto; la cuarta edad empieza a mediados del XVII y se detiene en la actualidad prometedora del XVIII finisecular. Sin embargo, es el siglo XVI la única época gloriosa para Velázquez, reconocida declaradamente por Malmontais («le seizième siècle, seule époque où les Belles-Lettres y aient brillé d'un éclat vif et pur», p. 111) y la que recibe los diversos marbetes. ${ }^{270}$

269 «L'enfance de la poésie espagnole, dont ce chapitre n'est qu'une rapide histoire, a ressemblé sous ce rapport à celle de cet art chez les autres peuples» (p. 56). Por ejemplo, considera a Villena un propagador de las luces en tiempos de barbarie («un philosophe, grand ami des muses, qui avoit imité le Dante, père de la poésie italienne, et précédé immédiatement Chaucer, le père de la poésie anglaise, auquel il ressembla sous beaucoup de rapports», p. 22), y de él traza destacados paralelismos con estos dos ilustres autores como primeros reformadores de la poesía y la lengua de sus países.

270 «Esta tercera edad fue el siglo de oro de la Poesia Castellana; siglo, en que no podia dexar de florecer la buena Poesia, al passo que havian llegado a su aumento las demas buenas Letras. Los medios solidos, de que la Nacion se havia valido, para alcanzar este buen gusto, no podian dexar de producir tan ventajosas consequencias. Se leian, se imitaban, y se traducian los mejores originales de los Griegos, y Latinos; y los grandes Maestros del Arte Aristoteles, y Horacio, lo eran assimismo de toda la Nacion» (pp. 66-67). La divulga- 
Tras remontarse como su fuente a los poetas hispanorromanos y la meritoria latinidad cristiana, hasta las invasiones bárbaras que contribuyeron a hacer desaparecer paulatinamente las ideas de lo bello y de lo sublime que los romanos habían inculcado, Malmontais esboza un cuadro de la diversidad lingüística peninsular en el que traza una serie de consideraciones preliminares sobre el estado actual de la lengua española y sus orígenes, resumiendo las teorías sobre el origen de la poesía castellana y prestando atención a los autores aragoneses, catalanes y valencianos. Como Velázquez, Malmontais subraya tres grandes ascendientes o revoluciones sobre la literatura española, el árabe —entonces origen remoto de la poesía moderna a la que legó el entusiasmo poético y la imaginería, redundancia, armonía y majestad de su lengua poética-, ${ }^{271}$ el trovadoresco o provenzal — como director del buen gusto—, ${ }^{272}$ ambos hondos y duraderos, y el italiano en el siglo XVI, sin incluir explícitamente la influencia

ción del sintagma Siglo de Oro, anejo a las excelencias referidas de los autores del siglo de Augusto y a la coetaneidad de los reinados («quando iba naciendo entre nosotros la buena Poesia en tiempos de Carlos V», p. 127), se extiende a Malmontais con expresiones como «bel âge» o "âge d'or» («l'âge d'or de la poésie espagnole et l'époque du rétablissement des Belles-Lettres dans le royaume») o "siècle de Charles V».

271 Malmontais, como Velázquez, también adjudica a esta cultura la restauración de la literatura en España y la transmisión del entusiasmo - «qualité brillante qui se développe naturellement dans des esprits possédés de la double passion de l'amour et de la gloire» (pp. 12-13)_; apoya este ascendiente frente al germánico sobre la formación de la poesía moderna («Il seroit superflu, je crois, d'aller rechercher l'origine éloignée de la poésie moderne dans les chants des Bardes et des Scaldes du nord; les fictions runiques pâlissent et disparoissent dès qu'on leur compare la richesse et l'ascendant de la langue des Arabes», p. 11); presenta pasajes similares al referir la rudeza y barbaridad gótica, a la que el francés nunca aplica las cualidades de belleza y sublimidad que reserva a los clásicos, y añade la contribución judía a las ciencias. Sin embargo, no comparte la preeminencia otorgada por Velázquez a la poesía arábiga sobre la provenzal, pues, si bien este les atribuye a ambas la práctica de los principios dramáticos, en su cotejo de logros y deméritos poéticos pese a los excesos de la primera, la segunda no habría superado los géneros de disputas y contiendas amorosas.

272 Malmontais concede una importancia aún mayor que su fuente a los trovadores («qui ont formé et dirigé, au-delà comme en deçà des Pyrénées, le bon goût de la poésie moderne», p. 14), amplía su censo de nombres con notas biográficas y formas métricas aludidas, y elogia también las asambleas poéticas pese a considerar justificadas las críticas que se les hicieron en su fase de decadencia. Estudiados entonces por Millot y reivindicados más tarde por Fauriel por su influencia en la renovación de las literaturas meridionales, los trovadores no solo habrían infundido un carácter propio a la lengua forjada por la influencia de romanos, godos y árabes, sino que además se les atribuyen los primeros ensayos dramáticos que habrían reanudado la práctica latina. 
francesa. En su valoración de los monumentos medievales, Malmontais acoge un pasaje de la entrada del Cid en Burgos de gran fortuna en historias y antologías — ausente en Velázquez, citado por Sarmiento y exhumado por Sánchez-, que el crítico describe sumariamente como un «récit en vers des aventures du célèbre $\mathrm{D}$. Rodrigue de Bivar» en tiradas asonantes. Meritorio por la remota época en que se compuso ("poème étonnant, malgré sa simplicité, pour le temps où il a paru», p. 37), su "touchante naïveté» es también digna de aprecio. En cuanto al resto de producciones de la primera edad, estimables por ciertas cualidades poéticas desperdigadas y por su moralidad, Malmontais sigue el repertorio propuesto por su fuente: no solo alude a varias de las obras berceanas, al Libro de la vida y hechos de Alexandro Magno -memorable por el azar de las conservaciones manuscritas, algunos detalles de valor costumbrista y expresiones justas y majestuosas - y a las obras de Alfonso X; también traduce la sentencia final del exemplo XX («De lo que contesció a un rey con un omne quel dixo quel faría alquimia») de El conde Lucanor; y, más comedido ante las dificultades de comprensión que plantea la obra de Juan Ruiz que su descubridor Velázquez — quien elogió sus hallazgos e innovaciones poéticas de su sátira, superior en invención al clásico Petronio-, Malmontais suprime varios pasajes de los extractados en contra de su costumbre por el español, limitándose a comparar con Rabelais este «bizarre poème» por su originalidad, tan apreciada por Sánchez y los estudiosos españoles posteriores. Bajo el magisterio de Sarmiento que proclamaba la España del siglo XIV como tierra de crónicas, el autor francés alude al manuscrito de la dedicada a Enrique III por el canciller Ayala, y selecciona entre el material editado por Argote de Molina la carta de Bayaceto traída por el embajador González de Clavijo. La segunda edad, ${ }^{273}$ caracterizada desde el reina-

$273 \mathrm{Al}$ terminar la segunda época, Malmontais recapitula sus conclusiones trasladando en diversos lugares de su exposición algunos pasajes de la principal fuente documental: «En résumant cet aperçu rapide des progrès de la littérature pendant le quinzième siècle, nous voyons que Juan de Ména avoit introduit dans la langue l'élévation du style. Jorge Manrique l'avoit poli, en lui donnant un système de versification plus naturel. Le marquis de Santillana commença à lui faire connoître l'harmonie des italiens; enfin Juan de la Encina prouva qu'elle étoit capable de se plier à tous les tons du drame, en donnant, sur l'art dramatique, des préceptes aussi complets qu'on pouvoit l'espérer alors» (p. 70). Así había terminado Velázquez su capítulo: «En esta segunda edad, comenzó la Poesía Castellana a mudar de semblante, perdiendo mucho de su primera rudeza. Juan de Mena la empezó a ensayar en 
do de Juan II por un mayor pulimiento lingüístico y — como afirma el crítico francés- por el declive de la influencia trovadoresca, el desarrollo de las luces y la expansión de una lengua y un imperio bajo la unión dinástica de Castilla y Aragón, ofrece asimismo dignos modelos («era digna de que la huviessen imitado los que poco tiempo después restablecieron entre nosotros la buena Poesía»), como subrayaba la fuente española. Malmontais erige a Villena en padre de la poesía en España y, a imagen de Velázquez, refiere una nómina de poetas recopilados en las principales compilaciones del Cuatrocientos como el Cancionero general o el de Baena, y entre las principales obras, formadas también en el estudio de Dante, destaca, de entre las composiciones del marqués de Santillana, sus sentencias morales — sobre todo el libro de los Proverbios y los consejos al príncipe D. Enrique, y la carta-prohemio, extractada por Sarmiento antes de su publicación íntegra por Sánchez-; el Laberinto de Mena («un des monumens principaux de la vieille poésie»), ${ }^{274}$ que mereció la exégesis del Pinciano; los Claros varones de Castilla, la Crónica de Juan II y las Sentencias y coplas de bien vivir del cronista y poeta Pérez de Guzmán; los versos de Macías recogidos también por Sarmiento; las Cartas del bachiller Fernán Gómez de Ciudad Real; las sátiras de Mingo Revulgo; la autoridad de Juan del Encina, precursor de la edad siguiente por sus muestras de buena poesía, y junto a Gómez Manrique, la gracia, pureza y moralidad de las coplas castellanas de su hijo, conocidas también por sus glosas. Más contundente que su modelo, Malmontais emprende además — como ya adelantara Luzán y confirmara el P. Andrés - un alegato reivindicativo del alto grado de civilización de la cultura medieval española. ${ }^{275}$

la grandilocuencia, que no conocía: D. Jorge Manrique, y Garci Sánchez de Badajoz, pulieron el estilo, y la adornaron con la pureza del lenguaje, y facilidad de la Rima: el Marqués de Santillana la sacó de las mantillas de sus coplas, haciendola hablar en el rithmo de los Provenzales, y de los Italianos: Juan de la Enzina hizo ver, que ella era capaz de sostener el artificio del Drama; y assi él, como D. Enrique de Villena dieron principio a la imitación poetica, haciendo hablar en Castellano al mejor de los Poetas Latinos; y dando los primeros documentos del Arte, el uno en el de la Poesía Castellana, y el otro en el de la Gaya ciencia. En un siglo tan rudo, y en que eran tan poco conocidas, y estimadas las buenas Letras, no se podían esperar mayores adelantamientos en nuestra Poesía» (pp. 56-57).

274 Reeditado en 1804 (Las obras del famoso poeta Juan de Mena).

275 «Tout ce que nous avons avancé prouve que les Espagnols n'étoient point dépourvus de science et d'instruction, à une époque où presque toute l'Europe étoit enveloppée dans les ténèbres de l'ignorance» (p. 58). 
La concesión a la influencia italiana en la centuria siguiente, si bien se saldó con cierta pérdida de su nacionalidad («sa diction mâle et dure [...] perdit un peu de son originalité par l'étude de l'école italienne»), también ganó en mejor gusto y perfección formal, compensaciones que ambos críticos conceden frente al desprecio que comenzaba a estigmatizar ideológicamente este influjo. ${ }^{276}$ Como los escritores y eruditos de mediados de siglo en su esfuerzo por recuperar la naturalidad del estilo y el genio nacional frente al gongorismo, ${ }^{277}$ Malmontais vuelve los ojos hacia el XVI, fecundo en oradores sagrados, grandes poetas, buenos críticos, novelistas excelentes e historiadores de primer orden, en el que renacen todas las artes, las ciencias y el buen gusto, inspirado en las fuentes de la Antigüedad y los modelos de los italianos modernos que enlazan con Petrarca - Sannazaro, Bembo, Ariosto, Fracastorio, Trisino-. Más aún, frente al silencio de Velázquez, el francés promociona el enaltecimiento de los autores más representativos de la tercera época al rango de clásicos junto a sus modelos grecolatinos. Basándose también probablemente en las ediciones contemporáneas y en los parnasos poéticos ${ }^{278}$ para su selección de ejemplos, a los que añade extensas notas biográficas, introduce varios representantes de los géneros en prosa de esta época. ${ }^{279}$ Expone así la producción

276 «supieron juntar al modo de rimar de los Italianos todo lo demás en que consiste la buena Poesía; esto es, la imitación, la invencion, las imágenes Poeticas, la magestad de la diccion, la hermosura, y facilidad del estilo, y el genio, para lo grande, y maravilloso" (p. 57). En el prólogo al tomo XVI (1796) de la colección de Ramón Fernández, Quintana ya tachaba de imitativo este siglo.

277 Malmontais esquiva el debate contemporáneo contra los galicismos de las últimas décadas del siglo y, pese al reconocimiento general en esas décadas de la transformación del estilo prosístico, sigue afirmando que el XVIII no ha descubierto aún el antídoto eficaz contra el gongorismo.

278 «Pour conserver la mémoire de cette époque brillante, les Espagnols ont inventé un Parnasse sur lequel ils ont placé neuf de leurs plus célèbres poètes. Ce sont: Garcilaso de la Vega, Luis de León, Villegas, Lupercio et Bartholomé Argensola, le Prince d'Esquillache, le Comte de Rebolledo, Quevedo et Lope de Vega» (p. 111).

279 Tras la mención de la obra de Joan Martorell, el lugar de honor de la novela está reservado a Cervantes («le meilleur des esprits»), respetada fuente documental de la historia del teatro, guía del buen gusto, crítico atinado en su Viaje del Parnaso, y hasta los años treinta del XIX, como para Marchena o Maury, el «historien de Don Quichotte» (véase para más detalle sobre la recepción cervantina de ese período J. Álvarez Barrientos, «Sobre la institucionalización de la literatura: Cervantes y la novela en las historias literarias del siglo XVIII", Anales Cervantinos, t. XXV-XXVI, 1987-88, pp. 47-63). Malmontais mantiene la opinión de Nasarre sobre esta obra («incomparable roman de Don Quichotte, le chef-d'œuvre du bon sens et les délices de tous ceux qui en connoissent le prix») como sátira eficaz de los libros 
más señalada de los reformadores petrarquistas del XVI que se imponen a la resistencia de la vieja escuela representada por Castillejo e instauran la «saine doctrine» tantas veces invocada por los críticos franceses. Caracterizado por la elegancia y flexibilidad estilística, Boscán, cuya fama irá en retroceso a lo largo del siglo, inaugura la poesía moderna. ${ }^{280}$ Mayor enaltecimiento recibirá siempre Garcilaso por la perfección formal de sus composiciones que rivalizan con los modelos inmortales ${ }^{281}$ —el Petrarca de la Poesía Castellana, en palabras de Velázquez («capaz hubiera sido de competir con el mejor de griegos y romanos», p. 77), cuya opinión reproduce el autor francés a propósito de su gusto depurado y personal, pese a leves incorrecciones deudoras de la estética anterior-. Sin embargo, Hurtado de Mendoza - cuyo mayor mérito reside en su obra histórica, a la altura de Tácito y Salustio-, aunque más estimable por sus composiciones burlescas, no suscita especial entusiasmo por la dureza de su verso, achacable a la «vieille école». Entre la pléyade de discípulos censados por Velázquez en diversos géneros ${ }^{282}$ sobresale la lírica de Herrera, cuya valo-

de caballerías, superior al resto de su producción. Asimismo, El diablo cojuelo de Guevara, conocido por la reputada versión de Lesage, responsable asimismo de la del Guzmán («bien inférieur au précédent sous le rapport des caractères») y del Gil Blas, basado también en la Vida del escudero Marcos de Obregón de Espinel; o las Aventures de Lazarille también difundidas por la BUR en agosto de 1781, inferior al talento de las Guerras civiles de Granada de Hurtado de Mendoza, a quien se atribuía hasta Morel-Fatio la autoría de la novela. Junto a él apunta otros maestros del género histórico como Mendoza, Mariana y Zurita por su decoro, la exactitud de sus juicios y la gravedad de su estilo. También elogia la República Literaria de Saavedra Fajardo, muy apreciado por Mayans, y la Introducción al símbolo de la fe de fray Luis de Granada — «le Bossuet de l'Espagne»_, modelo clásico de la oratoria religiosa por su majestad prosódica, y de la que traduce el íncipit del segundo capítulo.

280 Además de mencionar elogiosamente sus composiciones, Malmontais traduce parte de su narración del encuentro con Navagiero, episodio de la vida literaria de la época; su versión de la fábula de Museo, así como su célebre epístola a Hurtado de Mendoza, muy alabada por su recreación original del beatus ille, y cuya profundidad de pensamiento, expresión justa y combinación feliz de tonos la hacen digna de Horacio.

281 Desde sus sonetos morales y galantes de tono melancólico, sus elegías a imitación de Tibulo, o sus epístolas como la dirigida a Boscán, modélica por sus hallazgos poéticos y por la adecuación ejemplar del estilo al tema, hasta sus églogas, sobre todo la celebérrima égloga I, de inspiración bucólica rezumante de clasicismo, de la que traduce diversos pasajes.

282 La enumeración, ajena a divisiones cronológicas, estilísticas o generacionales, acoge a Gutierre de Cetina, Luis de Ulloa, Luis de Haro, J. de Montemayor, H. de Acuña, los estimados Saa de Miranda, F. de Medrano, P. de Padilla, G. Hernández de Velasco, J. de Guzmán, G. Bermúdez, Lope de Rueda, moldeador del teatro español, Torres Naharro, J. de la Cueva, Ercilla, Gil Polo y el alabado Montemayor. 
ración comparten ambos estudiosos — pues, si bien le reconocen méritos como la pureza de estilo, un pensamiento elevado o un selectivo buen juicio, le reprochan su exceso de lima-, y al que sobrepasa fray Luis de León ${ }^{283}$ — genio superior para ambos desde su promoción por Mayanspor su dominio no superado del arte, sus dotes poéticas innatas y su juiciosa selección de fuentes bíblicas, clásicas, neolatinas e italianas modernas en sus poemas ${ }^{284}$ y sus traducciones. Equiparados los Argensola a este último por Velázquez («después acá no ha tenido España otros dos Poetas tan buenos como ellos»), ejemplares por su resistencia al mal gusto, ${ }^{285}$ su elección se ve secundada por Malmontais, como también el notable espacio dedicado a Villegas, quien, apreciado asimismo por autores modernos como Cadalso, mentor de jóvenes poetas, acapara un cúmulo de comparaciones elogiosas con los grecolatinos por su buen gusto.

Si Velázquez - tras el examen retrospectivo desde la Vida y hechos de Alexandro, Los trabajos de Hércules de Villena, o el Laberinto de Mena, entre otros, hasta la épica culta renacentista ${ }^{286}$ justifica el aceptado estancamiento de la epopeya española ante los detractores extranjeros por el alto listón puesto por griegos y latinos, e incluso rebaja el mermado elogio a La Araucana por Voltaire, ${ }^{287}$ Malmontais, más comprensivo, halla en esta obra irregular («remarquable par des beautés du premier ordre, par des défauts sans exemple et par la manière singulière dont il a été composé»)

283 Tras la edición del humanista valenciano, el agustino fray Antolín Merino preparó otra más a principios del XIX (Obras, Madrid, Ibarra, 1804-1816, 6 vols.), que sería reeditada en 1885 (Madrid, Cñía. de Impresores y Libreros del Reino, 4 vols.).

284 Además de subrayar la excelencia de sus odas sacras («empreintes de toute la majesté des prophètes», p. 94), Malmontais también traduce varios pasajes de la oda al río Tajo "peut-être citée comme un chef-d'œuvre de poésie et de patriotisme» (p. 94).

285 Tras sus pasos, Velázquez citaba en distintos géneros autores como Juan de la Cueva, Espinel, Jáuregui, Argote de Molina, F. de Rioja, Pedro de Espinosa, F. de Figueroa, L. de Ulloa, y en el género descriptivo Bartolomé Cayrasco Figueroa.

286 El español incluye un inventario de poemas épicos cultos, que será recurrente para los críticos franceses posteriores, con nombres como Zapata, Urrea, Samper, Mesa, López Pinciano, Mosquera, Zárate, Esquilache, Virués, Lasso de la Vega, Gallegos, entre otros, de los que elogia a Argensola y en especial La Austriada de Rufo.

287 La inadecuación de la materia elegida con el género épico o la mezcla de géneros y tonos, pese a los buenos versos de Ercilla, se imponen en la condena de Velázquez, aún más severo que Voltaire, quien en el Essai sur la poésie épique (1723) que acompañaba a su Henriade eximió de los cargos habituales el discurso del viejo Colocolo a los indios (1. ${ }^{\mathrm{a}}$ parte, canto II). 
más pasajes dignos de memoria que el precipitado veredicto de su compatriota. Como contrapeso a los reconocidos defectos en el plan, el enlace de las partes, la inconveniencia de las situaciones y el trazado de los caracteres, se demora en el poema ${ }^{288}$ para realzar sus verdaderas cualidades como la energía de sus conceptos, el vigor sugerente de sus detalles y la elegancia, sonoridad y nervio de su verso. Entre los autores que, a su juicio, conservan a fines del XVI el buen gusto por sus excelencias pese a sus desigualdades, ambos estudiosos tributan alabanzas a Quevedo. Mientras que Velázquez seleccionaba sus traducciones de Epicteto y Focílides, algunas sátiras y canciones y la edición de las poesías del bachiller de la Torre, Malmontais - aun destacando su talento poético en las composiciones amorosas y satíricas - privilegia, por su buen gusto, juicio certero e incluso delicadeza de sentimientos, ${ }^{289}$ su prolífica prosa, ${ }^{290}$ que lo emparenta con los humoristas ingleses del XVIII y con Rabelais; ${ }^{291}$ así como la religiosidad y extensa erudición de sus discursos morales y de su correspondencia en latín con Justo Lipsio, Chifflet y Scoppius. Tras la decadencia de las artes y las ciencias sobreviene en la cuarta edad el declive literario con un estilo premeditadamente oscuro y una hinchazón cultista en todos los géneros. Mientras que en los años cincuenta Velázquez con cierto hastío rehusaba descender al origen de la corrupción del gusto - al que contribuyeron Góngora y sus seguidores en la poesía, Gracián en la elocuencia con su Agudeza y arte de ingenio, y Virués, Lope y Montalbán, imitados a ultranza por Calderón, Salazar, Candamo y Zamora en el teatro-, Malmontais, asumiendo los contraataques españoles de los años ochenta, la achaca a Marini y su escuela, dictamen aceptado mayoritariamente en el XIX.

288 Dando fe a la estima cervantina que, como otros contemporáneos, rindió homenaje al poeta, Malmontais alaba, por ejemplo, la primera estrofa, el retrato de María Bazán que también traduce, el emocionante episodio XX del canto I con el deambular de Tegualda entre los caídos en la batalla, en busca de su marido, y pondera la empatía del poeta al presentar con sensibilidad a los salvajes araucanos («il a senti avec finesse et présenté avec art les idées d'un peuple sauvage»).

289 «Ses discours moraux prouvent la profondeur de son érudition et l'élévation de ses sentimens religieux; ses ouvrages littéraires, la sûreté de son jugement et la délicatesse de son goût» (p. 113).

290 "Je l'ai réservé pour l'article des prosateurs parmi lesquels est sa vraie place, quoique dans la multitude de ses productions poétiques, on en trouve plusieurs qui ne se ressentent nullement de l'époque de décadence à laquelle il vivoit» (p. 112).

291 «il posséda particulièrement cette tournure d'esprit que les Anglais admirent dans Swift et Butler, et dont Rabelais, chez nous, eût incontestablement le mérite original» (p. 114). 
La promoción de los contertulios de Velázquez — las reflexiones teóricas $^{292}$ y la práctica teatral de Montiano, las disertaciones de Torrepalma, las églogas de Porcel, comparables a su juicio a las garcilasianas- halla un eco más amortiguado en las páginas de Malmontais: se mantienen sin fisuras los elogios a la reforma patriótica de Luzán por la solidez de su exposición de los principios universales del arte en su Poética (1737), y por su ejemplo como poeta e introductor de modelos con sus adaptaciones teatrales del drama sentimental tan elogiadas por su amigo; la muy alabada antología del Parnaso español, o la autoridad europea de un Gregorio Mayans, elogiado sumamente por el francés por su biografía cervantina, izada a obra maestra pronto traducida al francés, ${ }^{293}$ por sus Cartas morales, militares, civiles y literarias, sus vastos estudios de historia y cosmografía y su labor restauradora de las letras; en cambio, las tragedias de Montiano, mentor de Velázquez, no son tan celebradas. ${ }^{294}$ A este grupo acreditado Malmontais añade asimismo los nombres de eruditos como Antonio Mayans y el prestigioso Juan Iriarte; traductores e historiadores de esa cuarta edad, encabezados estos por Solís; ${ }^{295}$ un Feijoo poco conocido en Francia y enaltecido como pensador, crítico y vulgarizador ingenioso en su Teatro crítico universal, ${ }^{296}$ digno de rivalizar con

292 Su protegido señalaba asimismo su deuda documental con la Philosophia antigua poetica de López Pinciano.

293 Vie de Michel de Cervantes (1740), a cargo de Pierre Daudé, ministro calvinista (1681-1754). Véase Quérard, ob. cit., t. II, p. 400.

294 No obstante, tanto Virginia (1750) como Ataúlfo (1753) habían sido traducidas al francés junto a su discurso por M. d'Hermilly (Dissertation sur les tragédies espagnoles, París, G. F. Quillau, 1754).

295 Entre las historias del XVIII cita la obra del marqués de San Felipe (Comentario sobre la guerra de 1700), traducida al francés bajo el título Mémoires pour servir à l'histoire d'Espagne sous Philippe $V$, ya reseñada en la prensa cosmopolita francesa de la época. También es muy elogiado el agustino Enrique Flórez con su España sagrada (L'Espagne sacrée o Histoire ecclésiastique de l'Espagne) de la que ensalza la pureza de su estilo y la imparcialidad y acierto de sus juicios, tanto más llamativos en su opinión por la materia abordada y la nacionalidad de su autor. De Campomanes cita su Historia de los templarios, y del duque de Almodóvar, su Historia del establecimiento de las naciones europeas en las dos Indias, que juzga superior a la de Raynal por su estilo y la calidad de sus reflexiones.

296 Contó con una traducción incompleta al francés (Théâtre critique et moral, París, Clément, 1742-45) por Vaquette d'Hermilly a partir de la edición de 1777. De esta miscelánea, varios de cuyos títulos refiere, Malmontais traduce también el comienzo de su primer discurso, Voz del pueblo, tan recurrente en manuales y antologías posteriores, así como un pasaje de Du Vice et de la Vertu, además de enumerar una nutrida relación de artículos de su obra. 
Addison, Bourdaloue y Buffon, sin que el desfase de varias de sus aserciones sobre asuntos científicos merme su mérito — si bien su fama irá decayendo con el transcurrir del siglo- ; un meritorio padre Isla — conocido también por su Voyage au pays des singes, su polémica traducción del Gil Blas, ${ }^{297}$ y su resumen de la Historia de España-, de cuya original novela satírica, Fray Gerundio, heredera de la tradición de Quevedo y Guevara aunque demasiado localista y prolija, ${ }^{298}$ traduce varios pasajes muy frecuentados en las antologías e historias, como, por ejemplo, el retrato de su mentor; el jesuita expulso Montengón, con novelas morales como el elogiado Eusebio, exento de los sofismas del estilo francés; Iriarte, de gusto excelente en su correcta y magnífica traducción del Arte poética de Horacio y en su poema didáctico sobre la música — pese a cierto decaimiento del verso y la sequedad de su minuciosidad descriptiva-, por la claridad y propiedad de su estilo y la encomiable exposición de su asunto, más adecuado al género que el de Viera o el famoso y excelente poema de Céspedes sobre la pintura al que los franceses no han igualado en elegancia; y - superado en hondura conceptual y sublimidad por Montengón- el Meléndez Valdés de los logrados poemas de juventud ("pièces fugitives»), canciones, odas, silvas y letrillas felizmente inspiradas en Anacreonte y Metastasio.

El artículo dedicado por Malmontais íntegramente al teatro, foco de influencia social tan eficaz como el púlpito y entonces aún más que la prensa, pone de relieve su importancia fundamental en el ideario ilustrado como liza polémica en la que se dirimieron en España debates

297 Aventuras de Gilblas de Santillana robadas a España, por LeSage, restituidas a su patria y a su lengua nativa por un Español zeloso, Madrid, 1797, 4 vols en 4. ${ }^{\circ}$. Además de esta versión del P. Isla tan elogiada hasta finales de siglo, B. M. de la Calzada había presentado en 1792 su Genealogía de Gil Blas de Santillana, continuación de la vida de este famoso sugeto, que demuestra el vigor de la polémica a fines del XVIII.

298 Frente a su otra obra igualmente satírica (Voyage au pays des singes) —ingeniosa y divertida crítica del ingenio, usos y ridiculeces de las provincias españolas, que podría ser leída con placer en otros países-, la monotonía y localismo de su novela, fallida en sus propósitos, adelanta uno de los reproches esgrimidos décadas después a la literatura española contemporánea cuando se rebaje el valor de la singularidad española frente a otras culturas ("Je ne crois pas cependant que cet ouvrage fût lu avec un grand intérêt en France, parce qu'il porte tout entier sur un ridicule peu commun et, surtout, peu saillant parmi nous», p. 139). 
estéticos e ideológicos. Tras las noticias sobre sus orígenes, ${ }^{299}$ el autor francés aborda el estudio de los géneros dramáticos canónicos en su devenir histórico haciéndose eco puntualmente no solo de Boileau o Bohours, sino también de las opiniones del acérrimo y vehemente Nasarre, y sobre todo de un comedidamente contemporizador Luzán (Poética, cap. XV, libro III), ${ }^{300}$ con cuya actitud el prudente Velázquez se muestra más afin. Sin rehuir como en su fuente la mención de los autos sacramentales, entonces ya suprimidos, Malmontais se centra en el caso paradigmático de Lope $-\mathrm{y}$ secundariamente en Calderón, pese a su predominio en las representaciones de la época y al prestigio de que gozaba entre una parte del público instruido del XVIII-, a los que también enjuicia sin ejemplificar. Admirado ante la singularidad de Lope

299 Además de consultar la edición cervantina de Nasarre y los discursos de Montiano, Malmontais enumera diversas composiciones de entre las más numerosas que incluyen Velázquez o Mayans, desde los orígenes religiosos del género, como la comedia de Villena, los diálogos insertos en los cancioneros, las églogas de Encina, las obras inspiradas en los grecolatinos de Villalobos, Pérez de Oliva o Simón Abril, las tragedias de Díaz de Fregenal, las patéticas Nises de Bermúdez — primeras tragedias dignas de estima en las que se inspirará Lamothe en el género sentimental- Virués o más tarde Argensola; además de La Celestina — novela dialogada conforme a la opinión general que aprecia asimismo el primer acto sobre el resto hasta finales de siglo- , que también tacha de inmoralidad y cuyo estilo y corrección clásica alaba. Malmontais apunta diversas traducciones francesas y alguna inglesa (The Spanish Rogue) coetáneas de la tragicomedia. Entre los buenos autores dramáticos alude, por ejemplo, a las aportaciones de precursores como Lope de Rueda con sus pasos Tholomea o La duquesa de la Rosa, Naharro, Castillejo, o el innovador y desigual Juan de la Cueva, frente a un mediocre Guillén de Castro reducido, a ojos de ambos críticos, a proveedor de material para el genio de Corneille.

300 «Me contentaré con decir por mayor, y en general, que en todos comunmente hallo rara ingeniosidad, singular agudeza, y discrecion, prendas muy essenciales para formar grandes Poetas, y dignas de admiracion: y añado, que en particular alabaré siempre en Lope de Vega la natural facilidad de su estilo, y la suma destreza, con que en muchas de sus Comedias se ven pintadas las costumbres, y el carácter de algunas personas. En Calderon admiro la nobleza de su locucion, que sin ser jamás obscura, ni afectada, es siempre elegante; y especialmente me parece digna de muchos encomios la manera, y traza ingeniosa, con que este Autor, teniendo dulcemente suspenso á su Auditorio, ha sabido enredar los lanzes de sus Comedias, y particularmente de las que llamamos de capa y espada, entre las quales hai algunas, donde hallarán los Criticos muy poco, ó nada que reprehender, y mucho que admirar, y elogiar. Tales son las Comedias Primero soi yo: Dar tiempo al tiempo: Dicha, y desdicha del nombre: Qual es mayor perfeccion: De una causa dos efectos: No hai burlas con el Amor: Los empeños de un acaso, y otras» (pp. 115-116). Sobre esta toma de partido en el contexto cultural español de la primera mitad del XVIII, véase J. Checa, art. cit., 2002. 
en el canon europeo («cet homme étonnant, le génie le plus fécond, et peut-être le poète le plus heureux que la terre ait jamais enfanté», p. 160), el crítico francés inserta apuntes biográficos de este extraordinario autor cuya fecundidad irreprimible, su vivaz ingenio y su celebridad no hallan parangón hasta Voltaire, ${ }^{301}$ y cuyas piezas teatrales más presurosas - frente a la opinión reticente de Velázquez, para quien algunas de sus églogas, junto a varias elegías y epigramas, son más dignos de estima que la mayor parte de sus obras_ 302 están escritas con más corrección y elegancia que las más cuidadas de otros contemporáneos suyos. Reconocido su deslumbrante talento poético que oculta las deficiencias estructurales, persisten tenazmente, sin embargo, los principales cargos proclamados por Nasarre que pesan sobre su producción dramática - apenas representada entonces en su forma original, a no ser en adaptaciones ad usum de los comediantes, truncadas por cortes censores, o reescritas en las refundiciones de entresiglos-. La vivaz pintura de caracteres y los sublimes esfuerzos de su genio natural se ven oscurecidos por el desorden de su imaginación, la infiltración del mal gusto y la adulación al gusto popular. Su mayor condena se funda, no obstante, en su rebelión consciente contra los preceptos de los antiguos y las unidades — base de «tout intérêt dramatique»— vulnerando la verosimilitud, la división genérica, el decoro en la asignación del tono y el lenguaje según la clase social, y la abigarrada espectacularidad de asuntos poco adecuados a las tablas, como entierros o procesiones, en las

301 «cet homme extraordinaire qui, par la nature et la fécondité de son talent; par l'enthousiasme qu'il excita, par les richesses et les honneurs dont il fut comblé, par l'époque relative où il vécut, offre des rapports frappans avec l'écrivain qui, chez nous, pendant le dix-huitième siècle, a presque exclusivement occupé la scène et la renommée» (pp. 156-157).

302 Sin llegar al apasionamiento de Nasarre, Velázquez tampoco estima la mayor parte de sus obras: ni sus fallidos poemas épicos La Dragontea, El Isidro, La Jerusalén conquistada — aun cuando juzga conveniente la publicación del examen por Juan Pablo Mártir Rizo- y La conquista de la Bética, que incurre en los mismos errores denunciados pese a su mejor estilo y concepción; ni su poética El Arte Nuevo, texto que no incluye en su repertorio final «porque no le contemplo el más arreglado». Los únicos títulos dramáticos que menciona son los de las tragedias canónicamente reconocidas por su autor: "Entre las obras de Lope de Vega se encuentran El Duque de Viseo, Roma abrassada, La bella Aurora, El Castigo sin venganza, La inocente sangre, y El Marido mas firme, que no son mejores que las Comedias, y Tragicomedias de este Autor: y verosimilmente tampoco lo será la Aristea Tragedia del mismo Lope, de que hai memoria en un Catálogo de sus Poesias» (p. 122). 
puestas en escena contemporáneas. De igual modo, reconociendo la supremacía de Calderón sobre los epígonos de Lope, Malmontais lo acusa de pervertir el gusto nacional, ${ }^{303}$ conforme a los enjuiciamientos de Nasarre, quien, si bien también admitió la superioridad de su ingenio, minada, no obstante, por su emancipación de los modelos antiguos al fiar en su sola imaginación, censuró acerbamente este desvío en nombre del ideario estético e ideológico neoclásico ${ }^{304}$ y rechazó su representatividad nacional ( $\mathrm{E}$ s verdad, que para disculparle, quieren decir, que retrata la Nacion; como si toda ella fuesse de Caballeros andantes, y de hombres imaginarios», p. 112) frente a interpretaciones posteriores. Asimismo, el estudioso francés entresaca los ejemplos de sus coetáneos - Solís, Moreto y Zamora, cuyo orden variará entre los historiadores y críticos posteriores, ${ }^{305}$ a los que añade a Guillén, omitiendo a Rojasde la jerarquía de autores de Luzán atendiendo a su respeto de las normas del arte, su decoro, comicidad, cuidadoso estilo, adecuado trata-

303 Si ciertos críticos como Bernardo de Iriarte habían rescatado algunas de sus piezas del baldón por ser susceptibles de «arreglos» al canon clásico, Malmontais extiende con cierta reserva esa conmutación de pena a varias de sus obras, que no llega a nombrar, basándose en su mayor moralidad: «son théâtre n'est autre chose qu'une école du vice, où celui-ci triomphe toujours; où le beau sexe apprend qu'il doit tout sacrifier aux impressions de l'amour, mépriser les sages avis, et céder en toute occasion à l'artifice des séducteurs. Il n'est sorte d'encouragement qu'il ne donne au plaisir et à la licence, et ses arguments sont d'autant plus dangereux qu'ils sont revêtus d'une expression séduisante. Son talent serait digne d'éloges s'il en eut fait un meilleur usage. Quelques-unes de ses pièces, cependant, peuvent échapper à la censure par le mérite d’un peu plus de décence» (p. 161).

304 El resumen crítico de Malmontais recuerda los rigurosos argumentos desarrollados por Nasarre. La susceptibilidad neoclásica en lo tocante a la jerarquía social y familiar, núcleo básico del Estado, censura la presentación en escena ante el pueblo de las mujeres aguerridas e indóciles del drama barroco, de pasiones violentas, y malos ejemplos corruptores que incitan con una retórica seductora y brillante a los excesos, la disconformidad y el medro social. La construcción de las comedias calderonianas suscita su condena en nombre de la razón y el arte al achacarle la falta de unidad de acción — diluida en asuntos mal trabados-y de introspección psicológica, así como el abuso de enredos y acciones trenzadas, recurso este último revalorizado más tarde, si bien los anteriores suelen provocar mayores resistencias entre los franceses del XIX a la aceptación de la excelencia del dramaturgo.

305 Solís, en absoluto inferior a sus ojos a Calderón, por su estilo elegante, en especial con La gitanilla de Madrid, El alcázar del secreto y Un bobo hace ciento; Moreto con El desdén con el desdén, y Zamora con las otras dos, El hechizado por fuerza y Castigo de la memoria. 
miento de los asuntos propios del género y reflejo de las costumbres del tiempo con gusto. ${ }^{306}$ De este modo, pese a reproches veteranos como el hibridismo genérico y temático, la imposición de la plebe, o la irreverencia ante las normas — con la prestigiosa excepción de un Cervantes afirmado en los sanos principios de lo bello y lo verdadero-, más de medio siglo después de las adaptaciones de Duperron (1738) y tras la aún cercana selección de Linguet, Malmontais no juzga deleznable en su conjunto el singular teatro antiguo español («le vieux théâtre espagnol»). De proverbial abundancia, la variedad e imaginación de sus talentos, que no se limitaron, como el resto de dramaturgos europeos, a la pintura de caracteres y pasiones - y que tampoco les niega- ofrecen también hallazgos poéticos y dramáticos en intrigas, estilo y materia, cuya adecuación general a los valores universales de la buena comedia ${ }^{307}$ se vería confirmada, a su juicio, por los acertados préstamos de autorizados autores de los teatros anejos al canon central como Corneille, Molière, Gozzi o Goldoni. De igual modo, en su revisión de la dramaturgia española del XVIII, Malmontais señala en primer lugar las meritorias pero insuficientes tentativas de la tragedia moderna española por fundar una poética más razonable con la Hormesinda o Guzmán el Bueno de Moratín padre, la aún exitosa y electrizante Numancia destruida de Ayala, o una estimable Raquel de García de la Huerta, cuyas incongruencias por su intemperancia crítica contra el irrefutable modelo francés atribuye a descontentos personales. Su examen de la comedia española dieciochesca se interna en una ruta transitada por estudiosos posteriores, al elogiar en primer lugar las comedias urbanas de Iriarte - primer reformador del género por la regularidad del ritmo, la verdad de sus caracteres y la naturalidad del lenguaje y de la fábula, desenredada de los intrincados lances barrocos-, cuyos esfuerzos en pro del géne-

306 «Porque la buena Critica, como enseña Horacio, no ha de llevarlo todo con tanto rigor, ni con tan escrupulosa nimiedad, que repare en algunas faltas pequeñas, quando todo lo demás de una obra es bueno» (p. 116). Por ejemplo, se añaden los nombres de Domingo de D. Blas, o Francisco de Rojas (De fuera vendrá quien de casa nos echará o Abre el ojo), Francisco Candamo, José Cañizares con El dómine Lucas, El Músico por el Amor, entre otras.

307 «'indique ces heureux larcins faits par des Italiens et des Français, pour prouver que le théâtre espagnol n'est pas dépourvu des ressorts qui ont constitué dans tous les temps et dans tous les lieux l'essence de la bonne comédie» (pp. 165-166). 
ro noble - como El señorito mimado (L'Enfant gâté) y La señorita malcriada (La Demoiselle mal élevée) — habrían alcanzado, no obstante, un éxito más rotundo, e incitado al ejemplo, si los hubiera dotado de más dinamismo e ingenio verbal; tras él, las piezas, de éxito desigual, de Leandro Fernández de Moratín, apreciado por su conocimiento de las convenciones teatrales, el decoro y las reglas con El café, su mejor obra por su ingenio y comicidad, junto a la más aventajada La mojigata ("comédie de caractère bien pensée, bien écrite»), superiores a El viejo y la niña, de tono y estilo más fríos. Finalmente, en su capítulo monográfico sobre los fondos de la Biblioteca del Escorial con que clausura su repaso histórico, Malmontais enumera traducciones españolas —en que cifra la riqueza de esta literatura-,${ }^{308}$ procedentes de la tradición clásica $^{309}$ que privilegia sobre las bíblicas y romances; ${ }^{310}$ gramáticas, medianas poéticas y retóricas, escolios y sobre todo comentarios a la

308 «la plus grande richesse littéraire des Espagnols est dans ce genre, où ils ont prouvé toute l'étendue et toute la flexibilité de leur langue; j'ajouterai de leur esprit» (p. 183). Malmontais destaca particularmente la excelencia de las traducciones del siglo XVI que llegaron tan lejos como es posible en ese género desde los griegos a los modernos.

309 La variedad de este repertorio, adelantada por Velázquez y Pellicer, abarca los diversos géneros (épica, lírica, tragedia, comedia, fábula, preceptiva, filosofía). Como ejemplos de meritorias traducciones tanto por su valor implícito en tanto segundo texto como por el referente grecolatino escogido, Malmontais menciona entre las más estimadas la Odisea de Gonzalo Pérez; la Ilíada manuscrita de Cristóbal de Mesa; la Medea de Eurípides por Pedro Simón Abril; hermosos fragmentos de Museo, Píndaro, Teócrito y Anacreonte por Boscán, Luis de León o Villegas; versiones de Aristóteles, Platón, Eurípides, Aristófanes, Esopo o Luciano. Dentro del panteón latino destaca el trío poético de la época de Augusto con Virgilio, tan recurrente desde el marqués de Santillana en las versiones de sus églogas por Encina, las Geórgicas en verso blanco de Juan de Guzmán, alumno del célebre Sánchez de las Brozas, la Eneida en octavas rimadas de C. de Mesa, además de Hernández y la excelente de Luis de León, superior a todas; Horacio, cuya Arte poética es traducida con brillantez por Espinel, Luis de Zapata y T. Iriarte; y Ovidio, con las reescrituras de sus Metamorfosis por F. Mey y de sus Epistolas por F. de Aldana. Junto a ellos, además de las traslaciones de los Padres de la Iglesia, añade la elogiada traducción de Terencio por Simón Abril, y en especial las muy meritorias de los Comentarios de César a cargo del caballero Azara, y, por las enriquecedoras notas que la acompañan — debidas en realidad a la labor del erudito Pérez Bayer, responsable asimismo de la introducción-, la obra histórica de Salustio por el infante don Gabriel de Borbón.

310 Por ejemplo, además de las traducciones del latín, apunta las versiones del provenzal o lemosín por Ausias March, del hebreo por Fray Luis, y de otras más del portugués, italiano y francés a lo largo del XVIII. 
producción española coetánea como los censurados apologistas gongorinos — cuya abundancia e indiscriminación crítica deplora-, ${ }^{311}$ así como diversos cancioneros y recopilaciones poéticas y romancísticas presentes en su mayoría en Velázquez, ${ }^{312}$ a las que añade algún hallazgo en la enseñanza de lenguas. ${ }^{313}$

En esta encrucijada de siglos y estéticas, el ensayo de Malmontais constituye un tramo intermedio en el reconocimiento europeo de la calidad de la literatura española ante la inminente publicación de la historia de Bouterwek y la difusión del romanticismo schlegeliano. Aun cuando los genios tutelares del crítico pertenecen a la «bonne école des anciens» y la preeminencia atemporal del buen gusto, la razón y las reglas junto a la proclamación de las luces ilustradas son valores respetados, su moderación se observa asimismo en la presencia reiterada de conceptos revitalizados positivamente como la imaginación, la originalidad —acotada en los límites consabidos de raigambre clásica también latentes en Diderot o Mme de Staël—, o la sublimidad de ciertos autores españoles atentos a las sanas doctrinas y cumplidores de la imitatio creadora. De este modo, a la vez que - como su coetáneo La Harpe, sus principales fuentes españolas e incluso Bouterwek en la generación siguiente - tacha de falaces extravagancias las novelas de caballerías de errantes caballeros e intrigas galantes - conocidas también en reediciones populares en la Francia del XVIII-, ensalza los poetas ejemplares del siglo XVI y algunos del XVII por su cumplimien-

311 Malmontais ataca la temeridad de la crítica española en su devenir al canonizar obras contemporáneas que no son clásicas, como los Proverbios de Santillana, los comentarios a la obra de Mena —incluso los de Garcilaso_- y particularmente acerbo se muestra con las glosas explicativas de la obra gongorina - ejemplificadas en las de C. de Salazar y Mardones sobre la Fábula de Píramo y Tisbe — primera fábula mitológica burlesca-, pese a la utilidad de su desciframiento- - junto a las que traduce algunos pasajes de composiciones de Góngora como la oda burlesca al Manzanares.

312 Así se refiere a los manuscritos más antiguos de colecciones de poemas como el de Baena, el de Hernando del Castillo, El jardin de amadores de Lorenzo de Ayala (Valencia, 1588), el Romancero general de Miguel de Madrigal (1604), el de Flórez (1614) o la primera parte del Tesoro de divina poesía (Valladolid, 1605) de Pedro de Espinosa, compilación, bastante estimada, de la primera parte de Flores de poetas ilustres de España.

313 Repara asimismo en la novela Histoire d'Aurélio et Isabelle fille du roi d'Écosse (Bruselas, 1608), editada en versión cuatrilingüe (español, inglés, francés e italiano) dispuesta en columnas paralelas, que considera un libro «fort précieux pour l'histoire littéraire du $\mathrm{XVI}^{\mathrm{e}}$ siècle». 
to de la retórica clásica, y encomia el provecho imponderable de la traducción ${ }^{314}$ por su ampliación del caudal lingüístico, la difusión de buenos modelos y —bajo la imagen aristofanesca de «l'abeille castillane»— el ejercicio adecuado de la mimesis. Incardinado en la corriente hispanófila del XVIII francés, expone una mesurada apología de la comedia barroca, al tiempo que rechaza el melodrama finisecular distanciándose incluso de los sainetes de Ramón de la Cruz; ${ }^{315}$ y, como la prensa francesa de años recientes, difunde una selección de respetados autores modernos en sus diversos géneros, desde los ensalzados humanistas ilustrados o el alabado Feijoo hasta el aprecio moderado de las reformas teatrales de Iriarte y Moratín, o de la lírica juvenil de un Meléndez de triunfal acogida en ciernes entre la crítica extranjera. Así pues, este ensayo de vulgarización secunda los esfuerzos de los prestigiosos intelectuales españoles desde la primera mitad del XVIII por reintegrar la cultura española al canon europeo representado aún entonces por el centro francés, en trance de derrocamiento. Su selección de las principales riquezas - mayoritariamente respetuosas de las normas - del patrimonio literario español y de sus abundantes fondos bibliográficos, su contextualización en la evolución general - como la prelación civilizadora en la Edad Media o las aportaciones al teatro europeo reivindicadas por los apologistas de las décadas finales del XVIII - contribuyen a la difusión con bastante fortuna entre el lectorado francés de un repertorio básico elaborado por los ilustrados —en el que el crítico incide en predilecciones como su reverencia cervantista, su esfuerzo comprensivo hacia la épica, su admiración por el talento torrencial de Lope, o por los clásicos del XVI, Fray Luis sobre todo, e incluso su respeto por Quevedo, por ejemplo-y completado con una ojeada a la actualidad literaria.

314 La práctica traductora no solo precisa conservar el ritmo e imágenes del texto original, sino que Malmontais nota asimismo la difícil ósmosis por la que el traductor procura penetrar en la sensibilidad del autor y que recuerda la empatía moderna de Bouterwek al leer a Fray Luis: «que l'esprit du traducteur s'échauffe, s'étende, s'élève comme celui de l'auteur original, et l'on sent combien il est difficile de se maintenir dans cet état de transformation artificielle» (p. 183).

315 Su expresión verbal («langage pittoresque») es el único aspecto alabado de sus sainetes, que suscitan indirectamente la presencia esporádica de lo pintoresco en Malmontais, en una aplicación similar a la establecida por La Dixmerie al calificar a la lengua española, tema de estudio de una de las lecciones insertas en su publicación. 


\subsubsection{La tríada difusora}

El alemán Bouterwek junto a su compatriota A. W. Schlegel y el suizo Simonde de Sismondi forman la tríada pionera que ejerce una influencia arraigada - pese a la evolución del método crítico y filológico y de la investigación documental a lo largo del XIX - en los antólogos, redactores de manuales y estudiosos de la literatura española en Francia. Editados tempranamente en la lengua cosmopolita del período de entresiglos, estos estudios fundamentales, la historia de la literatura española de Bouterwek, concebida como tal, y los cursos universitarios de Viena - de contenido teórico capital—y de Ginebra — más apresurado pero llamado a una gran fortuna difusora - trazan la senda por donde se adentrarán los hispanisants franceses en su lento y relativo reconocimiento de la independencia y calidad de una literatura periférica como la española. Habiendo asimilado las aportaciones de los ideólogos, las bases del romanticismo schlegeliano y las reflexiones sobre el influjo de las instituciones en la formación civil de una sociedad, sus sucesores aceptarán paulatinamente a lo largo del siglo la descentralización del canon, manteniéndose, sin embargo, respetuosos con la tradición clasicista del panteón francés en proceso de canonización nacional.

\subsubsection{F. Bouterwek}

Tras veinte años de investigación en su historia general, ${ }^{316}$ el profesor kantiano Friedrich Bouterwek (Oker, 1766-Gotinga, 1828) ve traducido al francés en 1812 el estudio que sobre la literatura española había editado en 1804 como parte integrante de una vasta empresa

316 La obra que le daría una fama más duradera que sus ensayos filosóficos y sus novelas apareció bajo el título Geschichte der Poesie und Beredsamkeit seit dem Ende des dreizehnten Jahrhunderts, en 12 volúmenes (Gotinga, Röwer, 1801-19) dedicados a las literaturas nacionales europeas (italiana, española, portuguesa, francesa, inglesa y alemana), de los que el tomo tercero (1804) estaba dedicado a la literatura española y el cuarto aparecía encabezado por un prefacio común a esta y a la literatura portuguesa. Véanse J. J. A. Bertrand («Figures d'hispanologues: Dieze, Bouterwek») y el estudio preliminar de C. Valcárcel Rivera y S. Navarro Pastor en su edición (Madrid, Verbum, 2002) del primer tomo de la traducción al español publicada con valiosas anotaciones por José Gómez de la Cortina y Nicolás Hugalde y Mollinedo, Historia de la literatura española. Desde el siglo XII hasta principios del XVI, Madrid, Imprenta de D. Eusebio Aguado, 1829. 
colectiva, ${ }^{317}$ concebida por el teólogo y orientalista Johann Gottfried Eichhorn con el propósito de emular, y aun superar, la obra imponente del jesuita español Juan Andrés (1784-1806). ${ }^{318}$ Publicada en la Francia napoleónica en guerra, dos años después del ensayo de Malmontais y de la reedición de la precoz Espagne littéraire de La Dixmerie, la traducción bastante fiel de Mme Steck, ${ }^{319}$ aunque aligerada del abundante contingente de ejemplos en español del original, ${ }^{320}$ contribuyó a su difusión entre los estudiosos y los emigrados españoles establecidos en Francia e Inglaterra - antes de la traducción inglesa de 1823-, así como en España durante la última etapa del régimen fernandino. ${ }^{321} \mathrm{Su}$ acotación del vasto concepto de literatura, aún vigente en el modelo español, en dos grandes demarcaciones - poesía y prosa y sus subgéneros, que integran la recapitulación de las obras de crítica literaria, desgajada en los capítulos finales en Velázquez y Malmon-

317 Geschichte der Künste und Wissenschaften seit der Wiederherstellung derselben bis an das Ende des achtzehnten Jahrhunderts (Gotinga, 1796-1820). Su cometido consistía en trazar el panorama de las ciencias y las artes en Europa desde el renacimiento de las letras hasta finales del siglo XVIII. Ese afán exhaustivo de completitud de los conocimientos generales — antigua filosofía, exégesis sagrada, física, matemáticas, literatura moderna-, aunque articulado en un horizonte estético e ideológico distinto, es claramente percibido por contemporáneos como Stapfer, el editor francés de la presente traducción, que define el proyecto como "espèce d'encyclopédie historique», a modo de summa que recoge el legado del pasado y lo transmite con sus aportaciones a la posteridad. Véase también la introducción de C. Valcárcel Rivera et ál. (ob. cit.).

318 Véase el «Estudio preliminar» de P. Aullón de Haro en la edición de J. García Gabaldón, S. Navarro Pastor y C. Valcárcel Rivera (Juan Andrés, Origen, progresos y estado actual de toda la literatura, Madrid-Valencia, Verbum-Biblioteca Valenciana, 1997, vol. I, pp. XIX-XCV).

319 Histoire de la littérature espagnole, traduite de l'allemand de M. Bouterwek, professeur à l'université de Gottingue, par le traducteur des lettres de Jean Muller (Mme de Steck [d'après Barbier], avec une préface par M. Stapfer [pp. 1-55]), París, Imprimerie de J. Gratiot. Chez Renard, Pauline, frères Michaud, 1812, 2 t. Sirvió de base a la traducción española de 1829, aunque Valcárcel y Navarro (ob. cit., p. XLII) observan indicios de consultas al texto original alemán.

320 Un colaborador anónimo, conocedor de las tres lenguas, se habría ocupado de verter al francés las citas ejemplificadoras originales conservadas, aunque en número más reducido que en la fuente alemana.

321 El abundante aparato de notas y correcciones de la traducción española, que abarca únicamente el primer libro de Bouterwek (Desde el siglo XIII hasta principios del XVI), la convertirán en un notable referente, consultado por los estudiosos franceses. 
tais - se consumará definitivamente en los títulos de las traducciones europeas de esta obra. ${ }^{322}$ Conocedor de las principales historias antecesoras en las que incardina su estudio, ${ }^{323}$ Bouterwek organiza en su discurso el acopio y revisión minuciosos de las fuentes disponibles, la inserción pertinente de noticias biográficas con la mención de las obras conocidas de cada autor, el análisis sucinto de sus principales producciones y la selección ejemplificadora de abundantes extractos para dar idea del estilo y del carácter de las obras ante el lectorado extranjero. Desde la perspectiva asumida de filósofo e historiador ofrecía como novedad sustancial la presentación autónoma de su materia de estudio a la luz del sentido histórico de los fenómenos culturales. Como su propósito es historiar los progresos del gusto y las letras en España y sus adaptaciones a los avances de la civilización, en su examen diacrónico de la literatura española desde sus orígenes medievales hasta finales del XVIII atiende principalmente a las obras representativas que han contribuido a ello, ${ }^{324}$ y reflexiona sobre sus particularidades históricas - como la discutida tendencia innata a la intolerancia, nacida de la lucha secular contra el islam; o, tras el fracaso en haber formado el pri-

322 El título original en alemán Histoire de la poésie et de l'éloquence chez les peuples modernes, se ve abreviado en las sucesivas traducciones (1801-19). Por ejemplo, la inglesa, a imagen de las traducciones francesa y española ya consignadas, History of Spanish and Portuguese Literature, by ..., translated from the original German by Thomassina Ross, 2 vols., Londres, Boosey \& Sons, 1823.

323 Sobre los enfoques de los precursores españoles véanse, por ejemplo, Checa (art. cit.) o Urzainqui (art. cit.). Entre sus precedentes italianos, franceses y alemanes coetáneos consulta a Signorelli, Dieze, Eichhorn y el suplemento de Blankenburg en el Diccionario de Sulzer (Litterarische Zusätze zu Johann George Sulzers allgemeiner Theorie der schönen Künste, Leipzig, 1796-98), entre otros. Las alusiones a las historias que se adentran en la producción intelectual española del XIX y en sus vicisitudes políticas, como la continuación de la obra de Bouterwek por E. Brinckmeier (a la que añade el subtítulo Die Nationalliteratur der Spanier seit dem Anfange des neunzehnten Jahrhunderts) de 1850, observan unos cortes cronológicos, un inventario de nombres (Gorostiza, Martínez de la Rosa, Bretón, Gil y Zárate, Rivas, Hartzenbusch o Larra, entre otros) y unas premisas similares.

324 Así, orilla aquellas que conformarían la historia de otros campos de interés como, por ejemplo, la indagación en las colecciones teatrales del XVII para trazar las preferencias sociológicas y la formación del gusto nacional («Cependant, si l’on voulait faire l'histoire du goût national en Espagne et de la manière dont il s'est formé, il ne serait pas inutile de consulter ces recueils, pour y chercher quelles étaient les pièces favorites de la nation dans une époque ou dans une autre», p. 176). 
mer modelo de monarquía constitucional, ${ }^{325}$ las consecuencias del despotismo político y religioso, cuya mayor presión coincidiría paradójicamente con su etapa de esplendor ${ }^{326}$ - . Las teorías literarias en alza y el concepto herderiano de nacionalidad inclinan al autor a rastrear sus características esenciales, enalteciendo no solo la tradición popular y original —romántica, según la difusión schlegeliana—, ${ }^{327}$ surgida del fermento medieval marcado por las vicisitudes históricas de las invasiones germánicas y la dominación musulmana, ${ }^{328}$ sino también la absor-

325 Bouterwek se muestra conforme con la interpretación liberal de Villalar: «À l'avènement de Charles Quint au trône, l'esprit de liberté qui vivait encore dans les royaumes de Castille et d'Arragon, s'était manifesté par des efforts énergiques; et si ces mouvemens n'avaient eu qu'une issue malheureuse, on doit en imputer la faute aux divisions de la noblesse et du tiers-état, qui n’avaient pas su se réunir pour leur intérêt commun. Si cette réunion s'était opérée [la de la nobleza y el tercer estado], peut-être l'Espagne aurait-elle offert le premier modèle d'une monarchie à la fois constitutionnelle et vigoureuse. Le destin lui a refusé cet honneur; mais si l'on put opprimer la liberté et la conscience des Espagnols, on ne put enchaîner leur génie» (t. I, pp. 223-224).

326 «La période la plus brillante de la comédie espagnole, comprend le temps qui s'écoula sous le gouvernement des trois Philippe, de 1556 jusqu'en 1665, et jamais l'inquisition ne fut plus cruelle et ne répandit plus de sang que dans cette période. Sans doute, la littérature de ce siècle offre des traces nombreuses d'un fanatisme barbare; mais ces traces sont isolées, et l'impression pénible que les déclamations violentes des poëtes espagnols produisent sur un esprit libéral, est aussitôt adoucie par des traits de la plus aimable et de la plus généreuse sensibilité. Ce caractère est si bien empreint dans leur littérature, que si, après avoir lu l'histoire politique des Espagnols dans le seizième et le dix-septième siècle, et sur-tout celle de leur conduite en Amérique et dans les Pays-Bas, on vient à faire connaissance avec leurs poëtes, on est tenté de croire qu'on a voyagé chez deux peuples différens» (t. II, p. 222). Sin embargo, tras esta declaración más comedida que las posteriores de Sismondi, paga tributo a lugares comunes de la leyenda negra sobre las singularidades del carácter nacional cuando apostilla: «Pour trouver du pathétique dans ces horreurs [las tragedias de Bermúdez, destacables a pesar de su delectación en lo tremebundo], il fallait être espagnol, et accoutumé dès l'enfance à étouffer les sentimens de la nature, dès que la voix de ce qu'on appelait la justice se faisait entendre par l'organe de l'autorité royale ou écclesiastique; mais il fallait bien aussi cette altération dans le caractère d'un peuple si naturellement généreux, pour que les fêtes sacrées où l'on brûlait comme des bûches les Juifs et les hérétiques, fussent devenues, ainsi que les combats de taureaux, un amusement national» (t. I, p. 361).

327 Conceptos asumidos que Bouterwek expuso en el prólogo a su historia de la literatura italiana.

328 «Du mélange de ces deux caractères si voisins l'un de l'autre, naquit l'esprit de la chevalerie espagnole, qui n'était au fond que l'esprit de la plupart des nations européennes de ce temps, et s'en distinguait seulement par une forme particulière, mais qui, sous cette forme et jusqu'à un certain point, fit des Arabes un peuple européen, et des Espagnols un peuple oriental» (t. I, pp. 58-59). 
ción de las fuentes clásicas y la naturalización de las influencias foráneas renovadoras al fundirlas con el invariable carácter nacional. Sus dos forjadores primigenios, los godos desde el norte y los árabes desde el sur, le habrían legado, respectivamente, su arraigado culto a la caballería — contraviniendo la opinión mayoritaria en el XVIII español, que la atribuía a los musulmanes-, y estos últimos su gusto por lo maravilloso, su ardiente imaginación, la exuberancia retórica, el entusiasmo poético e incluso la tendencia al hibridismo genérico. ${ }^{329}$ Sin una definición explícita del carácter nacional de su literatura, Bouterwek descubre su huella en el romancero, la noble sencillez de la prosa y el mundo novelesco del Amadis, ${ }^{330}$ el apasionamiento de la retórica cancioneril, la sentenciosidad de sus obras morales, el dogmatismo de las ortodoxas poesías religiosas del XV o de los escritos de moral teológica, la comicidad de las novelas del gusto picaresco, o el modelo teatral del XVII que acertó a encarnar el acervo popular de su público. ${ }^{331}$ En ese sentido revitalizador de amalgama como predicaba Schlegel, y sin reivindicar abiertamente una originalidad excluyente que promoverán críticos posteriores, Bouterwek ensalza, como fruto de la ósmosis entre la tradición española prevalecedora y los clásicos grecolatinos y los modernos contemporáneos, los versos de Fray Luis ${ }^{332}$ y Villegas,

329 «Les Espagnols, continuellement en rapport avec les Arabes, et habitués à toutes les espèces d'orientalisme, remarquèrent moins vite que tout autre peuple la différence qui existe entre la prose et la poésie» (t. I, p. 111).

330 "cette simplicité noble dont l'auteur même de l'Amadis paraît avoir entrevu l'idée, et qui est le véritable caractère de la prose romantique» (t. I, p. 295).

331 «de tout temps, [el público español] a toléré et même admiré les combinaisons d'idées, les plus bizarres et les plus entortillées, pourvu qu'elles parussent neuves et ingénieuses, mais qui, de tout temps aussi, a proscrit, plus sévèrement que tout autre défaut en poésie, la pesanteur et la dureté du style, et surtout de la versification» (t. I, pp. 332-333).

332 Este argumento de armonización de influencias difundido por Bouterwek aún sobrevive en Tannenberg, quien se extraña a fines de siglo, pese a la atención dispensada por Villemain en sus lecciones de los años treinta y a la presencia del poeta en las historias, del poco eco alcanzado por Fray Luis entre el lectorado francés y europeo culto («Du lyrisme espagnol on ne connaît un peu en France que le Romancero, et tout au plus a-t-on quelque idée aussi, par l'influence qu'il exerça sur notre genre précieux, de ce que fut le jargon inintelligible du Gongorisme. Se doute-t-on que les Espagnols ont une poésie savante, d'inspiration toute classique, et que leur Fr. Luis de León, avant André Chénier, Leopardi ou Keats, réalisa l'union la plus parfaite de la forme antique et de la forme moderne? Imagine-t-on un poète espagnol sans la violence de la couleur, l'emphase déclamatoire ou la subtitlité raffinée? Non, sans doute; est c'est néanmoins pour des qualités toutes contraires de goût et de mesure que Fr. Luis de León s'est vu proclamer le prince des lyriques espa- 
las églogas de Garcilaso, ${ }^{333}$ las novelas pastoriles de Montemayor ${ }^{334}$ o la lírica de Meléndez Valdés en la renovación cuajada a finales del XVIII, al tiempo que proclama la innovación radical del Quijote — primer modelo clásico de la novela moderna- o de Calderón.

Formado en el estudio de las fuentes de la Antigüedad en las que se afinan los métodos filológicos de las universidades alemanas, Bouterwek admira la cultura humanista del Cuatrocientos y del Quinientos, y - con reticencias conforme a un concepto más exigente que diverge de los procedimientos del XVI ${ }^{335}$ y de la práctica francesa aún común- aprecia la aportación enriquecedora de las traducciones de grecolatinos sobre todo, de los modernos italianos, de los franceses posteriormente, y en menor medida de los ingleses. La regularidad de las obras clásicas del XVI y del XVII españoles, inculcada por el nutriente antiguo, anterior a la teorización clasicista francesa, pule así las formas más irregulares del patrimonio nacional. Su proclamación de la primacía universal de lo bello como concepto estético y de los valores de naturalidad y equilibrio de la retórica clásica — deleitándose en la sencillez bucólica del género pastoril frente al rechazo creciente de sus continuadores - lo llevan a rechazar la mezcla de

gnols [...]», ob. cit., 1903, p. 175). Páginas más allá, tras alabar su exquisita pureza formal, excepcional a su juicio en la poesía española aun contando con numerosos discípulos e imitadores entre los que considera a Valera y Menéndez Pelayo, traduce su oda "A la Ascensión», tomada de la vieja edición de 1816 y recurrente desde Villemain en los estudios franceses.

333 «fondit dans cette imitation, d'une manière si heureuse, le caractère de la poésie romantique et la correction des anciens, que ses églogues, quoiqu'une seule, peut-être, soit un chef-d'œuvre, surpassent cependant de beaucoup toutes les poésies italiennes du même genre, si l'on en excepte l'Arcadie de Sannazar» (t. I, p. 251).

334 Los franceses ya conocían La Diana por los extractos publicados en la BUR en noviembre de 1778. Aunque en grado diferente de los arriba citados, para Bouterwek esta obra, pese a sus defectos e irregularidades achacables a la manera española, también responde a su concepto de poesía, ejemplifica el carácter romántico y muestra a su vez cierta unidad y coherencia convenientes al género elegido.

335 "Il faut convenir aussi, que dans un siècle où la nation et la langue étaient encore si profondément imbues de l'esprit romantique, on n'aurait pu rendre en espagnol la poésie des anciens dans toute sa pureté, sans faire également violence au génie de la langue et à celui de la nation» (t. I, p. 330). No obstante, son grandes sus elogios al riguroso quehacer personal de Fray Luis, y al mérito de la traducción de las metamorfosis ovidianas de F. Mey — también elogiadas por Malmontais—, que «se lit comme un ouvrage moderne». 
tonos y géneros codificados ${ }^{336}$ y a despreciar no solo la mayoría de las novelas de caballerías, sus versiones a lo divino y las nouvelles, sino también las variantes poéticas barrocas, condenadas como desviaciones del buen gusto. Más profundo, sin embargo, es el surco que lo separa de sus precedentes respecto al nuevo concepto de mimesis, como deja sentado en su refutación de las bases teóricas de Luzán. ${ }^{337}$ Su disidencia del molde clasicista francés - aun reconociendo la benéfica influencia francesa sobre la rehabilitación de la prosa española del XVIII, sancionada favorablemente por su claridad, precisión y elegancia - se manifiesta asimismo con mayor contundencia tanto en la aceptación de una mayor libertad consciente frente a la rigidez postclasicista como en la promoción de otros sistemas literarios excéntricos, en especial la vindicación del teatro nacional del XVII («la plus brillante partie de leur littérature»). Injertada esta vez en la narración histórica, esta parte, la más estimada por su autor y que no llegó a ser publicada por sus traductores españoles, presenta un análisis comprensivo de la dramaturgia de Lope y Calderón, caballo de batalla de las controversias ideológico-literarias del XVIII español, en una nueva fase más propicia desde los indicios valorativos españoles de finales de la centuria anterior.

Las fuentes confesas en la edición de Bouterwek, heredero del hispanismo alemán del siglo XVIII, revelan los notables fondos de la Universidad de Gotinga como apuntan a la inmensa labor editorial del XVIII español. El haz de referencias del estudioso alemán respetadas por sus traductores franceses como complemento al cuerpo del texto abarca ediciones antiguas y modernas de los principales autores abordados, antologías - la analecta de Sánchez, la Colección de Poetas castellanos (Madrid, 1786) patrocinada

336 «En général, le bon sens des écrivains espagnols a toujours insisté sur une juste séparation des domaines de la poésie et de la prose, et jamais ils n’ont protesté plus hautement contre la confusion des limites de ces deux genres, que dans la première moitié du seizième siècle, c'est-à-dire, dans le temps même où la littérature était plus que jamais inondée de romans de chevalerie; productions bâtardes, dont l'effrayante multiplication menaçait d'une ruine commune et la véritable poésie et la véritable éloquence» (t. I, p. 362).

337 Bouterwek discute su concepción de la poesía basada en la naturalidad y elegancia para entretener el espíritu e ilustrar la razón, el utile dulci y la moral: «La véritable poésie, cet essor hardi de l'imagination vers un monde idéal plus beau que le monde réel, où le poëte va puiser l'esprit vivifiant dont il anime ses imitations de la nature, ne fut plus qu'un accessoire, un ornement de la poésie dont l'essence était l'élégance et le naturel» (t. II, pp. 214-215). 
por Ramón Fernández, el elogiado aunque insuficientemente discriminador Parnaso español de Cerdá y López de Sedano, la Biblioteca española... de Sempere y Guarinos o el Theatro hespañol de García de la Huerta- y las principales historias, suplementos y estudios, ${ }^{338}$ de algunos de los cuales, como el opúsculo de Velázquez, toma distancias. ${ }^{339}$ La obra consta de un extenso prefacio - en el que se aborda el origen y evolución, méritos e influencias entre sí de los romances peninsulares y sus características poéticas $^{340}$ hasta el triunfo del castellano, así como los rasgos de este y un resumen de sus formas estróficas - y tres libros precedidos respectivamente de una introducción histórica a cada período, en los que la división cronológica por siglos y reinados y su segmentación en secciones revelan su intención didáctica. El primer libro - desglosado en dos secciones correspondientes a las dos primeras edades - abarca la historia de la literatura española desde fines del siglo XIII hasta los diez primeros años del XVI. El segundo comprende la entronización de Carlos I hasta la segunda mitad del XVII, período en que la literatura española continúa su marcha ascendente hacia el cenit al paso de las conquistas en su expansión política mundial. Esta amplia franja, mantenida largo tiempo en las periodizaciones de la literatura española de manuales, historias y textos de carácter diverso, se parcela de nuevo en dos partes en torno a un irreprochable Cervantes y un

338 Lugar principal ocupan los ilustrados y eruditos españoles del XVIII mencionados - pese a la ausencia del padre Andrés_, desde la obra de Velázquez, aumentada con los añadidos de Dieze; Sarmiento, a cuya influencia Valcárcel atribuye en parte las oscilaciones críticas de Bouterwek entre racionalismo y Romanticismo (ob. cit., p. XXXII); Eichhorn, responsable del primer tomo de la Histoire générale de la civilisation et de la littérature (Allgemeine Geschichte der Cultur und Litteratur des neuern Europa, 1796-99), solicitado para tratar de la lengua vasca y de las controversias literarias de las novelas de caballerías; hasta los ineludibles Mayans y Siscar y Nicolás Antonio; una Histoire générale des troubadours; el Glossaire de Ducange, en especial su prefacio; el Epitome de las Historias portuguesas de M. de Faria y Sousa; o detalles sobre la idiosincrasia española en el recurrente Bourgoing, con las noticias recientes añadidas sobre su literatura actual por sus traductores alemanes Fischer y Tychsen.

339 Aunque reconoce su valor patriótico contextualizando la obra en los años de su redacción, denuncia, sin embargo, que «il a plutôt embrouillé qu'éclairé l'histoire de la poésie espagnole. Sa critique est entièrement dans le sens de la critique française, quoiqu'avec une teinture de patriotisme espagnol» (t. II, p. 223).

340 Por ejemplo, como Malmontais, presta atención al mosaico de lenguas, y para ilustrar las dificultades de comprensión del valenciano recoge títulos medievales editados en el XVIII como el Livre de les Dones de Mosén Jaume Roig (Valencia, 1735). 
Lope de avasalladora influencia. El tercer libro, concebido como suplemento abreviado respecto a la fase culminante anterior, sin ninguna frontera señalada que marque nítidamente la regeneración literaria desde la depresión del reinado de Carlos II, se extiende hasta las postrimerías del XVIII. Habiendo descartado el estudio de la poesía hispanoárabe en beneficio del análisis de la literatura romance, Bouterwek procura ordenar su materia, dispuesta cronológicamente, en grandes cortes históricos, en virtud de su propia evolución intrínseca atendiendo a la jerarquización genérica de méritos en torno a los grandes nombres - como preconizarían Sismondi, Villemain y los estudiosos franceses hasta finales de siglo- por su condición de modelos o por su influjo sobre sus contemporáneos. Además de la ampliación retrospectiva de la cuarta edad, culminante en el reinado de Carlos III con la restauración del buen gusto, y la justificación con reservas de la validez demarcadora del reinado de Juan II $^{341}$ — cuya importancia residiría, a su juicio, no en una innovación en la historia literaria, sino en la introducción exitosa de la moral y las ciencias en el campo de la poesía, el perfeccionamiento de las antiguas formas líricas en lengua vernácula y el mecenazgo de las letras-, su variación más significativa respecto a la periodización heredada de Velázquez atañe a la compleja tercera edad, ${ }^{342}$ que desglosa en segmentos cronológicos, a la vez que, en bene-

341 «Il nous semble cependant que si cette période a produit des ouvrages de plus longue haleine et d'un ton plus élevé, si l'on peut lui faire honneur du perfectionnement de l'ancienne poésie castillane, elle n'en forme pas plus une époque nouvelle dans l'histoire de celle-ci, puisqu'elle ne lui a point fait prendre de caractère nouveau» (t. I, p. 142).

342 «Aucune révolution littéraire ne s'est faite en Espagne depuis l'introduction du style italien dans la poésie espagnole, jusqu'à la décadence de la littérature dans les dernières années de Philippe IV. Les écrivains de la dernière moitié de cette période, que quelques critiques espagnols ont surnommé les corrupteurs $d u$ gồt, n'ont fait en grande partie que marcher dans la route que leur avaient ouverte, dans les siècles précédens, un grand nombre de poëtes et sur-tout de poëtes dramatiques. Plusieurs de ces écrivains qu'on accuse d'avoir corrompu la littérature, eurent pour contemporains d'autres écrivains célèbres, zélés promoteurs de la correction classique; et cependant, ils eurent bien plus d'influence que ces derniers sur le goût général. Confondre parmi les corrupteurs du goût, un Calderon qui acheva de donner au théâtre de son pays sa forme toute nationale, est une idée qui ne pouvait venir à des Espagnols que dans le dix-huitième siècle, lorsqu'il fut de mode en Espagne, comme ailleurs, d'appliquer à tous les ouvrages du génie, les règles prescrites par la critique française» (pp. 229-230). Asimismo, en una nota a la p. 252 reclama reajustar los márgenes y ciertas atribuciones de las dos últimas edades de Velázquez adelantando la penetración del género italiano a la segunda, y la generación de Virués, Lope y otros a la tercera. 
ficio de su exposición, promociona exitosamente al centro del canon a Cervantes y Lope. ${ }^{343}$ Esta parcelación cronológica se complementa con el uso menos frecuente de ciertos marbetes aplicados a la escurridiza época de esplendor en torno a grandes personalidades políticas o literarias como los heredados «siècle de Charles Quint» por el siglo XVI, o «siècle d'or», ${ }^{344}$ «âge d'or» o "bel âge», junto al «siècle des trois Philippe» ${ }^{345}$ y los ocasionales «siècle de Cervantes» $\mathrm{y}$ «temps de Cervantes et de Lope de Vega»,346 que cubren a veces esa franja difusa entre centurias.

En su revisión del corpus de los orígenes Bouterwek excluye de su concepto de poesía como expresión del sentimiento a la mayor parte de las obras del medievo, a excepción particularmente de los romances, el Amadís, las poesías cancioneriles de expresión más contenida y menos retórica cuando retoman las formas populares, o los villancicos por su gracia y delicadeza — como el de Escrivá "¿Qué sentís, corazón mío?»-, musicados y glosados más tarde. De esta manera, ni el cantar de gesta —entonces el primogénito de los poemas modernos, según la denominación de Sánchez-, reducido a una informe crónica en verso, ni las obras de Berceo, ni el Libro de Alexandre — bajo el título de Poema de Alexandro Magno-, al que reprocha sus anacronismos y fabulación («grotesque mélange d’inventions insipides et de ridicules travestissemens», p. 88), suscitan su

343 «Le siècle de Cervantes est l'époque de cette lutte entre la correction du genre italien, et la liberté audacieuse du genre national. Alors encore Lope de Vega brillait aux yeux de sa nation d'un plus vif éclat que Cervantes; son parti fut victorieux. Il nous paraît donc utile, pour saisir plus facilement l'ensemble de l'histoire littéraire de l'Espagne, de choisir pour point de repos le temps marqué par l'influence supposée de Cervantes et de Lope de Vega, sur la littérature de leur pays. C'est, sans doute, un phénomène assez remarquable qu'un Cervantes qui fait époque dans la littérature de l'Europe entière, n'ait pas eu cependant assez d'influence sur sa propre nation pour commencer une nouvelle époque dans son histoire littéraire» (t. II, p. 230).

344 «Enfin, depuis que les bons écrivains de l'âge d'or de la poésie espagnole, grâce à d'élégantes éditions modernes, sont entre les mains de tout le monde, et depuis que le besoin nouveau de penser et de connaitre s'est fait sentir en Espagne, et y excite le développement de toutes les facultés de l'esprit, il n'y a rien d'avantageux que l'on ne doive espérer de cette réunion des belles-lettres et des sciences» (p. 250).

345 Por ejemplo, «Dans le siècle des trois Philippe, de 1556 jusqu'à 1655, dans ce siècle qu'on peut appeler l'âge d'or de la littérature espagnole, l'esprit national, ainsi que les forces de la nation, avait cédé peu à peu à l'influence d'un système de gouvernement calculé pour le détruire» (t. II, p. 188).

346 Por ejemplo, "On peut regarder en général le temps de Cervantes et de Lope de Vega, comme l'époque où la littérature historique des Espagnols commença à former cet ensemble complet qui la rend si remarquable» (t. II, p. 113). 
favor. Un aprecio moderado recibe Alfonso X como mecenas adelantado a su tiempo y promotor de la lengua y la poesía. En la enumeración de otras composiciones como la crónica atribuida a Alfonso XI, los poemas de Rabbi Santo y Alonso González de Castro, relega El libro de buen amor - mentado como Dona Quaresma, Don Carnal et Don Almuerzoa un breve párrafo con el mismo pasaje ejemplificador tomado de Velázquez pese a reclamar para él una mayor atención crítica. Impermeable a las lejanas poéticas medievales, Bouterwek tampoco se rinde a la mayoría de las composiciones contenidas en colecciones ${ }^{347}$ como el Cancionero de poetas antiguos de Baena o el Cancionero general de F. del Castillo, que constituyen a sus ojos un resto de barbarie gótica por la parquedad de contenidos, la aridez de sus canciones morales y su predilección por las alegorías, su extenuante exhibición formal - monótona pese a su diversidad métrica y temática - o su acendrada lucha entre la razón y la pasión, distantes de la perfección clásica a la que Petrarca alzó el estilo de los trovadores. Entre las famas del Cuatrocientos ya reelaboradas por los españoles, Bouterwek aprecia notablemente a cultos humanistas como Villena - que recibe elogios mesurados por enaltecer el cultivo de la poesía y las ocupaciones liberales con su Arte de trovar («espèce de poétique intitulée la science gaie (la gaya ciencia)», t. I, p. 147), su participación en la expansión de las modas de trovadores limusinos en el reino de Aragón, y sus obras y traducciones-y particularmente Santillana, por su moralidad y saberes —ante todo su carta-prohemio, el Doctrinal de privados y el más editado hasta entonces libro de los Proverbios - más que por su contribución poética, de la que destaca pasajes no desdeñables de su alegoría a la muerte de Villena, en la estela de Dante, o la introducción de la sombra de un penitente don Álvaro, no superados en sus composiciones amorosas. Reticencias comunes a Quintana despierta la labor poética de un Juan de Mena que habría sacrificado su talento a la pedantería

347 «il suffit de connaître un seul de ces poëtes, pour avoir une idée de tous les autres. Il nous paraît plus instructif de considérer sous un point de vue général des ouvrages si analogues [...]» (p. 169). Así, de entre los numerosos autores recogidos en los cancioneros Bouterwek menciona a Fernando Pérez de Guzmán, Rodríguez del Padrón, Alonso de Santa María o de Cartagena, García Sánchez de Badajoz, Gómez Manrique, el bachiller de la Torre, Álvarez de Villapandino, Sánchez Calavera, Ruy Páez de Ribera, Juan Tallantre, el vizconde de Altamira, Diego López de Haro, Guevara, o, además de las contribuciones de Santillana o Mena, por ejemplo, halla más poesía en las estimadas estancias morales de Jorge Manrique, glosadas en su tiempo y rescatadas por la edición de 1779. 
y la sumisión al poder en su ambicioso y fallido Laberinto ${ }^{348}$ — superior, con todo, al resto de sus obras como la Coronación, el Tratado de vicios y virtudes y sus poemas amorosos-, y en el que advierte destellos poéticos en pasajes que cantan las hazañas y calamidades de la patria. Tras excluir de su escrutinio los misterios, moralidades y representaciones burlescas por su mediocridad, así como los diálogos alegóricos de los cancioneros o la sátira de Mingo Revulgo por su indeterminación genérica, Bouterwek señala como precursores del drama literario del siglo siguiente las églogas dialogadas en verso de Juan del Encina y, por su influencia posterior, la inclasificable y difundida Tragicomedia de Calixto y Melibea ${ }^{349}$-reprobada por la pobreza de invención y la crudeza de un ejemplo terriblemente aleccionador y excesivamente descriptivo, y elogiada por la fuerza psicológica de caracteres como el de la alcahueta y la naturalidad innata del diálogo en el alabado primer acto anónimo-. Asimismo, su escueta selección de las crónicas medievales en romance, en deuda de todos modos con la imponente difusión editorial dieciochesca, da cabida prin-

348 «Si cet ouvrage était devenu ce que l'auteur avait l'intention d'en faire, il mériterait bien de faire à lui seul une nouvelle époque dans l'histoire de la poésie espagnole; mais, tel qu'il est, et avec ses beautés réelles, trop vantées par quelques littérateurs, si l'on veut bien le regarder comme un chef-d'œuvre, ce ne peut être, du moins, que comme un chefd'œuvre gothique: il appartient au temps qui l'a vu naître, et n'offre nulle part des traces de ce génie supérieur qui s'élève au-dessus de son siècle» (t. I, p. 161).

349 Bouterwek refiere diversos títulos de traducciones suyas al francés y al inglés como signo de su éxito. En la década siguiente a su historia la imprenta de León Amarita reedita esta obra (Madrid, 1822), que no contará en Francia con traducciones modernas hasta la versión de Germond de Lavigne acompañada de un ensayo histórico de 1841 (La Célestine, tragi-comédie de Calixte et Mélibée, París, Ch. Gosselin, y 1843; luego completada y revisada en 1873, París, Lemerre, y en 1883, París, Flammarion). El profesor A. Fée incluyó diversos fragmentos por él traducidos en su estudio de 1873. También Tannenberg (ob. cit., 1903, pp. 185-186) en su reseña de la producción crítica de Menéndez Pelayo asumirá las opiniones de rigor sobre esta obra de difícil clasificación y sin equivalente en la literatura moderna, como nueva frontera en su tiempo para la novela y el drama ("C'est une longue comédie en prose, ou plutôt un roman dialogué qui dépasse les limites étroites du théâtre et ne fut jamais représenté»). Retomando varios de los juicios sostenidos por sus predecesores franceses a partir de los años cuarenta como Puibusque o los colectores del último tercio del XIX, centra en la protagonista - cuyo carácter habría convertido la obra, a su ver, en el primero de los «romans picaresques» - la genealogía de personajes cómicos franceses como Macette, y recurre a un más frecuente paralelismo con el drama shakespeariano de Romeo y Julieta ("mais elle est encore un drame de passion, le poème d'un amour juvénile, presque enfantin, comme celui de Juliette et de Roméo, et aboutissant aussi à une catastrophe tragique, où périssent les deux amants, Calixte et Mélibée»). 
cipalmente a las empresas de Alfonso X, lastradas por la heterogeneidad indiscriminada de sus materiales, la sequedad de su narración y su ausencia de encadenamientos causales, así como las de López de Ayala y Pérez de Guzmán —editados ambos en 1779—, de estilo monótono y ajenas aún al moderno concepto histórico; en cambio, de la prosa del XV destaca como exponente prometedor por la precisión de su estilo los Claros varones de $\mathrm{H}$. del Pulgar, poeta y traductor de los clásicos.

Los elogios más notables del alemán en su examen de la producción española medieval — de enjuiciamiento menos comprometido que el del conflictivo siglo XVII- se destinan a El conde Lucanor ${ }^{350}$ de Juan Manuel («le plus beau monument de la littérature espagnole») — juzgado desde la suficiencia del Ochocientos por su moralidad privada y política, la preciada y supuesta ingenuidad de su estilo y su comedimiento frente a las desmesuras de las nacientes novelas de caballerías-y, por su modernidad narrativa, a la Crónica de don Pedro Niño, conde de Buelna de Gutierre Díez de Games ${ }^{351}$ y a la Crónica de don Alvaro de Luna, atribuida a Álvar García. Sin embargo, su mayor homenaje, deudor del culto al primitivismo, es el rendido a un romancero exaltado como género nacional y popular («la poésie romancière»), primigenio, inimitable y, sin pulimiento ni estudio, alejado de la perfección clásica. ${ }^{352} \mathrm{Su}$ acceso a las antiguas colecciones como, entre otras, el conocido Romancero gene-

350 El crítico toma de la edición de Argote de Molina las nociones biográficas, el inventario de sus poesías cancioneriles y obras en prosa y el epílogo «Discurso sobre la poesía castellana». Además de subrayar el ascendiente oriental, se traducen varias sentencias con el original en nota, junto a algunas coplas suyas, además del exemplo XLI. La analogía, apuntada por Bouterwek, entre la fábula del cuervo y la zorra (exemplo V) y la versión de Lafontaine ("On est frappé de la ressemblance qu'il y a entre la fable espagnole et la fable française, entre la naïveté sans art de Juan Manuel et la naïveté ingénieuse de La Fontaine», p. 98) suscitará la réplica nacionalista de Puibusque treinta años más tarde.

351 No sería trasladada al francés hasta 1867, en que se edita la traducción a cargo conjuntamente de A. de Circourt y de Puymaigre (Le Victorial: chronique de Don Pedro Niño, comte de Buelna, par Gutierre Diaz de Gamez, son alferez; trad. de l'espagnol, d'après le manuscrit, avec une introduction et des notes historiques, París, V. Palmé).

352 «Mais jusqu'à ce qu'il plaise à quelque homme de lettres de débrouiller ce chaos de romances, en les rangeant du moins selon l'ordre chronologique, il sera impossible de découvrir par quels degrés la romance historique des Espagnols est parvenue de sa grossièreté primitive à l'espèce de beauté relative qu'elle a acquise, et qui n'a pu s'élever jusqu'à la perfection classique, parce que ce genre de poésie lui-même n'a jamais été classique en Espagne» (t. I, p. 124). 
ral, el de Miguel de Madrigal (1604), el de Pedro de Flores (1614) y especialmente el Cancionero de romances de Amberes (1555) que tiene a mano, se ve dificultado por la lejanía de las bibliotecas españolas y la carencia, paulatinamente cubierta, de modernas ediciones clasificadoras. Bouterwek divide estos "petits tableaux» de intensidad poética en romances narrativos — históricos, caballerescos, ${ }^{353}$ a su juicio los más antiguos, y galantes- y romances líricos — como el famoso del conde Alarcos, que traduce en prosa, o Rosafresca, a la que añade, con cierta ironía racionalista por la distinta condición zoológica de sus personajes, el romance Fontefrida - Su apertura temática da pronto paso a las variantes mitológicas y bíblicas, ${ }^{354}$ pastoriles, moriscas ${ }^{355}$ y satíricas en sus diversos avatares hasta la ramificación del género en canciones populares. Los romances históricos, cuyo único mérito son los detalles poéticos que evocan una situación y sugieren un modelo inspirador para el género triunfante de la pintura histórica («Il serait à souhaiter qu'un peintre, homme de génie, étudiât cette riche source de tableaux intéressans», p. 156), aparecen representados en sus diversos subgéneros sin distinguir el romancero viejo del nuevo, desde el recuerdo de los orígenes -el conmovedor romance del rey Rodrigo, el ciclo cidiano («Fizo hazer al rey Alfonso», "Al arma, al arma! sonavan», "Vitorioso buelve el Cid» o el del casamiento con Jimena) — hasta las recreaciones pintorescas de los moriscos («Tanta Zayda y Adalifa», «De los trofeos de amor»o «La hermosísima Balaja»). En suma, Bouterwek dictamina que la poesía castellana guardó fidelidad hasta el final de esa centuria a las viejas formas nacionales sin seguir el ejemplo de un guía director. ${ }^{356}$

353 Por ejemplo, «En la selva está Amadís», junto al ciclo de los paladines de Francia como Gaiferos o Calaínos.

354 Así, «En las obsequias de Héctor», o el planto del rey David por su hijo Absalón «Con rabia está el rey David».

355 Bouterwek remite a la Historia de los Vandos de los Zegris y Abencerrages, caballeros moros de Granada, de Ginés Pérez de Hita (en su edición de Lisboa, 1616 y en una contrefaçon de París de 1660, ambas a su vista), así como a una antigua recopilación de las obras de Encina (Cancionero de todas las Obras de Juan de la Enzina, 1501, Sevilla) conservada en la biblioteca de Wolfenbüttel.

356 "La poésie castillane était, comme la science gaie des troubadours, un bien commun placé sous la sauve-garde d'une espèce de démocratie littéraire qui ne permettait à aucun génie dominateur de s'élever au-dessus des autres» (p. 214). 
En el período siguiente el constreñimiento político y religioso bajo los Habsburgo no solo afectó al estudio de las ciencias y la filosofía, sino también a los diversos géneros dejando, no obstante, libre curso a la novela, y en especial a la poesía, que, en opinión de Bouterwek como de Quintana, habría expresado el incólume carácter nacional, independiente de mecenazgos o cortes literarias semejantes a la de Luis XIV. El juicio de Bouterwek asienta opiniones comunes sobre el enriquecimiento memorable de la lírica del XVI; el naufragio de la abundante épica culta, ${ }^{357}$ achacado a un mesianismo nacionalista que añade al reproche habitual a la primacía de los hechos históricos sobre la ficción — críticas de las que no exime a La Araucana de Ercilla, despojada de la condición poética por su carencia de unidad y desenlace y por el desequilibrio de su planteamiento, a pesar de sus cualidades estilísticas, bellas descripciones y logradas escenas de amor-; el nacimiento de la novela cervantina o el surgimiento del «genre moderne» con el Lazarillo y las obras del gusto picaresco.

Entre las deudas con sus predecesores españoles se halla también la constatación de la primera controversia literaria entre la tradición castellana de un Cristóbal de Castillejo —apreciado por Velázquez frente a la mayor reticencia de Bouterwek, que aún le reconoce cierta gracia estilística- y la innovación de los pétrarquistes en la primera mitad del XVI; la filiación de la nueva poesía respecto a los italianos modernos desde Petrarca y Sannazaro, y sobre todo a las fuentes antiguas de Virgilio y Horacio principalmente; así como la filtración del canon de autores forjado en el período finisecular del XVIII español — Boscán y Garcilaso, que lo sobrepasó en maestría y calidad, como los hacedores de la esperada reforma lírica, conformando junto a Hurtado de Mendoza la llamada primeramente escuela

357 Entre los innumerables títulos, Bouterwek alude a los textos de Mesa, Mosquera, López de Zárate, Sanz, Zapata, Urrea, Samper, Mey, Laso de la Vega, o el más logrado Pelayo de Pinciano. Entre los nuevos géneros mixtos, a caballo entre la épica y la novela, señala el cultivo de los idilios, que imitarían los antiguos a la manera de romances como forma preferida frente a los modelos contemporáneos italianos de Ariosto y Boyardo, que habrían sido recibidos como novelas de caballerías ("On ne peut douter que ce genre bâtard n'ait contribué à détourner les Espagnols de cultiver le genre de l'épopée romantique dont l'Italie a fourni les premiers modèles; mais il est vraisemblable aussi que le caractère de la nation répugnait à ce mélange de badinage et de sérieux qui était devenu comme essentiel à l'épopée romantique des Italiens» (p. 326). 
italiana, después escuela clásica del XVI, y sus discípulos- ${ }^{358}$ El primero por orden de prelación, editado por Sedano, es Boscán, cuya evolución poética observa el crítico en los tres tomos de sus obras, desde el gusto cancioneril y petrarquista ("El sentir de mi sentido», titulado en la traducción «La Mer d'amour») hasta la asimilación personal del gusto italiano conseguida en las composiciones como "Claros y frescos ríos», más que en sus sonetos. Su búsqueda trabajosa de la depuración clásica —ejemplificada en sus epístolas en tercetos a imitación de Tibulo y Horacio como la dirigida a Hurtado de Mendoza, sus poesías didácticas, su Octava rima o la traducción de Museus, en la que también se demoró Malmontais- lo convierte, no obstante, en un modelo por la pureza del lenguaje y la elegancia de su estilo. Más cumplido aún por su cercanía a la dulzura de Petrarca y por un contenido tono melancólico es el Garcilaso de las églogas — que, junto a alguna elegía rezumante de clasicismo, imágenes y comparaciones felices, como la dedicada a Boscán al pie del Etna, aventajan al resto de su obra-, y cuya edición de 1765 elogia el alemán por la imparcialidad, patriotismo y espíritu liberal de su prologuista. La excelencia reconocida de la primera égloga, de originalidad plenamente garcilasiana lograda en el cauce del género, contrasta con el hibridismo de la segunda, fallida por su inadecuación entre fondo y forma. ${ }^{359}$ Sin embargo, aún más estima le merece a Bouterwek un Hurtado de Mendoza, paradigma del humanista y político del Renacimiento («le véritable esprit espagnol du siècle de Charles Quint»), forjado de una pieza con grandes dotes y erudición. El historiador vindica su universalidad literaria, cimentada en el sedimento clásico y en su respetuoso cultivo de la tradición nacional («il était cependant assez bon patriote pour ne pas dédaigner l'ancienne poésie de sa nation, et assez éclairé pour préférer les classiques anciens aux Italiens modernes»): no solo valora sus magistrales epístolas, entre las mejores de la literatura moderna

358 Tras el triunvirato clásico secundado por grandes poetas como Fray Luis o Herrera, se enumera el inventario conocido de Velázquez con las ampliaciones de Dieze y breves noticias de estimables autores secundarios en los diversos géneros, entre los que destaca, por ejemplo, a Fernando de Acuña, el muy apreciado Gutierre de Cetina, Pedro de Padilla, Saa de Miranda o Gil Polo, solo superior a J. de Montemayor en estilo.

359 Frente al retorno al tono y reglas de la tercera égloga, bastante clásica, Bouterwek subraya: "Comme Garcilaso n'a imité des anciens que des pensées et des images isolées, et non la forme de ses églogues, il s'est cru permis de varier cette forme à son gré; mais ici son goût ne l'a pas toujours bien guidé. La seconde et la plus longue de ces églogues est un mélange hétérogène de genres disparates» (p. 256). 
— como las dirigidas a Boscán o a Zúñiga—, sus alegres poesías líricas al antiguo estilo y sus sátiras, más estimadas que otras composiciones suyas cuyos defectos de musicalidad le afean los críticos españoles; sino que también ratifica su fama en el género histórico ${ }^{360}$ por su concepción moderna e innovadora y su estilo modélico, digno — salvo cierto abuso retórico— de Salustio o Tácito y a cuya lectura animaba Mayans, excelente editor de la obra íntegra (1776) cuya escrupulosidad filológica tanto aprecia el erudito alemán; y constata la celebridad de su atribuida novela cómica — de la que destaca la abstracción de sus caracteres y su anticlericalismo-, continuada por un mediocre Luna. Bouterwek no suscribe totalmente la promoción de Herrera en el canon a instancias de Estala, responsable del discurso preliminar del tomo 5 de la colección de Ramón Fernández. Sin embargo, aun aceptando su lenguaje personal comparable en riqueza y pompa al de los antiguos, aun proclamándolo modelo moderno en la oda pindárica - especialmente con la celebrada Oda al sueño, única en su género y de valor intemporal - y poeta clásico no tanto por su superioridad como por su prelación, el crítico rebaja el mérito de sus innovaciones poéticas como fruto de un sistema extraño y artificioso en busca de la sublimidad en lugar de la inspiración; atribuye su éxito a las disputas entre los partidos literarios en liza y se muestra más severo con sus comentarios teóricos, a los que reprocha una medianía de conocimientos, escaso gusto y poca claridad de ideas. Como término ad quem, fray Luis de León cierra el parnaso de los poetas más valiosos de esta generación de discípulos, ocupando un lugar preferencial aún no superado por la perfección clásica de su estilo, forjado en la familiaridad con Horacio, el buen gusto que gobierna su poderosa imaginación, y la elevación moral de sus ideas. La excelencia luisiana se revela no solo en la prosa de La perfecta casada (La Femme telle qu'elle doit être, ou l'Épouse parfaite), sino ante todo en sus poemas originales - las odas "A la noche serena» pese al leve reproche a las últimas estrofas, «A Felipe Ruiz» y sobre todo "Vida del cielo» y la muy feliz imitación horaciana de la «Oda al río Tajo»—. Si bien el cotejo entre ambas personalidades poéticas —el arte pagano de Horacio, y la naturalidad y efusión cristiana en Fray Luis - en el tratamiento de la oda no le decide a darle a ninguno la primacía, Bouterwek se demora con gusto en sus muy celebradas y modé-

360 «après ceux de Machiavel et de Guichardin, la première production historique de la littérature moderne qui mérite d'être comparée aux ouvrages classiques des anciens» (p. 279). 
licas traducciones de los grecolatinos y los italianos modernos incluidas en el segundo libro de su edición («Aucun poëte n’a mieux connu que Luis de Léon la véritable manière d'imiter les anciens dans la poésie moderne», t. II, p. 309), cuyo ejemplo, aunque riguroso, habría estorbado, no obstante, otras prácticas que hubieran podido formar la poesía española sobre los modelos de la Antigüedad.

Implantada en el corazón del canon se levanta la figura señera de Cervantes, el único autor español de admiración inderrocable en Europa, cuyas obras - jerarquizadas por su valor estético- Bouterwek reivindica en su totalidad, distanciándose en varios de sus postulados de la opinión de predecesores — como Nasarre o del autorizado Vicente de los Ríos en su prestigiosa edición de 1781- y de numerosos continuadores. En la cúspide se halla su obra maestra, el Quijote, de estilo clásico —en el centro de las querellas entre antiguos y modernos, valorada ya por los españoles y exaltada por el Romanticismo en expansión-; pese a ciertos defectos, es considerada no solo ejemplo de roman comique y moral pragmática — aspecto reclamado más tarde por Hubbard- («roman comique et livre de morale pratique», t. II, p. 11), sino también una obra artística original — una suerte de género mixto de poema narrativo- cuyo tono lo singulariza de los modelos antiguos y caballerescos medievales. Trascendiendo el puro divertimento o la sátira supuestamente eficaz, la novela penetra otros sentidos que el alemán aprecia, por ejemplo, en su uso paródico de la retórica de sus referentes, o en el injerto de novelas cortas que contribuyen a la unidad del conjunto - y que defiende como muestra de su genio poético frente a la práctica francesa habitual de desgajarlas_-. ${ }^{361}$ Tras la novela cervantina por antonomasia, Bouterwek coloca inmediatamente el Viaje del Parnaso ${ }^{362}$ («le plus spirituel des ouvrages de cet homme

361 Una de las críticas de Quérard a la traducción de H. Bouchon-Dubournial le reprochaba su omisión del episodio de El curioso impertinente (Le Curieux Impertinent) — como también había hecho Saint-Hyacinthe-, luego impreso por separado bajo el título de Le Mari trop curieux (París, 1809), arbitraria extrapolación bastante censurada en el XIX.

362 J-.M. Guardia lo traducirá en la segunda mitad de siglo (Voyage au Parnasse de Michel Cervantes, traduit en français pour la première fois avec una notice biographique, París, Jules Gay, 1865). Sancha le había añadido en su edición de 1784 (en la Adjunta al Viaje al Parnaso. Publicanse ahora de nuevo una tragedia y una comedia inéditas del mismo Cervantes; aquella intitulada La Numancia, esta El Trato de Argel) las dos piezas dramáticas de la primera época cervantina, que fundan los análisis críticos del teatro cervantino en el XIX. 
extraordinaire», t. II, p. 20), también apreciado por Malmontais; y a la zaga las novelas ejemplares, de las que elogia sobre todo la Belle Bohémienne, ${ }^{363}$ superior a la de El licenciado Vidriera — traducido más tarde por Viardot (Le Petit-fils de Sancho Panza, 1838)_, y la meritoria novela pastoril La Galatea. Solitario ante la indiferencia o renuencia crítica general, Bouterwek no solo vindica sus versos sino que, desestimando el veredicto de Nasarre - tachado de confuso e inferior al prefacio cervantino-, reivindica también su teatro erigiendo a su autor, a pesar de sus lunares, en el Esquilo español. Esta admiración cervantista, en particular por las dos piezas más recurrentes de las ocho accesibles desde Sancha — La Numancia, por su grandeza y vigor, difundida por Esménard, y Los tratos de Argelno traducidas al completo hasta Royer junto a sus entremeses - la reconocida expresión de su fuerza cómica-, lo lleva más lejos que Schegel al proclamar su superioridad sobre el drama lopesco; finalmente, más convencional, relega al último lugar su novela bizantina Persiles y Sigismunda, pese a la excelencia de su estilo, una mediocre suma de aventuras monótonas, inverosímiles y mal trabadas. ${ }^{364}$

363 Versionada y anotada por Coste d'Arnobat (Nouvelles espagnoles de Michel de Cervantes, en la edición atribuida a Levebvre de Villebrune) a la manera clasicista de las «belles infidèles» (véase R. Pageard, «Une curieuse figure d'hispanisant français: Coste d'Arnobat», Revue de Littérature Comparée, oct.-dic. 1958, pp. 560-565 especialmente) bajo el título de La Bohémienne, nouvelle espagnole (La Gitanilla) (Madrid y París, 1775) precediendo a la del Amant libéral (El amante liberal) del año siguiente, esta novela sería muy apreciada en el XIX por su costumbrismo. Además de esta difundida adaptación, reeditada anónimamente en 1802 (Nouvelles choisies, imitées de Cervantes et autres auteurs espagnols, París, chez Gérard) que también comprendía tres novelas arregladas de Montalbán, las ediciones decimonónicas de las traducciones del XVIII recogen algunas asimismo conocidas como las de P. Hessein (París, 1707), Saint-Martin de Chassonville (Ámsterdam, Arkstée, 1768), la popular y denostada de Florian, ya aludida, sobre dos de las novelas de la colección del autor, o la antes referida de Petitot, precursoras de las de Bouchon-Dubournial y la tan celebrada de Viardot.

364 Opinión esta mantenida a lo largo del XIX ante el lectorado francés, que desde principios del XVIII disponía de la traducción de Mme le Givre de Richebourg (Persile et Sigismonde, histoire septentrionale, París, Gaudouin, 1738; Ámsterdam, 1740), varios de cuyos fragmentos había impreso la $B U R$ en julio de 1776. Quérard añade que ya incluía la biografía cervantina redactada por Mayans y Siscar, traducida y anotada por Daudet, y adjunta la sospecha del abaté Lenglet sobre la autoría de la traducción al atribuirla a Maugin de Richebourg. Dicha traducción dieciochesca se convierte en el texto mediador de esta obra cervantina en Alemania y fuente secundaria de acceso para sus lectores. A principios del XIX se difundió asimismo en Francia otra más, a cargo de H. Bouchon-Dubournial (Persiles et Sigismonde, ou les Pèlerins du Nord, París, Nicolle, 1809). 
A partir de las indicaciones de sus predecesores sobre las corrientes teatrales de este período Bouterwek reorganiza sus clasificaciones desglosando los principios opuestos que rigen la experimentación paralela de un grupo de partidos desde la primera mitad del XVI a fin de crear un teatro nacional: el partido de los eruditos, con los conocidos Villalobos, Pérez de Oliva, Simón de Abril, dotados de buen gusto, pero de poca imaginación y estudio insuficiente, abocados al fracaso por su falta de conexión con el público y por la carencia de un guía; el de los moralistas en la estela de La Celestina; el magisterio de Torres Naharro - considerado por Nasarre fundador del teatro español, y citado por N. Antonio, Dieze, Blankenburg o Signorelli, y traducido en la década siguiente por Labeaumelle- sostiene el tercer partido, cuya fusión con el cuarto o popular, encabezado por Lope de Rueda ${ }^{365}$ y por Juan de la Cueva, ${ }^{366}$ triunfará en la escena española como género nacional hasta culminar en Calderón. Junto a Cervantes el otro miliar del siglo es Lope de Vega («c'est à ce poëte que commence réellement l'époque où le drame nouveau prit possession, en Espagne, de tous les théâtres», t. II, p. 352), por su aportación como dramaturgo frente a otros géneros en que suele mostrarse más bien un imitador fiel cuando no inculca un mal ejemplo. ${ }^{367}$ Apoyándo-

365 Pese a la inclusión de extractos y pasajes suyos en disertaciones como la de Puibusque (1843), Lope de Rueda tardaría más en ser traducido en Francia hasta la edición de La comédie espagnole por Germond de Lavigne (París, L. Michaud, 1883), que comprendía Le Masque, Le Convive, Cornu et content, Payer et ne pas payer, Les Olives, Le Rufian couard, Eufemia, Les Deux Aveugles.

366 Las disputas de su tiempo constituyen a ojos de la crítica del XIX un avatar de la vieja querella de antiguos y modernos, de clásicos y románticos. Así, se subraya la reivindicación teórica de Juan de la Cueva — a la que Bouterwek niega la condición de poética-, en la línea de Encina y Pinciano, y en favor de la emancipación de los modelos antiguos, insuperables no obstante en arte y genio, para adaptarse al espíritu de la modernidad de su tiempo y circunstancias.

367 Por ejemplo, además de la Colección de Obras Completas de su teatro, el crítico se documenta en la Colección de las obras sueltas assi en prosa como en verso de D. Frey Lope Felix de Vega Carpio (empezada en 1726 y terminada en 1779, con 21 tomos), entonces disponible aunque incompleta. De este modo repasa el resto de su producción en los diversos géneros: desde poemas épicos como La Jerusalén conquistada, inferior al Tasso pero con bellos pasajes, La hermosura de Angélica, La corona trágica, Circé, y Dragontea; églogas como la Arcadia; su Arte nuevo; el mediocre Laurel de Apolo; El peregrino en su patria y La Dorotea - caracterizada como novela dramática que en Francia había sido extractada en la primera serie de "romans étrangers" publicada en la BUR en enero de 1782 - y sus novelas cortas; hasta su colaboración en el Romancero general; su recopilación como licenciado Tomé de Burguillos; sus poesías religiosas, epístolas y sonetos —algunos de ellos excelentes- o su original Gatomaquia. 
se en consideraciones añejas que insisten en su divertimento sin finalidad moral, en la mezcla de tonos, la desatención al trazado de caracteres, o en su condición mayoritaria de "poëmes dramatiques» o novelas representadas - y, por tanto, potencialmente abiertas como este género narrativoBouterwek emprende una apología de su fórmula dramática, de entidad propia respecto al teatro grecolatino y al moderno, y que bajo el nombre de comedia acoge piezas apartadas de la clasificación canónica. A partir de la voluminosa colección de sus obras teatrales selecciona algunos ejemplos, pertenecientes a diversos subgéneros: las heterogéneas "comédies spirituelles» de carácter religioso, en las que agrupa los incomprendidos y denostados autos sacramentales («fictions allégoriques» o "drames théologiques») como La Chute de l'homme, y las irregulares vidas de santos - a su juicio, de mayor interés dramático como San Nicolás de Tolentino-, que comparten la pompa escenográfica y musical «d'un véritable opéra»; las loas, entremeses y sainetes (burlesques intermèdes); y las comedias profanas. En este tipo las heroicas reemplazan a las tragedias canónicas como, por ejemplo, El gran duque de Moscovia o, entre las mejores, Las almenas de Toro (La Forteresse de Toro), por su inspiración en el romancero, si bien algunas de ellas ostentan ese título como El castigo sin venganza; junto a ellas, las vertiginosas comedias de capa y espada de intrigas inverosímiles y galanterías licenciosas como La villana de Getafe, al lado de otras como La viuda valenciana, de intriga más trabada y con el mérito infrecuente de la unidad de acción. De este modo, aunque su producción dramática no esté exenta de reparos — como sus pasajes de retórica artificiosa, explicables por sus descuidos, o la reiteración de tipos, no menos certeramente caracterizados-, incluso en sus obras más informes Lope deja trazas de un genio nacional que el arte solo no podría suplir.

Entre los seguidores contemporáneos de Lope, como Pérez de Montalbán o Virués, descuella un Calderón digno de memoria en Europa y cuyas obras, editadas también por Apontes, lee principalmente en la antología de su defensor García de La Huerta, ${ }^{368}$ admirador del ingenio subli-

368 Catálogo alphabético de las comedias, tragedias, autos, zarzuelas, entremeses y otras obras correspondientes al theatro español, Madrid, Imprenta Real, 1785-86. No obstante, también se tiene noticia de la antigua y estimada edición de las obras calderonianas a cargo de su hermano, y de la más completa, al cuidado de Juan de Vera Tassis, en diversos volúmenes desde 1682 hasta 1691. Muy valorada por los bibliófilos del XIX era también la de Madrid de 1760 en 10 vols. 
me y los conocimientos del dramaturgo barroco. En la controversia sobre la corrupción del gusto en el XVII el crítico alemán, en otra fase más propicia que la prematura de Huerta, rompe una lanza como su compatriota Schlegel por la exaltación calderoniana, tras las comedidas rehabilitaciones españolas en el XVIII de lo que se ajustaba a las normas. Pese a los reparos en nombre de la verosimilitud clásica — contra el hibridismo genérico, el injerto de poemas, por ejemplo sonetos, en ciertas situaciones de este teatro en verso, o la comicidad burlesca de los graciosos y sus bromas escatológicas en dramas y entremeses-, en el difícil cotejo de méritos entre ambos maestros y sus continuadores, Bouterwek da la palma a Calderón como creador de un nuevo género de comedia que perfecciona el molde lopesco dentro de sus márgenes. ${ }^{369} \mathrm{Su}$ superioridad se manifiesta en todos los órdenes: desde un magistral equilibrio compositivo - acumulando peripecias complicadas sin que decaiga el interés-, verosimilitud y variedad inventiva; una mayor profundidad psicológica de sus caracteres generales - especialmente los femeninos de sus comedias costumbristas-, si bien menos variados («si ce n'est de beaux caractères, du moins de beaux traits de caractère»); la fluidez y naturalidad incomparables de sus diálogos, la elegancia de su verso y su estilo - como en las relaciones incluidas frecuentemente en sus obras - , hasta la espectacularidad de su depurada concepción artística. Ante tamaño repertorio de excelencias, son disculpables los defectos contra el gusto -imputables en su mayoría al género adoptado-, pues, si esas piezas no están construidas para servir de modelos — según la concepción general de Bouterwek sobre las comedias barrocas-, el autor guardó coherencia con sus propias normas. Además de aludir a sus obras mitológicas — destinadas a los festejos cortesanos- y a sus menos estima-

369 Esta primacía se inclinará en favor de Lope y otros dramaturgos de su escuela con Menéndez Pelayo, cuyos argumentos generales resume y divulga Tannenberg (ob. cit., 1903, pp. 192-193), así como su inversión de los enjuiciamientos difundidos por Bouterwek: por ejemplo, salvo en El alcalde de Zalamea, Menéndez Pelayo había considerado a Calderón — aunque último eslabón de los grandes representantes españoles- no solo inferior a su ilustre predecesor en genio creador, en ejecución, en un sentido profundo de la vida manifiesto en la ingenuidad de las escenas populares lopescas, su tratamiento intuitivo de la historia o en el trazado de caracteres — pues frente a la penetración de Lope en la psique femenina y su estudio de la naturaleza humana, los tipos abstractos calderonianos se inspirarían en un falso idealismo-; sino también a Tirso en virtus comica, fantasía, sutileza psicológica e idealismo; y a Alarcón en regularidad, gusto clásico, moral delicada y justa dicción. 
bles obras históricas que españolizan la materia antigua o ajena, ${ }^{370}$ Bouterwek se detiene en determinados subgéneros cultivados con enorme calidad por Calderón — que en ocasiones también procura dignas y elegantes lecciones morales-: por un lado, sus comedias de costumbres o dramas españoles («à notre avis comme les précurseurs ou les frères aînés du drame romantique moderne», p. 266), articulados en torno al punto de honor - como en Los empeños de un acaso-, licenciosos enredos y poderosas pasiones como los celos —así en La Dame Esprit follet (título vigente desde las adaptaciones del XVII francés de La dama duende), aunque insatisfactoria para un gusto más exigente- - Sin embargo, más prudente que el moralista Sismondi, Bouterwek desmonta los airados argumentos del lejano Nasarre — que achaca al celo irreflexivo en la aplicación de las máximas francesas a un modelo diametralmente distinto como el teatro español-: no solo pone en duda la fiabilidad y alcance de la interpretación ideológica de la sociedad española de aquel momento histórico a través de estas ficciones - distinguiendo, en todo caso, entre representatividad nacional y expresión de los rasgos particulares de una clase social—, sino que también justifica el lenguaje poético puesto en boca de lacayos y sirvientas por la imitación de sus amos, si bien concede que la extravagancia de aquella retórica, entonces apreciado signo de distinción — como en Vienne le malheur pourvu qu'il vienne seul (Bien vengas mal, si vienes solo)—, solo sería soportable por los españoles. Por otro lado, la etiqueta anchurosa de comedias heroicas comprende géneros diferentes y de calidad desigual ${ }^{371}$ que acoge tanto las piezas menos estimables de su autor — de gran puesta en escena con desfiles, batallas y magníficos festines - como verdaderas tragedias, entre las que se encuentran las obras maestras calderonianas fundadas en la historia nacional, como la conocida El secreto a voces, además de "pastorales romanesques» como Echo et Narcisse, o espectaculares óperas como $E l$ mayor encanto Amor (Amour est le plus grand des Enchantements). Por últi-

370 Son verdaderas tragedias, por ejemplo, Coriolan (Las armas de la hermosura), Alexandre (Darlo todo y no dar nada) y Heraclius o Todo es Engaño - título de la calderoniana En esta vida todo es verdad y todo es mentira, difundido por Corneille en su L'Heraclius espagnol, y por los comentarios de Voltaire-, que critica por la confusión de peripecias y situaciones novelescas, reproche del que exime a Finezas contra finezas, llena de interés y sensibilidad.

371 «Il ne se montre au-dessous de lui-même que dans quelques-unes de ses comédies héroïques» (t. II, p. 151), aunque en su mayoría las alaba por la dignidad y la delicadeza de gusto. 
mo, de entre las tragedias sacras aún examinadas con la prevención común a los neoclásicos en nombre de la razón y la moral, ${ }^{372}$ y vinculadas con los anómalos dramas sacros o autos sacramentales, recibe grandes elogios $\mathrm{La}$ devoción de la Cruz (Les Merveilles de la Croix), «drame étrange» de la primera etapa calderoniana. No obstante, su obra maestra es, a su entender, la espléndida tragedia cristiana El príncipe constante, en cuyo análisis se demora. Si bien no respeta las unidades de lugar y tiempo, en cambio muestra una escrupulosa observancia de la unidad de acción: la sucesión de situaciones patéticas y emocionantes — en las que imbrica acertadamente, al estilo de la comedia nacional, la melancólica acción secundaria de los amores de Muley y la princesa de Marruecos - se anuda admirablemente en torno al heroico sufrimiento del protagonista, culminante en la apoteosis final del príncipe mártir al frente del ejército portugués. Sin embargo, pese a la preeminencia de Calderón, la sumisión al molde lopesco de la pasmosa riqueza teatral de este período - inaudita en Europa y concentrada en unos cincuenta añosno justifica a juicio de Bouterwek su división en escuelas. El conocido repertorio de autores, escogidos por sus esfuerzos de regularidad, comicidad, indagación psicológica y moralidad conforme a la horma clásica, sigue esencialmente la jerarquía ya apuntada por Velázquez y los eruditos y antólogos españoles con obras diferentes de las consagradas en el canon romántico. ${ }^{373}$

372 «ce qu'on a fait en ce genre de plus imposant et de plus ingénieux; mais l'association des idées religieuses aux extravagances les plus absurdes, qui semble être de l'essence de ces pièces, blesse tellement la raison et même le sens moral, qu'on se trouve obligé de féliciter les nations qui sont privées d'un amusement de cette espèce» (t. II, p. 166).

373 Bouterwek señala en primer lugar el Solís de El alcázar del secreto (Le Château du Mystère) y La gitanilla de Madrid, elogiado desde Nicolás Antonio; y Moreto, cuyo talento cómico - a excepción de las bromas del gracioso - y análisis de caracteres se estiman superiores a los de Calderón, con De fuera vendrá quien de casa nos echará (Celui qui viendra du dehors nous mettra dehors), y discípulos de la regularidad y el tono de Terencio, tan admirado por los dramaturgos del XVIII. Repartidos en un párrafo, respectivamente, Juan de Hoz con la comedia de figurón El castigo de la miseria (L'Avarice punie) y sin ejemplo alguno Tirso de Molina; Francisco de Rojas, cuyas comedias de intriga son comparables a las calderonianas como la aplaudida Entre bobos anda el juego (Où les sots jouent, le jeu est bon), y menos feliz en las comedias heroicas como Casarse para vengarse (Mariage par vengeance), omitiendo aún las pronto consagradas en el XIX; el gongorista Agustín de Salazar y Torres, autor, sin embargo, de la celebrada comedia heroica Elegir al enemigo; y en último lugar, Mira de Amescua con El caballero sin nombre (Le Chevalier sans nom). El crítico completa este listado de dramaturgos con Antonio de Mendoza, Vélez de Guevara, Cubillo, Coello, Godínez, Matos Fragoso, a la vez que reclama una mayor difusión para obras más antiguas de Ruiz de Alarcón o Guillén de Castro, en los que, sin embargo, no se detiene. 
Tras Cervantes y Lope, el primer puesto entre los poetas del nuevo período de acuerdo con las divisiones heredadas de grupos y corrientes es asignado a los respetados Argensola —-sobresaliendo Lupercio en la lírica, las epístolas y sátiras horacianas, y Bartolomé en el género didáctico y el soneto satírico- Su falta de genialidad se compensa con un innegable talento, elegancia clásica y un sentimiento verdadero de la poesía, que los convierten junto a Fray Luis, en los poetas españoles más correctos. La complejidad de corrientes en la intensa fermentación poética de las que habla Baasner se refleja en la división de Bouterwek, quien señala la dificultad de separar claramente los discípulos de la escuela clásica ${ }^{374}$ de los del partido llamado extravagant —influenciado por los marinistas italianos -375 que, como Faria y Souza, exageran las licencias de Lope sin su brillantez y tino. Tomando la división básica de Velázquez sobre esta segunda fase de disputas literarias que apunta al exacerbamiento de la afectación en las dos escuelas, Bouterwek se refiere a los cultoristes como Salcedo Coronel o Pellicer de Salas y los conceptistes con Alonso de Ledesma, Félix de Arteaga o Alonso de Castillo Solórzano. La condena a Góngora, jefe de la escuela, se limita a sus poemas mayores, mientras que se elogian sus sonetos satíricos y romances burlescos, superiores a los de Castillejo, y sus canciones en viejo estilo, llenas de naturalidad y poesía, ${ }^{376}$ también

374 Así, los epígonos de los clásicos del XVI llamados Cinquecentistes españoles, cuyos méritos radican en la elegancia y corrección en diversos géneros con Espinel, Cristóbal de Mesa, Juan de Morales, Agustín de Tejada, Rey de Artieda, G. Morillo, Soto de Rojas, Barahona de Soto, Luis Martín, Martínez de la Plaza, Baltasar de Alcázar, Argote de Molina. El historiador afirma que entre los principales petrarquistas de este período se hallan Francisco de Figueroa, Suárez Figueroa, Cayrasco Figueroa o Arguijo.

375 "Cette nouvelle espèce de poésie n’était guère autre chose que l'ancienne poésie nationale avec tous ses défauts, mais dépouillée de son antique énergie et de sa bonhomie naïve, polie, raffinée, contournée, rendue absurde à force d'art, et par dessus tout cela bavarde et radouteuse» (t. II, p. 89).

376 Considerado el principal responsable de los desmanes retóricos de la poesía del XVII y de sus epígonos dieciochescos, de Góngora suelen valorarse a lo largo del XIX sus composiciones breves, romances - en especial los moriscos, subgénero que goza de gran consideración-y letrillas, al tiempo que, pese a cierta atención más indulgente de Amador de los Ríos, los críticos franceses suelen condenar con mayor o menor contundencia sus poemas mayores. Como recuerda H. W. Sullivan (El Calderón alemán. Recepción e influencia de un genio hispano (1654-1980), Fráncfort del Meno-Madrid, Vervuert-Iberoamericana, 1998, p. 157), Herder escogió varios de los romances gongorinos para una breve antología en $1778-79$. 
recogidos en la encarecida selección a cargo de Estala (1787). Por su parte, la fuerte personalidad literaria de Quevedo («après Cervantes, le plus spirituel de tous les écrivains espagnols», t. II, pp. 119-120) suscita una valoración ambigua. Si Bouterwek ensalza como Malmontais su enorme ingenio y sólido talento, no siente tanto aprecio por sus obras — rebeldes a las normas clásicas y de estilo desigual-, al punto que lo presenta como un frívolo contraejemplo acusándolo de abdicar de su papel de guía para someterse acomodaticiamente a las modas. ${ }^{377}$ Bouterwek valora ante todo la prosa de sus obras teológicas y ascéticas, y principalmente de las cómicas y satíricas —novedosas a su entender por su lograda asociación entre sus máximas morales y la imaginación-, más conocidas fuera de España — sobre todo sus Sueños ${ }^{378}$ y Visiones, o El Gran Tacaño (ou du capitaine de voleurs surnommé don Pablos), quizá "le plus burlesque de tous les romans du même genre»— que las compuestas en verso como jácaras, bailes, romances o sonetos burlescos que necesitan comentarios explicativos; relega sus poesías serias a una medianía —en primer lugar las poesías pastoriles del bachiller de la Torre, superiores a sus canciones, sonetos como el sentencioso "Buscas en Roma», que traduce, u odas pindáricas de escaso aprecio-, y le niega incluso verdadero sentimiento poético al observar su propósito de traducir en verso el Enchiridion o el Manual de Epicteto. Más reconocimiento alcanza, en cambio, Villegas por la incomparable gracia de su estilo como en su famoso idilio «De un pajarillo» tomado de sus Delicias. ${ }^{379}$

377 «Avec cette espèce d'universalité et une facilité à faire des vers presque égale à celle de Lope de Vega, Quévédo serait devenu, sinon le premier poëte de l'Espagne, du moins un écrivain classique qui aurait eu peu d'égaux, s'il avait pris sur le goût de son siècle et de sa nation autant d'influence qu'il lui en laissa prendre sur lui-même; mais Quévédo, homme du monde quoique savant, s'était accoutumé de trop bonne heure à respecter toutes les formes de convention" (t. II, pp. 119-120).

378 De los primeros, inspirados en Luciano, alaba su adecuación genérica con un estilo cortante y el humor de otros pasajes del Último juicio, Sueño del Juicio final o de las Calaveras, aunque nota la monotonía de sus ataques en varios de ellos y rechaza sus aspectos escatológicos.

379 En cambio, las traducciones de Jáuregui, exceptuando su Aminta, ya no tienen a ojos del alemán tanto mérito como a los de Malmontais, y tampoco le parece una buena elección tomar como modelo al Lucano de la Farsalia, también editada por Ramón Fernández en 1789 junto al Orfeo. Asimismo, Bouterwek añade a Borja y Esquilache solo por su buen gusto, aunque escribieron romances excelentes; y por su talento sin gusto a Ulloa, Rioja, Gravina, el conde de Rebolledo, Melo o Villamediana. 
Si la poesía lírica y dramática alcanzaron su esplendor antes de despeñarse por el abuso retórico, el despotismo político y religioso hizo mella en otros géneros en prosa al estorbar su perfeccionamiento por la libre imitación de los modelos antiguos, haciéndolos replegarse en la retórica. Entre los historiadores de la segunda mitad del XVI, ${ }^{380}$ además de Hurtado de Mendoza, se mencionan cronistas reales como Ocampo, Morales o Zurita - de estilo seco para distinguirse de la novela-, la historia del jesuita Mariana, ${ }^{381}$ clásica solo por su estilo, calidad a la que Solís añade el interés filosófico en su famosa obra que el crítico ha consultado en la hermosa edición de 1776. Los ensayos infructuosos en otros géneros como la prosa didáctica, ${ }^{382}$ la oratoria, el diálogo y el género epistolar, de carácter ceremonioso y solemne, ${ }^{383}$ se complementan con la mediocre abundancia de poéticas y retóricas, inferiores al modelo aristotélico $^{384}$ — de entre las que destaca, pese a su escasa repercusión, la Philosophia antigua poética de López Pinciano, la más sagaz del siglo aunque no del mejor estilo- y los censurados escolios y comentarios gongoristas. En la segunda mitad del XVII se consuma el estancamiento de la prosa en narraciones de diversa condición, ${ }^{385} \mathrm{o}$ en los textos heterogéneos del

380 El traductor de los ejemplos advierte de las omisiones del autor alemán, como, por ejemplo, el cronista de Indias Antonio Herrera o el Inca Garcilaso, traducido al francés desde principios del XVIII, y de cuya confusión con el poeta previene al lector.

381 Su celebridad propició varias traducciones al inglés y al francés, como la de 1733 en La Haya o la de P. Charenton de 1785, y la edición española más estimada, según afirma Bouterwek, de 1780, precediendo a la suscripción patriótica de Valencia cinco años después.

382 El crítico destaca el diálogo y los discursos de Pérez de Oliva - cuyo estilo tampoco le parece modélico para el género-, Morales, Valles y Cervantes Salazar, editados conjuntamente en Valencia en 1772. En el género alegórico menciona la novela Labricio de Mexía. Son ejemplos no superados hasta Gracián, autor bien conocido en la Francia de su tiempo — por ejemplo, su L'Homme de cour (1684) a cargo de Amelot de la Houssaiey reimpreso frecuentemente bajo el Antiguo Régimen.

383 Bouterwek saca sus ejemplos principalmente de Mayans (Cartas morales, militares, civiles y literarias de varios autores españoles, recogidas, etc., Madrid, 1734): así, una carta de Felipe II a D. Juan de Austria y otra al duque de Alba. También se refiere a otras de Solís, más sencillas pero sin la sutil ligereza del género, durante el período gongorista.

384 Aunque reconoce el escaso ascendiente de toda poética, el crítico alude a otras de carácter aristotélico y que juzga de nula utilidad como las de Mondragón, Sánchez de Viena o Juan Díaz, entre otros.

385 En ese amplio conjunto de obras, Bouterwek menciona la evolución de las novelas de costumbres, llamadas romans comiques o romans de fripons o del gusto picaresco, desde el 
jesuita Gracián en los que — salvo el sobresaliente Criticón, cuadro alegórico y moral de la vida humana - su autor derrochó su ingenio como $E l$ Discreto, el Oráculo manual, desigual colección de máximas útiles, o su Agudeza y arte de ingenio, denostada e influyente recopilación de los principios rectores de su estilo y cuyo único valor residiría en su condición de documento para la historia crítica de la literatura de su tiempo. Las predilecciones literarias de Bouterwek en el período de apogeo privilegian, por su universalidad, su enriquecedora originalidad o su capacidad de fusión de las influencias extranjeras y de los modelos clásicos con la tradición nacional, la obra de Cervantes — genio instintivo, además de sólidamente juicioso ("Ce n'est pas que plus d'un poëte d'un grand talent n'ait brillé à côté de Cervantes; mais de tous les poëtes de l'Espagne, Cervantes est le seul qui appartienne au monde entier», t. II, p. 34)_, de fray Luis de León, Garcilaso, el humanista Hurtado de Mendoza o Calderón; y por su carácter romántico, el drama heroico de Lope o, por ejemplo, la novela pastoril de Montemayor.

En el período que arranca en la segunda mitad del XVII el teatro es asimismo el género más señalado ${ }^{386}$ con las escenas puramente novelescas de El esclavo en grillos de oro de Bances Candamo; el elogiado El hechizado por fuerza de Antonio de Zamora, valorado entre las piezas de carácter, pese a sus excesos, por su comicidad y mayor ajuste a las reglas; o las comedias de figurón de Cañizares, en especial la graciosa pero basta El dómine

Lazarillo hasta el Guzmán, ambos parcialmente difundidos por la BUR (agosto de $1781 \mathrm{y}$ julio de 1776, respectivamente) y de estilo natural y correcto, hasta continuaciones que considera de mala calidad como la de Mateo Luzán, o La picara Justina de Úbeda ("pendant aussi fade que pédantesque du roman comique de Guzman d'Alfarache», p. 106), descollando sobre todas ellas La vida del escudero Marcos de Obregón de Espinel (1618), guía útil y moral en el mundo; así como colecciones de cuentos y anécdotas como los Diálogos de apacible entretenimiento de Gaspar Lucas, la novela política de Pellicer de Salas, la prosa poética de Pérez de Montalbán, y por su rareza las novelas de estilo preciosista de Mariana de Carvajal. 386 Aun así, considera que debe mencionar a varios poetas, entre los que sobresale la autora de la provincia ultramarina de la Nueva España, Sor Juana Inés de la Cruz, de la que destaca pese a la variedad desigual de su obra, sin gusto ni conocimientos literarios, según afirma el auto alegórico Le divin Narcisse — superior a los de Lope, si bien el traductor apunta que Bouterwek se ha olvidado del Polifemo de Pérez de Montalbán—, sus prólogos y sus notorias canciones, cánticos sagrados y cantatas, que juzga de gran interés para una hacedera historia poética del catolicismo. Por otro lado, Bouterwek ratifica la poca influencia francesa a principios de siglo cuando prevalecía el gongorismo representado por un Gerardo Lobo, por ejemplo. 
Lucas, entre las más regulares de la dramaturgia española. A su juicio, el relevo dinástico y la inevitable influencia francesa se revelan beneficiosos para la política y la literatura - a impulso de la fundación de academias, los esfuerzos de europeización, el legado del siècle de Louis XIV y un enciclopedismo bifronte, que, si bien contribuyó a abatir el fanatismo, también agostó el entusiasmo poético-, sucediendo a la decadencia de la ancienne littérature de principios del XVIII hasta el logro consumado de la renovación en los últimos diez años de la centuria. No obstante, Bouterwek señala que ese ascendiente hubiera sido más feliz si el espíritu nacional no hubiera perdido tanto vigor, habiéndose adelantado así su fusión sin el lastre de la fase imitativa y la trabajosa aclimatación de la influencia extranjera. ${ }^{387}$ Hasta las excelencias literarias del período finisecular y la aportación mayor, a la altura de sus contemporáneos europeos, de la littérature savante, crítica y erudita, su valoración del XVIII es, pues, la de un período sumido primero en el gusto francés — desde la fundación de la Academia Española y la reforma de Fernando VI- hasta la restauración de las letras y el buen gusto bajo Carlos III, y dividido entre casticistas y cosmopolitas de fuerzas igualadas de los que no surge un guía literario de renombre indiscutible. De este complejo reajuste cultural Bouterwek difunde esa antinomia ideológico-literaria —el bando cortesano o "parti de la bonne compagnie» luego llamado galicista, que prefiere las composiciones regulares y clásicas de los franceses, ${ }^{388}$ y el nacional, aferrado al gusto antiguo de las obras teatrales de Lope y Calderón- en las disputas sobre la modernización de la cultura española y su integración en la órbita francesa dominante. Si bien en la primera mitad del siglo no halla un solo poeta español digno de ser citado frente a la opulencia anterior - no tanto por la alteración del genio nacional cuanto por su lucha con el foráneo-, el momento de mayor auge de la polémica estalla a mediados del siglo en el campo teatral por la experimentación con las viejas formas, tra-

387 «pour faire marcher la littérature espagnole de pair avec la littérature française; pour apprendre des Français en quoi consiste la véritable élégance, sans sacrifier à l'élégance des beautés d'un ordre supérieur» (t. II, p. 193).

388 «cependant il cherchait à prouver qu'on pouvait encore trouver des beautés dans cette ancienne littérature, même en les appréciant selon les principes du goût français. Ce parti voulait en même temps, pour ne pas laisser les Français exclusivement en possession du domaine du goût, perfectionner la littérature et sur-tout le théâtre espagnol» (t. II, pp. 193-194). 
ducciones e imitaciones del francés y del inglés, y alcanza la renovación de la prosa, como ejemplifica el prólogo de Capmany a su Filosofía de la elocuencia. $^{389}$

De entre los reformadores de mediados del XVIII como el prestigioso Mayans, elogiado por su labor erudita y difusora con sus Orígenes - de los que selecciona la Oración en que se exhorta a seguir la verdadera idea de la eloquencia española-, y con más reservas su Retórica — tachada de seca compilación de las ideas de Aristóteles y de los escritores modernos-, o Nasarre y Montiano, Bouterwek se detiene en las diversas obras de su compañero Luzán - fundador de la escuela francesa en España- y principalmente en su Poética, ${ }^{390}$ más por la influencia que ejerció como código referencial adoptado por los cultos que por una excepcionalidad y originalidad teóricas que le refuta. A partir del análisis pormenorizado de su primera edición, el crítico elogia la elegancia, claridad, orden y erudición de su discurso y la novedad de su aplicación sistemática a la literatura española de los antiguos principios aristotélicos — conocidos directamente por su predecesor Pinciano, al que Luzán, en cambio, no cita-, si bien tamizados por intermediarios franceses - Rapin, Corneille, Crousaz,

389 Bouterwek concluye que los prosistas del XVI han recuperado por fin su consideración primera, pero señala las vacilaciones suscitadas, ante el incremento de aportaciones léxicas francesas, a fin de restablecer la pureza del «ancien langage classique». Muestra de la importancia contemporánea de la literatura en prosa y la elocuencia, esta obra de Capmany — trasunto de la Encyclopédie, como demostró Checa («Una retórica enciclopedista del siglo XVIII: la Filosofía de la elocuencia de Capmany", Revista de Literatura, 50, 1988, n. ${ }^{\circ}$ 99, pp. 61-99)—y su prólogo —esfuerzo ordenador de los conceptos que lo precedieron - ilustran asimismo la oposición vigente entre los partidos en liza, puristas y gentes de mundo. Como es su costumbre, Bouterwek aboga por una ecuánime contemporización que conserve el legado antiguo modernizando ciertos aspectos a tenor de la marcha de la civilización, las aportaciones científicas y las nuevas ideas. Liberada ya del gongorismo - gracias en gran parte a los servicios del ejemplo francés-, la prosa española ya está, pues, dispuesta a reanudar de nuevo el prestigio del XVI en ensayismo, erudición, ciencia, traducciones o historia — por ejemplo, la Historia de América de Juan Bautista Muñoz, planteada desde otro punto de vista diferente del de Robertson-, obras en suma bien escritas por lo general, aunque en la actualidad aún carezcan de un estilo deslumbrante y singular.

390 La Poética, o Reglas de la Poesía en general, y de sus principales especies, Zaragoza, 1737, 1.a edición. 
Lamy o Mme Dacier - e italianos - Muratori o Gravina- Sin embargo, aunque reconoce su genuino sentimiento de la belleza poética - y la ausencia asimismo de verdadero genio en sus versos- denuncia su error, compartido con los clasicistas franceses, acerca del verdadero objeto y la definición de la poesía — en tanto imitación de la naturaleza en lo universal o en lo particular, y de los distintos géneros y especies- y cuya esencia también limita por su reductor enfoque moral, ${ }^{391}$ tal como demuestra, por ejemplo, en su aprecio, insuficiente a juicio del alemán, de los dramaturgos del XVII. ${ }^{392}$ Entre los hitos patrióticos de la segunda mitad del siglo Bouterwek cuenta ediciones literarias eruditas como la de Sedano o la incompleta pero meritoria colección de dramas áureos de García de la Huerta — de fogoso pero mediano e irregular talento como crítico y poeta-, y de quien prefiere como logro cumplido su tragedia clásica Agamenón vengado ("essai assez heureux où l'auteur a tâché de fondre ensemble les formes antiques et les formes de la poésie romantique», p. 231) sobre su digna Raquel;393 y en tercer lugar, en busca de la conciliación entre la elegancia francesa y las formas nacionales, la obra de Iriarte, brillante traductor y primer fabulista clásico español por su riqueza métrica, gracia y originalidad, del que traduce un

391 «Trompé par cette idée gothique, qu'il étayait d'un passage mal entendu d'Horace, et qui est née d'ailleurs avec la littérature moderne, il ne pouvait s'élever à l'idée générale de l'activité de l'esprit dans le domaine du beau, ni comprendre que cette activité de l'esprit, sous certaines conditions, a déjà par elle-même une valeur morale, puisqu'elle perfectionne et agrandit l'existence de l'homme» (t. II, pp. 213-214).

392 Aunque no le quita toda la razón a sus críticas - y se la da a propósito de los discutidos autos sacramentales, que Luzán, por otra parte, se limitó a describir breve y cautelosamente-, Bouterwek le reprocha su exposición sin miramientos de las debilidades de Lope o de Calderón sin conceder el justo valor al genio, preferible en bastantes casos, a juicio del alemán, a la fría elegancia.

393 Esta pieza, considerada aún a fines de siglo «régulière, bien conduite, d'un style noble et pur» es una de las obras más nombradas de su producción, junto a sus sonetos y romances, que juzga excelentes como su Egloga piscatoria (1760), y sus notables traducciones del francés. Su calidad teatral, inferior a su también admirado Calderón, le resta fuerza a su aspiración reformadora, como en este voluntarioso ensayo de tragedia, híbrido de la herencia nacional y deudora de las reglas franceses - con una escrupulosa unidad de acción, sin mezcla estrófica y cuidado patetismo-, en contraste con sus decantados propósitos nacionalistas. El crítico alaba, con todo, el contraste entre los dos poderosos aristócratas, en particular D. García de Castro, que destaca sobre la mediocridad e insuficiencia del resto de caracteres, y, como la crítica decimonónica que lo sigue, no registra las implicaciones políticas e ideológicas del planteamiento del autor. 
pasaje de «El oso, la mona y el cerdo». ${ }^{394}$ Principal difusor de la fama de Meléndez Valdés en el extranjero, Bouterwek ensalza particularmente —además de sus odas románticas, elegías y sonetos, su epístola a Jovellanos en la dedicatoria de sus poesías, su comedia Las bodas de Camacho o sus disertaciones sobre la filosofía moral- sus odas anacreónticas, romances líricos y canciones populares -insuperables en gracia voluptuosa-, por su fidelidad a la naturaleza, armoniosa versificación, estilo clásico y preciso, moderna elegancia y delicadeza moral que perfecciona los moldes antiguos de Horacio, Tibulo, Anacreonte y Villegas, impregnándose a su vez de las influencias inglesa y alemana. ${ }^{395}$ Asimismo, además de constatar la vitalidad literaria de ese período por la notable variedad de propuestas de los diversos géneros cultivados, ${ }^{396}$ Bouterwek — cuya redacción es anterior a los desas-

394 Elogiado en la prensa europea de su tiempo, traducido en Inglaterra, Alemania — casi por completo por Bertuch (Leipzig, 1788) — y Francia en colecciones colectivas de autores españoles y europeos (véanse Bragt, ob. cit., o Quérard, ob. cit., por ejemplo) y en ediciones individuales, además de publicaciones en español a principios del XIX, el Iriarte fabulista gozó de notable estima entre los franceses de su generación y de la siguiente: desde Florian, que reconoció su influencia, hasta la traducción en verso de J.-B. Lanos (París, Desenne, 1801), la más completa en prosa de Lhomandie (París, Antoine Bailleul, 1804), si bien solo se atuvieron a 67 fábulas de la primera colección del autor; o ya en la primera mitad del XIX, la versión de Charles Brunet (Fables littéraires, 1838), entre otras. Si sus estrenos teatrales originales son relativamente apreciados, tras su adiestramiento en la traducción selecta de comedias francesas, en cambio su poema sobre la música, como a Malmontais, tampoco le merece tanta aprobación a Bouterwek, por el escaso carácter poético del asunto y el distanciamiento del crítico respecto del género didáctico.

395 «Si l'espagnol ne s'y faisait pas reconnaître à ses peintures animées, on croirait lire un poëte anglais ou allemand traduit en espagnol» (t. II, pp. 242-243).

396 Por ejemplo, cita las estimadas tragedias regulares de Moratín padre; las comedias y entremeses de Ramón de la Cruz; las traducciones de Corneille, Voltaire, Molière, o de Shakespeare - como las versiones de Otelo por Teodoro de la Calle o de Hamlet por el muy apreciado Moratín hijo-, las de los dramas sentimentales de Mercier, o de novelas francesas e inglesas; las obras modernas de Comella, más cercanas, sin embargo, a la manera antigua; la lírica de Noroña, traductor también de Dryden; poemas didácticos recientes como La Diana de Nicolás Fernández de Moratín; las sátiras de Cadalso y de Leandro Fernández de Moratín; el poema épico México conquistada de Juan de Escoiquiz, junto a pastorales y traducciones de Gessner; escritos en prosa como L'Homme heureux de Almeida, La Femme heureuse, de Morino, o la traducción del alemán de L'Art d'être toujours content por Uz, entre otras; así como un eclecticismo evidente sobre todo en las nuevas novelas en competencia con reimpresiones de antiguas como Cassandra o La Leandra de Valladares de Sotomayor (Madrid, A. Ulloa, 1797). Para no contravenir su deber de historiador, recuerda que no debe silenciar las odas de León de Arroyal o las anacreónticas, a imitación de Villegas, de una dama anónima (¿Gertrudis de Hore quizá?). 
tres de la guerra - fía en la vivificación de la savia nacional y la antigua poesía popular en esas décadas finales respaldadas por la actividad de buenas academias como las de Sevilla y Barcelona.

Esta primera historia autónoma de la literatura española desde el nuevo y pujante centro intelectual europeo promueve su rehabilitación general sancionando su carácter distintivo — más nacional que cualquier otra literatura europea-, aceptado paulatinamente por los críticos franceses. En nombre de los principios universales de la belleza, el gusto, la naturaleza y la razón e incluso del equilibrio clásico - únicos a los que debe someterse la imaginación - atiende al relativismo de los sistemas particulares por siglos y regiones, por encima de las interpretaciones particulares de la rectora poesía griega, italiana o francesa. En su alegato final el crítico reclama justicia hacia la literatura española —o castellana, con más propiedad, como señala-, rebatiendo la acusación de parvedad con la abundancia de obras propiamente literarias, genuinamente poéticas y de sello original («dont la plus grande partie lui appartient exclusivement») cuando aún estaban en germen en la prestigiosa Italia. No solo juzga incontestable la elegancia y corrección clásica de muchos de sus autores, dignos por su gracia y perfección formal de los modelos grecolatinos - fuentes originales antes del tamiz clasicista francés_, sino que muchas de las poesías españolas más irregulares, incluidas las del teatro del XVII - y sobre todo las calderonianas-, alcanzan en el más alto grado el encanto de la armonía y el ritmo («en Espagne, les auteurs dramatiques les plus féconds se sont montrés grands poëtes jusque dans leurs fautes», t. II, p. 254). Es más, puestos en una balanza, Cervantes vale por todos los galicistas, cuyo mayor mérito reside en la corrección de una prosa bastante buena, calzada en un verso rimado con regularidad al dictado de la crítica francesa. Su receptividad hacia esta literatura atenúa el rigor habitual hacia los autos sacramentales, ${ }^{397}$ pese a los reparos habituales en nombre del

397 «Il faudrait être bien ébloui de l'éclat de la poésie espagnole, pour ne pas trouver la monstrueuse mysticité de leurs autos, même de ceux de Calderon, aussi monstrueuse qu'elle l'est en effet; mais il faudrait aussi être devenu, à force de philosophie, incapable de sentir la poésie hardie du catholicisme, pour ne pas sentir celle des autos espagnols. Que n'aurait-on pas pu faire de cette poésie, si la raison avait bien voulu s'en mêler, non pour la réduire à l'exactitude de la prose, mais pour donner à ses fictions mystiques plus de noblesse et de régularité» (t. II, p. 255). 
gusto y la moral («quoique dans l'emploi qu'ils en ont fait on ne puisse les citer comme des modèles»), pues de todos los pueblos modernos, el español ha sido el único en descubrir la poesía del cristianismo católico.

A la luz de las nuevas teorías, Bouterwek sienta asimismo en el extranjero las bases de la reivindicación, de raíz popular, del patrimonio literario español, abanderado por los romanceros y los dramas áureos. Sus oposiciones entre lo nacional y lo foráneo - italiano o francés- conjugan sus deudas con las fuentes españolas, con el magisterio de los clásicos grecolatinos y con cierta influencia de Schlegel, al defender las necesarias adaptaciones a la tradición nacional en favor de una fusión enriquecedora, confirmando así su capacidad de asimilación — no copia de modelos ajenosy de creación original —encarnada paradigmáticamente en los innovadores Cervantes y Calderón, gigantes europeos, en grandes poetas como Fray Luis o en humanistas vindicados como Hurtado de Mendoza-. Por otra parte, tras defender en la veta oriental que recorre la obra de sus poetas un orientalismo de gran belleza y grandiosidad, sin más ejemplos, frente a otro de mal gusto - el que suscitará probablemente el desagrado de Sismondi-, Bouterwek reivindica la importancia de esta literatura en Europa como faro para la alemana, correctivo del clasicismo francés y digna contendiente de la italiana, más familiar para Sismondi y entonces difundida en Francia por los ideólogos. ${ }^{398}$

El prólogo con que el protestante Philippe-Albert Stapfer ${ }^{399}$ introduce la historia refleja con prudencia esta actitud diferente de los postulados del postclasicismo aún reinante, ${ }^{400}$ y sirve de piedra de toque para valorar la recepción en Francia de la obra y su asunto. Difusor de la literatura y el pensamiento alemanes, Stapfer justifica esta elección por su novedad, importancia y solidez en el campo tan poco explorado de la literatura espa-

398 Por ejemplo, vindica su prosa áurea sobre la italiana: «Il ne faut pas oublier, à cette occasion, la prose classique de l'âge d'or de la littérature espagnole, qui l'emporte de beaucoup sur la littérature italienne par le nombre d'ouvrages en prose qu'elle possède, aussi recommandables par la vigueur que par l'élégance du style» (t. II, p. 254).

399 Véase, por ejemplo, Goblot, Documents pour servir..., p. 210.

400 Como ejemplo del arraigo de la superioridad francesa sobre la literatura española incluso entre los críticos moderados, Stapfer recuerda la anécdota de un anónimo «homme d'esprit» que, tras haber acusado a Montesquieu de ligereza por su «boutade» de las Lettres persanes, no dudó en "proclamer que ses trésors littéraires, évalués si haut par elle-même, ne peuvent que nous indemniser assez médiocrement des frais d'exploitation». 
ñola, en franca desventaja respecto a la italiana o la inglesa en el horizonte de conocimientos del lectorado francés. ${ }^{401}$ Para afrontar la indiferencia, cuando no la resistencia de parte de la crítica, el prologuista apela a la perspectiva del «littérateur philosophe» ante la gran paradoja de la civilización española, más que al estudio estético y al realce de su producción literaria. ${ }^{402}$ El caso español constituye a sus ojos un fenómeno cultural singular en la historia del espíritu humano, en tanto lección ejemplarizante para el resto de naciones. El examen de su devenir explicaría el fracaso histórico de una naturaleza pródiga en dones, y su entonces incuestionable parquedad de aportaciones a las ciencias y a las letras, por las coerciones políticas impuestas al desarrollo de sus facultades y las influencias que en sus coyunturas históricas han modelado su carácter. Dos principios generales, reiterados por la mayoría de críticos e historiadores franceses del XIX, ${ }^{403}$ apare-

401 Stapfer remite a su público también a dos obras de reciente edición: el ensayo de Malmontais, conocido en Francia pero nunca mencionado por Bouterwek, y la traducción francesa del informe viajero de Joseph F. Rehfues (L'Espagne en Mil Huit Cent Huit, ou Recherches sur l'état de l'Administration, des Sciences, des Lettres, des Arts, du Commerce et des Manufactures, de l'Instruction Publique, de la Force Militaire, de la Marine, de la population de l'Espagne et sur le caractère de ses habitans, faites dans un voyage à Madrid en l'année 1808; suivi d'un fragment historique intitulé "Les Espagnols du XIV siècle», traduit de l'allemand, París-Estrasburgo, chez Treuttel et Wurtz, 1811).

402 "Ce sont ces considérations d'histoire philosophique, ces problèmes de haute littérature, qui rendent celle d'Espagne intéressante pour ceux même qui ne veulent pas en faire l'objet d'une étude approfondie; ce sont aussi ces problèmes, qui donnent un prix tout particulier à l'ouvrage de M. Bouterwek: car c'est plus leur solution et l'histoire de cette littérature en général, de son origine, de ses progrès et des révolutions qu'elle a subies qu'il faut y chercher, que des détails biographiques et une analyse étendue de ses productions» (pp. 42-43).

403 En la estela de Mme de Staël y en consonancia con Sismondi, Stapfer invoca la acción opresiva de las instituciones sobre la literatura. No obstante, frente al suizo, no solo repara tras su lectura de Bouterwek en la instrucción, circulación de ideas, viajes y estudio de los antiguos en las diversas fases de su historia, sino que activa un cotejo favorable con los antiguos griegos: así, las buenas cualidades del carácter nacional español —como, por ejemplo, energía, perseverancia, capacidad de sufrimiento, gravedad, vocación heroica y dignidad - permiten este paralelo positivo en tanto ciudadanos partícipes en los asuntos públicos antes de su decadencia, y su valoración de la afortunada etapa gloriosa de la civilización española — propiciada por el azar "sous le règne de Charles Quint»— está en deuda con las lecciones de Montesquieu en L'Esprit des lois («Les ressorts qu'on croit exclusivement appartenir aux républiques, se combinaient avec les effets qu'on ne peut attendre que d'une vaste monarchie», p. 9). Por otra parte, este enfoque se refleja también en la decisión del editor de añadir - pese a su reconocida excentricidad respecto al tema central de la obra - la traducción de un fragmento del alemán Engel ("Le Songe de Las Casas»), 
cen, por tanto, planteados en la demorada reflexión de Stapfer a la luz del estudio de Bouterwek: el enfoque de la historia literaria desde una perspectiva filosófica que abarca el concepto de civilización - englobador de todas sus manifestaciones culturales- y la asunción del concepto de carácter nacional forjado en los orígenes, como entidad suprema y atemporal en permanente tensión con las influencias foráneas («L'histoire de la civilisation de l'Espagne n'est que le tableau d'une lutte perpétuelle de ses habitans avec les langues et avec les littérateurs de l'étranger [...]»). Stapfer observa rasgos singulares de la nacionalidad española en las etapas de esplendor de las principales culturas que se han sucedido en la Península, representadas por nombres como Trajano, Marco Aurelio y los estoicos en época romana; y Cortés y Carlos $\mathrm{V}$ en su tiempo de máximo esplendor («On ne peut se dissimuler que leurs défauts, comme leurs qualités brillantes, n'aient été, à toutes les époques subséquentes, que trop généralement les qualités et les défauts caractéristiques des auteurs de leur nation»). De este modo, la filiación de autores nacionales de diversas épocas se manifiesta tanto en la tendencia común a la hinchazón retórica y el desvío de los modelos clásicos desde los hispanorromanos, ${ }^{404}$ como en la fidelidad al buen gusto y el sentido crítico encarnados en el emparejamiento de Quintiliano, considerado por Stapfer el mejor escritor español,

publicado por primera vez en el periódico de Schiller Horen (Tubinga, n. ${ }^{\circ} 3,1795$ ). En el contexto de las polémicas emergentes de nuevo a lo largo del XIX contra la trata de negros, este texto antiesclavista y religioso recrea la visión de un moribundo padre Las Casas ante el juicio de Dios, y cuyo arrepentimiento y abnegación humanitarista, tras la visión de las consecuencias de su consejo de sustituir la mano de obra india por la importación africana, le logra al fin el perdón divino y la beatitud.

404 «presque tous les auteurs qui ont signalé l'âge du déclin de la poésie et de l'éloquence romaines, étaient d'origine espagnole» (p. 21). Stapfer cita como ejemplos a Séneca, Mela, Columela, Lucano, Floro, Marcial, Silio Itálico, Higinio, Prudencio y Juvencio, Orosio e Isidoro. Sin embargo, el frustrado cultivo del género épico en la literatura española desde los modelos latinos, comúnmente aceptado entonces por la crítica, propicia en Stapfer una revisión de los argumentos habitualmente esgrimidos para su enjuiciamiento: sin dejar de atribuirlo por ello a un gusto nacional equivocado, refuta la opinión vigente determinada por la influencia del clima, las instituciones, el ascendiente de modelos contemporáneos o una tendencia innata (pp. 26-27). Así, el prologuista exime de tal responsabilidad a los escritores hispanorromanos, formados en Roma y arrastrados por el gusto contemporáneo irrefrenable sobre el que también influyeron ("Chaque période d'activité littéraire a son maximum déterminé par la masse d'instruction et par l'étendue de la sphère des idées que le talent peut exploiter», p. 33). 
con Cervantes. ${ }^{405}$ No obstante, para el crítico la constante que ofrece indefectiblemente la historia de la literatura española es su dilema entre sus particulares Escila y Caribdis, la imitación servil de los antiguos y los excesos de la imaginación descontrolada. Como la mayor parte de estudiosos franceses posteriores al tratar de la literatura española, Stapfer asume la defensa de la imitatio no como copia indiscriminada de modelos extranjeros, sino como maduro proceso de selección y emulación. Su toma de partido por un justo medio ideal coincide con los consejos dictados por Schlegel a los autores modernos en busca de la originalidad de sus literaturas nacionales, y se manifiesta particularmente al enjuiciar a los escritores españoles del XVIII. ${ }^{406} \mathrm{La}$ influencia schlegeliana —a través asimismo de una comparación con la práctica moderna de las bellas artes italianas, rivales dignas de los clásicos ${ }^{407}$ — se manifiesta al afirmar que el cultivo literario del acervo nacional hubiera insuflado a esta literatura una mayor independencia y originalidad y ejercido una mayor influencia moral. Al evaluar ante sus lectores la literatura española, Stapfer presenta sus conclusiones de la materia expuesta por el alemán: a su juicio, el siglo XVI, centuria de plenitud canónica desde los ilustrados, es un período fallido. El triunvirato clásico de reformadores, emparejados con los italianos Dante, Petrarca y Boccaccio en la Edad Media, y Ariosto, Tasso y Maquiavelo en su mismo siglo, y acompañados en el parnaso de la lírica por Herrera, fray

405 «Il est assez singulier que Quintilien et Cervantes, les deux écrivains qui font le plus d'honneur à l'Espagne, se soient distingués par une critique si saine et si fine du mauvais goût et des travers de leur siècle, au milieu de compatriotes qui n'étaient occupés qu'à corrompre l'un et à accréditer ou à propager les autres» (nota de p. 29). La gran excepción que acepta es el padre Isla, que añade a aquellos.

406 «Si les créateurs des littératures modernes n’avaient pas trop perdu de vue ce principe, elles se rattacheraient davantage aux mœurs, aux sentimens, aux institutions de nos aïeux, à nos usages, à notre religion; et nous n'aurions pas des littératures hybrides ou décolorées, tantôt composées d'élémens hétérogènes, et péchant par la base de leur constitution, tantôt formées sur un type étranger à nos idées et à notre manière d'être, n'offrant, en un mot, qu'une littérature grecque en caractères occidentaux, un mauvais calque de la littérature des anciens, une image faible et terne d'un original brillant de force et de couleurs, une copie comparable à ces froides gravures qui sont destinées à reproduire à nos yeux les tableaux des Rubens et des Titien" (pp. 40-41).

407 «et en ne traitant, à leur exemple encore, et à celui des grands peintres de l'Italie (les seuls d'entre les modernes qui, dans leur art, se soient élevés au-dessus des anciens), que des sujets analogues à notre manière d'être, liés avec nos intérêts les plus chers et puisés dans nos annales religieuses et politiques» (pp. 49-50). 
Luis de León y Villegas — cuyas anacreónticas son insuperables para los modernos - constituyen un grupo selecto cuya guía no habría sido debidamente atendida por sus contemporáneos, decididos por orgullo nacional $^{408}$ a apartarse de los modelos perdurables. De esta manera, Stapfer señala que en lugar de autores nacionales, que hubieran potenciado sus riquezas literarias con el estudio de los clásicos, de acuerdo con la práctica de la imitatio, los epígonos se convirtieron en simples imitadores de los italianos, renunciando así a la savia nacional. Es más, incluso en sus escritores más influyentes se observan indicios de esa tendencia que explican las razones de un supuestamente fulminante declive, sin apenas cenit ni transición, a su juicio. A ese encastillamiento literario —opinión llamada a persistente fortuna entre varios críticos franceses - se sumaría el sofocamiento de las libertades ejercido por el despotismo político y su instrumento inquisitorial. Tras dictaminar categóricamente la desaparición de la literatura en España durante unos cien años, Stapfer examina el siglo XVIII español, que comienza a ser lentamente depreciado a los ojos de los franceses, a la luz de la nacionalidad literaria («ce mouvement ne put ni ressusciter l'ancienne littérature, ni en créer une nouvelle», p. 40) y sanciona la insuficiencia de los esfuerzos de autores instruidos por extender las luces y aclimatar la elegancia francesa en castellano, en lugar de recurrir a la tradición patria para lograr su régénération. De hecho, Stapfer afirma la ausencia en la España de 1812 de una poética o una retórica de calidad

408 Sin embargo, la vigencia de este topos reiterado entre los estudiosos franceses en la realidad cultural española decimonónica —antes del recrudecimiento nacionalista de mediados de siglo— - sería desmentida por Mérimée en sus tempranos artículos de Le Globe, al poner en la picota el provincianismo de los círculos españoles: «Et nous devons observer ici que Montesquieu, Voltaire et la plupart des étrangers qui ont écrit sur l'Espagne, ont donné une fausse idée des Espagnols, en disant que ce peuple est un des plus fiers et des plus vains de l'Europe: pour ce qui tient à la littérature et aux beaux-arts, cela est tout-àfait inexact. Pour l'Espagnol, l'homme qu'il voit tous les jours à la promenade n'est pas le savant, l'artiste ou l'homme de lettres: c'est seulement l'homme de sa connaissance. Sa vanité (si tant est qu'il en ait) s'exerce sur des objets qui ne sont plus, ou s'attache à ceux qui ne sont pas encore; mais elle dédaigne ceux qui passent immédiatement sous ses yeux. A cet égard, on peut regarder l'Espagne comme le paradis des morts, les limbes de ceux qui sont à naître, et le purgatoire des vivants. Une production nationale du siècle présent n'y est estimée qu'autant qu'elle fait allusion aux mœurs ou aux institutions ultramontaines [habla del período de censura fernandino]; en un mot, on ne lui accorde d'autre mérite que celui qu'elle emprunte; et pour qu'elle soit goûtée par les Espagnols, il faut qu'elle n'ait rien d'espagnol» (13-XI-1824, p. 122). 
adaptadas a la lengua y el genio nacionales. $\mathrm{Al}$ ahondar en otras razones del fracaso de esta literatura - pese a sus cualidades innatas y su capacidad de discernimiento-, Stapfer, poco al corriente de las revisiones españolas recientes, echa en falta un corpus de obras maestras variadas y modélicas - en suma, un canon ejemplar - que forme a su vez al público capacitado para juzgar y consumir producciones modélicas — que garanticen las estructuras del intercambio literario-, antes de concluir halagüeñamente, no obstante, elogiando la cultura, el genio de la lengua y un revitalizado carácter moral de España.

\subsubsection{A. W. Schlegel}

Dos años después, bajo el título de Cours de littérature dramatique $e^{409}$ ve la luz la traducción de las lecciones magistrales sobre el género dramático dictadas en Viena por August Wilhelm von Schlegel (1767-1845) en 1808, editadas en alemán entre 1809 y 1811 y revisadas entonces para su difusión en Francia. En su prefacio su traductora, Mme Necker de Saussure — avezada en la redacción de tratados pedagógicos y prima de la anfitriona de Coppet- encarece bajo el anonimato el ambicioso enfoque general del estudio y la novedad de sus principios teóricos. Del nuevo corpus doctrinal que promueven los Schlegel en su rastreo de los orígenes, destaca su admiración por la Antigüedad y la Edad Media, el ensalzamiento del cristianismo como única fuerza fecunda de inspiración poética — postura parcialmente aceptada por Chateaubriand y Mme de Staël—, así como su profesión del idealismo fichteano, que en cambio suscita mayor controversia. Como ya es de sobra conocido, Schlegel acuña un sentido diferente del uso aplicado al término clásico —independizado de su vinculación a un determinado grado de perfección vigente desde los compendios canónicos alejandrinos - e impulsa el relativismo de la noción del gusto como criterio literario, aunque el objeto del arte sigue siendo la búsqueda y consecución de la belleza. Conocido ya en Francia por la publicación de su cotejo entre la Phèdre de Racine y la de Eurípides

409 La edición consultada es la reedición íntegra de esta traducción, que tiene en cuenta el reajuste terminológico de ciertos conceptos ya asumidos desde la eclosión del Romanticismo: París, Lacroix, Verboeckhoven et Cie Éditeurs, Librairie Internationale, 1865. Nouvelle édition revue et annotée, 2 t. La introducción corre a cargo de Eugène Van Bemmel (pp. v-xiv). 
(1807), considerado como un miliar en la difusión del Romanticismo en Francia - y que había suscitado los elogios de un Mercier, por ejemplo-, la rigurosa aplicación de sus teorías al teatro francés, aunque ya atenuada en esta edición, distó de suscitar una acogedora bienvenida, como demuestran las precauciones preliminares de la traductora tal como ya hiciera su predecesor Stapfer. Si bien el timbre de gloria indiscutido de las lecciones es el vasto estudio sobre la dramaturgia griega, Schlegel aborda en calas cronológicas el análisis teórico de un canon seleccionado de las literaturas latina, italiana, francesa, inglesa, española y alemana. Inmersa en la corriente contraria al clasicismo francés que impulsara Lessing para la renovación y ampliación del horizonte literario alemán, la exaltación de Calderón, que forma junto a Sófocles y Shakespeare el triunvirato venerado por el crítico, suscita arraigadas reticencias que se mantendrán en Francia a lo largo del siglo, especialmente por la comparación ventajosamente favorable al dramaturgo español con que Schlegel lo realza sobre Molière, bastante maltrecho por la arremetida del autor alemán. ${ }^{410}$ Ante la negativa de este a reconocer un teatro nacional francés, esto es, nutrido de sus raíces populares, la traductora invoca el argumento relativista esgrimido por el autor en favor de un análisis de las producciones francesas no solo en virtud de la imitatio de los clásicos. Al hilo de estos conceptos, Mme Necker añade a la dicotomía en la que descansan las lecciones -el espíritu clásico, modelado en la Antigüedad, y el moderno, nacido de la Edad Media - un tercer componente que determina un tipo específico de cultura moral cuyo mayor exponente habría sido la sociabilidad francesa. ${ }^{411}$ Lejos de ser una influencia banal o paralizadora en su conjunto, como también denunciaba Rousseau, esta singularidad francesa en la que se con-

410 Sin embargo, la reacción más acerba provino de un prestigioso alemán afrancesado, Heine. Medio siglo después, el editor de la traducción señala que, si bien SaintMarc Girardin omitió toda mención del autor alemán en su Cours de littérature dramatique - fundado sobre presupuestos similares así como en sus reflexiones sobre la Nature de l'émotion dramatique-, el prestigioso Villemain en su Tableau du dix-huitième siècle, además de reconocer el valor pionero y trascendental de su cotejo entre ambas Phèdres y sus estilos y cosmovisiones, convirtió las críticas del alemán en un elogio de la producción francesa.

411 Sobre sus relaciones con el modelo de la «conversation française» puesto en práctica por los Modernos, de larga prosapia en los salones desde el XVII hasta sus versiones del XIX, véase, por ejemplo, M. Fumaroli, "La conversation", en Trois institutions littéraires, París, Gallimard, 1990, pp. 111-210. 
jugan el decoro y el gusto se habría manifestado asimismo en el paradigma de su tragedia, que, pese a sus defectos, estaría, como pretende la traductora, más cerca del ideal que la propia tragedia griega e incluso más próxima de la acepción schlegeliana del drama romántico. El ascendiente formativo de la conversación como propagadora de ideas contiende así con la entonces reivindicación de lo primigenio, de un estado ideal anterior a la corrupción innata de la vida en sociedad, a fin de salvaguardar la contribución civilizadora de Francia en el contexto de las nuevas teorías.

La lección decimosexta, bastante reducida en provecho de la dramaturgia inglesa en la edición de 1814, revisa con entusiasmo y parquedad el estudio del teatro nacional español ${ }^{412}$ del XVII organizado en torno a la apoteosis de Calderón. A partir de sus fuentes confesas —el apologético y restringido Theatro hespañol de García de la Huerta, la historia de Bouterwek y el estudio de Blankenburg, con los que afirma estar en desacuerdo respecto a varios de sus juicios que no precisa- y aunque condena la selección reductora vigente desde Linguet en su transmisión al resto de Europa, Schlegel hereda añejas valoraciones sobre las obras teatrales españolas como su condición de novelas en escena ${ }^{413}$ o la incidencia del clima en el genio de los pueblos, ${ }^{414}$ y se rinde al ideal heroico y galante de los dramas caballerescos («inventions ingénieuses et hardies, de la gaîté, une clarté parfaite et un mouvement facile dans l'intrigue»), difundido por las traducciones, y su inconfundible aire común risueño y dinámico. No obstante, reclama atención hacia otros subgéneros basados en un acervo de fábulas caballerescas, históricas y míticas que encarnan la nueva teoría

412 Por ejemplo, tras los estudios de Tieck, desde 1793 Schlegel se muestra atento a la dramaturgia española. Así, su Schauspiele von Pedro Calderon de la Barca, übersetzt [in Versen] (1803-1809), además de una crestomatía de poetas griegos, italianos, españoles, portugueses, ingleses y franceses traducidos al alemán a cargo también de W. Schiller, Wolf, G. Boohe, etc. (1835). Su hermano Friedrich había publicado en 1802 su Alarcos, ein Trauerspiel.

413 «On voulait retrouver ces romans sur la scène, et lorsque des poètes, parvenus au plus haut degré de culture morale, se mirent à les refondre, les animèrent par le sentiment et l'harmonie, et changèrent des fables grossièrement ourdies en fictions aériennes et brillamment colorées, il résulta, du contraste même du fond et de la forme, un charme inconnu et irrésistible» (t. II, p. 361).

414 «Il est impossible de refuser le nom de comédies de caractère à plusieurs pièces de Calderon, et cependant on ne doit pas s'attendre à trouver des peintures bien finement nuancées, chez des poètes méridionaux auxquels une sensibilité ardente et une imagination impétueuse ne laissent ni le loisir, ni le sang-froid qu'exige l'esprit d'observation» (t. II, p. 365). 
romántica. ${ }^{415}$ Como preámbulo a su análisis, presenta brevemente las circunstancias históricas que han moldeado el carácter nacional español, indisociable de su producción literaria dotada de una desbordante imaginación y una arraigada inclinación hacia lo maravilloso, heredada de las novelas de caballerías y exaltada en las piezas teatrales, y registra la periodicidad de las protestas de los críticos españoles en favor de la imitación de los antiguos clásicos y su derrota ante el gusto genuino nacional. Schlegel acota su examen entre los remotos orígenes de su poesía ${ }^{416}$ y la decadencia agravada en el XVIII por la conservación de formas ya ininteligibles y la imitación mediocre de obras extranjeras. Más virulento que Bouterwek, extrema su oposición entre partidos y expresa su enemiga ideológica contra los neoclásicos, empeñados en imponer el modelo francés y el mensaje moral y didáctico. ${ }^{417}$

El crítico alemán dispone tres grandes épocas bajo el patronazgo de tres maestros, considerados como los tramos representativos de la evolución teatral española ${ }^{418}$ desde Cervantes y Lope hasta el cenit calderoniano. De las dos piezas de la primera época cervantina más consultadas —editadas ambas por Sancha, La Vie d'Alger y su muy admirada La Destruction de Numance — ${ }^{419}$ la primera, defectuosa a su juicio en razón de su composición más temprana, estaría lastrada por un exceso de relatos, un

415 «la comédie d'intrigue, malgré la prodigieuse fertilité d'invention et tout l'esprit ingénieux qu'on y a déployé, ne compose pas la partie la plus précieuse du théâtre espagnol. C'est dans les compositions merveilleuses, empruntées à la mythologie ou aux fables chevaleresques, et dans les pièces tirées de l'histoire, que le génie national s'est développé avec le plus d'éclat et d'originalité» (t. II, p. 344).

416 Formas primitivas como la chanson y en especial el romance, de atribuido origen árabe y definido como un relato guerrero que irá dando cabida progresivamente a temas más variados tratados con arte «mais où le brillant des couleurs faisait toujours dominer la partie pittoresque» (t. II, p. 356).

417 «Des essais isolés ont été tentés pour rendre la tragédie régulière, c'est à dire pour lui donner la coupe française, et le drame déclamatoire de Diderot a même trouvé des imitateurs. J'ai lu une comédie espagnole qui tendait à recommander l'abolition de la torture» (t. II, p. 367).

418 Entre otros dramaturgos de la época se limita a citar a Guillén de Castro, Montalbán, Tirso de Molina y Matos Fragoso.

419 La Numancia es su obra más considerada. Su primer traductor francés, Esménard, la incluye en la colección de Ladvocat, vols. 24 (1823), y la define como una "comédie à tiroirs", aunque descubre escenas deslumbrantes e inspiradas. Además de la traducción de Royer, también Ochoa la insertaría en su Tesoro del teatro español (París, vol. v, ed. 1898). 
desarrollo deficiente de la acción y el escaso relieve concedido a los personajes. Es en la segunda donde Schlegel reconoce la sencilla grandeza de los antiguos en el poder del destino encarnado en el enemigo romano, y en la similitud funcional de los personajes alegóricos con los coros griegos para dirigir los sentimientos que suscita la obra. Schlegel la colma de elogios por la acción heroica que desarrolla, la expresión del terrible dolor colectivo, el patetismo espartano y su arraigado sentimiento patriótico. De igual modo, se niega a considerar tan detestables como cree el último editor, Nasarre - quien los juzgaba infundadamente sátiras del mal gusto de la época-, y con él la mayoría de críticos posteriores, sus ocho comedias y ocho entremeses que publicó en 1615 ya en desventaja ante el favor de la fórmula lopesca. Si bien representan a su parecer un esfuerzo frustrado por buscar el éxito de Lope - fundado en «la variété, la bigarrure, les plans merveilleux et les grands coups de théâtre»— a costa de renunciar a sus principios, rescata dos de esas obras, Les Esclaves chrétiens dans Alger y Le Labyrinthe de l'amour, alabadas incluso por su estructura, y que a su juicio bastan por sí solas para refutar la opinión extendida entre los críticos españoles sobre su carencia de talento dramático. Sin embargo, la aprobación crítica de un Cervantes erigido en voz condenatoria de los desvaríos del mal gusto popular a favor de la imitación de los antiguos clásicos frente al arraigo nacional del drama romántico arranca a Schlegel un reproche por su sumisión a las reglas, ${ }^{420}$ y conviene que, pese a sus dotes, las cualidades

En el XVIII López de Sedano escribió Cerco y ruina de Numancia, I. López de Castro, Numancia destruida, y, ya en el XIX, A. Sabiñón su tragedia Numancia. A. Hermenegildo (La Numancia de Cervantes, Madrid, SGEL, 1976) ha examinado los principales enjuiciamientos críticos del XVIII y XIX. Entre los principales defectos achacados, el haz de censuras abarca desde la presencia de personajes alegóricos y morales, las impropiedades históricas, o la falta al decoro con la insinuación del canibalismo, hasta la inoportunidad de la escena amorosa en medio de las atrocidades de la guerra, o la elevada altura moral de Escipión, el enemigo.

420 «Il paraît même que tout n'était pas poésie dans son âme, et qu'il s'y trouvait un côté de froideur qui le portait à rejeter, comme contraires à la vraisemblance ainsi qu'à la nature, les jeux hardis de l'imagination et le goût pour le merveilleux. Il a insisté sur la nécessité de la séparation des genres, sans vouloir sentir que l'art romantique, dans toutes ses productions, cherche à amalgamer intimement les éléments divers de la poésie, ainsi que Cervantes lui-même l'a fait dans ses romans et dans ses nouvelles, où il a été véritablement animé par l'esprit espagnol; mais il n'en blâme pas moins le changement des temps et des lieux, sur la scène, comme une faute contre les convenances» (t. II, p. 349). 
del autor español lo inclinaban hacia el género épico — la novela, aún no reconocida definitivamente como género- «en prenant ce mot dans le sens le plus étendu, pour désigner la peinture des événements au moyen du récit» (p. 348). Es, pues, en su prosa donde —a pesar de su indudable vocación dramática atestiguada en numerosos pasajes de sus obrashabría encarnado el sentimiento nacional, conforme a la representación romántica, totalizadora, híbrida, moderna e innovadora.

El lento reconocimiento europeo de las excelencias modélicas del teatro de Lope - también de nuevo el género más adecuado a sus dotes porque en él podía limar sus defectos ${ }^{421}$ — no hallará, sin embargo, en Schlegel ${ }^{422}$ la acogida relativamente comprensiva y extensa que le dispensó Bouterwek. Aunque el talento inagotable de Lope superó a Cervantes y, gracias a efectos más deslumbrantes, conquistó el favor del público — ambición en sí no reprochable_- la exaltación habitual de su pródiga naturaleza creadora se ve contrarrestada por una sucesión de reticencias que, por una parte, prueban un vago conocimiento de la obra lopesca — de la que se destacan aquellos aspectos considerados afines a la estética romántica-, y por otra, lo relegan a un segundo plano en favor de la consagración calderoniana. Para Schlegel, el dramaturgo español sobresale ante todo en las obras de tema histórico, inspiradas en romances y rudas tradiciones que evocan recias personalidades - Las almenas de Toro (Les Créneaux de Toro), presente en Bouterwek, a la que añade El rey Wamba y Les Étourderies de jeunesse de Bernard Carpio (Las mocedades de Bernardo del Carpio)_, y en las comedias de costumbres contemporáneas, de estilo más refinado como en La viuda toledana y La hermosa fea. A juicio de Schlegel, desconocedor de las refundiciones que en España reescribían y divulgaban el caudal del teatro áureo, estas composiciones presentan situaciones interesantes y de comicidad incomparable, al punto que - como ya había preconizado Linguet dentro de la estética clásica y en

421 «Certainement, c'est dans le genre dramatique que cet écrivain, qui a été tour à tour trop loué et trop déprécié, devait paraître avec le plus d'avantage, parce que le théâtre était la meilleure école où il pût se corriger de ses principaux défauts, l'incohérence, la diffusion et l'étalage de l'érudition» (t. II, p. 350).

422 "Il suffit au reste de lire quelques-unes de ses pièces pour en connaître le genre, et l'on doit craindre d'autant moins de ne pas tomber sur les plus distinguées, qu'il n'atteint, dans aucune en particulier, à une hauteur extraordinaire ni à une grande profondeur» (t. II, p. 350). 
busca de la renovación dramática francesa - aconseja rescatar esas piezas y adaptarlas a las nuevas expectativas modernas por su potencial efecto teatral ("et il y en a peut-être fort peu qui, si elles étaient retravaillées et revêtues d'un coloris plus moderne, ne produisissent un grand effet au théâtre», p. 351). No obstante, los defectos que Schlegel percibe en la escritura lopesca recuerdan los ya tópicos lunares atribuidos también por las retóricas españolas: una imaginación poderosa pero desordenada que acumula sin medida invenciones y fábulas extraordinarias, y una ejecución descuidada y superficial pero que infunde sentimiento a sus personajes y a sus vitales versos. Conforme a las habituales analogías entre las artes, lo compara con un dibujante hábil que esboza rápidos croquis, menguado elogio ( Il ne manque aux ouvrages de Lope, outre de la profondeur, que cette finesse dans les aperçus qui est le mystère de l'art», p. 351) que no le concede la excelencia universal y la condición europea en su tiempo, que otorga a Calderón.

Admirado y también respetado en gran medida en la España del XVIII, Calderón alcanza la cumbre canónica en el curso de Schlegel, quien, incitado por el hispanista alemán Tieck, cifra en él la perfección del drama español («un génie aussi fertile, un écrivain aussi laborieux que Lope, et un bien meilleur poète, un grand poète», p. 351), la encarnación del carácter nacional y la piedra de toque para contextualizar a los grandes autores contemporáneos en su siglo. Su reivindicación hallará eco en la querella calderoniana, una primera introducción del romanticismo schlegeliano por la interpretación selectiva publicada por el converso Böhl de Faber antes de las proclamaciones de Durán. ${ }^{423}$ Superior a Lope en entusiasmo, en dominio de la escena, en fecundidad y reflexión, con un estilo puro y colorista, y a sus contemporáneos y epígonos en profundidad, vigor y audacia, Calderón constituye el summum de la concepción romántica del Poeta, el hacedor dotado de genio creador. La acostumbrada clasificación temática de sus obras comprende cuatro tipos mayores: las sagradas — inspiradas en la Biblia, leyendas religiosas y hagiografías—, las históricas — dedicadas a la historia patria y ambientadas preferentemente en la Edad Media—, las

423 Véanse, por ejemplo, sobre su recepción calderoniana en la primera mitad del siglo en España, H. Sullivan, "Calderón's reception in Spain during the Romantic era 18001850», Ottawa Hispanica, 4, 1982, pp. 27-54; y también L. Romero Tobar, «Calderón y la literatura española del siglo XIX», Letras de Deusto, n. ${ }^{\circ} 11,1981$, pp. 101-124. 
mitológicas — de anécdotas fabulosas a las que, junto a los temas de regiones septentrionales, el espíritu nacional no logra aclimatarse- y las de costumbres contemporáneas. ${ }^{424} \mathrm{~A}$ partir de su consulta en la edición de Apontes, ${ }^{425}$ la concepción calderoniana de la obra totalizadora en tanto espectáculo global, como sus festejos cortesanos — «des opéras poétiques» que acogían otras artes como la música, la danza, la pintura, la escultura y las artes mecánicas-, a la que contribuye poderosamente el colorido poético de sus versos a pesar del riesgo de las reiteraciones, y su rigor intelectual en que nada se libra al azar, ganan los sufragios de Schlegel. No obstante, son sus composiciones sacras ${ }^{426}$ las que suscitan la admiración del crítico por la expresión intensa con su más rica poesía de la primigenia ligazón con el mundo, ${ }^{427}$ su inspiración bíblica y el valor renovado de la alegoría, especialmente manifiestos en las representaciones del Corpus. Ante la difícil comprensión de sus autos sacramentales y obras religiosas en el extranjero, como la relativa reticencia del erudito Bouterwek y el mayor recelo de los críticos franceses - de educación volteriana, racional y clasicista - ante el teatro religioso del Siglo de Oro, ${ }^{428}$ Schlegel prefiere orillar

424 Como señala Parker (La imaginación y el arte de Calderón. Ensayos sobre las comedias, Madrid, Cátedra, 1991, p. 184, nota 8), sus comedias de capa y espada eran más populares fuera de España entre sus contemporáneos que las tragedias y tragicomedias.

425 Schlegel, que sabe del catálogo de obras reconocidas que remitió Calderón en 1680 al duque de Veragua, echa en falta en la compilación de Apontes piezas como la comedia inspirada en el Quijote, cambios de títulos como El Tuzani de la Alpujarra, que en la recopilación aparece como Amar después de la muerte, y omisiones de sus sainetes, que no ha podido leer. Aparte de la colección de Pedro de Pando (Autos sacramentales, alegóricos y historiales del insigne poeta español don Pedro Calderón de la Barca, Madrid, Manuel Ruiz de Murga, 1717), la edición de Apontes de parte de los autos sacramentales calderonianos (Autos sacramentales, alegóricos y historiales del phénix de los poetas, 1760), en seis tomos, constituye la referencia para las ediciones de principios del XIX como la difundida de sus Obras sueltas por Juan Jorge Keil (Leipzig, 1827-30).

426 "Les pièces sacrées de Calderon peuvent, à quelques égards, être réunies à ses drames historiques, car bien que revêtues d'une plus riche poésie, elles portent toujours fidèlement l'empreinte de l'histoire de la Bible ou de la légende» (t. II, p. 354).

427 «Quel que soit le sujet de sa poésie, elle est un hymne de réjouissance sur la beauté de la création, et il célèbre, avec une joie toujours nouvelle, les merveilles de la nature et celles de l'art, comme si elles lui apparaissent tout à coup, dans leur jeunesse primitive et dans leur plus éclatante splendeur» (t. II, p. 366).

428 «Mais, à moins de faire connaître les pièces sacrées de Calderon par une traduction poétique, il est impossible d'en donner aucune idée, et je ne pourrais même en parler sans traiter une question difficile, et sans examiner jusqu'à quel point l'allégorie peut être admise dans les ouvrages dramatiques» (t. II, p. 355). 
prudentemente las obras religiosas («ces productions extraordinaires») limitándose a caracterizar a grandes rasgos el resto de su obra. Frente a los pertinaces reproches de raigambre clasicista que, no obstante, le sobrevivirán, el crítico defiende la rectitud moral ${ }^{429}$ de las comedias calderonianas en comparación con las de la Antigüedad pagana, que urden sus desenlaces por medios inmorales para satisfacer la sensualidad o el egoísmo; desvela como Bouterwek la presencia de análisis psicológicos de sus caracteres; y reivindica la vivencia vehemente, generosa y ennoblecedora del honor - «susceptibilité délicate» de la que no se margina a las mujeresy que, con el amor y los celos, constituyen los resortes principales de estas piezas. Las variaciones del desenlace encauzan un final cómico en el que el conflicto de las fuerzas morales en juego no conlleva graves consecuencias, o un final trágico en el que el honor desempeña el papel de destino hostil — argumento retomado hasta Menéndez Pelayo — que acorrala a aquellos que no pueden obedecer sus leyes sin aniquilar su felicidad y convertirse en culpables.

Sus ataques contra los neoclásicos españoles, ${ }^{430}$ tachados de sumisos a los modelos del canon dominante francés en detrimento de sus glorias nacionales, germinarán en décadas posteriores con la lenta desvalorización de las obras del XVIII en reseñas y manuales en nombre de la búsqueda de la originalidad y la diferencia. El crítico no solo aprueba la resistencia del clero o el celo vigilante del pueblo por el mantenimiento de las antiguas costumbres, sino que llega incluso a aplaudir las ventajas de la situación casi insular de España, que la habría aislado de Europa y le habría permitido dormitar en el siglo XVIII («que pouvaient-ils faire de mieux?»). El

429 El idealismo de esta interpretación esencialista del carácter nacional uniformemente percibida en el XIX se asienta sobre la fórmula dramática triunfante, bien diferente de la que difunden los entremeses y las primeras piezas, de naturaleza más escabrosa y burlesca, del período de tanteo de Lope, tal como estudió I. Arellano en Convención y recepción. Estudios sobre el teatro del Siglo de Oro, Madrid, Gredos, 1999.

430 «Les mêmes Espagnols qui sont infidèles à l'ancien goût national, font grand bruit des drames prosaïques et moralistes de Moratin; mais il n'y a pas de raison pour nous d'aller chercher en Espagne, ce que nous avons d'aussi bon ou d'aussi mauvais chez nous. La grande masse des spectateurs paraît cependant s'être préservée de cette influence étrangère; il y a quelques années, un bel esprit de Madrid ayant entrepris de soumettre à la règle des trois unités une pièce de Moreto, à juste titre fort admirée (el Parecido en la corte) le parterre fit un tel tapage, qu'on ne put l'apaiser autrement qu'en annonçant l'ancienne pièce pour le lendemain» (t. II, p. 368). 
conservador Schlegel no comparte, por tanto, las expectativas de los autores españoles que percibían con esperanza esas décadas finales por la recuperación de las letras. En virtud de su fidelidad a la tradición nacional, las dramaturgias española e inglesa, relegadas a los márgenes por el centralismo universalista de La Harpe, regresan con honores al centro del canon europeo en la interpretación de Schlegel. De este modo, la promesa de regeneración de las letras españolas a partir de sus propias fuentes - preconizada por los sabios y eruditos del XVIII a partir de los grandes modelos clasicistas del XVI y, en su etapa de apertura, con su promoción de los modernos - erige ahora declaradamente también a Calderón, revitalizado por el alemán, ${ }^{431}$ en genio tutelar y mentor de la nacionalidad española. Asimismo, el consejo que Schlegel dirigía a sus compatriotas ${ }^{432}$ de adaptación y apropiación selectiva de la materia extranjera conforme al genio nacional, frente a su sesgada e incompleta interpretación de la literatura española del XVIII, se prodigará, tras su paulatina aceptación, como en el prólogo de Stapfer, en las páginas de numerosos manuales e historias a partir de mediados de siglo y en reseñas francesas y españolas. ${ }^{433}$

\subsubsection{Simonde de Sismondi}

$\mathrm{Al}$ año siguiente de la traducción francesa de Bouterwek y coincidiendo con la edición inglesa de De l'Allemagne de su anfitriona Mme de

431 «Si la poésie romantique venait à se réveiller dans la vieille Europe ou dans le nouvel hémisphère, il se trouverait indubitablement qu'elle aurait passé d'un heureux instinct à la connaissance réfléchie de ses propres ressources. Les Espagnols reviendraient avec une estime raisonnée à ce qu'ils avaient aimé par inclination naturelle, et, sans s'inquiéter d'une critique pointilleuse, ils suivraient, d'après des principes assurés, les traces glorieuses du plus grand de leurs poètes» (t. II, pp. 368-369).

432 «La question qui doit nous occuper n'est pas de reproduire passivement chez nous le théâtre grec, espagnol ou anglais; mais, selon mon opinion, de trouver une forme dramatique qui admette, à l'exclusion des règles fondées uniquement sur des conventions arbitraires, tout ce qu'il y a de vraiment poétique dans les formes adoptées chez d'autres peuples: quant au fond, nous devons faire dominer et ressortir le caractère propre à la nation allemande» (t. I, p. 61).

433 Por ejemplo, Flitter (ob. cit.) sobre la asimilación de las teorías schlegelianas en la crítica española, o, sobre su impregnación en revistas culturales francesas de la envergadura de la cosmopolita Revue des Deux Mondes, M. ${ }^{a}$ R. Álvarez Rubio (La literatura española en la prensa cultural francesa..., tesis doctoral presentada en la Universidad de Oviedo en 2004). 
Coppet, Jean-Charles-Léonard Simonde de Sismondi (1773-1842) ${ }^{434}$ publica bajo el título De la littérature du Midi de l'Europe $e^{435}$ las trece lecciones que dedicó a la literatura española en su curso público de Ginebra durante el invierno de 1811 a 1812. Esta aislada incursión de su autor — publicista, agrónomo y ya reconocido historiador medievalista- en el estudio de las literaturas se convertiría en una referencia de recurrente consulta a lo largo del siglo junto a sus influyentes escritos de economía política y ciencias sociales. Su exposición divulgativa — comentada tempranamente por los exiliados españoles antes de su reseña en publicaciones de Barcelona y Cádiz ${ }^{436}$ y de la traducción española ${ }^{437}$ editada treinta años después - se presenta como una "histoire abrégée de toutes les littératures du Midi» (t. I, p. 348), más afín a las conferencias en boga, ${ }^{438}$ rehuyendo en su título la denominación declarada de la exhaustiva historia de Bouterwek. Dirigido a un auditorio mundano con el que el autor comparte su formación en la estética clásica del XVIII — que proclama la primacía de lo bello, la verdad, la imitación de la naturaleza y el buen gusto junto a una reivindicada sensibilidad-, su curso se apropia las pautas del género y,

434 Véanse de su bibliografía, por ejemplo, Alfred Berchtold, «Sismondi (1773-1842). Genevois et Européen", en Cinq portraits, Lausana, L'Âge d'Homme, 1997, pp. 107-130; sobre todo J.-R. De Salis, Sismondi (1773-1842). La vie et l'ceuvre d'un cosmopolite philosophe, París, 1932, reed. Ginebra, Slatkine, 1973; y de igual modo, Carlo Pellegrini, Il Sismondi e la storia delle letterature dell'Europa meridionale, Ginebra, 1926, así como las actas del coloquio internacional Sismondi européen ( Ginebra-París, Slatkine-Honoré Champion, 1976), que mencionan asimismo otro estudio en ruso de Boris Reizov (Entre el clasicismo y el Romanticismo, Leningrado, 1962).

435 París, chez Treuttel et Würtz; Estrasburgo, même maison de Commerce, 1813. Imprimerie de Chapelet. El estudio ocupaba parcialmente el vol. III e íntegramente el IV. Las ediciones posteriores (una segunda, aumentada en 1820 y una tercera en 1829) incluyeron diversas modificaciones que atañían sobre todo a la revisión de las traducciones del español.

436 Véase Salis, ob. cit., p. 202. Se trata del Diario Mercantil gaditano (números de los días 10, 17 y 24 de mayo de 1818) y de El Europeo de Barcelona ("El Romanticismo», aparecido entre 1823 y 1824).

437 Historia de la literatura española desde mediados del siglo XII hasta nuestros días, dividida en lecciones, traducida inicialmente por D. José Lorenzo Figueroa y completada por J. Amador de los Ríos, Sevilla, Imprenta de Álvarez; Madrid, 1841-42, 2 vols. en 4. ${ }^{\circ}$

438 Salis ya había destacado el parentesco de este estudio con otros cursos prestigiosos como el Lycée de La Harpe, las conferencias de Ginguené en el Ateneo de París, o los recientes de Schlegel en Viena, y así afirmaba: «Cet ouvrage tient à la fois du manuel, de l'anthologie, de la vulgarisation scientifique, du traité d'esthétique, de l'essai philosophique» (ob. cit., p. 193). 
acotando su examen a la literatura de ficción, propone una revisión comentada apelando a la emoción que despiertan en él las obras analizadas. ${ }^{439}$ Asimismo, como Malmontais, incorpora a su explicación didáctica detalladas noticias biográficas, añade y comenta nuevos pasajes — procedimiento que Bouterwek había reservado para su defensa del drama barroco- y adopta el método comparativo atendiendo con una mayor flexibilidad a otros sistemas cuyos valores estéticos han de someterse, sin embargo, a reglas atemporales.

Liberal cosmopolita, Sismondi profesa la fe de principios del XIX en el progreso del género humano y, como sus precursores, imbrica decididamente su estudio en la revisión filosófica de esta materia literaria, que marca con una fuerte impronta moralista al vincular lo justo con lo bello y la virtud con la imaginación durante las diversas etapas que atraviesa la historia española. El fenómeno literario («une conséquence naturelle de l'histoire politique, des institutions sociales, de la religion») aparece condicionado, a su juicio, por el grado de libertad y de felicidad social alcanzado y su contribución al avance del espíritu humano. Dando un paso más que sus antecesores, enfoca así su discurso a través de la lectura de los hechos socio-políticos, ${ }^{440}$ religiosos e incluso económicos, interrelacionados e insertos en la narración, acentuando el peso de los aspectos sociológicos —en especial la naturaleza del gobierno que rige esos pueblos y moldea su carácter más que el clima-, a los que vincula el criterio de

439 Como reclamaron S. Ballayé («Un historien devant la littérature», en Sismondi européen..., p. 273: «Le dessein principal du livre est de faire partager aux lecteurs le plaisir (ou l'ennui) que l'auteur lui-même a éprouvé») y R. Villeneuve ("De la littérature du Midi de l'Europe: le lecteur Sismondi», en Sismondi européen..., pp. 275-286), la aportación de Sismondi podría enfocarse no tanto por su ambigüedad respecto a las teorías románticas, sino por la asunción de un papel crítico como lector en nombre de la subjetividad, que respeta, no obstante, las premisas universales.

440 Sismondi enjuicia el gobierno de los monarcas españoles — desde Carlos V, cuyas pretensiones a la monarquía universal se saldaron con funestas consecuencias, o un sombrío Felipe II, desprovisto del genio de su padre pero más español que este, hasta la dinastía borbónica, cuyo fundador en España, de melancolía acorde con la gravedad castellana más que con la energía necesaria para la regeneración nacional, no goza, frente a algunos de sus sucesores, de su aprecio por su escaso talento, gusto y conocimientos-. Este dictamen sociopolítico, prácticamente ausente en Bouterwek, es retomado por sus continuadores franceses como, por ejemplo, Puibusque (1843) o Hubbard en su examen contemporáneo (1876). 
buen gusto como seña de los pueblos civilizados. Más cercano a ciertos postulados del prólogo de Stapfer que a las formulaciones más comedidas de Bouterwek, Sismondi incide con más ahínco en la fractura que provocan el despotismo político y el fanatismo religioso institucionalizado: no solo idealiza retrospectivamente una Edad Media de tolerancia musulmana heredando la idea española de la influencia de su magnificente civilización sobre los trovadores — rebatida por Schlegel—, y vindica la caballería literaria - no el feudalismo- como beneficioso motor de progreso, sino que atribuye a sus estertores la brillantez distintiva bajo los primeros Habsburgo, cuyo régimen político condujo a su aislamiento de Europa.

Tributaria de los trabajos de los eruditos españoles del siglo XVIII, especialmente del padre Andrés, y de los estudiosos alemanes, en particular Bouterwek, y más familiarizada con la lengua italiana que con la española, su exposición recurre a ediciones y estudios mediadores, ${ }^{441}$ principalmente antes de llegar a la época de esplendor. Como Bouterwek, abandona la perspectiva comparatista global lograda por Juan Andrés, y se acoge a la influencia que cada cultura, abordada por separado, ha ejercido sobre las otras y, dentro de cada una, a la excelencia de representantes ("dont la gloire appartient à toutes les nations, et dont le génie perce à travers toutes les langues», p. 326) como Cervantes, en cuya universalidad conviene, o Lope y Calderón, que no suscitarán pese a esta declaración igual favor. En nombre de la razón, el sentimiento y las premisas estéticas universales como el sentido de la belleza y la verdad supremas y la imitación de la naturaleza, Sismondi admite también el relativismo de otras reglas particulares intentando enjuiciar las obras de otros sistemas de acuerdo con las estéticas en que fueron concebidas, manteniendo, con todo, su lealtad hacia el legado francés: si entre sus aceptaciones de las teorías alemanas acata en especial la singularidad de la nacionalidad literaria española como encarnación del concepto de romanticismo schlegelia-

441 Entre sus fuentes reconocidas — eruditos españoles desde N. Antonio, el Velázquez anotado por Dieze, el padre Andrés junto con Bouterwek (véase Salis, ob. cit., pp. 173-203) y Schlegel, también familiar de Coppet y de quien consultó sus lecciones y Vorlesungen antes de su traducción en Francia - recurre asimismo al conocido libro de viajes de Laborde (Voyage pittoresque de l'Espagne, 1806, e Itinéraire descriptif de l'Espagne, 1808). 
no, ${ }^{442}$ esta exclusividad recursiva — frente a la francesa moderna, clásica por su imitación de los antiguos - tampoco la alza, a su juicio, a la cima literaria. Habiendo tratado de la brillante literatura árabe en otro tomo, su examen de la literatura española está en deuda con sus predecesores, no solo en enjuiciamientos y periodización con sus correspondientes cortes seculares en la evolución literaria y sus polémicas asimilaciones de las influencias extranjeras: así, los orígenes medievales hasta la corte de Juan II y los Reyes Católicos; ${ }^{443}$ el amplio período siguiente, ${ }^{444}$ en el que el siglo

442 Sismondi invoca la utilidad de esta teoría, cifrada en el fondo tradicional, el culto al amor, la caballería y la religión como fuentes de inspiración y nacionalidad, para observar la autarquía de la literatura española: "Cependant ce fonds d'images et d'aventures que les Espagnols ont tant travaillé, est celui même auquel on a donné, de nos jours, le nom de romantique. Ce sont les sentimens, les opinions, les vertus et les préjugés du moyen âge; c'est cette nature du bon vieux temps à laquelle toutes nos habitudes nous rattachent; et puisque l'antiquité chevaleresque a été mise en opposition avec l'antiquité héroïque, il est intéressant, même comme expérience littéraire, de voir le parti qu'une nation spirituelle et sensible a pu en tirer, lorsqu'elle s'est enfermée dans cette seule enceinte, qu'elle a repoussé toute idée nouvelle, toute importation étrangère, et les résultats de toute expérience faite d'après d'autres principes» (t. IV, p. 256).

443 Aunque se mantiene la aureola del mecenas Alfonso X, Sismondi no demuestra la sensibilidad de Sánchez ante Berceo, del que escoge episodios de su Vida de Santo Domingo como la aventura del cautivo liberado por la sombra del santo, o el erróneamente atribuido poema sobre La batalla de Simancas que ya había sido descartado por el colector español. De pareja mediocridad le parece el Libro de Alexandre, ejemplificado en los consejos de Aristóteles al joven Alejandro cuando este es armado caballero. Aún más desinterés que su referente le inspira la sátira de Juan Ruiz cuya insignificancia no merece a sus ojos ni un extracto. En contrapartida, elogia la precisión estilística de las poesías de Ayala o de Juan Manuel, y, en términos semejantes a Bouterwek, destaca su Conde Lucanor, muestra de la gravedad española, que en un cotejo de posterior fortuna compara con el Decamerón, y del que traduce el exemplo XLI. También se refiere al mecenazgo de Villena, El Centiloquio de Santillana y sus obras de moral y política si bien elogia la frescura de sus romances, como la exquisita sensibilidad de la Vaquera de la Finojosa; en cambio, relega a un Mena, ahogado por la erudición, a un mérito secundario; en su intransigencia hacia los cancioneros destaca, no obstante, la pasión devoradora de los versos de Alonso de Cartagena, junto a otros poetas como Rodríguez del Padrón o Sánchez de Badajoz; y tampoco olvida el Amadis atribuido a Vasco Lobeira y La Celestina, cuyo primer acto recibe el aprecio general.

444 Sismondi respeta el censo habitual de autores del XVI, consultados algunos de ellos en las ediciones examinadas por Bouterwek: así, Boscán, Garcilaso, maestro de la égloga por su gran pureza de estilo, imágenes impregnadas de melancolía y cadencia melodiosa; Mendoza, Herrera — admirado por su nuevo lenguaje sin el fervor estalista, cuya Oda al sueño también traduce y lo consagra como «le plus vraiment lyrique de l'Espagne»—, el más correcto Ponce de Léon —error común al referirse a fray Luis de León-, Miranda, 
XVI encarna el apogeo de "la littérature classique espagnole», y en el que, bajo el marbete predominante de «siècle des trois Philippe», coexisten más tarde el buen gusto y la corrupción gongorina hasta el decaimiento progresivo en todos los ámbitos político-económicos y culturales, vigente aún a principios del XVIII; y en esta última centuria - cuyo censo heredado de autores se respeta— ${ }^{445}$ la oposición entre los galicistas del partido cortesano y los defensores del sistema antiguo - encarnado principalmente en el teatro de Lope y Calderón-, el rechazo de los dramas sacros y autos

Montemayor o Ercilla. Del repertorio conocido del siglo siguiente el crítico incluye pasajes, por ejemplo, de los Argensola, Villegas o la honrosa mención de Quevedo, junto a un Góngora cuyos esfuerzos por dilatar los límites de la lengua y la poesía se extendieron no solo a sus poemas mayores, sino también al resto de su producción y arrastraron a numerosos seguidores (gongoristes) apoyados en la retórica del predicador Paravicino y en la cortesana del conde de Villamediana.

445 El siglo XVIII también decae relativamente a sus ojos pese a los patrióticos esfuerzos de un meritorio Luzán — confirmado como reformador del gusto pero de más sutileza que energía e imaginación creadora-, Sedano, Montiano — cuyas tragedias tacha de frías-, García de la Huerta, Iriarte y Meléndez, movidos por el afán de resucitar el glorioso ejemplo nacional. En el repertorio dominante de los principales autores del XVIII, tras constatar el cambio de mimesis de la interpretación alemana sin más implicación personal, Sismondi ensalza la Poética de Luzán — por su erudición, claridad, fineza y elegancia de estilo-y justifica su toma de partido por el afrancesamiento del gusto nacional, en la convicción de que según la opinión predominante no había más crítica que la expuesta por los escoliastas de Góngora ("C'était pour les attaquer qu'il étudia avec soin les principes d'Aristote et ceux des littérateurs français» [no menciona a los italianos], p. 224). El crítico repite comentarios de Bouterwek en el enjuiciamiento de la Raquel de García de la Huerta, tampoco considerada su obra maestra pese a sus esfuerzos de sencillez y de conjugar el modelo antiguo español con las reglas clásicas; y en el aprecio de Iriarte — tratado con más detalle- por sus Fábulas literarias (1782), próximas a los antiguos romances, de las que traduce en prosa L'Âne et la flûte con su refrán de canción popular y L'Ours et le Singe, mientras que su opinión sobre su poema didáctico sobre la música, pese al buen gusto del autor, tampoco es positiva («n'est trop souvent dans la partie scientifique que de la prose rimée»); también cita al alemán cuando celebra a Meléndez Valdés "comme le poète des Grâces, un poète digne des meilleurs temps de la littérature espagnole», admirador de Villegas y cuya maestría no ha llegado a alcanzar, aunque se diferencia de su maestro en la mayor delicadeza y moralidad de sus poesías anacreónticas, en algunos de cuyos idilios muestra el cruce entre el talento pintoresco meridional y la influencia inglesa y alemana. Entre los poetas cómicos que introducen el gusto francés con sus costumbres elegantes y la tierna sensibilidad entonces en boga, y cuyas obras no eran muy difundidas en Europa ("comme ils paraissent avoir peu de prétention à l'originalité, ils excitent une curiosité moins vive»), menciona a Nicolás Fernández de Moratín, autor de tragedias regulares pero tenido siempre por autor secundario, a su hijo Leandro, mejor considerado, y a Comella, juzgado un tiempo el más próximo de todos ellos al antiguo teatro nacional antes de quedar olvidado en los manuales. 
sacramentales de su primera mitad, y en la segunda - frente a Schlegel y tras Bouterwek- el triunfo del patriotismo literario conjugado con el espíritu moderno que reúne la elegancia clásica con el genio español - representado por los poetas del XVI y del XVII—, y fructifica en Meléndez y Moratín. Ese débito se manifiesta también en otros aspectos estructurales y valorativos como, por ejemplo, su organización de la materia dentro de las redes de los tres grandes géneros sancionados por la preceptiva clásica junto a los nuevos ingresos; la posición central de Cervantes, autoridad crítica y documental reconocida que encabeza la lista de autores clásicos bajo los tres Felipes, y cuya obra, desglosada en dos capítulos para el teatro y la novelística — con su Quijote como divertida sátira impregnada de melancolía («car le ridicule porte ici sur l'enthousiasme et la vertu»), definida a su vez como retrato nacional ${ }^{446}$ y que encarnaría en sus protagonistas el contraste entre el «esprit poétique et celui de la prose»—, Sismondi somete parcialmente a la jerarquización de Bouterwek más que a varios de sus juicios; ${ }^{447}$ o la inserción en el discurso del examen del teatro y sus clasificaciones temáticas, en torno principalmente a un detallado Lope y tras él a Calderón.

Con todo, la influencia de sus referentes se revela en especial en la comedida asunción de la nacionalidad literaria española a través de los mismos hitos que en Bouterwek sin apartarse de gran parte de sus valoraciones — salvo para desarrollar sus argumentos atendiendo a los aspectos pintorescos o reforzando de manera más determinante la lectura ideológi-

446 «La Manche et les déserts de la Sierra Morena nous sont connus par lui, l'Espagne nous a été dévoilée; ses mœurs, ses coutumes, l'esprit de ses habitans se peignent dans ce miroir fidèle, et nous connaissons mieux cette nation originale par Don Quichotte que par les récits et les observations du voyageur le plus scrupuleux» (t. III, pp. 362-363). Sismondi también elogia el talento cervantino de excitar el interés del lector en las novelas cortas intercaladas, ensalza la belleza de su estilo e incluye algunos trozos de crítica literaria insertos en el Quijote.

447 Si bien reitera los defectos del Persiles y justifica la languidez de La Galatea por su tono adecuado al género y su calidad propia («cependant, et la pureté des mœurs et l'intérêt des situations, et la richesse d'invention et le charme des poésies qui y sont entremêlées, placeront toujours la Galatée parmi les ouvrages classiques de l'Espagne»), varía los ejemplos de sus novelas ejemplares en virtud de su pintoresquismo costumbrista como $L a$ Gitanilla, L'Amant libéral, L'Espagnole Anglaise, o Rinconete y Cortadillo —incluida entre las obras picarescas y en la que aprecia su comicidad más que su crítica ético-social—, y, en cambio, no concede en absoluto a su poesía lírica el aprecio que le dispensara el alemán. 
ca- Así pues, ayudado de textos intermediarios ${ }^{448}$ con que aumenta los ejemplos del repertorio de referencia, ${ }^{449}$ consagra el romancero como el género nacional — también desde una perspectiva racionalista como acervo crédulo y sin pulimiento de canciones populares, y como educador de sus oyentes en tanto transmisor de sus grandes gestas, según señalará asimismo Martínez de la Rosa- A partir de la Dissertation sur le Cid de J. de Müller, ${ }^{450}$ se extiende en la glosa del argumento del cantar de gesta, asimismo investido de simbolismo patrio. Documento histórico de los remotos tiempos bárbaros de influencia árabe, al que niega valor literario como crónica apenas versificada en rimas pedestres, su verdadero mérito estribaría en la sugerente pintura de costumbres de los albores de la etapa caballeresca - como en la descripción dramática de las cortes («la partie la plus piquante de ce poëme», t. III, p. 136) — y en la que, a ojos de un condescendiente Sismondi, su ingenuidad suple el talento. Más categórico que Bouterwek, también dictamina tras la sencillez de los primeros tiempos el estancamiento de la literatura española a partir del siglo XIV, sobre cuya monotonía, afectación y rudeza descuella aisladamente el Rimado de Palacio del canciller Ayala. Esa atonía propicia futuros juicios bastante negativos acerca de esa etapa del otoño medieval: los excesos retóricos de la lírica trovadoresca y cancioneril del XV sellan la decadencia de la literatura castellana («la nation entière se croit appelée à chanter d'idéales amours; le ridicule devient sublime; c'est un effroyable chaos»). Sin embargo, Sismondi se distancia asimismo de sus predecesores en ciertas valoraciones del período de cenit llamadas a gran fortuna en Francia: mediatizado por

448 Así, la traducción de Herder (Der Cid, 1803 y 1810, y que Sismondi confundió con versiones de los originales) a partir de Creuzé de Lesser, a su vez basado en la versión de Couchu en la BUR (1782-84), junto a la edición de Meige Tesoro escondido de todos los famosos Romances, assi antiguos como modernos del Cid (Barcelona, 1626), y otras colecciones originales de 1614 y 1626 . El crítico glosa pasajes desde la juventud del héroe, la venganza de Diego Laínez, el desafío del conde Gormaz o las demandas de Jimena, hasta su encumbramiento, muerte y victoria póstuma.

449 Además del repertorio cidiano, Sismondi alude a romances como el de Fontefrida, presente en Bouterwek junto a moriscos como los de zegríes y abencerrajes, y añade, por ejemplo, el ciclo de Bernardo del Carpio, el rey Rodrigo - luego traducido por A. Hugo-, los hijos de Arias Gonzalo, o el conde Alarcos, difundido por Friedrich Schlegel.

450 La biografía de Müller de 1805 se fundaba en el trabajo incluido en una edición de los romances de Herder que el benedictino padre Risco (La Castilla y el más famoso castellano, 1792) había escrito a partir de la Historia Roderici y del cantar de gesta del héroe. 
su enfoque ideológico, sanciona contundentemente un desajuste entre la asimilación española de su condición de potencia militar y política de conquista constrictora de las libertades, y la creación artística que, evadiéndose en el mundo bucólico del XVI, ${ }^{451}$ incumple, como señalaba también Quintana, ${ }^{452}$ su compromiso con la sociedad de su tiempo. A pesar del acopio de materiales pacientemente expuestos por los ilustrados españoles — herederos de la erudición precedente-, recogidos por Malmontais y Bouterwek, para mostrar la riqueza de este patrimonio nacional, Sismondi resta peso al humanismo renacentista reforzando con su versión de la alianza entre armas y letras —en la pluma presurosa de soldados antes que de instruidos hombres de letras, que toman préstamos de la clásica Italia sin pleno conocimiento y los adaptan mal a su naturaleza- una corriente adversa ${ }^{453}$ a la aportación española de este período. Por otra parte, mientras ratifica con más detalle otros autores del XVIII recogidos en Bouterwek, añade como Malmontais algunos más de la segunda mitad de esa centuria como el elogiado padre Isla, sucesor de Cervantes, comentando diversos pasajes de su recurrente novela original —a su entender, la obra más espiritual del XVIII — cuya comicidad juzga digna de Rabelais; o los sainetes de Ramón de la $\mathrm{Cruz}^{454}$ que ponen en escena las costumbres populares madrileñas.

No obstante, donde plantea mayores discrepancias es en su análisis del teatro barroco, llamado romántico como encarnación de la poética

451 «Peut-être la poésie efféminée des classiques espagnols leur était-elle également suggérée par la dignité même de leur caractère; mais c'est aussi pour cette raison que la poésie castillane ne pouvait être, sous le règne de Charles-Quint, qu'une fleur passagère, et qu'au milieu de tout son éclat, on démêlait déjà les symptômes de sa prochaine destruction» (pp. 322-323).

452 En el prólogo al tomo XVI (p. XI, 1796) de la colección de Ramón Fernández ya considera imitativo este siglo.

453 "L'Espagne ne prit point une part active à ce zèle d'érudition et de poésie antique, qui donna tant de vie au seizième siècle; aucun des poètes qui se sont distingués chez elle n'a la réputation d'être un érudit, ou un grand poète latin ou grec; en revanche, presque tous sont des soldats, dont l'âme active et élevée cherchait un autre essor encore que celui des actions» (pp. 498-499).

454 Publicados en la recopilación Teatro o colección de los sainetes y demás obras de don Ramón de la Cruz y Cano (Madrid, 1786-91), junto a sus comedias — como Le Bal (El sarao) y Le Bal vu par derrière (El reverso del sarao) o El divorzio feliz-, dramas y entremeses, reflejos de la nueva realidad social, loas y prólogos tales como Los vaqueros de Aranjuez — que precedió a la traducción de El barbero de Sevilla - y romances. 
desarrollada por los alemanes y de la que desconfía por su excesiva libertad. ${ }^{455}$ En un excurso comparativo entre las derivaciones de las normas clasicistas sobre el sistema francés ${ }^{456}$ y las nuevas unidades (de "manière, intérêt et mœurs») que, junto a la irrenunciable de acción, rigen el romántico, Sismondi expone ante el lector ambas concepciones afirmando la atemporalidad de conceptos comúnmente aceptados entonces — como la imitación de la naturaleza, la verosimilitud, la función educadora del teatro, el estudio genérico del ser humano y el cultivo de la introspección psicológica, o la poetización de la realidad-. Y, a la vez que proclama el

455 Seis años después en una argumentada reseña («Dissertation sur le genre de la poésie dramatique espagnole», Journal des Débats, 1819, pp. 434-441) acerca de una disertación en latín de H. L. Heiberg (Copenhague, 1817) sobre la obra calderoniana — sobre todo La devoción de la Cruz, drama religioso; La vida es sueño, drama metafísico; Para vencer amor, querer vencerle, drama psicológico; y Amor, honor y poder, drama moral, según las divisiones del reseñado-, Raynouard expresa sus reparos a la carencia de una doctrina romántica fundamentada en conceptos más precisos. Si bien acepta que la influencia del cristianismo y las costumbres caballerescas introdujeron modificaciones esenciales en las literaturas modernas, y juzga evidentes los hallazgos de piezas teatrales que no han observado las reglas, incluso en las tragedias de los clásicos griegos, el crítico echa en falta en su reseñado una diferenciación más nítida entre la definición del carácter de la literatura romántica — basado en sentimientos, opiniones y costumbres del fondo nacional- y las formas que lo desarrollan ("Que ce caractère particulier soit nommé romantique, ou qu'on lui donne toute autre dénomination, si le genre auquel il appartient plus spécialement differe du genre classique en quelques points, du moins l'un n'exclut pas l'autre, et ils ne sont pas incompatibles», p. 435). A su entender, si se eliminaran las reglas ligadas al género clásico numerosas obras de pueblos que apenas han cultivado la literatura serían del género romántico, e incluso la mayoría de las tragedias francesas de tema religioso o caballeresco pertenecerían, según esto, al género romántico por el fondo y al clásico por la forma, mientras que sucedería a la inversa con otras obras extranjeras. Aunque valora el análisis literario de Heiberg, le reprocha la confusión de su armazón teórica: por ejemplo, su apelación al simbolismo cuando aborda el romance en Calderón sin señalar al respecto sus aportaciones y perfeccionamientos ( Heiberg conclut que le drame de Calderon est le drame espagnol national; ce qui permettroit de le considérer comme romantique, parce que la romance constitue la poésie nationale espagnole: mais il ajoute que ce poète offre un caractère romantique plus spécial, en ce que ses drames sont symboliques», p. 439).

456 A imagen del paralelismo schlegeliano entre las Fedras de Eurípides y Racine, Sismondi compara el tratamiento del Edipo según ambas concepciones. En su examen no omite algunas de las limitaciones que originó el férreo dominio de las unidades — no solo la exclusión de temas históricos, sino defectos como la ruptura de la unidad, que, en la recreación de Voltaire, por no escenificar el desenlace cruento introdujo en su lugar una fábula extraña a la acción en los primeros actos debilitando además la concentración del análisis psicológico-, y procura mostrar de igual modo cierta ecuanimidad ante las inverosimilitudes de ambos sistemas, como, por ejemplo, la provocada por la versificación teatral en detrimento de la imitación de la naturaleza. 
magisterio de Corneille, Racine y Voltaire - linaje heredero de la tradición antigua transmitida por la translatio culturae frente a las desviaciones españolas-, en virtud de su consolidación de las normas clásicas precisamente por su liberación de las constricciones de antecesores mediocres como Jodelle y Garnier, también desacredita como juez autorizado al vocinglero populacho español —ajeno a la mejor y más sana parte de la corte, según rezaban las disposiciones de la Academia, y menos instruido que los antiguos griegos-, en evidente contraste con la temperancia de Bouterwek o el entusiasmo de Schlegel ante el patio popular. Desde tres perspectivas - como historiador, moralista y lector individual, inmune al misticismo de Schlegel y respetuoso de la tradición clásica- Sismondi acomete, pues, la dramaturgia española, representada por la tríada consagrada en Europa por los alemanes. Si bien concede el parangón entre Cervantes y Esquilo —-más basto y grandioso, de sentimientos más violentos y primitivos, que los modelos más depurados de la Antigüedad, inspiradores del francés clásico - por la imponencia del tema patriótico, la profundidad emocional, la presencia de personajes alegóricos y la asunción de la unidad de acción y de interés, el crítico también marca la divergencia cervantina en la preeminencia de la parte lírica y la poca importancia otorgada a las unidades de tiempo y lugar, sacrificadas en aras de la emoción como en sus dos piezas teatrales de rigor («suite de tableaux enchaînés par un intérêt historique»), La Numancia y Los tratos de Argel (La Vie d'Alger). Aunque esta es de las dos la peor valorada pese a su evocación pintoresca de la vida en Argel, y en la que adivina una intención política de cruzada para liberar a los cautivos, ${ }^{457}$ la primera también incurre en contradicciones, achacables, como señalara Schlegel, a su falta de oficio teatral. Aun respetando la unidad de acción, la crueldad y violencia del asunto escenificado — como la terrible agonía de la madre amamantando a su hijo—, ${ }^{458}$

457 Sismondi también se refiere a la multiplicidad de acciones y al patetismo de situaciones como las represalias sobre el hermano del inquisidor Miguel de Aranda, la desgarradora despedida de madre e hijo tras su subasta en el mercado de esclavos, la apostasía posterior del muchacho, el milagro de la fuga de Pedro Álvarez, o el desenlace de los trinitarios.

458 Otros pasajes como la incursión de Morandro y su amigo en el campamento romano para robar un pedazo de pan para Lira, la admiración que esta desesperada hazaña provoca en los romanos, o el suicidio del último numantino despeñado de las murallas a los pies de Escipión, llaman también la atención del crítico, que no deja de subrayar el patriotismo de la obra como epopeya dramática e imagina la profunda impresión que hubo de provocar su reciente representación en las ciudades españolas sitiadas. 
tal vez subyugantes pero no catárticos, están, con todo, lejos de suscitar verdadero placer estético.

Frente a los clásicos del XVI y tras esta revisión cervantina, el teatro de Lope, encarnación a ojos de Sismondi del paradigma de la civilización española acotada en su momento de hegemonía mundial, ${ }^{459}$ inaugura el período de la poesía romántica. Pese a la perdurabilidad de su investidura como creador del teatro nacional, el veredicto de Sismondi sobre Lope como prolífico improvisador equidistante de la perfección y la representatividad de toda doctrina, ya sea romántica o clásica, ${ }^{460}$ testimonia la lozanía de asentadas opiniones a su respecto. Pese a admitir su chispa de genio, el estudioso, en el ángulo opuesto a Schlegel o Bouterwek, tacha sus obras de materiales informes y ajenos a las reglas fundamentales, que no deparan fruición estética al lector y no transmiten enseñanzas aprovechables que no conciernan a la historia cultural. ${ }^{461}$ Menos parco que Schlegel pero menos receptivo que Bouterwek — con quien comparte las ediciones de consulta-, Sismondi afirma conocer solo treinta piezas suyas, número sobrado, a su entender, para valorar su talento y defectos, como también suficiente es el análisis de una de sus intrigas para hacerse una justa idea del resto de su vastísima producción. ${ }^{462}$ Continúa así la difusión en Fran-

459 «C'est sous ce point de vue que je chercherai à faire remarquer en lui les préjugés et la morale des Espagnols, leur conduite en Amérique, et leurs sentimens religieux, à une époque qui répond à peu près aux guerres de la Ligue» (t. IV, p. 5).

460 «Ses pièces ne sont pas moins éloignées de la perfection romantique que de la perfection classique» (t. III, p. 521).

461 «je sens que la prodigieuse fécondité de Lope cesse entièrement d'être un mérite aux yeux de ceux qui sont fatigués par les détails; mais si nous n'avons plus rien à y apprendre comme art dramatique, considérons ses comédies comme un tableau des mœurs espagnoles et des opinions régnantes» (t. IV, p. 5).

462 Sismondi repite la vieja observación acerca del hibridismo de las piezas españolas y sus analogías con el género novelesco («Depuis Lope il n’y eut plus proprement ni comédie ni tragédie; le théâtre espagnol ne représenta plus que des nouvelles mises en action» t. III, p. 521), pese a dos ejemplos considerados de mediocre calidad, subtitulados por su autor como tragedias canónicas, y también citados por Velázquez (Rome embrasée y Le Mari le plus intrépide ou Orphée). Inspiradas en su historia nacional, las piezas lopescas no se basan en los grandes acontecimientos de Estado como los dramas políticos de Shakespeare, sino que injertan las glorias del pasado en la prevalecedora e intrincada intriga noveles$\mathrm{ca}$, que Sismondi ejemplifica escogiendo una de las de estructura más sencilla y por ello de más mérito en el teatro español, como el drama heroico de la familia de los Meneses, La discreta venganza (La Vengeance adroite). 
cia del juicio pertinaz que le reprocha su precipitación compositiva y su abdicación consciente de la responsabilidad moral de dirigir el gusto atendiendo a la construcción verosímil de la intriga y la pintura de caracteres, en lugar de entregarse al encanto poético. No obstante, ha de reconocer destellos de su talento artístico diseminados en sus obras, como su capacidad para cautivar la atención desde la primera escena, su recreación costumbrista, la variedad y dinamismo de los enredos y sus sorprendentes desenlaces, o sus magistrales exposiciones, emergentes con naturalidad de la acción — como en sus dramas caballerescos Lo cierto por lo dudoso (Le Certain pour le douteux) y Pobreza no es vileza (Pauvreté n'est pas bassesse)—, en vez de los largos discursos que ralentizan el teatro francés. La ficción dramática se convierte asimismo en un enjundioso documento sociológico y moral, de tanta validez como un testimonio histórico, que reflejaría acríticamente los prejuicios y comportamientos sociales de su tiempo y nacionalidad $^{463}$ — como la susceptibilidad del punto de honor que castiga con la muerte la coquetería femenina (así en Le Certain pour l'incertain), pero también como el ejercicio de la justicia en sus dramas heroicos ( $L a$ Vengeance discrète), o la dignidad y nobleza de sus protagonistas, como Juan de Meneses, ante la adversidad-. Atento a su impacto mimético sobre un público popular, no iniciado en el arte y susceptible de desmandarse, Sismondi también denuncia, como hicieran los ilustrados, la exaltación de la rebeldía contra el orden y los representantes de la ley, emparentando las obras lopescas con los melodramas franceses y los dramas románticos alemanes contemporáneos. ${ }^{464}$ Heredero volteriano del Siglo de las Luces, no solo condena la represión del despotismo político y su impronta misoneísta, sino también la poderosa influencia del clero. Su presencia la percibe en la casuística, en la alianza de contrarios como la devoción y el brutal desprecio por la vida ajena como en La Vie du vaillant

463 «le théâtre espagnol est une peinture aussi vraie que piquante d'une nation digne de toute manière d'exciter une vive curiosité» (t. III, p. 503).

464 El crítico clama así contra la admiración popular hacia los hombres que se han hecho famosos por sus crímenes: «la valeur tournée contre la société, les luttes sanglantes contre les magistrats, les corrégidors, les archers, les soldats, n'ont été que trop souvent l'héroïsme à la mode sur les théâtres d'Espagne. Long-temps avant les brigands de Schiller, long-temps avant les chefs de voleurs de nos mélodrames, on avait, chez les Castillans, supposé que la vertu, la valeur, la grandeur d'âme, étaient l'apanage des proscrits» (t. IV, pp. 17-18). 
Cespédès, en prevenciones religiosas - como el reconocimiento de la iglesia como lugar sagrado de asilo o el arraigo de la superstición popular-y sobre todo en la vigencia del fanatismo - bestia negra de enciclopedistas, volterianos y liberales - y su responsabilidad moral en la decadencia de la nación y el sometimiento de América, que el XIX sigue exorcizando, ${ }^{465}$ y que Sismondi ejemplifica en el Arauco domado de Lope, traducido en la década siguiente por Labeaumelle, y cuya altura poética alaba.

Cuatro años después de la edición parisina de Sismondi, las reticencias de rigor hacia Lope sobreviven en las reseñas bien documentadas del ilustre Raynouard a la segunda edición inglesa del conocido estudio —editado en la década anterior- de lord Holland, ${ }^{466}$ amigo de Jovellanos y anfitrión de numerosas personalidades liberales españolas en el exilio inglés. Animada por Quintana, esta obra crítica constituye un hito notable en el reconocimiento de Lope, y en especial de un Guillén de Castro despreciado antaño por Velázquez, y que va adquiriendo lustre a la sombra de Corneille hasta ir recuperando su estatura en el curso del siglo. Raynouard mantiene cierta reticencia hacia Lope, en cuya obra ${ }^{467}$ y vida — descuidada por los españoles_ se detiene, como Malmontais o Maury,

465 La actualidad reactivada por aquellos años de las campañas antiesclavistas y la revisión del balance de la conquista americana — presente en la decisión de Stapfer de adjuntar la traducción del sueño de Las Casas a la edición de Bouterwek - se refleja asimismo en los comentarios de Sismondi sobre la Araucana, por ejemplo, a la que también desestima literariamente como historia en verso: en el extremo contrario a Malmontais, el crítico atribuye a la precipitación de Voltaire su dictamen sobre la obra, a su juicio, demasiado tolerante y permisivo.

466 Some account of the lives and writings of Lope Felix de Vega Carpio and Guillen de Castro, by Henry Richard Fox Lord Holland, Londres, Thomas Davison, 1817, 2 vols. La primera edición data de 1806. Los artículos de Raynouard fueron publicados en el Journal des Savans en 1817 ("Vie de Lope de Vega par Lord Holland», pp. 643-656; "Notice sur la vie et les ouvrages de Guillén de Castro», pp. 725-735, y "Dissertation sur le genre de la poésie dramatique espagnole», 1819, pp. 434-441).

467 Así, Raynouard da la razón al juicio severo de Holland respecto a La Arcadia, "pastorale hérö̈que» en prosa y verso; cita La Hermosura de Angélica, que decae ante Ariosto e incluso ante Las lágrimas de Angélica, de su rival Barahona de Soto; conoce su colección editada bajo el seudónimo de Tomé de Burguillos; registra sus ataques a Góngora en comedias suyas como Amistad y obligación, o en su poema el Laurel de Apolo, escrutinio de méritos contemporáneos; y menciona otras obras suyas como su Jerusalén conquistada, Los pastores de Belén, el Triunfo de la fe, Las fortunas de Diana, novelas en prosa -inferiores a las cervantinas-, el poema épico Circe, la alegoría La Filomena, el poema la Corona trágica, y sus autos sacramentales. 
precediendo también a las reflexiones pioneras de Fauriel en el curso 1838-39 de la Sorbona sobre su teatro - tema después recurrente en las aulas universitarias del XIX-. Pese a la reputación de Lope como «exemple unique dans l'histoire de la littérature», proclamada por su discípulo y primer biógrafo Montalbán, el crítico juzga de mayor interés el artículo sobre Guillén de Castro por su relación con la literatura francesa. En su reseña erudita y literaria de la primera parte del estudio de Holland se muestra bastante comedido, sin internarse en las reflexiones ideológicas de su admirado Sismondi, y - salvo en determinados pasajes de un punto de vista de arraigado clasicismo- sigue las ideas generales transmitidas y las conclusiones del reseñado, por otra parte muy elogiado. ${ }^{468}$ Forzado a señalar solo lo más destacable de su referente — como su análisis de La Estrella de Sevilla_, ${ }^{469}$ Raynouard también apunta la ramificación de las intrigas en piezas como La fuerza lastimosa, ejemplo de obras más cercanas al carácter canónico de la tragedia, que a su vez ofrecen, pese al exceso de duelos y disfraces, menos imperfecciones en el trazado de caracteres. Teniendo en su memoria la condena de Boileau a la violación de las unidades dramáticas, Raynouard cifra, no obstante, el mayor mérito de Lope

468 «Je ne suivrai point lord Holland dans l'examen du système de composition de Lope; il faudrait se livrer à trop de détails et de discussions» (p. 651). No obstante, asiente a varias de sus afirmaciones: por ejemplo, también juzga excesivos sus juegos de palabras, censura su responsabilidad como mal ejemplo; recuerda las relaciones con Mariner y los dramaturgos valencianos, sus disputas con otros ingenios como Cervantes o Góngora - a quien Raynouard considera dotado de ingenio e imaginación como en pequeñas piezas aún reputadas, pero desprovisto de buen juicio-; y discute otras: así, señala los extensos conocimientos de Lope; reclama un examen más atento y justo del poema épico Jerusalén conquistada, inferior, sin embargo, a Tasso; proclama la superioridad en el género pastoral de su Belén, y hace refutaciones puntuales de erudición a las declaraciones del inglés, que tacha de precipitadas y erróneas a veces. En cuanto a sus dramas sacros, Raynouard, cercano a los neoclásicos, se sorprende de la autorización del gobierno español a la composición y representación de tales piezas como El animal profeta.

469 En el examen, acto por acto, de La Estrella de Sevilla, entonces atribuida a Lope, Raynouard comenta además pasajes omitidos por Holland. Por ejemplo, considera un rasgo de genio la destreza en presentar el duelo entre Tabera y Sancho Ortiz de las Roelas - escena que a su entender tendría éxito en todos los teatros- como una ocasión para ejecutar la orden real; elogia la entrevista del acto II entre el rey y Sancho Ortiz de las Roelas, y las escenas en que interviene Estrella por el contraste entre su conocimiento de los acontecimientos y el del público. También repara en el papel del gracioso, especie de bufón cuya injerencia considera fuera de lugar, que adopta la perspectiva tanto de un personaje como del espectador con la finalidad de salvar la conciencia del dramaturgo y desarmar de antemano al crítico. 
- cuya influencia innegable sobre los teatros europeos constituye su mismo elogio, como notara Malmontais - en la exuberancia de sus imágenes y, conforme al juicio crítico español, en la pureza de su lenguaje.

Así pues, a los dones ya reconocidos a los grandes dramaturgos españoles como una inigualada capacidad de fabulación y una poesía cautivadora, y a las censuras habituales como el desvío estético y la veterana acusación de inmoralidad, Sismondi añade la atribución declarada de esta última al pernicioso régimen político-religioso, cuyos desmanes, como la perversión del sentimiento cristiano, la crueldad de la sociedad y la venganza sanguinaria en el ámbito privado, alcanzan su apogeo en la interpretación sismondiana de la obra de Calderón. A principios de siglo, los franceses escatiman en general sus elogios a este dramaturgo frente a la profundidad de Shakespeare. Partiendo únicamente de las comedias de capa y espada, Calderón encarna, por ejemplo para Mme de Staël, un goce epicúreo de la vida y una superficialidad risueña compenetrada con una fe firme, asociación propia de las tierras sureñas frente a las tormentas interiores que asolan el mundo shakespeariano, y avatar anterior a la sombría imagen calderoniana retenida por los críticos posteriores. Si ya Tieck, principal difusor y legado para los Schlegel, lo caracterizó como poeta católico, y los hermanos Schlegel lo encumbraron como modelo cristiano, Sismondi no renuncia a esta interpretación pero desde un ángulo hostil, invistiéndolo como poeta de la Inquisición, restándole moralidad y exaltación poética, y, aunque le reconozca sus dones literarios, insiste en sus licencias retóricas contra el buen gusto. ${ }^{470}$

En suma, si en su reconocimiento de la validez relativa de otros sistemas poéticos diferentes Sismondi acepta la singularidad de la nacionalidad literaria española, romántica por fondo y expresión, no le reconoce una calidad semejante a la francesa, nutrida en las fuentes clásicas. De este modo, al juzgarla "beaucoup moins classique que toutes les autres» ${ }^{471}$

470 Tampoco admira el enaltecimiento católico de su Purgatoire de Saint Patrice ni de La Aurora de Copacavana ni los escrúpulos de honor de La Dame revenant, por ejemplo, ni de La Dévotion à la croix. Anticlerical contrario a la mezcla de religión y literatura, Sismondi se muestra acerbo con la literatura devota, y, como Viardot, también se distancia de los místicos.

471 «qu'elle s'était beaucoup moins formée sur le modèle des Latins et des Grecs, qu'elle s'était surtout beaucoup moins soumise aux lois et aux critiques des jurisconsultes de la littérature, et qu'elle en avait conservé un caractère plus original et plus indépendant» (t. IV, pp. 497-498). 
desde sus maestros árabes hasta la renovación italiana del XVI en la pluma de sus hombres de armas, el crítico también soslaya los trabajos de los eruditos españoles o de Malmontais que destacaron la abundancia y calidad de sus autores en los cauces comunes del clasicismo y la erudición, e incluso de Bouterwek, respetuoso de su pasado literario y que afrontaba a su respecto de manera más ecuánime la tensión entre originalidad y mimesis. De la defensa del patrimonio nacional de los ilustrados en pro de su europeización Sismondi retiene principalmente, como muestra de las raíces singulares, el poso oriental distintivo de su compleja civilización. ${ }^{472}$ A sus ojos, su principal interés, además del valor de las obras de la remota Edad Media, reside en su condición de transmisora del exotismo como adelantada en Europa de Oriente ${ }^{473}$ — región del extremo Mediterráneo cuyas deficiencias de organización y gobierno, denunciadas recientemente por Volney, atenúan, no obstante, su fascinación-. Aun así, Sismondi deja bien sentado que no pretende de ningún modo dar la preferencia a la belleza oriental sobre la clásica y expone incluso su desagrado al encontrar esa imaginería en la poesía española cuando, en cambio, lo aprecia en los cánticos sagrados y la poesía genuinamente oriental. ${ }^{474}$ Esta excentricidad

472 «Sous un autre rapport encore la littérature espagnole est pour nous un phénomène, et un objet d'étude et d'observation. Tandis que son essence est tirée de la chevalerie, ses ornemens et son langage sont empruntés des Asiatiques. Dans la contrée la plus occidentale de notre Europe, elle nous fait entendre le langage fleuri et l'imagination fantastique de l'Orient» (t. IV, pp. 258-259).

473 «Si nous considérons la littérature espagnole, comme nous révélant en quelque sorte la littérature orientale, comme nous acheminant à concevoir un esprit et un goût si différent des nôtres, elle en aura à nos yeux bien plus d'intérêt; alors nous nous trouverons heureux de pouvoir respirer, dans une langue apparentée à la nôtre, les parfums de l'Orient et l'encens de l'Arabie; de voir, dans un miroir fidèle, ces palais de Bagdad, ce luxe des califes qui rendirent au monde vieilli son imagination engourdie, et de comprendre, par un peuple d'Europe, cette brillante poésie asiatique qui créa tant de merveilles» (t. IV, p. 259).

474 «je ne prétends point justifier ces hyperboles gigantesques qui offensent souvent notre goût, cette profusion d'images par laquelle le poète semble vouloir enivrer tous les sens à la fois, et ne jamais éveiller une idée sans l'entourer de tout le prestige des odeurs, des couleurs et de toutes les harmonies. Je veux faire remarquer seulement que ce qui nous surprend sans cesse, ce qui nous rebute quelquefois dans la poésie espagnole, est la forme constante de la poésie des Indes, de la Perse, de l'Arabie, et de tout l'Orient; que c'est-là ce que les nations les plus anciennes du monde, et celles qui ont eu la plus haute influence sur la civilisation universelle se sont accordées à admirer; que nos livres sacrés nous présentent à chaque page des traces de ce goût gigantesque, de ce langage tout figuré, que nous écoutons alors avec respect, mais qui nous blesse dans les modernes». 
literaria y geográfica relega a la cultura española a una especie de tierra de nadie por su cualidad ni tan clásica ni tampoco tan oriental. A fin de cuentas, esta literatura - poco traducida y cuyas obras no alcanzan por lo general una reputación europea indiscutible - estaría anclada en el pasado y no habría enriquecido con grandes aportaciones la modernidad. Frente a los italianos, que han conocido tres grandes épocas literarias - la antigua con Dante, la de la imaginación clásica con Ariosto y Tasso, y la de la razón y el ingenio aplicados a las artes, con Alfieri y Goldoni-, Sismondi, como mucho, solo admite a la luz de la interpretación alemana un momento de esplendor, la edad de la caballería, ${ }^{475}$ en la historia literaria española. Su verdadero tesoro es el viejo romancero, popular venero de imaginación de un pueblo ajeno a las reglas del arte, y cuya ingenuidad se revela superior al pulimiento e imitaciones de los períodos posteriores. Esta tajante opinión, tamizada por una lectura ideológica más determinante que en sus predecesores, achaca el anquilosamiento a las trabas impuestas por la tiranía y el despotismo. ${ }^{476}$ Por esta razón, aunque afín pero más limitador que Bouterwek, Sismondi proclama en sus conclusiones generales sobre la andadura de esta literatura la continua reiteración de esta en círculos concéntricos en torno a un fondo raigal cuya originalidad se hace cada vez más lejana: de esta manera, ni Boscán ni Garcilaso infundieron una nueva savia a sus formas porque, al fin y al cabo, repitieron las mismas ideas y sentimientos románticos, esta vez a la manera italiana, como tampoco lo logró el relevo del teatro de Lope y Calderón. ${ }^{477}$ El rumbo de esta literatura lo decepciona: desde el cantar de gesta y el roman-

475 «la littérature espagnole n'a proprement qu'une seule période, c'est celle de la chevalerie, toute sa richesse est dans la loyauté et la franchise antiques; son imagination n'est fertile qu'autant qu'elle est ignorante; elle crée sans relâche des prodiges, des peintures et des intrigues, pourvu qu'elle ne se sente point gênée par les bornes du possible et du vraisemblable. La littérature espagnole brille de tout son éclat dans les anciennes romances castillanes; tout le fond de sentimens, d'idées, d'images et d'aventures, dont elle a disposé dans la suite, se trouve déjà dans cet ancien trésor» (t. IV, pp. 255-256).

476 «si l'esprit avait été nourri comme il doit l'être, si la pensée avait été libre, les classiques espagnols seraient enfin sortis de leur sentier circulaire, et ils auraient marché dans le même sens que les autres nations» (t. IV, p. 256).

477 «Le théâtre espagnol commença, et pour la troisième fois ce fonds primitif d'aventures, d'images et de sentimens, fut mis en œuvre sous une nouvelle forme. Lope de Vega et Calderon produisirent sur la scène les sujets des anciennes romances et firent reparaître dans le dialogue dramatique ce qui depuis long-temps se trouvait dans les chants nationaux" (t. IV, p. 256). 
cero no ha encontrado nada que iguale «ni l'auguste simplicité et l'héroïsme de son vrai caractère, ni le charme des brillantes fictions dont il a été l'objet» (t. IV, p. 254), y todo lo que ha venido después no ha suscitado en el estudioso, ni mucho menos, una admiración sin reservas. ${ }^{478}$ Con todo, no por ello deja Sismondi de recomendar la readaptación de los viejos modelos al presente y la superación de los viejos prejuicios para hacer mejor uso del acervo nacional de acuerdo con el espíritu moderno. ${ }^{479}$ Predecesor de Fauriel y Villemain, este influyente curso, fiel al legado clasicista francés acerca de las literaturas modernas y creyente en los valores del homo universalis, difunde así entre su lectorado y en su lengua materna una visión panorámica de enorme repercusión en la que, pese a rectificaciones puntuales, se estancarán varios críticos generalistas de fines de siglo, frente a otros investigadores germanistas o hispanisants más atentos a las renovaciones documentales y metodológicas.

\subsection{Las décadas de los años treinta y cuarenta: impulsos y recapitulaciones}

En torno a las décadas de 1830 y 1840 surgen numerosos estudios, recopilaciones, compendios, cursos generales y artículos sobre la civilización española, de diversa importancia y receptividad, que se suman a las traducciones, breves reseñas y artículos generales del decenio anterior. Las vicisitudes políticas generadas por el enfrentamiento entre el Antiguo Régimen y las fuerzas liberales habían permitido difundir en el extranjero las vindicaciones de los exiliados españoles que entraron en contacto directo con los centros culturales europeos, desde las ediciones de antologías tan difundidas como la Espagne poétique (1826-27) de Juan Maury en Francia, la consultada colección de Ocios de los emigrados españoles (1824-28) desde Londres, los tomos de Liaño publicados en francés en Berlín, o los de Bocous en Bélgi-

478 «Au milieu des jeux si animés de l'imagination espagnole, notre goût a été sans cesse blessé par l'enflure et la prétention, ou, notre raison rebutée par un travers d'esprit qui arrive souvent jusqu'à l'extravagance; nous ne pouvons jamais nous expliquer à nousmêmes comment tant d'imagination peut s'allier avec un goût si bizarre, et tant d'élévation dans l'âme avec une recherche si éloignée de la vérité» (t. IV, p. 254).

479 "C'est en connaissant tous les temps et la vérité de toutes les histoires, que nous pourrons donner une vie nouvelle aux représentations de la chevalerie» (t. IV, p. 257). 
ca, ${ }^{480}$ entre muchos otros, amén de un amplio número de estudios parciales. En los años siguientes, las recién fundadas cátedras de literatura extranjera asumen su análisis al amparo del naciente comparatismo, de raíces dieciochescas, impulsado por Villemain; a su vez, se benefician del desarrollo espectacular de la prensa periódica, que canaliza en las revistas culturales resúmenes y reproducciones parciales de discursos inaugurales y lecciones —afectadas en el curso del régimen de Julio por el ambiente tumultuoso de las tensiones políticas e ideológicas-, así como da acogida a numerosas colaboraciones de estudiosos. Sus argumentaciones contribuirán a corregir varias de las aseveraciones de los textos fundacionales que numerosos profesores generalistas, antólogos y autores de manuales destinados a la enseñanza o a la divulgación reproducen, en ocasiones literalmente, aún a finales de siglo. Hasta Baret, catedrático de lenguas extranjeras de Clermont-Ferrand - precedido en este período por el estudio comparatista de Puibusque_- y la incursión en la producción contemporánea de Hubbard, ningún hispanisant francés emprenderá la tarea de elaborar una historia de la literatura española tras el curso popularísimo de Sismondi. Sin embargo, la comedida consideración hacia estos estudios —orientados duraderamente por el gusto particular de los eruditos y refrendados ahora por los organismos oficialesdemuestra en estas décadas un relativo esfuerzo por contribuir a la difusión de la nueva disciplina a partir del material y las bases estéticas recibidas de la vanguardia alemana, aun dentro de los parámetros de la investigación universitaria francesa, más inclinada a la historia cultural que al análisis filológico de los documentos literarios.

\subsubsection{Desde la tribuna de la prensa: Prosper Mérimée y Juan Florán}

Las aportaciones de la prensa periódica de la época a las interpretaciones difundidas por las historias autorizadas constituyen otro afluente de información de suma importancia en el desarrollo de los

480 Junto al abate J.-B. L'Écuy y a Ganilh, el catalán J. Bocous, colaborador del Dictionnaire historique de Feller, se ocupó de un Essai sur les Littératures espagnole, italienne et anglaise que encabezó el suplemento a la quinta edición del diccionario (París, 1817-19), precedido asimismo de un Précis historique de la Révolution française, y que según Quérard (ob. cit., t. I, p. 363) serían suprimidos en las dos ediciones ulteriores (1826 y 1827) en las que participó su autor. 
estudios sobre la literatura vecina. Al tiempo que divulgan la nueva disciplina, también enriquecen sus conclusiones y a menudo constituyen un foro de intercambio serio de pareceres que contribuyen al afianzamiento paulatino de las obras y los autores españoles en el canon europeo en trance de remodelación. Muestra de las discusiones que sigue despertando este acervo literario son, por ejemplo, dos voces atentas a la evolución española que se pronuncian desde la tribuna de la prensa cultural parisina durante las décadas del afianzamiento romántico en Francia. Sus reflexiones abordan los dos haces dominantes en la aproximación a esta literatura: el teatro moderno y el barroco — conocido entonces en Francia por las traducciones de Labeaumelle-, así como los orígenes medievales de la nacionalidad literaria.

Dos años antes de la publicación de la antología de Maury, un joven Prosper Mérimée mostraba una incipiente inclinación por las cosas de España, entregando en noviembre de 1824 cuatro artículos ${ }^{481}$ a Le Globe en los que evalúa sumariamente las innovaciones de la escena española a fines del XVIII y las glorias de su teatro nacional - Lope, Calderón y un Guillén de Castro también reivindicado por lord Holland-. Aun criticando el supuesto desdén de los reformadores españoles — pese al fracaso popular de Moratín padre e Iriarte, a los que suma a Trigueros - por su patrimonio dramático divergente de las normas clasicistas francesas, Mérimée objeta a su vez los reproches entonces acostumbrados —la insumisión a las reglas aristotélicas; la españolización de la historia y las costumbres ajenas; la dispersión y multiplicidad de peripecias en detrimento de la conversación, la trabazón de la intriga y la profundización en los caracteres; y en particular el estilo preciosista o culto, error capital en que habría incurrido incluso Cervantes en su Numancia, traducida por Esménard-. No obstante, su disposición favorable al drama nacional español se evidencia no solo en el emparejamiento, aún inusual en Francia, de Shakespeare con Calderón -e incluso su superioridad por el excepcional Alcade de

481 «Espagne. Art dramatique en Espagne. L'acteur Maiquez» (n. ${ }^{\circ}$ 29, 13-XI-1824), «L'acteur Maiquez. M. Cienfuegos» (n. ${ }^{\circ}$ 30, 16-XI-1824), «Espagne. Théâtre espagnol moderne. Comella» (n. ${ }^{\circ}$ 33, 23-XI-1824), «Moratin» (n. $\left.{ }^{\circ} 34,25-X I-1824\right)$. 
Zalamea $^{482}$ - y cuyo Mágico prodigioso ${ }^{483}$ anuncia como precursor del Fausto, sino también al anteponer la calidad estética de Guillén sobre Corneille, a contracorriente de los juicios habituales de sus compatriotas ${ }^{484}$ e incluso de aquellos que procurarán repartir los méritos entre ambos.

Tras reparar en las fallidas iniciativas de la creación de la junta censora con Moratín y Estala, la escuela de declamación de Castellanos y las transformaciones que introdujo en la técnica actoral el célebre Máiquez, alumno aventajado de Talma, dando paso a una mayor competencia profesional en la naturalidad del recitado, en la escenografía y el vestuario, así como en un reverdecer de las comedias y tragedias clásicas, Mérimée apun-

482 Si el texto calderoniano fue refundido por Solís para su escenificación en España (El garrote más bien dado o El alcalde de Zalamea, 1810), la versión de Linguet —antes de la traducción de Esménard-inspiró un melodrama en 3 actos en prosa y de gran espectáculo a P.-J. Charrin (Amour, honneur et devoir, ou Le Rapt, París, Barba, impr. Hocquet, 1815), representado ese año en el Ambigu-Comique (K. van Bragt, ob. cit., p. 571). La selección calderoniana de Labeaumelle, básica en la difusión del teatro español y precedida por una biografía del autor, comprendía Gardez-vous de l'eau qui dort (Guárdate del agua mansa), Le Peintre de son déshonneur (El pintor de su deshonra), Le Prince Constant, Louis Perez de Galice, Il ne faut pas toujours caver au pire y Le Siège de l'Alpujarra, mientras que Le Dernier duel en Espagne y L'Alcade de Zalaméa estuvieron a cargo de Esménard. En la década de los treinta Ochoa dio a la imprenta, además de una selección de autos sacramentales, una antología titulada Teatro escogido de Calderón (París, Baudry, 1835).

483 Editada por Ochoa en su colección de Tesoro del teatro español desde su origen (año 1356) hasta nuestros días (París, Baudry, 1838), la primera traducción al francés será la de Th. de Puymaigre (Le prodigieux magicien, Metz, impr. de S. Lamort, 1852). A partir sobre todo de los años setenta se publican ediciones sueltas de esta obra. Por ejemplo, el conde Lafond traduce del inglés la tragedia Dorothée, vierge et martyre, seguida de El mágico prodigioso, sacado de la Vierge martyre de Massinger. En 1875 sale a la luz otra edición de A. Ramírez (París, J. Delalain). La memoria académica de A. Sánchez Miguel, traducida al francés por Magnabal (Calderón et Goethe [ou le Faust et] Le Magicien prodigieux, París, 1883), también sigue, pese a la refutación de Ochoa, las sugerencias comparatistas de Mérimée y de otro ilustre hispanisant como Ph. Chasles. Véase Horn-Monval, ob. cit.

484 Siete años antes, la reseña de Raynouard al estudio de lord Holland señalaba el interés particular del drama español Las mocedades del Cid, primera parte (Les exploits de la jeunesse $d u$ Cid, première partie) para la literatura francesa frente al resto de sus obras, como, por ejemplo, Las maravillas de Babilonia, cuyo examen estimaba inútil. El único mérito que concedía a Guillén — rebajado a dar forma al acervo romancístico- era el haber servido de base para una de las más bellas tragedias de Corneille. De este modo, ensalza y reivindica frente a Holland la imitatio enriquecedora del dramaturgo francés, que mejoró a su modelo en su planteamiento, situaciones, indagación psicológica, estilo, imágenes y versos, suprimiendo personajes y acciones secundarias, e incidentes inadecuados a las conveniencias teatrales o la jerarquía social. 
ta sus preferencias al comentar varias obras de tres autores finiseculares, Cienfuegos, celebrado en España como excelente lírico, ${ }^{485}$ Comella y Moratín. De las tragedias impresas del primero - las, a su juicio, mediocres Idomeneo y Pítaco o Zoraida, ambientada en las rivalidades granadinas de abencerrajes y zegríes, de tema más adecuado a la lírica - solo aplaude La condesa de Castilla por su asunto y tono plenamente trágico, su diálogo animado, conciso y bien versificado y el desarrollo de su intriga y de sus caracteres, pese a la morosidad de su desenlace. En cambio, aun habiendo depurado el estilo culto y suprimido el gracioso del modelo antiguo, la incursión del prolífico y exitoso Comella en el maniqueísmo moral, los golpes de efecto y la retórica sentimental del melodrama, así como la inobservancia de la historia y su recurso a la espectacularidad en obras como Federico Segundo en el campo de Turgau, suscitan la reprobación del joven crítico. Su rechazo de las licencias de este género popular se conjuga a su vez con su escrutinio censor del teatro moratiniano por su sumisa obediencia a las reglas y la frialdad innata de su talento («En un mot, Moratin est pour moi un exemple de ce qu'avec les règles classiques peut faire un homme médiocre mais instruit», p. 150), a notable distancia de la admiración que le tributan otros contemporáneos españoles y franceses. ${ }^{486}$ A partir presumiblemente de la colección de Ladvocat y quizá de alguna de las ediciones en español, ${ }^{487}$ y sin advertir las denuncias del autor a ciertas costumbres

485 Ya eran conocidas las ediciones impresas en Francia para el mercado de lengua española, como sus Poesías, recogidas en 1798 (París, Th. Barrois, 1821).

486 En 1820 se hacen numerosas ediciones de sus comedias sueltas en Baudry, y compilaciones en la misma editorial, en años sucesivos, de sus obras dramáticas y líricas. La única edición reconocida por el autor fue la de París, Duplessis, 1827. También en Masson e hijo, Tournachon-Molin, Parmentier en los años veinte, CONAM-Bossange père (véase Quérard, ob. cit., t. 6, 1834, pp. 286-287). Su fama lleva a incluirlo en manuales de español como Éléments de conversation espagnole, ou dialogues espagnol et français (atribuido a Baldwin), París, Théophile Barrois fils, 1803. Más tarde tampoco se le deja de lado, pues a mediados de siglo hay nuevas ediciones: E. Hollaender acomete la traducción de varias piezas, las habituales El viejo..., El café, El barón, La Fausse Dévote (La mojigata), El sí... (Théâtre espagnol. Les comédies de D. F. de Moratín, París, L. F. Didot fr., 1855), adaptaciones a la sátira moderna como en 1860 (París, J. Barbré), empezada por G. de Nerval y terminada por A. Fleury: Le nouveau genre ou le Café d'un théâtre, comédie critique, 1 acte en vers. Ya en 1899 pasa a los programas de estudios y manuales escolares como la traducción de Dubois, profesor del lycée de Toulouse, que en colaboración con F. Oroz entrega piezas como La comédie nouvelle y Le Oui des jeunes filles (París, Garnier fr.).

487 Th. Chatelain tradujo en Ladvocat sus cinco comedias originales (Le Oui des jeunes filles, Le Vieillard et la jeune fille, La Comédie nouvelle ou le Café, Le Tartuffe femelle y Le Baron). 
sociales españolas, Mérimée discute su eficacia cómica por el sarcasmo envidioso y sangrante que percibe en su primer éxito, El café, o la inadecuada elección como protagonista de un carácter despreciable en El barón; y critica el formalismo de otras piezas originales suyas - también representadas recientemente algunas de ellas en versiones francesas - ${ }^{488}$ por su languidez y previsibilidad y por el convencionalismo de sus tipos, situaciones triangulares, sentimientos virtuosos y fatigosas lamentaciones, a la vez que rechaza las pretensiones del dramaturgo al incluir criados mentirosos, ladrones y malos consejeros cuya verosimilitud en escena solo está al alcance de Molière o Regnard. Así, no aprecia la sumisión neoclásica del Oui des jeunes filles (El si de las niñas) a la voluntad del tío, un "galant homme» generoso como sus tocayos de comedia y cuyo tratamiento novedoso le confirman para su sorpresa conocidos suyos españoles; y solo exonera de los cargos expuestos a Muñoz, el doméstico de Le Vieillard et la jeune fille (El viejo y la niña), del que «'humeur triste et chagrine jette quelque gaieté sur trois actes mortellement longs» (p. 149), y a los caracteres mejor acabados de la protagonista de La mojigata (La Femme hypocrite) — que en su patria consideran su obra maestra-, cuya impostura permanece en los márgenes de la comicidad, junto al del estudiante que la corteja por interés. Aun reconociendo al reseñado su claridad y sencillez estilísticas, notables en la retórica española, su obra dramática desmiente en gran parte, a su juicio, los principios que el autor confesaba profesar en su prólogo y pretendía haber cumplido - una fábula sencilla, caracteres inspirados en la naturaleza y en las costumbres nacionales, diálogos vivaces, estilo de buen tono, alguna arista cómica, moral conveniente-. Sin defectos llamativos ni los hallazgos deslumbrantes tan comunes en Calderón o Lope («Certes, il serait injuste d'en demander davantage à Moratin, mais jamais auteur n'a prononcé de meilleure grâce sa propre condamnation»), Moratín es sentenciado en el último artículo a una honorable medianía sin rivales en el parnaso español («où nous le laisserons en paix jouir de sa gloire»).

488 El si de las niñas dio lugar a otra comedia-vaudeville en un acto del mismo título (Le Oui des jeunes filles) por Dupeuty, Villeneuve y Jouslin de Lasalle, representada el 3 de marzo de 1823 en el Teatro del Gymnase-Dramatique, y editada en 1824 (París, Pollet). Véanse K. van Bragt, ob. cit., p. 576; Wicks, ob. cit., t. 2. Asimismo, El viejo y la niña inspiró una comedia-vaudeville en un acto titulada le Vieillard et la jeune fille (Barba, 1824), escrita en colaboración por Brazier, Mélesville y Carmouche, y representada en París. 
Nueve años más tarde el emigrado liberal Juan Florán ${ }^{489}$ (Cartagena, 1802-Madrid, ?) presenta a L'Europe Littéraire, ${ }^{490}$ publicación de vida efímera, ocho artículos bajo el título general de «État actuel de la littérature espagnole», recogidos más tarde en volumen. Aunque en un principio este enunciado prometía ocuparse también de la literatura contemporánea, el prematuro cierre de la revista detuvo el repaso en los siglos medievales.

489 Conocido en los círculos literarios franceses, Florán se relacionó en su exilio con notables escritores franceses románticos, con algunos de los cuales trabó amistad, como Léon Gozlan. Véanse, por ejemplo, Vicente Llorens (ob. cit.), Robert Marrast (José de Espronceda y su tiempo, Barcelona, Crítica, 1989), o la Enciclopedia Universal Ilustrada, Madrid, Espasa (t. 24, 1924, p. 113). Antiguo alumno de Arjona, participó activamente en el Trienio Constitucional (1820-23) como ardiente orador de la Sociedad Landaburiana de los comuneros en Madrid. Hubo de huir de la represión fernandina rumbo a Francia e Inglaterra, donde permaneció hasta 1835, en que fue al fin admitido en las últimas listas de la amnistía. Vigilado un tiempo por la policía francesa y los espías españoles del régimen absolutista, y de criterio muy independiente, experimentó una evolución desde el radicalismo al moderantismo, el apoyo a la dinastía e incluso el conservadurismo. Más tarde marqués de Tabuérniga, fue nombrado cónsul de España en Londres. Murió en un olvidado retiro madrileño en fecha incierta. Como numerosos compañeros de infortunio con inquietudes literarias, se dedicó en su destierro a reseñar obras dramáticas representadas en los teatros franceses y colaboró en numerosas publicaciones inglesas y francesas: por ejemplo, prologó y reseñó el libro de Camille Leynadier, Les gitanos, París, A. Desrez, 1835; tradujo la obra tan reeditada y polémica de Mrs. Fanny Trollope (Domestic Manners of the Americans, 1832) bajo el título Costumbres familiares de los americanos del Norte (París, 1835), aderezada con copiosas notas, observaciones y correcciones, cuyo talento y calidad alaba Llorens. Se cita además otra traducción suya al francés de Adventures of a younger son de Edward John Trelawny (París, 1833). A lo largo de su intensa actividad periodística se aventuró asimismo en empresas como la fundación y dirección en 1837 de la breve revista editada en París El Orbe Literario. Interesante poeta, estimado por sus contemporáneos y severo consigo mismo, se resistió a publicar sus versos, varios de los cuales fueron elegidos por el colector Ochoa, íntimo camarada suyo, en su antología de 1840 Apuntes... (pp. 512-517). Entre sus obras propias destacan también Mémoires d'un cadet de famille, Études sur la littérature originale des Espagnols — resultado de los artículos que vamos a tratar, muy elogiados por Ochoa en sus Apuntes... ("cuyos fragmentos merecieron los mayores aplausos cuando se publicaron en la Europa Literaria»), quien se abstiene de mencionar otras colaboraciones suyas en la prensa francesa no firmadas, por respeto a su voluntad de anonimato.

490 Revista del cosmopolitismo romántico europeo, contaba entre sus accionistas, además de V. Bohain y A. Royer, con autores de la talla de Balzac, Heine o Hugo. Llevaba como subtítulo Journal de la littérature nationale et étrangère, de la que la política está formalmente excluida. Véase Th. Palfrey, L'Europe littéraire (1833-1834). Un essai de périodique cosmopolite, París, Champion, 1927. Aparte de reseñas de otras obras, sus ocho artículos aparecieron a lo largo de 1833 en las siguientes fechas: 17-V; 10-VI-; 1-IX; 15-IX; 6-X; 13-X; 10-XI; 5-XII-1833. 
Ante la displicencia con que la crítica francesa regatea la entrada de nombres españoles en el renovado canon occidental, la nómina de filósofos, poetas, oradores e historiadores, proclama Florán desde la metrópoli francesa, es bien amplia en el pasado como en el presente, y no comprende excepciones que resalten sobre un supuesto y sempiterno páramo intelectual en España. ${ }^{491}$ A lo largo de sus entregas, el articulista español declara su imparcialidad crítica en nombre de lo bueno y de lo bello universales, ${ }^{492}$ a la vez que asume el relativismo historicista con que se valoran las distintas épocas discerniendo lo particular de lo universal. Al tanto de las últimas teorías, Florán abraza la poesía «du cœur et de l’imagination» que aspiraba a expresar el estado interior del hombre, acepta las contraposiciones que enfrentan la poesía árabe o romántica a la pagana o clásica ${ }^{493}$ — sin rebajar ninguno de ambos opuestos — y el materialismo antiguo a la espiritualidad cristiana, a la que niega su papel como generadora de una literatura en Europa ${ }^{494}$ — «car celle du Midi est plus ancienne que l'Évan-

491 Florán se propone contribuir a esclarecer el estado de opinión en Francia reivindicando la ineludible aportación española a la historia intelectual europea y preconizando como criterio evaluador la equidad de juicio sobre la rivalidad literaria entre naciones: «La littérature espagnole a ses détracteurs comme elle a ses partisans. Les allemands l'élèvent jusqu'aux cieux; les Anglais l'étudient. Pourquoi les Français, qui ont tant de rapports naturels avec les Espagnols, sont-ils partagés, sur leur littérature, en deux opinions contraires? Pourquoi ces deux opinions sont-elles également exagérées? Serait-ce qu'on ne connaît pas assez l'Espagne intellectuelle pour la juger? Ou que l'esprit de parti ferait peser seulement sur les Espagnols la censure des défauts qui ont entaché toutes les littératures, et qui caractériseront toujours une période nécessaire dans la marche de l'intelligence? Ceux mêmes qui célèbrent Caldéron et Cervantès ne peuvent s'empêcher de les regarder comme des exceptions de la nullité littéraire de cette nation. Eh! Quels sont après eux les écrivains, demandent-ils, dont l'Espagne puisse se glorifier?» (art. $\left.1 .^{\circ}\right)$.

492 "Certes, il en faut convenir, il n'y a de beau que dans la nature, la nature est la même partout, c'est la vérité de tous les temps; mais l'observation est aussi une vérité et n'appartient qu'aux modernes. Sous combien de milliers de formes diverses ne nous présente-t-elle pas cette nature dans l'Orient et l'Occident, dans le Nord et le Midi?» (art. 6. ${ }^{\circ}$, p. 391).

493 "Les deux poésies [árabe y pagana] se trouvèrent face à face: le génie romantique rappelait sa naïveté, ses croyances vraies, ses enchantemens, ses fées, ses amours célestes et sa patrie; le génie de l'antiquité montrant, derrière un nuage d'or, les dieux heureux d'un climat de bonheur, les attributs symboliques de sa mythologie, son ciel de saphir, peuplé d'intelligences et de passions, et le charme irrésistible de tous ses monumens»(art. 5. ${ }^{\circ}$, p. 336).

494 «Dépouillez ce qu’on appelle littérature moderne des élémens grecs, des teintes runniques et des connaissances du panthéisme, dont elle s'est formée, et vous verrez ce qu'il vous en reste dans un latin barbare, dans des disputes métaphysiques, et dans quelques préceptes, sublimes, il est vrai, mais peu nombreux pour faire un système moral de la nouvelle religion» (art. 4. ${ }^{\circ}$, p. 220). 
gile, et celle du Nord est fille de son climat et mère du terrible Odin et de ses druides»—, así como la exaltación de lo popular — suprema encarnación "du grand et du beau», evocada en sus recuerdos infantiles de romances y en las improvisaciones en boca de ciegos y músicos ambulantes por Valencia y Murcia.

Las cualidades del carácter nacional, nacido de la fusión entre la cultura del norte y la determinante civilización musulmana que le imprime su carácter distintivo con los atributos ya conocidos —entusiasmo, riqueza imaginativa, fatalismo, intensidad pasional y voluptuosa, amor a la independencia, la caballería y el honor-, recorren como una veta la literatura española vivificada por la pervivencia del espíritu caballeresco, ${ }^{495}$ valorado a la luz de la revisión progresista de la Edad Media. Florán no solo se rebela contra la consideración que mostraban Malmontais o Bouterwek por la práctica traductora de los autores grecolatinos, ${ }^{496}$ sino que refuerza la distinción entre la originalidad nacional y los sucesivos períodos de imitación de lo extranjero en sus diversas fases. Invocando las ideas de ilustración y libertad, el crítico español afirma que la savia nacional se nutrió de sus propias raíces desde el cantar de gesta hasta la labor de Alfonso $\mathrm{X}$ al cultivar todos los géneros que contribuyen a la felicidad social (art. 5. ${ }^{\circ} . .^{497}$ Lejos de la admiración de Malmontais por la influencia trovadoresca, Florán la rechaza por extranjerizante; atribuye a la escuela de gramática latina promovida por el Concilio de Letrán (1215) la decadencia y conclusión de la época original de la literatura española, aún languide-

495 «'exaltation chevaleresque de tous les sentimens; la confiance que l'homme contracte par une longue habitude de vaincre; la candeur d'un âge où chacun ne pouvait que ce qu'il valait, et ne valait que ce que l'on estimait; la guerre et la gloire; l'amour et la loyauté, et une croyance pure, noble et indépendante: voilà le fond de la poésie nationale, et dont on découvre les germes, quoique peu développés, dans le poème du Cid. Nous le retrouvons dans Juan de Mena, et puis dans Lope de Vega et Calderon» (art. 1. ${ }^{\circ}$ ).

496 «Par rapport aux Espagnols, je suis convaincu que la restauration des études classiques leur a barré le chemin du perfectionnement, et que ce sont elles qui les retiennent dans l'état d'infériorité littéraire où ils sont vis-à-vis des Grecs et des Romains» (art. 6., p. 393).

497 Templado su radicalismo de los agitados años del Trienio con sus arengas en el café madrileño de la Sociedad Landaburiana, Florán se encamina progresivamente hacia un liberalismo bastante más moderado que abrazará finalmente. En estos artículos ya aboga por una monarquía liberal, avalada por remotos precedentes en las instituciones y costumbres vigentes en una entonces revisada Edad Media, de la que elogia el papel civilizador de la nobleza y su compromiso contra el despotismo del poder real y eclesiástico. 
ciente durante el reinado de Juan $\mathrm{II}^{498}$ — brillante período de transición (art. 7. ${ }^{\circ}$ ) pese al exceso que degradó sus cualidades en artificiosidad-, y censura el gobierno de Isabel I por su apoyo a la instauración del despotismo y la Inquisición. A partir del XV la literatura deja de ser expresión del genio nacional ${ }^{499}$ para someterse a las veleidades de la sociedad y la presión del poder. Sus artículos sugieren, pues, por su hostilidad ideológica hacia el período siguiente - común entre los críticos españoles liberales, como apuntó Blecua-, otro tramo en el alejamiento nacionalista del aprecio a la reforma italiana renacentista, cuyos modelos clásicos son considerados como importación de una cultura exánime. ${ }^{500}$

A partir de los textos originales consultados en las antologías de Sánchez, Casiri, Quintana y Maury, Florán reclama un estudio conjunto de la cultura española ${ }^{501}$ y se propone decididamente corregir, como otros compatriotas, diversos descuidos y juicios errados de Bouterwek y de su epígono Sismondi: ${ }^{502}$ así, toma partido por la orientación de Conde y de los eruditos españoles desde el padre Andrés, al atribuir la institución de la

498 «Les derniers poètes, les derniers philosophes, les derniers historiens de l'école nationale, en un mot, les derniers Espagnols et jusqu'au dernier rejeton du sang royal de Castille, tout s'était formé à la cour de don Juan II, où s'était façonné d'après les leçons de ses élèves» (art. 8. ${ }^{\circ}$, p. 289).

499 "Ce n'était plus le caractère espagnol, il avait disparu sous un mélange indéfinissable de superstition et de scepticisme, de bravoure et de soumission, de galanterie et de sensualité, qui ne conservait nul de ces traits décisifs qui faisaient de l'Espagne un peuple singulier dans la vieille Europe» (art. 8. ${ }^{\circ}$, p. 292).

500 «Poésie, histoire, philosophie, érudition et critique, tout était national chez eux, lorsqu'on introduisit en Castille le goût classique d'une nature déjà formulée, la tendance d'une société qui n'existait plus, et le reflet d'illusions qui s'étaient dissipées, quand se brisa le prisme d'une croyance abjurée» (art. 7. ${ }^{\circ}$, p. 293).

501 «Presque tous les écrivains qui ont publié quelques observations sur l'Espagne intellectuelle, n’ont remarqué dans le sujet de leur méditation que la partie poétique, tandis que la plupart de ceux qui ont traité directement la poésie espagnole n'y ont trouvé que des productions isolées, sans rapport moral avec la société, ou sans importance artistique dans le reste de la littérature» (art. 5. ${ }^{\circ}$, p. 335).

502 "'Jaurais peut-être mieux fait de continuer l'ouvrage sur la littérature espagnole de M. Sismondi que de recommencer une longue et vieille histoire pour arriver à nos jours et parler de mes contemporains. Mais il y a dans le livre de ce savant philologue des erreurs si graves, et, malgré le talent et l'érudition dont il est plein, il y règne une telle confusion, que le public n'aurait pas manqué de nous croire souvent en contradiction, surtout lorsque je me serais permis d'expliquer les circonstances qui éveillèrent l'imagination des Espagnols; les causes qui hâtèrent la marche de leur intelligence, ou celles qui nuirent à son développement; enfin, le caractère qui détermine la nationalité de cette littérature» (art. 3. ${ }^{\circ}$, p. 124). 
caballería a la influencia árabe; reivindica el deseo de libertad y la tolerancia como impulsos de la Reconquista, en lugar de un arraigado fanatismo religioso anterior y propicio a la implantación del Santo Oficio, insistiendo además en la distinción entre las decisiones gubernamentales y la moral de sus ciudadanos. Y, sobre todo, frente a la severidad de sus antecesores extranjeros, Florán rompe una lanza en tierra extraña por el patrimonio nacional, enfrentándose argumentadamente y con sensibilidad literaria a la crítica adversa que pesaba sobre la literatura medieval española. En su recorrido cronológico y bastante minucioso por sus hitos acostumbrados en los diversos géneros con diversos ejemplos traducidos, las preferencias del crítico se inclinan por los representantes de la nacionalidad en su devenir: la poesía romancística («la plus ancienne, la plus belle et la plus nationale»), el estilo sencillo del código alfonsino, el Amadís, la muy elogiada Danza de la muerte - muestra ejemplar de la literatura moderna, ${ }^{503}$ atribuida a Sem Tob, autor de las Poesías a Don Pedro-, la Coronación de Mena, dotada de "grâces les plus piquantes d'une imagination féconde et romantique» - aunque reconoce el perjuicio que su erudición ocasionó a su enorme talento poético («il aurait été le plus grand poète espagnol, s'il eût été le moins savant de son époque», art. 7.o)—, las serranillas del marqués de Santillana, que encarece como Quintana en su Tesoro, así como, al igual que Bouterwek, su poema sobre la sombra de Álvaro de Luna; el primer acto de La Celestina, a pesar de los reparos morales que suscita el tratamiento del asunto; las coplas de Jorge Manrique («la seule inspiration poétique de cette période», art. $8 .^{\circ}$ ), último ejemplo de la poesía nacional; y secundariamente el Libro de Alexandre como documento intelectual e histórico («tableau fidèle des mœurs espagnoles»). Sin embargo, su tacto poético se esmera en revelar la calidad literaria de Berceo, reivindicar a Juan Ruiz y sobre todo exponer el talento artístico del cantar de gesta.

De Gonzalo de Berceo, ${ }^{504}$ el primer poeta conocido de Castilla, elogia ante todo la armonía expresiva, y, más novedoso, en lugar de recurrir a

503 «j'ai vu la première personnification morale de la littérature moderne sans que le poète tombe dans les froids détours de l'allégorie mystique» (art. 5. ${ }^{\circ}$, p. 335).

504 La opinión general sobre este autor queda recogida sucintamente en el estudio de I. Uría (Panorama crítico del mester de clerecía, Madrid, Castalia, 2000). Hasta mediados del siglo XIX, suele mantenerse el error — subsanado en la centuria precedente por el P. Mecolaeta y, por mediación suya, por el P. Sarmiento (Memorias para la Poesía y poetas espa- 
la Vida de San Millán y de Santo Domingo, confiesa su predilección por la Vie de Sainte Aurea, ${ }^{505}$ que, pese a los defectos achacables al estado de la lengua, ofrece verdaderos hallazgos poéticos («Cette œuvre fade, grossière, est souvent bien compensée par des beautés vraiment poétiques», p. 128) como, por ejemplo, la fulgurante aparición de las tres vírgenes a Oria —en la segunda visión, culmen de la obra— ${ }^{506}$ o el destello de imágenes como la blancura de las palomas que ellas sostienen, más resplandeciente que la de la nieve no pisada. Son aún mayores las alabanzas tributadas al arcipreste de Hita — en la cúspide del canon medieval castellano, ante la sorpresa y desconocimiento general- por su irreverente talento, la descripción de las costumbres de su tiempo, su erudición y originalidad, la variedad rítmica de sus composiciones, su imaginación, la gracia y flexibilidad de su estilo, y su reanimación del gusto nacional al insertar coplas y romances, y a quien concede incluso el supuesto mérito de introducir el cultivo de las letras latinas en los estudios. Progresivamente aceptado por los franceses, Ruiz es considerado como en Sánchez el precursor de la primera revolución literaria en España, hasta el extremo de ser investido de la responsabilidad que Malmontais confería a Villena y de sobrepujar al infante don Juan Manuel, tan apreciado por Bouterwek. No obstante, es al cantar de gesta ("première épopée romantique»), datado por Florán en el siglo XI, al que dedica mayor espacio para vindicar no solo su rango de exponente nacional del "caractère individuel de la poésie espagnole» impregnado del fatalismo árabe, sino también su valor literario en rezago de la fama de su protagonista como icono popular nacional, equiparado tempranamente a los míticos semidioses homéricos. Florán da crédito a la imagen literaria del virtuoso héroe castellano hasta personificar en él la moral española y el espíritu de la caballería, caracterizados a su ver por

ñoles, Madrid, 1775, n. ${ }^{\circ}$ 577-581) y finalmente el editor Sánchez- de considerarlo monje del monasterio de San Millán. Sobre los nueve poemas exhumados por Sánchez (Vida de Santo Domingo de Silos, Vida de San Millán de la Cogolla, El sacrificio de la misa, El martirio de San Lorenzo, De los signos que aparecerán antes del Juicio, Milagros de Nuestra Señora, Duelo de la Virgen el día de la Pasión de su hijo, Vida de Santa Oria) los historiadores y comentaristas manifiestan sus preferencias a lo largo del siglo.

505 También traduce el pasaje del primer día del Juicio Final, perteneciente a los Signos que aparecerán antes del Juicio.

506 Véase la introducción de I. Uría en su edición de la obra de Berceo, organizada restableciendo la redacción original (Vida de Santa Oria, Madrid, Castalia, 1988). 
la bravura, la generosidad, la mesura, el patriotismo, la lealtad, el valor de la palabra dada, la religiosidad tolerante y el respeto a la tradición y al trono. Esta semblanza apologética del personaje histórico contrasta con su suspicaz descalificación del personaje cervantino por antonomasia, don Quijote. ${ }^{507}$ Aunque Sismondi expuso primero el argumento del cantar y sus pasajes representativos tomados del examen de Müller, Florán —atento a la interpretación de Quintana - ahonda en los principales episodios de la colección de Sánchez que glosa, comenta y traduce. ${ }^{508} \mathrm{Si}$ concede su condición de esbozo en comparación con los perfectos acabados de la Antigüedad clásica como también por la primacía de situaciones antes que demorados análisis psicológicos - aunque a menudo en el género consagrado estos corresponden más bien a recreaciones de las costumbres de la época-, sus episodios realistas revelan un gran talento observador, dado el estado de la lengua y la literatura de su tiempo («leur accent grossier ne nous inspire ni l'ironie ni le dégoût»). A lo largo de sus artículos Florán valora altamente la maestría artística y conmovedora, plenamente consciente, del cantar tanto en el dinamismo del estilo - a pesar de la oscuridad de su lenguaje, no siempre comprensible sin explicaciones filológicas - como en el trazado de caracteres — por ejemplo, en la aventura inventada del león, ya encomiada por Sismondi, que realza la antítesis dramática entre los infantes de Carrión y el Cid-, o la coherencia interna entre sus tres grandes partes en torno a la figura del protagonista — como

507 "C'est pour cela qu’il [el Cid] en sera toujours le héros, le beau idéal du caractère, et le type de leur nationalité. Don Quichotte n'est que la parodie du Cid. Ce sont les deux faces morales de l'Espagne ancienne et de l'Espagne moderne» (art. 3. ${ }^{\circ}$, p. 125). En su declaración parece oírse aún el eco de la censura de ciertas críticas del XVII y del XVIII que vieron en la obra una andanada contra el genuino espíritu de la caballería y una desleal sátira antiespañola, o tal vez pese también la valoración preponderante de la obra como sátira aleccionadora en el XVIII. Véase A. Rivas Hernández, Lecturas del Quijote. (Siglos XVII$X I X)$, Salamanca, Colegio de España, 1998.

508 Por ejemplo, también alaba el sugerente y abrupto comienzo in medias res — si bien reconoce que probablemente el original tuviera un principio más canónico-y en especial la emoción de la despedida entre el Cid y su familia, subrayada por Quintana en su antología, de la partida de sus hijas con los condes de Carrión, o los detalles de delicadeza de Félez Muñoz al socorrer a sus primas vejadas, apreciados por Sismondi. Asimismo se detiene en las recurrentes escenas de guerra como la toma de Alcocer, la victoria sobre el orgulloso conde de Barcelona, o la conquista de Valencia. Como otros exiliados españoles que también vindican la calidad del cantar, como J. Blanco White en Londres, Florán recalca la capacidad del anónimo autor para conmover, junto a cualidades ya aceptadas como su realismo y una atribuida fiabilidad histórica. 
la intensificación climática del drama, culminante en la segunda parte con la afrenta de Corpes, y la magistral graduación de las demandas y sus variaciones del «decir sin decir» en las Cortes de Toledo-. Florán se detiene particularmente en este último episodio, digno de un gran poeta por la lograda expresión del color local y su credibilidad, y subraya su talento incomparable en narrar las escenas guerreras, especialmente la grandeza épica del combate judiciario que cierra espléndidamente el poema con la apoteosis del héroe.

Juicios tan positivos como los de este crítico, acompañados de un análisis tan pormenorizado y certero, no suelen hallar eco en las ediciones de las historias de la literatura consultadas, mucho más sumarias incluso en sus alabanzas, y renuentes aún a fines de siglo a conceder valor literario a este cantar de gesta que no será traducido hasta $1858,{ }^{509}$ como tampoco a las otras obras revisadas por el español. La contribución de Florán - deudor de la prestigiosa herencia ilustrada y comprometido defensor nacionalista del patrimonio cultural — participa así de las nuevas teorías puestas en circulación por los románticos alemanes proclamando el espíritu nacional forjado en la primera edad velazqueña, a través de un examen fundamentalmente literario de ejemplos representativos apenas conocidos, comentados con la sensibilidad personal de un hombre de letras.

\subsubsection{Louis Viardot}

Dos años después de los artículos de Florán, mientras España se veía sacudida por la primera guerra carlista e iba asistiendo a las representaciones teatrales románticas más reivindicadas en las promociones canónicas contemporáneas, Louis Viardot (Dijon, 1800-París, 1883) ${ }^{510}$ saca a la luz

509 Además de ser objeto de estudios como el de Francisque Michel (1846), el cantar será traducido por Damas-Hinard unos veinte años más tarde, Poème du Cid, texte espagnol accompagné d'une traduction française, de notes, d'un vocabulaire et d'une introduction, París, Impr. Impériale, 1858.

510 Sobre su trayectoria personal e intelectual véanse, por ejemplo, Larousse (t. 15, 1876, pp. 978-979), A. Zviguilsky (coord.), «Actes de la Table Ronde sur Louis Viardot (1800-1883)", Cahiers Ivan Tourguéniev, n. ${ }^{\circ} 8$ (contribuciones al homenaje celebrado el 5-V-1983 en el Institut d'études hispaniques de París); M. L'Hôpital, «Louis Viardot», Mémoires de l'Académie des Sciences, Arts et Belles-Lettres de Dijon, 1947-1953, pp. 28-38; o también entre las colecciones y semblanzas de su tiempo, cabe citar, por ejemplo, 
una obra titulada Études sur l'histoire des institutions, de la littérature, du théatre et des beaux-arts en Espagne, ${ }^{511}$ que prudentemente, pese a sus afinidades con el discurso de las historias literarias, no presenta como tal según el respetado modelo de Bouterwek, sino como un examen que participa a partes iguales de la exposición diacrónica de sus inmediatos predecesores y de la tipología genérica a la manera de Velázquez. Por entonces este escritor ya tenía en su haber varias obras publicadas sobre España — sobre todo, y tras los pasos de Conde ${ }^{512}$ y Maury, su Essai sur l'histoire des Arabes et des Mores d'Espagne (París, Paulin, 1832), bien recibido por las reseñas literarias y que le franqueó las puertas de la Real Academia Española- y comenzaba a gozar del reconocimiento de sus compatriotas, como afirmaba la Revue de Paris ese año («Après MM. Carel et Mérimée, personne, parmi nos jeunes écrivains, ne connait mieux l'Espagne et ses antiquités que M. Viardot»).

Cuando publica esta revisión crítica sobre la historia y la literatura españolas — recapitulación parcial de varios artículos publicados independientemente entre 1830 y 1834 - este hispanisant, uno de los más respe-

L. Huart, Galerie de la Presse..., París, 1841. Como tantos otros, Viardot inició su aproximación a la cultura española a raíz de la invasión de los Cien Mil Hijos de San Luis, en funciones de administración y avituallamiento de las tropas. Tras este viaje revelador entró más tarde en contacto con la élite española y obtuvo gran predicamento en España, traducido y condecorado con la orden de Carlos III. Colaborador de numerosas publicaciones a lo largo de su carrera (Le National de Carrel, Le Siècle, Le Globe, la Revue des Deux Mondes, la Revue de Paris, La Liberté de Penser, L'Artiste, Le Musée des Familles, entre otras), en 1841 editó y participó con Georges Sand y P. Leroux, y más tarde P. Duprat, en la Revue Indépendante (1841-48). Librepensador atento a la actualidad política, efímero funcionario teatral al frente del Théâtre Italien, feliz traductor cervantino y del Lazarillo, coleccionista de arte y promotor de su joven esposa la cantante de ópera Pauline García, Viardot cultivó diversos géneros de creación como novelas y relatos de viajes (Lettres d'un Espagnol, 1831, o Souvenirs de chasse, al que agregó en 1849 cinco nuevos capítulos), se interesó asimismo por otras literaturas extranjeras como la rusa, asesorado por su amigo Turguéniev y X. Marmier, y dio a la imprenta numerosas traducciones y ensayos de variada temática.

511 París, Paulin, libraire-éditeur, imprimerie de Dezauche, 1835. Pronto sería traducida al alemán y al español.

512 Desde 1825 el lectorado francés cuenta con una traducción de su obra póstuma bajo el título Histoire de la domination des Arabes et des Maures, en Espagne et en Portugal, depuis l'invasion de ces peuples jusquà leur expulsion définitive, rédigée sur l'histoire traduite de l'arabe en espagnol, et trad. de l'espagnol par De Marlés, París, Eymery, tachada de infiel según Demogeot (1884) frente a la versión alemana más exacta y fiel de Ch. Kutschmann (Carlsruhe, 1824-25). 
tados del XIX francés, se halla una vez más de regreso de la Península con nuevo material y se dispone a editar su traducción de la obra histórica que su amigo el conde de Toreno había ido preparando en París. ${ }^{513}$ De igual modo que el buen gusto, la retórica clásica y el rechazo del hibridismo genérico conservan su autoridad sobre este crítico firmemente liberal ${ }^{514}$ para quien, a la manera schlegeliana, el teatro español de su edad dorada, en tanto expresión de su nacionalidad, es ya fundamentalmente romántico, ${ }^{515}$ las demás pautas asentadas por sus antecesores son asumidas en su planteamiento al abarcar en conjunto la civilización española desgajada en sus partes principales: ${ }^{516}$ abre el ensayo la edición conjunta de sus trabajos sobre la historia de las instituciones que el autor completa ahora; a continuación trata de la historia de su literatura, cuyo teatro constituye el objeto de un epígrafe independiente; finalmente, lanzando un tácito mentís a

513 Histoire du soulèvement, de la guerre et de la révolution d'Espagne..., con la colaboración de D’Ayllon y de Ferdinand Bascans, París, 1835-38.

514 La ideología liberal de Viardot se manifiesta en su lectura de la controvertida revuelta de los comuneros como una rebelión en nombre de la defensa de las antiguas libertades frente al despotismo de los Habsburgo; sus reproches a Fernando III por el enraizamiento del fanatismo, pese a ensalzar su reinado entre dos hitos («le plus glorieux entre ceux de Charlemagne et de Charles-Quint»), o en varios comentarios que presentan como «libres penseurs» a un escéptico Juan Ruiz, un Villena y un Santillana adelantados a su siglo por sus conocimientos.

515 «En Espagne, au seizième siècle, le romantisme se trouve déjà aux prises avec les théories rigides des observateurs des préceptes d'Aristote».

516 La primera parte comprende el «Etude sur l'histoire des assemblées nationales en Espagne. (Première partie). Anciennes assemblées, jusqu’à Charles-Quint» (pp. 1-55), seguida de otro capítulo, "Assemblées modernes, depuis Charles-Quint» (pp. 56-97) y de un apéndice sobre las provincias vascas (pp. 97-103), de acuerdo con una división cronológica similar a la periodización aplicada a la literatura. Su autor deja constancia de su favorable acogida en la traducción entre los mismos españoles («l'histoire des assemblées nationales, que les Espagnols n'ont pas jugé indigne d'être traduite et répandue comme une espèce de catéchisme à l'ouverture de leurs cortès actuelles», p. 609), con cuyas personalidades más señaladas, como Mendizábal, Toreno, Olózaga o Martínez de la Rosa, mantiene contacto. Su «Étude sur l'histoire de la littérature espagnole» ocupa las páginas 105-310, mientras que el dedicado al teatro español, que había sido publicado en la Revue des Deux Mondes (15-V-1833, pp. 423459), además de otros avances en Le Globe («De l'influence du théâtre espagnol sur le théâtre français», n. ${ }^{\circ}$ 62, 18-IV-1830), aparece paginado con breves retoques a continuación (pp. 311-372). La parte que cierra la obra, «Étude sur l'histoire des beaux-arts en Espagne» (pp. 373-383), con un apartado específico dedicado al Museo de Madrid (pp. 383-439), había aparecido bajo el título «Le Musée de Madrid» en la Revue Républicaine en 1834. Véase P. Guinard, P. Dauzats et Blanchard..., ob. cit. En este apartado final, además de alabar el patrimonio de obras maestras de escultura y arquitectura disperso en iglesias y catedrales, y en el que puede entrar, Viardot traza unas pinceladas sobre el acervo musical español. 
las afirmaciones categóricas de Bouterwek sobre la menor calidad y abandono de las otras ramas artísticas, subestimadas por el cultivo poético de su siglo de oro, ${ }^{517}$ se detiene en sus bellas artes, fundamentalmente la pintura - contemplada en el Museo de Madrid—, cuyo estudio no abandonará en años posteriores. ${ }^{518}$

Este examen de la literatura española se articula en cuatro partes regidas por la periodización acostumbrada. En primer lugar, atiende a la historia paralela de la lengua y de la literatura españolas en progreso hacia su plenitud en el siglo XVI, acompañada de traducciones con sus modelos a la vista, y segmentada en las dos épocas de rigor: la primera llega hasta el umbral del siglo XV y la segunda marca la transición hacia el período siguiente, encarnada principalmente en la corte castellana de Juan II. Las dos partes siguientes acometen el catálogo ejemplificador («revue»), ${ }^{519}$ exclusivamente en su lengua original, de los autores más representativos desde el siglo XVI hasta el XIX, para valorar con ejemplos comentados el cultivo y fortuna de los géneros, subgéneros y especies en torno a la división troncal de poesía y prosa. Bajo los marbetes — «Siècle d'Or» ${ }^{520} \mathrm{o}$ «Grand siècle littéraire», a imitación de la acuñación fran-

517 «À l'égard des autres beaux-arts, ils furent peu cultivés en Espagne pendant cette période, et l'intérêt exclusif de la nation pour les talens de l'esprit, cet intérêt auquel la poésie dut son âge d'or, nuisit aux progrès des autres arts, en appelant tous les hommes de génie dans une seule carrière» (Bouterwek, ob. cit., t. I, p. 228).

518 Coleccionista y estudioso del arte, editará varios trabajos sobre las bellas artes españolas, entre los que destacan sus Notices sur les principaux peintres d'Espagne, ouvrage servant de texte aux gravures de la galerie Aguado (1839), los volúmenes de su colección Les Musées de l'Europe, guide et memento de l'artiste et du voyageur, que serán ampliados desde 1843 en ediciones sucesivas; o su miscelánea de trabajos suyos sobre historia, arte y literatura españoles reunida en volumen bajo el título Espagne et beaux-arts. Recueils d'articles et fragmens divers, París, L. Hachette, 1866.

519 La metáfora de la ascensión a la cumbre reproduce uno de los criterios rectores de la selección canónica vigente en las historias y manuales: «au lieu de raconter à quels temps, à quels hommes, appartiennent les essais, les découvertes, les progrès de la langue et de la littérature, de monter enfin, par les degrés de la chronologie, d'époque en époque et d'auteur en auteur, je dois, parvenu au sommet, faire halte, étendre la vue, et, suivant la nomenclature des œuvres de l'intelligence, passer des individus aux espèces, et de l'ordre de dates à l'ordre de matières» (p. 167).

520 «atteints par les Français, dévancés par les Italiens, ils [los españoles] ne reprendront leur place qu'après les grands succès d'Isabelle et de Charles-Quint, dans ce siècle fertile en beaux génies comme en guerriers célèbres, qu'ils appellent, avec un juste orgueil, leur siècle d'or» (p. 149). 
cesa- que celebraban la tercera época, se acoge a autores dispares como, por ejemplo, un incomparable Cervantes, un Garcilaso primus inter pares, fray Luis de Léon, fray Luis de Granada, los Argensola, Quevedo o Gracián, a los que se suele cotejar con autores franceses, y con los que se reúne Solís — en la estela de Velázquez, Malmontais, Bouterwek y Sismondi- como último representante en tiempos de decadencia. La última parte retoma el hilo diacrónico reproduciendo la valoración difundida por Bouterwek de una extensa cuarta edad en la que al declive - germinado en la época anterior por el alambicamiento formal, y culminante bajo Carlos II y las primeras décadas de un siglo XVIII sometido a la imitación francesa- sucede en las postrimerías del reinado de Felipe $\mathrm{V}$ un renacimiento ( «l'espèce de renaissance qu'eut la littérature espagnole après l'époque des imitations étrangères», p. 189) ya en sazón bajo Carlos III. Viardot se suma así a los votos unánimes que lanzan anatema contra el mal gusto ${ }^{521}$ gongorista que arrastró a contemporáneos suyos como los ilustres Lope y Calderón o Villegas, Ledesma y Jáuregui, entre otros muchos. Del mismo modo, tras los desastres de la guerra de 1808 nuevos indicios prometedores de un resurgimiento que recoja el legado de fines de siglo le inspiran confianza en la recuperación del país gracias al retorno de los exiliados.

Si bien en la primera parte de la obra Viardot se remonta a la época de la intensa romanización, como para Bouterwek y Sismondi, la historia literaria española se inicia en la Edad $\mathrm{Media}^{522}$ tras la fusión de la población hispanorromana con los pueblos invasores. Con esta primera simbiosis se mezclan en el mosaico de lenguas peninsulares una influencia árabe determinante —origen aún aceptado de la poesía española y la provenzal—, y siglos después la italiana y la francesa. El poderoso ascendiente de la brillante cultura hispanomusulmana, avanzada cultural de Europa sobre los reinos cristianos, sigue marcando, por tanto, la primera edad velazqueña de la literatura española, genuina y raigal en estos críticos, precediendo a su estancamiento respecto a los reinos transpirenaicos en las centurias inmediatas. Frente a las renuencias de sus predecesores y

521 El estudio aparece encabezado por una reveladora cita de Walpole que reza «Le mauvais goût qui précède le bon goût est préférable au mauvais goût qui lui succède».

522 «Finit l'histoire des lettres latines, et commence celle des nouveaux idiomes qui sortirent des débris de la langue universelle» (p. 111). 
apelando a un mejor conocimiento de los estudios españoles, ${ }^{523}$ Viardot muestra una actitud más receptiva hacia las calidades de su literatura medieval, ${ }^{524}$ realzadas con ejemplos generalmente menos frecuentados entre los franceses. De esta manera, aun sin negar la condición impuesta de crónica rimada ni tampoco ahondar en su análisis como Florán, atenúa la crítica al cantar cidiano, meritorio por su prelación sobre el páramo europeo contemporáneo («nulle part une étincelle d'esprit créateur, une trace d'imagination ou de bon goût», p. 117), en virtud de su tema, digno de Homero, su realismo y sus proporciones como epopeya nacional y cristiana; aprecia la regularidad de las cuartetas monorrimas berceanas como en sus De los signos..., obra que escoge para mostrar su talento poético («Lorsqu’il osait décrire les approches du jugement dernier, il savait mettre une certaine majesté dans ce tableau terrible», p. 121); ensalza el tono épico y la asombrosa erudición clásica, pese a sus anacro-

523 Como hiciera Florán, Viardot también reprende las negligencias de Sismondi: «Dans son bel ouvrage sur les littératures du Midi, M. de Sismondi, après avoir longuement cité le Rimado de palacio d'Ayala, se borne à mentionner dans une note le nom de l'archiprêtre de Hita, dont les poésies ne lui semblent pas assez piquantes pour mériter un extrait. Cette sentence, plus que sévère, est contredite par l'opinion de tous les Espagnols, pour qui l'archiprêtre de Hita est le premier poète des temps antérieurs à la fixation de la langue et de la prosodie. Je pense comme eux, et j'ai dû faire précisément le contraire de mon devancier. M. de Sismondi s'était également montré bien rigoureux pour Gonzale de Bercéo (qu'il appelle Gonzalez), dont le style lui semble partout lâche, trivial et traînant. Il n'avait pas lu ses Signes du jugement dernier. Au reste, en arrivant dans son travail à la littérature espagnole, M. de Sismondi avait avoué que c'était la partie la plus difficile de sa tâche, parce qu'il n'avait pu puiser à toutes les sources, et parce que la langue de l'Espagne lui était moins familière que celles de la Provence ou de l'Italie» (en nota, p. 144).

524 La bibliografía que aduce Viardot incluye, además de su reciente ensayo de 1832 (completado en 1851 bajo el título de Histoire des Arabes et des Maures d'Espagne), obras de Aldrete, Mayans (De los orígenes de la lengua española), Capmany (Teatro histórico-crítico de la elocuencia española que había sido reeditado en Barcelona en 1832) y Nicolás Antonio; la colección de refranes de Juan de Iriarte; la versión descubierta por Casiri y traducida por Creus del Poème de Joseph; la ineludible antología de Sánchez y las comentadas de Quintana y Maury que, junto a ediciones presumibles de los escritores seleccionados, le suministran textos y ciertas opiniones - reflexiones sobre los rasgos de la lengua poética o pasajes sobre Góngora y Luzán, o sobre los orígenes de la novela, y la prelación de Pérez de Hita en el género narrativo de Scott y Saavedra, por ejemplo_-, así como las extensas notas, en especial en su apéndice sobre la comedia, del Arte poética de Martínez de la Rosa —inserta en sus Obras literarias (París, 1827) que ya reseñara el crítico francés en Le Globe - y que Viardot reconoce como guía al tratar diversos aspectos de su estudio. 
nismos, del Libro de Alexandre, ${ }^{525}$ atribuido como de costumbre a Lorenzo de Segura, a quien otorga asimismo la autoría del Poema de Fernán González; retiene las crónicas latinas de Silos, de Lucas de Tuy, Rodrigo Ximénez de Rada, Pedro Juan (Thesaurus pauperum) y otras que llama de «higiene y filosofía médica»; extracta pasajes de la vieja prosa del Fuero Juzgo; elogia a Alfonso X como monarca adelantado a su tiempo por su monumento legislativo y sus trabajos históricos y literarios; traduce el exemplo XXXV de la «novela moral» del infante don Juan Manuel, cuyo inventario de obras enumera; y, sin alcanzar la exaltación de Florán, admira especialmente el talento poético y satírico, la libertad filosófica, el sentido crítico e independencia del poder del arcipreste de Hita, a quien considera de nuevo un precursor de Rabelais. De su Libro de buen amor, aún titulado Guerre du Carnaval et de dame Carême, de gran riqueza métrica y temática de procedencia oriental y clásica — sátiras como la excelente del dinero, fábulas y cuentos eróticos- y cuyo valor artístico y costumbrista alaba («Rien de plus original et de plus divertissant que les détails de ce singulier poème», p. 142), traduce por su gracia y energía fragmentos de dos de sus fábulas - la de las ranas que pedían un rey, y la de los dos ratones. Las sofisticadas cortes del Cuatrocientos ofrecen los logros de Villena, Santillana, H. del Pulgar — superior en sus Claros varones... al cronista López de Ayala - o Nebrija. Mena, en cambio, no alcanza a sus ojos el rango de Hita ni siquiera de Berceo, y a pesar de la introducción del verso de arte mayor y de la belleza de ciertos pasajes recurrentes en las antologías, funda como Quintana el éxito de su Laberinto en su lisonja a los potentados. Superior le parece también Juan del Encina por su gusto más depurado, las cualidades de su teorización, la gracia de su estilo e imaginación, y la calidad de sus églogas representadas. Asimismo, antes de abordar la tercera etapa dedica un espacio al viejo linaje romancístico, verdadera poesía nacional de España, cuya metamorfosis histórica ejemplifica a través del cotejo entre un romance viejo (Desafio del Cid) recogido en las compilaciones del Quinientos y otro morisco (Le Défi du More Tarfé) del romancero nuevo.

525 Aparte del íncipit, que juzga pomposo, Viardot aprecia destellos poéticos y saberes enciclopédicos que ilustra con pasajes como las descripciones de las armas de Darío, de la ciudad de Babilonia, de la tienda de Alejandro, adornada con las pinturas de los meses del año, así como las sentencias y moralidades desperdigadas, o las muy elogiadas cartas del rey agonizante a su madre la reina Olimpias. 
Un paso más allá que Malmontais y Bouterwek y en consonancia con Stapfer, Sismondi o Florán, Viardot precede a las categóricas afirmaciones de Ticknor al tachar de extranjerizante el período renacentista («le caractère original et distinctif de sa troisième époque littéraire fut encore une imitation; non plus indigène et domestique, en quelque sorte, comme celle des Arabes, à la première époque, mais cette fois entièrement exotique et étrangère: l'imitation des Italiens») antes de la recuperación paulatina del carácter nacional. En su repaso genérico sus preferencias se inclinan en primer lugar hacia la poesía lírica, muy bien representada, y definida anchurosamente como «tout ce qui est poésie sans être poème; tout ce qui s'écrit en vers, depuis l'ode jusqu'au madrigal, en parcourant les divers degrés intermédiaires» (p. 183). A la vez que apela a la comprensión del horizonte de expectativas suscitado en cada época, ${ }^{526}$ Viardot proporciona una suerte de antología selecta de los subgéneros más utilizados desde la prestigiosa égloga, cuya forma imperecedera en la lectura perviviente de Teócrito, Virgilio, Tasso o Gessner trascendería el desfase de su cultivo. Favorecida por las condiciones armoniosas de la lengua, la templanza del clima y un tono dulce y contenido («où la grâce et la pompe de l'enveloppe poétique peuvent faire oublier l'exiguïté de la pensée», p. 195), la pastoral española es la más digna de contender con las extranjeras. La excelencia suprema la alcanzó la égloga I de Garcilaso, cuyos versos «non-seulement classiques, mais populaires, appris dès l'enfance et devenus proverbes, sont dans la mémoire et la bouche de tout le monde»; y tras él, sus discípulos Herrera, F. de la Torre, Balbuena, Lope, Montemayor, Saa de Miranda, Jáuregui, Figueroa, P. de Espinosa, Barahona de Soto o Villegas. De las diversas variantes de la oda, más convencional y permeable a las modas, ${ }^{527}$ desde graves canciones como la elegía de Jorge Manrique a ligeras anacreónticas, alaba la modélica oda horaciana de fray Luis de León por su pureza y naturalidad estilísticas, como su majestuosa «Profecía del Tajo», la llamada «Noche serena» y la dirigida "A Felipe Ruiz» ("Cuándo será que pueda»); elogia las odas heroicas y morales justamente célebres de Herrera, de versificación más pulida, mayor variedad rítmica y

526 «Il faut donc, en général, pour rendre justice à un poète lyrique, essayer de remonter à son temps, d'adopter les opinions et le goût qui régnaient alors; il faut surtout s'en rapporter au jugement de ses contemporains» (p. 185).

527 Entre otros ejemplos, cita a Francisco de la Torre, Mira de Amescua, Góngora, fray Diego González, Luzán, Nicolás Fernández de Moratín, Vaca de Guzmán y González Carvajal. 
originalidad respecto a sus fuentes, y aún más la Canción a las ruinas de Itálica de Rioja ("en ce genre, le plus beau morceau de la langue espagnole», p. 188), junto a las composiciones admirables de Meléndez Valdés («A las Estrellas» y "A la Gloria de las artes»). La sátira aparece representada por el arcipreste de Hita, Torres Naharro, Castillejo, los Argensola —aunque demasiado graves, más cercanos al modelo horaciano con pasajes admirables en la sátira "Contra la marquesilla» de Lupercio y "Contra los vicios de la corte» de Bartolomé- y un Quevedo especialmente dotado cuyo tono transmite al resto de sus composiciones a riesgo de excederse en burlas e ingenio. Tras la Epistola moral a Fabio del capitán Andrés Fernández de Andrade, atribuida entre otros a Rioja hasta el descubrimiento de A. de Castro en 1875, se incluyen muestras de este género de Lope, Góngora, Manuel de Melo, Jorge Pitillas o Jovellanos. Entre los múltiples ejemplos de letrillas — del arcipreste de Hita, Santillana, Quevedo, Diego de Mendoza, Gil Polo, Esquilache o Cadalso, Iglesias y Meléndez Valdés - destacan la gracia y vivacidad magistrales de Góngora y Villegas. La fábula, otro de los subgéneros cultivados en España con honorable medianía a imagen de Lamothe y de Florian sin alcanzar la perfección de La Fontaine, cuenta con exponentes como Juan Ruiz, los Argensola, Samaniego y, en particular, el innovador Iriarte con «El mono y el titeretero», «El gozque y el macho de noria» $\mathrm{y}$ «El oso, la mona y el cerdo». Si solo se mencionan los madrigales de Luis Martín, del epigrama, menos difundido que en Francia, se citan ejemplos de B. de Alcázar, Polo de Medina, Cadalso o Pablo Jérica. Por último, frente al desinterés de Maury se ensalza el soneto burlesco cervantino con estrambote, al que se añade el «Soneto de repente» de Lope sacado de La niña de plata («Un soneto me manda hacer Violante»), sobre otros modelos estimables como Juan Arguijo o Garcilaso.

Como manda la tradición, el cultivo del poema épico en España - a excepción del cantar de gesta, excepción para su tiempo, y en menor medida, del poema culto de Ercilla - sigue revelándose ante el crítico francés inferior al de los antiguos y aun de los modernos Tasso o Camoens, ${ }^{528}$ si

528 En esa clasificación Viardot incluye los poemas religiosos de Berceo, el Alexandre y el Fernán González atribuido a Lorenzo, por valor documental más que por mérito, a los que suma los abundantes poemas épicos del XVI y del XVII como el Bernardo de Balbuena, La Austriada de Rufo, la Conquista de la Bética de Juan de la Cueva, Montserrat de Virués o La Jerusalén conquistada y la Circe de Lope, citados también por Quintana. 
bien las parodias del género demuestran gran imaginación —el poema burlesco de Don Carnaval y doña Cuaresma de Juan Ruiz, La gatomaquia de Lope o La mosquea de Villaviciosa, un tanto pedante pero de ingeniosos caracteres-, a la vez que el prometedor Moro expósito de Saavedra (Le More enfant-trouvé ou Cordoue et Burgos au Xe siècle), enlazando con Ariosto y el contemporáneo W. Scott, ya apunta al género de novela poética, ${ }^{529}$ como su autor insinúa atinadamente a juicio de Viardot, conforme con el prólogo de Alcalá Galiano. Con todo, Viardot se demora en la defensa de La Araucana, la mejor, más nombrada y no siempre bien conocida epopeya renacentista. Sin contradecir las censuras a la carencia de unidad y poeticidad del poema - fundadas en la primacía de la historicidad de los hechos sobre la ficción, la dispersión y prolijidad de episodios ajenos al asunto y de fantasmagorías, o la ausencia capital de un motivo patriótico ("c'est oublier le caractère distinctif de l'épopée, pour donner à son œuvre l'attribut plus spécial de la tragédie», p. 175)—, replica a los ambiguos elogios de Voltaire —aún rebajados por Velázquez- ensalzando no solo la brillantez de ciertas situaciones dramáticas comparables al modelo homérico cuando no superiores - como la estatura trágica del caudillo Caupolicán sobre el aqueo Agamenón-, o la riqueza de sus descripciones, sino también el ímpetu y variedad de sus combates, la perfección de sus discursos, el desarrollo de sus caracteres y la delicadeza en la expresión de sentimientos.

En tercer lugar, la poesía didáctica, cuyos paradigmas - Pope, Boileau e incluso Delille - no son siquiera emulados, es el género más desfa-

529 Si la elección del género romancístico, adaptado felizmente al ritmo de la narración y al diálogo de la comedia en la literatura española, merece las alabanzas del crítico por su fluidez en esta leyenda, no obstante, sus cortas proporciones y su monotonía dificultan a su juicio el enlace de los acontecimientos, la variación de episodios y la profundización en los sentimientos o en los caracteres. Viardot le reprocha al autor asimismo una introducción demasiado contenida y un desenlace frío. Cincuenta años después, el ruso Tannenberg (La poésie castillane...) la sigue considerando su obra maestra (Le Bâtard maure), concebida como una amplificación de ese ciclo romancístico. Como la mayor parte de los críticos del XIX, celebra especialmente sus pasajes descriptivos, el color local y la reconstrucción histórica, pero también concuerda en sus reproches con las acusaciones de improvisación en un estilo, aunque armonioso, abundante, y cuya monotonía entorpece su lectura al tiempo que recuerda como Luzán había desaconsejado el uso del romance endecasílabo para las composiciones extensas. 
vorecido en calidad ante Viardot. Tras ciertos pasajes del Exemplar poético de J. de la Cueva y el celebérrimo poema sobre la música de Tomás de Iriarte, cuenta un puñado indudable de composiciones - La Diana o arte de la caza de Moratín padre, Las edades del hombre de fray Diego González y varias epístolas de los Argensola - sobre las que descuella el celebrado poema de la pintura de Pablo de Céspedes y el Arte poética de Martínez de la Rosa, cuya aportación más meritoria residiría en sus extensas notas documentales.

La mermada producción en prosa de calidad, ${ }^{530}$ achacada a la influencia nefasta de la Inquisición, no contempla el escaso cultivo de las ciencias - de las que descarta el Teatro crítico de Feijoo, útil en su momento pero inferior en audacia y alcance a la escuela francesa del XVIII-, ni obra alguna de metafísica, filosofía o legislación. Siguiendo el estudio aludido de Capmany — que no incluyó ningún fragmento de oración fúnebre o sermón-, Viardot observa, como Sismondi, aparte de algunas homilías de A. de Guevara, el sorprendente vacío de obras de elocuencia religiosa de mérito semejante a las francesas, y cuya ausencia se atribuye comúnmente a la deficiente educación de los sacerdotes, al espíritu escolástico superviviente y a la expansión del gusto cultista. Insiste, no obstante, en la mediocre abundancia de obras teológicas olvidables de autores como Sánchez, Escobar e incluso Molina, a excepción de las hermosas páginas de san Juan de la Cruz y con más reserva de Santa Teresa, bien apreciada en Francia desde el XVII, y a la que acusa de dogmatizar antes que argumentar. El recelo de Viardot hacia los asuntos religiosos y la ampliación temática de la escritura femenina se manifiestan en su enjuiciamiento de esta autora, ${ }^{531}$ de entre las escasas entonces conocidas como María de Zayas, Mariana de Carvajal o Bernarda de

530 «Ainsi, aucune œuvre de philosophie, soit qu'elle demeure dans la spéculation, comme la métaphysique, soit qu'elle descende à l'application, dans la religion, la législation et la politique; aucune ouvre de science, soit naturelle, soit exacte, appartenant, par la hauteur du style autant que par celle du sujet, à ce qu'on nomme la littérature» (p. 217).

531 "C'est qu'en voyant Thérèse oublier deux fois son sexe, se faire plus qu'homme, en quelque sorte, et, comme Jésus enfant, disputer avec les docteurs, je prends ses livres en dégoût, moins encore par aversion pour les matières qu'ils traitent, que parce qu'elles l'ont gâtée et perdue pour de meilleures choses» (pp. 225-226). 
Ferreira, cuyas obras desestima. Las obras morales ${ }^{532}$ representativas abarcan títulos habitualmente mencionados - El conde Lucanor, el Diálogo de la dignidad del hombre, la Exposición del Libro de Job y La perfecta casada (La Parfaite Mère de famille) de fray Luis de León, la Guía de pecadores de fray Luis de Granada, El gobernador cristiano de fray Juan Márquez, o el mediocre El hombre feliz independiente del mundo y de la fortuna, o el arte de vivir contento del padre Almeida, compuesto, según el crítico francés, a imitación del Telémaco de Fénélon- así como una serie de escritos a medio camino entre la teología y la moral como Dictámenes (Centuries d'avis prudens) y Obras y días del jesuita Nierenberg, junto a las Empresas politicas de Saavedra y Fajardo, modelo estilístico tan admirado de Mayans y de gran reputación europea. Pese a las dificultades de interpretación y el abuso retórico, Viardot elogia por su portentosa imaginación, conocimientos, capacidad de observación e inagotable ingenio las Visiones, los Sueños ${ }^{533}$ — Les étables de Pluton (Las zahúrdas de Plutón), Le songe des têtes de morts (El sueño de las calaveras), entre los que incluye Les épîtres du chevalier de la tenaille (Cartas del caballero de la tenaza) - y La vie du grand Tacaño, que han labrado la fama de un Quevedo moralista, ensalzado parejamente a Lope en mérito y defectos. Junto a él, El Criticón de Gracián, que declara uno de los textos más importantes de la literatura española, a la espera de una mayor difusión y del que alaba su concepción artística, variedad y simetría de sus partes. Del infrecuente género epistolar, según la opinión mayoritaria, cita algunos ejemplos difundidos por Mayans y Capmany, en virtud de su cercanía a las fronteras del género más que por su conformación evidente, y que, a su juicio, tampoco alcanzan la eminencia

532 «Je donne ce nom, dans la littérature espagnole, non pas précisément à des écrivains qui ont formulé en maximes et en sentences, comme Vauvenargues ou Larochefoucauld parmi nous, certaines vérités morales et d'une application pratique, il n'est pas sûr que des leçons données sous une semblable forme eussent trouvé grâce devant l'inquisition; mais aux écrivains qui, laissant à part l'extase ou la controverse, dégageant la morale du dogme, et séparant la terre du ciel, ont tracé les devoirs sociaux à côté des devoirs religieux, et se sont adressés moins aux chrétiens gagnant le salut qu'aux hommes vivant sur la terre en familles et en nations» (p. 226).

533 Las traducciones recibieron diversos títulos: Voyages récréatifs du chevalier de Quevedo (París, 1756), rédigés et traduits de l'espagnol, a cargo del abate Bérault-Bercastel, historiador eclesiástico, aunque La Geneste también los había traducido (París, 1667, 1683). Ya en el XIX aparecieron bajo el título de Les Visions de Quevedo a cargo de M. L. (París, Blanchard, 1812), edición accesible a los lectores decimonónicos. 
de los franceses: ${ }^{534}$ el Centón epistolario del bachiller Hernán Gómez de Ciudad Real — lindante con las memorias y el discurso histórico, y comparable al diario de Pierre de L'Estoile sobre el reinado de Enrique IV de Borbón o a las memorias de Saint-Simon-; las cartas de Santa Teresa, más bien disertaciones teológicas, aclaraciones y consejos en materia de profesión de fe reservados a la vida conventual; algunas epístolas familiares en estilo llano del cronista Hernando del Pulgar, Isabel la Católica, Juan de Ávila, A. de Guevara, las popularísimas en su tiempo de Antonio Pérez, así como las de Quevedo o Solís.

Viardot refiere asimismo las distintas épocas que marcan la evolución del género histórico en España desde la tradición oral, las crónicas latinas medievales y las romances de Alfonso X o López de Ayala, hasta los primeros logros por su gusto, orden y sentido general de H. del Pulgar, del que se habrían apartado los historiógrafos posteriores como fray Prudencio de Sandoval y Pedro Mexía. De los modelos de retórica aticista que asumen un concepto moderno del género ${ }^{535}$ el crítico ensalza pese a su estilo duro la celebérrima Historia de la guerra contra los Moriscos de Granada de Hurtado de Mendoza y, en particular, la Expedición de los catalanes y aragoneses contra turcos y griegos de Moncada ("la plus saillante de toutes celles qu'a produites l'Espagne dans le même genre historique, peut rivaliser avec les meilleurs œuvres analogues des littératures étrangères», pp. 251-252). Dispensa una acogida más reticente a la Historia general de España del jesuita Mariana, por la indiscriminación crítica de sus fuentes y por un censurado rigor con los poderes terrenales. Más mérito reconoce a la Historia de la conquista de las islas Molucas de Bartolomé de Argensola, la Historia de la guerra de los Paises Bajos de Coloma, la valiosa e incompleta Historia de los movimientos, separación y guerra de Cataluña en tiempo de Felipe IV de Melo

534 «mais, dans toutes ces collections, il n'y a rien qui approche, je ne dirais pas des hautes confidences d'un Voltaire épanchant son cœur et sa raison avec d'Alembert ou Frédéric, mais seulement des aimables causeries d'une madame de Sévigné» (p. 235).

535 Carecen de este enfoque («la recherche consciencieuse du vrai, droiture du jugement, hauteur des vues générales, intelligence des déductions, à tout ce qui forme enfin la philosophie de l'histoire», p. 242) a su juicio, los menos relevantes Mármol y Bleda, o Juan de Ferreras con sus confusas efemérides, como también, a pesar de sus méritos, la inconclusa Crónica General de España de Ocampo y los Anales de Aragón de Zurita. La historia eclesiástica aparece sumariamente representada por fray José de Sigüenza, fray Diego de Yepes, P. Martín de Roa. 
reimpresa en 1808 tras su redescubrimiento por Capmany, o la mejor organizada Historia crítica de Masdeu, más consciente en el XVIII de su misión de historiador. Rayana en el género novelesco — licencia excusable por las maravillas del mundo descrito- - destaca por su retórica elegante la Historia de la conquista, población y progresos de la América septentrional, conocida con el nombre de Nueva-España del prestigioso Solís, a la que sucederían dignamente por su estilo cuidado la Histoire critique de l'Inquisition de Llorente (1818) — con cierta reserva, dado su carácter erudito antes que literario-, y la prometedora Historia del levantamiento del exiliado Toreno, héroe e historiador de la guerra de la Independencia.

La aportación española a la novela («terre classique du roman»), otro de los puntales genéricos de este escrutinio - en el que Viardot acota los límites entre historia y epopeya y su genealogía desde las fábulas indias, las parábolas, rapsodias y los cuentos de tradición helenística, leyendas y libros de caballerías-, consistiría principalmente en la novela de costumbres (roman de moeurs). ${ }^{536} \mathrm{El}$ crítico propone una combinación de las propuestas sobre la génesis del género en España entre el origen árabe y el francés de las novelas caballerescas. Su permeabilidad temática se manifiesta en su copioso repertorio desde el Amadís de Gaula y sucesores de valor como Palmerín de Inglaterra, Don Belianis, Le Miroir de chevalerie o Tirant le Blanc, hasta la obra de Ginés Pérez de Hita, cuya filiación con la novela histórica contemporánea revela las deudas de la literatura moderna con la española. ${ }^{537}$ El epítome del «roman de mœurs» es el Lazarillo, ${ }^{538} \mathrm{del}$

536 «Je n’ai, sur l'histoire du roman en Espagne, qu’une seule observation générale à présenter, qu'une seule proposition à soutenir: les Espagnols ont reçu de nous le roman de chevalerie, et nous ont rendu le roman de mœurs» (p. 258).

537 «à côté de ces fables [recogidas en romances populares sobre Abencerrajes y Zegríes], il y avait, dans l'œuvre de Perez de Hita, des descriptions de fêtes, des peintures de mœurs et de coutumes qu'il était aisé de copier fidèlement et difficile d'altérer, puisqu'il écrivait sur des traditions toutes récentes, ayant devant les yeux les monumens du pays et les débris du peuple qu'il avait à peindre. Ce mélange de faux et de vrai, ce récit d'évenemens supposés où figurent des personnages réels, des lieux connus, des mœurs bien représentées, c'est précisément ce qu'on nomme aujourd'hui le roman historique. Perez de Hita est de trois siècles l'ainé de Walter-Scott» (p. 262).

538 Viardot, que desestima la continuación de Luna por su inferioridad respecto a la obra original, publicó por entregas su traducción del Lazarillo de Tormes en el periódico Le Siècle a partir de 1836 (véase, por ejemplo, R. Guise, "La fortune de Lazarillo de Tormès en France, au XIX siècle», Revue de Littérature Comparée, t. XXXIX, 1965, pp. 337-357), incluida también en diversas ediciones de la Histoire de Gil Blas de Santillane de Lesage, como la de 1846. 
que reivindica su unidad desfigurada por la yuxtaposición de aventuras cómicas extrapoladas y truncadas en difundidas versiones francesas, y realza su amarga crítica social, comparable al Gargantúa de Rabelais. En su estela incluye las versiones del género picaresco (genre picaresco) de Lesage, a las que dedica un excurso comparativo, además de la Historia de las aventuras del bachiller de Salamanca don Querubin de la Ronda por Solís, o el Marcos de Obregón de Espinel. Sin embargo, la excelencia innegable del género la encarna por su originalidad creadora la novela cervantina ${ }^{539}$ por antonomasia, el Quijote, cuya representatividad del alma española - pese a Florán-y del ser humano trasciende la sátira de las novelas de caballerías («c'est un livre de philosophie pratique, un recueil de maximes, ou plutôt de paraboles, une douce et judicieuse critique de l'humanité toute entière», p. 280). Con argumentos ya habituales alaba la unidad del plan, a la vez que la diversidad de peripecias, el enlace artístico de sus episodios, los diversos tonos de su estilo, así como la superioridad de la segunda parte, que desarrolla la potencialidad de sus protagonistas y reafirma su compenetración desde la monomanía del hombre de bien Alonso Quijano, adalid idealista y de razón educada, hasta la sensatez perspicaz de Sancho, que va dejándose arrastrar por los sueños de su amo. ${ }^{540}$ El cultivo cervantino del género comprende asimismo su Galatea, las novelas ejemplares, naturalización de la novella italiana - de las que destaca Le dialogue des chiens (Coloquio de los perros Cipión y Berganza), el admirable «tableau de mœurs» de difícil traducción Rinconete y Cortadillo, además de las insertas en el Quijote como Le Curieux Malavisé (El curioso impertinente) y Le Capi-

539 Cervantes es el autor más traducido por Viardot. Antes de su versión de las novelas cervantinas (1838), reeditadas en torno a mediados de siglo de nuevo (1857 y 1864), publicó la elogiada y muy difundida de L'Ingénieux hidalgo don Quichotte de la Manche..., avec notes et notice sur la vie et les ouvrages de l'auteur (1836 y de nuevo en 1864), referente para la traducción de Turguéniev. Asimismo, asesorado por este y por Marmier, el crítico también trasladó al francés a otros autores extranjeros como los rusos Gogol y Puchkin.

540 Coincidiendo en parte con la opinión cauta de Maury sobre las limitaciones de las traducciones francesas del Quijote, cuya pleitesía al buen gusto hacía que sacrificaran en gran medida la variedad y contraste de tonos del original, frente a la mayor calidad de las inglesas, Viardot, que preparaba su cuidadosa traducción de la novela, denuncia las licencias de sus predecesores, en particular la denostada versión póstuma de Florian (1799) y del difundido Filleau. Los reproches del crítico (p. 285) inciden en la desfiguración del texto cervantino y de su excelente estilo por supresiones, añadidos y confusiones que desmantelan la ambigüedad de la obra y la empobrecen, aunque, pese a todo, su excelente calidad permite la legibilidad de las versiones. 
taine captif (El cautivo), a las que añade La Tante supposée (La tía fingida)—, que recomienda al público francés como mejor lectura que los cuentos góticos entonces de moda; y finalmente el Persiles, clásico por su estilo pero defenestrado por los reproches de costumbre a su deficiente construcción de inverosímiles caracteres, alambicados sentimientos e intrigas tan intrincadas como las calderonianas. Su relevo no es retomado hasta la novela de Isla, ${ }^{541}$ sátira mordaz que no recibe su mejor crítica, al igual que hiciera Malmontais, por su monotonía y localismo que le restan interés.

La cuarta parte registra los signos de decadencia que se extienden hasta mediados del XVIII. El rechazo a la propuesta barroca española se articula principalmente en torno a un cismático Góngora, dotado de las calidades de un buen poeta pero ángel rebelde, como señalaba Maury, contra las sanas doctrinas a las que impuso su escuela de cultos. Tras la explicación de los procedimientos principales de esta escuela difundidos por Bouterwek —el abuso de figuras retóricas como la metáfora, el neologismo, la inversión sintáctica o los hipérbatos-, señala que el mal gusto invade todos los géneros — las traducciones de Jáuregui, el poema lopesco Circé, tan bárbaro como el Polifemo gongorino, el teatro calderoniano, los sermones de fray Hortensio Paravicino o la poesía cortesana del conde de Villamediana-. No obstante, aun arrastrados por estas corrientes, los maestros como Quevedo o Lope, entre otros, desperdigan calidades inalcanzables para sus epígonos. Así, la extrañeza que despierta en Viardot la Agudeza y arte de ingenio de Gracián, teoría de una secta sin leyes, se compadece con los grandes elogios que le suscitó su Criticón. Al igual que Maury, Viardot estima notablemente la labor reformadora de Luzán con su Poética y su práctica literaria, y enumera notables logros desde Feijoo, su pareja en la prosa, el conde de Torrepalma con su Deucalión, Porcel, Montiano, Nicolás Moratín, Cadalso por sus poesías y sus Cartas marruecas, García de la Huerta, Iglesias, un elogiado Meléndez Valdés, cumplido poeta por sentimiento y expresión al reunir las lecciones de los modelos del buen siglo — la vivacidad de Villegas, la nobleza de Garcilaso, el ímpetu de Herrera-; eruditos como Masdeu, Juan Andrés, Llorente; Isla,

541 Desde 1822 se cuenta con otra traducción (K. Van Bragt, ob. cit., p. 666): Histoire du fameux prédicateur frère Gérunde de Campazas, dit Zotes: écrite par le P. Jean Isla, sous le nom du licencié don Francisco Lobon de Salazar, etc. traduite de l'espagnol par F. Cardini, París, André. 
Campomanes, Jovellanos, Ramón de la Cruz, Leandro Fernández de Moratín, Cienfuegos y Marchena. Como es habitual en este tipo de discursos, el autor confía en los esfuerzos de los continuadores - como Argüelles, Quintana, Gallegos, el duque de Frías, Gallardo, Martínez de la Rosa, Ángel Saavedra, Trueba o Toreno- de la obra «encore récente de la renaissance littéraire» en nombre del progreso de su nación bajo el nuevo régimen de libertad. El XVIII no supone, pues, un corte en la tradición literaria, sino que, como en Malmontais, Bouterwek, Quintana o Maury, es reivindicado por el equilibrio entre los buenos modelos pasados y las influencias extranjeras, frente a la prensa cultural francesa en torno a la década siguiente, que sustituirá el relevo de esa centuria por los esfuerzos de las generaciones españolas venideras en busca de su nacionalidad. ${ }^{542}$

A modo de clausura de su síntesis divulgadora, y tal como hiciera Malmontais, Viardot dedica un artículo monográfico al teatro español desde sus orígenes medievales hasta sus tiempos presentes, sin desatender las interrelaciones entre los sistemas dramáticos a ambos lados de los Pirineos, asunto aún sensible para la crítica francesa. Aunque vincula el origen del teatro a los espectáculos de los juglares ${ }^{543}$ — raíz de la poesía y el drama modernosque reunían la danza, la música y la poesía, si bien carecían de una verdadera disposición escénica, el crítico francés considera acertadamente que es en la iglesia, en torno a la celebración del ritual religioso, donde nace el teatro medieval, tal como había sucedido en el teatro antiguo, a la sombra de los ritos paganos. En su repaso al origen de diversos géneros teatrales, ${ }^{544}$ Viar-

542 Así, por ejemplo, los reseñadores de revistas del prestigio de la Revue des Deux Mondes -influenciados por las teorías schlegelianas y partidarios de una vía conciliadora entre las diversas influencias que garantice la expresión genuina del carácter nacionalincluyen a los principales autores españoles analizados de los años treinta y cuarenta en la que llaman école nationale, diferenciándolos así de los excesos de la llamada école romantique, y los animan a adaptar los ilustres modelos de la nacionalidad literaria, a la nueva sociedad del XIX (M. ${ }^{a}$ R. Álvarez Rubio, La literatura española...).

543 A este respecto, aduce testimonios como la Crónica General de España, pasajes de Las Partidas alfonsinas o la respuesta de Alfonso X a la petición del trovador Giraud Riquier para que delimitara los nombres y atribuciones de los que entretenían honestamente al público.

544 Viardot se remonta a las obras de carácter dramático más antiguas mencionadas en los anales españoles e historias literarias extranjeras, corrigiendo varias aserciones de sus predecesores como Sismondi - la comedia alegórica de Villena, la Comedieta de Ponza de Santillana, nunca representada y descubierta por Martínez de la Rosa en la Bibliothèque Royale; la producción de Juan del Encina; o el caso particular de La Celestina. 
dot comenta detenidamente la celebración de los misterios, los excesos de las fiestas carnavalescas (fêtes de l'âne o des fous) y la pervivencia de usos ancestrales en festividades religiosas españolas. ${ }^{545}$ Asimismo señala un doble nacimiento del género en la España del siglo XVI — tras los precedentes en años anteriores a los presentados por los historiadores-, propiciado tanto por los ensayos teóricos y dramáticos de Torres Naharro en Italia como por la experimentación teatral de Castillejo o Lope de Rueda — considerado el creador del teatro popular-y sobre los que reclama una mayor atención crítica. A la hora de presentar la situación del teatro español en los siglos XVI y XVII —acudiendo a testimonios de Mariana, el famoso prólogo cervantino a sus comedias, o noticias desperdigadas en el Quijote, citas del Pinciano o el recurrente El viaje entretenido de Agustín de Rojas Villandrando desde su reedición de 1793-, sus transformaciones materiales, la disposición estructural del espectáculo en escena — loa introductoria, entremeses, jornadas —, los principales focos de irradiación dramatúrgica - Madrid, Sevilla, Valencia- y las obras principales, Viardot se somete a la división canónica de comedia y tragedia y reproduce las informaciones difundidas por Bouterwek: el cauce culto y de frágil arraigo por donde penetran los modelos clásicos con los habituales Villalobos, Pérez de Oliva o Simón de Abril, desconocidos del público que siguió aferrado a la tradición de farsas y bufonadas; las polémicas —en las que observa un avatar precursor de las controversias entre "ces autres classiques et romantiques»— entre los preceptistas aristotelizantes como Pinciano o Cascales y los defensores de la libertad creadora y la adaptación a las circunstancias de la sociedad española como Juan de la Cueva, y su resistencia común a la confusión genérica en nombre del buen gusto. Entre las tragedias más logradas se recuerdan las de Juan de Malara, de inspiración bíblica, las históricas y mitológicas de Virués, las inspiradas en la historia romana y en la tradición popular — como Los siete infantes de Lara- de Juan de la Cueva o las Nises de fray Jerónimo Bermúdez. Más severo es su enjuiciamiento de las tragedias de L. de Argensola y de una ya olvidable y decepcionante Numancia cervantina, despojada del aura heroica, comedidamente respetada por Sismondi, que le otorgaron Bouterwek y Schlegel. Tras los intentos frustrados

545 El autor aporta un interesante testimonio personal sobre la pervivencia en España de los antiguos usos y tradiciones populares carnavalescas, especialmente de las que se relacionan con el ciclo de la Pasión en Semana Santa y durante la Cuaresma, aunque no indica la región donde los presenció. Viardot los tacha de irreverentes y de ofensivos contra la religión, el buen gusto y las buenas costumbres. 
de los humanistas y sus ensayos universitarios, el modelo lopesco consumó duraderamente el hibridismo genérico - frente a una mayor prudencia de la práctica teatral shakespeariana-. Aunque Lope prefirió a la disciplina y gravedad de la tragedia las comedias heroicas, el sentido trágico discurre vigorosamente en gran número de obras dramáticas ya escenificadas en su mayoría a principios del XIX ("Ce n'est donc point le goût, mais la forme même de la tragédie qui a manqué à l'Espagne») como Sancho Ortiz de las Roelas - la refundición de Trigueros-, el Tetrarca de Jerusalén de Calderón, Del rey abajo ninguno de Rojas, La muerte de Julián de Médicis de Enciso, Los bandos de Verona o Los amantes de Teruel de Montalbán.

Máximo exponente dramático español ${ }^{546}$ emparejado con Shakespeare y fundador incontestable del teatro moderno, en cuyo repertorio mencionado ya se asienta el corpus más conocido de la revisión decimonónica, ${ }^{547}$ Lope de Vega transmite su legado a sus discípulos, de entre los cuales, Calderón, el más excelso de todos, lo iguala en talento versificador, y lo supera en los aún reprobados autos sacramentales, las comedias divinas, dramas heroicos y, en particular, en las habilidosas y dinámicas tramas de sus traducidas comedias de capa y espada, ${ }^{548}$ desde sus comienzos con $E l$ carro del cielo hasta su crepuscular comedia cortesana Hado y divisa («Il faut se borner à considérer Calderon comme auteur de comédies de capa y espada»). ${ }^{549}$ El enjuiciamiento de la dramaturgia española arrastra los lastres acostumbrados que reconocen su variedad combinatoria de intrigas

546 El universal Lope, como lo llamaba también Maury, si bien cultivó prácticamente todos los géneros literarios, sigue soportando el reproche recurrente («mais toujours au second rang, génie incomplet et inférieur, précisément parce qu’il est ou veut être général, et dont l'appréciation appartient à l'histoire du théâtre», pp. 188-189).

547 De él cita, por ejemplo, La moza de cántaro, La dama melindrosa, Los milagros del desprecio, La esclava de su galán, La bella malmaridada, Por el puente, Juana, Amar sin saber a quién, El perro del hortelano, El acero de Madrid, El anzuelo de Fenisa, La hermosa fea, Lo cierto por lo dudoso, La discreta enamorada.

548 Subgénero este, más editado («Certes, si l’art dramatique était uniquement l’art de combiner une action, de la compliquer d'autres actions parallèles, d'entasser les incidens, les surprises, et de serrer étroitement le nœud pour couper ensuite brusquement tous ces fils emmêlés, Calderon serait le premier auteur comique du monde»).

549 De él enumera obras como, por ejemplo, La Vie de Sémiramis fille de l'air (La hija del aire), Les Exploits de Roland et du géant Galafre au pont d'Amantible (La puente de Mantible), La dama duende, Casa con dos puertas mala es de guardar, El secreto a voces, No hay burlas con el amor, Peor está que estaba, y le atribuye Les Aspics de Cléopâtre (Los áspides de Cleopatra), título también de otra comedia de Rojas Zorrilla, y La Jalousie de Rodomont. 
sobre un mismo esquema, negándole la profundidad psicológica que se concede, en cambio, al teatro de caracteres inglés y francés. En su enumeración desordenada de generaciones - Mira de Amescua, Miguel Sánchez, Tárraga, Aguilar, Vélez de Guevara, Figueroa, La Hoz, Diamante, Mendoza, Belmonte, Cáncer, Enciso, Salazar y Bances Candamo- dentro del inventario respetado desde Velázquez, Viardot refleja la promoción francesa entonces en curso que, espejo de las revisiones españolas, incumbe principalmente a un apreciado Moreto y a los rehabilitados Tirso de Molina, F. de Rojas, Ruiz de Alarcón, o Guillén de Castro. Moreto, ya inferior a Calderón en invención y disposición, lo supera en sobriedad y claridad expositiva, en intrigas más despejadas, un mayor respeto a la unidad de acción, y la naturalidad de sus diálogos, cuyos defectos son achacables a su escuela, a tal punto que, a juicio de Viardot, sería su obra dramática la que en la actualidad congeniaría con el gusto francés y sus expectativas. ${ }^{550}$ Aun reconociendo su brillantez compositiva, Viardot prefiere sus comedias más sobrias y de estructura más nítida y lineal como El desdén con el desdén, modelo de la menos lograda Princesse d'Élide de Molière, aunque elogia sus comedias de figurón como El lindo don Diego o El marqués del Cigarral, gustadas desde el XVII, de doble y triple intriga sólidamente trabadas. Asimismo reivindica ante la crítica extranjera al aplaudido Tirso de Molina, ${ }^{551}$ tan difundido en la España de entresiglos hasta los años treinta del XIX, y

550 «Il me semble que, si on ouvrait un concours entre tous les théâtres de l'Europe, et qu'il fallût représenter celui de l'Espagne par une seule pièce, on ne pourrait mieux choisir, au milieu des innombrables richesses qu'il possède, que la comédie de Moreto intitulée El desden con el desden (L'Indifférence contre l'indifférence), dont Molière a donné dans la Princesse d'Élide, une copie décolorée». Esta obra será pronto traducida, junto a varios entremeses, en 1838 bajo el título Doña Diana, por H. Jouffroy (Leipzig y París, Brockhous et Avenarius, 1838). A fines de siglo los dramas de este autor ya más consolidado propiciarán la traducción de Alfred Gassier (Le théâtre espagnol, París, Ollendorf, 1898). De Moreto, Viardot menciona, por ejemplo, El desdén con el desdén, Trampa adelante, No puede ser guardar una mujer, La confusión de un jardín, De fuera vendrá quien de casa nos echará, El lindo don Diego, El marqués del Cigarral.

551 Viardot amplía el repertorio habitualmente citado en las historias con ejemplos que escoge de entre las mejores obras de los principales autores representados en España: así, de Tirso de Molina cita El vergonzoso en palacio, El pretendiente con palabras y plumas, Marta la piadosa, Por el sótano y el torno, Amar por señas, No hay peor sordo, Don Gil, el de las calzas verdes; de Francisco de Rojas, Donde hay agravios no hay celos, Lo que son mujeres, Entre bobos anda el juego, Abrir el ojo, o aviso a los solteros o Del rey abajo, ninguno; y de Solís, las ya conocidas de los estudiosos, El amor al uso, Un bobo hace ciento, La Gitanilla de Madrid. 
digno de una buena acogida en los teatros franceses, por su talento epigramático comparable al de Beaumarchais, en especial su comedia Don Gil de las calzas verdes, que goza del favor real, por la graciosa malicia de sus diálogos, tan bien construidos, no obstante la inverosimilitud de sus planteamientos. En el período siguiente los modelos dramáticos procedentes de Francia se imponen entre los hombres de teatro españoles como las apreciadas en su tiempo Virginia y Ataúlfo de Montiano, a pesar de las adaptaciones no siempre felices de la Hormesinda de Fernández de Moratín, Don Sancho García de Cadalso, o la Raquel de García de la Huerta, que anteceden a la verdadera tragedia de principios del XIX. Las piezas de Cienfuegos - frente a los reparos de Mérimée once años atrás-, el Pelayo de Quintana, la patriótica La viuda de Padilla, Morayma o Edipo de Martínez de la Rosa entroncan así, en opinión de Viardot, con Sófocles, Séneca, Corneille, Voltaire, Lamothe y Dryden. Del mismo modo, tras los intentos fallidos de Zamora o Cañizares, o los meritorios dramas lacrimosos de Luzán y Jovellanos, la esperanza de un género cómico nacional se fía a los ensayos del naciente XIX tras los pasos de los sainetes de R. de la Cruz $^{552}$ y las comedias de Moratín y de Martínez de la Rosa. Tras este apretado panorama de la historia del teatro español, Viardot extrae dos conclusiones de la pretendida ausencia de modelos contemporáneos sólidos y de la influencia de nefastas corrientes literarias de la época, que corroboran añejos reparos estéticos y morales. Según la opinión general, la desorientación teatral contraviene las normas de la comedia clásica de forma y finalidad, y se manifiesta, por una parte, en el trenzado de argumentos en detrimento del análisis psicológico, confundiendo los cauces de la novela con los de la comedia, y por otra, concentrándose exclusivamente en el entretenimiento y abdicando de la enseñanza moral e incluso de todo intento de reflexión filosófica. Citando a Voltaire y a Fontenelle, el crítico recuerda también que numerosas obras dramáticas españolas ejercieron una influencia inmediata sobre el teatro francés. Sin embargo, si bien Corneille y Molière, los dos ejemplos más ilustres de la imitación de modelos españoles, se inspiraron en ellos o incluso los copiaron - recurso

552 Viardot halla en los sainetes modernos, en especial los de Ramón de la Cruz - herederos de los entremeses e intermedios que habían surgido de los viejos juegos de escarnio- una semejanza formal con los proverbes dramáticos franceses que, sobre un frágil cañamazo, arman escenas de ingeniosa picardía. 
aún más habitual entre autores secundarios como Scarron, Quinault, Th. Corneille o Rotrou, en cuanto a temas, argumentos o caracteres-, sigue mantiendo que también adoptaron los recursos y materiales que convenían a la práctica francesa corrigiendo los defectos de construcción y la inverosimilitud de sus fuentes. ${ }^{553}$

En su revisión histórica de méritos y puesta al día de la opinión crítica general sobre esta literatura ante el lectorado francés —amén de los matices personales de su autor-, Viardot no solo retiene la periodización, repertorio y clasificación de autores y escuelas; respetuoso de criterios estéticos normativos entonces aún aceptados a ambos lados de los Pirineos, asume también las teorías schlegelianas de la nacionalidad literaria española y ofrece un muestrario de textos en todos los géneros difundiendo autores menos nombrados en el extranjero como un citado Ruiz de Alarcón o el aplaudido Tirso de Molina junto a otros contemporáneos que conoce personalmente. Al tanto de las vicisitudes políticas actuales, traductor en ciernes de sus maestros consagrados, y en contacto además con estudiosos y aficionados españoles, la valoración más comprensiva y de primera mano de este crítico sobre la cultura española, frente a la reluctancia de manuales e historias anteriores, se suma a las reivindicaciones y enfoques de Quintana, Maury, Florán u Ochoa.

\subsubsection{Cursos magistrales y manuales de transición}

Con su inclusión en el plan de estudios de las recientes cátedras estatales, el estudio de la literatura española —aún subsumido en hábitos docentes que propician la exposición retórica y la dispersión investigadora más que el análisis filológico, concentrado en determinadas facultades y en desventaja respecto a otras culturas a lo largo del siglo- no solo se beneficia de la publicación de traducciones y reediciones, sino que adquiere cierto reconocimiento oficial por la docencia de individualidades cuyas

553 Esta comunidad de fuentes y procedimientos le sugiere, de acuerdo con el sistema literario adoptado frente al criterio lingüístico y nacional, la asignación de las obras escritas en otra lengua pero conformes a la misma estética, a la literatura referencial. Así, Viardot señala que las escasas piezas teatrales del XVIII de cierta originalidad, escritas dentro del gusto francés, pertenecerían a la historia de este teatro con el mismo derecho que las primeras composiciones de los dramaturgos franceses corresponderían a la historia del teatro español. 
lecciones y cursos inaugurales son en ocasiones extractados en la prensa cultural, transcritos estenográficamente o editados en volumen. Como ejemplo de las tendencias de estos discursos académicos, paulatinamente articulados en torno al eje vertebrador de la influencia alemana, hemos espigado por la repercusión de sus profesores varias lecciones de finales de los años treinta y de la década de los cuarenta, impresas en folleto o insertas en prensa, que junto con los manuales contemporáneos muestran su deuda con las historias autorizadas.

El análisis global de la civilización que ampara los diversos estudios rige en gran medida los acercamientos de los primeros titulares de las cátedras de París y de provincias — que, atentos al desarrollo cultural de Alemania e Inglaterra, dan la primacía renovadora al Norte-, al tiempo que se consagra como criterio de valor la originalidad distintiva de esta literatura frente a los primeros manuales e historias que también valoraban la imitatio clásica y universal. Figura de renombre como mediador de culturas, Philarète Chasles (Manvilliers, 1798-Venecia, 1873) revela tempranamente su inclinación hacia la historia de las costumbres, las mentalidades y el comparatismo, que cristalizará en su colección de artículos sobre las influencias culturales franco-españolas en los períodos de esplendor de los siglos XVI y XVII, más tarde recogidos en volumen bajo el título Études sur l'Espagne et sur les influences de la littérature espagnole en France et en Italie. ${ }^{554} \mathrm{La}$ compenetración entre su ininterrumpida labor de publicista ${ }^{55}$ y su docencia universitaria a lo

554 Esta recopilación de artículos — sobre todo a propósito del teatro español del XVII y de las relaciones entre ambas literaturas en sus respectivas etapas de auge, en especial desde la regencia de Ana de Austria-, publicados en la década de los treinta en la Revue de Paris principalmente, y modificados en parte para su edición en volumen (París, Amyot, 1847), difundirían entre los estudiosos franceses posteriores un repertorio de obras de autores españoles menos frecuentados, como Ruiz de Alarcón, asentarían revisiones románticas de la producción calderoniana y darían también la pauta para cotejos ulteriores entre ambas culturas y dramaturgias, incluidos en historias y trabajos académicos desde Puibusque (1843) o Baret — como en sus artículos «De l'imitation espagnole en France au dix-septième siècle» incluidos en su volumen Espagne et Provence (1857) — hasta las referencias insoslayables en las colecciones del último tercio del XIX. Para más detalles sobre la argumentación de Chasles en esta colección de artículos periodísticos véase M. ${ }^{a}$ R. Álvarez Rubio, La literatura española...

555 Además de su obra literaria, Chasles va desarrollando una labor crítica, traductora y comparatista en numerosos periódicos y revistas desde sus primeros pasos durante la Restauración. Véanse J. Bourdeau, «La critique des littératures étrangères. Philarète Chasles», en Le Livre du Centenaire du "Journal des Débats", 1789-1889, París, Plon, 1889, pp. 478- 
largo de su trayectoria profesional — jalonada de premios académicos como su Tableau de la littérature française au XVI siècle (1828), nombramientos oficiales al frente de la Biblioteca Mazarina en 1837 y de la cátedra de lenguas y literaturas de origen germánico del Norte de Europa en el Collège de France (1841), o reconocimientos como la Legión de Honor - evidencia la permeabilidad de ambos cauces de difusión cultural y la condición aún no especializada de la disciplina. Años antes de estas promociones que, sin embargo, nunca le abrieron las puertas de la Academia Francesa, su lección inaugural en el Ateneo ${ }^{556}$ —contemporánea del estudio de Viardot, con quien presenta varios puntos de contacto- ejemplifica algunas de las principales líneas maestras seguidas por los críticos franceses de la literatura española en el XIX, como la asunción de las teorías schlegelianas y la difusión de la sociología staelista. Con una larga estancia en Inglaterra en su bagaje y conocedor de las nuevas corrientes románticas alemanas, el crítico proclama la peculiaridad de ambas culturas distintivas en el conjunto de las nacionalidades europeas entonces tradicionalmente más mencionadas. ${ }^{57}$ No obstante, la margi-

487; B. V. Zdraveva, «Philarète Chasles, ou l'Excentrique», ob. cit., 1930, pp. 160-177; K. Jones, "Le rôle de Philarète Chasles ou La section littéraire de 1830 à 1835", en La Revue Britannique, son histoire et son action littéraire (1825-1840), Ginebra, Droz, 1939, pp. 115-138; y fundamentalmente el exhaustivo estudio de Cl. Pichois, Philarète Chasles et la vie littéraire au temps du Romantisme, París, Librairie José Corti, 1965, 2 vols. Apunta este que, de 1829 a 1840 principalmente, Chasles se interesa por la cultura europea meridional. Su primera publicación relacionada con la cultura española tras sus obras de creación de ambiente maurófilo es la traducción — con anotaciones propias - del estudio de Bentham sobre la situación del liberalismo en España en los momentos cruciales de la invasión de 1823, Essais de Jérémie Bentham, sur la situation politique de l'Espagne, sur la constitution et le nouveau code espagnol, sur la constitution du Portugal, etc., etc. traduits de l'anglais, précédés d'observations sur la révolution de la péninsule et sur l'histoire du gouvernement représentatif en Europe, et suivi d'une traduction nouvelle de la constitution des cortès, París, Bossange, 1823.

556 "Cours de M. Philarète Chasles à l'Athénée: Littérature étrangère comparée: Séance d'ouverture», Revue de Paris, t. XIV, 17-I-1835.

557 Chasles se complace en la personificación ideal y generosa del mito español frente al utilitarismo del mundo anglosajón: «L'Espagne est un guerrier chrétien qui chante, qui prie, et qui écrit sur un bouclier, à la lueur des feux du camp, l'épopée de ses victoires. L'Angleterre est un capitaine de vaisseau visitant toutes les plages, chargeant son navire de tous les trésors, se parant de diamans et d'aigrettes empruntés aux nations lointaines, mais conservant toujours son costume de marin anglais, ses prédilections insulaires, son poignard à lame courte, et son caractère ineffaçable». 
nalidad geográfica ${ }^{558}$ de España, personificada en el genio lírico y cuyo enérgico carácter nacional moldean la herencia árabe y gótica y apenas modifican la influencia italiana y francesa —en coincidencia, por ejemplo, con Villemain frente a las sanciones posteriores-, sigue pesando en esta valoración histórica haciendo a su vez reverdecer en cierto modo, desde la postura estética opuesta, los ataques de los reformadores españoles del XVIII a la autarquía misoneísta de los apologistas. El estudioso no solo hermana a los dos grandes modelos vitales y literarios respectivos, Shakespeare y un Cervantes plenamente consciente de su valía 559 — de intención principalmente cómica más que aleccionadora en su novela, cuya ligazón con la tradición occidental ratifica por su ascendiente sobre Voltaire, Swift o Le Sage-, sino que, influenciado por los alemanes, desecha las vacilaciones francesas y adelanta a Calderón como representante nacional — con quien se emparejará al inglés más adelante como reflejo de la relativa aceptación del nuevo canon- y por quien demuestra un mayor aprecio que por Lope, defendido por algún contemporáneo como el traductor Damas-Hinard. Al igual que Viardot, en sus diversos cursos y estudios monográficos Philarète Chasles —al corriente de la bibliografía alemana de Blankenburg, Eichhorn, Bouterwek y los principales estudiosos alemanes, atento a las ediciones de autores españoles, entusiasta del teatro de Ruiz de Alarcón y del gran Calderón, que trató en lecciones y artículos periodísticos- concibe España, tierra meridional, fundamentalmente católica y caballeresca, como un país romántico por carácter y por tradición, y avanzadilla histórica de este movimiento entendido a la manera schlegeliana. Si bien desoye la concesión de Bouterwek a la capacidad de asimilación de la literatura española en favor de una originalidad un tanto autárquica, también en

558 «Si, au milieu de ses conquêtes, il [el genio español] reçoit de l'Italie et de la France des nuances qui le modifient, rien ne peut le faire renoncer à son génie national. L'Angleterre, non moins indépendante, mais que sa position centrale rend accessible à toutes les impressions extérieures, trouve moyen de conserver son originalité propre, sa pensée libre, sa sève nationale, en acceptant les importations italienne, espagnole, française» (p. 248).

559 Émile Chasles (1827-1908), aunque más iniciado en la literatura inglesa, le dedicará un estudio bajo el título Michel de Cervantes, sa vie, son temps, son xuvre politique et littéraire (1866). También será alabada la biografía del autor por E. Mérimée, cuya tesis doctoral sobre Quevedo (Essai sur la Vie et les cuvres de Francisco de Quevedo, París, A. Picard, 1886) recibiría asimismo los parabienes de Menéndez Pelayo, tal como recuerda Tannenberg (ob. cit., 1903, p. 152). 
nombre de un criterio más estético que moral y bajo la poderosa influencia de Schlegel reprocha a Sismondi ciertas omisiones y le refuta sus taxativos enjuiciamientos extraliterarios al teatro barroco. Sin embargo, aun preconizando la imparcialidad ante códigos tan distintos, Chasles no derrumba el mito, sino que prefiere contextualizar en su tiempo histórico la imagen de barbarie retenida por la renovada lectura ideológica, como supervivencia medieval no solo del fanatismo, la superstición y los restos de feudalidad, sino también de virtudes caballerescas heredadas de épocas más rudas del pasado.

Desde esta perspectiva englobadora enfoca también sus cursos, dictados en su reciente cátedra de las literaturas de la Europa meridional — creada ex profeso para él por Villemain - en el Collège de France, otro hombre de letras, el filósofo de formación germanista, liberal y pronto republicano Edgar Quinet (Bourg-en-Bresse, 1803-París, 1875). En una de sus lecciones ${ }^{560}$ leídas antes de ser depuesto por Salvandy a causa de sus ataques contra la Compañía de Jesús y contra la política gubernamental, Quinet, de gran predicamento entre la descontenta juventud de las postrimerías del régimen, seguía presentando la experiencia histórica española como un ejemplo de la decadencia provocada por el dominio del despotismo político y religioso. Con inflamada elocuencia el orador cifraba el renacimiento en los modelos italianos de Ariosto y Tasso y trataba su influencia sobre su dominadora política, España, rebajando el mérito de poetas tan celebrados en la Península desde la reivindicación ilustrada como Garcilaso, Boscán o Mendoza a simples imitadores y, tras la apropiación de Colón, otra muestra más de los plagios tomados de Italia. Influido en su interpretación simbolista de la historia de la cultura española por la revisión sismondiana de la alianza de las armas y las letras, no es en estos autores donde Quinet, admirador del mito napoleónico, percibe la originalidad patria y el augusto tono de los héroes antiguos, sino en las memorias, cartas y discursos de los conquistadores y exploradores como Cortés, Pizarro, Albuquerque o Magallanes, a los que admira por la grandeza de sus hechos y la expresividad y energía de su lenguaje y

560 «De la Renaissance dans l'Europe méridionale», 1-I-1843, Revue des Deux Mondes, t. I, suplemento, pp. 161-172. 
estilo. ${ }^{561}$ De igual modo, identifica en la obra de autores como Ercilla, Cervantes, Lope o Calderón, marcados por los riesgos de la vida militar, el genuino carácter nacional, definido por valores afectivos como el sentimiento exaltado de la realidad y la sinceridad y desbordamiento emocional («je répondrai hardiment que ce caractère est la profusion même de la passion et de la vie dans le domaine de l'art»). A este profeta de una Europa bajo los ideales de la república laica, más pendiente de categorizaciones acerca de la cultura en devenir que del análisis intrínseco de las obras, la representatividad del drama le sugiere la percepción de la historia española como una intriga secular («longue tragédie de cape et d'épée»), un antitético «drame éternel» religioso entre la Cruz y la Media Luna que se perpetúa en su período de gloria, tan lejano de la impotencia política de la España contemporánea. Los restos de esta mezcolanza de civilizaciones, a los que superpone sus numerosas lecturas, le saldrán al encuentro en su recorrido por España, ${ }^{562}$ propiciado indirectamente por su polémica destitución.

561 «Et si je voulais donner ici un exemple des rares ouvrages où les modernes ont retrouvé le ton de l'Antiquité, je me garderais bien de le chercher parmi les écrivains de profession de la renaissance, un Guichardin, un Mendoza; mais je le demanderais à ces hommes de fer qui jamais n'ont touché une plume que lorsqu'ils ont été obligés de dépeindre à la hâte, ou, pour mieux dire, de révéler d'un trait les îles [...]: rien de l'enflure propre au génie castillan».

562 Durante su viaje, en el que incluyó una breve excursión a Portugal, Quinet también parece reconocer los personajes del romancero y del cantar en las tierras y el paisanaje de Castilla, observa aún latente el espíritu de caballería del Amadís en la vida española, y tiene en mente a los poetas del XVI. El viajero no solo respeta las paradas acostumbradas de todo periplo español decimonónico — desde corridas de toros a pinacotecas y espectáculos-, sino que, atento al pulso de la sociedad contemporánea, también escucha a los principales oradores en las sesiones del Congreso —un Salustiano Olózaga en acción, Cortina, Joaquín López, entonces presidente del Consejo, Martínez de la Rosa y otros, de los que inserta breves pasajes traducidos-, asiste a las lecciones públicas del Ateneo, y difunde los nombres de sus autores más celebrados, confirmando así la impresión general ratificada en la prensa literaria francesa de más autoridad, que apuntaba a un nuevo y efervescente período de "pleine renaissance littéraire». Entre estos últimos, hace perdurar la fama de Larra - ya conocido entre los franceses por aquellos años en artículos dedicados - como panfletario popular y original - aunque sin la elegancia de un Courrier-, heredero de Quevedo y de Cervantes, y divulga a poetas como Espronceda, investido de la misión del poeta, y repertorios en escena como las representaciones de La vie est un songe, ya editada entonces en España, o de dramaturgos como Zorrilla sobre todo con su polémico y aplaudido El zapatero y el rey, Rodríguez Rubí, Martínez de la Rosa o Gil y Zárate, reseñados en esa década en las principales revistas culturales francesas. Sobre este libro de viajes, véanse, por ejemplo, J. Boudout, «Edgar Quinet et l'Espagne", Revue de Littérature Comparée, XVI, 1936, pp. 82-90; o E. Medina Arjona, "Mes vacances en Espagne, de Edgar Quinet: del pueblo y su lengua", Transitions, primavera 2005, vol. 1, n. $^{\circ} 1$, pp. $49-55$. 
Más académicas, las clases magistrales de su transitorio sucesor, JeanJoseph-Stanislas-Albert Damas-Hinard (1805-1891), ${ }^{563}$ se inscriben igualmente en las pautas habituales de las historias, ratificando conceptos vigentes como la nacionalidad literaria, la ligazón de la realidad histórica y social del XVII con su teatro, la atracción hacia su comportamiento heroico y patriótico en la guerra de la Independencia, que la historiografía liberal anuda con la época prerromana y la Reconquista, o la asunción ya acuñada del carácter nacional, leal, monárquico y caballeroso. En la segunda de las tres accidentadas lecciones que consiguió leer -19, 26 de abril y 3 de mayo de 1847 - reproducidas al poco en folleto ${ }^{564}$ desde las páginas de Le National junto a su defensa a raíz de los tumultos estudiantiles, Damas-Hinard subraya el interés de su estudio para los franceses («Ainsi donc, en France, étudier les productions de l'art espagnol, c'est étudier, pour ainsi dire, les origines de notre propre théâtre») y reivindica con prudencia el ascendiente francés en la España contemporánea. ${ }^{565}$ El estudioso se ciñe a su tema sin permitirse los excursos ideológicos ni humanitaristas de Quinet, y, con una retórica menos colorista y vigorosa, se limita a difundir nociones generales ya aceptadas: desde la consagración del romancero popular como depósito de las tradiciones nacionales; la presentación de la que llama escuela italo-española del XVI, siglo extranjeri-

563 Nacido en Madrid en 1805, Damas-Hinard, como tantos otros jóvenes, abandonó la abogacía por el estudio de la literatura, en la que se inició en los años románticos con sus Chants sur Lord Byron, sus Mémoires de la comtesse Dubarry, y repertorios de citas como Napoléon, ses opinions et ses jugements sur les hommes et sur les choses. Su intensa dedicación a las literaturas extranjeras, en especial la española, varios de cuyos principales autores tradujo al francés, le granjeó el aprecio de Salvandy, entonces ministro de Instrucción Pública, quien lo colocó al frente de la cátedra del Collège de France en sustitución de Quinet. Tras este paréntesis docente tan breve por el hostil recibimiento de las aulas partidarias del destituido, en 1848 es nombrado bibliotecario del Louvre y en febrero de 1853 uno de los secretarios de la emperatriz Eugenia, puestos en los que prosigue sus estudios sobre la literatura vecina. Traductor experimentado, no solo participó en la versión francesa de los clásicos latinos del compendio de Nisard, sino que se adentró en la literatura española con textos de Calderón, Lope, el Quijote, el Poema del Cid y la colección romancística ya aludida, muy alabadas entonces, como confirma la noticia del Grand Larousse du XIX siècle (t. 6, p. 35).

564 Une leçon au Collège de France. Discours sur l'histoire et l'esprit du théatre espagnol. Avec un avant-propos, París, Chez Benjamin Duprat, Libraire de l'Institut et de la Bibliothèque Royale, 1847.

565 «Mais pour que l'Espagne triomphe dans la lutte difficile où elle s'est engagée, elle a besoin de la France: je ne parle point ici, vous le comprenez, d'influences politiques, diplomatiques; non, elles seraient inefficaces ou dangereuses; je parle d'un concours tout moral, émanée de l'opinion» (p. 32). 
$z^{2} \operatorname{ce}^{566}$ que declina la herencia nacional importando métricas y rindiéndose a la mimesis de modelos italianos y paganos restaurados por el Renacimiento en la pluma no de literatos profesionales, sino de guerreros; la ineludibilidad del Quijote («badinage incomparable»); la referencia a la expresión de «siècle d'or» de los grandes nombres de la segunda mitad del XVI y primera del XVII como Lope, fundador de la comedia caballeresca, risueña y heroica, y Calderón; la breve declaración con que arranca su discurso, sobre los vaivenes en Europa del crédito de su teatro, ya por fin reconocido y comparable con el griego antiguo, principalmente por su fecundidad; hasta el afianzamiento de la nacionalidad literaria francesa a través del comparatismo en el estudio de ambas dramaturgias, ${ }^{567}$ bajo la tutela de los estudios de Chasles o de la disertación de Puibusque en 1843, al que nos referiremos más adelante.

En este siglo de exaltación de la historia y de la taxonomía por su predilección editorial por «bibliotecas», diccionarios y compendios bibliográficos de los diversos géneros y saberes, las prensas estampan también numerosos resúmenes y manuales divulgadores como el Atlas historique et chronologique des littératures anciennes et modernes, des sciences et des beaux-arts en veinticinco cuadros sinópticos coordinados por Adrien Jarry de Mancy. ${ }^{568}$ Testimonio de la fuerte impronta de la cultura secularizada en Francia desde mediados del XVII, Jarry propone en los años precedentes a la

566 «'admire sincèrement les poètes espagnols de l'école italienne; mais quand je vois ces poëtes appliquer tout leur talent, toute leur industrie, à reproduire avec un soin servile les sentimens, les idées, les images d'une civilisation disparue; quand je vois, par exemple, Fernando de Herrera, d'ailleurs un écrivain si habile, célébrer la victoire de Lépante - la victoire de la Croix sur le Croissant!- en employant des figures empruntées à la mythologie grecque, j'éprouve je ne sais quel secret dépit de ce manque d'accord entre la poésie du sujet et l'œuvre du poëte!» (pp. 19-20).

567 «Montrer suivant quelles lois de l'esprit français le grand Corneille a fondé notre théâtre en s'inspirant des poëtes espagnols —à la même époque où Richelieu fondait la puissance de la France sur l'abaissement de la maison d'Autriche».

568 Para esta obra (1827-29) — cuyo título sigue como ... d'après la méthode et sur le plan de l'Atlas de A. Lesage (comte de Las Cases), et propre à former le complément de cet ouvrage, París, chez Jules Renouard, 1831 (en la edición consultada)—, continuada en 1835 por el Tableau complémentaire de l'Atlas des littératures..., Jarry apeló a la colaboración de hombres de letras como Depping, Denis, Gustave Planche, Loève-Veimars o Chodzko. Antiguo alumno de la École Normale Supérieure, en la promoción de 1813 (véase, por ejemplo, Grand Larousse du XIX siècle, t. 9, 1873, pp. 913-914; o Goblot, Documents..., p. 297), profesor del Colegio de San Luis de París en 1820 y más tarde de la Escuela de Bellas Artes, bibliotecario, colaborador en prensa como en la prestigiosa revista Le Globe, y pródigo autor de ediciones escolares, cuadros estadísticos, preparación de exámenes y pruebas 
fundación de las cátedras un compendio accesible y de rápida consulta mediante paralelos didácticos político-literarios, que, si constituye un signo de los valores que integran la concepción de un lector culto y moderno - abierto a un horizonte cultural más amplio—, no pretende renunciar por ello - como tampoco lo hizo la magna empresa de Eichhorn - al proyecto totalizador de coordinar una Historia General de las literaturas, abarcadora de la historia del espíritu humano a través de las diversas lenguas y literaturas nacionales. Jarry declaraba que esta aportación pretendía subsanar la omisión de la literatura española — pese a la importancia de la obra latina de Nicolás Antonio- en antecesores como Bossuet o el Atlas historique de Lesage, y citaba como estudios de referencia inexcusable la historia del P. Andrés, la muy elogiada de Bouterwek y, tras él, su epígono Sismondi. De este modo, el «Tableau historique de la littérature espagnole, en Europe et en Amérique», ${ }^{569}$ a cargo de Ferdinand Denis, ${ }^{570}$ presenta las

de acceso del alumnado, Jarry de Mancy (1796-1862), como otros colegas suyos en sus respectivas disciplinas, aplicaba a esta parcela de estudio en expansión el método sinóptico adoptado por el conde de Las Cases para exponer los componentes de la historia política y genealógica de las distintas naciones.

569 Inserto en Histoires des littératures étrangères, n. ${ }^{\circ}$ XII. Incluye datos estadísticos sobre el número de alumnos de las universidades españolas en 1826, un listado de autores arábigo-españoles, la nomenclatura de los principales autores de la Península y de las repúblicas americanas, así como de jesuitas célebres y de miembros de la Real Academia de la Historia. En este resumen los siglos XV y XVI constituyen la Edad de Oro bajo los reinados de los Reyes Católicos, Carlos V y Felipe II; en cambio, ante el penoso estado político y literario contemporáneo, carente de sustancia, su regeneración parece inspirar poca confianza al redactor, al punto de considerar como único interés literario la aportación futura de las provincias independizadas.

570 Jean-Ferdinand Denis (1798-1890), polígrafo y estudioso de los dialectos orientales y de la cultura peninsular y americana, además de escribir obras de ficción y novelas románticas como Ismael Ben-Kaizar (1829), abordó temas muy diversos. Apasionado de los viajes, en 1816 visitó Hispanoamérica —en especial Argentina y Brasil, donde recopiló abundante material para escribir una historia completa del imperio y de otras regiones del sur del continente- - A su regreso a Francia lo editó antes de partir de nuevo, esta vez hacia Portugal y España. En 1838 fue nombrado bibliotecario del ministerio de Instrucción Pública, en 1841 conservador de la Biblioteca de Sainte Geneviève y en 1865 sucedió a Brotonne como su administrador. Aparte de sus Chroniques chevaleresques de l'Espagne et du Portugal (París, 1839) y una celebrada traducción del Romancero Español en 4 tomos, el resto de títulos apunta a campos de estudio muy variados como las ciencias naturales, resúmenes sobre la historia de la cultura y la literatura de Portugal y de Brasil, estudios sobre las ciencias ocultas, ensayos e incluso un manual bibliográfico, así como numerosas colaboraciones en revistas, compilaciones y diccionarios. Véanse, por ejemplo, la Nouvelle Biographie Générale (t. XIII, 1866, pp. 638-641) o el Grand Larousse Universel du XIX siècle (t. 6, p. 139). 
mismas divisiones que en el resto de casos junto con una ojeada («coupd'œil») al decurso histórico de su literatura, un esbozo de cronología comparada política y literaria y una bibliografía selecta. En la década siguiente, la compilación recopilatoria Littératures du Midi (Italie, Espagne et Portugal) ${ }^{571}$ de otro normalien, Émile Lefranc, ${ }^{572}$ amparada ya por la expansión del estudio de lenguas extranjeras en la universidad francesa, también dedica su segunda parte a la literatura española. Dirigida a los estudiantes y gens $d u$ monde que solían acudir a las clases magistrales, esta obra está concebida a modo de complemento auxiliar de las lecciones ex cathedra. Antiguo colega de Jarry de Mancy, cuyo Atlas tiene en cuenta, Lefranc lleva a cabo una labor de taracea ensamblando abundantes fragmentos — a menudo literales, si no con leves alteraciones - de textos autorizados como principalmente $e^{573}$ la traducción francesa de Bouterwek — de quien toma la periodización, ${ }^{574}$

571 París-Lyon, Librairie Classique de Perisse frères, 1843 (en rojo aparece consignada la fecha de 1842). Este volumen formaba parte de una obra más extensa, Histoire élémentaire et critique de la littérature, renfermant, outre des détails biographiques et des considérations générales sur les auteurs, l'examen analytique de leurs principaux ouvrages, avec deux tables, l'une des matières, et l'autre des auteurs; par M. Émile Lefranc, auteur d'un cours d'histoire, et de plusieurs autres ouvrages relatifs à l'enseignement de la jeunesse (1838-44). La obra, concebida como manual didáctico dirigido a los jóvenes estudiantes y a los lectores cultos («résumé de tout ce qui a été écrit de meilleur sur ces deux matières»), abarcaba las distintas literaturas europeas establecidas de acuerdo con la inveterada división geográfica Norte-Sur.

572 Divulgador de extensa experiencia editora, publicó numerosas obras escolares dirigidas a la enseñanza primaria y secundaria, a instituciones femeninas y comunidades docentes religiosas. Sus compilaciones abarcan un vasto campo temático: mementos metodológicos, memorias y premios académicos, bibliotecas, traducciones del griego, gramáticas, ediciones de la Biblia y de autores grecolatinos, cuadros cronológicos, selecciones de máximas, o ensayos sobre la educación obrera. Antiguo profesor de lengua latina del duque de Burdeos y del duque de Berry, y más tarde agregado universitario, también editó resúmenes de historia moderna, geografía, arte, filosofía y compendios de historias de literaturas nacionales.

573 Pese a la nutrida bibliografía de consulta que ofrece en anexo, son escasas sus fuentes referenciales directas. También recurre con cierta frecuencia al Tableau de la littérature au moyen-âge de Villemain y a su Essai sur Pindare, que insertaba asimismo la traducción de la oda de Fray Luis «En la Ascensión»; y remite a los Études littéraires de Gruice (chez Périsse frères) que incluía también traducciones de Herrera, del fabulista Iriarte o, por ejemplo, la «Oda a las estrellas» de Meléndez Valdés.

574 En los tres grandes períodos, de extensión y atención desigual, segmentados en secciones didácticas bien compartimentadas por siglos y géneros: el dilatadísimo (711-1516) «De la invasión de los árabes hasta Carlos V»; «De la Casa de Austria hasta el advenimiento de la Casa de Borbón (1516-1701)»; y «De la llegada de los Borbones hasta la actualidad (1701-1821)», en realidad, veinte años antes de la edición de la obra. Lefranc añade algunos autores de fines del XVIII como Masdeu, Llorente, Conde o Muñoz a los mencionados en las historias precedentes, ya aludidos por Maury en sus preliminares, sin introducir las generaciones contemporáneas. 
conceptos, juicios, divisiones didácticas u organización genérica, injertando en los subgéneros prosísticos una sección de "littérature mêlée» que agrupa textos eclesiásticos, historias y memorias- y secundariamente la edición de Sismondi con sus añadidos al anterior en el período final y cierta huella clasicista. El manual, parcelado pormenorizadamente en secciones también introducidas por resúmenes históricos preliminares, se cierra con los esperanzados votos acostumbrados por el recobramiento de la antigua gloria literaria gracias a las buenas ediciones modernas de sus ilustres maestros de «l'âge d'or».

\subsubsection{Literaturas paralelas: Adolphe de Puibusque}

Al calor del comparatismo que comienza a prosperar en la primera mitad del siglo XIX destaca por sus repercusiones la historia comparada de las literaturas española y francesa ${ }^{575}$ —en entredicho, no obstante, por críticos como Brunetière a fines de siglo- de Adolphe-Louis de Puibusque (París, 1801-1863), ${ }^{576}$ publicada bajo los auspicios de la Academia Francesa el mismo año que la recapitulación de Lefranc. Apoyada por las instituciones culturales y políticas, ${ }^{577}$ esta laureada y extensa disertación

575 Histoire comparée des littératures espagnole et française, París, chez G.-A. Dentu, imprimeur-libraire, 1843 , en $8 .^{\circ}$.

576 Hijo del vizconde de Puibusque, administrador militar y escritor, el joven Adolphe ocupó temporalmente el cargo de subprefecto bajo la Restauración antes de dedicarse a la literatura: Poemas premiados en academias de provincias; numerosos artículos en diversas publicaciones periódicas como Le Plutarque français, la Revue du Midi, el Recueil des jeunes personnes; e incursiones eruditas en el examen de la administración municipal (véase Larousse, 1875 , t. 13, pp. 402-403). Aunque se contaba con alguna reescritura en el XVIII, según documenta, por ejemplo, F. Ramos Ortega (art. cit., p. 31), es de Puibusque la primera traducción íntegra al francés de El conde Lucanor en 1854, a cuyo corpus añadió otra historia, una de las más dramáticas, suministrada al traductor por Ticknor: De ce qui advint à don Lorenzo Suarès Gallinato lorsqu'il décapita un prêtre rénégat (el exemplo XXVIII «De lo que contesció a don Llorenço Suárez Gallinato»).

577 En el prólogo a la publicación Abel-François Villemain (1790-1870), aún ministro de Instrucción Pública y secretario perpetuo de la Academia desde 1834, proclama, relevando a Sismondi, la necesidad de un análisis global de ambas culturas, a partir del estudio de sus rasgos originales respectivos, a fin de examinar "sur quel point le génie français a été temporairement modifié par un autre plus grave et moins exact peut-être». $\mathrm{Al}$ igual que asume la nacionalidad literaria española, tierra aún virgen para la exploración crítica ("ce côté du Midi moins classique et moins romain que l'Italie et dans lequel ils croyaient pouvoir saluer avec reconnaissance une hâtive aurore, une révélation anticipée de l'é- 
nacionalista en torno al tema propuesto ("Quelle a été sur la littérature française, au commencement du dix-septième siècle, l'influence de la littérature espagnole?») cumple directrices tales como la fidelidad a valores atemporales como el buen gusto, la imitación de la naturaleza, la razón, el comedimiento, la naturalidad, la verdad y la belleza como objetos de la poesía, proscribiendo la desviación estética — como el cultismo, identificado con la heterodoxia maldita - que liga al descarrío moral, ${ }^{578}$ a través de las sucesivas fases históricas. A partir de un amplio repertorio de fuentes comunes a las historias como consta en su bibliografía, ${ }^{579}$ su acerca-

cole nommé plus tard romantique»), exalta la cualidad distintiva de la francesa. Como hiciera Stapfer en su presentación de Bouterwek al público francés, rastrea la nacionalidad española desde los tiempos de Lucano y Séneca a través de una serie de rasgos particulares e intemporales ya asentados en la interpretación crítica de esta literatura que insisten en su carácter oriental y la apartan de la influencia clasicista italiana («originalité indépendante, forme d'imagination, goût: dès le moyen âge, elle montra son tour particulier de génie méridional, sa gravité, sa pompe, et cette ardeur plus orientale qu'enflammait encore le belliqueux contact et le mélange d'une population et d'un culte apportés d'Afrique et d'Asie»). Tras reconocer que el redescubrimiento español de las últimas décadas estuvo marcado por la reacción contra la supremacía francesa, Villemain considera que ya no es tiempo de limitarse a cotejos puntuales que midan autores como Calderón y Racine, y postula, a través de su elogio de la obra de Puibusque, un estudio concienzudo y ponderado de la literatura vecina, equidistante de las restricciones de críticos franceses y la excesiva, a su juicio, admiración de otros extranjeros.

578 Como afirma en su conclusión: «Au milieu de divers rapprochemens que nous avons essayés, le principal parallèle, celui du seizième siècle espagnol et du dix-septième siècle français, ne nous a pas fait voir seulement l'abaissement d'une littérature et l'élévation de l'autre, mais cette lutte constante du vrai et du faux qui est, à l'ordre intellectuel, ce que la lutte du mal et du bien est à l'ordre moral» (t. II, p. 343).

579 Entre las numerosas fuentes a que alude en sus apéndices el autor, cabe destacar, además de la impronta de Bouterwek, las obras de Schlegel, Sismondi y lord Holland, el ensayo de Malmontais bajo anonimato, el muy citado Tesoro de Quintana, la atendida antología de Maury y su estudio preliminar, los textos de Marchena y Capmany, el estudio histórico de Moratín, reeditado por la Real Academia y en 1838 por Ochoa; referencias puntuales al padre Andrés, Signorelli, N. Antonio, Blankenburg, Mayans; ediciones de autores españoles como, por ejemplo, las Obras de Luis de Granada por L. Muñoz (Madrid, Ibarra, 1788), las de fray Luis de León por el P. Merino, el repertorio teatral cervantino por Nasarre, el estudio de V. de los Ríos en su edición del Quijote, o las colecciones de Ramón Fernández en su edición de 1808 y de Sánchez en la reedición de Ochoa; testimonios específicos de un período abordado como los de Rojas Villandrando o las referencias del padre Nidhard sobre la vida teatral del XVII, o más recientemente el tratado de C. Pellicer; así como entre los franceses, relatos de viajes como el de Mme d'Aulnoy, conocidos juicios de Voltaire o de Florian, hasta traducciones de Germond de Lavigne y los respetados ensayos de Magnin y Villemain. 
miento a la literatura española se funda en su utilidad para el examen especular de la propia literatura francesa («nous n'irons recueillir les exemples étrangers que pour les ranger sous les principes nationaux, et pour en tirer une application qui nous soit utile», t. I, p. 10). Su principio estructurador estriba así en el cotejo diacrónico entre dos lenguas, dos literaturas y dos genios nacionales paralelos, y en su relación con la buena doctrina estética, desde sus respectivos orígenes, su culminación en un momento sincrónico de su devenir —el difuso Siglo de Oro español, a caballo entre el XVI y el período de los tres Felipes, y el Grand Siècle-, vértice de mayor perfección tras un largo y trabajoso proceso formativo («c'est de leur apogée, comme d'un point culminant, que notre regard doit embrasser toute l'action de ces influences intellectuelles», p. 2) y el diverso alcance respectivo de sus influencias alternantes. Al mismo tiempo Puibusque difunde exitosamente un canon ya consagrado a principios del XIX de autores españoles y, en la estela de la conciliación sismondiana, retoma en su narración histórica, apostillada en el anexo final, el comparatismo de Villemain al servicio de un reforzado Volksgeist ${ }^{580}$ («En étudiant le génie espagnol dans toutes ses expressions, vous pourrez suivre l'histoire de l'Espagne dans toutes ses phases», t. I, p. 92); adopta los fundamentos de Bouterwek en sus principales conceptos, clasificaciones y antimonias, periodización y marbetes, material, enjuiciamientos y predilecciones ${ }^{581} \mathrm{y}$, como Sismondi,

580 Sus reflexiones reflejan arraigados topoi sobre los caracteres nacionales. Por ejemplo, censura las licencias dramáticas españolas a propósito del cultivo de la tragedia y su adecuación a un tiempo y lugar concretos frente a la abstracción universal en la que cree Puibusque: «en Espagne, pays d'assimilation violente la tragédie n'avait que cette alternative, se transformer ou périr; en France, où l'on a et plus de propension et plus d'aptitude à imiter, la tragédie pouvait, en s'animant d'un intérêt nouveau, prendre sans péril une figure grecque ou romaine» (t. I, p. 239).

581 Así, Puibusque acentúa las dicotomías entre la originalidad del fondo herderiano, de fuerte huella oriental, y la artificiosidad de las composiciones cultas que vetea esta literatura desde los denostados cancioneros del XV hasta la condena de Góngora y sus epígonos; acata las divisiones en escuelas y grupos poéticos y teatrales y aborda el XVIII conforme a la oposición general entre dos sistemas; asume diversos topoi sobre el ser nacional español en su devenir, desde la afirmación del celo religioso como aglutinante contra el enemigo común, la gravedad y moralidad de obras representativas, el descuido de la verosimilitud, la tendencia a la fantasía, la caballerosidad y el honor, o la boga de la poesía, cuyo prestigio creció protegido por la nación, coincidiendo en parte con las reflexiones de Bouterwek y Quintana, en lugar de contar con un apoyo institucional como en Francia, proclamada desde el XVII nación literaria (véase M. Fumaroli, Trois institutions...); subraya aún más, en su evaluación de los derroteros pasados y presentes de la literatura española, el dile- 
hace acopio de ejemplos menos frecuentados, dispone más traducciones y asume varios de sus apuntes histórico-sociológicos, ${ }^{582}$ a los que superpone su fidelidad a principios universales de raigambre clasicista.

Más que al análisis autónomo de la literatura española esta disertación - inmersa a su vez en el período de forja del concepto de clasicidad con que se inviste a su siglo XVII— ${ }^{583}$ está fundamentalmente orientada a la reivindicación de la nacionalidad literaria francesa, a partir del paralelismo privilegiado en su etapa histórica de máximo apogeo político y literario con una reconocida literatura original como su vecina del sur. Puibusque encabeza su introducción con una cita de Plinio (epístola VII, 9) en defensa de la imitatio («L'imitation de choses excellentes en fait trouver de sem-

ma entre regeneración o imitación, innovación y copia, escollos particulares en los que zozobran a su juicio los autores españoles («Ils [los poetas del XVI] étaient donc menacés de perdre en originalité ce qu'ils gagneraient en correction; ils avaient à craindre ou de tomber dans l'imitation des nationaux, la plus servile et la plus improductive de toutes, lorsqu'elle ne s'attache qu'aux formes, ou de se fourvoyer en cherchant des routes nouvelles, t. I, p. 255); acude a un mismo repertorio de anécdotas y textos conocidos, que también amplía respecto a su referente, y coincide con varios de sus juicios, como el rechazo a los romans de chevalerie, tachados igualmente de extravagantes, o a la decepcionante épica, o la falta de originalidad y de aceptación de sus poéticas; y hereda preferencias como, por ejemplo, su elogio de El conde Lucanor — la mejor obra del siglo XIV en la Península por su respeto a la razón y el buen gusto, y de mayor moralidad que los fabliaux franceses-, del que escoge el exemplo XX («Ce qui advint à un roi, par le fait d'un homme qui s'était présenté à lui comme alchimiste», subtitulado por el crítico "Avertissement donné aux dupes», del que traduce además las coplas finales).

582 Por ejemplo, sus veredictos críticos sobre los gobernantes españoles; su afirmación de que la literatura nacional se forma en el período anterior al despotismo ("Mais Quintana croit-il donc que les fortunes littéraires se font aussi vite que les fortunes politiques? Oublie-t-il que Charles-Quint, entouré d'une cour militaire et flamande, toujours en guerre ou en voyage, sans enthousiasme, si ce n'est peut-être pour l'Italie, parce que François I en était idolâtre, aurait plutôt tué que vivifié la poésie nationale, si le mouvement n’avait été donné avant lui par les mains toutes espagnoles d'Isabelle et de Ximenès?» (t. I, pp. 137138); o sus reacciones censorias a la poesía pastoril española — pese a los alabados méritos de Montemayor, Gil Polo y de La Galatea cervantina-, presentada como una parodia platónica y campestre propicia para la evasión, y mendaz y hueca al alejarse del idilio y de la égloga por derroteros estéticos erróneos («La pastorale n'avait été qu’un mensonge dans l'Europe entière, dès qu'elle s'était écartée de la naïveté de l'idylle et de l'églogue: partout le bel-esprit, raffiné par Marini, Gongora ou Voiture, avait forcé l'invraisemblance par l'exagération du romanesque», t. I, p. 329).

583 Véase sobre este particular H. Stenzel, «La construcción de épocas clásicas en las literaturas francesa y alemana», en L. Romero Tobar (ed.), Historia literaria..., 2004, pp. 189-208. 
blables») como emulación razonable y necesaria para el progreso de las culturas sin menoscabo de su singularidad, que discierne los modelos apropiados bajo la guía del arte y el buen gusto. En esta cualidad de juiciosa discriminación, asimilación y recreación de fuentes diversas, dirigida por guías ilustres nutridos de clasicismo, ${ }^{584}$ se asentaría el carácter distintivo y original de la literatura francesa. Sus alabanzas — aun sin restar muchos méritos a la literatura meridional de referencia en un esfuerzo de contemporización_- ${ }^{55}$ se dirigen a los fautores de la identidad francesa, respetuosos de los verdaderos fines ético-estéticos, frente a la práctica española, cuya nacionalidad radica en el genuino fondo popular de origen medieval y no en una categoría clásica comparable a las grandes obras del parnaso francés, como demuestran, por ejemplo, parte de los autores del XVIII, imitadores de modelos "plus nombreux que choisis». De este modo, si Bouterwek realzaba la calidad de las obras españolas frente al yugo clasicista impuesto desde Francia, Puibusque defiende su patrimonio nacional disintiendo rotundamente del comedido cotejo del alemán entre la ingenuidad (nä̈veté) sin arte de don Juan Manuel y la ingeniosa del maestro Lafontaine, al que mantiene en la cúspide del canon en este género — aún estimado un tiempo en el XIX en ediciones, traducciones y publicaciones periodísticas—; o, más aún, vindicando su independización del repertorio teatral español —analizado en función de su influencia— ${ }^{586}$ con la exalta-

584 «En racontant les périls de notre nationalité littéraire, nous aurons donc à signaler à la reconnaissance publique ces esprits inébranlables, ces talens incorruptibles qui nous ont servi de digues, et qui ont su féconder notre littérature en utilisant jusquau limon déposé sur nos rives» (t. I, p. 9).

585 Puibusque preconiza una suerte de equilibrio o justo medio al dirimir las deudas respectivas. Si desacredita el desdén de Montesquieu en sus Lettres persanes o las concesiones de Voltaire a favor de Diamante sobre Guillén de Castro, sin embargo, su condescendencia con la vehemencia - ya corregida por Moratín u Ochoa- de polemistas del XVIII como Nasarre y Huerta por su patriotismo no atañe a estudiosos como el padre Andrés y lord Holland («interprètes passionnés des préjugés italiens et anglais»), a los que, como su prologuista Villemain, acusa de parcialidad al rebajar los méritos del teatro francés, para solo concederles que las cualidades genuinas del teatro español no son comunicables a las escenas extranjeras.

586 En sus apéndices el crítico inserta diversas referencias acerca del ascendiente español en Francia desde las obras de Antonio Pérez, recuperado por Chasles en la Revue des Deux Mondes, hasta apuntes sobre episodios culturales como las giras teatrales en el séquito principesco, y traducciones, versiones y recreaciones dramáticas por autores como Quinault, Montfleury, Hauteroche, Dancourt o Lesage. 
ción nacional de un Molière original, que encarna la verdadera comicidad al fundir la representación de las costumbres de su siglo y país con la ejemplaridad universal. Piedra de toque en los cotejos de pasajes entre ambas dramaturgias — por ejemplo, su versión de El burlador de Sevilla atribuido a Tirso, conocido en Francia principalmente por la relectura del primero-y genio de la estirpe de Shakespeare, Alfieri, Schiller o Calderón, no es en cambio con este último ${ }^{587}$ —en retroceso tras la exaltación de Schlegel sin por ello izar tampoco a Lope-, sino con el Cervantes novelista ("toujours vrai sans cesser d'être comique») con quien se le empareja y en quien ve cumplidas las pautas clasicistas. ${ }^{588}$

La obra está articulada en tres grandes partes conforme a la periodización histórico-literaria vigente alternando el examen de una y otra literatura: la primera abarca los siglos anteriores al XVII y comprende un esbozo comparativo de la historia de ambas lenguas y el análisis del carácter distintivo de sus literaturas al paso de la observación de sus influencias recíprocas medievales y su asimilación del renacimiento del XIV. Esta revisión se bifurca en sus trayectorias respectivas ${ }^{589}$ al abordar el ascendiente italiano sobre el desarrollo de los géneros literarios, enmarcado en la atmósfera cultural de su época, de corta pero feliz duración en España, y la «Renaissance classique» del XVI. La segunda parte abraza un amplio período a partir del siglo XVII, en torno a un Cervantes firmemente asen-

587 Contemporáneo de otros autores como Enciso, Pedro Rosete, Rojas, Diamante, Salazar, Tirso y Solís, además de la inevitable alusión a sus autos sacramentales, de él se citan entre su variada producción en diversos géneros, por ejemplo, El príncipe constante, o las comedias Guárdate del agua mansa (Gardez-vous de l'eau qui dort), o No hay burlas con el amor (On ne badine pas avec l'Amour).

588 «toutes les qualités, qu'on admire dans son Don Quichotte sont justement celles que le théâtre n'avait pas: le naturel, le bon sens, la mesure» (t. I, p. 298).

589 En equilibrio con el primero, el segundo volumen está dedicado a la literatura francesa desde el siglo XVII hasta principios del XIX. Puibusque aborda primero la penetración de la influencia española a través de tres vías: la corte en el contexto de la Liga, el ascendiente del Hôtel de Rambouillet y el teatro — desde las primeras imitaciones del teatro español en la escena francesa y la reacción corneliana hasta la reforma de la comedia francesa con la irrupción de Molière y su imitación del teatro antiguo y del contemporáneo italiano y español—. Después de tratar los comienzos de la hegemonía francesa, en el curso del XVIII se refiere a Lesage, Florian y Beaumarchais así como a las tentativas de independencia de las literaturas fronterizas como la española, inglesa y alemana, y las aportaciones de Mme de Staël y de Chateaubriand antes de cerrar su revisión en los primeros años de su siglo con un breve inventario de autores. 
tado en el centro del canon —como Molière en el francés-, seguidor de la verdad y la belleza en sus obras, reformador de la lengua, ejemplo de estilo comparable a Pascal y a los prestigiosos Saavedra Fajardo y Solís; ${ }^{590}$ y, como en Stapfer, guía crítico sin relevo al que también se le reprocha no haber enderezado el rumbo del teatro español. ${ }^{591}$ A este primer independiente ${ }^{592}$ suceden aquellas personalidades de singular talento reconocido

590 «le seul [Cervantes] qui opéra sur la prose espagnole un travail analogue à l'œuvre de Pascal sur la prose française; il faut suivre long-temps sa trace pour trouver, dans le domaine des écrivains, deux types de genres: Diégo de Saavedra, le plus grand homme du règne de Philippe IV, et Antonio de Solis, le seul grand homme du règne de Charles II" (t. I, p. 322).

591 Puibusque cita entre sus entremeses («intermèdes») La Garde embarrassante (La guarda cuidadosa) y Les Deux Bavards (Los habladores), que en su opinión hubieran podido proporcionar materia para dos comedias.

592 El capítulo VII del estudio le está dedicado exclusivamente: en primer lugar, su Quijote lo consagra como creador de la novela cómica y moral al haber fundido los dos extremos, antes tratados separadamente, de héroes caballerescos (preux) y pícaros (fripons), y cuyo legado retoman el novelista W. Scott y Molière («légataire universel de tous les génies comiques»). Puibusque defiende la obra de las críticas suspicaces que, como la de Florán diez años antes, le reprochaban que ridiculizara a su nación («dans aucun cas un poète national n'aurait pu se décider à livrer les preux au ridicule; les commentateurs qui ont attribué cette pensée impie à Cervantes, sont tombés dans une erreur grossière», t. I, pp. 286-287). Definida como sátira que combina a su juicio el divertimento jocoso con cierta bonhomía, se alaban asimismo la moralidad de sus burlas, la armonía y unidad del conjunto, la paulatina influencia recíproca de sus protagonistas - un loco cuerdo, Alonso Quijano, entusiasta confundido de época; y un sensato Sancho que se deja arrastrar por los sueños y la locura de su amo-, la rica variedad y concordancia de tonos y lenguajes y la verdad de su tratamiento - remitiendo como ejemplo en sus anexos al reciente análisis médico de Antonio Hernández Morejón (Bellezas de medicina práctica descubiertas en el Ingenioso Caballero Don Quijote de la Mancha, Madrid, Tomás Jordán, 1836), género de documentaciones entonces ya en boga- De sus Nouvelles, caracterizadas por el talento inventivo, la naturalidad y verosimilitud generales de su composición, su moralidad y excelente estilo, y cercanas, a su juicio, a la estructura de los dramas contemporáneos y que inserta en la tradición de predecesores como el Patrañuelo y los fabliaux en la línea del Decamerón y de los Cuentos de Chaucer, escoge por el patetismo de las situaciones y la poeticidad de sus caracteres, pese a sus imperfecciones, L'Estramadurien jaloux, La Servante célèbre y La Gitanille de Madrid (corregido a lápiz, de Séville). La incursión cervantina en el género bucólico aún recibe los sufragios del estudioso, quien afirma la calidad de las poesías incluidas y constata principalmente el gran éxito de la versión y añadidos de Florian - acerbamente criticados por Viardot y algunos bibliógrafos- en su Galatée, roman pastoral, imité de Cervantes (París, Didot l'aîné, 1783, 1. ${ }^{a}$ ed.), que la difundió en el extranjero, a su vez traducida al español por Casiano Pellicer (La Galatea de Miguel de Cervantes, imitada, compendiada, concluida; trad. del francés..., Perpiñán, Alzine, 1817, 1824; y Burdeos, Lawalle jeune, 1824) (Quérard, ob. cit., t. II). Finalmente Puibusque también traduce algún trozo del Voyage au Parnasse, como el pasaje del navío alegórico. 
—Lope y Quevedo a la cabeza, Góngora, Gracián y los cultistas - cuya rebeldía de las reglas no es menos condenada por Puibusque, además de acometer la comparación entre ambas dramaturgias desde la «école antique» teatral ${ }^{593}$ española hasta la primacía de la «école nationale». La tercera parte recorre la centuria siguiente hasta principios de su siglo tomando como modelos a Cienfuegos, Quintana y en especial a Martínez de la Rosa, cuya fama en Francia lleva al crítico a proclamarlo «le guide qui manque à l'Espagne» (t. II, p. 515).

La periodización global de su acercamiento a la literatura española hace resaltar dos grandes períodos: el ciclo de Juan II desde Alfonso X, a cuyo progreso contribuye poderosamente Francia, y el ciclo de los tres Felipes, durante el cual la rival transpirenaica emerge como potencia influyendo posteriormente sobre su modelo en el XVIII. De este modo, tras la reconocida influencia italiana, que habría moderado su imaginación desbordante, Puibusque subraya el trascendental ascendiente francés, más intelectual, que habría guiado el razonamiento autocrítico. Asimismo, en su aproximación a la literatura medieval española, también rebaja la importancia en el desarrollo cultural europeo de dos fuentes prestigiosas - la escuela griega, que acusa de corruptora de la enseñanza religiosa, y, desvinculándose de ciertas teorías de los españoles, la escuela árabe, que habría degradado la enseñanza filosófica- Como sus predecesores, el crítico alaba la poesía heroica y censura las extravagancias de la novela caballeresca y las alegorías. Su favor hacia la poesía romántica entendida a la

593 Además de remitir al estudio de Moratín a propósito de sus orígenes religiosos y primeros pasos, y a fuentes ya aludidas sobre el período prelopista como Signorelli, y sobre la vida teatral y sus condiciones materiales en su tiempo de esplendor a extractos de Rojas Villandrando, Quiñones de Benavente o Pellicer, Puibusque considera a los poetas castellanos del XIV y XV los padres del teatro. El crítico se atiene a los hitos de costumbre: en tanto precursora de la escuela nacional, La Celestina, monstruosa pero fascinante, elogiada por el trazado de ciertos caracteres, el dramatismo de varias escenas como, por ejemplo, la despedida de Melibea de su familia («Pour apprécier à sa juste valeur la force dramatique du bachelier Ferdinand de Rojas, si l'on comparait les deux faces les plus opposées de son œuvre, le pathétique et le burlesque, on trouverait autant de verve et de naturel d'un côté que de l'autre», t. I, p. 198); y entre sus imitadores, a falta aún de un verdadero teatro, señala a Timoneda, Torres Naharro, Castillejo, la experimentación con lo maravilloso de Alonso de la Vega y Gil Vicente, los ensayos de Juan de la Cueva, o el mejor de todos ellos - por su sencillez, división de estilos y decoro, pese a ciertas inverosimilitudes_- Lope de Rueda, del que traduce pasajes de su paso Las aceitunas. 
manera schlegeliana, como verdadera expresión del carácter nacional en España, se manifiesta a lo largo de la disertación en su enfoque de obras como el Cantar de Mio Cid, accesible en la reedición de Ochoa, ${ }^{594}$ los apólogos, las sátiras, el romancero — como el celebrado romance del conde Alarcos, presumible inspiración, a su juicio, del dramático de Blanca de Borbón-, ciertos pasajes de Juan Ruiz o del Laberinto, o las crónicas, ${ }^{595}$

594 En 1843 este crítico ya disponía de la edición anotada del cantar que Ochoa publicó en París en 1842 (Colección de los mejores autores españoles antiguos y modernos, París, Baudry), reimpresión de la obra de Sánchez, ampliada con la continuación de Pedro José Pidal.

595 El repertorio sucinto heredado de Bouterwek será progresivamente ampliado en Francia con aportaciones como la heterogénea antología de J.-F. Denis (Chroniques chevaleresques de l'Espagne et du Portugal suivies du Tisserand de Ségovie, París, Ledoyen, 1839), que incluía además la traducción de un drama de Ruiz de Alarcón. Su variada selección peninsular, tomada principalmente de las compilaciones cronísticas de Alfonso el Sabio, F. Lopes, Ayala, Alcocer, Duarte Nunes de Liam, Hierónimo Mendoza, Bernardino de Sahagún o el cronista del valido castellano don Álvaro de Luna, se adentra asimismo en el siglo XVI con cartas, discursos, crónicas de Indias y textos de diverso género. Los pasajes traducidos redundaban en la opinión general en torno a rasgos distintivos de la recreación romántica como la energía y pasión de caracteres, e incluso la rudeza y crueldad, la valentía en la batalla, la gravedad religiosa, la pervivencia del sentimiento caballeresco. Del siglo X se incluye Les Sept Infans de Lara, a partir de la crónica alfonsina (pp. 1-28); del XI, Sainte Casilda. Légende espagnole, sacada de la Historia o descripción de la Imperial Cibdad de Toledo... por P. de Alcocer (1551); del XII, La Prise d'Évora, tomada de la Crónica de Cister de fray Bernardo de Brito; del XIII, Le Mauvais Roi et bon vassal, de la Primeira parte das crónicas dos Reis de Portugal... (Cr. de D. Sancho II) (1774) de Nunes de Liam; sobre sucesos del XIV tratan varios textos (Histoire de Dona Constança Manuel, tomada de la Crónica de el Rey Dom Alfonso o quarto... de Ruy de Pina (1653); y en especial la Chronique d'Inez de Castro surnommée Port de Héron, en la redacción de Fernan Lopes del siglo XVI, o La garza de Portugal. Véritable récit où l'on rapporte l'histoire lamentable de dona Inez de Castro, surnommée Port de Héron. Romance Espagnole, así como fragmentos de poesías del rey don Pedro, todo ello acompañado de notas y de otro texto, Les Amours d'un fils d'Inez de Castro; de la corte castellana Denis reproduce los pasajes relativos a María de Padilla, al maestre de Santiago y a la reina Blanca de Borbón tomados de la crónica de Ayala; del siglo XV introduce el romance del conde Alarcos y de la infanta Solisa, alabados por Mme de Staël y Grimm, así como la Histoire véritable de Damoiselle Théodor, conte espagnol; La mort d'Albayaldos tomada de la Historia de las guerras civiles de Granada de G. Pérez de Hita, un extracto de la Historia y topografía de Argel de Diego de Haedo que contenía el pasaje Barberousse et le Sultan Sélim Entemi, y un fragmento ("Le premier jour de la traite à Lagos, royaume des Algarves») de la crónica del condestable don Álvaro de Luna, elogiado como político; del XVI espiga trozos misceláneos sobre la conquista de Cortés («Chronique traditionnelle»), "Le naufrage de Sepúlveda et de dona Lianor de Sa» («une chronique et un poème»), la carta de Pedro Vas de Camina sobre el descubrimiento de Brasil, un fragmento de «La mort du roi Sébastien, suivie des Malheurs de la belle Virginie» así como «Le rénégat et la juive, chronique portugaise». 
señas todas ellas de un linaje popular ${ }^{596}$ perpetuado en su teatro del XVII como ya había recordado Sismondi. Puibusque refuerza, por ejemplo, la interpretación nacionalista y religiosa del cantar de gesta —en cuya huella musulmana insiste así como en su realismo-, que culmina en el triunfo cristiano como constaba ya en Viardot («c'est une victoire de la croix sur le croissant, c'est enfin l'Espagne chrétienne personnifiée dans le plus illustre et le plus populaire de ses guerriers», Études, p. 118). Sin embargo, la tenaz resistencia de los enjuiciamientos franceses — pese a este último y a Florána su reconocimiento artístico mantiene - como a una gran parte de la producción española en su diacronía - su condición de testimonio histórico, fijado en el pasado y sin una ejemplaridad sugerente y perdurable. ${ }^{597} \mathrm{Su}$ contundente rechazo a la llamada escuela del artificio, que abarca las composiciones de Berceo — también relegado a una nota junto a su inventario-, descritas como Légendes en edificante prosa versificada a fin de despertar la piedad antes que crear poesía, ${ }^{598}$ no alcanza, sin embargo, íntegramente a otras obras que pese a sus imperfecciones reflejan la ingenuidad literaria de los orígenes y la representatividad del ser español: por ejemplo, la imponente compilación dirigida por Alfonso X; el Poema de Alexandre —atribuido

596 «'Espagne est le pays de l'Europe qui a cultivé ce fonds précieux avec le plus de constance. Tandis qu’à la surface de sa poésie brillaient des fleurs exotiques, transplantées avec plus ou moins de bonheur, les apologues, les satires, les romances, les chroniques continuaient à peindre les mœurs, le caractère, l'esprit castillan; et bien que le cours de ces expressions populaires ait été plus d'une fois obscurci, il n'a jamais été interrompu» (t. I, pp. 69-70).

597 Aunque Puibusque disiente de la severidad de Quintana en su juicio del cantar, coincide con él en achacar en cierta medida sus imperfecciones al estado aún informe de su lengua, y reclama el mérito de la inventio sobre los escasos datos de la historia, la fuerza de su expresión épica, y la naturalidad de diversos cuadros y situaciones. Asimismo, también selecciona pasajes emocionantes como el destierro del héroe, la muy elogiada despedida en San Pedro de Cardeña, comparable según Quintana a la de Héctor y Andrómaca, o la entrada en Burgos y el episodio de la niña, también apreciados por Villemain en sus lecciones públicas; o en el canto II, las bodas y el juicio de Dios, cuya transición, en cambio, juzga demasiado abrupta. Igualmente, añade algún ejemplo de la épica renacentista sobre la materia cidiana como Los famosos y heroicos hechos del invencible caballero el Cid Ruy Díaz de Bivar en octava rima de Ximénez de Ayllón (Alcalá de Henares, 1568, 1579).

598 No obstante, el crítico se permite, a imagen de Sismondi, una limitada concesión cuando apunta cierta audacia poética («lorsqu'il ne traîne pas sur un texte, par exemple dans son introduction aux miracles de la Vierge, il laisse échapper des éclairs d'imagination, et son vers en s'élévant devient plus harmonieux. Par malheur, ces éclairs-là sont rares, et le rythme dont il fait usage alourdit beaucoup sa marche», t. I, p. 377). 
entonces a Lorenzo Segura y rescatado por Sánchez a indicaciones de Cerdá- por su valor documental, color local, ambicioso plan e inventio, vasta erudición y ortodoxia, a pesar de su censurada medievalización del héroe griego, su monotonía y un abigarrado ensamblaje de fuentes francesas y orientales («traditions incohérentes de l'Asie et de l'Afrique, surchargées d'ornemens européens par des mains françaises», t. I, p. 42); o el poema del arcipreste de Hita, sátira híbrida e indigesta, destinada al regocijo antes que a la corrección moral, que, si bien viola reglas básicas como la unidad y el decoro, logra expresar las costumbres nacionales en algunas escenas aisladas, apólogos y retratos. ${ }^{599}$ Como Sismondi, Puibusque critica severamente la poesía culta y minoritaria de la llamada segunda edad de ambas literaturas, abundante en moralidades, poemas alegóricos y hagiografías, por su imitación indiscriminada y excesiva de modelos foráneos. La consideración de que gozaban diversos autores en las historias y estudios de principios de siglo ha seguido decayendo: si bien Villena — cuya poética juzga análoga a la de Molinier - conserva cierto prestigio como mecenas de las literaturas castellana y catalana, Santillana - aunque genuino poeta desaprovechado por su tendencia a las alegorías, a excepción de versos populares como sus serranillas, en particular la famosa Vaquera de la Finojosa - es derrocado como oráculo del buen gusto de su tiempo, y ve un tanto mermada su autoridad como sabio erudito y traductor. Tanto él como Mena - cuyo Laberinto, salvo varios pasajes de rigor de reconocido carácter nacional, es criticado duramente por errores compositivos como la sustitución de la Providencia por la Fatalidad en tanto causa que rige los destinos de los personajes, o la escasa acción que sostiene un andamiaje de oscuras y pedantes abstracciones - son superados, con matices, por «les chants patriotiques de Manrique $^{600}$ et les tableaux agrestes du bachelier de la Torre». Ante escollos como

599 A la vez que alaba el lirismo del poeta y retoma su vieja analogía con Rabelais, Puibusque atenúa el rigor de su crítica a la moralidad de la obra — de la que traduce, entre otros, fragmentos del prólogo y la disputa entre el griego y el romano-, al considerarla como fruto de una sociedad joven aún no corrompida.

600 Con todo, aun aceptando que descuellan en la literatura de su tiempo, las coplas manriqueñas tampoco suscitan su plena aprobación: «offrent à l'analyse une homélie plutôt qu'une élégie; des lieux communs sur la vie et la mort y sont revêtus d'un style noble, et profondément empreints de cette tristesse religieuse qui pénètre l'âme. C'est un ouvrage d'une pureté sans exemple au quinzième siècle. Ce n'est pas un chef-d'œuvre; des inutilités, des longueurs en affaiblissent l'effet, et l'on est choqué, à chaque strophe, du désaccord que présentent la gravité des pensées et le sautillement du ryhtme» (t. I, p. 139). 
la degeneración de las ideas caballerescas «si propres à l'imagination", por ejemplo en el Amadís, o la moda cortesana de juegos de ingenio como los recopilados por Baena ${ }^{601}$ o Villasandino, Puibusque juzga al igual que Florán que la nacionalidad no podía resurgir más que de una reacción contra la escuela trovadoresca, que tacha de influencia dañina frente a las alabanzas ya lejanas de Malmontais. El crítico asienta este enjuiciamiento adverso respecto a los cancioneros en su errónea y corruptora concepción de la poesía como una ciencia combinatoria que produce ejercicios retóricos vacíos de sentimiento, disquisiciones amorosas que deifican a la mujer entregándola a las zozobras de la pasión, y torneos intelectuales que mezclan temas religiosos y profanos, oscilando de manera discordante entre la contención y la licencia, entre la ardorosa declaración amorosa y las blasfemias poéticas a ambos lados de los Pirineos. ${ }^{602}$ Así pues, la necesaria regeneración —consumada en Italia en el XIV, en España en el XVI y en Francia en el XVII- debía proceder del estudio de los bienvenidos modelos italianos — sobre los que los autores españoles se impondrán pese a sus defectos- y de la Antigüedad. Si Puibusque ratifica su hegemonía mundial, una vez conquistada la unidad política bajo el signo de una sola literatura, una sola lengua, una sola Iglesia y un solo Imperio, adelantándose a Francia, también reitera varios topoi como su orgullosa resistencia proverbial a recibir asistencia extranjera. En esa fase trascendental del XVI ${ }^{603}$ destacan como

601 Este cancionero sería editado por Ochoa en 1851 (Madrid, Imprenta de la Publicidad, a cargo de M. Rivadeneyra) con un estudio preliminar del marqués de Pidal.

602 Si bien Puibusque tacha el período final del medievo de fuegos fatuos, incluye el repertorio habitual de obras y autores: además de referirse a las composiciones poéticas de F. Imperial, se remonta a las crónicas de López de Ayala — calificadas de diario más que de historia en su acostumbrada comparación con Joinville-, Gutierre de Gámez, Gómez de Ciudad Real, Pérez de Guzmán, o el artificio visible de H. del Pulgar; y las composiciones de Mena, Manrique, A. de la Torre en el idilio y la égloga, R. Cota, a quien se atribuían, entre otras, las Coplas de Mingo Revulgo, y Encina cierran la literatura de esta etapa. Mientras, el lema de Alain Chartier ("À Dieu l'autel, au Roi le trône, aux Français la France») lo eleva al rango de poeta nacional a ojos del crítico.

603 Aunque reconoce el mérito histórico de Boscán y sus rasgos nacionales, no deja de apuntar sus incorrecciones («Toujours Castillan par l'expression passionnée, par l'image et même par l'hyperbole, il ne se montre qu'à demi Italien par l'adoucissement du rythme et la parure des vers», t. I, pp. 141-142). En cambio, la preeminencia de Garcilaso - de quien elige un pasaje de la primera égloga por su melancolía, ingenuidad y frescura ( Elisa y los cabellos que me has dado") — permanece intacta así como argumentos aducidos por Bouterwek tales como su retorno al carácter primitivo de la pastoral tras el ensayo dramático de Encina, o la fusión garcilasiana de metros como el soneto elegíaco de Petrarca, la oda erótica de Horacio, o los tercetos y octavas italianos. 
iniciadores Boscán, Garcilaso como admirado poeta clásico, y tras sus huellas Hernando de Acuña, Gutierre de Cetina, Hurtado de Mendoza, Francisco de la Torre, Saa de Miranda, Montemayor, fray Luis de León — muy elogiado por su "Profecía del Tajo" y sus odas morales, y del que traduce pasajes de sus églogas y su prólogo-, o Herrera, cuyas odas de inspiración bíblica exalta. ${ }^{604} \mathrm{El}$ poema épico de Ercilla, ejemplo frustrado de lucha entre las dos escuelas en liza - la antigua que cree observar en los primeros cantos y la toscana que afirma encontrar en los últimos-, sobresale, sin embargo - pese a los reproches de costumbre a los que suma su fallida recreación del color local frente al cantar de gesta y los poemas medievales del Alexandre y del Laberinto-, por su tono severo, la evocación original de parajes o el trazado de caracteres como la aguerrida Glaura. En cuanto a la prosa, nacida en este período sin grandes modelos anteriores según la opinión entonces mayoritaria, además de tratar de los historiadores - destacando un lúcido Mariana sobre la aridez retórica de los importantes Zúniga, Ocampo, Zurita, Morales o Mendoza y el estilo florido del renombrado Solís-, los novelistas ${ }^{605}$ y los autores de filosofía y moral como el Diálogo de la dignidad del hombre o la polémica apología de Las Casas, también aborda los buenos ejemplos de elocuencia sagrada de «l'école spiritualiste» ${ }^{606}$ como fray Luis de Granada — con un fragmento de la

604 Entre sus obras más nombradas desde el XVIII, Puibusque alaba sus odas de inspiración bíblica y de exaltación patriótica como la "Canción en alabanza de la divina majestad por la victoria del señor Don Juan de Austria» — de la que traduce un pasaje y cuyas imágenes serán retomadas por poetas posteriores como Jáuregui o Meléndez-, así como la "Oda al sueño» o la dedicada al «Infortunio del rey don Sebastián». Consideradas el relevo de Fray Luis, sus composiciones evocan en el crítico las vibraciones de un inmenso órgano por la grandeza de su temática y la flexibilidad de su estilo.

605 Tras los precedentes de Timoneda con su Patrañuelo, Montemayor o Gil Polo, además de las novelas cervantinas, las de Pérez de Montalbán, o las aún depreciadas de María de Zayas y de Mariana de Carvajal, motejadas de metafísica galante, Puibusque incluye entre las obras del goût picaresque — novelas satíricas en las que no reconoce su fuerte moralismo en favor del divertimento-, aparte del Lazarillo, el Guzmán de Mateo Alemán, o la novela de Vicente Espinel, el Don Pablos, y Le Diable boiteux. En contrapartida, resta valor a los hoy reconocidos barrocos franceses como Scarron hasta el Gil Blas de Lesage, que, si supera a Espinel, no conjuga los caracteres representativos de los protagonistas del Quijote.

606 «La partie la plus noble et la plus utile de la prose, celle qui comprend l'éloquence, la morale, la critique, exigeait les mêmes tempéramens que l'instruction religieuse: ils la disposèrent à la modération; c'était la préparer au bon goût» (t. I, p. 184). 
Introducción al simbolo de la fe-, fray Luis de León, Santa Teresa con su famoso soneto ya traducido por Maury, y sin el entusiasmo de Viardot, un san Juan de la $\mathrm{Cruz}^{607}$ que conforma con los dos anteriores y los prosistas Diego de Estella, Malón de Chaide o F. de Zárate la literatura mística de este período.

Entre las escuelas de la etapa siguiente el magisterio de los Argensola —más apreciados que en Quintana en virtud de su acción de diqueclausura la de los clásicos, encabezando el bando en que se integran los ya conocidos Figueroa, Gil Polo, Espinosa, Barahona, Espinel, Balbuena, Arguijo, el traductor Jáuregui o el aclamado Villegas, cuyos experimentos métricos en sus anacreónticas y cantilenas — como "Del pajarillo», "La abeja en el rosal» o "La lucha del amor», no superadas por Iglesias, Cadalso o Meléndez Valdés y muy gustadas aún por la juventud moderna salvo leves defectos- suscitan reparos semejantes a los anotados por Maury. Frustradas en el teatro y la épica, y arruinadas en poesía por su didacticismo, estas sanas doctrinas quedaron en desventaja ante la anarquía literaria de los llamados independientes, entre los que se condena irremisiblemente el gongorismo difundido por su fundador - despojado incluso de las cualidades habitualmente reconocidas («un de ces versificateurs sans inspiration, qui ne s'attachent qu'à l'élégance de la forme», t. II, p. 356), al punto de atribuir el talento admitido de sus romances moriscos a la poeticidad inherente al subgénero, y que esconde la nulidad de su pensamiento bajo una premeditada oscuridad estilística- y sus principales seguidores como Villamediana, Paravicino y finalmente Gracián, cuya obra constituye el epitafio de la literatura del XVII. No obstante, al frente del grupo poético de disidentes de toda norma Puibusque celebra el genio poético de Quevedo, cuya extremosidad también deplora («s'attaquant aux imperfections de la nature humaine, au lieu de faire la guerre aux vices de l'homme social, il dépassa le but de toute morale utile»). Así y

607 Frente a una mayor aceptación de Viardot, este poeta, más docto en el dogma que tocado por la inspiración poética, solo comparte con la fundadora carmelita, a ojos de Puibusque, el celo reformista: «Un carmélite déchaussé, San Juan de la Croix, quoique mieux guindé dans les profondeurs du dogme, ne réussit pas à en faire sortir de plus éloquentes révélations. Il avait pu s'associer aux habitudes contemplatives de Sainte-Thérèse, en l'aidant à réformer le couvent d'Avila, mais il ne ressentit ni les émotions de la femme ni les ravissemens de la Sainte, et il ne fit qu'une version élégante des ardens dialogues qu'elle improvisait en conversant avec les anges» (t. I, pp. 269-270). 
todo, de entre la amplitud y variedad de géneros que cultivó en prosa y verso - de los que escoge por ejemplo el romance «le Malencontreux», ya publicado por Maury («Pariome adrede mi madre»)—, vindica sus sueños y textos morales en prosa, ${ }^{608}$ cuyo difícil desciframiento los ha relegado en la estima y divulgación de su obra.

La primacía de las normas clásicas en su concepción de los géneros teatrales se ejemplifica en el teatro francés del Grand Siècle y el italiano, ${ }^{609}$ frente a las divergentes propuestas españolas e inglesas, desarrolladas a su libre albedrío a partir de su origen medieval, y adscritas a sus respectivas idiosincrasias nacionales, la fe meridional y el escepticismo del Norte. Partidario de la sencillez y verosimilitud de diálogos, situaciones y caracteres, tomados del natural y elevados al rango de lo universal, Puibusque no solo no discute los reproches comúnmente lanzados a las obras dramáticas españolas como novelas dialogadas por su rebeldía contra las unidades, el decoro, la vedada mezcla de temática religiosa y profana, o la división genérica radical, sino que condena su error al haberse apartado de las fuentes clásicas de autoridad y magisterio supremos. Renovado su estatus de creador del teatro vecino, Lope sigue provocando una crítica relativamente reticente que lo consagra ante todo como intérprete de las pulsiones de la sociedad española por tomar «sa nation telle qu'elle est, telle qu'au fond elle a toujours été, ardente, curieuse, passionnée, exaltée, avide surtout de sensations vives, et facile aux grandes émotions» (t. I, p. 326). Indudable genio poético («le plus heureux des poètes espagnols») y nacional como Calderón, Puibusque lo celebra por su remozamiento del romancero y por la sencillez y naturalidad de sus letrillas, que, como en el poema "Filomène», le ganaron la admiración de Cadalso. Aunque el disertante francés — aun admitiendo la irregularidad de su producción y achacando sus defectos a su épocasuaviza el rigor de Quintana y recoge el haz de características de su producción cómica, sancionada en un presuroso Nouvel Art Dramatique — como cierta sencillez, extroversión e inmoralidad y color local—, no por

608 «C'est ce qui explique pourquoi les œuvres morales de Quévedo, naguère si lues et vantées, sont tombées maintenant dans un abandon très-voisin de l'oubli» (t. I, p. 231). Como Quintana, también recuerda a su seguidor, el poeta e historiador Melo.

609 "Les théâtres de France et d'Italie, au contraire, formés dès leur début sur les modèles de l'antiquité, se sont astreints à des règles fixes, et ont aspiré à l'homogénéité qui les distingue» (t. I, p. 317). 
ello deja de afirmar, en resumidas cuentas, que el aprecio que puede suscitar se funda principalmente en algunas de sus obras aisladas. ${ }^{610}$

Con el correr del siglo se había ido cumpliendo al fin el deseo de Velázquez, quien lamentaba el truncamiento del proyecto de Nasarre, pues de "publicar juntas las Comedias escogidas de este [de Francisco de Roxas], y otros Comicos nuestros con la correspondiente analisis, y Critica sobre cada una de ellas en particular, nada tendríamos oi que desear sobre este asumpto» (ob. cit., p. 118). Además de la recapitulación en el anexo final ${ }^{611}$ de los dramaturgos más o menos conocidos junto a los más célebres bajo el período de los tres Felipes, Puibusque se extiende en su segundo tomo en cotejos textuales de varias de estas fuentes españolas con sus contemporáneos del otro lado de los Pirineos. Si bien observa los originales españoles de sus modelos consagrados como un Guillén de Castro — de escenas alabadas por su fuerza y acompañadas de extractos traducidos y comentados- y un regular Moreto - el más irreprochable en estilo natural pese al visible trabajo de lima - con su insoslayable El desdén con el desdén ("parmi les quatre meilleures comédies du répertoire castillan»), ${ }^{612}$ también se hace eco progresivamente de la rehabilitación en España de autores y repertorios hasta entonces menos nombrados en entradas bibliográficas, como un apreciado Rojas Zorrilla con su monárquico García del Castañar, un Ruiz de Alarcón ${ }^{613}$ ya

610 Puibusque menciona diversas obras suyas como, por ejemplo, La Prude amoureuse (La discreta enamorada), Prodiges du dédain (Los milagros del desprecio), La Prude difficile (La Dama melindrosa), La Belle laide (La hermosa fea), Le Chien du jardinier (El perro del hortelano) o también L'Acier de Madrid (El acero de Madrid).

611 Así, se menta a los habituales Candamo, Cañizares o Zamora, a cuyos repertorios de costumbre se añaden algunas obras más, junto a Góngora, Mira de Amescua, Quevedo o Monroy, entre otros menos conocidos.

612 Además de esta obra, elogiada por su indagación psicológica — no obstante cierta reticencia ante el protagonismo del gracioso, que rige la intriga frente a la heroína imponiéndose sobre un indeciso don Carlos, o el rechazo a las habituales injerencias jocosas-, el crítico también cita El lindo don Diego, No puede ser guardar una mujer (On ne peut garder une femme), la comedia de espectáculo Le Roi vaillant et justicier, ejemplo del contraste entre lo patético y lo burlesco del drama del XVII, tan gustada en España por sus grandes efectos, junto a otras veteranas en las historias como De fuera vendrá..., aún estimada por la originalidad y verosimilitud, pese a ciertos excesos, de sus caracteres.

613 Conocida fuente del Menteur de Corneille por su Verdad sospechosa, reivindicado en la Francia del XIX por Chasles desde las páginas de la Revue de Paris, traducido por Denis y adaptado por Lucas, Ruiz de Alarcón es incorporado al canon de dramaturgos españoles del XVII en antologías y manuales decimonónicos. Su tendencia a una mayor regularidad canónica en la sencillez del plan, la moralidad de las situaciones y el perfil de sus caracteres le granjearon una notable estima entre los críticos. 
redescubierto en Francia, y en especial un Tirso de Molina a cuyo ingreso atiende con notable pormenor. Incluido por la crítica actual en la escuela lopesca, de este último dramaturgo — silenciado por Signorelli y Sismondi, mencionado sumariamente por Bouterwek, relegado por Blankenburg, celebrado por Lista y Ochoa, registrado en Viardot, recuperado editorialmente por Hartzenbusch, ${ }^{614}$ y traducido en las décadas siguientes por Royer, Monet o Gassier - suele mencionarse en las historias su colección teatral, ${ }^{615}$ compuesta por partes añadidas con varios años de intervalo - y entre las que destaca sobre todo el enredo de La Dévote amoureuse (Marta la piadosa) y Le Damné pour n'avoir pas eu foi (El condenado por desconfiado), a la altura esta, a su juicio, de los mejores autos sacramentales de Calderón-, mientras que sus novelas eran de más difícil acceso.

Rozando el ecuador del siglo, Puibusque valora grandemente el influjo salutífero de la literatura francesa ${ }^{616}$ en la España del XVIII y su papel mediador en la comunicación de culturas ajenas. En comunidad de material y juicios con Bouterwek y Sismondi, asume la división de esa centuria

614 Tras la publicación del Teatro escogido de Fray Gabriel Téllez (Madrid, Yenes, 183942, 12 vols.), su mismo editor sacaría a la luz pública las Comedias escogidas de Fray Gabriel Téllez (Madrid, Rivadeneyra, 1848). Las traducciones de sus obras engrosan colecciones de la segunda mitad del siglo como las editadas en 1854 por Charles Potuin de El burlador de Sevilla, la obra más conocida de sus adaptaciones y versiones extranjeras, en Le Séducteur de Séville (Bruselas, Libr. Aug. Pagny, 1854) o la selección de Royer, que incluía Le Séducteur de Séville et le convive de pierre, La Sagesse d'une fermme, La Paysanne de Vallécas, Le Damné pour manque de foi, Don Gil aux chausses vertes.

615 Aparte de esa principal fuente de consulta sobre este autor, dado el mal estado de los trozos conservados en la Bibliothèque Royale, los estudiosos recurrían también a los fragmentos biográficos de Montalbán. De entre la pluralidad de subgéneros que cultivó Tirso, Puibusque enaltece sus dramas religiosos como El burlador, que declara superior en profundidad metafísica, estructura y caracteres a un monótono, enredado y caricaturesco No hay deuda que no se pague y el convidado de piedra de Zamora; apunta su predilección por la psicología femenina y elogia su talento cómico, su fina observación, musicalidad y brillantez formal, que antepone en sus comedias de costumbres a la moralidad requerida - como, por ejemplo, en la maliciosa La Dévote amoureuse (Marta la piadosa), modelo retomado por Moratín en La mojigata - y en ocasiones a la coherencia interna -como en los inverosímiles enredos de El amor médico-; asimismo, ejemplifica sus obras históricas con la impactante La Sagesse d'une femme, y con la trilogía inspirada en el triunfo, muerte y apoteosis de Pizarro (Todo es dar en una cosa, Amazonas en las Indias, La lealtad contra la envidia).

616 «Si l'école française ne régénera point la littérature castillane, elle en facilita la régénération de deux manières: d'abord, en arrêtant le mauvais goût; puis, en excitant une émulation nationale» (t. II, p. 302). 
en dos bandos o escuelas, nacionalistas y gallicistes, a propósito de la reforma alentada por los principios franceses. En nombre de un justo medio Puibusque denuncia, por un lado, el anacronismo flagrante de los que como García de la Huerta — nuevo Castillejo que se habría abstenido de atacar a su respectivo Boscán colmando de críticas a los franceses y a sus imitadores españoles - pretendían resucitar la España del XVI «sans tenir compte ni du changement des mœurs, ni de la tendance des idées, ni de leur insuffisance personnelle» (p. 305); ${ }^{617}$ y, por el otro, la sumisión a ejemplos foráneos de sus contrarios - como las traducciones de dramas lacrimosos de La Chaussée por Luzán, los intentos de reproducir la regularidad francesa por Montiano o la elegancia formal por Velázquez, por ejemplo-, cuya carencia de obras maestras modélicas Puibusque sentencia con un retruécano («on avait eu du génie sans goût, on n’avait plus du goût sans génie», p. 306). Así pues, la centuria se habría saldado, a su entender, con una "trop courte renaissance», sostenida por la corte de los primeros Borbones - que alcanzó, no obstante, su mayor intensidad durante el gobierno de Carlos III con prohombres reputados como Carvajal, Floridablanca, Campomanes, Gálvez, Aranda, o un Jovellanos del que solo menciona su comedia lacrimosa El delincuente honrado, rebajada a una traducción del Honnête criminel de Fenouillot de Falbaire-, pero al fin, como ya repararan Bouterwek o Stapfer, descabezada de un rector de gran talento y autoridad semejante a Metastasio. En esta tensión subyacente entre la parcialidad por la originalidad nacional y el respeto a los beneficios de la influencia francesa, Puibusque sale también en defensa de la «école française» del XVIII — período predominante en estudios y progreso metódico conforme a la opinión general- ${ }^{618}$ ante la crítica españo-

617 «il avait pour auxiliaires les vieux poètes endurcis dans leurs préventions, les jeunes écrivains qu'exaltait leur patriotisme, et la multitude qui s'indignait d'être accusée d'ignorance» (t. II, p. 304).

618 En el seno de la tertulia de la condesa de Lemos, sede de la Academia poética del Buen gusto, que vincula al ejemplo de los salones parisinos, destaca la claridad, elegancia y observancia de los principios aristotélicos en la Poética de Luzán; la teorización y práctica de Montiano en el cultivo de tragedias conformes a las reglas respetadas por Racine; el Deucalión del conde de Torrepalma o las églogas de Porcel, tan alabadas en su tiempo por Velázquez. Asimismo, subraya el abundante flujo de traducciones de modelos franceses como Voltaire, Molière o Corneille en el curso del siglo, y menciona a los recurrentes padre Isla, elogiado por su originalidad y fino ingenio, Iglesias de la Casa, ya presentado por Maury, o Nicolás Fernández de Moratín, entre otros. 
la contemporánea proclamando el españolismo de autores formados en el molde francés. ${ }^{619}$ Pese a esta vindicación sesgada en nombre del ascendiente francés y la preservación de sus buenos modelos, se aprecia ya cierto reajuste en la estima por algunos escritores de ese período: si se mantienen las alabanzas al patriotismo del ilustre Mayans, la variedad genérica de Iriarte, ${ }^{620}$ el buen gusto de Cadalso, más apreciado como poeta y satírico que como ensayista, ${ }^{621}$ o las buenas piezas dramáticas de un contradictorio García de la Huerta por su Raquel de temática nacionalista y su traducción de la Zaïre volteriana, la admiración hacia Meléndez Valdés es ya más moderada, ${ }^{622}$ el mérito incontestable de Moratín como reformador en la historia dramática española ${ }^{623}$ se impone sobre su calidad artística al definirlo como discípulo de Molière, y la originalidad de los alabados sai-

619 «Et le doux Meléndez, et le sage Quintana, et l'ingénieux Yriarte sont-ils moins bons Castillans que les Fey-Joo, les Isla, les Iglesias, les Arriaza, parce qu'ils sont à la fois élégans et tempérés, pleins de lucidité, d'harmonie et de raison?» (t. II, p. 307).

620 Puibusque ejemplifica su producción desde sus comedias — como su juvenil Hacer lo que hacemos (1770) y otras piezas originales mencionadas en historias-, su conocido poema a la música - que había logrado la aprobación de Bouterwek por su plan y su estilo, pese a encontrarlo, como el crítico francés, "trop peu poétique et trop didactique»—, sus traducciones del francés y del latín — como su versión del Arte poética horaciana, tan atacada por Sedano en el contexto de las polémicas de su tiempo-; y sobre todo sus Fables littéraires (1782), que gozaron de tanto éxito en Europa aún en las primeras décadas del XIX, en ediciones independientes o como cierre de repertorios ajenos o misceláneas como, por ejemplo, la dispuesta por Alea (Quérard, ob. cit., p. 16) La Juventud ilustrada, o las virtudes y los vicios, obra traducida del francés de Mma. Dufresnoy; seguida de algunas Fábulas de Yriarte, Lyon, Cormon et Blanc, 1827.

621 Sus ineludibles Cartas marruecas (en el texto principal tituladas erróneamente Lettres Mexicaines) siguen rebajadas, como en Maury, a una débil imitación de Montesquieu; así como su tragedia clásica Sancho García no pasa de ser un intento fallido. Sin embargo, Los eruditos a la violeta (Les Érudits à la fleur d'orange, o Érudits à la violette) de 1771 constituyen, en su opinión, su mejor imitación de la sátira volteriana; y en sus poemas Loisirs de ma jeunesse, poésies lyriques (Ocios de mi juventud o poesías líricas) advierte su filiación con la respetada tradición literaria de Villegas reavivando la poesía anacreóntica en su siglo.

622 «on a reconnu que Meléndez avait moins d'originalité et de force que de grâce, de douceur et de pureté. Elève de l'école française, il a reproduit aussi quelques beautés de Pope et de Thompson; il y a dans ses odes et dans ses romances le même charme que dans ses églogues» (t. II, p. 497).

623 "Que sont auprès de lui ses plus célèbres devanciers, les Candamo, les Zamora, les Cañizarès?» (t. II, p. 307). Además de sus estudios eruditos, Puibusque menciona su primera comedia, Le Vieillard et la jeune fille y en especial Le Café de 1792 ("satire très vive du dérèglement de l'art dramatique, et des extravagances auxquelles se livraient tous les imitateurs des drames étrangers», t. II, p. 501). 
netes de Ramón de la Cruz —editados ese año por Durán—— ${ }^{624}$ es atribuida por Puibusque no solo a la herencia de Lope de Rueda y Cervantes, sino también a la formación del autor en el provechoso estudio del venerado comediógrafo francés ( $\mathrm{N}^{\prime} y$ reconnaît-on pas mieux les mœurs espagnoles que dans les anciennes comédies de figurón?»). Ante la abundancia de obras recientes en el umbral del siglo entrante Bouterwek ya había delegado el estudio más pormenorizado de los contemporáneos en investigadores posteriores, ${ }^{625}$ remitiendo asimismo a bibliografías que se van incrementado paulatinamente en manuales como el de Lefranc o al abrigo de las reseñas periodísticas. Sin embargo, de la nueva producción Puibusque selecciona los esfuerzos de Álvarez de Cienfuegos —en particular su prosa, superior a sus correctas obras dramáticas como Zoraida, La condesa de Castilla y sobre todo Idomeneo-, un muy elogiado Quintana - como crítico por su prólogo al Tesoro del Parnaso («excellent morceau d'histoire littéraire et de critique»), poeta de calidad y dramaturgo con su conocido Pelayo, bella tragedia que considera imitación de Lewis- y su respetado Martínez de la Rosa. Aunque no parece muy al tanto de la actualidad literaria española y de su experimentación y alcances, el dictamen final de Puibusque insiste en su desorientación ("Alternativement trompée par ses apologistes, ou découragée par ses détracteurs, la littérature espagnole est sortie de la bonne route, et n'a pu y rentrer», t. II, p. 350), debida principalmente, a su entender, a la intransigencia de los principios alternativamente asumidos. Si la bienhechora influencia francesa — que frenó los desmanes del cultismo y restableció el buen gusto- no es suficiente por sí sola para sacar adelante a la postrada civilización espa-

624 Colección de los sainetes, tanto impresos como inéditos de D. Ramón de la Cruz, con discurso preliminar de D. Agustín Durán, y los juicios críticos de los señores Martínez de la Rosa, Signorelli, Moratín y Hartzenbusch, Madrid, Yenes, 1843, 2 vols. Desdeñado por Signorelli, mencionado sin gran simpatía por Malmontais y citado con mayor interés por Bouterwek y Sismondi, Ramón de la Cruz es elevado en el curso del siglo a la categoría de representante del sentir nacional por sus recreaciones del costumbrismo popular madrileño, y mencionado en la prensa cultural española en el curso del XIX. Habiendo apuntado su aprendizaje en los buenos modelos franceses, Puibusque lo convierte también en el importador del vaudeville en España, e incluso distingue ecos del humor "gaulois» en sus sainetes.

625 «Il faut laisser à d'autres écrivains plus à portée de connaître les productions récentes de la littérature espagnole, le soin de nommer tous les autres poètes qui se sont distingués dans les dix dernières années du dix-huitième siècle» (ob. cit., t. II, pp. 240-241). 
ñola, Puibusque da un consejo reiterado por otros críticos españoles y franceses de la época cuando declara sus deseos de una pronta recuperación literaria —ya no lograda, por tanto, en el XVIII— ( (C'est en associant l'esprit de perfectionnement soutenu par Luzan à l'esprit de nationalité défendu par La Huerta, qu'elle [España] préparera une renaissance digne de son ancienne splendeur», t. II, p. 350). En suma, preconiza la depuración de rasgos distintivos nacionales - como el sentimiento de la pasión y el orientalismo, reminiscencia a menudo inoportuna de los tiempos caballerescos como apuntaba Sismondi frente a la defensa más comedida de Bouterwek-, en equilibrio con los buenos modelos («Puisse-t-elle [España], sans dédaigner les dons du commerce étranger, se souvenir que ses plus riches trésors sont dans les veines de son territoire», p. 351). Fuente regeneradora y sacrosanta ${ }^{626}$ que exige entrega completa y preserva de la decadencia, como subraya en su alegato («nous ne demandons pas qu'on soit de son pays de langage seulement; il faut en être d'esprit et de cœur», t. II, p. 354), el culto a la nacionalidad rige la argumentación del crítico. Su estudio militantemente francés propone una solución de compromiso a la problemática ausencia de una literatura nacional —es decir, popular, de acuerdo con las teorías entonces en vigor-, condición que será nuevamente puesta en tela de juicio por Taine años más tarde. ${ }^{627}$ Así pues, Puibusque asume, por una parte, las directrices clasicistas de la Academia, que exalta la grandeza inmarcesible de los autores del Grand Siècle; y, por otra, el comparatismo de su valedor Villemain, al servicio de la originalidad de la más clásica de las literaturas europeas por su resistencia a las desviaciones del gusto y por su capacidad de selección y asimilación fundada en la imitatio, al tiempo que apela al viejo e inalienable «esprit gaulois». La posición geográfica de Francia en el seno de la civilización occidental («au milieu de cet inmense cercle de peuples attentifs, la France, debout comme un phare, recevant et renvoyant la lumière de l'Orient à l'Occi-

626 «Naturelle et sainte pour les littératures comme pour les États, la nationalité est le faisceau qui unit toutes les forces intellectuelles et morales d'un peuple; elle se forme d'un ensemble de conditions et de circonstances spéciales; origine, position, mœurs, tout, jusqu'au climat, influe sur son caractère, et la frappe d'une marque distinctive. Mais, quels que soient les types nationaux, malheur aux littératures qui les méconnaissent ou les altèrent!» (t. II, p. 354).

627 Su indagación lleva a M. Espagne a afirmar a propósito de este período: «Au pays du classicisme, la sociologie tient lieu de littérature nationale» (ob. cit., p. 268). 
dent, et saluée par toutes les voix du nom de nation missionnaire!», t. II, p. 357) sirve, por tanto, de argumento para un misoneísmo proferido como un mandamiento que impele a sus lectores franceses a cumplir las expectativas de sus instituciones a fin de intensificar los intercambios culturales, la sociabilidad y la cultura a través del cauce francés y de su ejemplo.

\subsection{En el meridiano del siglo: recepciones de Ticknor en Francia}

Editada en el filo de la década siguiente a este estudio francés que exaltaba ambas nacionalidades literarias en paralelo, la historia de la literatura española publicada en el siglo XIX que reúne prácticamente todos los sufragios de la crítica — adelantándose a la monumental del español Amador de los Ríos - es la documentada History of Spanish Literature (Londres/Nueva York, 1849) del americano George Ticknor (1791-1871). Decisivas ambas en la radicalización de la actitud anti-francesa en España y la sanción definitiva de la idea de espiritu nacional, ${ }^{628}$ la segunda, en cambio, no siempre se granjeó el aplauso de la crítica francesa, que le escatimó en ocasiones su condición de verdadera historia de la literatura. ${ }^{629}$

628 L. Romero Tobar, «Algunas consideraciones del canon literario durante el siglo XIX», art. cit., p. 14.

629 Historia critica de la literatura española, 1861-67 (7 vols.). Más tardía, aunque bien conocida y apreciada por su exhaustividad, la obra de Amador de los Ríos, respetado anotador de Sismondi y autor de mencionadas obras históricas — algunas de las cuales como sus Estudios sobre los judios (1848) fueron traducidas-, suscitó ciertas reticencias entre algunos críticos franceses. El primer tomo (1861) de su Historia había sido reseñado con detalle en la Revue Britannique por A. de Latour ("Correspondance d'Espagne. A. M. le directeur de la Revue Britannique. Don José Amador de los Ríos. (Histoire critique de la littérature espagnole)", agosto de 1862, pp. 451-468). Latour elogia su rigor y erudición y advierte su eclecticismo en torno a las dos corrientes que recorren la literatura española, en particular, su poesía («celle de l'inspiration originale, nationale, spontanée, populaire, énergique et naïve, et celle de la tradition gréco-latine, modifiée suivant les temps et les circonstances et par les influences qui lui arrivent du dehors, de la France ou de l'Italie»); con todo, echa en falta la mención de otros estudiosos como A. Pichot, Böhl de Faber o Maury, discute algún detalle y le aconseja finalmente un estilo menos oratorio y grandilocuente. En cambio, Baret, nacionalista francés irritado por 
Deudora de los estudiosos precedentes, fruto de años de trabajo parsimonioso y de meticulosa recopilación de fuentes primarias asesorada por alemanes — Julius y Wolf - y españoles — Böhl, por ejemplo, gracias a la mediación tal vez de W. Irving, o el joven Gayangos, su corresponsal, proveedor de fondos bibliográficos y temprano cotraductor en España-, la historia de Ticknor recogió críticas mayoritariamente favorables y mereció los honores de la traducción divulgativa, ${ }^{630}$ a cargo del experimentado

el tono del español, en su severo comentario por extenso de 1875 (art. cit. «Observations...») muestra su incomprensión global ante la obra, como ya apuntó Romero Tobar (art. cit., El Gnomo, 1996). Baret vuelve en contra de Ríos — que tacha de receloso y veladamente mezquino en sus puntillosas apostillas a los deslices de Ticknor- su reproche de falta de unidad matriz en la historia del americano, acusando a su vez al español - amparado en las teorías de raigambre alemana- del defecto capital de carecer de un verdadero juicio crítico: no solo en su partidismo católico, ciegamente sometido a los dictados ortodoxos de la Iglesia, o su enfoque misoneísta de las doctrinas esencialistas de religión y patria — defendidas sin la contención de Ticknor-, sino también al confundir arqueología y literatura viendo arte por doquier y sin discriminación («Pour nous qui, avec tous les maîtres, n'admettons en littérature qu'un art unique, celui qui réussit à produire le beau, et qui croyons reconnaître le beau littéraire à ce trait particulier d'exprimer en langage parfait des vérités éternelles sur Dieu, sur l'homme ou sur la nature, nous éprouvons quelque difficulté à comprendre le système de M. de los Rios», p. 46). A su juicio, Ríos también flaquea en su cometido frente a la envergadura de la historia del americano, por su menor aportación documental novedosa — como el poema «insignifiant" Les rois mages, la localización del manuscrito de la Crónica en coplas de Alfonso $X I$, o la ampliación de datos sobre los Bocados de oro-, y por haber adoptado un estilo impropio de la imparcialidad de un historiador, a ratos entre el tedioso de las memorias y el declamatorio y airado de la polémica. Su planteamiento a la hora de trazar la historia de la civilización española a través de su arte literaria también provoca disentimientos en Baret: asumiendo que la verdadera España, cristiana y moderna, nace del medievo, discute la preeminencia otorgada por Ríos a la herencia latina —echando además en falta que no hubiera indagado en los orígenes iberos- frente a la influencia musulmana, y vindica el ascendiente de una más rica literatura francesa. Tannenberg, más moderado, reproducirá varios de los juicios transmitidos por estudiosos consultados en su edición de 1903 (p. 155) cuando señala que su inconclusa historia, imponente por sus proporciones y su valiosísima documentación, deja que desear por su método, según le aseguran, afirma, así como por su estilo ("d'une boursouflure intolérable»), del que puede juzgar.

$630 \mathrm{Su}$ autoridad se ve refrendada asimismo por su traducción al español bajo la responsabilidad de Pascual de Gayangos y de Enrique de Vedia (Historia de la literatura española, traducida al castellano con adiciones y notas criticas por ...), Madrid, Imprenta y Estereotipia de M. Rivadeneyra, 1851-56; Bailly-Baillière, 1851), muy tenida en cuenta en la traducción francesa (Histoire de la littérature espagnole de G. Ticknor... traduite de l'anglais en français pour la première fois, avec les notes et additions des commentateurs espagnols D. Pascal de Gayangos et D. Henri de Vedia, París, Hachette/Durand, 1864-72, 3 vols. en $8 .^{\circ}$ ). 
Joseph-Germain Magnabal (1819-1894). ${ }^{631}$ Incorporada como referencia de autoridad a las principales bibliografías de la época, aun así no siempre suscitó rendidos aplausos en todos los estudiosos o aficionados franceses, respetuosos, sin embargo, de la virtud innegable, pero de doble filo, de su minuciosa erudición. La breve mención elogiosa ${ }^{632}$ del germanista SaintRené Taillandier en su reseña de 1854 a propósito del estado de la investigación hispanista se ve secundada por una corta referencia de aprecio de Baret en su susceptible examen de Amador de los Ríos, sobre el que proclama - tras el forzoso reconocimiento de su mérito- la superioridad del americano como primer historiador de la literatura española — por encima de Bouterwek-, por su moderación y ecuanimidad, su sólida, variada y extensa erudición y su estilo imparcial y menos difuso. No obstante, con la distancia del tiempo, cuando Tannenberg concede que Ticknor, documentado autor de la única obra de conjunto, muy útil e insoslayable pese a la suspicaz afectación española de no considerarla más que un buen manual bibliográfico, ${ }^{633}$ y lector fiable de las obras que enjuicia («quand on sait comment, en matière de littérature espagnole, les jugements se transmettent tout faits d'un auteur à l'autre»), no es más artista ni crítico

631 Emplazado en diversos establecimientos y sedes de educación secundaria con una agregación en letras en su haber (1853) antes de emprender una carrera administrativa en el ministerio de Instrucción Pública, Magnabal destaca a partir de los años sesenta como fecundo traductor, principalmente de memorias académicas — de Antonio Sánchez Moguel o Domingo Doncel y Ordaz, por ejemplo-; estudios de críticos contemporáneos como José Güell Renté (Considérations politiques et littéraires, París, Michel Lévy Frères, 1863), de quien traslada asimismo varios relatos, leyendas, tradiciones y ensayos, o de Felipe Picatoste, de Manuel de la Revilla o de Pi y Margall, por ejemplo, sobre Don Juan en la crítica española (1893), así como Le théâtre espagnol contemporain (1886) de Cánovas del Castillo; obras históricas contemporáneas - de F. Janer (Condition sociale des Morisques d'Espagne, causes de leur expulsion, ses conséquences..., 1859), A. de los Ríos (Études historiques, politiques et littéraires sur les juifs d'Espagne, París, Imprimerie Administrative de Paul Dupont, 1861), o P.-J. Pidal (Philippe II, Antonio Pérez et le royaume d'Aragon, 1867) - y antologías de pasajes anotados de historiadores clásicos como Hurtado de Mendoza (Morceaux choisis de la Guerre de Grenade publiés avec notice, argument analytique et notes en français..., París, Hachette, 1876) y Solís (Morceaux choisis de la Conquête du Méxique..., ese mismo año).

632 "La littérature espagnole et ses historiens modernes», Revue des Deux Mondes, t. VIII, 15-X-1854, pp. 278-317.

633 «Les Allemands les ont tellement gâtés [a los españoles] par leurs éloges, que la réserve plus prudente des Anglo-Saxons ou des Français est toujours mise par eux sur le compte "des préjugés de race et de religion" ou de la "malveillance superficielle" " (ob. cit., 1903, pp. 149-150). 
sensible que Wolf, sino ante todo un sabio erudito, en cierto modo ratifica retrospectiva e indirectamente algunos de los reproches de Prosper Mérimée.

La temprana reacción de este último, la más reservada e incluso reticente en su momento - quizá también por desencuentros personales, como aventura Meregalli-, insistió sobre todo en el talante compilatorio y prolijo del libro haciendo resaltar tácitamente, por contraste, su propia erudición sobre la literatura española y su vivencia del carácter español. ${ }^{634}$ Miembro ya entonces de la Academia Francesa y de la de Inscripciones y Bellas Letras, de regreso de su tercer viaje a España, ${ }^{635}$ con una gran experiencia directa poco frecuente en estos estudiosos y su conocimiento bibliófilo, Mérimée hila ante todo una serie de reflexiones sobre el tema que es objeto de la investigación del erudito americano. ${ }^{636}$ Siempre con la mirada puesta en Ticknor, los requisitos que Mérimée exige de los historiadores de la literatura comprenden el estudio profundo y constante de esa lengua y su cultura, capacidad de enjuiciamiento, la preciosa virtud de la paciencia, buen gusto, una apreciación no sometida a principios estéticos excluyentes, e independencia de los prejuicios nacionales. Mérimée predica, pues, una suerte

634 «De la littérature espagnole. History of Spanish Literature, by George Ticknor; 5 vols., in-8. ${ }^{\circ}$, Nueva-York», Revue des Deux Mondes, 15-IV-1851, pp. 274-288. Posteriormente formará parte, junto con otros artículos suyos, del volumen Mélanges historiques et littéraires en CEuvres complètes de Prosper Mérimée (París, Calmann-Lévy) editado en 1855 (pp. 239-263). M. Bataillon («L’Espagne de Mérimée d'après sa correspondance», Revue de Littérature Comparée, XXII, 1948, p. 60) reparó en el tono de la crítica y subrayó el interés de sus reflexiones sobre la literatura española: «Il lui consacre un compte rendu dont l'étude serait d'importance capitale pour la compréhension de son hispanisme car il y mit le meilleur de ses réflexions sur l'histoire de l'Espagne, sur les rapports de la littérature naissante avec la littérature provençale, sur le roman et sur le théâtre espagnols du Siècle d'Or».

635 Mérimée emprendió seis viajes a España datados en 1830, 1840, 1846, 1853, 1859 y 1864.

636 Bataillon (art. cit., p. 60) subraya particularmente su disentimiento de las conclusiones de Ticknor sobre la Edad Media, etapa de forja del carácter nacional realzada por las teorías entonces vigentes: "Il se flatte que ses recherches sur le moyen âge péninsulaire l'ont conduit à une connaissance profonde des tendances du peuple espagnol. Mais s'il est si assuré de cette connaissance, si sûr de discerner l'original et l'excellent dans la littérature de l'Espagne comme l'essentiel dans son histoire, c'est qu'il a conscience d'avoir mis sa science historique à l'épreuve de contacts intimes avec l'Espagne vivante. Il a appris beaucoup par la tradition orale». 
de ósmosis del historiador con su objeto de estudio y esboza el perfil del crítico ideal, al que no todos los colegas de su tiempo podían aspirar. En este sentido, el americano Ticknor se ve favorecido por esa procedencia excéntrica, ajena a rivalidades nacionales históricas, y la frecuentación anglosajona de la obra de Shakespeare lo ha preparado para la lectura de un autor como Lope de Vega. Sin embargo, el análisis de la obra imponente de Ticknor no es laudatorio. Desde luego, Mérimée destaca su vasta y escrupulosa documentación y su familiaridad con la lengua y los escritores estudiados. A pesar de ese amplísimo bagaje, los principales reparos conciernen a la voluminosidad de la obra, convertida en un exhaustivo inventario, a su estilo descuidado, su falta de amenidad y a diversos fallos de organización e interpretación de la materia, fruto en gran parte todo ello de su origen escolar, reconocido en el prefacio por su autor. ${ }^{637}$

En primer lugar, la historia de Ticknor contraviene la concepción de historia literaria que prevalece entre los críticos franceses, partidarios de una selección de ejemplos representativos ( $A \grave{A}$ mon avis, les auteurs médiocres, dans toutes les langues se ressemblent beaucoup, et ce n'est pas chez eux qu'il faut étudier les traits distinctifs d'une littérature»), pues el reseñador pretende rastrear «la manière des grands écrivains, véritables représentans du goût espagnol», es decir, los signos de identidad nacionales de entre lo más granado del ingenio colectivo. Igualmente, discute la idoneidad de la anchurosa y veterana división de la primera etapa — de fines del siglo XII a principios del XVI-, que el mismo Ticknor contradice implícitamente con varios de sus análisis, en favor de una periodización más ajustada. Ante el examen atento de los hechos históricos, el escritor francés refuta la sesgada interpretación nacionalista asumida por el americano de esa etapa («comme des produits spontanés du génie et du caractère national», p. 277). Le reprocha, así, el no haber llevado a cabo un estudio más profundo de la historia de España, de sus ramificaciones y de sus relaciones con la literatura, lo que habría proporcionado a su

637 En tanto ampliación, en principio, de noticias y ejemplos contenidos en el Syllabus of a Course of lectures on the History and criticism of Spanish Literature de 1823 (Thomas R. Hart, "George Ticknor's History of Spanish Literature: The New England background», PMLA, n. ${ }^{\circ}$ LXIX, 1956, pp. 76-88). 
obra «une liaison et une méthode» que le faltan. Desde esta perspectiva, le discute la atribución del carácter de la primitiva poesía castellana exclusivamente a las costumbres guerreras, por lo que juzga más pertinente rastrear las posibles causas de "cette austérité qui contraste tant avec la molle délicatesse de leurs voisins» en las leyes e instituciones del reino de Castilla. Asimismo reivindica un mayor hincapié en las ya conocidas relaciones con los árabes, la Francia meridional y las lenguas románicas que moldean la literatura en la Península. Por ejemplo, destaca la huella de los cuentos e historias orientales, ${ }^{638}$ la influencia de la literatura provenzal - campo de estudio impulsado por prestigiosos autores como Raynouard y Fauriel—, y reprocha a Ticknor el relegamiento de la literatura medieval catalana, con autores como Muntaner o Miguel Carbonell y sus Chroniques d'Espanya. Mérimée pone en duda también la supremacía que otorga a los cronistas castellanos de la época en variedad, pintoresquismo, poeticidad, lealtad y religiosidad; defiende la excelencia de Froissart en ciertos aspectos sobre Ayala o el cronista de Alfonso X, y rebate esa pretendida devoción al rey apoyándose en los hechos históricos que atestiguan el enfrentamiento feroz entre la nobleza levantisca y la monarquía que aspira a fortalecer su autoridad. ${ }^{639}$ El historiador de Pedro el Cruel ${ }^{640}$ no puede evitar preguntarse «où $\mathrm{M}$. Ticknor a vu la loyauté et la foi religieuse espagnoles dans les chroniqueurs du XIV ${ }^{e}$ siècle». En consecuencia y sin abdicar de la idea de nacionalidad, ${ }^{641}$ Mérimée rebate en todo caso la lectura ideológica esencialista de Ticknor respecto a los rasgos que integran el carácter español supratemporal como el fervor religioso y la lealtad al soberano. Así, se burla de su interpretación de las causas de la into-

638 En obras como el Roman d'Outremer, versión de la lejana historia de Guillermo de Tiro, o El conde Lucanor.

639 Véase así, por ejemplo, J. Gimeno Casalduero, La imagen del monarca en la Castilla del siglo XIV, Madrid, Revista de Occidente, 1972.

640 "Histoire de don Pèdre Ier, roi de Castille» (1, 15-XII-1847; 1, 15-I, 1-II-1848) luego editada en volumen (reeditada con introducción y notas de Gabriel Laplane, París, M. Didier, 1961).

641 "Je demande pardon de ces longues dissertations historiques à propos d'un ouvrage proprement littéraire, mais il m’a semblé qu’il est nécessaire de connaître la vie d'un peuple, si je puis ainsi parler, pour apprécier convenablement les idées qui lui sont propres et sa façon de les exprimer», es decir, empapándose de la vida cotidiana, de su historia, contextualizando la literatura en la vida, aprehendiendo su expresión particular (p. 282). 
lerancia, el despotismo y el fanatismo que el americano achaca al exceso de celo ("Voilà encore une de ces assertions qu' on devrait laisser aux gens qui croient que tous les Espagnols portent des résilles et des fraises", p. 281) y no a la implantación de la Inquisición, la supresión de la libertad de pensamiento y la corrupción cortesana de la nobleza no sometida políticamente de modo definitivo hasta las postrimerías del reinado de Carlos V. En este punto Mérimée expone una serie de disquisiciones sobre el ser de España y su civilización, alineándose junto a los que basan el problema del Santo Tribunal, instrumento de control del poder, en causas económicas y en la xenofobia española, un nacionalismo excluyente que aliena a moros y judíos, agravado en tiempos de anarquía y de revueltas.

Más conforme con el dictamen del historiador americano acerca de los grandes períodos siguientes, al referirse al Quijote el crítico francés se adhiere a varias opiniones veteranas que sostenían la intencionalidad satírica de Cervantes en nombre del buen gusto y cuya eficacia correctora secó el cauce de las publicaciones de ese género. En cambio, se burla de otras interpretaciones decimonónicas vigentes en otros críticos como la simbolización — sancionada por Sismondi- en los dos personajes principales de la poesía frente a la prosa. Su reflexión sobre la permeabilidad de las relaciones entre vida y literatura lleva al autor francés, allegando sus argumentos al mundo conocido de sus lectores contemporáneos, a establecer una analogía entre el quijotismo de la época de Cervantes y el bovarismo en Francia, cuando recuerda las hostilidades de ciertos sectores conservadores contra el género novelístico y las disposiciones dictadas contra los folletines y las novelas por entregas ( $N$ N'entendons-nous pas dire tous les jours que les dames qui enfreignent l'article 212 du Code civil y ont été entraînées par la lecture des romans?», p. 284). Reseñado y reseñador suscriben la condición novelesca del teatro español, una de las líneas maestras perdurables desde el XVIII, y la recurrencia de los resortes habituales de sus dramas, los celos y el honor. El realismo en la novela y el idealismo de la comedia nueva plantean a ojos del francés una paradoja tampoco resuelta por el americano ("pourquoi un peuple dont les romans ont peint avec tant de fidélité la nature et les mœurs nationales n'a, dans les drames, que des tableaux de fantaisie», p. 285). Casi treinta años después de sus tempranas colaboraciones en Le Globe Mérimée mantiene la valoración general sobre este género 
emblemático, ${ }^{642}$ escenificación de tipos convencionales — galanes celosos y padres autoritarios-, a excepción de dos obras destacadas del canon áureo —Le Chien du Jardinier y L'Alcade de Zalamea-, ejemplos en los que observa un más profundo análisis psicológico. ${ }^{643}$ Cuando en 1877 publique en la Revue des Deux Mondes su prólogo a la traducción del Quijote por Lucien Biart (París, Hetzel), Mérimée volverá sobre las mismas conclusiones: Lope continúa siendo a sus ojos un habilísimo improvisador, un poderoso encantador poético dueño de una retórica de fuegos de artificio; y la ineluctable constante en los juicios paralelos de las historias del XIX francés que enfrenta el teatro español, en especial su comedia lopesca, y Shakespeare se resuelve esta vez en merma para el primero. En el mundo convencional de Lope sus personajes principales, obsesionados por el pundonor y repetidos incansablemente en innumerables imbroglios, desmerecen en variedad y divertimento de los protagonistas de la comedia dell'arte y soslayan el estudio profundo de las pasiones, timbre de gloria de las obras del dramaturgo inglés para los críticos franceses.

Del mismo modo que en 1824 declaraba contundentemente: «À ce système dramatique vraiment barbare se joint un style qui, à notre sentiment, ne l'est pas moins», Mérimée se detendrá de nuevo en 1851 en la retórica barroca, a la que, aun considerándola como antaño de "mauvais goût», con-

642 Si en su lejano artículo del 23 de noviembre de 1824 señalaba la desatención e indiferencia de Lope y también de Calderón, Guillén de Castro y «les tragiques du second ordre» respecto a las reglas aristotélicas, en 1851 sigue reprochándoles un desequilibrio entre la abundancia de peripecias y la escasez de "conversations»; y reconociéndoles la habitual imaginación desbordante, un derroche de ingenio - que es lo que a su juicio ha reavivado de nuevo el favor en Europa - y no pocos hallazgos felices, pero «rarement des développemens bien suivis et des caracteres bien peints». Como entonces, exceptúa el personaje de Crespo del Alcade de Zalaméa, "qui me parait bien au-dessus de tous ceux que Shakespeare nous a laissés», celebra Las mocedades del Cid de Guillén por encima de la versión de Corneille y ensalza El mágico prodigioso de Calderón, que le sugiere cierto paralelismo con Fausto («sans l'inquisition, je crois même que l'Espagnol nous aurait donné un diable un peu plus diable que le triste Méphistophélès»), también propuesto por Chasles en sus reseñas en la Revue de Paris.

643 «Tandis que les romanciers, observateurs exacts et souvent profonds, ont reproduit avec succès des individualités ou des vices répandus, les poètes dramatiques n'ont créé que des personnages de convention, agissant toujours d'après certaines règles invariables, accessibles seulement à certaines passions héroïques dont la forme est toujours la même. Sauf de très rares exceptions, comme le Chien du Jardinier de Lope de Vega, ou l'Alcade de Zalamea de Calderon où se trouvent des individualités remarquablement étudiées, les drames espagnols reproduisent uniformément les mêmes personnages: des amans jaloux et des pères fort chatouilleux sur l'honneur» (p. 285). 
cede un valor histórico y también artístico en tanto fuente de placer estético con ilustres exponentes a lo largo de la literatura universal como Esquilo o Shakespeare, o Lope y Calderón - de quien escoge un pasaje de sus predilectos El mágico prodigioso y El alcalde de Zalamea-. Mérimée, con cierta ecuanimidad historicista como la que ostentaba Chasles en sus reseñas sobre el drama español, busca liberar de prejuicios al lector francés cuando vindica la capacidad de disfrute estético y de sensibilidad de los espectadores de los dramas de Lope, Calderón y otros dramaturgos de la época, ${ }^{644}$ en el mismo grado que sus contemporáneos del París de los modernos años cincuenta («ne faut-il pas supposer qualors on demandait au drame une autre sorte de plaisir que celui qu'on y cherche aujourd'hui?», p. 287). Asumiendo sin mayor demora unas conclusiones muy semejantes a las expuestas en 1824, Mérimée evoca el drama español como un espectáculo complejo alejado, sin embargo, de la cotidianeidad por la maravilla poética y fruitiva, al conjugar en escena la recitación del verso y el espectáculo visual. Sin pensar en las creaciones calderonianas de gran espectáculo para la corte, el autor francés aproxima el ejemplo contemporáneo de la representación operística que forma con el libreto, la música, la escenografía y el juego de los actores un espectáculo total, como señalara Schlegel. Sin pretender rehabilitar el estilo culto de esplendente versificación, sino explicarlo en su contexto como una forma refinada para iniciados ( $J e$ crois qu’il ne fut qu'une forme, appréciable à des esprits plus littéraires que ceux d'aujourd'hui», p. 288), tampoco se resiste a cotejar el consagrado drama español con el teatro francés contemporáneo, más concentrado en el análisis que en el sentimiento y que ha desterrado de la escena el verso («Le goût moderne pour la réalité et pour l'illusion tend à chasser le vers de la scène»). Estos comentarios sobre la literatura española lo conducen por otros derroteros en torno a la literatura francesa contemporánea al poner en guardia contra el progresivo arraigo en el drama de esa tendencia realista que el escritor considera peligrosa y estéril para la creación si se lleva a sus extremos. ${ }^{645}$ Aunque Mérimée afirma sentir cierta aprensión

644 "Jadis le public savait goûter deux plaisirs à la fois: il s’intéressait à une fable dramatique, tout en appréciant les beautés du style, et le plaisir principal, je crois, était dû à l'expression poétique. On ne cherchait pas encore l'illusion théâtrale, et le moyen de la produire en effet sur une scène presque dépourvue de décorations et flanquée de banquettes, où se faisaient voir en grandes perruques les courtisans et les gens à la mode» (p. 287).

645 «À force de rechercher le naturel, nous pourrions bien en être réduits à une espèce de pantomime sans développemens et sans style, où toute la gloire appartiendra aux acteurs et aux machinistes. C'est ainsi qu'a fini, dit-on, le théâtre antique». 
por haber sido demasiado severo con Ticknor («et peut-être lui ai-je demandé un autre ouvrage que celui qu'il a voulu faire. Il y a bien des manières d'écrire l'histoire»), concluye, con todo, que en su concepto — como indirecta y comedidamente en el de otros críticos posteriores- el erudito americano ha compuesto más bien un catálogo excelente, útil para las bibliotecas por su meticulosidad, sus abundantes análisis y traducciones fieles y elegantes, antes que una verdadera historia literaria, es decir, una selección representativa y certera, piedra de toque de la condición de un buen crítico («il ne faut pas chercher dans son livre d'aperçus d'ensemble, de jugemens originaux, encore moins une étude de littérature comparée»), condición que sibilinamente le niega y que Tannenberg observa en la competencia humanista de un Menéndez Pelayo.

\subsection{Segunda mitad del siglo XIX: positivismo, militancia ideológica, continuidades}

Las historias y manuales franceses de la segunda mitad de siglo asumen también como premisa mayor la identificación de la nacionalidad literaria y política. Si se impone decididamente la tendencia, ya desarrollada en las décadas anteriores, a la comparación de las literaturas ajenas con la francesa, erigida en aduana europea, se repiten asimismo juicios veteranos sobre la literatura cotejada, se asientan conceptos anteriores e informaciones convertidas en lugares comunes, se perpetúa un inventario básico junto al incremento documental y se consagra el nuevo siglo como un fecundo renacimiento que, en conformidad con críticos españoles como Durán, suplanta al XVIII en el entroncamiento con los modelos del pasado glorioso. ${ }^{646}$ Con el correr de los años, los límites de aquella cuarta

646 No obstante, frente a la tendencia de las historias y manuales franceses contemporáneos, la reseña de la obra crítica de Menéndez Pelayo por Tannenberg (ob. cit., 1903, pp. 181-182) aún mantiene en su glosa de los juicios críticos del santanderino el prestigio de los líricos del período de entresiglos, tan celebrados desde los tiempos de Malmontais y Bouterwek («La poésie lyrique est le genre où les Espagnols, sous la servitude du goût français, conservèrent le mieux leur originalité. La fin du dix-huitième siècle est marquée chez eux par une renaissance lyrique dont ils sont à juste titre très fiers, avec Meléndez, qui retrouve l'élégance des classiques, Jove-Llanos, qui fustige dans des satires vibrantes la noblesse de son temps, Cienfuegos, tempérament romantique [...] et enfin le plus illustre de tous, Quintana»). 
edad anunciada por Velázquez se van ensanchando desde la revisión de Malmontais y Bouterwek, reajustándose al flujo de las nuevas producciones en la división por siglos. Si bien a principios de la centuria los estudiosos y antólogos se detenían en los aledaños de sus narraciones y luego se limitaban a menciones sumarias de la producción contemporánea con mayor o menor pormenor, es en el último cuarto del XIX cuando estos textos comienzan a desprenderse de los escrúpulos de algunos colectores e historiadores por evaluar a los autores de los años inmediatos, en rezago de la atención dispensada en algunos folletos, memorias académicas y en particular en artículos de la prensa cultural ${ }^{647}$ — fuentes, a su vez, de las historias literarias-, mientras que las escasas monografías sobre la actualidad se demorarán hasta finales de siglo. Paradójicamente, un coetáneo del afianzamiento de los circuitos universitarios hispanistas, Tannenberg, autor de algunas de ellas, constata en estas décadas un desdén general del público francés hacia la literatura vecina, que atribuye a la banalización romántica del color local español —a la que habrían contribuido los propios españoles a pesar de sus protestas posteriores-, la dependencia política y financiera del país respecto de las grandes potencias europeas, y sobre todo el triunfo de las culturas del norte sobre las de raigambre latina. En el tránsito al siglo XX, cuando las miradas críticas retornan al sur,

647 Adelantándose a los boletines, memorias de las diversas facultades, cuadernos pedagógicos centrados en la difusión del español y selecciones escolares que espigan sus ejemplos en autores contemporáneos, destacan informados hispanisants como los colaboradores de la decana Revue des Deux Mondes; nombres tan respetados como Antoine de Latour, autor de numerosos trabajos sobre la vida cultural española, sus tradiciones y patrimonio artístico, impresiones de viajes y artículos de crítica literaria entregados principalmente al católico y liberal conservador Le Correspondant o a la Revue Britannique, y más tarde editados en volumen — como, por ejemplo, L'Espagne religieuse et littéraire (París, Michel Lévy, 1863), Études littéraires sur l'Espagne contemporaine (1864), o Espagne. Traditions, moeurs et littérature (1869)—; o funcionarios como Magnabal y docentes universitarios que traducen y reseñan obras contemporáneas en sus diversos géneros, como Tannenberg o el conservador Armand-Germain de Tréverret, catedrático de literaturas extranjeras de Burdeos de 1869 a 1899, que recopiló en volumen (La littérature espagnole contemporaine, París, 1885) sus artículos del Correspondant sobre novelistas del realismo contemporáneo como Pérez Galdós, Pereda, Teodoro Guerrero, dramaturgos como Echegaray y poetas como Campoamor, y sobre todo que trasladó al francés memorias académicas y estudios de sus colegas españoles como Sánchez Moguel, Castelar, o el conocido libro de Cánovas sobre «El Solitario», además de análisis comparatistas como el tratamiento literario en Saint-Réal, Alfieri, Schiller o Núñez de Arce del famoso don Carlos de Austria, hijo de Felipe II (1887). 
hacia regiones desde antaño más atractivas para Francia como la Italia de D’Annunzio y Fogazzaro que difunde la nueva «Renaissance latine» —en la que se incluirían las traducciones de Galdós, Pereda, Blasco Ibáñez o la Pardo Bazán—, Tannenberg apela como Brunetière a la responsabilidad de la crítica para restablecer a la literatura española en el movimiento contemporáneo europeo del que había sido excluida injustamente. En cambio, las reflexiones del simbolista polaco Teodor Wyzewa ${ }^{648}$ achacan ese desinterés general a la dificultad de la lengua, al gusto de su literatura por el análisis de los sentimientos, y al empeño español en conservar un carácter nacional muy acusado que privilegia temas y preocupaciones locales, en tanto que Francia está ya en otro estadio cultural diferente. Escindida la apreciación francesa general de esta literatura entre la denuncia de las desviaciones que no cumplían las expectativas del rasero clasicista, y las advertencias a sus escritores contemporáneos de la necesidad de adaptar a la nueva sociedad la herencia tradicional — tachando habitualmente sus obras de inmaduras, pese a sus logros, o de copias de los modelos foráneos-, la preciada originalidad consagrada desde Bouterwek y Schlegel a la que animaban los críticos se torna a finales de siglo reprochable localismo, marginándola de nuevo ante parte del lectorado común.

Por otro lado, a partir de los años setenta las cuñas ideológicas de las primeras historias, de signo liberal, cobran mayor relevancia en la documentación histórico-literaria dando en algún ejemplo republicano, aislado en el entorno más conservador del cursus honorum universitario analizado. Los estudiosos de la literatura española de esta época no deslindan sus comentarios literarios de las reflexiones sobre las recientes vicisitudes de la

648 «Entraînés vers le Nord, attirés par l'étrangeté, peut-être aussi par l'obscurité du brumeux génie septentrional, nous avons perdu de vue le développement intellectuel de ces races latines, qui, durant tant de siècles, avaient pensé, senti, créé à l'unisson de la nôtre. Il n'a pas fallu moins que la traduction d'un roman tolstö̈en de M. D’Annunzio, l'année dernière, pour nous rappeler l'existence d'une littérature italienne. Et de la littérature espagnole nous continuons à ne rien savoir, ou peu de chose, tandis qu'il n'y a pas si petit écrivain scandinave que l'on ne réussisse à nous faire admirer. La littérature espagnole existe, cependant: et rarement peut-être depuis le XVII ${ }^{\mathrm{e}}$ siècle elle a été si vivante. Mais je crains que longtemps encore nous continuions à devoir l'ignorer: car elle s'obstine à garder un caractère national très marqué, à rester essentiellement locale, à exprimer des sentimens et à parler une langue que seuls des lecteurs espagnols sont en état de comprendre» ("Revues étrangères. Revues espagnoles», Revue des Deux Mondes, 15-XI-1894, p. 453). 
vida política de la España contemporánea, que se debate entre la reacción y el progreso, en rumbo, no obstante, hacia su modernización. Dentro de este lento proceso de institucionalización de la disciplina, que irá desarrollándose según criterios geográficos vinculados a diversos intereses regionales, nos detendremos principalmente en cuatro historias de diverso alcance acotadas entre 1866 y 1880. Las dos primeras, de orientación ideológica divergente bajo el II Imperio, comparten su especificidad y la exclusividad de su dedicación a la literatura española, mientras que las dos últimas, inscritas en las colecciones generales de historias literarias europeas en boga, se someten al orden conservador bajo la Tercera República.

\subsubsection{La primera historia francesa de la literatura española: Eugène Baret}

En la década siguiente a las primeras ediciones americana e inglesa de Ticknor y a su traducción española (1851-56), el catedrático de la Facultad de Letras de Clermont-Ferrand Eugène Baret (Bergerac, 1816-París, $1887)^{649}$ publica la primera Histoire de la littérature espagnole depuis ses ori-

649 Antiguo normalien como tantos otros estudiosos como Jarry de Mancy, Lefranc o Latour, Baret muestra un cursus honorum que cumple las expectativas promocionales de sus colegas. Frustrado ministro de Instrucción Pública en el gobierno temporal de Maximiliano de Habsburgo en México, Baret, catedrático de literatura extranjera desde 1854, fue nombrado en 1869 decano de la Facultad de Letras de Clermont-Ferrand, rector de la academia de Chambéry en 1875 e inspector general de instrucción pública desde la década de los setenta. Sin embargo, en 1880 fue retirado de sus cargos por su defensa de las congregaciones enseñantes y por su incompatibilidad con la política de los gobiernos republicanos. Traductor del español y del latín, es autor de numerosos estudios sobre la literatura latina y galo-romana, monografías sobre la literatura medieval y alguna incursión en la literatura inglesa. Como continuación de la publicación póstuma de Fauriel (Histoire de la poésie provençale, a cargo de Jules Mohl, 1846), donde se recalcaba la influencia de los trovadores en la renovación de las literaturas meridionales, Baret publicó Les Troubadours et leur influence sur la littérature du midi de l'Europe, avec des extraits et des pièces rares ou inédites (1867). Desde su tesis doctoral (De l'Amadis de Gaule et de son influence sur les mours et la littérature au XVI et XVII siècles, 1852, 2. ${ }^{a}$ ed. 1873) dedicó una atención preferente, aunque no exclusiva, a España, de cuya cultura trató en diversos artículos publicados en medios académicos y en estudios: no solo de su literatura (Du poème du Cid et ses analogies avec la chanson de Roland, 1858; Espagne et Provence: études sur la littérature du Midi de l'Europe, 1857; Mémoire sur l'originalité du Gil Blas de Lesage, 1864), también de su historia (Fernando de Valenzuela, 1880, publicado primero en prensa); además de reseñar trabajos de sus colegas (por ejemplo, Observations sur l'histoire..., art. cit., 1875, o Du poème du Cid traduit par Damas-Hinard, Moulins, Desrosier, 1878). En contacto con eruditos e 
gines les plus reculées jusquà nos jours ${ }^{650}$ de autoría francesa, que, pese al ambicioso título, excluye como su inmediato antecesor la producción contemporánea del XIX. ${ }^{651}$ De menos fuste que sus predecesoras — con las que comparte la organización del material, su parcelación por siglos, similar jerarquía de obras y principales valoraciones- y menos estimada por sus contemporáneos, esta obra — parte, a su vez, de una colección de historias literarias generales bajo el II Imperio- se presenta como un ensayo o «tableau de la litterature espagnole» (p. x), limitándose como era preceptivo a las obras maestras de valor depurado que merecen ser conocidas de toda persona culta. ${ }^{652}$ No solo ha asumido coordenadas de costumbre como la correlación político-literaria o la aceptación del modelo retórico y lingüístico del XVI con Mendoza, Cervantes o Melo — cuya pureza y originalidad opone por su fuerza y abundancia al cultismo del XVII y a los galicismos contemporáneos-, sino que confirma decididamente la habitual caracterización del ser español, monárquico y religioso, a través de su

investigadores españoles como Milà i Fontanals, sus estudios sobre la literatura española se vieron recompensados con el título de académico correspondiente de la Academia Española y numerario de la de Historia como socio extranjero. Viajó a España al menos en tres ocasiones consecutivas, en cuyo transcurso, además de otras paradas ineludibles en el periplo español del XIX, se detuvo en el Burgos del Cid, como el prestigioso profesor de la Sorbona, el católico liberal F. Ozanam, y asistió a las sesiones de la Academia de la Historia.

650 París, Dezobry, Tandou et Cie, 1863.

651 Aunque reconoce el renacer contemporáneo, sigue juzgando que España aún vive gobernada por el espíritu de la Edad Media como en su etapa gloriosa. Sin embargo, más por falta de iniciativa que de originalidad, en los tiempos presentes ha perdido aquella primacía de que gozara entonces. De este modo, previene del peligro de encastillamiento, reproche similar al que se achacaba el paulatino declive de su período de hegemonía mundial, y observa las vacilaciones de sus creadores, de entre cuyas obras más señaladas apunta, por ejemplo, El tanto por ciento de Ayala, considerado por Baret un imitador de Ponsard y Dumas, y elogiado más tarde por Tannenberg.

652 Si bien su crecido listado bibliográfico tiene en cuenta la crítica reciente francesa, alemana, española e inglesa, no descuida historias más lejanas, estudios eruditos españoles del XVIII, artículos de la prensa cultural, e incluso traducciones al francés que ponen las obras españolas al alcance de un lectorado medianamente instruido. Con todo, las obras más citadas en su estudio abarcan desde la obra magna de Ticknor, elogiada por su gran servicio a las letras, su traducción española anotada por Gayangos, cuyos fundamentales estudios sobre literatura medieval también menciona, junto a los primeros tomos de la historia de Amador de los Ríos, la antología de Quintana, la disertación de un estimado Puibusque, los estudios de Wolf, de Chasles, Puymaigre y Villemain, los artículos de Viel-Castel en la Revue des Deux Mondes, la rica colección española de Rivadeneyra, las obras del propio Baret y diversas traducciones desde Denis a Damas-Hinard, Germond de Lavigne, Edelstand du Méril, Royer o Lafond. 
literatura. Si apunta la tendencia al énfasis en los ilustres hispanorromanos e incide en la decisiva impronta oriental, Baret encarna su nacionalidad en el romancero - digno del título schlegeliano ${ }^{653}$ y aún transmitido por boca de los arrieros de una punta a otra del país-, superior estéticamente a los trabajados versos de Garcilaso o al artificio de los romances nuevos de Quevedo, Góngora o Sepúlveda; así como en los refranes populares, la sentenciosa gravedad medieval, la contemplación mística en comunión con el paisaje, o el teatro del XVII: los únicos géneros, en suma, originales («la religion et la nationalité d'un peuple sont les deux sources principales de sa poésie lyrique», p. 172) que se desarrollan en los grandes siglos de la literatura española. Dentro de la periodización canónica por siglos comprendida en tres grandes tramos - los orígenes hasta la entronización de Carlos V; el «Siècle d'or» de su literatura desde 1516 hasta la muerte de Felipe IV (1665); el asentamiento de los Borbones hasta un nebuloso presente que se detiene en las postrimerías del XVIII— ${ }^{654}$ el profesor francés conjuga la exposición cronológica con el examen valorativo de los géneros en verso y en prosa, y las correspondientes noticias biográficas de sus autores principales durante la etapa de esplendor. ${ }^{655}$ Asimismo

653 «aussi la poésie naissante de l'Espagne fut-elle obligée de se borner à des récits oraux qui se perpétuèrent pendant des siècles, et devinrent le germe, le principe des romances, des chroniques, des romans chevaleresques, du théâtre, c'est-à-dire de cette partie éminemment nationale de la littérature espagnole, qu'on ne peut mieux caractériser que par le nom de romantique» (p. 177).

654 Aunque Baret recuerda las diferencias entre los críticos sobre la valoración de esta época, asume que la decadencia política y literaria y la copia de los modelos foráneos habrían agostado su originalidad. Su única aportación habrían sido notables trabajos eruditos de autores como Flórez, los Mohedano y otros historiadores de la literatura, entre otros estudiosos. Su muestrario de nombres comprende las referencias habituales desde Luzán, Moratín padre, Cadalso — de entre cuyas obras señala la mediocridad de las Cartas y de su Florinda al haber pretendido inoportunamente hacia 1780 tratar en ese género un tema tan repetido en los romances-, J. Pitillas, la reacción nacionalista de García de la Huerta, un discutido Iriarte frente a un Samaniego preferido a su entender por los buenos jueces, un desvalorizado Meléndez — cuyas anacreónticas y bucólicas («à peu près oubliés aujourd'hui») son amplificaciones de lugares comunes_- un Cienfuegos demasiado francés, Iglesias, Noroña, Jovellanos, D. González, Lista; así como las piezas teatrales de Zamora, Cañizares, Comella, o Moratín, reivindicado ante su injusto olvido; Villarroel, el marqués de San Felipe, Feijoo o Isla.

655 «Au lieu de donner l'histoire de chaque auteur suivant l'ordre chronologique, nous adopterons désormais l'histoire des genres. La prose et la poésie formant une grande division naturelle, nous la suivrons, en réservant pour la fin le genre dramatique, fleuron le plus brillant de la couronne littéraire de l'Espagne» (p. 137). 
tras los pasos de Ticknor atiende a las grandes corrientes culturales —en las que engarza, por ejemplo, las escuelas españolas del XV, la primera influencia italiana en Mena, la reforma ${ }^{656}$ y el movimiento místicojunto a las reflexiones de rigor sobre las consecuencias esterilizadoras del despotismo político en las disputas literarias del XVII.

En la estela del comparatismo francés y de su respetado Puibusque, Baret construye asimismo su historia sobre puntuales cotejos con las principales literaturas europeas y con los modelos clásicos de la Antigüedad; establece analogías entre las evocaciones literarias y el arte pictórico ( $\mathrm{La}$ peinture des Espagnols est un excellent commentaire de leur poésie», p. 150 ), y proyecta sobre la literatura vecina los debates contemporáneos. ${ }^{657}$ Los paralelismos de obras españolas y extranjeras coetáneas comprenden, por ejemplo, el parangón acometido en estudios suyos anteriores entre el cantar español con la Chanson de Roland - como un común entusiasmo religioso y guerrero y un admirable «merveilleux chrétien», a contracorriente del despego de Sismondi, así como semejanzas entre pasajes, rituales, fórmulas, secuencias narrativas y personajes_- las conocidas similitudes de la Francia meridional con la zona fronteriza española, la inmersión en movimientos de alcance europeo como el sometimiento común a la cultura italiana en el XVI, o la extensión de corrientes parejas como el marinismo italiano, el gongorismo español, el eufemismo inglés, que liga incluso con ciertas prácticas románticas. ${ }^{658}$ Las veteranas comparaciones de la dramaturgia barroca de Lope y secundariamente de Calderón con la prestigio-

656 Baret recurre principalmente a Mac Crie, historiador de la Reforma en España, así como a los artículos de J. M. Guardia en la Revue de l'Instruction Publique (25-X-1861 y 4-IX-1862). Además de referirse a los protestantes de Valladolid, entre los autores que llama librepensadores cita a Valdés, Pérez de Pineda, Cipriano de Valera, junto a Sánchez de las Brozas, S. Abril, Oliva Sabuco o Azpilcueta Navarro.

657 En nombre de los buenos principios literarios que tamizan la realidad en un grado de idealidad aceptable por la razón y en contra de movimientos contemporáneos como el realismo, elogia las novelas cervantinas, por ejemplo, su Gitanilla ("La Bohémienne de Cervantes est sur la limite du réel et de l'idéal, qui est le vrai but de l'artiste, peintre ou romancier», p. 553), desestimando la continuación de Avellaneda («un esprit aussi dépourvu de grâce que de finesse, qui n'a pas même compris le fond de l'ouvrage charmant qu'il ose continuer: un réaliste qui n'entend de l'art que le côté matériel, et n’en possède ni l'esprit ni la vie», p. 563).

658 "Góngora, comme Marini en Italia, comme Lilly en Angleterre, comme certains romantiques en France, laissa de côté le bon gôut qui ne rapportait rien, pour se faire le promoteur d'un système de style capable d'étonner l'attention publique» (p. 168). 
sa tragedia griega — que sancionan su vínculo en el logro de la catarsis, su patetismo y un origen común nutrido de tradiciones y religiosidad- se completan también con la reivindicación de la nacionalidad dramática de Molière por su atención hacia el público popular, ${ }^{659}$ frente al elitismo ilustre de la universal tragedia raciniana, determinada por el elevado rango social de sus espectadores. De igual modo, tras algún breve apunte disperso en Stapfer o Maury, alguna sugerencia de Bouterwek a propósito de la potencialidad temática del romancero para la pintura histórica, la mayor acogida del pintoresquismo en Sismondi, o, por ejemplo, las evocaciones descriptivas de Rénal, aparte naturalmente de los estudios específicos de Viardot, Baret incorpora explícitamente a su discurso la inveterada asociación entre artes contemporáneas — sustentada en ejemplos heredados, en el impresionismo del autor y en el repertorio de artistas conocidos entonces-, de cierta fortuna accesoria en varios manuales posteriores. ${ }^{660}$

El crítico francés suma los nuevos descubrimientos eruditos, incluidos exclusivamente por su interés filológico, ${ }^{661}$ al repertorio habitual de

659 «c'est précisément ce souci du peuple, ce soin de lui plaire et de parler sa langue, qui rend si nationale la comédie de Molière, qui la fait durer au théâtre» (p. 285).

660 Así, el patetismo literario de la obra de Berceo ("gothique poésie»), las similitudes entre los motivos literarios de pasajes del Libro de Alexandre y la pintura o las miniaturas medievales; o los lamentos de los discípulos en los versos de «En la Ascensión» de Fray Luis, evocadores del lirismo del cuadro de san Antonio de Murillo en la catedral de Sevilla. Baret retoma la analogía de Maury cuando vindicaba la actualidad del estudio de Herrera para los jóvenes poetas modernos comparándola con el magisterio de Miguel Ángel entre los artistas; relaciona el fervor poético de los místicos, representado por el soneto "A Jesús crucificado" de Santa Teresa, la Safo española, con las llanuras castellanas ("Il faut avoir visité pour bien le comprendre ces plaines de la Castille, où l'horizon désert et brûlant, offre je ne sais quel ascétique aspect, ces collines rougeâtres, aux flancs desquelles s'élève la patrie de la Sainte, Avila de los Caballeros. Rapprochez de ce sonnet la fameuse ode de Sapho. Dans l'antiquité, sous la plume d'une femme, l'amour a trouvé la même sobriété dans l'énergie, moins la pudeur», p. 174); compara el toque magistral de Calderón con el de su contemporáneo Velázquez; y vincula un atribuido colorido descriptivo del Lazarillo o los detalles más pintorescos del Rinconete con los pintores españoles Ribera y Murillo, más conocidos por los franceses tras la exposición en el Louvre de la colección privada de Luis Felipe.

661 Por ejemplo, desde los primeros documentos como el Fuero de Avilés hasta los principales monumentos de la literatura medieval, junto a menciones añadidas como, por ejemplo, los textos de Pedro Alfonso, la Crónica de los Cuatro Reyes, la edición de Pidal y Janer en Rivadeneyra de la Vida de Apolonio, La Adoración de los Magos, la crónica en verso de Fernán González, La conquista de Ultramar estudiada por Gayangos, Los bocados de oro, los Castigos, el Corbacho del arcipreste de Talavera, o las obras de Juan de Padilla. 
principales hitos consagrados en la Edad Media desde el cantar de gesta hasta el siglo XV. ${ }^{662}$ Esta centuria aparece de nuevo como un ambivalente período de transición («âge d'érudition et de critique, plutôt que d'invention originale»), no tanto la etapa crepuscular de una nacionalidad aún genuina como postulaba Florán, sino también la precursora del esplendor siguiente, adelantada a Francia y situada en una encrucijada de influencias - la restauración de los estudios clásicos con Nebrija, la pervivencia de los modelos trovadorescos y la difusión de los italianos-, que, no obstante, se aparta de las tradiciones nacionales. De esta manera, tan concluyentemente como sus precursores Baret, tras detenerse en el autor castellano más importante de la época, el marqués de Santillana, ${ }^{663}$ da la palma a los

662 Tras remitir a la traducción del cantar por Damas-Hinard, Baret varía los ejemplos de esta obra — cuyo realismo reconoce únicamente, refutándole la intencionalidad artística y la calidad compositiva ("poésie mal ébauchée»), inferiores al arte del cantar francéscomo el pasaje, a su juicio, sublime y no apuntado por Villemain, de la escena de las mujeres contemplando la batalla desde los muros de Valencia. Asimismo, destaca otras obras de los autores medievales: si Florán enalteció la Vida de Santa Oria, Viardot Los signos y Ticknor se deleitó en los Milagros, Baret alaba la Plainte de la Vierge (Loores de Nuestra Señora) por su sublimidad, patetismo y poeticidad frente al resto de la producción berceana, aunque muestra también cierto aprecio por San Millán como signo del candor religioso de las creencias de la época; ratifica la filiación del Libro de Alexandre con los modelos de la Antigüedad, por ejemplo, en pasajes tan recurrentes como la descripción de la tienda de Alejandro en Babilonia, así como con las fuentes francesas; subraya las fuentes orientales de $E l$ conde Lucanor, concebido como un manual de política pragmática; marca la primacía del divertimento sobre la lección moral en El libro de buen amor - del que incluye citas habituales además de recalcar la originalidad del cuento del diablo y el ladrón-, señala sus semejanzas con los fabliaux, su superioridad sobre el Roman de la Rose, y las similitudes del talento y circunstancias de su autor con Chaucer y Rabelais - a quien no iguala, sin embargo, en erudición y genio-, desestimando la propuesta por Wolf con Cervantes; aborda a López de Ayala apoyándose en Puymaigre y Villemain; incluye a Santob de Carrión, y entre los autores del XV, aplica las valoraciones de costumbre al Laberinto de Mena, de calidad poética en aquellos pasajes morales o patrióticos — como el extracto realzado desde Quintana de la muerte del conde de Niebla-, antes de cerrar su revisión de ese período con $L a$ Celestina y el Amadís. En suma, conserva la imagen de la «näiveté substantielle» y el primitivismo de la Edad Media, así como su tendencia al simbolismo de alegorías y máximas.

663 Publicados el estudio de Puymaigre y la monografía de Amador de los Ríos sobre el marqués, además de las referencias contenidas en Ticknor, que Baret incluye en su bibliografía, el crítico francés organiza su producción conforme a la tradición crítica que privilegiaba los Proverbios, su obra más citada por los bibliógrafos, a la vez que su carta referencial, su Doctrinal de privados, el valor histórico del Centiloquio, las obras citadas por Bouterwek sobre el fin ominoso del valido, la batalla naval entre aragoneses y genoveses, sus refranes, o sus serranillas, que considera calcos de las pastourelles provenzales, entre las que destaca la conocida Vaquera de la Finojosa, también apreciada por Sismondi, además de señalar como aportación personal del autor castellano su Diálogo de Bias y Fortuna. 
prosistas del XV —desde el Centón epistolario, la crónica de Álvaro de Luna, los elogios a Alfonso de la Torre, a Pérez de Guzmán o H. del Pulgar - sobre sus poetas - salvo la prestigiosa excepción de las emotivas coplas de Jorge Manrique, glosadas por Rodrigo de Valdepeñas tiempo después y en las que apunta la huella de la Ballade des dames du temps jadis del francés Villon-. Si los lejanos dictámenes de Sismondi contra la prosa cuatrocentista se ven derogados, las sentencias denigratorias contra los cancioneros cortesanos como colección de rimas pobres de ideas y sentimientos, desdeñosas de los romances populares, conservan su autoridad en el veredicto que condena esta poesía - cuya única virtud reconocida es la transmisión de un afinado instrumento a sus sucesores- a un recuerdo histórico o arqueológico.

El balance de los diversos géneros poéticos del Siglo de Oro acoge la consagrada nacionalidad del romancero popular, ${ }^{664}$ la exigua poesía didáctica - en la que destaca un parcialmente rehabilitado Arte nuevo de Lope («badinage spirituel parsemé de conseils judicieux»), las composiciones de los Argensola y el admirable poema de Céspedes, digno a su juicio de las Geórgicas virgilianas y de Lucrecio-, la poesía épica, representada genuinamente por las gestas medievales superiores a la mediocridad sancionada de la renacentista, encabezada por un secundario Ercilla; la brillante lírica, en la que Baret sigue respetando sobre los poetas cultos memorables de ese ancho período $^{665}$ la perfección inmarcesible de Garcilaso — aun con reservas por su censurado abandono de la tradición nacional, confirmado

664 En la clasificación del romancero viejo destaca particularmente por su patetismo el ciclo de los siete infantes de Lara junto a los de Bernardo del Carpio y el Cid; se detiene en los moriscos como "Alhama», el de «Desafío de Tarfé» comentado por Viardot, o los famosos de Lope, y señala su apertura a más temas, por ejemplo, desde los que llama «romances de mœurs» a falta de otra etiqueta, hasta su reverdecer patriótico como grito de guerra a partir de 1808, o los tratamientos burlescos que dieron lugar a jácaras o a trovas como en la actualidad.

665 Los jalones de costumbre incumben, además de Castillejo, a un Boscán despojado de la calidad de poeta; los admirables poemas de Rioja; los Argensola, en los límites del gusto, distinguidos junto a Quevedo y Lope; un Góngora motejado de charlatán literario que violentó impunemente la lengua y del que selecciona su «Oda a la Armada Invencible», entre otras composiciones, y a cuyos comentaristas reprueba junto a sus seguidores, culteranistas y conceptistas como Alonso de Ledesma, o un Gracián que tacha de sofista en su Agudeza, si bien muestra más indulgencia con su Criticón, que le recuerda el Voyage du pélerin (Pilgrim's progress) de Bunyan. 
recientemente por Ticknor- ${ }^{666}$ admirando pese a su énfasis la voz poética y patriótica de Herrera, ${ }^{667}$ y rindiéndose ante un fray Luis de León en la cima del canon con «En la Ascensión», tan alabada por Villemain; las composiciones de Fray Luis, las de Santa Teresa y las místicas de san Juan de la Cruz - como su Dialogue entre l'âme et le Christ son époux-, que constituyen el único valor original de la lírica sacra; finalmente la exitosa fórmula lopesca de la poesía dramática, cuyos antecedentes, influencias, centros neurálgicos precedentes como Sevilla y la activa escuela de Valencia — de intensa vida cultural en la época con Guillén de Castro, cuyo lirismo es más elogiado, Tárrega, Aguilar o Mira de Amescua- y condiciones materiales y escénicas documenta con cierto pormenor, así como los principales géneros — entre los que incluye los autos- y los dramaturgos contemporáneos de Lope y Calderón en el nuevo orden ya asentado de Moreto, Tirso, Rojas y Ruiz de Alarcón.

La segunda parte, dedicada a la prosa, da cabida a escritores moralistas, políticos y críticos - Antonio de Guevara con su Horloge des princes (Relox de principes), por ejemplo; Antonio Pérez, estudiado ya por Bermúdez de Castro y Mignet; ${ }^{668}$ y el ineludible Quevedo ${ }^{669}$ —; predicadores y místicos - Santa Teresa, san Juan de la Cruz, cuya Subida al monte Carmelo y la Noche

666 Baret le reprocha severamente tanto su imitación italiana como clásica. Si bien su sensibilidad y gusto lo equiparan a su juicio con un Malherbe, pese a la belleza de pasajes de gran naturalidad y sencillez conmovedora en la égloga I o en su conocida "Oda a la Flor de Gnido", no considera suficiente su alabada perfección formal.

667 Encarnación, a juicio de la crítica, de la inspiración sublime de los profetas, y para Baret también del verdadero poeta, por sus esfuerzos en la búsqueda de un lenguaje poético y sus procedimientos descritos, a pesar de cierto alambicamiento y oscuridad que preceden a los cultistas. Además de reconocerle, contrariamente a Bouterwek, el valor de sus comentarios a Garcilaso Baret se propone difundir su talento tras los análisis de sus odas de inspiración bíblica y patriótica por Puibusque en 1843 .

668 En sus trabajos respectivos titulados, el primero, Antonio Pérez, secretario de Estado del rey Felipe II, estudios históricos (por D.), Madrid, Establecimiento tipográfico, 1841, y el segundo, Antonio Pérez et Philippe II, París, Impr. Royale, 1854.

669 De él repite Baret los enjuiciamientos acostumbrados que exaltan su riqueza y dominio lingüísticos y la sagacidad de su talento («d'une verve incroyable, d'un talent immense, auquel il n'a manqué, comme à la plupart des écrivains espagnols, que le contrepoids d'une raison calme et d'un jugement tempéré», p. 398) e inciden en su oscilación entre los extremos del buen gusto y la vulgaridad ( $Q$ Quevedo ne sait pas garder dans le choix de ses plaisanteries la mesure du bon goût, la décence, ni même la clarté, dans le choix de ses expressions», p. 408), en especial en sus excelentes sátiras y en el género burlesco, en el que descuella con sus Visiones o su Grand Tacaño ou Histoire de Don Pablo de Ségovie, si bien aduce que su verdadero genio se plasmó en las atribuidas Lettres du chevalier de l'Épargne, desde su traducción por La Geneste. 
oscura del alma lo colocan "parmi les meilleurs écrivains de sa nation", traducidos ambos por el P. Bouix; Luis de Granada, digno de Bossuet y de Massillon, Luis de León, Malón de Chaide o Zárate, entre otros-; historiadores renombrados que ilustran la maestría y fecundidad del género en España -Ocampo, Morales, Garibay, Abarca, Zurita, un Mariana ejemplar por su lengua clásica y cuya lectura recomienda con precaución; Hurtado de Mendoza, Moncada, o el imponente Melo, al que Solís solo supera en su retórica colorista-; y novelistas (nouvellistes) en sus diversos géneros: la novela de caballerías con el Amadis de Gaula, tema de su tesis doctoral, cuyas principales conclusiones resume; el limitado género pastoril desde Montemayor o Miranda, que evocan una comparación con la Astrée francesa, hasta La Galatea cervantina o La Arcadia de Lope; el llamado gusto picaresco ${ }^{670}$ encabezado por el magistral Lazarillo, sucesión de tipos nacionales y de «tableaux de genre» - de los que entresaca el pasaje inimitable del engaño cuando el niño comparte a escondidas el racimo de uvas con el ciego, o el de la venta de indulgencias - y modelo de Lesage y del Rinconete cervantino. Baret apunta que este género canalizó el análisis psicológico y la filosofía moral que los franceses reflejaron en su teatro, aunque, pese a su representatividad nacional y su valor costumbrista, las novelas españolas carecen a menudo de gusto estilístico y de naturalidad. La producción de Cervantes, conceptuado como humorista y genio superior a su tiempo, ocupa un lugar preferencial desde su obra mayor - de profundo simbolismo en ambos caracteres protagonistas, sublime ironía que trasciende la sátira del género de caballerías y cuya intercalación de novelas cortas atribuye a un deseo de proporcionar variedad a sus lectores- a las doce ejemplares, de las que destacan por su recreación costumbrista las veteranas lecturas de Rinconete y La Bohémienne.

La extensa parte dedicada a la poesía dramática desde sus orígenes a fines del XV, su formación y bifurcación en drama religioso y profano, sus fundadores —Encina, Gil Vicente, Torres Naharro y Lope de Rueda—, a los

670 Entre sus representantes cita a Vélez de Guevara o Alemán, cuyo Guzmán de Alfarache suscita su admiración por la galería de tipos que le recuerdan las mejores escenas de Balzac, como retrato a la vez de la nación y de los rasgos universales de la condición humana, además de un notable mérito estilístico que, sin embargo, lastran sus extensas digresiones. Superior a sus contemporáneos en calidad compositiva, moralidad y buen gusto es, a su juicio, la Histoire de l'écuyer don Marcos de Obregón de Espinel. Como no podía ser menos, reivindica la originalidad de Lesage aduciendo pruebas de su tratamiento original, que, a pesar de sus préstamos, conforma en conjunto un héroe más francés que español. 
que añade, en la alabada traducción de Germond de Lavigne, la preceptiva Celestina - cuyo mayor mérito se asigna ya a Rojas y cuyas escenas de introspección y patetismo vividas por la pareja protagonista rivalizan con las de la Fedra raciniana o las de Romeo y Julieta-, comprende las paradas de rigor: las dos piezas cervantinas —en especial una grandiosa Numancia, también apreciada por Fauriel en sus cursos, pero impotente ante un poderoso teatro nacional- y la demora en un Lope - a su juicio, el representante aún señero de la dramaturgia española- que se impone a contracorriente sobre un mermado Calderón cuyo mayor talento reside en sus autos sacramentales. ${ }^{671}$ No obstante, es la humanidad personal de Lope — cuyas notas biográficas y nutrido repertorio desarrollan los cursos académicos y las entradas de los diccionarios bibliográficos - la que vence a sus obras, principalmente profanas, dotadas de las mismas virtudes reconocidas y lastradas por los viejos defectos. Entre ellas sobresalen las piezas heroicas ${ }^{672}$ — cuya concepción, sin un desenlace necesariamente desgraciado, hace análoga al drama francés contemporáneo - y en especial sus dramas de capa y espada — modelos a su ver de los vaudevilles franceses_, varios de los cuales traducirá en $1869-70,{ }^{673}$ tras los pasos de Damas-Hinard ${ }^{674}$ y E. Lafond, ${ }^{675}$ también consultados por los

671 Baret acomete el análisis de uno de sus autos sacramentales (El divino Orfeo) y señala la división crítica entre Voltaire y Sismondi, por un lado, y Schlegel y Chasles, más vindicativos, por el otro.

672 Como Mudarra González, Le Mariage dans la mort (El casamiento en la muerte), Le Châtiment sans vengeance (El castigo sin venganza), Les Chevaliers commandeurs de Cordoue (Los comendadores de Córdoba) y la atribuida L'Étoile de Séville (La Estrella de Sevilla).

673 En su selección de Euvres dramatiques, Baret escogió dramas y comedias como L'Étoile de Séville, Le meilleur alcade est le Roi, Amour et honneur (La fuerza lastimosa), Le Cavalier d'Olmedo (El caballero de Olmedo), Le Mariage dans la mort, Le châtiment sans vengeance, Mudarra le Bâtard, Les Caprices de Belice (Los melindres de Belisa), L'Eau ferrée de Madrid (El acero de Madrid), Le Chien du jardinier (El perro del hortelano), Le Certain pour l'incertain (Lo cierto por lo dudoso), La Demoiselle servante (La moza de cántaro), Aimer sans savoir qui (Amar sin saber a quién), La Fausse ingénue (La boba para los otros y discreta para sí).

674 Sus traducciones en diversas entregas habían incluido también Le Chien du jardinier, Le meilleur alcade est le Roi, La Découverte du nouveau monde par Christophe Colomb (El Nuevo Mundo descubierto por Cristóbal Colón) L'Enlèvement d'Hélène (El robo de Helena).

675 Este estudioso incluyó diversas piezas del autor español o a él atribuidas (París, Libr. Nouvelle, 1857): L'argent fait la noblesse (Dineros son calidad), La Jeunesse de Bernard del Carpio (Las Mocedades de Bernardo del Carpio), Le Mariage dans la mort, L'Étoile de Séville, La Couronne méritée (La corona merecida), Le Châtiment sans vengeance, Los Tellos de Meneses, Le Campagnard dans son coin (El villano en su rincón), Le Chien du jardinier, Si les femmes ne voyaient pas (Si no vieran las mugeres), L'Eau ferrée de Madrid, Les Fleurs de Don Juan, ou au pauvre la richesse, au riche l'indolence (Las flores de don Juan). 
redactores del Larousse $d u X I X^{e}$ siècle para su artículo sobre el dramaturgo. La nacionalidad del drama lopesco, tipo consumado del teatro romántico schlegeliano («L'originalité du théâtre espagnol profane est plutôt celle d'une race que d'un homme», p. 303), junto a los autos y dramas calderonianos — como las asentadas La devoción de la Cruz y El mágico prodigioso-, propicia la comparación con los aún venerados modelos griegos antiguos que confirman una sensibilidad, un sentimiento de la naturaleza y un apasionamiento en común más próximos al teatro antiguo de Aristófanes, Esquilo o Eurípides que a las obras francesas de su tiempo. La catarsis de la tragedia griega y raciniana se manifestaría nítidamente en varios pasajes de Lope como el reconocimiento de Mudarra por Gonzalo Bustos, paralelo a la Electra de Sófocles, o la conmovedora despedida de la madre de sus hijos pequeños ${ }^{676}$ en La fuerza lastimosa. ${ }^{677}$ Igualmente sumiso al gusto del público, en lugar de haber ahondado en los caracteres — varios de ellos indudablemente célebres_, ${ }^{678}$ la coherencia de Calderón tan alabada por Bouterwek es ahora criticada al reprocharle una excesiva inspiración en sus propios recursos. Pese a la mayor regularidad e imaginación de sus comedias de espectáculo y sus excelentes dramas heroicos, Baret — cuya predilección favorece, como Damas-Hinard, a su predecesor- le niega verdadero color local y denuncia como es costumbre el alambicamiento y la afectación de su estilo. Como una más de las vueltas y revueltas de las imágenes nacionales, las obras calderonianas — reconocidas personificaciones del culto a la religión y la caballería de talla semejante al Cid o a don Quijote- reflejarían a juicio del crítico las costumbres medio africanas de la España de entonces, tan denostadas antaño por la propaganda de los viajeros franceses del Siglo de Oro. ${ }^{679}$ En el camino emprendido por Viardot o Puibusque en sus estudios, y con

676 «Le plus bel éloge que l'on puisse faire de ce morceau, c'est de montrer par la comparaison qu'il n'est pas inférieur à une des plus fameuses scènes de l'antiquité, aux adieux d'Alceste, dans la tragédie d'Euripide qui porte ce nom» (p. 274-275).

677 Obra ya traducida por Esménard bajo el título Amour et honneur (La fuerza lastimosa) junto a La Perle de Séville (La niña de plata, que Damas-Hinard traduciría más tarde como La Belle aux yeux d'or), mientras que Labeaumelle pasó al francés L'Arauque dompté, Fontevéjune, Le meilleur alcade est le Roi, Le Chien du jardinier y Persévérer jusqu'à la mort (Porfiar hasta morir).

678 Entre sus caracteres más destacados cita a Herodes, Gutiérrez, Lope de Almeida, Juan de la Roca, Segismundo, Lope de Figueroa, Pedro Crespo y Fernando de Portugal.

679 Véase, por ejemplo, J.-F. Schaub, «¿Empieza África con los Pirineos? Los relatos de viaje en la formación de los tipos nacionales: el caso franco-español en el siglo XVII», El Basilisco, Oviedo, n. ${ }^{\circ}$ 7, 1991, pp. 61-68. 
más detenimiento Viel-Castel, Chasles o Latour en sus artículos monográficos, o Royer en sus traducciones, Baret prosigue la rehabilitación y difusión de dramaturgos menos conocidos aún a esas alturas del siglo: de Moreto, el profesor francés sigue prefiriendo su muy elogiada Dédain pour dédain, destacada por su análisis psicológico $-\mathrm{y}$ comentada a partir de pasajes tomados, y a veces corregidos, de Viel-Castel - sobre el resto de su producción, ${ }^{680}$ en la que asimismo sobresale su obra maestra del género heroico consagrada por el Romanticismo, El rico hombre de Alcalá (Le Roi vaillant et justicier), comparable a los dramas de honor calderonianos. Tirso, por la variedad de su poesía, su riqueza lingüística, modélica naturalidad, gracia e ingenio malicioso, descuella en las comedias de carácter e intriga, ${ }^{681}$ pero para su análisis Baret escoge el terrible y admonitorio Burlador (Le Séducteur de Séville), semejante en sobrecogimiento al Hamlet y la versión de Molière y de Byron. Del repertorio de Rojas ${ }^{682}$ se detiene en uno de sus dramas promocionados por el Romanticismo como García del Castañar ou Après le roi, personne, ${ }^{683}$ alabado por sus descripciones poéticas, el contraste entre el bucolismo del primer acto y la acción terrible que lo sucede, y en especial el relato de García al rey tras su venganza. Ruiz de Alarcón, presentado por Denis, Lucas o en particular Chasles — cuyos pasajes rectifica en ocasiones - sobresale entre sus contemporáneos por su penetración psicológica y una infrecuente intención filosófica, ${ }^{684}$ característica de las normas clásicas

680 Como La Ressemblance, En avant la russe, Le Beau don Diègue —ensalzada como una de las mejores comedias de figurón-, La Nièce et la tante, que Viel-Castel había analizado en sus artículos, revisados y reeditados en 1882 (Essai sur le théâtre espagnol, París, G. Charpentier).

681 Su obra maestra sigue siendo la comedia de enredo Don Gil de las calzas verdes, pero también valora como Puibusque Marta la dévote (Marta la piadosa) o La Villageoise de Vallecas (La villana de Vallecas).

682 La crítica censa otra obras suyas ya conocidas como No hay padre siendo rey, Los áspides de Cleopatra, Donde no hay agravios no hay zelos, Entre bobos anda el juego, Abrir el ojo, etc. Pese a su ampulosidad se continúan apreciando su vigor expresivo y la sublimidad que logra en ocasiones.

683 Además de la versión representada de Lucas en 1848 de esta obra puesta en escena en París el año anterior por la compañía de Juan Lombía, el drama, que ya contaba con una refundición de Solís (Del rey abajo ninguno, o El labrador más honrado, 1820), pasó a formar parte de las selecciones posteriores como, por ejemplo, la de Ch. Habeneck (1862) bajo el título Hormis le Roi, personne, ou le plus noble des Laboureurs (Garcia de la Chataigneraie) o la del profesor A. Fée (1873).

684 Por ejemplo, Ganar amigos, Las paredes oyen, El tejedor de Segovia o La verdad sospechosa, para detenerse en el análisis del Examen de maridos por Chasles. 
de la comedia. El veredicto final de Baret sobre el teatro español confirma, pues, la opinión general en Francia: sus graves defectos por la premura compositiva, los abusos de ingenio y de retórica, su imaginación desbordante, sus inverosimilitudes y extravagancias serían subsanables gracias a una revisión más cuidadosa y a un estudio más atento de los clásicos, y, aunque no es un teatro de caracteres como el francés - superior en este aspecto- ${ }^{685}$ ofrece eminentes cualidades igualmente atractivas desde la intensidad de sus pasiones, el vigor de la defensa del honor y la grandeza de sentimientos que nunca incurren en la inmoralidad, hasta un consumado arte en el trenzado de intrigas y un asombroso dominio del diálogo.

En suma, esta historia francesa de recapitulación indirectamente vindicativa del patrimonio propio, sometida a las concepciones heredadas en nombre de la originalidad y el buen gusto, continúa en la segunda mitad de siglo los enjuiciamientos valorativos de la producción española en lugar de un análisis filológico. Si en décadas anteriores los principales catedráticos de literaturas extranjeras se inclinaban por la preponderancia septentrional que se impondrá en el curso del siglo, Baret aún invoca la comunidad latina de las culturas meridionales. Sin embargo, conquistada ya la aceptación de su singularidad, Baret, como el resto de estudiosos franceses, continúa rebatiendo a la literatura española el primer puesto en la producción europea, ${ }^{686}$ regateándole el explícito reconocimiento de Bouterwek. Como Sismondi medio siglo antes o Taine en años cercanos, el crítico la presenta como «un tout achevé» cuyo carácter distintivo, ya logrado, encierra en una franja temporal clausurada en el pasado, aunque paradójicamente confíe, como era normativo, en la renovación contemporánea. ${ }^{687}$

685 «Mais il manque de ce caractère de généralité dans la peinture des caractères, dont le théâtre français partage le beau privilège avec le théàtre des Grecs. Donc, sous le rapport de la raison, de la sagesse, de la vérité générale, de la vraisemblance, le théâtre espagnol ne peut être mis en comparaison avec le théâtre français» (p. 375).

686 «qui ne saurait prétendre à occuper le premier rang parmi les productions du génie européen, mais qui n'en est pas moins originale, curieuse, aussi digne d'être étudiée qu'elle est mal jugée et peu connue» (p. 1).

687 «Par un effet de la destinée particulière au peuple espagnol, sa littérature forme un tout achevé qui peut être observé comme on étudie la littérature des langues mortes. La littérature espagnole véritablement originale a eu son commencement, son apogée et sa fin» (p. 2). 


\subsubsection{Una historia comprometida: el caso republicano de Gustave Hubbard}

El combativo republicano Gustave-Nicolas Hubbard (Fourqueux, Yvelines, 1828-París, 1888) ${ }^{688}$ —uno de los disidentes franceses refugiados en España a raíz del golpe de Estado de 1851 al igual que otros hombres de letras y periodistas como Xavier Durrieu ${ }^{689}$ o Hugelmann, ${ }^{690}$ relacionados con los círculos culturales y políticos españoles - publica en 1876, de vuelta a su país, una Histoire de la littérature contemporaine en Espagne $^{691}$ concebida como la continuación de su conocida Histoire con-

688 Amigo de Gambetta y militante republicano antibonapartista, estuvo vinculado a sociedades secretas — su hermano Arthur, condenado por haber tomado parte en el complot de la Opéra-Comique (1853), se exilió y fue amnistiado en 1859-. Gustave entró en la escuela de administración de Carnot en 1848 y tras su disolución al año siguiente en la Facultad de Derecho. En 1851 se convirtió en secretario del comité encargado de la propagación de las "Sociétés de prévoyance». A consecuencia del golpe de Estado del Príncipe Presidente abandonó París y se refugió en España, donde continuó su labor periodística con la fundación en 1856 del periódico La Gaceta de los Caminos de Hierro. No regresó a París hasta 1868 y allí colaboró en numerosos periódicos republicanos. Sus artículos aparecieron en Le Journal des Économistes, La Presse, L'Industrie, La Nation souveraine. En 1876 fue nombrado secretario de la comisión del presupuesto de la Cámara de diputados. De entre sus numerosas obras, centradas en su mayoría en asuntos de economía política y temas candentes entonces como la gestación y gerencia de las cajas de ahorro y seguros mutuos, destaca, por lo que atañe a España, su célebre Histoire contemporaine d'Espagne (1869-84, 6 vols.). Véase Grand Larousse Universel du XIXe siècle (1873, t. 9, p. 424).

689 Bien conocido en los círculos madrileños como lo fuera en los franceses, este veterano de la revolución del 48 también es referencia para Hubbard como autoridad fiable al tratar del teatro en los comienzos del reinado de Isabel II: «Nous ne croyons pouvoir mieux faire, pour donner une idée exacte de ce qu'étaient les théâtres à Madrid au lendemain de la régence d'Espartero, que de reproduire ce que disait en 1844 dans la Revue des Deux Mondes M. Xavier Durrieu, un de ces rares Français qui ont longtemps habité l'Espagne et ont pu en parler en parfaite connaissance de cause» (p. 214). Sobre este autor véanse M. H. Duclos (Histoire des Ariégeois (comté de Foix et vicomté de Couserans). De l'esprit et de la force intellectuelle et morale dans l'Ariège et les Pyrénées Centrales, vol. 6, t. II, «Section des publicistes», pp. 564-607, reimpresión de la edición de 1881) y M. ${ }^{a}$ R. Álvarez Rubio («Xavier Durrieu. Apuntes en torno a un hispanista olvidado", Cuadernos de Filología Francesa, Cáceres, 1999 , n. ${ }^{\circ} 11$, pp. 165-182; y La literatura española en la prensa cultural francesa...).

690 R. Pageard, "Gabriel Hugelmann et sa Revue espagnole et portugaise devenue Revue des races latines (1857-1864)», Iris, CERLIAM, Université Paul Valéry-Montpellier, 19862, pp. 107-148.

691 París, Charpentier et Cie, Libraires-Éditeurs, 1876. Diversas partes de la obra fueron publicadas con anterioridad en prensa como la primera de ellas, "Les lettres, les arts et les sciences en Espagne, depuis l'avènement de Ferdinand VII jusqu'à sa mort: 18081833», La Philosophie positive, sept.-oct. 1871, pp. 277-327. 
temporaine d'Espagne. Conscientemente presentada como tal bajo una idea matriz — en este caso, la lucha secular entre la reacción y el progreso- que, a su juicio, define por principio el género, su revisión transita por derroteros ideológicos divergentes de los de sus coetáneas y sucesoras en Francia, si bien retoma el fondo documental autorizado y la mayor parte de las interpretaciones ético-estéticas precedentes. ${ }^{692}$ Historiador, economista político y pensador anticlerical como Sismondi, Hubbard acomete así el análisis de la literatura como otro fenómeno cultural más ${ }^{693}$ de la civilización española, ${ }^{694}$ en la que se imbrican los acontecimientos políticos y los grandes cambios sociales, punteados con datos estadísticos y sociológicos. Tras el fracaso de la breve experiencia republicana española, el crítico postula una obra de tesis en el marco de las disputas decimonónicas entre Estado e Iglesia recrudecidas en la segunda mitad de siglo, contra el despotismo y el oscurantismo clerical, ${ }^{695}$ a los que se atribuyen la parálisis de la investigación científica y el amordazamiento de la libertad. Enfocada, pues, su historia hacia la contemporaneidad y ya no hacia el pasado, como aún sucedía en las historias de

692 Además de la influencia más o menos declarada de las historias precedentes, entre sus fuentes recurre también a artículos de la prensa cultural como la veterana Revue des Deux Mondes, a propósito del teatro y la novela de los años recientes, junto a los estudios de Chasles en la Revue de Paris, editados luego con modificaciones en volumen sobre el drama áureo; relatos de viajes como el de Quinet de 1843; biografías de literatos del día como la Galería de la literatura española de Ferrer del Río; o, por ejemplo, obras literarias costumbristas en tanto documentos sociológicos como las Escenas matritenses de Mesonero Romanos, consultadas principalmente para su panorama retrospectivo de los ocios de la burguesía madrileña en los estertores del reinado fernandino y la década de los treinta - como el furor de la ópera italiana, el arraigo de las comedias caseras, o las representaciones del viejo repertorio y de los clásicos franceses bajo la censura cerril del P. Carrillo.

693 En 1854 el publicista A. de Nettement (Histoire de la littérature française sous le gouvernement de juillet, París, Lecoffre) aún seguía admitiendo, como Mme de Staël, una variedad de géneros desde las belles-lettres hasta la elocuencia parlamentaria, la prensa, la religión, la filosofía, la economía política y social o la historia, en tanto fenómenos culturales acotados en coordenadas políticas e históricas definidas.

694 «Sachez la valeur qu’une société accorde à la religion, à la philosophie, au drame, à la poésie, à l'éloquence, au roman: vous pourrez mieux l'apprécier qu'en analysant les faits de la vie intime de ses écrivains ou en étudiant scrupuleusement tous ses genres de versification et de style» (p. 3).

695 «[Espagne] façonnée par l'inquisition à ne pas penser, et à jouer avec les mots en s'interdisant les idées, elle a particulièrement à redouter les esprits vagues et nébuleux, qui en lui rappelant sa gloire passée cherchent à l'embrigader de nouveau dans l'armée de l'Eglise, sous la bannière de Sainte-Thérèse et de Loyola» (p. 257). 
Ticknor o Baret, su aleccionadora introducción indaga en los cimientos del carácter nacional durante los períodos anteriores y denuncia inercias y presiones históricas entre las causas de su decadencia - como el fanatismo religioso, que equipara con el misticismo, el deseo de dominación y avidez de los hidalgos, o, por ejemplo, las correrías aventureras, todavía por corregir, en busca de un rápido enriquecimiento- Cada capítulo de esta primera parte aparece bajo el patronazgo de un género emblemático como el picaresque, producto y espejo de su tiempo ${ }^{696}$ —desde el Lazarillo, Rinconete, el Guzmán, el Marcos de Obregón o El diablo cojuelo hasta el Gil Blas - o de paradigmas de su cultura como el exaltado cantar nacional del Cid, la denostada tutela de la religión sobre las conciencias, encarnada en el general de los jesuitas, san Ignacio de Loyola o en la fundadora santa Teresa de Ávila, o la ambición expansionista de los Habsburgo, representada por los enérgicos soldados del imperio en la conquista americana como Ercilla, y en Europa como Garcilaso, o un Cervantes de valor universal. La materia contemporánea, su principal objeto de análisis, está distribuida en tres libros: el primero aborda las letras en España desde la revolución de 1808 hasta la muerte de Fernando VII en 1833, extensa etapa dividida en varias secciones - desde la guerra de la Independencia, el primer período absolutista (1814-1820), la revolución de 1820 a 1823, el represivo segundo período absolutista (1823-1830), que escinde física y políticamente a la intelectualidad española en el exilio y la Península, y como último tramo, enfocado desde la perspectiva francesa dominante, la revolución de Julio (1830-33)—; el segundo (1833-43) trata del Romanticismo durante diez años marcados por la primera guerra carlista y la regencia de Espartero; el tercero abraza el movimiento literario durante el reinado de Isabel II y desde la revolución de septiembre hasta 1875.

$\mathrm{Su}$ discurso cronológico incardina los géneros en los principales acontecimientos político-sociales y los subsume en el seno de las grandes etapas culturales sobre cuya asimilación española proyecta las discrepancias habitualmente arraigadas en diversos sectores de la crítica: si, por un

696 Del mismo modo, la novela francesa contemporánea refleja a su vez los vicios de su tiempo: «il [el género picaresco] est le produit de l'exaltation de l'esprit d'aventure, de l'hypocrisie monacale, du mysticisme, et du dédain du travail; comme ceux de nos romans modernes qui peignent la société française à partir de 1830 reproduisent bien les excès de la cupidité et de l'agiotage modernes» (p. 63). 
lado, pone en duda la idoneidad de la penetración del Renacimiento en la época de Juan II, prefiriendo como el lejano Schlegel una preventiva singularidad española más valiosa que su adscripción a los grandes movimientos internacionales; ${ }^{697}$ por otro, tras registrar la interpretación schlegeliana de las reseñas catalanas en el segundo período absolutista, ${ }^{698}$ y habiendo adoptado firmemente el concepto moderno de Romanticismo en tanto periodización decimonónica en un nuevo tramo cultural — sin soslayar su alcance ideológico más renovador y políticamente contestatario-, no solo juzga erróneo el modo general en que en principio se absorbió el movimiento en España, sino que además considera que la melancolía que tiñe esas composiciones revela una imitación en desacuerdo con el clima y la naturaleza del carácter nacional. Remontándose a su recepción en España, Hubbard reprueba sus vínculos con los viejos cauces estético-ideológicos, ${ }^{699} \mathrm{y}$, a imagen de los pasos de ambas escuelas

697 Los ecos de esa suerte de segregacionismo sismondiano o de los reproches de Ticknor a la sumisión imitativa de lo foráneo resuenan en los comentarios de Hubbard cuando duda de los parabienes de la influencia renacentista, ávidamente recibida en España y mal comprendida por falta de seguridad en sus propias capacidades: "L'Espagne n'a pas été indifférente à tout ce grand mouvement intellectuel auquel on donne le nom de Renaissance: elle a absorbé avec ardeur, surtout dans les classes élevées, tout cet amas de livres qui furent alors jetés dans la circulation; mais il reste encore bien douteux s'il n'eût pas été mieux pour elle de se développer simplement dans son originalité native. Toutes ces importations étrangères, agissant sur elle presque coup sur coup, ont troublé son essor: se croyant incapable d'atteindre jamais par elle-même à cette perfection qu'elle entrevoyait dans les autres langues, elle se laissa dominer de tous côtés par la triste maladie de l'imitation, et elle crut s'assimiler alors qu'elle traduisait et copiait servilement" (p. 28).

698 En Barcelona, más receptiva que la capital, se difundieron las nuevas ideas románticas gracias a El Europeo de Aribau y López Soler, propagador de la estética alemana de Schiller, entre otros. Hubbard cita a uno de sus colaboradores, Leopoldo Feu, portavoz de las teorías de Schlegel: «Aribau, dit-il [Feu], et surtout Lopez Soler se distinguent avant tout par une physionomie spiritualiste; leur affection pour le moyen âge et les usages de la chevalerie, l'importance qu'ils accordent à l'éducation de l'homme, leur enthousiasme pour l'art musical et l'opéra italien, leur aspiration au romantisme dans le bon sens du mot, leur respect profond pour les coutumes nationales en tant qu'entièrement liées avec la religion, le climat, les lois et les autres éléments sociaux, tout cela indique une renaissance prochaine et salutaire, très-notable dans une société gênée depuis si longtemps comme la nôtre par des préoccupations religieuses et politiques» (p. 105).

699 En su recelo ante la recuperación de los modelos áureos procedentes de un tramo cultural desfasado, Hubbard también muestra indirectamente su mayor afinidad con los modelos clásicos grecolatinos y franceses: «Non pas que, comprenant bien dès l'origine la portée de cette révolution littéraire, on se bornât alors comme aujourd'hui à voir en elle 
en Francia, achaca el origen de sus discusiones sobre los nuevos métodos literarios a la abundancia en los primeros años treinta de "faux classiques» contra cuyas distorsionadas premisas se rebelan los románticos, suscribiendo así ciertos juicios de autores mencionados como Lista, Hermosilla o Martínez de la Rosa, que señalaban el predominio entonces de un «faux appétit de licence et d'émancipation». De esta manera, caracteriza las principales obras españolas de la nueva estética difundida por autores extranjeros como Hugo, Byron, Lamartine o Scott como patrióticas, fundamentalmente inmaterialistas pese a su apariencia religiosa, y de tendencia realista pero de estilo afectado, y cuyos desmanes dramáticos provocarían en la década siguiente una pasajera reacción clásica. No obstante, Hubbard halla los frutos más granados de esta renovada vitalidad en la lírica antes que en el teatro, más remiso en principio a su juicio por la boga de las refundiciones de Calderón y Moreto, hasta el triunfo definitivo del Romanticismo y el abandono de la manera moratiniana con la Marcela de Bretón de los Herreros.

La revisión histórico-ideológica de esta literatura — considerada en general más enérgica que modélica— respeta las divisiones y conceptualizaciones de costumbre, ${ }^{700} \mathrm{y}$ sin demorarse en todos los nombres se lleva a cabo en calas significativas a la luz de su representatividad nacional, desde

l'expression de cette loi naturelle que, notre société étant tout autre que celle de l'antiquité, tout autre aussi doit être notre littérature. Le mouvement ne fut pas dès l'abord compris ainsi: beaucoup n'y virent qu'un retour aux antiques romances, aux drames des seizième et dix-septième siècles. Au lieu d'admirer les odes, idylles, églogues, faites dans le goût des anciens auteurs grecs, ou les tragédies exécutées suivant les règles d'Aristote, d'Horace et de Boileau, c'est Calderon, c'est Lope de Vega qui devenaient seuls dignes de l'enthousiasme et du respect universels» (p. 107).

700 Hubbard asume las pautas iniciales y períodos de rigor, desde la aproximación a los orígenes de la lengua y del pueblo, los autores hispanorromanos, la «école littéraire hispanique» o la huella de la civilización musulmana, presente en un fondo léxico repertoriado por Sarmiento y Burriel, que el crítico sigue citando, en la transmisión del estilo asiático legado a los andaluces y en una tolerancia religiosa contrapuesta al proselitismo belicoso y fanático de los cristianos («Incessamment excités à la lutte, à la revanche, au mépris de la vie, les Espagnols acquirent peu à peu ce même fanatisme auquel ils avaient été naguère incapables de résister; et nous voyons ainsi se créer dans le malheur ce sombre caractère de goût belliqueux, de prosélytisme ardent et d'intolérance religieuse qui dès lors va devenir pour longtemps le signe distinctif et de la nationalité et de la littérature espagnoles», p. 10). 
su Edad Media ${ }^{701}$ con el Poème du Cid ${ }^{702}$ — de mayor intensidad que belleza artística, al que sigue negando una intención literaria y un plan cuidadoso, a la vez que confirma su cotejo con otros cantares medievales europeos como el de Roldán, ya anotado por Baret, y de los Nibelungos ${ }^{703}$-,

701 Como en Viardot o Florán, por ejemplo, el carácter nacional de la primera edad se mantiene con vigor hasta el siglo XIII con la obra del reformador y mecenas Alfonso X, cuyas cantigas se juzgan, en cambio, olvidables; bajo la influencia trovadoresca que afecta al desarrollo del gusto novelesco, se destacan la moralidad, ternura y amor conyugal de los romances castellanos, superiores asimismo a los cancioneros del XV, también desacreditados por su artificio y entre cuyos poetas no le merecen apenas interés ni Mena, ni Santillana - a excepción de sus serranillas, como la aún popular de la Finojosa-, aparte de un Villena consagrado desde tiempo atrás como un doctor Fausto y otros autores como Gómez de Cibdareal, mientras se mantiene la estima por las coplas de J. Manrique.

$702 \mathrm{Al}$ igual que los nuevos descubrimientos documentales sobre autores respetados como don Juan Manuel arrojan luz sobre sus tumultuosas vidas políticas, el bagaje de las nuevas aportaciones eruditas sobre la realidad histórica del Cid a partir del desarrollo del arabismo (Dozy, 1849) descubre dos encarnaciones superpuestas del protagonista: el guerrero histórico perteneciente a la segunda mitad del XI, rememorado en crónicas cristianas y musulmanas, y el héroe legendario, culmen de virtudes y paulatinamente esencia de la nacionalidad española. Si para los conservadores encarna valores eternos como la religión, el respeto a la monarquía y el honor, como ya apuntara Bénichou (art. cit.), para los republicanos como Hubbard ejemplifica sobre todo el héroe reivindicativo que no se doblega al poder omnímodo e injusto del rey ("ce guerrillero hardi, qui parle haut aux rois de la terre, qui méprise l'aristocratie efféminée des cours, qui n'apprécie en fait de grandeur que celle du héros, qui combat le glaive nu et le front haut, qui s'approprie les armes à la main le butin et les richesses, et qui néanmoins a toutes les vertus de la famille, et sait aimer sa femme et ses enfants, qu'est-ce autre chose encore aujourd'hui que l'hidalgo castillan, l'homme de lui-même, qui, malgré tout son fanatisme religieux et ses passions monarchiques, ne met jamais rien au-dessus de la dignité personnelle», pp. 16-17). El historiador francés lo contempla de acuerdo con las premisas vigentes que lo enraizaban en el linaje de héroes homéricos como en Maury o Florán ("C'est en lui que le peuple espagnol a voulu retracer ses propres exploits: il est l'Achille d'une autre guerre, bien plus longue et plus accidentelle que celle de Troie», p. 16), y lo reivindica ante la mirada francesa, mediatizada por el héroe caballeresco de Corneille. Para Hubbard el pasaje más dramático del poema siguen siendo las bodas de las hijas del Cid con los condes de Carrión, como documento histórico de las fuerzas en liza que refleja los sentimientos de grupo frente a la poderosa nobleza leonesa, y cruza a modo de veta recurrente la cultura española ("Le Cid ne refuse pas l'obéissance à son roi; mais il est avant tout un alcade populaire: il protège les hidalgos indépendants, les vilains, même les musulmans vaincus, contre la rapacité des hommes de cour. Il est aussi l'homme des moulins, c'est-à-dire le paysan, ennemi de l'oisif»).

703 En el cotejo entre modelos ya ha declinado la referencia a los de la épica antigua: "C'est au contraire une série de scènes diverses, d'incidents variés, de narrations n'ayant entre elles d'autre lien que le personnage qui en est le sujet: nulle analogie avec l'Iliade et l'Enéïde; au contraire une ressemblance très-grande avec toutes les chansons de geste qui ont trait à notre Roland, avec tous les chants qui, dans les Niebelungen, peignent le vieux germanisme» (p. 20). 
el romancero, la contribución de Alfonso X, la influencia trovadoresca y la lírica del XV en las cortes de Juan II y los Reyes Católicos, hasta los siglos XVI y XVII —ambos titulados «siècles de l'âge d'or» (p. 77)—, la influencia española sobre Francia en ese período, así como su reverso en un XVIII imitador de los modelos franceses. El crítico francés asume la tensión ideológica de los liberales españoles, expuesta por Blecua, ante la revisión de su etapa de máximo esplendor. Como Florán, también responsabiliza a Isabel I de la fanatización de la España del XVI, consumada bajo sus sucesores en una corriente que preconiza la acción o el sentimiento sobre la razón ${ }^{704}$ y enlaza a san Ignacio de Loyola y Santa Teresa con la famosa sor Patrocinio, controvertida consejera de Isabel II; como Sismondi y el librepensador Viardot, tacha el misticismo de extraña enfermedad e instrumento de manipulación; y tras la reafirmación de Ticknor, que culmina las reticencias de principios de siglo, rechaza contundentemente la estética pastoril del Renacimiento - aunque formalmente sus mejores autores sigan siendo dignos de admiración - como defección de la tradición nacional, como artificioso adormecedor de las conciencias y como espejismo literario que distrae la literatura y el pensamiento del desarrollo de su potencial, ${ }^{705}$ encaminándolo en su desorientación hacia la posterior degeneración del gusto («vrais importateurs du genre pastoral et bucolique qui va distraire plusieurs générations, détournées par l'Inquisition des vrais travaux de la pensée», p. 45). En consecuencia, Hubbard ensalza el patriotismo de Herrera — que compensa su alambicamiento con su elección poética de temas nacionales contemporáneos - por encima de la reprochable evasión de Garcilaso, a pesar de la armonía y la elegancia innegables de sus versos, ${ }^{706}$ e incluso vin-

704 También menciona a San Juan y a Luis de Granada y Luis de León —consagrado poeta lírico y orador sagrado-, que, no obstante, juzga inferiores formalmente a predicadores franceses como Bossuet o Massillon.

705 «Mais l'églogue, la pastorale sont-elles vraiment des genres où se développent le mieux toutes les puissances de la verve poétique? [...] tout l'enthousiasme de la jeunesse se bornant à acclamer ces vers aussi purs de forme que vides de pensées élevées, qu'était-ce sinon l'annonce prochaine de l'abîme où allait se plonger la société espagnole après les ardentes aspirations qui l'avaient poussée à la conquête du monde!» (p. 45).

706 "Garcilaso, si l'on ne veut considérer que l'harmonie du vers, l'éclat de l'expression, la beauté des images, la cadence du ryhtme, mériterait encore aujourd'hui la haute estime que lui accordèrent ses contemporains: jamais nul, comme dit Quintana, n’a orné la muse castillane de plus de grâces, et ne lui a fait parler un langage plus doux, plus pur, plus élégant et plus harmonieux» (p. 45). 
dica la experiencia vital de Ercilla, digno de ser difundido ante todo como tipo representativo de la sociedad española más que por la calidad literaria de su patriótica Araucana — conocida de oídas entre el lectorado francés pese a las nuevas traducciones— ${ }^{707}$ y cuya lectura también aconseja por los mismos motivos extraliterarios que le restaban mérito artístico a ojos de Sismondi. De igual modo, el crítico mantiene en el corazón del canon a Cervantes - cuyo Quijote es propuesto como breviario ejemplar de vida en nombre de la moral laica ${ }^{708}$ _, promociona a un Quevedo no solo erudito, diplomático y poeta incomparable, sino ante todo modelo de intelectual comprometido pese a su acción frustrada, ${ }^{709}$ e iza como representante genuino del genio dramático español a un Calderón frecuentado en ediciones y escenarios, sobre un Lope improvisador cuyas obras ya apenas hojean sus compatriotas. Esta aceptación de la consagración romántica calderoniana arrastra, sin embargo, ambigüedades en su selección paradigmática de La devoción de la Cruz — representante de las creencias a ultranza de la España de su tiempo y de la pasión que la engrandeció y abatió-, el drama de honor $A$ secreto agravio, secreta venganza, y la conmovedora La vida es sueño, consagrada como su obra

707 Tras algunas ediciones de los años veinte (Lyon y París, Cormon y Blanc, 1821, 1824), y la traducción abreviada de Gilibert de Merlhiac de 1824, la primera íntegra, editada ese último año, fue la de Hyacinthe Vinson - traductor de Dante, magistrado y bibliófilo que redactaría el apéndice de la historia de Demogeot de 1884 - de los ocho primeros cantos (Burdeos, 1824) y el canto I y XXXVII (Pondichéry, 1856), antes de la exhaustiva en 1869 de Alexandre Nicolas, especialista en Rennes, acompañada de un pormenorizado estudio. No obstante, Hubbard sigue considerando el poema épico —a excepción del íncipit a la sombra de Ariosto- una obra fallida por el prosaísmo de sus descripciones y su desproporción en el planteamiento que provoca más interés por los indómitos y sufridos salvajes.

708 La trascendencia universal de sus tipos humanos, reflejo a su vez de la idiosincrasia de su tiempo histórico —un Sancho egoísta y deseoso de riquezas pero inofensivo, frente a un generoso don Quijote, último vestigio de la aristocracia feudal, que como el Alceste de Molière desprecia los prejuicios y se rige por su conciencia-, los propone como referencias vitales para la reflexión: «Prendre leurs qualités, fuir leurs défauts: tel est notre principal devoir. De là l'étonnante supériorité de ce livre, qui peut servir de bréviaire dans presque toutes les situations de la vie, et où des prédicateurs intelligents trouveraient autant de sujets d'étude moral que dans l'évangile» (pp. 49-50).

709 Además de destacar su ironía fina y amarga, de mayor hondura que la habitualmente acordada a sus epigramas y sátiras, Hubbard lo exalta como representante de las virtudes de su momento histórico: «il appartient encore par ses qualités a cette grande Espagne où la jeunesse castillane était digne de la domination universelle à laquelle elle aspirait» (p. 65). 
maestra. ${ }^{710}$ La diferencia de épocas y de públicos respecto a los burgueses contemporáneos, junto a la idea ahincada desde Sismondi de que ambos dramaturgos barrocos confunden patriotismo y fanatismo sin discusión crítica, desestiman categóricamente a su entender su imitación actual. Sin modelos anteriores, pretendidamente autárquica y reflejo de su sociedad - apasionada, dada a la grandeza, la sublimidad y la imaginación pero prejuiciosa y de mentes sojuzgadas-, esa dramaturgia ${ }^{711}$ habría nacido de unas circunstancias y valores clausurados cuya reproducción en el tiempo presente supondría un lamentable retroceso en el progreso de la civilización española. Aun siendo más severo con un siglo XVIII apóstata de lo nacional y sumiso a los clásicos franceses y a las leyes de Boileau, Hubbard no puede menos que asentir al provecho de la corrección estilística y el destierro del gongorismo. No obstante, además de la crítica de Feijoo o del apreciado recuerdo de la novela del padre Isla, en su balance aún guardan su prestigio los prohombres del reinado de Carlos III como Aranda, Campomanes, Cabarrús, Moñino o un elogiado Jovellanos — de quien trata en especial sus discursos sobre los espectáculos y la ley agraria, y sobre economía social y crítica literaria-, que procuraron reintegrar a España en la modernidad europea, entonces bajo la influencia de los enciclopedistas, al igual que se revalorizan desde ángulos distintos la singularidad de los sainetes populares de Ramón de la Cruz y la regularidad del teatro de Moratín, digno sucesor de Molière. ${ }^{712}$

710 «D'un cadre absurde, violent, impossible, l'auteur tire des situations et des effets qui prouvent à la fois et la force de son imagination et l'élévation de son esprit. Malgré ses tendances théologiques, malgré une certaine affectation, malgré le cultisme qui parfois obscurcit son style, Calderon n'est jamais ennuyeux et très-souvent il est sublime» (p. 58).

711 El crítico acata las referencias obligadas a los orígenes religiosos del teatro y la evolución dramática desde los misterios a los diálogos pastorales, La Celestina, las imitaciones de los clásicos, o los pasos y coloquios de Lope de Rueda - que suscita la aparición del término baroque («Il [Lope de Rueda] jouait de lui-même sur les places de Madrid de véritables œuvres dramatiques, alors que le clergé en était encore à des mystères et à des moralités aussi niaises que baroques», p. 54)—, así como a los progresos materiales de la escena española. Sumiso al canon repertorial de los dramaturgos españoles en Francia como Baret, Hubbard destaca al Tirso de la Paysanne de Vallecas (La villana de Vallecas) y El burlador, el Moreto de Dédain contre dédain, el Rojas de García del Castañar ou Après le roi, personne; o el Ruiz de Alarcón de Le Menteur, entre otras piezas suyas ya comentadas por Chasles.

712 «on ne saurait jamais trop admirer la grâce parfaite, la finesse de tact, et l'intention délicate avec laquelle cet ingénieux écrivain sut transporter à Madrid le style et la perfection des meilleures pièces de Molière» (p. 68). 
El recorrido por la producción del XIX, jalonado por los principales hechos político-sociales, discurre asimismo entre la antítesis ideológica de libertad y despotismo que gobierna la obra. Al trazar la fisonomía de cada período, Hubbard constata las extraordinarias transformaciones de la sociedad española al calor de los avances revolucionarios — como, por ejemplo, el fecundo desarrollo de la prensa periódica y la difusión de la literatura entre las clases sociales bajas - y examina las regresiones durante las etapas de coerción. En el primer libro (1808-1833) aborda las consecuencias deplorables del yugo del catolicismo, que ahogó los tímidos esfuerzos de los reformadores, hombres religiosos de razonamiento enciclopedista, por romper con un pasado que los marginaba de la civilización europea. Hubbard denuncia la manipulación reaccionaria del patrimonio español del período de esplendor, ${ }^{713}$ que abocó a los intelectuales de principios del XIX a contradicciones irresolubles entre su espíritu democrático y su intolerancia religiosa al confundir patriotismo y defensa de la fe. En esta época en que florecen la oratoria y las colecciones periódicas con Alcalá Galiano, Gallardo o Martínez de la Rosa entre otros, el más cercano a la realización de estas aspiraciones fue Quintana — del que, además de recordar sus obras dramáticas, extracta la "Oda a Balmis o a la imprenta" y su «Oda a España después de la revolución de marzo»—, digno aún de las alabanzas de Tannenberg a fines de siglo. ${ }^{714}$ Entre las vacilaciones lite-

713 «Les amis de Ferdinand VII, intéressés à exploiter le courant d'opinion, se prirent tout à coup d'une forte passion pour les siècles de l'âge d'or, en haine de Godoy qu'ils s'acharnaient à présenter comme un criminel importateur des coutumes françaises. Si le courant des idées démocratiques n'était pas venu tout à coup faire diversion, l'Espagne littéraire se serait, pour ainsi dire, volontairement suicidée dans un élan de patriotisme» (p. 77).

714 Su temple democrático y su patriotismo serán asimismo apreciados por el crítico ruso-francés Tannenberg, que igualmente lo respeta como dramaturgo, crítico e historiador, y cuyas obras podía consultar en la edición de Rivadeneyra y de sus Obras inéditas de 1870. Aunque lo declara el mayor lírico español del XIX, Tannenberg lo liga principalmente al siglo XVIII por su formación y su filantropía de raigambre francesa que apela a la razón, la fraternidad, la libertad o la tolerancia religiosa, y juzga su producción poética ya prácticamente cumplida entre 1795 y 1808 . Clásico en la forma y revolucionario en las ideas, que lastran, no obstante, su poesía, es un autor de calidad pareja a otros grandes europeos de su generación ("Il aura été le poète du dix-huitième siècle en Espagne, comme Alfieri en Italie, Schiller en Allemagne, Burns en Angleterre et Chénier en France», ob. cit., 1889, p. 12). Más distante respecto a las licencias del autor en su interpretación histórica del príncipe don Carlos, Tannenberg selecciona preferentemente sus odas al progreso y contra el despotismo, como la dedicada al «Panteón del Escorial» considerada su obra maestra, aunque encuentra aún más inspiradas sus odas patrióticas que lo consagran («sans égal peut- 
rarias $^{715}$ de la primera etapa absolutista (1814-1820) refiere los inicios teatrales de Saavedra y alaba particularmente la labor regeneradora de Lista como respetado intelectual («plus tard beaucoup trop hostile aux tendances du romantisme, aura toujours sa place dans l'histoire de son pays", p. 92), difusor del progreso y de las ideas modernas — aunque lamente su inclinación al doctrinarismo de Royer-Collard- desde la empresa periodística del Censor junto a Burgos, Miñano, Hermosilla o Gallego, entre otros, y como educador en el Colegio de San Mateo. Entre las repercusiones culturales de la amnistía a la muerte de Fernando VII sobresale la acogida en las columnas de las nuevas publicaciones a las cuestiones literarias y a artículos costumbristas como los de Mesonero - vinculado a los modelos extranjeros-, Serafín Calderón y sobre todo un polifacético Larra («le plus distingué de tous les auteurs de l'époque, celui que la nature avait doué du genre le plus original, et qui était capable d'exercer le plus d'influence sur ses compatriotes», p. 111), heredero del inimitable Quevedo y, junto con Escosura, partícipe en la boga de la novela histórica a la manera de Scott, que el crítico juzga aún por desarrollar plenamente debido al rezago de una sólida documentación histórica. ${ }^{716}$

El segundo libro abraza una década (1833-1843) plena de transformaciones político-sociales, culturales, como el afianzamiento de la influencia francesa, y literarias como la naturalización del Romanticismo ("Considérée au point de vue purement littéraire, la période de 1833 à 1843 n'est que le développement spontané, naturel, particulier à l'Espagne du mouvement romantique inauguré en $1830 »$, p. 115). La ausencia de un autor que encarne y lidere las aspiraciones nacionales se ve parcialmente

être parmi les modernes, et c'est comme tel qu'il est resté surtout populaire», p. 19) y cuyo eco resurgiría al calor de la Septembrina en los versos de Núñez de Arce, a su juicio, «le plus grand des poètes castillans qui vivent aujourd'hui» (ob. cit., 1903), y bien conocido de autores correligionarios franceses como L. Ulbach.

715 «Soit crainte de la censure, soit difficulté à se décider entre notre école classique, et le genre de l'ancien théâtre espagnol, les auteurs n'osaient rien imaginer d'eux-mêmes. Tantôt ils se contentaient d'imiter et de traduire nos mauvaises tragédies du commencement de ce siècle, tantôt ils s'occupaient exclusivement de refondre les pièces d'Alarcon, de Moreto et de Rojas» (p. 88).

716 Hubbard reprocha al cultivo de este género en España, de material tan atrayente y pintoresco como poco estudiado, la insuficiencia y difícil accesibilidad de la documentación erudita necesaria para construir la ficción. 
compensada por la activa, y no siempre escuchada, intervención en el escenario cultural de estos años de los dos genuinos representantes del movimiento romántico, Espronceda ${ }^{717}$ y Larra («les deux hommes en qui se résume le mieux à nos yeux l'effort de l'Espagne moderne pour sortir de ses langes et de son impuissance», p. 104), cuyas trayectorias ideológicas, ajenas al dogmatismo y la disquisición filosófica, quedaron marcadas por los sucesos de La Granja. No es, pues, Zorrilla, cantor del viejo romancero, el poeta de los nuevos tiempos, sino Espronceda, cuyo Diablo mundo, pastiche a su juicio del Don Juan byroniano, le parece, sin embargo, admirable por su expresión moderna de la duda y la intensidad del sentimiento, junto a otras obras suyas entre las que traduce la «Oda del pirata».718 De igual modo, la traducción de varios pasajes de Larra, alabado también por su talento balzaciano, en los que el malogrado pamphlétaire apelaba a la formación y fortalecimiento de una clase burguesa para la organización de la sociedad española, confirma la vigencia de sus perspicaces reflexio-

717 «Espronceda, comme Byron, comme Alfred de Musset, est le représentant de cette géneration que nous avons vue réunissant à la fois le scepticisme religieux le plus complet, et les idées chevaleresques les plus élevées» (p. 108).

718 De entre las diversas ediciones parisinas de sus composiciones poéticas — como la selección de 1851 a cargo de Hartzenbusch (con El Pelayo, Poesías líricas, El estudiante de Salamanca y El diablo mundo), en la Colección de los mejores autores españoles de Baudry, luego aumentada con nuevas poesías inéditas en 1875 (París, A. Bouret e hijo)—, Tannenberg (ob. cit., 1889) tendrá en cuenta la publicación de 1869 en Garnier frères (Obras poéticas de Espronceda, precedidas de la biografía del autor, por A. Ferrer del Río). Este crítico alaba su factura poética, cuyo fondo estaría influenciado por Byron y Béranger, y alza sobre su tendencia a la fantasía macabra, como en su célebre "A Jarifa en una orgía", sus composiciones patrióticas más vibrantes, su Canto a Teresa, que lo habría convertido en el más grande elegíaco de la poesía castellana, o su composición más cumplida, El estudiante de Salamanca — que no sería traducido hasta finales de siglo por Foulché-Delbosc (L'Étudiant de Salamanque, poème..., París, H. Welter, 1893)—, por su virtuosismo formal, su riqueza lingüística y una admirable variedad rítmica que habría enriquecido la versificación española. Su mayor esfuerzo poético, el Diablo Mundo, marcado por el Don Juan byroniano, abrigó como el Fausto de Goethe o el Ashavérus de Quinet la ingenua pretensión de condensar la civilización moderna en un poema filosófico. Obra extraña, única en la literatura española contemporánea y original entre las de su género por su concepción y el protagonismo de un héroe primitivo en estado de naturaleza, es, pese a la impresión confusa que suscita, digna de admiración incluso en aquellos pasajes menos novedosos que revelan, con todo, «un très grand écrivain en vers». Espronceda representa a su entender el más clásico de los románticos españoles, superior también a Bécquer («Les poètes qui ont chanté l'amour avec des sanglots ne sont pas nombreux en Espagne. Je n'en vois que deux en ce siècle, Espronceda et Becquer; mais Becquer, avec un vrai tempérament de poète, n'a été qu'un artiste de second ordre», p. 76). 
nes. Pese a la sagacidad previsora de ambas personalidades, tampoco ninguno de los escritores coetáneos en el variado arco de tendencias - escépticas, eclécticas, católicas, clásicas y románticas - puede ofrecer un conjunto de ideas organizado con rigor. Atendiendo a la influencia de su posición social, Hubbard superpone el factor sociológico a la red genérica en su clasificación de autores y analiza en detalle en el contexto de los acontecimientos históricos su compromiso ideológico comprendiendo neocatólicos, las diversas ramas desgajadas de la familia liberal, moderados - que llama doctrinarios y de los que desconfía-, progresistas y demócratas, hasta republicanos. Recorre así el repertorio autorial contemporáneo a través de la sociedad española, desde excepciones en el seno de una aristocracia mayoritariamente conservadora, cuando no de simpatías carlistas, como, por ejemplo, el duque de Rivas, ${ }^{719}$ el conde de Toreno, elogiado por su inteligencia de estadista y por su obra histórica, o el duque de Frías, hasta aquellos hombres de letras profesionales surgidos de los distintos grupos de la burguesía, que en ocasiones desempeñaron también una carrera política, entre los que enumera, por ejemplo, a Burgos, un elegante pero superficial Martínez de la Rosa, un intelectual de la talla de Alcalá Galiano; Gil y Zárate como dramaturgo por su tumultuoso y alabado Carlos II, en cuyo inquisidor halla similitudes con el Frollo de Hugo, y también como autor del manual universitario de literatura española; Hartzenbusch, al que le reprocha no haber visto en el Romanticismo más que un regreso a las viejas comedias de capa y espada que ya fatigan al público; Bretón de los Herreros, el verdadero autor cómico de la época; García Gutiérrez, con su magnífico Trovador; junto a otros más, como un Rodríguez Rubí que lo decepciona, Pacheco, Ventura de la Vega, Fermín

719 Si lamenta su diametral evolución ideológica desde el ardor revolucionario de sus años mozos hasta su acendrado conservadurismo en sus años maduros, y refiere los defectos habituales del Moro expósito. Hubbard también da cuenta de la importancia de su drama romántico, un Edipo moderno a su juicio, percibido por la crítica de la época como un acontecimiento trascendental en el teatro del XIX que renueva el teatro español de Lope, Calderón, Tirso y Moreto con modelos extranjeros como V. Hugo. Décadas más tarde, Tannenberg (1889) — teniendo también a su disposición la edición de 1854-55 de las obras completas al cuidado del autor, que excluyó sus composiciones de juventud- coincidirá con otros críticos españoles y franceses en realzar su talento narrativo y descriptivo, de mayor estima, tampoco irreprochable, sobre su cultivo de otros géneros como la lírica, la historia o - aún entronizado como inaugurador del Romanticismo español - el teatro, cuyo éxito atribuye este estudioso a sus cualidades de poeta épico. 
Caballero o un atacado Donoso Cortés, abanderado del neocatolicismo del que abomina el autor. ${ }^{720}$

El tercer libro abarca el devenir literario desde la mayoría de edad de Isabel II (1843-1868) — período que sufre la gran tentativa neocatólica que dominó las camarillas cortesanas, el desarrollo de los negocios y la industria, la truncada sacudida revolucionaria de 1854 y 1856 que desembocaría en la Septembrina - hasta las experiencias del efímero reinado de Amadeo, la atormentada Primera República y el retorno de los Borbones, y repara en aspectos convergentes con la vida cultural de los primeros setenta como la instalación esporádica de centros protestantes en un momento en que el anticlericalismo declarado convive con el respeto a la religión católica. En este vasto tramo Hubbard señala tres inclinaciones predominantes en el compromiso ideológico de los escritores contemporáneos - neocatólicos, doctrinarios y demócratas republicanos- que reflejan las tensiones entre la admiración por el pasado, la atracción por las reformas del futuro y el temor al desorden, oscilando entre el individualismo y la asociación, el federalismo y la unidad nacional. Entre los poetas del relevo generacional ${ }^{721}$ alaba especialmente a Campoamor, artista digno de Milton y Dante, y en cuyo Drama Universal aprecia una heterogeneidad de corrientes desde el realismo y el escepticismo hasta el espiritualismo y el panteísmo; ${ }^{722}$ y se detiene en Zorrilla en tanto representante de los

720 Reseñado en la prensa francesa, traducido — sus Euvres ya habían sido editadas entre 1858 y 1859 con una introducción de su entonces amigo Louis Veuillot- e incluido paulatinamente en las historias literarias, Donoso es fustigado duramente por Hubbard como enemigo sistemático de la razón humana por su evolución ideológica bajo la influencia de Bonald y De Maistre hacia el conservadurismo neocatólico. Así, aunque reconoce su ardorosa naturaleza, disciplina intelectual y brillantez retórica, rebaja su aureola de orador y publicista en obras como el Essai sur le catholicisme, le libéralisme et le socialisme (1851, Barcelona), que juzga de lectura imposible por su estilo hueco y pomposo.

721 Además de referirse a Manuel del Palacio, menciona al marqués de la Pezuela, traductor de Tasso y Dante; Molins, el afamado Ochoa, Leopoldo de Cueto, el crítico Cañete, Pedro de Madrazo, junto a poetas como Enrique Gil, Pelegrín (también conocido como Abenámar), Romero Larrañaga, Fernández Guerra, y neos como Selgas o Arnao, entre otros.

722 Para su enjuiciamiento remite al prefacio de Fernández Royón a sus Doloras (Madrid, San Martín y Jubera, 1864). En cambio, Tannenberg (ob. cit., 1889, pp. 121157), en lugar de las mejores y fiables ediciones españolas, demasiado numerosas para mencionarlas, alude a la publicación de esta obra en Garnier y a la selección de sus poemas además de la edición más completa aunque incorrecta de F. A. Brockhaus (Obras escogidas, 
oropeles neocatólicos como en su poema La Cruz y la Media Luna, de retórica seductora e insustancial, y en Ventura de la Vega —al que atribuye una influencia indiscutible en la literatura del XIX-, que renunció al ejemplo de sus condiscípulos Espronceda y Larra. Si censura acerbamente la carencia de un estudio profundo y un trabajo de lima en las obras de Zorrilla ("pas encore une seule ouvre bien complète avec ses caractères bien dessinées, son dénoûment bien ordonné», p. 181) — sobre todo en su Don Juan Tenorio, ${ }^{723}$ en el que se demora denunciando además su inmoralidad por su exaltación de héroes ajenos a toda prudencia, justicia o probidad ejemplar en situaciones inverosímiles que pretenden conmover al espectador-, en cambio, aun reprochando a Ventura de la Vega su claudicación ante un público elitista para el que habría desplegado sus dones a modo de talentos de sociedad desprovistos de pasión inspiradora, Hub-

Leipzig, 1885-86, 3 vols.). Al igual que Hubbard, ensalza el Drama universal como "les plus belles pages qu'il ait écrites au point de vue de la facture, de la largeur du développement poétique, de la puissance imaginative. La conception en est très profonde, et on peut le considérer comme une des œuvres les plus originales et les plus fortes de la poésie contemporaine» (p. 159). Para este crítico, Campoamor, creador del género de la poesía filosófica en su patria, infundió a su literatura una nota original inconfundible. No solo habría comenzado en España la reacción contra el Romanticismo sino que representaría en la actualidad las dos tendencias esenciales, filosófica y realista, de la poesía contemporánea ("c'est pour cela que depuis cinquante ans sa réputation n'a fait que croître chaque jour et que la jeune génération le vénère comme un de ses maîtres préférés», p. 157).

723 «inspirée à la fois par le mysticisme de Calderon et l'esprit aventureux de Tirso de Molina, justement populaire parce qu'elle caractérise bien la tournure d'esprit de toute une nationalité, mais où l'auteur n'a réellement à revendiquer, comme invention propre, qu'une versification facile et un dialogue assez animé» (p. 189). Décadas más tarde, si Tannenberg (ob. cit., 1889) le sigue rindiendo tributo por su talento poético ("Je crois bien qu'il n'y a pas eu en ce siècle d'organisation poétique supérieure à celle de Zorrilla», p. 97), que por sus cualidades como por sus defectos permanece a sus ojos como «la personnification la plus complète et la plus populaire du romantisme espagnol» (p. 118), coincide, no obstante, en considerarlo inferior a Rivas o Espronceda y menos innovador, a excepción de sus leyendas - como las excelentes y más valoradas de El Cristo de la Vega, imitada por Rostand, El capitán Montoya y Margarita la Tornera - Poeta meridional de instinto más que de aplicación artística, autoirónico y gran recitador, como demuestra en sus giras acompanado de violín y violoncello en sordina, su influencia, en cambio, ha sido funesta y comparable, a juicio del crítico, en el extremo opuesto de la facilidad retórica, a la de un Góngora nunca olvidado ("Je ne sais si on l'a jamais comparé à Góngora; tous deux ont été de grands poètes, admirablement doués, qui ont corrompu le goût de leur temps. Le zorrillisme devint, vers le milieu de ce siècle, une maladie littéraire, analogue au gongorisme, caractérisée non plus par la subtilité raffinée et précieuse, mais par l'abus du lyrisme facile, l'incorrection, la banalité», pp. 118-119). 
bard ensalza su Hombre de mundo como muestra, a la altura de Moratín, de lo que prometía si no hubiera cedido a su proverbial pereza. La escena de mediados de los años cuarenta también consagró a respetados actores, variados repertorios ${ }^{724}$ y nuevos dramaturgos en boga como Rodríguez Rubí, tachado de arribista por haber desechado sus primeras inspiraciones populares; López de Ayala ${ }^{725}$ — procedente de la Unión Liberal y asociado a progresistas y republicanos, pero doctrinario leal a Montpensier-, cuyos esfuerzos por adaptar los géneros dramáticos a la sociedad moderna pondera; o Gómez de Avellaneda — especialmente el Alonso Munio, al que reprocha inconsistencia en la intriga y ciertos defectos en el desarrollo y el ritmo, reconociéndole también verdadera pasión-y Tamayo y Baus, ${ }^{726}$

724 Entre los actores más conocidos apunta los nombres de Matilde Díez, Teodora Lamadrid, Romea, Arjona, Valero, Ossorio, Mario o los hermanos Catalina. Amplio es también el inventario de autores señalados en diversos géneros en las décadas siguientes, desde Eguílaz, Olona, Serra, Díaz, Príncipe, Asquerino y otros de segundo orden, dedicados al teatro y al periodismo; libretistas de zarzuela como Camprodón, Salas y Arderius, Barbieri, Arrieta, Gaztambide y Oudrid; como diverso el panorama de espectáculos populares, desde bailes — habaneras, jotas, cachuchas, aires andaluces - a piezas de magia, obras originales y arreglos del francés que constata por observación directa el crítico.

725 Asimismo alabado por Tannenberg (ob. cit., 1903, p. 4) como verdadero poeta, de composición formalmente impecable y clásica y de finalidad moral como en su Tanto por ciento (1861) y Consuelo (1878). No obstante, «Il essaya, sans y réussir complètement, d'adapter la forme poétique de Calderon aux exigences de la pièce à thèse et de la comédie de caractère».

$726 \mathrm{Al}$ igual que Baret, Hubbard señala sus similitudes con los franceses Ponsard y Latour de Saint-Ybars. No obstante, insiste en la inadecuación de esa ruta clásica inspirada en Corneille y Voltaire, sobre la que juzga preferible en este caso, al dirigirse a las clases altas, la senda de Calderón y Shakespeare. Por su parte también Tannenberg lo destaca como el dramaturgo más interesante de la modernidad decimonónica española $-\mathrm{y}$ avanzado de un realismo que la escena de los últimos años del XIX ensaya frente al desaforado neorromanticismo de Echegaray-, y cuyos tres dramas La Folie d'amour, Affaires d'honneur y Un drame nouveau, que analizará más adelante junto a otras de sus piezas, juzga dignos de engrosar el repertorio europeo contemporáneo. Es más, aúna a la originalidad distintiva nacional - como su tradicionalismo, su catolicismo ferviente, la intensidad de las pasiones y la tendencia sentenciosa heredada de la tradición senequista española- y a cierto toque exótico que aprecia el crítico, una asimilación ejemplar de vasta cultura y escogidos modelos —desde los clásicos franceses, Schiller y Dumas hasta Lope y Calderón- que, junto a su perfección formal, tan infrecuente entre sus compatriotas, y a sus cualidades de raigambre clásica - como su estilo de precisión lapidaria, su dominio y comprensión de las exigencias de la escena, un cuidadoso análisis psicológico y la sobriedad de una acción reflexiva de acontecimientos encadenados lógicamente- lo singularizan en el panorama español. Experimentador poético, Tamayo cumple a ojos de Tannenberg el arraigado concepto de la imitatio original («Il suffit de constater, pour s'en convaincre, comment il procède quand il 


\section{que por cansancio de la desmesura del drama romántico ${ }^{727}$ recuperan momentáneamente la tragedia clásica, género anacrónico e inviable en los}

adapte une pièce étrangère: il prend le sujet, mais modifie entièrement les caractères et le style, et il en résulte une pièce originale, portant, à ne pas s'y méprendre, la marque du génie espagnol», ob. cit., 1903, p. 7). Sin detenerse en su examen — acompañado, como de costumbre de resúmenes y pasajes traducidos - en otras obras suyas citadas que juzga menores, el crítico observa en su producción dos maneras separadas por el intervalo de 1856 a 1862: entre las de su primera etapa destaca Virginia (1853), de vigoroso y conciso corte shakesperiano, considerada por los españoles la obra maestra de la tragedia romana en España, y que compara en diversos pasajes con el tratamiento temático de Alfieri o Latour de SaintYbars; La Riche-femme (La rica hembra, 1854), retorno a la tradición nacional de la comedia que, pese a su psicología superficial en conjunto, enlaza, más que ninguna otra moderna, con la brillantez poética de Lope o Tirso, y cuyo primer acto — dramatización de una vieja crónica- contiene una de las exposiciones teatrales más bellas; La Boule de neige ( $\mathrm{La}$ bola de nieve, 1856) por su acabado formal, aun dentro de las convenciones de su género; y su gran éxito en las escenas rusas, italianas y alemanas, la Folie d'amour (Locura de amor, 1855), primer ensayo de drama psicológico, de calidad suficiente para convertirlo en una obra clásica, y sobre el que, además de mencionar el prólogo de Pidal a la edición de las Obras completas del autor (1898-1900) en el que la considera su obra maestra, recuerda varias reseñas francesas de 1898 cuando fue representado en París — como la dedicada al autor en el Journal des Débats del 27 de junio por Faguet, o en La Liberté del 8 de julio por S. Rzewuski-. En cambio, para Tannenberg no es esta su mejor obra ni tampoco, a pesar de los plácemes de la crítica española que la presentan como la cumbre de su fama y del teatro contemporáneo, su Drame nouveau (El drama nuevo, 1867), también traducida y representada en el extranjero - por ejemplo, la puesta en escena parisina del actor italiano Novelli, sobre una limitada traducción, inferior quizá al arreglo de Paul Delair para el actor francés Coquelin en su gira americana-. Aunque la presencia de ciertos recursos un tanto forzados a la manera de Scribe rebaja un tanto su mérito, Tannenberg elogia su consumado oficio, la sobriedad e incluso musicalidad de su prosa, y su penetración psicológica, cuyo simbolismo genérico lo emparenta más a su juicio con Racine que con Shakespeare, como pretende el crítico español Revilla. La obra que el crítico ruso-francés consagra es Affaires d'honneur (Lo positivo, 1863), proceso sumario a la sociedad moderna y a su culto al duelo, que inaugura la segunda manera de su autor, caracterizada por una mayor madurez, reflexión e indagación en los caracteres. Injustamente recibido en su momento a causa de las polémicas religiosas y políticas, este drama de admirable factura compositiva, merecidamente elogiada en los comentarios ya referidos de Faguet y en los de Sarcey en Le Temps del 27 de junio o de Claveau en Le Soleil del 15 de agosto del mismo año, y comparable en fuerza y rigurosa trabazón lógica a las mejores obras de Dumas hijo o de Paul Hervieu, constituye para Tannenberg la obra de tesis más vigorosa del XIX español.

727 Igual dictamen mantendrá Tannenberg (ob. cit., 1903, pp. 2-5) cuando afirme que, pese a los méritos de Rivas, Gutiérrez, Hartzenbusch e incluso Zorrilla, «on peut bien dire qu'en général le drame romantique espagnol a exagéré encore les défauts du nôtre, qu’il est vraiment par trop vide et que la psychologie en est rudimentaire». Así pues, contra estas extravagancias habría surgido hacia mediados de siglo una reacción análoga a la experimentada en Francia encabezada por la llamada "école du bon sens» de Ponsard, Augier o Dumas hijo, a riesgo de caer a veces en el extremo contrario del prosaísmo y la lección moral. 
tiempos actuales. Sin embargo, gracias a los avances de la erudición Hubbard confía en las posibilidades del drama histórico como La rica hembra, escrito por Tamayo en colaboración con Aureliano FernándezGuerra Orbe, cuya cercanía al modelo teatral del XVII junto con las exigencias modernas y el respeto a la verdad de los hechos revelan una obra a su juicio más romántica que clásica. Además de tratar de los principales historiadores españoles en ejercicio, en el capítulo dedicado a los oradores el crítico recuerda los parlamentarios, entonces en la liza política, que encontró Quinet en su viaje por la Península en 1843 y explica su evolución. ${ }^{728}$ A estos nombres añade otros más recientes que prueban el vigor del movimiento correligionario español —estadistas, oradores, filósofos, economistas o funcionarios como Rivero, y los elogiados Ruiz Zorrilla, Figueras, Salmerón o Pi y Margall-e igualmente importantes como Emilio Castelar, el republicano demócrata más conocido hasta entonces en Francia, y cuyo talento reclama para las letras y las artes, donde residirían sus verdaderas cualidades de orador y poeta, más que en las altas responsabilidades del Estado. ${ }^{729}$ Entre los novelistas analiza-

728 Entre ellos alaba en especial al eminente Alcalá Galiano, que descuella por su gran elocuencia y calado intelectual por encima de los miembros referidos del partido progresista, que al fin alcanzó el poder, como Manuel Cortina o el destacado Olózaga, que comparten las tendencias románticas hacia el efectismo teatral y la fuerza colorista de su retórica, junto a un Joaquín López cuyo discurso carece de la elegante dicción y la forma literaria de sus predecesores, pero que suple con un hondo patriotismo y una sólida formación en jurisprudencia.

729 Comparado en tono y sensibilidad con el poeta Lamartine, presidente de la II República Francesa, Castelar es recordado no solo por sus celebradas arengas parlamentarias, sino también por sus novelas de juventud, sus cursos públicos — como las lecciones de 1858-61, que dieron lugar a su Historia de la Civilización en los primeros siglos del cristianis$m o$, a su entender variaciones retóricas por su carácter poético y musicalidad, más que estudios de calado teórico- semblanzas biográficas como la de Byron, misceláneas y relatos de viaje como sus Recuerdos de Italia (Madrid, 1872), en que cifra la esencia de su talento ("C'est là dans son véritable élément: les souvenirs de la religion maternelle, les beaux monuments, les grandes cathédrales, les statues, les richesses artistiques qu'il rencontre sur ses pas, le ciel bleu, la Méditerranée, Naples, Rome, Florence, Venise, toutes les merveilles de la civilisation l'exaltent et le transportent»). Esta sinceridad religiosa y su esfuerzo por conciliar la antigua fe con las aspiraciones de la democracia nueva mueven a Hubbard a aconsejar a sus correligionarios españoles no ignorar el poder estético y sentimental de las religiones, si bien en su fuero interno duda de la idoneidad de esta vía contemporizadora ( $E$ En cimentant le respect aux vieux usages, aux cérémonies catholiques, prenait-on la bonne route pour les modifier en ce qu'elles ont de contraire à la vérité; comment se débarrasser du surnaturel, du mystique après avoir contribué à leur donner tant de prestige et tant de force?», p. 265). 
dos ${ }^{730}$ Hubbard se demora particularmente en Fernán Caballero, revelada al lectorado francés por Latour desde Le Correspondant en 1857; aborda también la prolífica producción de Trueba — cantor optimista del ignorante y pobre de espíritu-, cuyo alcance popular acota el crítico, pues «ce qu'il entend par littérature populaire, c'est l'emploi de termes et de locutions en usage chez les personnes privées de toute instruction» (p. 312); y atiende asimismo a Bécquer, un hombre del siglo XIX, de naturaleza artística y creadora ("c'est un artiste de la décadence de notre école romantique») que funde ideal y realidad pero al que atemorizan la ciencia y la razón, ${ }^{731}$ y a su obra — como sus Leyendas influenciadas por Hoffmann, sus Cartas desde mi celda, de las que traslada al francés la cuarta, sus recopilaciones de tradiciones y dibujos de una España impregnada de tristeza, su Historia de los tem-

730 Por ejemplo, Antonio de Alarcón - ya presentado con dos traducciones de La Bonne Pêche y Le Cornet à pistons (15-V-1875) por el joven Louis-Lande en la Revue des Deux Mondes (15-V-1875) —, tachado de contumaz neocatólico que renegó de los ideales generosos de la revolución, y cuya obra repasa; o autores secundarios de calidad como un encarecido Vicente Pérez Escrich - leído por todas las clases sociales y cuya traducción reivindica por su utilidad para la sociedad francesa-, del que señala como su mejor obra Los ángeles de la tierra, protagonizada por un médico que conjuga su amor a la ciencia con la virtud y la familia; un Manuel Fernández y González, destacado en el género de aventuras a la manera de Dumas y ambientadas en diversas épocas de la historia española, pero menos estimado por su gusto por la evasión, la superficialidad de sus conocimientos, la reiteración de las situaciones y el perfil violento de sus héroes al margen de la ley, al relegar la ejemplaridad ciudadana en favor de la evasión del lector; así como Julio Nombela, Pilar Sinués de Marco o Fernando Martínez Pedrosa.

731 «Rien de précis ne lui convient: n’allez pas lui demander la netteté, la précision, la raison du dix-huitième siècle. Tout ce qui est sensé, judicieux, déplaît à ces natures, qui exagèrent l'art en voulant en faire le seul tout de la vie» (p. 315). Veinte años después Tannenberg (ob. cit., 1898, pp. 159-167) toma en parte su defensa no tanto como prosista - cuya estima estaba afianzada en la crítica española de entonces gracias a sus cuentos y leyendas a la manera de Hoffmann, las que Tannenberg llama sus cartas humorísticas, y sus estudios artísticos, en los que el crítico halla numerosas y exquisitas páginas sobre las antigüedades monumentales nacionales y un genuino sentimiento poético de la belleza de las ruinas_-, sino como poeta ( Il n'en est pas moins vrai que c'est comme poète surtout qu'il est resté populaire, comme poète des femmes et des amoureux; et on peut dire que c'est comme poète qu'il a apporté une note nouvelle dans la littérature espagnole, où il représente l'influence de la rêverie et de la sensibilité germaniques. Son recueil de Rimes peut être considéré comme un pendant à l'Intermezzo d'Henri Heine», pp. 161-162). Frente a las acusaciones entre sus compatriotas de afeminamiento, sentimentalismo e incorrecta versificación — que para Tannenberg sería más bien achacable a sus editores-, el crítico reivindica la frescura juvenil y la emoción sincera y conmovedora que siguen transmitiendo sus Rimas, varias de las cuales traduce, y en las que percibe sobre todo su familiaridad con Goethe, Schiller o Uhland. 
plos de España, testigo de su admiración por las catedrales, y sus versos como la traducida rima VII- La creciente difusión de Fernán Caballero en el extranjero propicia un análisis más detenido del conjunto de su repertorio $^{732}$ en el contexto de la cultura española contemporánea: aunque le concede imaginación, un notable talento evocador del gusto andaluz por los cantos y la música, descripciones pintorescas, un diálogo vivaz y una fina penetración psicológica en las pasiones y sentimientos de las mujeres del pueblo, Hubbard, sin embargo, deplora su monotonía frente a la variedad de Dickens o Balzac; señala las limitaciones de su ingenio, concentrado en tipos que encarnarían un ultramontanismo tendencioso que el crítico rechaza firmemente; y le discute asimismo la condición atribuida de verdadero pintor de las costumbres españolas, restringidas — según confesión de la propia autora además - a cuadros populares andaluces en los que injerta la recolección de refranes, dichos y coplas del acervo común. De este modo, el historiador se distancia de la cosmovisión de sus novelas mayores - entre las que sobresale ventajosamente La gaviota, de la que elogia el carácter de la protagonista, aunque su mérito radique en sus escenas y diálogos más que en su plan general-, que, en tanto partidaria del despotismo, la Inquisición y los lastres morales, ${ }^{733}$ desestima su comparación con G. Sand o Sterne, como pretendía Mérimée, ni siquiera con un Émile Souvestre, y la allega, a su juicio, al pensamiento de Chateaubriand.

732 Hubbard no solo elogia la selección de Germond de Lavigne sobre sus novelas de costumbres contemporáneas ( IIl a permis au public français de juger des tendances et de l'esprit de la romancière espagnole»), sino que también pasa revista al resto de sus composiciones confirmando su opinión acerca de la preeminencia de los cuadros de costumbres sobre la fábula, desde La Gaviota, Elia — cuya prédica a la resignación rechaza- o Clemencia, hasta Un été à Bornos (Un verano en Bornos) o Lágrimas, Pauvre Dolorès (;Pobre Dolores!), La Nuit de Noël et la fête des Rois (La noche de Navidad), Lucas Garcia, Don Judas Tadeo Barbo, Paz y Luz, Se taire pendant la vie et pardonner après la mort (Callar en vida y perdonar en muerte), Plus d'honneur que d'honneurs (Más largo el tiempo que la fortuna); obras costumbristas como La Pharisienne (La farisea), La famille Alvareda (La familia de Alvareda), Bonheur et chance (Dicha y suerte), L'Étoile d'Andalousie (La estrella de Vandalia), Le Servile et le libéral (Un servilón y un liberalito), Bien ou mal, reste avec les tiens (Con mal o con bien a los tuyos te den); hasta sus "relaciones", en las que busca la emoción del lector, como Justa et Rufina, La flor de las ruinas, La fille du soleil (La hija del sol), La conscience ne transige point (No transige la conciencia), Les deux amis (Los dos amigos) o L'Exvoto; así como traduce entre otros breves pasajes un extracto de sus Contes populaires andalous (Cuentos y poesias populares andaluces), Jean Soldat (Juan soldado).

733 «Pour nous résumer, disons qu'elle est en Espagne, pour le roman, ce que Balmès a été pour la théologie, ce que Donoso Cortes a été pour la politique, le représentant et le défenseur du passé» (pp. 290-291). 
Esta concepción de la literatura como compromiso moral con la sociedad explica la incitación de Hubbard a los escritores —en especial a los novelistas que argumentan con tan poderoso vehículo generador de opinión - para cumplir con el deber patriótico de contribuir a la emancipación personal de sus conciudadanos y a la prosperidad de una nación aprovechando su apartamiento geográfico y fomentando la independencia de juicio, el trabajo y el ahorro. ${ }^{734}$ De esta manera, el historiador no solo advierte del peligro de un creciente asalariamiento al servicio del poder, como ya señalara Mesonero, a fin de acceder a puestos políticos y administrativos, sino que también censura la inclinación de los folletines por las aventuras, contra la que el autor del Quijote también había reaccionado en su tiempo, o predica la separación - ya incipiente en autoridades tan respetadas por el crítico como Cervantes o Moratín- ${ }^{735}$ de la virtud moral y la fe religiosa. Nuevo avatar ideológico de las invocaciones intermitentes desde principios de siglo de un guía rector — de Quintiliano a un Cervantes prestigioso sobre los errados Lope, Quevedo y el estigmatizado Góngora, hasta un Luzán de fuerzas mermadas, y un Quintana y sobre todo un Martínez de la Rosa en la modernidad del XIX-, el moderno Voltaire español reclamado por Hubbard para que oriente como un faro por encima de banderías las décadas por venir del siglo fundiría el entusiasmo quijotesco, el materialismo de Sancho y la ambición de Gil Blas. ${ }^{736}$ Si esta

734 «Leur devoir serait d'aller en avant, de pousser leurs concitoyens au gôut du travail, au développement pacifique du travail intérieur, à la recherche de l'indépendance personnelle par l'énergie dans la lutte pour la vie et par l'épargne et la prévoyance; ils devraient comprendre que l'Espagne, grâce à sa position géographique, peut se faire une vie à part; elle n'est pas forcément mêlée aux grandes questions européennes. Pourquoi ne les laisseraient-ils donc pas de côté? Pourquoi ne répudieraient-ils pas le gôut des aventures, maladie inhérente à la race espagnole et fruit illégitime de sa malheureuse histoire? Pourquoi n'épureraient-ils pas le paganisme chrétien dans lequel elle se débat si tristement? Pourquoi ne cesseraient-ils pas d'exagérer le rôle de la foi? Pourquoi ne donneraient-ils pas à la science, à la raison la place qui leur appartient légitimement?» (p. 296).

735 «On ne sait pas encore en Espagne séparer la valeur morale, la vertu, de la foi catholique, tant que cette séparation si bien commencée du reste par Cervantes et Moratin n’aura pas été vulgarisée, le réveil de l'Espagne sera toujours douteux» (p. 296).

736 «épurant à la fois et l'enthousiasme de don Quichotte, qui aspire à trop de perfection, et le matérialisme de Sancho Pança, dont les appétits sont par trop grossiers, et l'ambition de Gil Blas, dont la conscience est par trop élastique! C'est une espèce de Voltaire que j'appelle» (p. 171). Invocación que recuerda indirectamente el predicamento de que gozaba también en España un republicano Victor Hugo, no mentado por el crítico, en las décadas finales del XIX. 
historia literaria se define por una decidida parcialidad ideológica, inédita en tal grado hasta entonces en los estudios contemporáneos de esta literatura, la materia tratada sigue siendo igualmente objeto de un uso instrumental tanto en su enfoque acerca del orientalismo de sus orígenes como en las propuestas para la mejora de su civilización en el futuro. No obstante, la experiencia en el país vecino de Hubbard — buen conocedor de la vida social y cultural española, espectador de las representaciones madrileñas, al tanto de sus reuniones y banquetes públicos, e invitado a las tertulias de Romea en el Teatro del Príncipe- facilita así la divulgación en Francia de un extenso corpus de autores contemporáneos poco frecuentados.

\subsubsection{Colecciones finiseculares de historias literarias europeas: de Alfred Bougeault a Jacques Demogeot}

Tras los pasos de precedentes de vocación enciclopedista como el padre Andrés, la empresa de Eichhorn o los compendios de Jarry o Lefranc, las colecciones de historias de las literaturas europeas mantienen la aspiración taxonómica y totalizadora del período de entresiglos. Contemporáneos del lento proceso de especialización impulsado por estudiosos de formación alemana como Paul Meyer o Gaston Paris, cuyo testigo recogen para el hispanismo naciente discípulos suyos como el formidable Morel-Fatio ${ }^{737}$ o el emprendedor E. Mérimée, primo del escritor, estos volúmenes divulgadores ${ }^{738}$ no desautorizan las bases retóricas de los estudios generalistas, $y$, si bien recapitulan los estudios más recientes, suelen invocar tenazmente ciertos argumentos ya superados de autores prestigiosos. Asimismo asienten con mayor o menor aquiescencia al enfoque difundido desde Bouterwek — referente citado por Bougeault, quien preconiza

737 En torno a los años ochenta Morel-Fatio, movido por la misma ambición de completitud y ahondamiento en las grandes demarcaciones temáticas, y formado en los análisis textuales de raigambre alemana, comienza a dictar sus lecciones en el Collège de France sobre la novela picaresca y la comedia española y más tarde sobre la literatura de los místicos, en especial de Santa Teresa, para ir ampliando paulatinamente su arco de estudio a la diacronía española sin olvidar el siglo XVIII.

738 De las diversas colecciones generales entonces publicadas, como la Histoire des littératures étrangères de Eugène Hallberg (1880), profesor de Toulouse, hemos escogido dos bastante reeditadas como muestra representativa. 
un análisis independiente de la literatura de cada nación para aprehender su esencia ${ }^{739}$ — junto a la nostalgia por la primacía francesa — abiertamente proclamada por Demogeot ${ }^{740}$ — en el arco de literaturas extranjeras. ${ }^{741}$

La Histoire des littératures étrangères de Alfred Bougeault (1817-1883), premiada por la Société d'encouragement au bien-Prix Raymond, aborda en su tercer tomo la literatura española agrupándola con las otras meridionales —italiana, portuguesa y la griega moderna recién incorporadaPublicada el mismo año que la historia anterior, esta compilación divulgadora también perpetúa el topos del ser español atemporal — caracterizado por un arraigado catolicismo polarizado entre la acción y la contemplación, y un indómito y patriótico espíritu de independencia forjado a lo largo de su historia- devolviéndolo, en cambio, al cauce conservador ${ }^{742}$ predominante en la universidad francesa de la segunda mitad del siglo. Tras los pasos de la crítica precedente, ${ }^{743}$ este profesor de literatura france-

739 Así, frente a la perspectiva de otros colegas, Bougeault aconseja rastrear en su propia diacronía la particularidad de una literatura: «il faut envisager un peuple et sa littérature dans leur essence propre, telle qu'elle résulte du caractère, des croyances et des mœurs, et non par le contraste qu'elle offre avec les autres pays» (Histoire des littératures étrangères, París, Plon, 1876, p. 351).

740 Histoire des littératures étrangères dans leurs rapports avec le développement de la littérature française (1880).

741 La diversidad de literaturas extranjeras de los cuatro puntos cardinales, reunidas en los tres tomos de Bougeault (la alemana, escandinava, finesa y húngara en el primero; la inglesa, neerlandesa y eslava en el segundo, y la italiana, española, portuguesa y griega en el tercero), se ve reducida a cuatro del norte y el sur, en los dos tomos de Demogeot (la italiana, española, inglesa y alemana), que comparten una misma introducción.

742 "Chaque peuple a son génie propre, son état psychologique et moral, dont les tendances se reflètent instinctivement dans l'étude de la philosophie. L'Espagne est trop fortement imprégnée de la foi catholique pour pouvoir passer facilement au rationalisme que certains professeurs voudraient lui inculquer; elle est croyante, mystique, spiritualiste jusque dans ses profondeurs: elle est inaccessible au doute et à la négation. Ces froides théories ne peuvent être comprises d'une nation généreuse, active, enthousiaste, qui sent vivement, et tourne vers le ciel toutes ses aspirations idéales» (pp. 432-433).

743 Este generalista recurre a una selección heterogénea de fuentes: desde las monografías medievales de Baret y sobre todo su historia, referente inmediato del que toma numerosos ejemplos, enjuiciamientos y analogías; hasta las historias de Bouterwek, Ticknor o Sismondi, al que rebate puntualmente apoyándose en los análisis de Chasles; las lecciones editadas de Villemain; el estudio de Schack; la edición de Durán del romancero y las traducciones del género por Maury y Damas-Hinard; referencias eruditas de Humboldt sobre la lengua vasca; así como, por ejemplo, estudios históricos sobre el medievo por Thierry y en especial por el arabista Dozy. 
sa en diversos centros, como el Instituto Alejandro y el Instituto Pedagógico de San Petersburgo, ${ }^{744}$ invoca la nacionalidad literaria que marca la manera de asimilar las novedades e influencias en consonancia con su carácter y necesidades, y que ve representada fundamentalmente en el romancero viejo, la poesía religiosa y mística ${ }^{75}$ del XVI — su mayor riqueza-, el universal Quijote, o el teatro popular del XVII, hasta la reanudación contemporánea tras el hiato del XVIII. La impregnación del romanticismo schlegeliano, asumido en el curso del siglo, se funde con ciertas pautas clasicistas de la tradición francesa, la herencia del idealismo institucionalizado por Cousin y la lectura moral de los discursos orientados a la instrucción. Ganado definitivamente por el concepto de originalidad frente a la imitatio clásica defendida aún por compatriotas suyos décadas antes, este profesor de literatura francesa concibe la poesía como un chorro de sentimiento desligado del consciente trabajo retórico ( La plus belle poésie est toujours celle qui s'ignore et qui coule de source, sans viser à l'effet par des mots et des images», p. 312). Esta cualidad define al verdadero poeta poseído por el ideal y la verdad, ${ }^{746}$ que Bougeault encuentra en más alto grado no en Garcilaso, sino, a semejanza de Baret, en fray Luis de León por su inspiración religiosa, ${ }^{747}$ o en Espronceda, el más ensalzado de los poetas románticos españoles a pesar de su mal du siè-

744 R. d'Amat (dir.), Dictionnaire de biographie française, París, Librairie Letouzey et Ané, t. 6, p. 1291.

745 Los paralelos apuntados por Baret resurgen en alguna asociación esporádica y tópica de Bougeault, que vincula de nuevo la pintura religiosa española con su lírica: "En Espagne, c'est dans les cloîtres, dans la vie religieuse et mystique que l'inspiration poétique trouve toute sa force et son éclat; c'est là aussi que la peinture, sœur de la poésie, a puisé ses plus hautes inspirations" (p. 313).

746 «La poésie est, certes, un des éléments les plus élévés de notre nature, mais à la condition, qu'elle soutienne et dirige l'instinct moral de l'âme, et ne perde pas de vue l'idéal, qui est son but suprême» (p. 413).

747 Aún en su edición de L'Espagne littéraire de 1903, al reseñar los comentarios de Menéndez Pelayo que lo ofrece como el más cumplido y perfecto de los prosistas de la España clásica y el más exquisito de los poetas, Tannenberg señala que fray Luis de León apenas era conocido en Francia, y traduce un pasaje del crítico a propósito de Los nombres de Cristo. Con este extracto ilustra su reseñador la variedad de matices del misticismo - en el que incluye, como era costumbre, al propio Fray Luis - frente a la postura crítica de Viardot o los estudios médicos de entonces ("n'est pas essentiellement, comme on l’imagine, quelque chose de violent et de pathologique. L'inspiration mystique est souvent unie au sens pratique le plus avisé, comme chez sainte Thérèse, ou, comme chez Fr. Luis de León, à une sérénité d'esprit toute platonicienne», p. 167). 
cle, ${ }^{748}$ y cuyo ejemplo vital suscita en el crítico la defensa de las reglas y del dominio moral del deber y la virtud.

A lo largo de trece capítulos Bougeault recapitula las principales interpretaciones y documentos sobre la literatura española siglo a siglo. Los tres primeros abarcan los orígenes hasta el siglo XV con la habitual caracterización de la lengua y sus progresos, y los acostumbrados resúmenes históricos: en primer lugar, los fundamentos de la nacionalidad a través de las vicisitudes de los pueblos asentados hasta el siglo XIII - los iberos, la intensa romanización y el temprano poder temporal de la Iglesia, las invasiones germánicas, los concilios, las invasiones musulmanas, la resistencia cristiana como guerra de liberación e independencia, y la lenta constitución de los reinos cristianos- En ese período, además de mencionar las obras de los hispanorromanos y la literatura latina medieval, se detiene en los principales hitos, sobre los que mantiene opiniones veteranas como, por ejemplo, los romances antiguos — que equipara a la "chanson française»— o el cantar de gesta, al que aún niega intencionalidad y valor estéticos, reconociéndole - como en el imponente pasaje de las Cortes de la tercera parte- la sencillez enérgica de una época precursora del arraigado heroísmo caballeresco. El segundo capítulo comprende los siglos XIII y XIV con las paradas conocidas, en las que también aprecia el uso del color local observador de las costumbres propias y originales. El tercero abraza finalmente el siglo XV, anunciado como "préparation vigoureuse à ce grand seizième siècle, qui sera pour l'Espagne un âge d'or littéraire» (p. 294), y lastrado a su vez por la imitación servil. En la centuria siguiente, marcada en su presentación histórica por las conocidas declaraciones contundentes sobre la ambición desmesurada de Carlos $\mathrm{V}$ y la opresión de un sombrío Felipe II, la avidez conquistadora o la expulsión de los moriscos que preludian el colapso final del imperio, Bougeault ordena su materia procurando conjugar el decurso cronológico con el criterio genérico y la producción autorial. Junto a la clasificación canónica en poesía — lírica y dramática—,

748 «Si la poésie consiste dans l'élan spontané de l'âme, dans la sincérité du sentiment, fût-il sombre et désespéré, la palme en revient incontestablement à José Espronceda [...]. Il appartient, il est vrai, à l'école des poëtes du doute et du désespoir qui a produit les Byron, les Musset, les Lermontof, enfants malheureux d'un siècle qui a perdu la foi et qui demande au néant le dernier mot de la vie; mais dans ces âpres accents d'un impuissant scepticisme, le jeune poëte espagnol a trouvé souvent l'émotion vraie de la passion et du désespoir» (p. 412). 
donde intercala un capítulo dedicado a la producción cervantina, ${ }^{749}$ reúne otros géneros del Quinientos - la fallida epopeya culta de tema contemporáneo, cuyo cometido como portavoz de las costumbres nacionales habrían cumplido las novelas de caballerías; el género pastoril de Montemayor, Alonso Pérez y Gil Polo, así como las ediciones romancísticas y su cultivo-; asimismo reparte entre este siglo y el siguiente el capítulo dedicado a la prosa: la historia - Ocampo, Morales, Gomara, Castillo, Las Casas, el Inca Garcilaso de la Vega, Zurita, Garibay, Mariana, Mendoza, Solís, Moncada, Montaner, Melo, Ávila, Zúñiga, Mexía, Sandoval, Coloma, incluso Pérez de Hita-, las memorias — las cartas y relaciones de Antonio Pérez-, la elocuencia y la moral — con Guevara, Santa Teresa y Luis de Granada-, y la novela picaresca —el Lazarillo, el Guzmán de Alfarache, Espinel y su Marcos de Obregón hasta la inserción del Gil Blas de Lesage como corolario-. En la estela de Quinet, el categórico Ticknor o Hubbard desde el extremo ideológico contrario, la reforma poética alentada por la imitación italiana, introducida por un Boscán, cercano a la rudeza del genio español y superado con creces por Garcilaso, suscita una misma condena en Bougeault como importación extranjera ajena a las inclinaciones nacionales. A semejanza de Baret, la dulzura de los versos garcilasianos — comparados con los de Malherbe más que con los de Petrarca - no sería suficiente, a su juicio, para un gusto exigente, sensible al "cri de l'âme ou l'écho profond de la pensée», calidades poéticas genuinas que sí advierte en fray Luis de León, en poetas místicos como Santa Teresa y san Juan de la Cruz, ${ }^{750}$ y en menor grado - a pesar de su tendencia a la grandiosidad y el artificio, germen del cultismo posterior-

749 El vigor de las consagraciones autoriales difundidas por las primeras historias explica la vigencia central de Cervantes en la exposición diacrónica («l'unité de l'homme nous paraît préférable à l'unité factice des genres littéraires», p. 329). La valoración de su novela acepta los argumentos más extendidos como epítome del carácter nacional español, además de obra filosófica y moral a partir de la dura experiencia de su autor. Tras la refutación de las interpretaciones simbólicas apriorísticas que oponen a ambos protagonistas por el dualismo idea/materia, imaginación/razón — desde los juicios de Sismondi o de Nettement, que lo exacerba como representaciones del alma y el cuerpo-, Bougeault la proclama «le fruit spontané de l'inspiration et du génie, comme toutes les productions sublimes de l'esprit humain» (p. 333), sin dejar de alabar sus contrastes cómicos, que, como en Puibusque, lo relacionan con Molière. Sin embargo, de su teatro solo reconoce, como Baret, la huella nacional en la fuerza estremecedora de ciertas escenas de su Numancia.

750 «quel éclat, quel charme ravissant dans le petit nombre de poésies qu'il a laissées, dans le Dialogue de l'Âme avec le Christ son époux, paraphrase admirable du Cantique des cantiques» (p. 313). 
en el Herrera de las odas inspiradas en las fuentes bíblicas. Orillando la reelaboración renacentista de la multiplicidad de fuentes y su concepto de mimesis, Bougeault justifica su predilección luisiana por su recogimiento religioso inspirado en la Biblia, su perfección estilística — adiestrada en el estudio de los modelos grecolatinos y distante de los frívolos juegos retóricos de los trovadores-, y por su instinto natural. Coartada por el despotismo político y literario, la literatura seiscentista, de la que alaba en especial la lírica de los Argensola y de Francisco de Rioja o de Villegas, se convierte en un arte ensimismado de conceptistes y cultistes, entre los que se cita, por ejemplo, a Góngora, Alonso de Ledesma, Gracián, Espinosa, Borja, o un Quevedo celebrado especialmente por su prosa crítica y burlesca. ${ }^{751}$ La representatividad nacional del teatro barroco español, por su expresión de las costumbres, creencias y prejuicios seculares españoles, se funda en los argumentos habituales, ${ }^{752}$ por los que Bougeault lo opone al drama más reflexivo de Schiller o a la docta elegancia de los franceses ("Chaque peuple crée un drame à son image; c'est le miroir vivant d'une société et d'une nation», p. 238). La obra dramática de Lope, imagen de su sociedad y molde de la dramaturgia nacional, ${ }^{753}$ sustentada en un cote-

751 «Moins profond, moins calme, moins maître de lui que Cervantes, il est, de tous les auteurs du siècle, celui qui s'en rapproche le plus comme peintre de mœurs et penseur ingénieux» (p. 379).

752 Tras ocuparse de los consabidos hitos — desde las obras de inspiración clásica, la escuela valenciana, la aportación de Lope de Rueda y Juan del Encina, o los esfuerzos de Torres Naharro ajustados a las normas clásicas, así como de las condiciones materiales en que se desarrolla-, desglosados en cuatro capítulos de acuerdo con las pautas habituales, Bougeault resume las características propias de la dramaturgia española. Pese a sus cualidades, no deja de ofrecer una producción imperfecta, lastrada por la enumeración de veteranos defectos como una exuberante imaginación, una premura compositiva que desatiende el pulimiento estilístico, la profundización en su asunto y un acabado armonioso así como una supuesta carencia de unidad, que le impiden la perfección ideal de raigambre clásica. La anomalía no menos nacional de sus autos sacramentales y obras religiosas, extrañas al gusto y costumbres extranjeras, invoca en Bougeault el viejo dictado de Bouterwek y de Ticknor: "Il faut être Espagnol, ou se bien pénétrer de l'esprit, des croyances naïves et fortes, des habitudes de ce pays, pour ne pas être choqué de ce mélange du sacré et du profane, de ces allégories bizarres, de cet appareil assez semblable à la pompe des opéras, qui se rencontrent dans ces drames sacrés» (pp. 348-349).

753 Como Baret, Bougeault da acogida a los ya habituales Solís, Moreto, Rojas, el Alarcón de La verdad sospechosa, un Guillén de Castro al que concede la primacía sobre Corneille como Mérimée medio siglo atrás; y un Tirso de Molina, cuyo Burlador encarece sobre Molière, y cuyas comedias de intriga y caracteres son particularmente celebradas por su moralidad y buen gusto frente a opiniones anteriores, así como por su magistral conocimiento de la lengua y su riqueza inventiva y estilística que compensan sus inverosimilitudes e irregularidades. 
jo positivo con las situaciones sublimes y conmovedoras del panteón griego, conserva su investidura schlegeliana ("Le romantisme ici triomphe et trouve tous les contrastes dont il se fait gloire: gravité et bouffonnerie, effets tragiques et farces grossières, sublime et ridicule», pp. 347-348) junto con recurrentes enjuiciamientos que, si ensalzan su portentosa imaginación, su observación fiel de las costumbres de su tiempo y su consumada maestría en anudar intrigas, también reprochan su hibridismo de géneros, tonos y planteamientos, sancionando su arte como vigoroso pero informe y desordenado. Más regular y reflexivo que su maestro e igualmente emblemático, Calderón destaca en Bougeault por sus terribles y estremecedores dramas de honor como $A$ secrète offense, vengeance terrible, y se somete al enjuiciamiento decimonónico que percibe en su obra una tensión de contrarios como la superstición y la devoción, el fanatismo y la piedad, la ferocidad y la grandeza heroica. En el fiel de la balanza ante los juicios encontrados sobre el teatro calderoniano, el crítico toma partido, como hiciera su predecesor Baret, por los profesores franceses en una pretendida valoración equidistante de los extremos: refuta los ataques estéticos y superficiales del lejano Voltaire, modera el entusiasmo de Schlegel como hiciera Villemain en 1843, y apoya las réplicas de Chasles a las andanadas sismondianas que confundían arte y moralidad, aceptando en cambio las censuras al alambicamiento expresivo del dramaturgo.

La escueta extensión otorgada al siglo XVIII —un capítulo de apenas doce páginas - se corresponde con la sentencia categóricamente severa de Bougeault, tan apartada de las vindicaciones de principios de siglo («le dix-huitième siècle est le plus pauvre en littérature qu'ait eu l'Espagne», p. 399). Su censo de autores e instituciones recoge sumariamente representantes de los principales géneros, estigmatizados por la esterilidad creadora y el baldón de extranjerizantes a la luz de la originalidad y la interpretación románticas de la identidad nacional: tras las huellas de Bouterwek, aun aceptando el esfuerzo de Luzán y su buen gusto, se insiste en el limitado e ineficaz carácter normativo de sus teorías falaces, que le habrían impedido apreciar las cualidades de poetas nacionales como Lope o Calderón, frente a las admoniciones del erudito Mayans para conservar la verdadera elocuencia española; Cadalso, de reconocido talento y gusto por la gracia de sus anacreónticas, por su «quelque chose d'ingénieux et de piquant» de la sátira Érudits à l'eau de rose (Los eruditos a la violeta), y por sus Cartas marruecas; la reacción posterior contra el gusto francés de 
García de la Huerta; un Meléndez de mérito formal pero despojado ya de la calidad inherente a un gran poeta («la vraie poésie se reconnaît à d'autres caractères»); Iriarte y Samaniego; un Cienfuegos de más fuerza que elegancia; Iglesias, Noroña, Trigueros, Jovellanos, Diego González, Escoiquiz o Lista; el teatro de Candamo, Montiano, o un Leandro Fernández de Moratín de alabado ingenio y finura, al que niega verdadera fuerza cómica; la prosa de Feijoo, las ineludibles aportaciones eruditas de Sarmiento, Sánchez, los Mohedano, Lampillas, la continuación de Nicolás Antonio por Rodríguez de Castro con su Biblioteca española rabinica, la España sagrada del padre Flórez o Pedro Antonio Sánchez, Masdeu, Conde y Capmany; o también, por ejemplo, la novela satírica del padre Isla. El fulgor que irradiaba aún a principios de siglo el reinado de Carlos III ya ha perdido brillo, quedando reducido a un esfuerzo frustrado («réussite imparfaite»). Por el contrario, en flagrante contraste, el siglo XIX - comprendido en los dos últimos capítulos-, nacido de la guerra de la Independencia consagrada como catalizador popular y patriótico que hizo frente a la invasión extranjera, alumbra una pléyade de autores inmersos en su convulso momento histórico y comprometidos ideológicamente. ${ }^{754}$ Tras los pasos de Hubbard, Bougeault sigue — desde un sesgo ideológico opuesto pero de valoraciones estéticas muy similares- su examen de los autores contemporáneos representativos de acuerdo con el género o el talante dominante en su producción: por ejemplo, poetas como Quintana o Gallego; un Martínez de la Rosa por el que la admiración ha ido decayendo y cuyo buen gusto no hace olvidar cierta medianía y una menor profundidad de conceptos; ${ }^{755}$ el duque de Rivas, elogiado por su drama romántico de 1835 y por la fluidez, brillantez retórica y riqueza versal de su poema descriptivo, a las que, sin embargo, sacrifica

754 «On doit s'attendre à trouver dans la littérature contemporaine de l'Espagne le reflet et l'expression de ses agitations politiques et sociales [...] Nous verrons que la plupart des hommes qui ont manié la plume ont aussi pris part de près ou de loin aux événements dont l'Espagne a été le théâtre pendant les soixante dernières années» (p. 408).

755 De su producción poética este autor dictamina, no obstante: «Les poésies de cet écrivain se distinguent par le gôut, la pureté de la forme et l'harmonie du style, plutôt que par la force de la pensée et la hardiesse de la conception; mais elles lui assurent un rang des plus honorables dans les lettres espagnoles» (p. 411). Por otra parte, Bougeault sigue celebrando como su mejor obra dramática la comedia moratiniana La niña en casa y la madre en la máscara, que había conocido una traducción francesa (La Mère au bal et la fille à la maison) en los años treinta. 
las ideas y la emoción poética; el elogiado Espronceda, valorado, no obstante, por su Diablo Mundo, que, a pesar de la belleza de ciertos pasajes, la riqueza de sus imágenes y estilo, no supera la calificación de pastiche, producto, a su juicio, de una imaginación enferma; el también malogrado Larra, pamphlétaire de juicio crítico firme y atinado a pesar de su propensión a la ironía; Zorrilla, vate del glorioso pasado español en los Cantos del trovador y cuyo consagrado Don Juan Tenorio juzga inferior a la obra barroca de desenlace más aleccionador y dramático que el arrepentimiento sentimental de su pieza; el Campoamor del Drame Universel, obra vigorosa «à la fois fantaisiste et philosophico-religieuse»; Manuel del Palacio, poeta satírico "aimable et spirituel, mais trop porté au scepticisme»; Ventura de la Vega con su aplaudido Homme du monde, así como Hartzenbusch, Antonio Gutiérrez, o Gil y Zárate, cuyos excesos románticos en su Carlos II el Hechizado provocaron en reacción un efímero regreso de las tradiciones clásicas («le courant des idées modernes n’est guère favorable à ce genre de résurrection», p. 421), con obras como una meritoria pero académica Virginia de Tamayo y Baus —inferior también a su drama histórico y nacional La rica hembra-, o una excepción valiosa como el Alonso Munio de Gertrudis Gómez de Avellaneda —-tragedia que aúna en sí la expresión del carácter nacional, nobles pensamientos y un estilo vigoroso- - más aplaudida que otras piezas como El príncipe de Viana o Saúl de la misma autora, también conocida por su cultivo de otros géneros; asimismo, López de Ayala, Eguílaz, Serra, Olona, Díaz o Asquerino; comediógrafos como un Bretón de los Herreros, con un gusto tamizado por sus lecturas francesas, y de ingenio pero sin hondura - que había sido más apreciado en la prensa cultural de mediados de siglo, como lo sería de nuevo por Tannenberg en las últimas décadas de la centuria $^{756}$ - o un Rodríguez Rubí, del que elogia pese a la monotonía del género de la alta comedia, sus piezas Bandera negra y La rueda de la fortuna. Junto a ellos, otros autores también tratados a lo largo del siglo por

756 Así en su estudio Un dramaturge espagnol. M. Tamayo y Baus (París, Librairie Académique Didier, Perrin et Cie, Libraires-Éditeurs, 1898, p. vii), más tarde integrado con modificaciones en L'Espagne littéraire (París, A. Picard et fils, 1903, p. 3), Tannenberg, como los críticos de la prensa cultural de mediados de los años cuarenta, confirma a Bretón - pese a las tenaces comparaciones con Scribe, al que supera en dominio lingüístico del verso y por ello difícilmente traducible - como "le poète comique espagnol du XIX siècle; il faut voir en lui le grand peintre de la bourgeoisie espagnole de 1830 à 1860». 
críticos como Latour —al tanto de la producción española coetánea-, como González de Tejada, M. A. Príncipe o Selgas. Bougeault ensalza asimismo la coherencia religiosa y monárquica de Cavanilles con el pasado histórico de España, o los valores burgueses conservadores de Ruiz de Apodaca en sus composiciones a la religión, la familia, la patria y las artes; escoge a historiadores como el alabado Modesto Lafuente por su claridad estilística y plan compositivo, de cuya Historia de España también extrae un trozo de su discurso preliminar, los marqueses de Pidal y Miraflores, Ferrer del Río, Miguel de Alcántara; selecciona los trabajos críticos sobre España de estudiosos extranjeros como Bouterwek, Herder, Heine, Ampère, Viardot, Damas-Hinard, Chasles o Ticknor antes de citar al conocido erudito Amador de los Ríos; menciona entre los oradores políticos a un alabado Donoso Cortés, campeón del catolicismo y enemigo del socialismo revolucionario y con cuyas opiniones simpatiza ante el desorden y los enfrentamientos contemporáneos; además de los progresistas Olózaga y Rosas o el líder demócrata y presidente de la Primera República, Emilio Castelar, cuyos escritos literarios elogia y compara con su modelo lamartiano al tiempo que critica su falta de pragmatismo político y sus ensoñaciones demagógicas. La enseñanza y divulgación de las teorías filosóficas modernas están representadas por Ramón Martí, Balmes, un estimado Sanz del Río, difusor de Krause, por su moral austera y su espiritualismo cristiano, junto a otros autores como Ramón de la Sagra y Tapia; la novela contemporánea acoge a Escosura y, frente a las críticas de Hubbard, un exitoso Trueba - muy elogiado por sus cuadros de sencillas costumbres campesinas-, la traducida Fernán Caballero - por sus altos valores religiosos y morales, su gracia poética y sus dotes de observadora («Le charme est moins dans la création de l'ensemble, dont la conception est un peu faible, que dans la finesse des détails, la touche gracieuse des nuances, la vivacité spontanée de la narration", p. 437)—, Pérez Escrich, el folletinista Fernández y González, el malogrado Bécquer («Il n'a pas eu le temps de donner la mesure de son talent; [...] c'est peu, mais cela suffit pour faire regretter qu'il n'ait pu donner davantage»), Nombela, Pilar del Marco Sinués o Alarcón.

$\mathrm{Al}$ igual que Baret durante el II Imperio, Bougeault defiende los lazos de la comunidad latina frente al empuje de las culturas septentrionales, y, tomando resueltamente partido por la Iglesia y la burguesía conservadoras en el contexto de la cuestión religiosa de la segunda mitad del XIX, denun- 
cia la influencia funesta de las teorías sociales francesas y el ejemplo negativo de sus revoluciones. A principios de la Restauración española, este profesor se adhiere firmemente a la imagen conservadora del ser nacional español, ${ }^{757}$ reanudando con los veteranos topoi de tierra feraz y paisanaje sobrio, virtuoso, católico y monárquico por experiencia histórica e inclinación. El ascendiente de estas historias universitarias sobre la transmisión de enjuiciamientos añejos y nociones generales en los resúmenes escolares, menos atentos los más a las evoluciones de la crítica o a las novedades literarias, se ejemplificará asimismo en el resumen didáctico del abate Blanloeil, Histoire de la littérature italienne et de la littérature espagnole, ${ }^{758} \mathrm{deu}-$ dor reconocido de Bougeault, o de autores más tempranos como el pertinaz Sismondi, ${ }^{759}$ y cuyo catolicismo militante de finales de siglo anima asimismo a los autores españoles a no cejar en la fe y en sus eternos valores nacionales. ${ }^{760}$

En la década siguiente a Bougeault, la difundida Histoire des littératures étrangères dans leurs rapports avec le développement de la littérature française (1880) de otro docente universitario, Jacques-Auguste Demogeot

757 «L'Espagne catholique et monarchique peut reprendre la marche de ses grandes destinées, en se mettant au niveau des progrès modernes; l'Espagne incroyante et révolutionnaire tendrait fatalement à la ruine» (pp. 443).

758 éd. revue et corrigée, Nantes, Lanoë-Mazeau, s. d., destinada a la enseñanza secundaria. El ejemplar consultado es una donación de 1908.

759 De acuerdo con su finalidad didáctica retoma conceptos, anécdotas y juicios desde un lejano Sismondi, el abate Raynal, o Villemain hasta algunos artículos de 1884 del conservador Correspondant. Dispone la materia (pp. 59-101) en torno a las biografías de los autores y el análisis de sus obras principales. Su exposición comprende el resumen preliminar de la opinión vigente sobre el origen de los españoles como pueblo y la formación de la lengua; y una periodización de la literatura española en cuatro épocas: la época de formación "ou des Romances» de la Edad Media hasta el siglo XVI; «l'âge d'or» con la extensión cronológica (el XVI y parte del XVII) y sus representantes ya preceptivos; la época de decadencia, a la que se adscribe sin paliativos el siglo XVIII; y, finalmente, el XIX, alzado a un «certain réveil des lettres» a partir de la intensa experimentación iniciada en los tumultuosos años treinta y cuarenta.

760 «Les œuvres de tous ces écrivains et de bien d'autres que nous n'avons pu citer, montrent qu'en Espagne l'esprit littéraire se réveille. Mais n'est-il pas à craindre qu'il ne retombe dans son assoupissement, étouffé par les révolutions qui bouleversent sans cesse le pays? Heureusement le peuple reste catholique. Que les écrivains s'inspirent de sa foi et de son glorieux passé! Ils parviendront ainsi à réconquérir leur indépendance et leur originalité, condition indispensable du génie» (p. 101). 
(París, 1808-1894), ${ }^{761}$ acata fielmente la acostumbrada perspectiva francesa en la línea de Puibusque - una de sus fuentes autorizadas junto a sus predecesores más recurrentes a estas alturas del siglo—. ${ }^{762}$ Concebida como complemento de su reeditada historia de la literatura francesa - y parte del proyecto universalista dirigido por el que fuera ministro de Instrucción Pública Victor Duruy_, proponía «une histoire générale du mouvement littéraire chez les nations modernes» en torno a la égida francesa. Esta condición generalista explica en su prólogo a la sexta edición de 1884 su defensa ante las críticas defraudadas de varios reviewers, al afirmar su intención divulgativa a fin de completar la enseñanza de un lectorado estudiantil y culto no especializado. ${ }^{763} \mathrm{El}$ alegato final de Puibusque halla eco en un Demogeot que asume como principio la concepción de una Francia como corazón del gran cuerpo europeo y su portavoz privilegiado

761 Profesor de 1826 a 1828 en el seminario de Saint-Nicolas du Chardonnet, donde había cursado sus estudios, enseñó también en diversas facultades de provincias (Beauvais, Rennes, Bord o Lyon). En 1843 fue nombrado responsable de la cátedra de retórica del Lycée Saint-Louis y sustituyó en sus lecciones a los prestigiosos Quinet, Ozanam y Nisard en París. Autor de numerosos artículos literarios y críticos en revistas especializadas — como la Revue de l'Instruction publique, la Revue des Deux Mondes, la Revue française, entre otras-, de estudios sobre Shakespeare, la literatura francesa y sus críticos, de historias sobre centros de docencia, informes comparativos sobre la enseñanza secundaria y superior en Inglaterra y Escocia, así como relatos bajo seudónimo, sus manuales alcanzaron un gran éxito editorial, en particular la célebre Histoire de la Littérature française depuis son origine jusqu'à nos jours (1857) y el Tableau de la littérature française au XVII siècle (1859). Véase, por ejemplo, Grand Larousse Universel, t. 6, p. 411.

762 En la extensa bibliografía aneja sobre las literaturas meridionales, las citas más abundantes ratifican la primacía de Ticknor y de un inderrocable Sismondi, junto a Villemain - con sus lecciones de la Sorbona y su Essai sur le génie de Pindare ya conocido de Lefranc en 1843-, Baret — con quien coincide en numerosas selecciones-, un estimado Puibusque - pese a los prudentes reparos de Brunetière-, Bouterwek, el estudio de Schack, los cursos de Fauriel, los juicios de Latour o de Chasles - cuyos ejemplos abrevia para su exposición-o un esporádico Tiraboschi. También menciona a Gayangos, Flores, Mayans, Casiri, Dieze, Sarmiento, Conde, Marina o Amador de los Ríos para el período medieval; artículos de prensa, diccionarios biográficos como el de Loménie y recurrentes traducciones francesas de obras españolas.

763 «on se plaint depuis longtemps qu'à la fin de leurs études, beaucoup de jeunes gens et de jeunes filles, que même un bon nombre d'hommes et de femmes du monde n'ont presque aucune connaissance des écrivains étrangers les plus célèbres et manquent de moyens faciles pour combler cette lacune. Nous avons voulu les y aider, en plaçant sous leurs yeux, dans un exposé sommaire mais non aride, l'ensemble du mouvement littéraire de l'Europe» (p. vii). 
(«Il semble que, pour devenir européenne, toute pensée locale doit d'abord passer par la bouche de la France», p. III) en virtud de un proceso discernidor de ósmosis: si en la Edad Media inspiró a las otras literaturas y exportó materias y formas, en el XVI absorbe, asimila y transforma la influencia italiana de la misma manera que en el siglo siguiente los modelos españoles, los ingleses en el XVIII y en el XIX los alemanes, erigiéndose en una suerte de aduana europea («L'histoire de la littérature française était donc déjà jusqu'à un certain point l'histoire de la littérature européenne», p. v). Abanderado de la norma de aspiración universal preservada por la Academia Francesa («Peu nombreux sont toujours les ouvrages significatifs qui ajoutent au domaine de la raison générale et viennent grossir le patrimoine commun de l'humanité», p. IV), más que un estudio "paneuropeo» de las literaturas nacionales más representativas que componen Europa en su devenir histórico, el manual de Demogeot aborda únicamente las influencias recíprocas de la francesa con las literaturas fronterizas $^{764}$ invocando la autoridad, lejana en el tiempo pero reeditada $\mathrm{y}$ vigente, de Villemain (Tableau de la littérature au moyen âge, "XIII" leçon», 1830), que predicaba el estudio de los grandes nombres emblemáticos por su originalidad y repercusión. ${ }^{765}$ De este modo, en su examen de la literatura española punteado por sus analogías con la referencial francesa, el profesor se detiene fundamentalmente en su irradiación sobre la Francia del XVII, ${ }^{766}$ en torno a los principales autores - encabezados por la pareja representativa ya difundida por Chasles, Cervantes y Calderón- y sus producciones agrupadas por géneros, omitiendo esta

764 «Nous abordons chaque nation dans l'ordre même où s'est exercée son influence sur notre littérature, c'est-à-dire sur la civilisation commune. L'ordre logique, l'ordre du développement des idées se confond en effet presque toujours avec l'ordre chronologique des événements; chaque nation, ayant son rôle, a aussi son tour de parole» (p. iv).

765 «mettre en relief les écrivains originaux, les grands noms devenus français par leur popularité, universels par leur influence, ceux qui appartiennent désormais à ce que Goethe appelle si noblement "la littérature du monde" (die Weltliteratur)" (p. vii).

766 Es más, bajo el patrocinio de Chasles y Puibusque, en los dos capítulos finales aborda como Baret el ascendiente cultural español en sus diversos aspectos, desde las modas, la conversación, el género epistolar — ejemplificado en las cartas de Antonio Pérez, sobre el que remite al historiador Mignet, y su influencia junto a Gracián y Guevara, en Guez de Balzac o Voiture-, hasta el teatro — con Hardy, Rotrou o Corneille- y la novela con el Gil Blas de Lesage, excelentemente traducido por Isla y cuya originalidad francesa sigue siendo reivindicada. 
vez el siglo XVIII y relegando el XIX $^{767}$ a un sumario apéndice —añadido en la sexta edición- de notas biográficas y obras señaladas. En su condición de resumen informado retoma argumentos ajenos ya consolidados acerca de su genio nacional, cuya definición - amalgama dualista entre el apasionamiento religioso del asceta y el orgullo heroico del soldado en una longeva Edad Media prolongada, al igual que su carácter oriental, hasta el XVII- coincide con acendradas opiniones conservadoras en la mayor parte de los manuales e historias, ${ }^{768}$ así como de su expresión literaria, brillante y popular pero poco regular - en contraste con la tradición francesa y su bon sens - y cuyo perfil inconfundible se dibuja desde el período romano, además de las influencias consabidas. Asimismo, Demogeot respeta las pautas acostumbradas como la revisión de los pueblos del solar hispano y sus lenguas, o las principales periodizaciones por siglos, etapas y contextualización histórico-cultural. Por ejemplo, como es de rigor, la nacionalidad española también se encarna, entre las obras medievales, ${ }^{769}$

767 Demogeot se limita a señalar que el XVIII invirtió los papeles de preponderancia entre ambas naciones. Entre los autores que incluye, junto a los hispanoamericanos (pp. 405-419), escoge a Conde; Leandro Fernández de Moratín, cuyas comedias considera justamente admiradas; Larra, que devolvió la lengua española a su pureza original; Toreno; Navarrete; Donoso Cortés; Martínez de la Rosa; Ochoa; Bretón de los Herreros; Fernán Caballero; Amador de los Ríos; el republicano Orense, relacionado con Hugo, Quinet y Charras; Hartzenbusch; Gutiérrez; Güell y Renté; Bermúdez de Castro; Figuerola; Zorrilla, proclamado autor nacional; Campoamor; Trueba; Castelar y Salmerón.

768 Por ejemplo, resuenan valoraciones añejas desde la cita sismondiana (t. IV, p. 259) sobre la mediación española de la fascinación oriental y el extrañamiento que aquella produce hasta el dictamen que, remontándose a Bouterwek y el suizo en línea recta hasta Baret, afirma el arraigo del catolicismo y la Inquisición como una forma de ciego patriotismo: «Peuple grand et magnanime jusque dans ses misères, jusque dans ses opprobes! C'est en le couvrant de la gloire de leurs conquêtes que Charles-Quint, que Philippe II, lui font accepter leur tyrannie: c'est en servant le sentiment national que le fanatisme y devient populaire: l'Inquisition n'est qu'une forme de son aveugle patriotisme. Le Castillan est catholique par point d'honneur: la croix est son drapeau. Le more, le juif, l'hérétique, c'est le vaincu, c'est l'étranger, c'est l'ennemi» (p. 169).

769 Además de incorporar obras como el conocido Apolonio, entre otras, Demogeot acata el inventario medieval recurrente, por ejemplo, con el Libro de Alexandre, que despierta más interés crítico a partir de Ticknor; las obras de Alfonso X, en particular Las Partidas, junto a breves pasajes de la Crónica General; un Conde Lucanor inferior al Decamerón, y cuyas lecciones prácticas — ejemplificadas con el exemplo XVI- recuerdan sin igualarlas Las mil y una noches e incluso «les spirituels récits" de los fabliaux franceses, aparte de mencionar otras obras del infante, para las que remite a la edición de Gayangos; un Juan Ruiz — precursor de Rabelais, como de costumbre, y también heredero de 
en hitos como la tradición viva de los romances - verdadera epopeya nacional análoga a los cantares de gesta franceses- en torno al célebre ciclo cidiano que desemboca en Corneille, junto al de Bernardo del Carpio, o los infantes de Lara; en composiciones monásticas como las poesías religiosas de Berceo, de piedad crédula e ingenua $;{ }^{770}$ o en la épica imponente — por su simbolismo y naturalidad más que por su conciencia literaria-, bajo la invocación del héroe castellano, esencia del ser español («le Cid est l'Espagne elle-même»), que recoge un haz de juicios arracimados en torno a la espectacularidad de las escenas de guerra, el enaltecimiento de la pose grave y heroica del protagonista en detrimento de los pasajes cómicos, y la emoción y patetismo de diversos pasajes, espigados del gran fresco de costumbres medievales y caballerescas que continúa atrayendo al público de fines

Rutebeuf- del que sobrevive la misma extrañeza de Malmontais ante su mezcolanza de géneros, tonos, devoción e inmoralidad, si bien la variedad poética y popular de diversas composiciones y su religiosidad le confieren originalidad al conjunto ("Cet incroyable mélange donne au livre de Don Ruiz une originalité bizarre, qui ne laisse pas de prouver, à défaut de gôut, une grande souplesse de talent et de style», p. 182); crónicas como las del canciller Ayala, con pasajes seleccionados por su patetismo, el Paso honrado, o las obras de Pérez de Guzmán, Alonso de Palencia y F. del Pulgar, deudoras de la retórica clásica; y a caballo entre el declive de la Edad Media y la aurora del Renacimiento italiano con Nebrija, la literatura cortesana imitada de los trovadores, en la que predominan la fría erudición y la alegoría, con la notable excepción en gracia y talento de las coplas de Jorge Manrique - cuya evocación del eterno ubi sunt? le trae a la mente, como en Baret y Bougeault, el poema Les Neiges d'antan (Ballade des dames du temps jadis) de Villon-, la inspiración patriótica de los episodios de las muertes del conde de Niebla y de Dávalos en el censurado Laberinto de Fortuna, o la importancia histórica de la carta-prohemio de Santillana.

770 A su ver, su profesión religiosa engendra «un certain effet qui ne laisse pas d'être poétique», aunque no le reconoce mayores méritos. No obstante, señala en sus cuartetas la presencia de lo maravilloso y la transformación de la naturaleza así como una innegable influencia francesa. Como Baret, Demogeot también concede su aprecio a Les Douleurs de la Vierge (Duelo de la Virgen en día de la Pasión de su Hijo) como feliz hallazgo dramático (salvo algún pasaje que contraviene el decoro en la expresión), pero admira aún más la ya valorada por Viardot Los signos..., de los que traduce un fragmento en que se cuentan los prodigios apocalípticos del séptimo día y el anuncio de los desastres del duodécimo (cuartetas 13, 14 y 19); también establece paralelismos con las demás artes en sus comparaciones («l'énergie un peu féroce où se complaît le poète, comme feront plus tard les peintres espagnols») acerca del desgarro físico y moral, reflejo, según varios críticos, de una tendencia de la cultura española por el sufrimiento que lacera el cuerpo y expurga el espíritu. 
del XIX. ${ }^{771}$ En su aproximación al período siguiente — que lleva en germen los signos de decadencia posteriores, cuyas causas ${ }^{772}$ radica como sus antecesores en la coerción político-religiosa que deriva en el cultivo exclusivo de la imaginación-, Demogeot compara el XVI («l'essor le plus glorieux de l'Espagne») con la cumbre francesa del Siglo de Luis XIV («Le seizième siècle fut pour la littérature espagnole ce que le règne de Louis XIV a été pour la nôtre, l'âge des œuvres classiques et d'une imitation originale», p. 202). El profesor francés dispone la exposición de la larga etapa de esplendor en el orden acostumbrado desde las diversas ramas de la poesía hasta el género histórico. ${ }^{773}$ De entre el inventario conocido de

771 Tras aducir la recapitulación de Ticknor sobre las opiniones diversas vertidas sobre el cantar (t. I, p. 12), Demogeot aún mantiene algunos de los juicios que divergen notablemente de las sagaces notas de Florán, en favor de la sugerencia de Sismondi que atenuaba su crítica apelando al valor de la ingenuidad sobre un talento consciente, a la vez que confirma su comunidad histórico-estética con los aventajados cantares franceses como la Chanson de Roland. El espectáculo de las escenas guerreras, la descripción de las costumbres y la emoción y dramatismo de los pasajes —en particular la gradación de las demandas del Cid durante la celebración de las cortes y el juicio en la liza- son bazas a menudo esgrimidas por los comentaristas en sus selecciones. Desde Villemain (Tableau de la littérature au moyen-âge en France, en Italie, en Espagne et en Angleterre, t. II, pp. 8587) se destacan escenas como el íncipit in medias res, siempre elogiado, en que el Cid, desposeído de sus bienes, vuelve la vista llorosa atrás viendo a sus tierras quedarse a lo lejos; su entrada en Burgos, de gran fortuna inspiradora a finales del XIX, y el episodio de la niña, cuya fuerza dramática es siempre alabada - la atmósfera de terror por la orden real y la amenaza del castigo, «la fierté vraiment chevaleresque del Cid», y su valor documental desde un punto de vista histórico-social—; así como otros fragmentos muy reiterados en historias y antologías y también reproducidos por Demogeot como el rescate de Bermúdez durante la toma de Alcocer (vv. 712-730), o entre otros más, aquel en que García Ordóñez le reprocha al Cid haberse dejado crecer la barba para amedrentar a la asamblea, y la respuesta de este (vv. 3281-3290).

772 En el capítulo correspondiente al declive como consecuencia del absolutismo político-religioso - aludiendo a perseguidos como Juan de Ávila, Luis de Granada, Luis de León, Santa Teresa o san Juan de la Cruz- y al vaciamiento de las formas literarias por influjo de corrientes como el gongorismo triunfante sancionado por Gracián, «Boileau du mauvais goût» con su también condenada Agudeza y arte de ingenio, Demogeot atiende como era norma a las diversas facetas del contexto histórico-cultural, teniendo además en cuenta la revisión de Ticknor.

773 El profesor francés clausura su examen con el género histórico a través de la gradación en calidad estilística y concepción, desde las crónicas de Ocampo, Sepúlveda, Mexía o Guevara, pasando por Zurita o Morales, hasta las obras artísticas de Mendoza o de Mariana, cumbre del período por su arte narrativo y sus descripciones pintorescas, además de Herrera y otros también estimables como B. L. de Argensola a pesar de su retórica, el Inca Garcilaso, Moncada, Coloma y Melo, y por último Solís. 
líricos, ${ }^{774}$ reafirma entre los que descuellan por su sensibilidad moderna, imaginación y sentimiento la elegancia de un Garcilaso - cuya escena campestre del canto de Nemoroso en la égloga I le evoca el efecto paisajístico de la Arcadia del clasicista Poussin - y la excelencia de Fray Luis ("plus vrai et par conséquent plus grand poète que Herrera») por la elevación de su lenguaje y la asimilación de las influencias poéticas en medidas castellanas en «la plus belle production de l'Espagne». Demogeot insiste en su clasicidad y su elegancia italiana más que en la originalidad, que en Baret lo independizaba de los modelos medievales y de los italianos renacentistas. Comparable ya su prosa a Fénélon, el editor de Santa Teresa - representada por el soneto habitual, en la que percibe el mismo entusiasmo e inspiración sincera-, es admirado particularmente por la calidad poética y atribuido fervor místico de "En la Ascención», también celebrado por Villemain en las citas veteranas sacadas de su Essai sur le génie de Pindare. Por su parte, la novela comprende sus relaciones con la epopeya — cuyo ejemplo renacentista habitual se ve rebajado a un cúmulo de mate-

774 Así, Demogeot señala la evolución poética de Boscán hacia la pureza clásica — in superar, por ejemplo, a un Malherbe-, con pasajes ya presentados por el lejano Bouterwek en su cotejo con Petrarca, además del inventario de sus obras, a las que añade su traducción de El cortesano de Castiglione; retoma la vindicación del humanista Mendoza («un des poètes les plus sensés et les plus aimables de l'Espagne», p. 215) por su fusión entre la poesía nacional y los modelos clásicos; aunque muestra cierta reticencia hacia Herrera («le poète du lieu commun sublime», p. 215) en cuanto a la expresión genuina del sentimiento, el artificio formal («il y a du Ronsard dans ce Jean-Baptiste Rousseau. Mais ce qui frappe et fatigue surtout le lecteur étranger, c'est l'absence de souplesse, de laisser-aller et de naturel», pp. 223-224), y frente a Baret retoma la opinión negativa de Bouterwek sobre sus comentarios garcilasianos, también le concede imaginación, musicalidad y grandeza en sus canciones y odas patrióticas y un brillo retórico adecuado a su lengua y nación ("cette Afrique de l'Europe», p. 223), que en Francia en cambio sería enfático; asimismo, tampoco olvida a los obligados Argensola, apreciando la equidad de juicio de Puibusque frente a la severidad de Quintana; y en su estela, a los consabidos Rioja, Figueroa, Espinel, Jáuregui, «le spirituel Quevedo» o, por ejemplo, un voluptuoso Villegas. De ese florilegio de nombres Tannenberg retiene varios de ellos en su sucinta enumeración tamizada por las valoraciones de su reseñado Menéndez Pelayo, cuyo Horacio en España también ha leído atentamente ( On n’attend pas que j’essaye ici, en glanant chez M. Menéndez y Pelayo, de grouper autour de Fr. Luis de León les principaux poètes de "l'âge d'or", le gracieux et touchant Garci-Lasse, le pompeux Herrera, l'harmonieux Jáuregui, les Argensolas, à la muse sentencieuse et réfléchie, mais parée pourtant de vives couleurs; et Francisco de la Torre si tendre, Lope si passionné, Gongora, si pauvre d'idée, mais si riche d'images; Quevedo dont la pensée subtile s'enferme dans un moule étroit qu'elle fait éclater, Quevedo, le satirique nerveux et brutal, écrivain prodigieux de verve [...] et tant d'autres encore», ob. cit., 1903, p. 181). 
riales yuxtapuestos para un poema aún por hacer, a la vez que se repite la idea difundida por Quinet de que la savia épica discurrió por este género narrativo y el drama - y sus diversos subgéneros: la novela caballeresca representada por el Amadis; 775 la decaída novela pastoril con un Montemayor influyente en Inglaterra y Francia, cuyo mérito perdurable consiste en el tono tierno y la gracia de su prosa y en sus composiciones líricas; la satírica, en la que, además de dedicar poco espacio a las obras propiamente picarescas ${ }^{776}-\mathrm{y}$ españolas por antonomasia—, inserta la producción cervantina: el Quijote, ${ }^{777}$ el Persiles («roman sérieux»), del que reproduce pasajes del prefacio traducidos por Sismondi y sus matizaciones favorables, y sobre todo sus novelas ejemplares, ${ }^{778}$ de gran talento inventivo al tiempo que documentos históricos más sugerentes que los textos de Mendoza

775 Además de remitir a los estudios históricos de Dozy, y también a las monografías de Baret a propósito de su refundición española por Garci Ordóñez de Montalvo, incluye citas de esta novela, alabada por la pureza de sentimiento y la moralidad, su estilo natural y la recreación costumbrista, pese a los defectos achacables al género como su prolijidad, monotonía e inverosimilitudes.

776 Bajo el marbete de "romans comiques», Demogeot subraya la originalidad del género — desde el Lazarillo y el Guzmán, seguidos de los habituales Justine la truande, Le Capitaine Pablos, Le Diable boiteux, o Marcos de Obregón, modelo este del muy superior Gil Blas-, y su carencia de un análisis más profundo que achaca a sus teorías sobre el arte de narrar y a su sumisión al gusto nacional.

777 Demogeot lo exalta como un clásico universal que conjuga las costumbres de su tiempo con la naturaleza moral humana: así, entre sus valores fundamentales no solo destaca la gran variedad de aventuras sin menoscabo de la unidad de la obra, sino también el desarrollo progresivo de sus personajes protagonistas, como, por ejemplo, Sancho, erigidos además en tipos universales. No obstante, lejos tanto de ser tipos planos como abstracciones, tal como querían Sismondi y otros - juicio que Demogeot atribuye erróneamente a Bouterwek-, el crítico niega que Cervantes se hubiera propuesto reflejar esa idea filosófica ("Cervantes ne fut point un faiseur de systèmes, il ne fut qu’un romancier de génie», p. 263).

778 Entre las de tono más serio y enfático, y de menor verosimilitud y calidad ante el parecer general, frente a las habitualmente elogiadas de tono más costumbrista, y lejos ya del aprecio de Saint-Fargeau, traduce trozos tomados de El amante liberal como los lamentos sentimentales de Ricardo de retórica alambicada y llena de alusiones mitológicas, o la jerga de Los dos hermanos; en cambio, juzga excelentes por su comicidad y pintoresquismo, las acostumbradas Rinconete y Cortadillo y La Bohémienne de Madrid (sic) por sus descripciones y variedad de diálogos — sin por ello preferirla a la novela de Victor Hugo ( $\mathrm{M}$. Baret donne la préférence à l'original espagnol. Mais l'original ne possède ni Claude Frollo, ni Quasimodo ni sa vivante cathédrale» (p. 271)_, así como un pasaje de una alabada L'Illustre Servante (La ilustre fregona) y un divertido Le Dialogue des chiens (El coloquio de los perros Cipión y Berganza) ("revue assez curieuse, mais pas assez piquante, pas assez vive des conditions les plus humbles de la société espagnole», p. 271), que le recuerda, no obstante, las conversaciones de don Quijote y Sancho). 
y Mariana por su preciosa recreación de las costumbres de la época, la verdad de su lenguaje y su característica maestría estilística.

Asimismo, la extensión más dilatada es la dedicada a un autárquico teatro nacional — desde los orígenes y las escuelas dirimidas desde la difusión de Bouterwek, ${ }^{779}$ las revisiones de Schack y la recapitulación de Ticknor-, surgido de su tradición sin modelos extranjeros y al servicio de la imaginación popular. La teoría y obra dramática de un Lope instintivo pero de juicio errado, y cuyo talento prodigioso y vital supera como en Baret la calidad de sus obras, soportan los longevos veredictos desde Schlegel y Sismondi, que, pese a Schack, le restan profundidad y envergadura: ${ }^{70}$ frente a su recurrente enlace de intrigas anudadas por el azar («bien au-dessous de l'art profond de Molière»), difíciles de seguir para un extranjero, y de tipos incesantemente repetidos, le concede, sin embargo, brillantez retórica, cierta pintura de caracteres y verosimilitud en la ficción y el lenguaje. Además de mencionar los entremeses lopescos, Demogeot recurre a Ticknor para la clasificación de sus piezas, cuyos ejemplos toma principalmente de las viejas traducciones de Ladvocat: ${ }^{781}$ las históricas, aún crónicas dialogadas como las de Shakespeare, en las que lo cómico linda con lo sublime - por ejemplo, La Découverte du Nouveau Monde par Christophe Colomb (El Nuevo Mundo descubierto por Cristóbal Colón) o La Fontaine aux brebis (Fuenteovejuna), vivaz recreación a partir de los magros datos históricos de un abuso de autoridad, de realismo, sin embargo, demasiado indecoroso para una escena francesa; la impactante Le meilleur alcade le roi, pese a las bromas del gracioso, especie de pícaro dramático

779 Desde la encabezada por La Celestina, obra no escrita para el teatro pero aún de controvertida definición, sobre la que siguen recayendo los reproches de inmoralidad, vulgaridad e incluso pedantería y de la que ya no se exalta el primer acto, sino, por influencia de la escena del balcón de Romeo y Julieta, la entrevista nocturna de los dos amantes en el acto XIX; hasta la escuela clásica y erudita y la convergencia de Naharro y Rueda - de calidad más rebajada-, Cueva y Virués en la popular luego triunfante. Tampoco deja de subrayar, como Schlegel, la vocación de Cervantes por la epopeya más que por el teatro, de cuya producción dramática menciona las dos piezas de costumbre sobre las que reproduce la opinión de Sismondi.

780 «Lope n'est pas un de ces poètes de tous les âges comme Shakespeare, comme Molière, comme Racine, qui reproduisent l'homme dans ses traits durables et permanents, c'est un improvisateur qui, dans une foule d'esquisses rapides, saisit et rend les caprices de chaque jour, les grâces et les afféteries fugitives de la société qui l'entoure» (p. 300).

781 La Nécessité déplorable (La fuerza lastimosa), Le Chien du jardinier, La Perle de Séville (La niña de plata) y Le meilleur alcade est le roi, editadas en 1822-23. 
cuya función define como solaz, parodia y crítica de la acción, y de papel más breve en obras intensas como L'Étoile de Séville-; las comedias de capa y espada o de costumbres — semejantes en esto a las consumidas por la burguesía francesa-, con la mediocre e inverosímil Le Moulin ${ }^{782}$ (El Molino) _ la única pieza de Lope incluida por Damas-Hinard en la colección de 1835- y una criticada Le Chien du jardinier, de la que reconoce el mérito de la introspección femenina; los extraños autos sacramentales y otras piezas de carácter religioso — de innegable superioridad estilística sobre alegorías y misterios pese a su extraña estructura y sus excesos-, de las que apunta algunos títulos insertos en El peregrino en su patria y registrados en las antiguas Obras sueltas de $1776 .{ }^{783}$ Su escuela, abiertamente nacionalista y de mayor libertad y gusto por el patetismo, presenta los autores ya reconocidos, escogidos principalmente - salvo ejemplos como Los amantes de Teruel de Montalbán- por su repercusión en la literatura francesa que sus dramaturgos aprovecharon y mejoraron con acierto: Tirso, principalmente representado por El burlador (Le Railleur de Séville), tipo europeo de fondo español; el sempiterno Guillén o Alarcón y su comedia de carácter, sabiamente depurados por Corneille en su Cid y Le menteur, como proclamara Raynouard a principios de siglo. Sobre un Lope derrocado, Calderón («le grand poète dramatique de l'Espagne»), ${ }^{784}$ encarnación de un catolicismo dirigido a los sentidos, excluyente y posesivo, y de un duradero y caballeresco medievo español, cifra de su tiempo y de su patria, se hace comprensible a los franceses si lo asimilan a los tiempos de su rey cruzado Luis IX. Su enjuiciamiento conserva prácticamente las mismas cualidades desde Bouterwek, a las que se suma la afianzada lectura ideológica con más favor que ante Sismondi — gran cultura e ingenio, estilo elegante, rica imaginación, entusiasmo lírico, ascético y apasionado, devoción y mundanidad ante una muchedumbre ignorante e irreflexiva a la par que avezada y exigente-. Demogeot coloca en el primer lugar de

782 Publicada en la entrega 51, tomo I, de 1836.

783 Por ejemplo, Le Salut de l'homme, Le Voyage de l'âme, L'Enfant prodigue, Le Mariage de l'àme et de l'amour divin y, entre los inspirados en fuentes bíblicas, La Naissance du Christ, La Création du monde et le premier péché de l'homme, L'Histoire de Tobie, La Belle Esther o Les Travaux de Jacob.

784 Con el correr del tiempo fueron varias las traducciones calderonianas editadas en Francia: entre las más recientes entonces, las incluidas en la colección de Latour (1871-73), A. Simonise (1873) o Morel-Fatio. 
su producción sus autos, ${ }^{785}$ luego sus dramas heroicos y sus piezas religiosas o devotas, entre las que incluye como el historiador alemán la famosa y conmovedora La devoción de la Cruz, ${ }^{786}$ que suscita encontradas críticas — de Chasles, mejor valedor en sus Études sur l'Espagne que Sismondi, toma Demogeot el resumen y análisis de varios pasajes como, por ejemplo, el primer duelo o la predestinación-; El mágico prodigioso, ${ }^{787}$ un Fausto español de poderosos efectos dramáticos encarecidos por Mérimée, pero cuyo trasfondo metafísico el compilador no percibe si no es la voluptuosidad de la intriga amorosa; o la también heroica Le Prince constant, traducida antaño por Schlegel. Y finalmente, sus piezas costumbristas, que arrastrarían los prejuicios de su tiempo, y los del siglo XIX, como prueba cierta ambigüedad persistente hacia el dramaturgo. Así, el crítico francés retiene los principales juicios sobre sus dramas, construidos sobre un puntilloso sentido del honor y terribles pasiones - como en el ya emblemático Le Médecin de son honneur -; mientras que para sus divertidas comedias de intriga — como Casa con dos puertas mala es de guardar (Maison à deux portes est difficile à garder) y L'Esprit follet (La dama duende), con varios de cuyos pasajes ejemplifica el arte consumado del autor—, ${ }^{788}$ remi-

785 Entre ellos cita Le Premier et le Second Isaac, La Vigne du Seigneur, Les Épis de Ruth, Le Divin Orphée o La Première Fleur du Carmel.

786 Según recoge Charles Monselet (De A à Z. Portraits contemporains, París, G. Charpentier et Cie, 1888, p. 46), en las fiestas celebradas en homenaje a Calderón por la Asociación Literaria Internacional se puso en escena una representación extraordinaria del dramaturgo español en la que, como señala este escritor y periodista, la fama sigue considerando la Dévotion à la Croix un «drame étrange et farouche», «le drame le plus caractéristique et le plus personnel de Calderon» ("C'est le drame catholique et fanatique dans toute son essence, et dans toute son horreur naïve»). Además de ser objeto de análisis literarios en la prensa cultural, esta pieza es escogida recurrentemente como en las selecciones de Damas-Hinard, Latour o L. Sandret (Théatre choisi de Calderon, París, 1884-86), en ediciones sueltas como la traducción del conde Lafond conjuntamente con $\grave{A}$ secrète offense, secrète vengeance (1877), y en antologías finiseculares como las de A. Ernst (Gautier, 1895) o de L. Rouanet (Drames religieux, A. Charles, 1898).

787 Tras la traducción en 1875 de Magnabal (El Mágico prodigioso, comedia en tres jornadas, por D. Pedro Calderón de la Barca. Nouvelle édition, publiée avec une notice, un argument analytique et des notes en français..., París, Hachette), en 1877 Morel-Fatio editaría el original en facsímil con sus variantes y anotaciones.

788 Traducidas ya por Damas-Hinard, quien entre 1835 y 1836 había incluido en las entregas de Chefs-d'ceuvre du théâtre étranger varias obras calderonianas: Le Médecin de son honneur, Maison à deux portes, maison difficile à garder, $\grave{A}$ outrage secret, vengeance secrète, De mal en pire (Peor está que estaba), que en ediciones posteriores titula De mal en pis. En 184144 añade para la edición de Gosselin La Dévotion à la Croix, L'Alcade de Zalamea, La vie est un songe, Le pire n'est pas toujours certain (No siempre lo peor es cierto), Bonheur et malheur du nom, (Dicha y desdicha del nombre) Aimer après la mort ou le siège de l'Alpujarra (Amar después 
te al prefacio de Latour a su traducción de 1871, donde alaba la perfecta construcción de sus complicadas intrigas, si menos inventivas que las de Lope, siempre deslumbrantes, naturales y entretenidas por sus equívocos, golpes de efecto e incluso encantadoras inverosimilitudes. El estilo retórico de su tiempo - por ejemplo, el saludo de Astolfo a Segismundo en La vie est un songe-, varios de cuyos procedimientos apunta como la diseminación de conceptos, su entrelazamiento y recolección final, aún choca al gusto francés del día, si bien repara en la autoironía del dramaturgo. Demogeot concluye, sin embargo, con una larga cita de Ticknor (t. II, cap. XXIV) que lo consagra como «un des phénomènes les plus extraordinaires de la poésie moderne», ratificando el mérito eminente de Calderón en sus pasajes más logrados por su versificación, arte, poeticidad y generalmente escrupulosa moralidad, en suma, su pleno talento sobre los defectos de su tiempo como encarnación de lo más noble y puro del carácter nacional español. Tras el examen culminante en los períodos de esplendor respectivo, esta historia parcial constituye, pues, bajo la Tercera República la afirmación nacionalista de la literatura francesa — diluida en el clasicismo- realzando tenazmente su asimilación inteligente de las aportaciones foráneas, cuyos análisis no dejan de ser en definitiva un complemento de su plan global.

\subsection{Antologías contemporáneas: algunos ejemplos (1826-1884)}

Breviarios auxiliares para el aprendizaje de una lengua, muestrarios estilísticos o ideológicos, tesoros, parnasos y bibliotecas del patrimonio literario, las antologías constituyen uno de los viejos cauces reconocidos sin paliativos del azaroso proceso de canonización de obras y autores. Si bien se deslizan en las historias de la literatura del XIX, ocasionalmente en relatos de viajes, y con relativa frecuencia en artículos literarios de la prensa cultural, estas muestras hallan principalmente cabida en colecciones concebidas con una vocación reivindicativa o divulgadora para un público medianamente culto que acude a las librerías, los gabinetes de lectura o las aulas universitarias. Gracias al desarrollo de las técnicas de

de la muerte), Le Geôlier de soi-même (El alcalde de sí mismo). En la edición de 1869 incluye Louis Perez de Galice (Luis Pérez el Gallego), Le Secret à haute voix, L'Esprit follet (La dama duende), Les Trois Châtiments en un Seul (Las tres justicias en una), Le Prince constant, Le Schisme d'Angleterre (La Cisma de Inglaterra). Vid. Horn-Monval, ob. cit. 
impresión, al crecimiento del mercado editorial francés y a la difusión de la alfabetización, comienzan a prodigarse en las décadas iniciales de esta centuria. No son escasas las dedicadas a la producción española, dado el relativo favor —avivado principalmente por la presencia de españoles exiliados que asegura una producción dirigida asimismo al público hispanoamericano, y por la fructífera actividad de libreros españoles y franceses_- ${ }^{789}$ de que goza esta literatura lentamente redescubierta y frecuentada con distinto aprovechamiento en el curso del XIX. Entre las antologías españolas ${ }^{790}$ más consultadas en la primera mitad del siglo por los estudiosos en Francia, cumple citar la selección teatral tan polémica de García de la Huerta, el Parnaso español de López de Sedano, o la voluminosa colección patrocinada por Ramón Fernández, ${ }^{791}$ concentradas principalmente en los períodos a partir de la época de esplendor e inmersas en los debates político-estéticos de su coyuntura histórica; a horcajadas entre ambos siglos, adentrándose en la centuria siguiente, las muy consultadas analectas de Quintana, y ya en el exilio francés la aún

789 L. Romero Tobar (ob. cit., 1994, p. 23) señala que, a pesar de las últimas aportaciones sobre las relaciones culturales anglo-españolas y germano-españolas: «Según los datos que poseemos, las relaciones editoriales y de comercio de libros entre España y los otros países de la órbita cultural occidental no fueron tan estrechas como las habidas entre Francia y España [...]». Véanse especialmente Quérard (ob. cit.), Vauchelle-Haquet (ob. cit., 1985, 2003); así como M. Núñez de Arenas («Impresos españoles publicados en Burdeos hasta 1850", en L'Espagne des Lumières au Romantisme, 1963, pp. 309-351), R. Marrast («Imprimés castillans et catalans en France: bilan provisoire et perspectives», en Histoire du livre et de l'édition dans les pays ibériques, Burdeos, Université de Bordeaux/PUF, 1986, pp. 53-60), J.-F. Botrel («Le commerce des livres et imprimés entre l’Espagne et la France (1850-1920)», en J. P. Étienvre y J. R. Urquijo Goitia (eds.), España, Francia y la Comunidad Europea, 1989, pp. 115-133, o también «La librairie espagnole en France au XIX ${ }^{e}$ siècle», en J.-Y. Mollier (dir.), Le commerce de la librairie en France au XIXe siècle. 17891914, París, Institut Mémoires de l'édition contemporaine (IMEC)/Maison des sciences de l'Homme, 1997, pp. 287-297).

790 Véanse, por ejemplo, la relación y análisis de R. M. ${ }^{a}$ Aradra, ob. cit., pp. 161-172.

791 Véase R. Andioc, «Ramón Fernández siempre será Ramón Fernández», en Del siglo XVIII al XIX. Estudios histórico-literarios, Prensas Universitarias de Zaragoza, 2005, pp. 677686. J. Checa («El libro: La Colección de poetas castellanos (1786-1798)», en Joaquín Álvarez Barrientos (ed.), Espacios de la comunicación literaria, Madrid, CSIC/Instituto de la Lengua Española, 2002, pp. 109-128) ha estudiado las divergencias estéticas e ideológicas de sus dos colaboradores, Estala, amigo de Moratín, y Quintana. El primero se encargó del prólogo y de los primeros tomos hasta el XIII incluido - en que lo releva Quintana, al frente de los publicados en 1795 (t. XIV), 1796 (t. XVI) y 1797 (t. XVIII)—, para retomar la antología en los dos últimos volúmenes. 
combativa de P. de Mendíbil y M. Silvela, o la de Marchena, hasta la vulgarización dirigida al público francés de la selección bilingüe de Maury. En las décadas siguientes descuella a su lado la activa labor difusora, en ambas direcciones, de Eugenio de Ochoa, desde la ambiciosa Colección de los mejores autores españoles iniciada por Baudry en 1838 hasta 1872, en la que promocionó todos los períodos históricos de la literatura española, sin descuidar su contemporaneidad - como era entonces el caso, singular en el panorama de los estudios franceses, de su compendio Apuntes para una biblioteca de autores españoles contemporáneos en prosa y verso de $1840 .{ }^{792}$

Además del Tesoro del contemporáneo Quintana —autoridad moral, literaria y política - y a cuya colección recurren principalmente los franceses de las décadas de los años treinta y cuarenta, entre los florilegios más difundidos en la Francia de los dos primeros cuartos de siglo alcanzó notable fama L'Espagne poétique ${ }^{793}$ de un emigrado de la primera oleada, Juan María Maury (Málaga, h. 1780-1845). ${ }^{794}$ En el exilio francés, lejos de una España postrada tras un terrible comienzo de siglo, Maury dedica sus horas al estudio como sus compañeros de los Ocios de los emigrados en Londres, con un «essai poétique» que recibió bastantes parabienes de la

792 Apuntes para una biblioteca de autores españoles en prosa y verso, París, Baudry, 1840, 2 tomos. Este repertorio, aparentemente no ponderativo e imparcial, incluía noticias previas concisas y una selección de pasajes ilustrativos de estilos heterogéneos y distintas generaciones, dispuesta por orden alfabético y acompañada de notas biográficas, de diversos autores nacidos o formados en el gozne de entresiglos, desde los respetados maestros del XVIII, como Pablo de Jérica o Moratín, excluyendo en cambio a Cadalso o Meléndez Valdés, hasta los condiscípulos del colector y otros contemporáneos.

793 Choix de poésies castillanes depuis Charles-Quint jusqu'à nos jours, mises en vers français; avec une dissertation comparée sur la langue et la versification espagnoles; une introduction en vers, et des articles biographiques, historiques et littéraires, París, P. Mongie, 1826-27, 2 vols. en $8 .^{\circ}$ Ouvrage orné de plusieurs portraits. Las copias reproducen los retratos de Alfonso X, Hurtado de Mendoza, Garcilaso, Herrera, Lope de Vega y Quevedo en el primer tomo y de Góngora y Meléndez Valdés en el segundo. Sus traducciones en verso también trasladan los títulos impuestos a las composiciones tomadas de las ediciones, de los que en general prescindiremos por economía de espacio.

794 Familiarizado antes de su exilio con el extranjero gracias a su viaje de estudios por Francia, Inglaterra e Italia, su reputación literaria más firme se labró con su antología bilingüe. En 1840, décadas después de su poema épico de 1806 La agresión británica, publicó en París su poema heroico Asvero y Almedora, antes de reunir en 1845 sus obras poéticas (Poesías castellanas, Valencia, 3 vols.). 
prensa periódica francesa ${ }^{795}$ de finales de los veinte. Su selección de autores - convenientemente presentados en detalladas noticias biográficas y evaluadoras - viene precedida de un discurso preliminar, bien documentado, en el que analiza el carácter de la lengua española, su métrica y prosodia en comparación con otras lenguas europeas, justifica su proceder ${ }^{796}$ y expone en verso los hitos de la historia de la literatura española - insertos en su contexto histórico y literario en notas explicativas y extensas apostillas en prosa- De este modo, observa en sus introducciones históricas a cada época — en especial en las últimas décadas - la influencia de la política sobre la literatura, consagra el romancero como el género nacional por excelencia; defiende el teatro del Siglo de Oro - marbete que, como en Bouterwek, vincula indirectamente a Lope más que a Calderón—— ${ }^{797}$ y preconiza el buen gusto de los buenos modelos, ya sean los clásicos españoles o los modernos más cercanos. Familiarizado con las historias de Bouterwek y Sismondi, en su documentación auxiliar cita con gran

795 Los juicios críticos, generalmente favorables, de las principales publicaciones (Le Moniteur, Le Journal des Débats, La France Chrétienne, La Revue Encyclopédique, L'Etoile, Le Mercure, Le Journal de Paris, Le Constitutionnel, L'Opinion, Le Courrier Français) encabezan el primer tomo del ejemplar consultado perteneciente a la edición de 1826. Todos ellos alaban la utilidad de su selección de poemas y su orden dispositivo, aprecian el talento narrativo de Maury en las noticias biográficas y las explicaciones históricas, así como la calidad y corrección de su texto, que les sugiere a algunos (L'Étoile) un profundo conocimiento de Racine y Boileau, mientras que otros también encarecen su color local (La Revue Encyclopédique), o señalan moderadamente en la variedad de piezas y tonos algunas incorrecciones (Le Constitutionnel). Más reticente, Le Mercure rastrea los defectos formales, aunque escasos, y proclama en nombre de la universalidad de su lengua («notre langue est celle de la littérature générale») la primacía del tribunal francés en Europa.

796 Maury explica sus criterios de traducción y las licencias adoptadas como, por ejemplo, los cambios de tono en el registro de niveles de habla o las habituales expurgaciones y recortes de textos como en otras antologías precedentes, en nombre del gusto para contrarrestar la prolijidad de los originales. En su esfuerzo por imitar en el molde francés la musicalidad lírica, la sencillez de los sentimientos y la huella oriental de las imágenes y el estilo, en combinaciones rítmicas cuya novedad ampara bajo el éxito reciente de la música española, el colector afirma acogerse al consejo de Delille (L'Homme des Champs) de apresar el espíritu de la obra y su tono general en lugar de ofrecer una copia en detalle («Nous avons pris un conseil adressé aux poëtes paysagistes par leur illustre maître: il les détourne de faire comme ces peintres sans goût», p. 39.

797 El marbete demarcador («siècle de Lopé de Véga») aparece ligado a un nombre ilustre como guía: «Lopé de Véga, et ce que l’on a appelé le siècle d'or de la littérature espagnole, sont venus trop tôt» (p. 286). 
estima los tomos costeados por Ramón Fernández, preparados y prologados por su amigo Quintana — admirado como poeta y referente crítico-— ${ }^{798}$ y la vindicación de Lope por lord Holland; ${ }^{799}$ con notable aprecio la antología de Manuel Silvela y Pablo Mendíbil — quien entonces preparaba en Londres una colección especial de romances anteriores al $\mathrm{XV}-$; con respeto las noticias proporcionadas por el padre Mariana o por Conde, así como las veteranas e ineludibles colecciones de López de Sedano y Sánchez; y, con más distancia por el trasfondo de las controversias lingüístico-ideológicas, los juicios de Marchena, cuyas lecciones estima en mucho pese a su prurito casticista ${ }^{800}$ y sus críticas intempestivas a Meléndez.

En su repertorio de autores españoles antiguos y modernos, mayoritariamente de los Siglos de Oro y del XVIII, Maury centró su elección primordialmente en la poesía lírica y sus subgéneros, descartando la épica y la dramática ${ }^{801}$ — de la que omite a Calderón, mientras que selecciona

798 Por ejemplo, convoca sus juicios sobre determinadas obras - como el cantar del Cid, El libro de buen amor, el aprecio por el Laberinto de Mena, al que reprocha su parcialidad y doblegamiento al poder, los elogios al infinito talento de Garcilaso, aunque no pusiera en ocasiones más arte y conveniencia en la disposición de poemas-, al igual que comparte su aceptación del compromiso del escritor con la sociedad.

799 De ese repertorio de fuentes en el exilio, la filiación inglesa tampoco es desdeñable con los trabajos de los Ocios de los emigrados españoles (1824-28), la mención de otros títulos como las Letters from Spain: printed for Henry Colburn, elogiosas con Quintana y que atribuye a un español, junto a otras ediciones, fundamentos para sus noticias. Además del anecdotario de Bourgoing, Maury está atento a la actualidad española al citar asimismo la nueva traducción horaciana de Javier Burgos.

800 «Et voilà comment, par un langage affecté, bizarrement et trivialement indigène, Don José Marchena est parvenu à défigurer le morceau de critique littéraire, d'ailleurs le mieux fait, peut-être, le plus nourri, le plus vigoureux qui ait jamais été publié», refiriéndose a su discurso preliminar de la colección de Burdeos de 1820. Aunque le niega verdadero talento poético y disiente de sus ataques de afrancesamiento contra el lenguaje poético de Cienfuegos y Meléndez, Maury, más partidario de las innovaciones necesarias al paso de los avances de las ideas modernas, encarece, no obstante, sus vastos conocimientos y la sagacidad de sus críticas — como en su jocosa refutación a Vicente de los Ríos (1790), quien definía el Quijote como poema épico-, a la vez que se hace eco de su broma erudita a propósito de un supuesto fragmento descubierto de Petronio.

801 Las excelencias de los géneros relegados, a pesar de sus imperfecciones, lo llevaron a sugerir un futuro suplemento, nunca publicado, que hubiera dado cabida, entre otros, a Ercilla y al joven Ángel Saavedra. Asimismo, también reclama una edición de la abrumadora producción teatral española que exigiría, en cambio, un esforzado trabajo colectivo. 
varias composiciones poéticas de Moratín ${ }^{802}$ así como versos cervantinos, ${ }^{803}$ menos apreciados que su prosa pero incluidos en homenaje a su gloria-. Superado el enfrentamiento de antes de la guerra entre estalistas y quintanistas, que se habría saldado finalmente con un canon de consenso según expuso Checa, Maury mantiene en la cúspide a Garcilaso, clásico tan apreciado en España, alza a Meléndez, entonces consagrado también por la modernidad europea, y ratifica en el extranjero a un Lope de Vega para formar un linaje poético emblemático. ${ }^{804}$ A este triunvirato rector suma la promoción de sus dos admirados amigos, Quintana y Arriaza, ${ }^{805}$ como representantes de su contemporaneidad y a quienes dedica su obra.

802 Si bien su fama se basa principalmente en su producción teatral —en la que sobresale El café, obra maestra de comicidad y sátira-, para cuyo examen remite al análisis de Andrés Muriel en la Revue Encyclopédique de febrero de 1827, Maury alaba la pureza de su lengua, el pulimiento de su estilo y su versificación modélica. Escoge varias poesías sueltas incluidas en las Obras dramáticas y líricas de 1825 (Auguste Bobée, imprimeur, 3 vols. en 8.º) como su satírica "Lección poética» de 1782, sus coplas de arte mayor "en fabla» a las bodas de Godoy («Al Príncipe de la Paz») y la oda elegíaca "A la muerte de don Josef Antonio Conde». En 1840 Ochoa optará también por caminos menos trillados con un variado muestrario - que igualmente prescinde de su teatro_ - con las odas «A los Colegiales de San Clemente de Bolonia», "A la muerte de don José Antonio Conde, docto anticuario, historiador y humanista», el soneto "Junio Bruto", el romance «Los días», la epístola «A Claudio, el filosofastro» y el cuento «El coche en venta».

803 Aunque incluye su soneto con estrambote ( $i$ Voto a Dios que me espanta esta grandeza»), sin por ello considerarla de calidad («bluette dénuée même d'ensemble»), se centra en su noticia biográfica de acuerdo con los datos tomados de las ediciones españolas de su obra cumbre por Vicente de los Ríos y Pellicer, y dedica algunos elogios a su novela pastoril la Galatea.

804 Desde esta perspectiva observa los hitos de la historia de la literatura española, confirmados figurativamente en la representación alegórica del grabado que inaugura las páginas de la antología: "On fait honneur de notre belle époque ancienne au jeune GARCILASO, décoré par ses contemporains du titre de prince des poëtes espagnols; l'andaloux Góngora a la triste gloire d'être reconnu pour chef de la révolution corruptrice qui a gâté le siècle de LOPE DE VEGA; le retour aux bons principes est dû aux soins de Luzan, auteur d'une excellente poétique, et de quelques poëmes estimables; le nom de MELENDEZ a droit aux premiers hommages de quiconque cultive ou apprécie la poésie espagnole moderne» (vol. I, pp. 34-35).

805 Quintana suscita los mayores elogios del colector por su talla moral, intelectual, y lírica, cuyo estilo enérgico rompe los moldes fijos de la versificación francesa. De él escoge tres poemas con tonos de dolor y esperanza como «A la expedición española para propagar la vacuna en América bajo la dirección de D. Francisco Balmi»; "A la hermosura», y "Al mar». Arriaza, versificador elegante y claro, cuya capacidad innata de pensar en verso lo hace sucesor de Lope, se inclina por los cantos descriptivos, la poesía erótica y la sátira, en la que destaca especialmente. De él traduce tres composiciones conocidas, aparte de su famosa oda "La profecía del Pireneo", la «Oda al Combate de Trafalgar», "La despedida» $\mathrm{y}$ «De la pintura y arquitectura». 
Su periodización por siglos arranca de los «Temps anciens» desglosados en dos épocas; el siglo XVI, considerado cumbre de la literatura española - cuya valoración se salda con su excelencia en casi todos los géneros poéticos y dramáticos («depôt immense d'esprit et d'imagination», p. 53) con la única resistencia de la epopeya-, como período de márgenes indefinidos está partido en dos divisiones: la primera se adentra en el XVII y la segunda abraza dos tercios de esta última centuria, en los que pervive el buen gusto. La demarcación siguiente pone de relieve las dificultades de acotar la realidad de las obras literarias según los criterios impuestos, ${ }^{806}$ en que se cumplen los pasos señalados por Bouterwek de asimilación de la poesía italiana, la formación en los modelos antiguos y finalmente el triunfo de la tradición («les élémens indigènes dominèrent, durant le dernier période de son éclat»). De este modo, en la etapa siguiente a caballo entre el XVII y XVIII desde el declive progresivo "sous le troisième et le quatrième Philippe», ${ }^{807}$ el mal gusto campa por sus respetos, si bien, cuando los autores siguen su instinto natural, ofrecen trozos dignos de las mejores plumas. En el XVIII la regeneración comienza bajo el reinado de Fernando VI — con autores de mayor juicio que talento poético cuyo mayor mérito reside en su oposición a las extravagancias de sus predecesores-, culmina en el esplendor del reinado de Carlos III, ${ }^{808}$ el último cuarto de siglo en que la literatura española está ya incardinada en la buena vía, ${ }^{809}$ y se detiene en los primeros años del XIX.

806 «'ordre des temps nous place maintenant entre la corruption croissante et la restauration tardive du goût, dans une période sans nom poétique. Ici, à défaut d'individus, nous avons fait un corps du genre national, en puisant dans divers auteurs, à différentes époques» (vol. II, p. 3).

807 «Seul et suppléant à ce qui manqua à ses deux amis, Boscan et Mendoze, le brillant Garcilaso a représenté dans notre Espagne poétique l'époque de Charles-Quint. Léon et Herréra, nés sous ce prince, auxquels nous avons adjoint Sainte-Thérèse et Cervantes, répondent à la période du long règne de Philippe II. Les Argensolas s’y rattachent par le caractère de leurs écrits plus particulièrement que ceux de leurs contemporains qui en illustrèrent comme eux les dernières années; Gongora, placé dans la première section par la date de sa naissance, appartient surtout à l'époque, où, sous les deux autres Philippe d'Autriche, domina le génie de Lopé de Véga, et fleurirent encore Quévédo et Rioja, ainsi que Villégas qui vit régner Charles II» (vol. II, pp. 219-220).

808 «l'école française ne s'est bien mariée aux manières espagnoles que sous le gouvernement de Charles III et la plume de Melendez» (vol. II, p. 221).

809 «Mais notre littérature se trouva de tous côtés remise sur la bonne voie, et l'époque actuelle a vu d'utiles efforts pour ramener à notre Parnasse tout ce qu'il eut anciennement de poétique, sans le laisser étranger aux acquisitions des temps plus éclairés qui ont brillé depuis» (vol. I, p. 34). 
En su presentación, Maury se muestra atento al canon medieval difundido desde el XVIII no solo de obras romances, sino también de poetas hispanoárabes. Su primera época comprende la evolución progresiva de la lengua y la prosodia desde el Poema del Cid —el "Achille castillan», sobrenombre que lo afilia a los modelos clásicos a la vez que se destaca su representatividad de «notre Espagne antique»-, del que incluye citas como la plegaria y la escena de la separación familiar en San Pedro de Cardeña; Berceo — del que inserta en nota el íncipit de los Milagros de Nuestra Señora-; el Libro de Alexandre, de mayor imaginación, calidad poética y erudición que las reconocidas por la crítica («un ouvrage marquant qui, néanmoins, n'est qualifié que de roman par quelques écrivains», p. 64) — del que selecciona un breve extracto de «El mes era de mayo, un tiempo glorioso", tan recurrente en las historias y antologías-; y una muestra de las Querellas del muy estimado Rey Sabio. Como jalón entre dos hitos como Alfonso X y Juan de Mena, la segunda época medieval arranca con la obra del arcipreste de Hita — por su don de la inventio y su estilo propio vivaz y malicioso pese a su descuido formal-, Villena, el marqués de Santillana — del que inserta la serranilla de la Vaquera de la Finojosa - además de la enumeración de otros apreciados por el colector, ${ }^{810}$ y a los que añade, como dos autores de transición y de filiación más acusada con los anteriores, a Boscán y Hurtado de Mendoza. Si el Laberinto de Mena — del que inserta el muy valorado pasaje del duelo materno ante el cadáver de Lorenzo Dávalos - sigue mereciendo a ojos de Maury un lugar honorable en la historia por la vigorosa personalidad poé-

810 Si bien añade a los nombres acostumbrados del llamado Don Santo, Pero Gómez, Juan Manuel — cuyos versos son inferiores, a su juicio, a los de Alfonso X-, otros hallados en la carta-proemio de Santillana - Rodrigo de Castro, el duque de Arjona, un Guzmán, Fernando Portocarrero, Pedro de Guevara, y muchos más hacedores de versos de la misma época, de entre los que el más destacado es Sánchez de Badajoz- y en los cancioneros de Ramón de Llavia y de Hernán del Castillo, su predilección personal se inclina particularmente por Jorge Manrique, que en su opinión merece, junto a Macías, un artículo independiente. De este se limita a reproducir la anécdota de sus trágicos amores. De aquel, además de la primera estrofa de una canción suya muy difundida hasta comienzos del XVI ("No sé por qué me fatigo»), incluye dos (la V y la XVI) de sus Coplas a la muerte de su padre, tan alabadas por su frescura poética ("Cette pièce de vers, quoiqu'un peu monotone, se fait lire avec plaisir, même aujourd'hui; car malgré sa date (70 ans avant Garcilaso) elle pourrait passer pour être d'un auteur vivant. Le langage y a une tournure plus moderne que celle qu'ont affectée quelques écrivains de nos jours», vol. I, p. 90). 
tica de su autor — pese a la coerción política que a su parecer, como al de Quintana, le restó profundidad-, por el contrario, no reciben su admiración como poetas ni Boscán ni Hurtado de Mendoza. Del primero, pese a su mérito reconocido en la reforma literaria del Quinientos, solo aprecia algunos sonetos como el traducido "Dexadme en paz, o duros pensamientos» - liberado de las redes de la retórica cancioneril que juzga predominante en sus poesías- así como su talento para la epístola, como la que dirige a Hurtado de Mendoza, por la amenidad y la conveniencia del tono. De este último, estimado notablemente por su historia así como sus sátiras, escoge una de las publicadas por su accesibilidad moral («Ten ya de mí compasión»).

El siguiente período cronológico se reparte en dos divisiones: la primera, extendida sin más precisiones hasta una parte del XVII, comprende, además de Cervantes, a un Garcilaso ${ }^{811}$ ensalzado por su modernidad («devenu classique, à quelques italianismes près: son tact exquis l'a fait si bien choisir dans le castillan que trois siècles n'ont pas vieilli son langage», p. 127), dotado en especial para la elegía, la oda, como la estimada Ode ad florem Gnidi, y en particular para la égloga —en especial la I, que traduce- - De ella destaca la apóstrofe a la diosa que no socorrió a la agonizante Elisa, recurso este, la intervención de la mitología pagana, que justifica ante el distanciamiento de sus contemporáneos decimonónicos, apelando a la relatividad del gusto en la historia y a la supervivencia del género en autores respetados como Corneille, Voltaire o Rousseau. ${ }^{812}$ Tras él incor-

811 Por ejemplo, Quérard (ob. cit., t. V, 1829, pp. 255-256) refiere tres ediciones de sus Obras en un corto lapso de tiempo en las tres primeras décadas del XIX en Francia: Lyon, Cormon y Blanc, 1821; otra anotada y notablemente corregida en ese mismo año, París, Théophile Barrois; una tercera, lujosa, de 1828 a cuenta de Ferrer (París, Didot). Sancionado como clásico moderno por sus contemporáneos en los comentarios del Brocense y de Herrera, nunca desapareció totalmente del canon, aunque padeciera cierto relegamiento hasta su reedición por Azara en 1765, muy reimpresa esta en el XIX hasta la edición de Navarrete en 1850. La crítica decimonónica suele destacar ante todo sus églogas y sus elegías por su evocación clásica, sobre sus sonetos morales y amorosos.

812 «Déjà, avant la corruption du goût amenée par Gongora, nous voyons en faveur l'emphase de l'expression, l'abus des images et la recherche dans les idées. Ce n'étaient pas là des manières bien applicables aux naïves confidences des bergers, et l'insolence sanguinaire des mours du temps ne paraît pas avoir dû faire un public bien propre à s'intéresser à l'innocence des agneaux. Disons plus: s'il fut jamais une langue et un pays en opposition naturelle avec l'églogue, ce furent bien le castillan et les Castilles: la langue, éminemment abondante en modes pompeux; le pays, dépourvu d'arbres, d'eau et d'habitans» (vol. I, p. 271). 
pora a Santa Teresa, cuyo estilo enérgico, sugerente y sensible alaba y de quien escoge por su piedad conmovedora el soneto "Al Cristo crucificado». Un sufrido fray Luis de León de dulzura idealizada suscita cuatro traducciones de su lírica personal — sus dos odas «La profecía del río Tajo» y «En la Ascensión», junto a otras dos composiciones que se le atribuían, "Coplas a una desdeñosa» y el epitafio "Al túmulo del príncipe don Carlos»—, a la vez que Maury excusa sus limitaciones en la traslación virgiliana, cuyo tono original no habría logrado recrear —uno de los escasos reproches de Bouterwek-, ante la severidad del lector moderno acostumbrado a las traducciones francesas. La fuerte individualidad artística de Fernando de Herrera y su incansable búsqueda de un sistema poético quintaesenciado no propician, sin embargo, gran entusiasmo en el colector («D'après notre sentiment, il lui manquerait une portion suffisante de ce don inné que la nature avait accordé abondamment à Garcilaso, et qu'elle prodigua depuis à Lopé de Véga», vol. I, p. 190), quien observa en su tendencia a la grandiosidad y lo extraordinario y en sus poemas amorosos la huella del artificio, también presente en los jóvenes poetas modernos, antes que de la verdadera pasión sentida. ${ }^{813}$ De cualquier modo, remite para su enjuiciamiento a la autoridad de los literatos y se inclina por sus poemas canónicos inspirados en los himnos y admoniciones bíblicas, como en su canción a la derrota de Alcazarquivir, la oda a Juan de Austria y sobre todo el himno a la batalla de Lepanto, que traduce junto a pasajes del Antiguo Testamento citados en la composición. Y, finalmente, un Góngora evocado como el ángel rebelde contra las normas, el decoro y el buen gusto, pero cuyo talento vindica el colector al tiempo que pone en guardia contra la impenetrabilidad cultista. ${ }^{814}$ Aunque su género más afín sería la sátira, Maury prefiere en esta ocasión un soneto de desengaño ( «La dulce boca que a gustar convida») y la composición "Guarda corderos,

813 Con todo, aconseja su estudio recurriendo a una analogía con modelos tan respetados del arte italiano como Miguel Ángel («Nous voyons dans les belles compositions d'Herrera des morceaux d'étude: de jeunes versificateurs pourront y trouver des leçons, comme des dessinateurs en vont chercher dans les tableaux de Michel-Ange: toutefois nous admirons sans nous attacher", vol. I, p. 190).

814 «Que les amateurs de la poésie castillane, qui trouveront de pareilles aberrations chez nos auteurs, se gardent donc de les prendre pour nationales; mais qu'ils y voient seulement une de ces vicissitudes fâcheuses que les littératures sont sujettes à éprouver quand elles sont arrivées à une certaine hauteur» (vol. I, pp. 247-248). 
Zagala», así como tres popularísimos romances moriscos suyos, incluidos en la sección siguiente, ${ }^{815}$ género en el que descolló como Lope, otro de los creadores del romancero nuevo, junto a las letrillas, sin lograr despojarse del todo del abuso retórico.

La segunda división abraza dos tercios del siglo XVII en los que sobrevive el buen gusto ${ }^{816}$ con Lope de Vega, los Argensola, Quevedo, Rioja - del que incluye la canción "A las ruinas de Itálica», la Epistola moral a Fabio, que entonces junto a otros más se le atribuía, aunque no le parece del todo trabada, y, como muestra de variedad de tonos, la silva «A la rosa»- y Villegas — que sucumbió también al mal gusto y a quien, además de discutirle su traslación acentual de los ritmos latinos y griegos que trocan los versos en prosa rimada, le reprocha la carencia de una idea clara sobre el objeto de imitación- ${ }^{817}$ A los Argensola, maestros en la epístola y cuyos sonetos son los más conocidos, ${ }^{818}$ les reconoce una serie de cualidades - fineza, elegancia, facilidad, claridad, corrección y pureza de lenguaje - que, si bien distan de la excelencia horaciana, son aun así los más cercanos a su modelo, y no por ello merecen la severidad de Quintana. ${ }^{819}$ Atención pareja a la de Lope recibe un admirado Quevedo, original en todos los géneros, cuyo extraordinario ingenio y dominio lingüístico no han sido alcanzados por ningún otro poeta español. No obstante, ratifica las observaciones de Marchena sobre el conflicto paradójico que muestra,

815 Los tres romances "L’Alarme, romance africano» (El rebato, «Servía en Orán al rey»); «Le Zenète, romance africano» (El Zenete, «Entre los sueltos caballos»); "Le Captif, romance mixto" (El forzado, "Amarrado al duro banco»).

816 Asimismo, valora a Jáuregui no como poeta, de verso elegante pero de escasa inventio, sino como traductor de la elogiada Aminta, superior a sus otras versiones de modelos latinos a la manera gongorina.

817 Elige una composición suya que pasa por modelo, "Al Céfiro» («Dulce vecino de la verde selva»), la cantilena "De un pajarillo» y el romance de marcado color nacional y, a su juicio, de más calidad, "A mejorar la vendimia», tomados de Las eróticas o amatorias.

818 Maury escoge de ellos varias composiciones: ("Al sueño»; «Llevó tras sí los pámpanos octubre»; "Yo os quiero confesar, Don Juan, primero»; "¿Quién casamiento ha visto sin engaños»; "Viéndose en un fiel cristal»; "El que tiene muger moza y hermosa») de Lupercio y dos más de Bartolomé («¿Esos consejos dás, Euterpe mia?» y «Dime, Padre común, pues eres justo»).

819 «La vivacité, la variété, la concision, la philosophie, l'aimable abandon, la grâce, l'urbanité qui charment et désolent dans le modèle, nul doute que les Argensolas n'en soient bien loin. Le sont-ils autant que l'atmosphère de Philippe II le fut de celle d'Auguste?» (vol. I, p. 327). 
por ejemplo, en la desigualdad de tonos de su obra, entre su instinto natural y la degeneración del gusto. Aunque apunta que su género propio fue el satírico y el burlesco, ${ }^{820}$ su elección se inclina por dos composiciones poco representativas como "A la codicia» ("Diste crédito a un pino») y una canción («Pues quita Primavera al año el ceño») del bachiller Francisco de la Torre. Y sin embargo, a pesar del ensalzamiento inicial, Maury declara preferir sus traducciones a sus obras originales y su prosa a sus versos. ${ }^{821}$

Es, pues, al universal, extraordinario y fecundo Lope ("qui a fait les délices de son pays et de son siècle») al que dedica mayor espacio aprovechando su extensa noticia biográfica y literaria ${ }^{822}$ para una reivindicación comedida del teatro áureo ante el público francés de la segunda década del siglo, aún reacio al Shakespeare representado en el Théâtre Français. Movi-

820 Maury destaca la predilección del autor por la hipérbole, en especial en el tono coloquial como en el romance "Le Malencontreux» («Pariome adrede mi madre») o el soneto burlesco "Le nouveau saint» "A un hombre casado y pobre» («Esta es la información, este es el proceso»).

821 Su obra en prosa fue más difundida en Francia que sus poesías, editadas a principios del XIX con destino al mercado español —y presentes, por ejemplo, como letra de composiciones musicales como los Caprichos líricos españoles para voz y guitarra de Manuel García (París, 1830) — . Por ejemplo, las colecciones editadas en los años veinte como la de T. Barrois (París, 1821) junto a poemas de Góngora (Poesías escogidas de D. Francisco de Quevedo y de D. Luis de Góngora). Quérard apunta que la impresión parisina contiene un número reducido de la recopilación temprana de sus poesías por González de Salas en El Parnaso español, [monte en dos cumbres dividido, con las nueve musas] (Madrid, 1648), continuada por Pedro Aldrete Villegas como Las tres Musas últimas castellanas. Segunda parte del Parnaso español, Madrid, 1670.

822 Su apología se ciñe al teatro sin dejar de apuntar las fallas del resto de su producción como su Laurel de Apolo, sus poemas épicos La Dragontea, La Jerusalén o la Corona trágica, de los que salva su apreciado poema burlesco La Gatomaquia; del mismo modo que el encanto de sus versos no oculta, por ejemplo, su profusión descriptiva. Heredero de la corriente preconizada por Quintana del compromiso del poeta con su sociedad, y en concordancia con Sismondi, Maury muestra de nuevo su rechazo a la moda pastoril al referirse al Jacinto o la Arcadia («Nous déplorerons ici l'espèce de fureur qui s'empara de nos poëtes pour un genre si opposé à l'esprit de la nation et au ton de notre littérature à l'époque où régna cette manie», vol. I, p. 271). No obstante, forzado por la costumbre y autoridad de selecciones anteriores, Maury escoge dos extractos adaptados de una de sus églogas («Idylle Hylas» y «Amarilis»), considerada un modelo del genéro y no exenta de reproches a su juicio, un "Soneto en culto» ("Cediendo a mi descrédito anhelante»), y ya más de su gusto, cuatro romances moriscos que corrieron de boca en boca desde el XVII, para la sección siguiente: L'Indiscrétion, "Mira, Zayde, que te aviso»; Le Cartel, «Si tienes el corazón»; Gazul, "Sale la estrella de Venus»; Zulem au combat de taureaux, "Aquel valeroso moro". 
do por un fin patriótico ${ }^{823}$ como en las próximas reivindicaciones de Ochoa, Maury invoca la autoridad de lord Holland, de quien toma diversos pasajes, para compensar el poco favor que gozaba entre la crítica extranjera desde el duro veredicto de Boileau, muy presente aún para Raynouard en 1817. Lejos ya de los argumentos detractores de Nasarre reproducidos por Malmontais, Maury rebate las acusaciones francesas que pesaban contra Lope: así, desestima las críticas de vulgaridad con la cortesanía del lenguaje, la brillantez de los papeles femeninos, o el adecuado recurso a la vestimenta cotidiana y costumbrista; justifica sus transgresiones voluntarias contra normas sancionadas por el clasicismo francés como la unidad de tiempo, por el sentido común y la lógica interna de la acción representada, así como por su deseo de contentar a un público ávido de evasión y fantasía antes que de regularidad. De igual modo, si bien asume, como los críticos del XVIII, la condición especular del teatro como fenómeno social que habría reflejado los desórdenes morales y cívicos de su convivencia política y social, sin embargo, procura defender a los dramaturgos de la responsabilidad que les asignaba Sismondi («nos auteurs dramatiques n'ont pas douté que ce ne fût de la sorte qu'il fallait être et agir», vol. I, pp. 265-266). Su evaluación de la dramaturgia lopesca asiente a los juicios del aristócrata inglés sobre la atribuida La Estrella de Sevilla, tales como la verosimilitud de su conflicto ético en el contexto de su tiempo, el asombroso encadenamiento artístico y la conveniencia de sus diálogos, la elaboración de la intriga, la construcción demorada de los personajes — no tan infrecuente en sus obras («il s'en trouve en très-grand nombre de vigoureusement tracés et parfaitement soutenus», vol. I, p. 266) — y en especial la elegante claridad de su versificación, que en la pieza predomina sobre el ritmo ceñido y la concisión del romance, y prevalece sobre todas las aberraciones, inverosimilitudes e inconsecuencias de otras obras suyas. En suma, proclama su ingenio, aunque errado, indiscutible, cuyo relevo tomarán sus herederos Calderón y Moreto. De este modo, como ya sugiriera Raynouard en $1817,{ }^{824}$ Maury clama también

823 «Notre sollicitude pour la gloire du fameux poëte castillan, principalement auteur dramatique, et l'intérêt national de cet ouvrage nous portent à présenter ici des aperçus plus étendus que ne le demanderait un genre qui n'entre point dans notre collection» (vol. I, p. 260).

824 Este catálogo razonado de todas sus obras, homenaje al dramaturgo y herramienta de estudio utilísima, facilitaría el análisis de sus composiciones fidedignas, que Raynouard proponía además acompañar con las citas de hermosos pasajes y sus principales imitaciones y enjuiciamientos. 
por una edición colectiva de sus obras, más completa que la disponible del XVIII y, sumisa a una depuración del material conforme a las normas («du genre de celui qui nous a servi à fixer l'objet de notre deuxième traduction [es decir, a partir de una selección con abreviaciones]»), digna de la aprobación de sus más acerbos detractores. ${ }^{825}$

El segundo tomo se abre con la franja restante de difícil definición, del siglo XVII hasta internarse en el XVIII, en la que presenta una copiosa selección de romances - género nacional por antonomasia, que no ha logrado, con todo, la elevación culta de Luis de León y Herrera- procedentes de diversos autores y épocas, editados, entre otros, por Juan de la Cuesta (1604) o la colección de Ramón Fernández (1794), cuyo prefacio contenía una disertación histórica y prosódica. Tras esbozar la descripción de las características del género — su rima asonante, la concisión de sus pinceladas descriptivas, la sencillez, vivacidad, naturalidad y precisión elocutivas, su evolución temática-, Maury traduce varios romances heroicos, empezando por el bien acogido ciclo del $\mathrm{Cid}^{826}$ desde el precedente de Creuzé de Lesser, que completa con notas históricas, y al que añade los de don Rodrigo y Pedro el Cruel; ${ }^{827}$ algunos romances moriscos de color local costumbrista, tomados de Lope y Góngora, los creadores del romancero nuevo; un ejemplo de los romances pastoriles, subgé-

825 La escrupulosidad filológica de Mayans, tan realzada por Bouterwek al referirse a su edición de la historia de Hurtado de Mendoza, está lejos de la intención de Maury y aun del colector Piferrer en 1845. Tras los precedentes refundidores de finales del XVIII y de las primeras décadas del XIX, Maury plantea una adaptación de esos géneros dramáticos a los modelos vigentes y las reglas universales: "Le travail du critique et poëte espagnol qui se vouerait à Lopé de Véga devrait s'étendre à deux opérations, dont la première, celle que nous avons faite, est sans doute la plus facile; après avoir élagué le mauvais et le superflu, il faudrait refaire les passages nécessaires pour lier les parties conservées. Alors le phénix, puisque ce fut là son nom, renaissant de sa cendre, offrirait au Parnasse moderne un poëte enchanteur", que habría obtenido incluso los plácemes de sus críticos más acérrimos como L’Année littéraire o Despréaux (t. I, pp. 285-286).

826 Con ocho romances: "Cuando Diego Laínez», "Non es de sesudos homes", "Grande rumor se levanta», "Sentado está el señor Rey», "Después del lamento triste», «En los solares de Burgos», "Pidiendo a las diez del dia» $\mathrm{y}$ «Fablando estaba en el claustro".

827 Del primero selecciona «Quando las pintadas aves» y del segundo «A los pies de Don Henrique». 
nero caracterizado por su frescura sin mayores méritos, ${ }^{828}$ junto a otras muestras populares. ${ }^{829}$

El siglo XVIII, bien representado y considerado, recibió la rica herencia del «siècle de Louis XIV» y los notables beneficios sociales y culturales ${ }^{830}$ de la civilización francesa contemporánea, cuya asimilación nacional desarrollada a lo largo del siglo se logra en las últimas décadas. ${ }^{831}$ Su narración de los acontecimientos políticos hasta la represión fernandina comprende el elogio de ilustres autoridades como Floridablanca, Campomanes, de quien menciona numerosas obras, Llaguno, Roda, Cabarrús o un Jovellanos muy elogiado como patriota y prócer de talla europea y coherencia ética. Omitido por Malmontais y por Bouterwek, Jovellanos, bastante editado en Francia a principios del XIX, ${ }^{832}$ posee un gran renombre

828 Como el romance mixto «Fernand et Alfide» (Lisardo y Alcida, «Apolo con su laurel»).

829 Clasifica las letrillas en tres secciones («Aunque con semblante ayrado»; La Persuasion difficile, "Cantando está Melibeo»; «Di ¿qué harás» $\mathrm{y}$ «Quien gentil señora pierde» en la primera; "Zagala, más que las flores»; "Mil veces voy á hablar»; "A aquel caballero, madre»; «Diga cuanto dijere» en la segunda; La marinera de Camoens, ejemplo de lírica tradicional entregado a Maury por Pablo Mendíbil y ausente en colecciones habituales, "Irme quiero, madre»; "La niña morena»; "Riñó con Juanilla» y «La moza Gallega», en la tercera). Asimismo entre otros metros cortos de «'ancienne école» añade seis apreciados ejemplos como el famoso "Ven muerte, tan escondida», "Solo el silencio testigo», "La Naturaleza humana», "Pastora con más cuidado», "Anda vé, con diligencia» y "Aquellos tiempos pasados». También inserta coplas y epigramas, y otras composiciones como "En Jaén, donde resido», «La noche estaba en su filo» y «Tres cosas me tienen preso» con acompañamiento de danzas para fandangos, boleros o seguidillas.

830 Entre ellas enumera las fundaciones de la Biblioteca Pública y de las Academias de la Lengua, de la Historia y de las Artes, o de reuniones privadas como la Academia del Buen Gusto, así como agrupaciones científicas y sociedades literarias, las convocatorias de concursos académicos, disertaciones y memorias, el desarrollo de la prensa periódica, junto a las escuelas de instrucción elemental, las casas de beneficencia o las mejoras en urbanismo y administración.

831 «On peut regarder ce dernier période de notre considération politique comme celui où notre poésie, eut, sinon les plus brillans succès, du moins la plus grande faveur: Guzman y Moratín, Iriarte y Meléndez» (vol. II, p. 227).

832 Además de su entrada temprana en diversos diccionarios bibliográficos y de las ediciones en español, contaba con varias traducciones. Por ejemplo, entre otras, las de discursos como el atribuido entonces al autor pero, según investigadores recientes, de León de Arroyal, Du pain et des taureaux, por L. Adrien B. (1826), o por Cuendias, Du pain et des courses de taureaux. Discours prononcés à Madrid en 1796, dans l'enceinte où ont eu lieu les courses de taureaux, traduit en français sur l'édition de Madrid, par M. G. de Cuendias, avec le texte en regard, Toulouse, impr. de Corne, 1838; o el Discours sur l'état florissant de l'Espagne (1826). 
entre los críticos liberales españoles e ingleses —como, por ejemplo, Edward Blaquière, ${ }^{833}$ coetáneo de Maury, que visitó la Península durante el Trienio Liberal-y poco después entre sus contemporáneos franceses, que incluyen con respeto sus obras literarias.

La primera de las dos nuevas divisiones que segmentan esta centuria analiza tres reformadores principales como Luzán, Cadalso e Iriarte, a la

833 Examen historique de la révolution espagnole, suivi d'observations sur l'esprit public, la religion, les mours et la littérature de l'Espagne, par ... Traduction de l'anglais par J. C. L., París, Rosa, 1823, 2 vols. Esta colección de cartas del autor, partidario de los liberales, registran su estancia en la España de los años del Trienio. Asesorado por españoles en cuyos trabajos también se funda - como, por ejemplo, la memoria histórica leída en la Academia de la Historia y su Histoire critique de l'Inquisition en Espagne (1817-18) de J. A. Llorente, J. J. de Mora, elogiado como buen poeta y uno de los mejores escritores políticos españoles, o Marina - así como por otros estudiosos y viajeros ingleses como Bowring (con sus Observations on the State of Religion and Literature in Spain, Londres, 1819), su información de primera mano fue traducida al francés el año de la tranquila invasión del duque de Angulema. En la carta XVIII (octubre de 1820) da una ojeada al panorama literario reciente. El prestigio de los ilustrados del reinado de Carlos III sigue incólume cuando afirma que la talla europea de los escritores y próceres de esa época, recogidos por Sempere o de Castro entre otros, sostendría ventajosamente la comparación con sus contemporáneos franceses e ingleses y aun los superaría (t. II, p. 226): por ejemplo, Floridablanca, Almodóvar, Campomanes a la altura de los filántropos más ilustres, Azara, Chumacero, Palafox, Roda, o la condesa de Montijo, Acevedo, Salas, Lardizábal, Olavide, Campilla, Trigueros, Moratín padre, Meléndez, Iriarte, o Isla, nombrado sucesor de Cervantes con su Fray Gerundio y elogiado por sus cartas como relevo también del alabado Feijoo, cuyos conocimientos asegura no haber sido superados. Sin embargo, a sus ojos el súmmum de sus elogios es Jovellanos, escritor y estadista cuyas ideas influyen sobre la reforma teatral de Moratín y Gorostiza, aún no consumada, y del que ensalza su informe sobre la ley agraria y las cartas a él dirigidas por Cabarrús, que a su juicio deberían ser consultadas a menudo por el resto de naciones. Blaquière liga el progreso de las letras al liberalismo («l'époque la plus glorieuse pour la littérature espagnole, est, sans contredit, celle où ses écrivains ont été appelés à célébrer la restauration de la liberté», p. 245), y, aunque no puede tratar en detalle de los actuales sabios y hombres de letras, enumera a Lardizábal, Toribio Núñez, Cambronero, Herreros, Salas, Cabrera, Hermosilla, Reinoso, Andújar, Clemente, O’Farrill, entre otros ( «Si le vide qu'ont laissé Trigueros, Melendez, Francisco de Salas, Moratín l'â̂né et Yriarte, dans la poésie didactique et satyrique, et Cienfuegos, dans le théâtre, n’a point été entièrement rempli, il y a cependant encore des écrivains vivans capables de rivaliser avec les plus renommés de leurs prédécesseurs», p. 235). De entre los más eminentes en los distintos géneros señala en el histórico a Reinoso, y sobre todo Quintana y Llorente, además de las anotaciones de Isla a la traducción de la historia de Duchesne; las tragedias de Cienfuegos, y entre sus sucesores, el Pelayo de Quintana y La viuda de Padilla de Martínez de la Rosa, las piezas teatrales de Saviñón y Gorostiza, así como la consagración en la escena del triunvirato ilustre del drama barroco (Lope, Calderón y Moreto); las sátiras de Gallardo, Mora y Miñano junto a los estudios de Flórez Estrada y Puigblanc. 
vez que menciona otros escritores del panorama literario. ${ }^{834}$ Sin ceder al distanciamiento de Bouterwek y el descrédito por Stapfer ${ }^{835}$ de la Poética de Luzán, ensalzada por Malmontais, ${ }^{836}$ moderadamente apreciada por Quintana, elogiada por Viardot $(1835)^{837}$ e incluso en la década siguiente por Puibusque y Piferrer (1845), ${ }^{838}$ Maury alaba su obra teórica, sin reproches, ${ }^{839}$ que marcó la senda para Moratín, Montiano y Cadalso («Bientôt on ne parla plus de Gerard Lobo, ni de la none du Méxique, ni du curé de Fruime», p. 239), y aprecia su obra poética. ${ }^{840}$ La estima por Cadalso, figura clave en la renovación poética del XVIII, elogiado por su cultura cosmopolita y su patriotismo, mentor y amigo de futuras promesas literarias y prohombres del reino como Jovellanos o Meléndez, y bastante editado

834 Por ejemplo, elogia en nota a Juan de Iriarte y sus sobrinos Tomás, Bernardo y Domingo, junto a otras personalidades como Candamo, Zamora, Condado, González, Iglesias, Tavira, Diego González. Asimismo estima a Nicolás Fernández de Moratín, también partícipe en la reforma, por su vigor y abundancia poéticos, cuyo canto épico es superior a sus poesías líricas, además de sus tragedias, notables pero escritas en un estilo más propio de la epopeya que del drama; de García de la Huerta, a cuyas obras también se refiere, apunta, en cambio, que iba en camino de ser un nuevo Góngora.

835 En la nota de la página 59 la describe como una poética tardía («d'ailleurs faible copie de Boileau et d'Aristote») que apenas se acomodó al carácter y las ideas nacionales como para influir positivamente en la regeneración literaria.

836 «Les préceptes généraux qu'elle renferme tenant au génie et à l'essence même de la poésie, sont applicables à celle de toutes les nations» (p. 144).

837 Viardot, informado de las teorías schlegelianas y no menos sostenedor del criterio del buen gusto, no solo lo valorará como poeta que abrió nuevos caminos, sino que su comprensiva Poética le merece un juicio meritorio («ouvrage de saine doctrine, il ajouta quelques exemples de bon goût, sinon d'élévation pindarique», p. 307).

838 «Précipitée de la haute splendeur où, durant le seizième siècle, elle [la literatura española] était parvenue, elle semble expirer vers le milieu de la période suivante, et cinquante ans s'écoulent sans qu'elle donne signe de vie. A Luzan était réservé l'honneur de porter remède à cette passagère léthargie. C'est lui qui, avec autant de sagesse que d'audace, entreprit, et par l'exemple et par le précepte, de relever de sa torpeur la littérature défaillante» (p. 370).

839 "On a commis, dans les collections modernes des poésies castillanes, un acte d'injustice autant que d'ingratitude envers cet écrivain, frappé d'une exclusion absolue. Ses compositions poétiques, sans être du premier ordre pour la verve, le sont pour la diction, et c'est bien quelque chose quand il s'agit de modèles offerts aux Espagnols» (vol. II, p. 237).

840 Poeta elegante superior a Boscán, el otro reformador del XVI — por ejemplo, con un poema burlesco contra los predicadores barroquistas de su época, el poema «El nuevo juicio de Paris», del que elogia el discurso de Amor, digno de cualquier epopeya moderna- y docto erudito de gran variedad y profundidad de conocimientos, Luzán se ve representado con la canción compuesta a la conservación de la ciudad de Orán frente a los moros. 
en Francia a principios del XIX, ${ }^{841}$ se trasluce en sus anacreónticas ${ }^{842}$ que enlazan con el ejemplo de Villegas, en el mérito de la Carta de Florinda y en obras reputadas como sus Eruditos a la violeta (Erudits à la fleur d'orange) — superior con su ironía ática a las Lettres marocaines, que lo colocan en desventaja respecto a Montesquieu no solo por la calidad del genio, sino también por la vigilancia política de su tiempo-. De Tomás de Iriarte, gustado por todo lector no solo como creador original de la fábula literaria, elegante e ingeniosa sin escarnio, que lo alza entre los clásicos - superando a Samaniego, en quien transparentan sus modelos franceses e ingleses-, destaca su talento minucioso en diversos géneros, oculto bajo una aparente naturalidad, y su contribución a la reforma teatral con sus traducciones y comedias. ${ }^{843}$

La segunda división que llega hasta la contemporaneidad del compilador y su etapa de formación comprende al adelantado de los líricos españoles, Meléndez Valdés — «Il se pourrait même que la majorité de nos lecteurs élevât le chantre des Étoiles au-dessus des lyriques espagnols de tous les temps», t. II, p. 295-, su condiscípulo José de Iglesias — destacado en la sátira y en las letrillas de ritmo ágil como «Mi numen parlero», de él traduce la cantilena "Muchacho inadvertido», las letrillas «Si yo en otro tiempo» y «En vano a la puerta llama», y la anacreóntica «Batilo, échame vino»—, sus discípulos Quintana y Cienfuegos, junto al conde de Noroña, Moratín y Arriaza. ${ }^{844}$ La gran calidad del lenguaje poético personal de Meléndez se manifiesta de manera genuina, a juicio del crítico, en la naturalidad y gracia de sus anacreónticas, églogas y

841 Además de sus Cartas marruecas (Perpiñán, Aizone, 1820) — que ya habían sido traducidas al francés en 1808 por Froment-Champlagarde bajo el título más explícito de Aperçu moral, politique et critique de l'Espagne - , en 1821 (París, Th. Barrois) hubo también una edición de sus Poesías. Véase Quérard (ob. cit., t. II, 1828, p. 7).

842 Las letrillas "Engañando está Dalmira», "El bien contentadizo del precio de las mugeres" y la anacreóntica "¿Quién es aquel que baxa».

843 Maury ha seleccionado lo más granado, a su juicio: sus fábulas — como las traducidas "La ardilla y el caballo», "El gusano de seda y la araña», "El oso, la mona y el cerdo" y "El té y la salvia»- y varias epístolas, mientras que su poema sobre la música le parece más bien un buen tratado en verso, al que prefiere la traducción de la epístola horaciana a los Pisones. Aun considerando superior esta a la de los cuatro primeros libros de la Eneida, el colector le discute ponderadamente algunos de sus razonamientos al traducir el ritmo.

844 Maury señala, no obstante, que de entre los poetas que, como Lista, despuntaban en la colección de versos de 1822, el que más prometía era Nicasio Gallegos. 
romances ${ }^{845}$ desde la edición de 1785 , a cuyos prefacios remite, y los añadidos de 1797, más que en su etapa posterior de poesía filosófica, notable introducción de un género nuevo pero a fin de cuentas imitador de modelos extranjeros como Pope, Young, Voltaire, Saint-Lambert, Thompson o Milton, cuya soltura rítmica y profundidad conceptual no alcanza con su verso. Partidario, no obstante, del compromiso del poeta con su sociedad, Maury reconoce la calidad poética de Noroña en la oda «A la paz entre España y Francia en 1795» - escogida por la oportunidad del tema frente a evocaciones orientales que, como en su apreciable poema épico Omniada, siente bastante ajenas-, mientras que rebaja la de Álvarez de Cienfuegos, más estimable como trágico, y cuya reputación literaria debería a su relación con Meléndez y Quintana. ${ }^{846}$ Esta antología que cierran sus dos amigos, el admirado Quintana y el mundano Arriaza, posee, pues, cierto valor de transición entre criterios clasicistas, los gustos de su tiempo y las promociones deudoras de los valores reivindicados en la España finisecular como el romancero, género nacional por excelencia, y la continuidad de un linaje poético que enlaza los modelos renacentistas con un espléndido Lope - paulatinamente vindicado como dramaturgo-y las excelencias de los autores del XVIII como Meléndez y su discípulo Quintana, maestro moderno de nuevas generaciones.

Tres años después del segundo tomo de Maury, el polígrafo y futuro agrónomo Victor Rendu (París, 1809-París, 1877) — procedente de una familia estrechamente vinculada al estudio y la enseñanza ${ }^{847}$ publica

845 El entusiasmo de Maury — como los historiadores y estudiosos extranjeros que no suelen detenerse en sus composiciones filosóficas - vibra ante sus odas y romances como el LVIII, «Le coucher du Soleil» («Cuando el claro sol se pone»), o el popular romance I, «Rosana en los fuegos» que traduce, además de alabar la oda XXX, «De las Navidades a Jovino» y la celebérrima "Oda a las estrellas».

846 Maury asistió en Madrid a la representación de sus tragedias, de las que Idomeneo le parece la más valiosa, aun sin grandes entusiasmos. Juzgando de mayor calidad sus dedicatorias, critica su desmesura y su ingenuidad afectada. No obstante, halla pasajes estimables en sus epístolas y odas, y selecciona dos composiciones bucólicas de mayor valor que el resto de su producción: el romance "El anciano y el fresno», el idilio «El túmulo», y la oda en honor de Bonaparte escrita antes de la invasión que le hizo levantarse contra él.

847 Los Rendu, de profesión católica, publicaron numerosas obras sobre jurisprudencia, religión, administración, historia y sobre todo educación. Tras sus preceptivos estudios de derecho, Victor se inició en la edición de manuales para enseñanza primaria y pronto se 
una antología de pasajes literarios españoles en su lengua original en prosa y en verso, bajo el título Leçons espagnoles de littérature et de morale, ${ }^{848}$ a imagen del popularísimo compendio educativo de Noël y De la Place. ${ }^{849}$ En el resumen liminar de su selección («Esquisse d'un tableau historique de la littérature espagnole», pp. 1-26) Rendu presenta un sucinto panorama histórico del devenir de la nación española y de su literatura basado en las opiniones entonces autorizadas, ${ }^{850}$ especialmente el reeditado estudio

interesó por la difusión docente de las literaturas extranjeras —en particular la inglesa-, uno de cuyos frutos es esta antología. Miembro de sociedades y academias científicas de provincias, e inspector general honorario de agricultura desde 1842, también editó a lo largo de su carrera estudios de ciencias naturales y agronomía, diversas traducciones de obras alemanas e italianas y varios escritos de carácter religioso y moral. Véanse el Grand Larousse Universel du XIXe siècle y la Enciclopedia Universal Ilustrada, Madrid, Espasa-Calpe, 1916, vol. 50, p. 845.

848 Précédées d'une notice sur la littérature castillane, París, chez Firmin Didot frères, libraires et chez Théophile Barrois, libraire, 1830. Baudry la reeditó en 1840.

849 El ejemplar que hemos consultado pertenece a la vigesimoprimera edición (Bruselas, J. P. Meline, libraire-éditeur, 1836): Leçons de littérature et de morale, augmentée d'une liste biographique des auteurs cités, et d'un tableau des vicissitudes de la littérature française, par le baron de Reiffenberg. Concebido como una suerte de parnaso ("espèce de muséum ou d'élysée français») de lo más granado de "deux plus beaux siècles de notre littérature», va acogiendo desde su $1 .^{a}$ edición de 1804 un gran contingente de autores modernos en los diversos géneros, desde la novela, el teatro, la poesía, la historia, la filosofía, la oratoria o el ensayo, para ir conformando el cuadro de la historia de la literatura francesa. Conforme a las minuciosas divisiones retóricas en uso, los colectores proponían «un choix exquis, en prose et en vers, des morceaux de notre langue les mieux écrits et les mieux pensés, dans les parties de composition les plus difficiles, et qui demandent le plus de soin: Narrations, Tableaux, Descriptions, Définitions, Allégories, Morale religieuse ou Philosophie pratique, Discours et Morceaux oratoires, Caractères ou Portraits, etc.» (p. V).

850 En años cruciales en la política francesa, su aproximación a la historia española y su ser nacional — marcado por la religión, la veneración del pasado, el patriotismo, el amor a la independencia y la libertad, y el entusiasmo, como proclamaba Florán-, Rendu también destaca la influencia indeleble de la civilización musulmana y se detiene en figuras como el Cid, ensalzado como ejemplo histórico nacionalista y caballeresco. El colector entresaca de Sismondi las ideas fundamentales y los principales nombres del censo autorial desde su Edad Media, el XVI como época de mayor gloria de la lengua, con Boscán y Garcilaso, el Hurtado de Mendoza historiador y novelista, La Araucana, fray Luis de León, Herrera; Cervantes como gozne de entresiglos, los Argensola, Luis de Soto, Juan de Morales, Iglesias de la Casa, Francisco de la Torre, Góngora, a la cabeza de los Cultoristos (sic), Quevedo que le recuerda al cínico Voltaire, Villegas o Solís; y en el XVIII los ineludibles Isla por su novela modélica en gusto y comicidad, Iriarte y Samaniego por la naturalidad de sus fábulas —inferiores, con todo, a Lafontaine- o Meléndez, ensalzado especialmente por sus composiciones bucólicas inspiradas en los modelos latinos, a los que iguala, a la vez que supera la égloga garcilasiana. 
de Sismondi, además de otras fuentes documentales como la Biographie universelle de Michaud, cuyo primer volumen apareció en 1811. Su sumario enjuiciamiento de la evolución teatral española se muestra reticente a la reivindicación alemana ${ }^{851}$ de un relegado Calderón o de un Lope de Vega excesivo en imaginación y premura compositiva - y al que Rendu censura su favor popular sobre un Cervantes consagrado como rector del buen gusto antes que como dramaturgo_; 852 se limita a la enumeración acostumbrada de dispensadores de materia al teatro francés del XVII como Moreto - con su comedia C'est impossible (No puede ser guardar una mujer), a la que recurre Molière para su École des maris-, Francisco de Rojas - suministro de Rotrou y Thomas Corneille, como había anotado sucintamente La Harpe-, o Juan de Hoz; y registra en el XVIII las tragedias normativas de Montiano, los sainetes de Ramón de la Cruz o los esfuerzos de García de la Huerta por emular a los antiguos dramaturgos, sobre los que descuella Leandro Fernández de Moratín, considerado entonces el mejor autor cómico español.

Aboliendo el criterio cronológico en favor del genérico, el colector incluye fragmentos modélicos de diversa extensión de los autores más editados en Francia en aquella época, pertenecientes en su mayoría al XVIII, seguidos en gradación temporal por los años contemporáneos, los siglos XVI y XVII, y en menor medida la Edad Media. En la primera parte el género histórico, dominante por el número de autores elegidos, aparece representado principalmente por el cronista de Indias Antonio de Solís, modelo de elocución, de quien se incluyen catorce pasajes de su Historia de la conquista de México, ejemplificando arengas ${ }^{853}$ y varias modalidades de dis-

851 «Long-temps son génie [de Lope] domina sur tous les théâtres de l'Europe, mais le génie bien autrement sublime de Racine et de Molière l'a exilé de la scène française; l'école allemande, seule, lui rend encore les honneurs divins, conjointement avec Calderon de la Barca, son compatriote et son rival de gloire» (p. 18).

852 Apoyándose en la opinión errónea de una recepción menguada a la novela cervantina Rendu declara: «Dans le même temps que l'on accueillait avec une froide indifférence le Don Quichotte de Cervantes, le peuple espagnol applaudissait avec transport aux pièces de Lope de Vega. Le bon goût a fait justice de cette iniquité: en France, Don Quichotte passe pour un chef-d'œuvre, et l'on se garde bien d'admirer la monstrueuse fécondité du dramaturge espagnol» (p. 17).

853 «Hernán Cortés antes de embarcarse para la conquista de México, anima sus soldados y la empresa»; "Cacumarzin, sobrino de Motezuma excita los mexicanos contra los españoles». 
curso epidíctico y argumentativo ${ }^{854}$ en las asambleas aztecas, el tan cultivado género del retrato ${ }^{855}$ de larga tradición, descripciones de enclaves, ${ }^{856}$ ritos y costumbres indígenas, ${ }^{857}$ tan del gusto de la época por el exotismo y el carácter pintoresco que ven reflejados, así como por su condición de valioso compendio vulgarizador de información antropológica y etnográfica; y, finalmente, narraciones de las batallas y asaltos. ${ }^{858}$ Lo sigue en frecuencia la afamada Historia de España de Mariana, referente reclamado por válido aún entonces para la construcción liberal de la historia nacional ${ }^{859}$ y presencia ineludible en las estanterías españolas. Los ocho pasajes, elegidos en episodios como los enfrentamientos entre los pueblos iberos y los fenicios, la lucha encarnizada por el poder entre César y Pompeyo, y la derrota de los visigodos ante la invasión musulmana, traslucen una serie de valores morales como el patriotismo, el coraje, el honor, la paciencia ante la adversidad y el estoicismo moral. Los trozos reproducen categorías retóricas como descripciones y cuadros de batallas, ${ }^{860}$ arengas a las tropas, ${ }^{861}$ discursos de disuasión y súplica, ${ }^{862}$ o el famoso canto a la naturale-

854 «Los enviados de Cortés piden de su parte a los tlascaltecas que le concedan el paso de sus tierras», "Respuesta de Magiscatzin, uno de los senadores de Tlascala», "Opinión contrapuesta de Xicotencal, general de las armas de Tlascala», "Discurso del padre de Xicotencal, ofreciendo a Hernán Cortés las llaves de Tlascala».

855 Así, «Retrato de Motezuma».

856 «Descripción de México y del templo del dios de la guerra».

857 "De la coronación de los reyes de México», "De la educación de los muchachos en México, baxo el reinado de Motezuma», «De los matrimonios en México, en tiempo de su conquista por Hernán Cortés», "Del estilo con que se cuidaba de la justicia en México, baxo el reynado de Motezuma", "Del estilo con que se medían y computaban los meses y los años en México, en tiempo de su conquista por los españoles».

858 Así, la descripción de la batalla entre indios y españoles en el río de Grijalva y la de la toma de Tabasco.

859 Véase P. Cirujano Marín, T. Elorriaga Planes y J. S. Pérez Garzón, Historiografía y nacionalismo español, 1834-1868, Madrid, Centro de Estudios Históricos, 1985.

860 Así, la batalla de Munda, en la que se enfrentaron César y Pompeyo, y la batalla de Jerez entre godos y moros.

861 El discurso de Baucio Capeto, caudillo turdetano en contra de los fenicios que querían instalarse, el discurso del rey Rodrigo «rey de los godos españoles, poco antes de pelear con los moros", el discurso de Tarif, general de los moros o de nuevo, otro discurso de don Rodrigo «antes de llegar a las manos con los moros en la batalla que fixo la suerte de España con la expulsión de sus enemigos».

862 Se trata del duelo de Egilona, mujer de don Rodrigo, que, cautiva de los moros, suplica favor y se somete finalmente a Abdalasis, su amo y pretendiente. 
za feraz de España. ${ }^{863}$ De Manuel José Quintana, a expensas de otros géneros también cultivados por su pluma, se recogen seis fragmentos de la primera serie de sus biografías liberales (Vidas de Españoles célebres, Madrid, 1807) pertenecientes al prólogo de la obra — en que el autor alaba a su modelo, Plutarco, por su maestría en la pintura de caracteres y sucesos de sus Vidas paralelas_-, a dos de las primeras vidas — la de un Cid político y guerrero, ${ }^{864}$ y la de Roger de Lauria y sus andanzas por el Mediterráneo oriental y por tierras de Bizancio- ${ }^{865}$ y por último a un pasaje inserto en la semblanza del Gran Capitán, en el que se narra el «Singular combate entre once franceses y once españoles» en 1502, entre los que descollaron García de Paredes y Diego de Vera. La crítica ilustrada de Cadalso, expuesta en tres fragmentos mutilados de la carta XIV ("Cómo se suele interpretar la voz victoria»), de la XXVI («Los catalanes») y de la VII («Mi tío el comendador»), convive, con dos de los monólogos pertenecientes a la noche I («Una noche en una cárcel») y a la II («El prisionero») de las discutidísimas Noches lúgubres ${ }^{866}$ —olvidadas de las historias y antologías francesas-, conformes en escenografía, sentimientos y expresión exaltada a los gustos románticos abiertamente exhibidos por entonces. A su lado, la apologética católica del ilustrado Pablo de Olavide ${ }^{867}$ tras su

863 "Fertilidad de la tierra de España», descrita como una zona templada surcada de contrastes orográficos pero sumamente fértil y abundante en bienes naturales, cultivos y productos.

864 De la Vida del Cid se toma un extracto del «Saqueo de Valencia» donde el narrador inserta parlamentos en pro del humanitarismo y la dignidad humana al señalar la ferocidad de los asedios, y otro sobre el desafío del conde Berenguel al Cid (1089) y su derrota.

865 Rendu escoge su discurso de defensa (1287) ante el rey Jaime II contra sus acusadores, y la descripción de la batalla naval en aguas de Malta (1283).

866 De esta obra constaba una traducción francesa a cargo de Ach. du Laurens (Les Nuits lugubres, París, Ponthieu, 1821), acompañada en el mismo volumen de Pièces fugitives imitées de l'anglais et de l'espagnol; sus Noches lúgubres, seguidas del Delincuente Honrado, drama en prosa, de Jovellanos (París, Th. Barrois, 1817, 1819; Burdeos, 1818, 1823), ediciones en las que aparecen ligadas ambas obras como representantes del patetismo y del drama sentimental tan gustados en ese período de entresiglos. Véanse Bragt y Vauchelle, ob. cit.

867 Pablo de Olavide, colonizador de Sierra Morena, alcanzó una gran fama a finales del XVIII entre los enciclopedistas por sus relaciones con el patriarca de Ferney y por la publicidad de su proceso inquisitorial, su autillo, que lo convirtió a ojos del resto de ilustrados europeos en un símbolo, pronto difundido por la semblanza que de él trazó Diderot (Véanse M. Defourneaux, Pablo de Olavide. El afrancesado, Sevilla, Padilla, 1990, y Perdices, ob. cit.). Esta gloria efímera no se consigna en los manuales literarios en los que luego apenas es nombrado, si bien seguirá estando presente en las bibliotecas privadas isabelinas (Martínez Martín, ob. cit.). No obstante, en los primeros treinta años del siglo su fama persiste, por ejemplo, en alusiones a su empresa colonizadora dentro de melodramas de ambiente oscurantista y fantasiosos vaudevilles. 
crisis de conciencia, El Evangelio en triunfo o historia de un filósofo desengañado (Madrid, 1797-98), verdadero best-seller de la época basado en la obra del abate Antoine-André Lamourette (Les Délices de la religion ou le Pouvoir de l'Évangile pour nous rendre heureux, París, 1788), también aparece en otros cuatro pasajes; ${ }^{868}$ al igual que cuatro fragmentos de los Himnos de la primera edad, traducidos por Ildefonso Miranda a partir de las lecturas para escuelas primarias, editadas y traducidas a su vez de la escritora inglesa Anna L. Barbauld por F. Thiercelin. ${ }^{869}$ La traducción de piezas teatrales en prosa queda reflejada en las versiones moratinianas del irrenunciable Molière con un trozo ${ }^{870}$ de la comedia El médico a palos, ${ }^{871}$ y del ya aceptado Shakespeare, con tres pasajes de su Hamlet ${ }^{872}$ (1798). El género novelístico ofrece asimismo abundantes muestras de dos estimadas traducciones de obras francesas - la versión de la novela prerro-

868 La «Invocación al omnipotente», canto de gracias y exaltación a Dios; «El nuevo testamento"; y dos extractos moralizantes como la admonición contra el vicio del juego («El juego») y la antítesis entre «La falsa y la verdadera felicidad».

869 "La presencia de Dios», texto religioso concebido como diálogo en torno a una alegoría de la pradera, y en el que canta la presencia de Dios en medio de los campos, en toda la naturaleza; el "Espectáculo moral del universo» ofrece la metáfora didáctica del orden en círculos concéntricos que abarcan toda sociedad desde la choza apacible y honrada del labrador ascendiendo hasta la aldea, la ciudad, el reino y el universo, sumidos todos en el temor de Dios; por último, «La noche», descripción bucólica en alabanza divina. Esta versión española apareció publicada detrás de la traducción de Alea de la que Rendu toma asimismo diversos pasajes en su antología (Pablo y Virginia, por Bernardino de St-Pierre, versión castellana por Don José Miguel de Aléa, [...] Nueva edición [...] aumentada con los Himnos de la primera edad [por Thiercelin, versión castellana por Yldefonso Miranda], Marsella, Masvert, 1826).

870 El diálogo entre Lucas, Ginés y Bartolo, del acto I.

871 En 1836 (Burdeos, Teycheney) se publicó la traducción anónima de la versión El médico a palos. Le Médecin à coups de bâton, comédie en trois actes, de Moratin, imitée du Médecin malgré lui, de Molière. Acte Ier. Traduction littérale (Katrin van Bragt, ob. cit., p. 576). Véanse R. Andioc, "Moratín, traductor de Molière» y "Más sobre traducciones castellanas de Molière en el XVIII» (Del siglo XVIII al XIX. Estudios históricos-literarios, 2005, pp. 221-254 y pp. 255-269, respectivamente) sobre la génesis y cotejo de la imitación moratiniana, representada en Barcelona en 1814, con su modelo francés y con otra versión anónima intermedia, El médico por fuerza. Según Andioc, sus editores de Londres en 1820 y de París en 1821 incluyeron la versión del autor, sin consultarlo, para imprimirla junto a sus comedias originales.

872 El monólogo de Hamlet, en la escena 4 del acto III; la visión del fantasma de su padre, en la escena 10 del acto I; y el monólogo del remordimiento de Claudio, el rey fratricida y usurpador, en la escena 22 del acto III. Moratín tradujo esta tragedia en 1798 tras la primicia de Ramón de la Cruz de 1769. Esta obra no fue incluida en su edición de Obras dramáticas y líricas (París, Bobée, 1825). 
mántica y rousseauniana de Bernardin de Saint-Pierre, Paul et Virgi$n i e,{ }^{873}$ por el afrancesado J. M. Alea, ${ }^{874}$ elogiada por su elegancia y fidelidad a su modelo; y la preparada por el padre Isla del tan disputado Gil Blas de Santillana de Lesage-, al punto que esta supera en frecuencia a los pasajes incluidos de Cervantes, el novelista español irrenunciable en toda antología, historia o manual, e incluso se impone a la fundadora del género picaresco, el Lazarillo de Tormes, recogida gracias a su popularidad en Francia, y de la que solo queda constancia en dos fragmentos cómicos de lectura moral - la etopeya del ciego y la aventura del jarrillo de vino-. De este modo, si bajo la firma del padre Isla se insertan once fragmentos, la abrumadora mayoría procede de su traducción, ${ }^{875}$ mientras que solo dos pertenecen a su novela original —el retrato del predicador mayor del convento (libro II, caps. III-V), etopeya muy reiterada en los comentarios de los manuales e historias literarias, y un pasaje de un cuentecillo jocoso («El equívoco, o el caso difícil», libro I, cap. IX)—. De Cervantes, que gozaba de gran reputación en España como uno de los modelos retóricos más admirados desde el siglo XVIII, se escogen nueve extensos fragmentos de su

873 El ejemplar que hemos consultado (París, Librería Rosa y Bouret y Cia, 1853) no está dividido en capítulos. Son cinco los fragmentos que el compilador titula «Infancia de Pablo y de Virginia", con la evocación bucólica de la vida virtuosa y feliz en medio de la naturaleza de la Nueva Francia, lejos de la sociedad metropolitana; «La esclava», sobre el regreso, a instancias de Virginia, de una negra marrona huida del maltrato de su amo, y el discurso de la muchacha ante el propietario en favor de la esclava, en el que se destaca el humanitarismo paternalista de la obra y el motivo poético de la fuerza persuasiva y conmovedora de la gracia y la belleza; el episodio del extravío de Pablo y Virginia de regreso a casa, con la descripción de los parajes arriscados y fragosos de la montaña; el excurso filosófico «El celibato», sobre la conveniencia de la soledad y la felicidad natural; $y$, por último, el naufragio en que muere la protagonista.

874 Se aprecia una intensa labor traductora durante el exilio liberal en Francia. Por ejemplo, de este afrancesado, profesor de lengua y literatura españolas en la Escuela Especial de Comercio de Marsella (Núñez de Arenas, art. cit., p. 255), Quérard (ob. cit., t. I, p. 16) refiere, además de alguna obra de pedagogía, un proyecto frustrado — su Nouveau Cours analytique de langue espagnole - del que solo habría visto la luz el discurso preliminar (París, Treuttel et Würtz; Marseille, Camoin, 1831), y que hubiera comprendido junto a las revisiones de los errores cometidos en las ediciones francesas de las Cartas marruecas cadalsianas (Lettres de Maroc), un volumen de poesías castellanas de los mejores autores y trozos selectos de prosa, con extractos del Quijote.

875 Los nueve pasajes insertos están extraídos de capítulos muy conocidos de la obra: «La cena de Gil Blas», en que recibe una lección del pícaro; «La limosna por fuerza», en que el viejo soldado exige a punta de escopeta su óbolo; «El padre de mi discípulo» de El bachiller de Salamanca; "el legado de Gil Blas», "Gil Blas enfermo», «El doctor Sangrado», «Gil Blas hace el papel de señor», "Gil Blas privado del arzobispo» y «Gil Blas burlado». 
Quijote, ${ }^{876}$ conocidos del público francés a través de las criticadas versiones del XVIII y de principios del XIX, antes de la triunfante edición de Viardot.

Mayor variedad de autores y épocas presenta la parte dedicada a la poesía, en cuyos géneros canónicos se acepta la inclusión del romancero a partir de tres fuentes: el Romancero del $\mathrm{Cid}^{877}$ para los dos romances del ciclo cidiano — «El Cid toma venganza del bofetón que dio a su padre el conde Lozano» («Pensativo estaba el Cid») y «Testamento del Cid Campeador» ("A la postrimera hora»)—; el Romancero general para el romance del rey Rodrigo "Lamentos del rey don Rodrigo" ("Las huestes de Don Rodrigo»), y la colección Antiguos romances españoles, ampliamente consultada, que suministra un romance sobre el conde Fernán González, "Alocución del conde de Castilla a su pueblo antes de la batalla contra Almanzor, rey de los moros» («El conde Fernán González»), y otro del romancero nuevo, "Combate entre un moro y un cristiano cerca de Granada» ("A vista de los dos reyes»). No obstante, el héroe privilegiado en la compilación de Rendu no es otro que Bernardo del Carpio, de cuyo ciclo se extractan nueve romances también sacados de esta última colección. ${ }^{878}$ Entre los poetas modernos el más aludido es Meléndez Valdés, con dieciséis composiciones, en las que abunda el poema rococó, galante y bucóli-

876 Siete de la primera parte, del capítulo I (bajo el epígrafe "Quién era Don Quixote», desde el íncipit hasta que da nombre a la dama de sus pensamientos); el principio del VIII con la aventura de los molinos de viento; el célebre discurso utópico de "los siglos dorados» sobre la edad de oro; parte del VI con «el escrutinio que hicieron el cura y maese Nicolás en la librería de Don Quixote»; y un fragmento que liga el final del capítulo II y pasajes del siguiente sobre «la vela de las armas. Don Quixote queda armado caballero»; el capítulo XXII íntegro con el episodio de la liberación de los galeotes («De la libertad que dio Don Quixote a muchos desdichados que mal de su grado los llevaban donde no quisieran ir; con otros no esperados sucesos»); y la conocida novela intercalada, con algunos cortes, de la "historia del cautivo", de los capítulos XXXIX, XL y XLI, a excepción de los sonetos que la acompañan. De la segunda parte se insertan dos pasajes: un largo fragmento del capítulo XLII sobre el discurso de D. Quijote a Sancho: «De los consejos que dio don Quixote a Sancho Panza antes que fuese a gobernar la Insula de Barataria», ejemplo ilustrativo del valor moral y la didáctica que perseguía la colección, y las celebérrimas «Bodas de Camacho" reproducidas en capítulos enteros (XIX, XX, XXI) y abundantes fragmentos del siguiente (XXII).

877 Véase Juan de Escobar, Historia y Romancero del Cid (Lisboa, 1605), edición de Antonio Rodríguez-Moñino, Madrid, Castalia, 1973.

878 "Alocución de Bernardo del Carpio a su ejército» ("Con los mejores de Asturias»), «Bernardo con los habitantes de León entra en campaña contra los franceses» («Con tres mil y mas Leoneses»), "Bernardo mata a Roldán y otros caballeros franceses en la batalla de Roncesvalles» («No tiene heredero alguno»), «Bernardo del Carpio sabe el secreto de su 
co, ${ }^{879}$ además de tres de sus odas filosóficas y sagradas de su segunda etapa, como la XI («La tempestad»), la XII («La tribulación») y la XVIII («Prosperidad aparente de los malos»). Los fabulistas españoles también son bien acogidos: Iriarte con cinco composiciones de sus Fábulas literarias ${ }^{880}$ y una ("La primavera») sacada de sus Obras misceláneas; y Samaniego con otras tantas de su colección. ${ }^{881}$ Los sigue Cadalso con una conocida anacreóntica ("¿Quién es aquel que baxa») y un epigrama («Epitafio», «Solo murió de constante»); Leandro Fernández de Moratín con otras dos composiciones («Las ruinas de naciones antiguas» y un fragmento del cántico religioso "A los padres del limbo»); y finalmente un poeta de la llamada escuela de Salamanca, Iglesias de la Casa, con su «Oda a la noche». De entre los poetas de las generaciones más cercanas, discípulos de Meléndez, Rendu no acude a Quintana, al que prefiere su condiscípulo Cienfuegos con cuatro poemas, ${ }^{882}$ al tiempo que delega la autoridad literaria que le atribuía Maury tres años antes, en el pujante Martínez de la Rosa, familiar para los parisinos y de cuya Poética se insertan extractos como "La Elegía» y «La Égloga» del canto IV. Los autores del Siglo de Oro tienen una menor representación cuantitativa por individualidades si se la compara con el espacio concedido a los formados en el XVIII, pero en conjunto forman un contingente nada despreciable. Ercilla, como representante egregio del poema épico con su Araucana, es el más reiterado con seis fragmentos recu-

nacimiento por medio de su abuela» («Contándole estaba un día»), «Lamentos del conde don Sancho Díaz en su prisión» («Bañando está las prisiones»), "Bernardo del Carpio pide al rey la libertad de su padre» ("Al Casto Rey Don Alfonso»), "Bernardo del Carpio pide otra vez la libertad de su padre. Respuesta del rey» ("Antes que barbas tuviese»), "Reconvenciones de Bernardo del Carpio al rey» («Mal mis servicios pagaste»), «Bernardo se presenta en palacio, donde reconviene al rey por su traición" ("Con solo diez de los suyos»).

879 Son, en su mayor parte, odas anacreónticas de la etapa juvenil del autor, escogidas sin orden y encabezadas solo por su título, como la oda II «El amor mariposa», la VI, la XII «La reconciliación», la XIII "El mediodía», la XV «De mis niñeces», la XXV «Elegía en la muerte de Nise», con lagunas deliberadas, la XLIII «De la noche», la XXXVII con cortes y omisiones. Asimismo, se han escogido la larga silva X "Mi vuelta al campo", reproducida íntegramente, una letrilla, la I «El amante tímido», la égloga IV «El zagal del Tormes» con cortes, y dos romances, el XXIX «La mañana» y el XXXIV «La tarde».

880 «El oso, la mona y el cerdo", "El pollo y los dos gallos», "El burro flautista», "La ardilla y el caballo" y "Los dos conejos».

881 «El charlatán y el rústico», "El zagal y las ovejas», "El gallo y el zorro», «La cigarra y la hormiga» $\mathrm{y}$ "El asno sesudo».

882 «El túmulo» («№ ves, mi amor, entre el monte»), su Himno a Baco («iOtoño! ¡Otoño! ¿le miráis que llega»), «El fin del otoño» («iAdónde rápidos fueron»), «La pastorcilla enamorada» con cortes («¿En qual hado nací tan funesto»). 
rrentes, ${ }^{883}$ seguido en frecuencia por Lope de Vega con tres composiciones —el soneto metapoético («Un soneto me manda hacer Violante»), la «Oda a mi barquilla» y un fragmento incompleto del diálogo amoroso entre Caupolicán y Fresia, del acto I de su Arauco domado, en el que ya se demoró Sismondi- Tras él, frente a la clamorosa omisión calderoniana, solo se admite entre los dramaturgos a Juan de Hoz con un romance de su comedia El avaro («Él vive en un desvancillo») y a Bermúdez con un trozo de su tragedia Nise lastimosa - la intervención del coro en el acto III, «El tiempo pasa y no vuelve» («Teme tus yerros, juventud lozana»)—. Cervantes también consta en esta sección con dos ejemplos, uno perteneciente a la patética escena de su Numancia elogiada por Esménard, con el diálogo entre la madre agonizante y su hijo hambriento ( $; \mathrm{O}$ duro vivir molesto!»), y el otro, su célebre soneto burlesco con estrambote. Asimismo, Gil Polo aporta dos breves composiciones tomadas de su novela pastoril ("A Galatea jugando a orillas del mar»y "Ninfa hermosa, no te vea»), mientras que Villegas cuenta con otras dos muy conocidas, «Del pajarillo» — tan alabada por Viardot—y su "Oda al céfiro». A la zaga sigue Garcilaso con un fragmento incompleto de su égloga I («Saliendo de las ondas encendido»), Juan del Encina con «El amor se vanagloria de su poder» («Ninguno tenga osadía»), Herrera y su célebre «Oda al sueño», fray Luis de León con su conocida «Profecía del Tajo», Francisco de la Torre con su «Oda a Tirsis», Francisco de Rioja y su atribuida epístola moral, acortada por su extensión ( ¿¿Qué es nuestra vida más que un breve día»), Juan de Arguijo con su «Soneto a la mudanza» ("Vierte alegre la copa en que se atesora»), Bartolomé de Argensola con otro habitual («Dime, Padre común, pues eres justo", que el compilador introduce bajo el título "Argumentos contra la providencia-Solución»), Pablo de Jérica con el epigrama en dos versos «Epitafio de un fraile», Quevedo con el soneto «A Roma sepultada en sus ruinas» y Góngora con una letrilla satírica ("Que esté la bella

883 Del canto XXV «Un indio desafía de parte de su cacique al capitán de los españoles» («iOh capitán cristiano! Si ambicioso»), del canto XV «Una tempestad en el mar Atlántico» («La mar era bonanza, el tiempo bueno») con cortes; del XXII «Discurso de un soldado araucano", donde se presenta la serenidad del araucano ante el trance de sufrir la amputación de las manos («Segad esa garganta»); del II, también con elisiones por su extensión «Discurso del cacique Colocolo, sobre la elección de capitán general de los araucanos, dignidad que pretendían juntamente todos sus émulos» ("Caciques del estado defensores»); del III "Discurso de un mancebo araucano, al ver huir a los suyos» («O ciega mente, del temor guiada») y del XXV "Discurso de un indio a sus conciudadanos poco antes de pelear» ( $\mathrm{O}$ valentísimos soldados»). 
casada»). También se acoge un ejemplo del poeta de cancioneros Alonso de Cartagena con «El mal de amor» ("La fuerza del fuego que alumbra, que ciega») y dos poemas anónimos —un cantarcillo ( llo, no te fíes») y «El pastor enamorado» («De este modo ponderaba»)—. La selección de Rendu privilegia, por tanto, una disposición retórica de autores recientes afines al liberalismo, junto a otros del XVIII — aún bastante editados y difundidos en las historias literarias—, además de los más conocidos por el público francés. Este notable rastreo de fuentes españolas, respetuoso de su canon y atento a las teorías en vigor, se interna por caminos menos trillados del romancero distintos del ciclo cidiano, de las versiones de Abel Hugo o de Maury; elige fragmentos significativos del Quijote como las reflexiones sobre la libertad o la utopía de la edad de oro; o atiende a sentimientos e iconos afines a la sensibilidad romántica. A su vez, no reniega de las lecciones clásicas como prueba su renuencia a la estética de los dramaturgos barrocos aún en 1830; y de acuerdo con la opinión general de la mediocridad novelística dominante tras Cervantes, opta por la superioridad de originales franceses muy respetados como la célebre novela de Lesage, que marca una inflexión en la novela picaresca hacia el aburguesamiento del héroe, o la rousseauniana de Saint-Pierre, actitud, en suma, acorde con la postura cauta de Sismondi, fiel a la herencia de la tradición clásica francesa.

Quince años después aparece publicado el Tableau de la littérature espagnole ${ }^{884}$ de Francisco Piferrer (Lloret de Mar, 1813-1863) ${ }^{885}$ en Tou-

$884 \ldots$ depuis le $12^{e}$ siècle jusquià nos jours, précédé d'une introduction sur l'origine de la langue espagnole, París, Baudry; Toulouse, chez l'auteur, 1845. La presente colección, dedicada a M. Mouseilles, rector de la Academia de Toulouse, se cierra con un recuerdo a sus compañeros de exilio. No es ajena a esta condición su empatía con aquellas personalidades abatidas por la adversidad, la pobreza, la ingratitud o la persecución política, cuyos datos biográficos incluye en su selección.

885 En la página de presentación de su historia aparece como «bachelier ès-lettres, professeur-suppléant de langue espagnole au collège royal de Toulouse». Efectivamente, bachiller en letras por la Universidad de París y regente por la de Madrid, profesó en el colegio de Toulouse hasta su retorno a España, y perteneció a la Academia Española Arqueológica de Madrid y a la Universidad de Francia. Son numerosas sus obras, como diccionarios y manuales de francés-español e inglés así como varios y apreciados estudios de heráldica, otro de filosofía y un conocido Diccionario de las Bellas Artes publicado póstumamente (Madrid, 1866). Véanse la Enciclopedia Universal Ilustrada (vol. 44, p. 818) y el Grand Larousse Universel du XIX siècle (t. 12, p. 998). La antología que comentamos se adelanta un año a la publicada en Barcelona por su tocayo, el importante Pablo Piferrer y Fábregas (Barcelona, 1818-1848) bajo el título Clásicos españoles. 
louse, uno de los firmes bastiones del hispanismo francés institucionalizado décadas más tarde. Este florilegio escolar incluye diversos fragmentos originales escogidos de los mejores autores españoles, dentro de una nómina más anchurosa y con un criterio eminentemente historicista. Al tiempo que los extractos seleccionados sirven para la enseñanza del idioma y permiten observar la evolución de la lengua, también se someten a la moralidad y a la invocación atemporal del buen gusto, conforme al ideal clásico de naturalidad, elegancia, claridad y equilibrio retóricos, ejemplificados principalmente en la elocución del XVI y del XVIII frente a los modelos barrocos. Empeñada en difundir la literatura española en todos los géneros más allá de los tópicos y del escaso número de autores nombrados - reducidos aún entre el público al teatro del XVII o a la novela cervantina- ${ }^{886}$ esta colección acata los juicios autorizados entonces vigentes, insistiendo en los factores reivindicativos de su calidad con un cariz nacionalista: la introducción a los orígenes y evolución de la lengua y su literatura desde el XII; ${ }^{887}$ las apostillas socio-políticas generales; la aceptación del período, marcado cronológicamente sin otro marbete anejo, entre el siglo XVI y el principio del XVII, como el de máximo esplendor literario; ${ }^{888}$ su influencia junto con la italiana mejor considerada por su clasicismo («tandis que l'Espagne est aujourd'hui généralement ignorée ou méconnue,

886 «Mettre donc cette importante et riche littérature à la portée de tous les amis des lettres, de ceux même qui ne cultivent point notre langue; montrer que l'Espagne a produit des ouvrages distingués dans tous les genres de composition, et détruire le préjugé, si accrédité aujourd'hui, qui réduit au théâtre de Calderon de la Barca, à celui de Lope de Vega et au Don Quichotte de Cervantes, tous nos monuments littéraires; tel est l'objet que nous nous sommes proposé».

887 El autor señala que en la Península las artes, las letras y las armas fueron cultivadas desde los tiempos más remotos, y cita a los grandes nombres prerromanos e hispanorromanos. Asimismo, marca la separación entre las diferentes literaturas según un criterio lingüístico, no de nacionalidades («à chaque époque les ouvrages des savants s'écrivirent dans la langue du peuple dominant, et c'est à la littérature de ce peuple qu'ils appartiennent, plutôt qu'à celle d'Espagne», p. 16). Sin embargo, al tratar de los orígenes de la lengua, tras remitir al lector a la introducción del Cancionero y Romancero de Durán y a la teoría de Sarmiento sobre la filiación latina, Piferrer prefiere decantarse por la propuesta de una lengua primitiva común o protoespañol («Il reste donc démontré, et par la plus saine logique, et par les plus incontestables autorités, que, rigoureusement parlant, la langue espagnole n'est point dérivé de la latine; mais que c'est une langue primitive, qui passant à travers les siècles a perdu une grande quantité de ses mots, et s'est enrichi d'un nombre immense de mots étrangers, pris des idiômes de divers peuples et particulièrement de la langue latine», p. 15).

888 Por ejemplo, «le haut degré de splendeur qu'elle [la poesía española] atteignit au $16^{\mathrm{e}}$ siècle est dû en partie à l'heureuse innovation de Boscá» (p. 128). 
sans qu'on puisse s'expliquer les motifs de ce dédain ou de cette ignorance», p. 7); así como las deudas de los clásicos franceses para con los grandes autores españoles. Piferrer ofrece un inventario autorcéntrico y rigurosamente cronológico por siglos, vertebrado en sumarias noticias biográficocríticas que soslayan la presentación de los movimientos literarios e ideológicos y de las clasificaciones genéricas, y preceden cada fragmento del corpus canónico. ${ }^{889} \mathrm{Si}$ bien el colector suele limitarse a retomar las valoraciones sancionadas que destacan las excelencias, defectos y temas tratados, también da su parecer a través de algunas opiniones diseminadas en las noticias preliminares - como su tibieza hacia Berceo o Boscán, o su entusiasmo exultante por Herrera-, o bien del número de composiciones presentadas o de sus omisiones. Asimismo orilla el romancero viejo, presente en cambio en la prestigiosa antología de Maury —aunque incluya algún romance de los autores escogidos_-; asume el Volksgeist del cantar de gesta; se distancia de la novela pastoril como la mayoría de sus contemporáneos; agrega el Guzmán de Alfarache y El diablo cojuelo; tras la extensa nómina del XVI y el XVII que concentra la producción dramática en Lope y Calderón y un infrecuente Vélez de Guevara, hace constar una nutrida presencia del XVIII reformista; y, cinco años después de la antología precursora de Ochoa, incorpora una selección de autores contemporáneos.

En el repertorio medieval ${ }^{890}$ presentado desde el siglo XII al XV, Piferrer se inclina de manera notable por el cantar cidiano, del que vindica resueltamente, como Florán, su valor literario e incluso erudito, por su inventio y la viveza y delicadeza de expresiones y recreaciones, a pesar de las habituales

889 De hecho, su selección ratifica la longeva pervivencia del prestigio ilustrado en la España del XIX y permite aplicarle también a la antología del catalán el juicio de Mainer (art. cit., p. 36) a la Biblioteca de Autores Españoles, que inicia su empresa difusora ese mismo año: «Esta presencia tan activa de lo dieciochesco significa, por sí misma, la consagración de un canon mixto donde el discurso político y el estudio histórico alternan con la creación artística».

890 Los fragmentos escogidos de todos los textos medievales van acompañados a pie de página de un glosario de términos del castellano antiguo traducidos al francés. Piferrer selecciona tres pasajes del cantar de gesta a partir de Sánchez (dos del primer cantar — la algarada de las huestes del Cid en Castejón, primera gradación ascendente en las hazañas del protagonista (vv. 461-491), la defensa del imprudente Pero Bermúdez (vv. 722-742)—; y el último, del segundo cantar según otras ediciones, con la ceremonia de los esponsales y casamiento de las hijas del Cid por decisión del rey, y el intercambio de regalos (vv. 2102-2156)); incluye por su prelación a Berceo, prácticamente olvidado y despojado de la sensibilidad poética que apreció en él Florán, pese a la ingenuidad y facilidad de su verso, con otros tres frag- 
críticas a su versificación; confirma la admiración hacia Alfonso X; toma la defensa, como Maury y Viardot, de un bien representado Libro de Alexan$d r e$, sobresaliente por su estilo sencillo, hallazgos expresivos deslumbrantes, su moralidad general y extraordinaria erudición, cualidades superiores en conjunto a los defectos reconocidos de los que vindica la medievalización de la materia conforme a la práctica de su tiempo («en un mot, mille beautés de premier ordre qui, avec la grandeur du sujet, constituent la vraie poésie épique»); exalta como Florán y Viardot el talento de Juan Ruiz, hito literario medieval — por encima de los reparos morales de rigor y su irreverencia hacia las costumbres y las conveniencias sociales- por su estilo, variedad rítmica, ironía e imaginación; encomia la colección de apólogos de El conde Lucanor, tan apreciada por Bouterwek por su fondo moral y conocimiento

mentos de la habitual Vida de Santo Domingo (2. cuarteta y parte de la 6. ${ }^{a}$; y de la 132 a la 140), los Loores de Nuestra Señora (estrofas 111-115) y dos extractos del milagro del cancelario de los Milagros de Nuestra Señora - la aparición en sueños de la Virgen al clérigo y sus órdenes para que readmita al cancelario, y el milagro en el sepulcro (cuartetas 106-115)—; inserta cuatro trozos de Alfonso X (dos de Las Siete Partidas - un fragmento del prólogo y otro de la V Partida (título I, ley 10)_, otro del Libro del Tesoro, y la dedicatoria de las Querellas); hace gran acopio de pasajes del Libro de Alexandre, atribuido entonces a Segura de Astorga (trozos descriptivos ("Iba aguisando Don Aurora sus claves»), la memoria del sitio de Troya, las reflexiones morales de la correspondencia con el rey Darío, la toma de Tiro, la consulta a los estrelleros, los proyectos de conquistar Europa, el sepelio de Alejandro con el cierre del poema, su testamento y la carta a su madre Olimpia); extrae siete escuetas lecciones morales en prosa de los apólogos de El conde Lucanor (exemplos XXIX «De lo que contesció a un raposo que se echó en la calle et se fizo muerto"; XLIX «De lo que contesció al que echaron en la ysla desnudo cuandol tomaron el señorío que tenié»; XLVIII «De lo que contesció a uno que provava sus amigos»; L "De lo que contesció a Saladín con una dueña, muger de un su vasallo»; XXXIII "De lo que contesció a un falcón sacre del infante don Manuel con una águila et con una garça»; XL "De las razones por que perdió el alma un siniscal de Carcassona»; XXV «De lo que contesció al conde de Provencia, cómmo fue librado de la prisión por el consejo que le dio Saladín»); ofrece cinco extensos pasajes de Juan Ruiz ("Aquí fabla del pleyto quel Lobo é la Raposa hobieron ante Don Gimio, Alcalde de Buxia»; «Enxiemplo de la propiedat que el dinero ha»; dos cánticas de serrana: «So la casa del Cornejo primer dia de Selmana» y "Cerca la Tablada»; «Enxiemplo del Ladrón que fiso carta al Diablo de su anima»; «De cómo morió Trotaconventos et de cómo el Archipreste fase su planto, denostando et maldesiendo la muerte»; y "Cántica de loores de Santa Maria»: «Santa Virgen escogida»); un larguísimo fragmento de la frecuentada y conmovedora «Muerte del conde de Niebla» (orden de Marte, copla 160) del Laberinto; dos poesías del marqués de Santillana, de quien destaca la fluidez y dulzura de sus composiciones ligeras (la canción «Querella de amor» y la «Vaquera de la Finojosa») y un trozo extenso de la carta-prohemio al condestable de Portugal; cuatro amplios pasajes de la Visión deleitable de Alfonso de la Torre; y de Hernando del Pulgar tres fragmentos de los Claros varones - título I (Enrique IV de Castilla), t. IV (D. Ínigo López de Mendoza, marqués de Santillana) y t. VI (de Juan Pacheco, marqués de Villena) - y otros dos de sus cartas (A D. Alonso Carrillo, arzobispo de Toledo, y al rey de Portugal). 
humano, de la que ofrece, sin embargo, siete escuetas lecciones morales de acuerdo con un sistema catequético; estima notablemente, como Maury y Viardot, la composición del Laberinto de Mena, de expresión enérgica y a veces sublime, pese a cierta dureza estilística; alaba la Visión deleitable de Alfonso de la Torre como obra maestra del XV, y se suma a los elogios generales a las cartas y semblanzas de Hernando del Pulgar.

En el siglo XVI ${ }^{891}$ Piferrer muestra una mayor admiración por las obras maestras garcilasianas con dos largos fragmentos de sus églogas (la I

891 Ante la disparidad de criterios sobre la valoración poética de Boscán, Piferrer se inclina por un juicio equidistante que, asintiendo al reconocimiento general de su contribución a la reforma italiana, no lo eleva sobre la mediocridad literaria. De él selecciona una pequeña composición cancioneril («Un ave no conocida), tres sonetos — "La hermosura de Filis» («En qual parte del cielo, en qual planeta»), "Amor continuado por costumbre» ("No alcanzo yo, por dónde, o cómo pueda»), «Sobre la dicha hermosura de Filis» («Mueve el querer las alas con gran fuerza»), y la renacentista canción II ("Claros y frescos rios»)—. También le despierta considerable estima, por su gusto, erudición y estilo majestuoso y conmovedor aunque desigual, la prosa de fray Luis de Granada, digno de Bossuet, del que toma cinco pasajes de su Guía de pecadores; escoge tres trozos del Diálogo de la dignidad del hombre de Pérez de Oliva; muestra, como Bouterwek, gran respeto por Hurtado de Mendoza, como cumplido humanista, diplomático y guerrero, del que elogia su historia (con pasajes de los libros I, III y IV), la atribuida novela de costumbres y crítica social (con largos y entrecortados fragmentos del episodio del escudero), y, sin criticar sus poemas, incluye una canción («En el mar sosegado al manso viento») y una letrilla («Esta es la justicia»); toma extractos del Epistolario y del Audi, filia et vide de Juan de Ávila, más atento a conmover aun a costa de su estilo; dos fragmentos de la continuación del Diálogo por Cervantes de Salazar; pasajes de las Moradas primeras de Santa Teresa (caps. I y II; caps. XXVII y XLII de Camino de perfección, trozos de una carta suya a uno de sus confesores (1562) y de Exclamaciones o meditaciones de una alma a Dios), elogiada convencionalmente como santa fundadora y por su poder de convicción a pesar de ciertos reproches a su estilo demasiado abundoso; más parco y severo que Viardot con Juan de la Cruz, al que atribuye obras ascéticas y no místicas, Piferrer señala su estilo desigual, aunque original, expresivo y sublime, y del que escoge más ejemplos en prosa (glosas y explicaciones a la Noche escura del Alma, cap. IX; fragmentos del cap. I del Cántico espiritual, de Avisos y sentencias espirituales, y de una carta desde Segovia (1588) a la priora del convento de carmelitas descalzas de Córdoba) que en verso (un largo pasaje de su poema Diálogo entre el Alma y Cristo su esposo, "¿A dónde te escondiste / Amado y me dejaste con gemido?»); introduce un largo fragmento del Guzmán ("C'est un roman qui se recommande par le naturel du récit, la richesse de l'invention, et la pureté du style», p. 252); dedica elogios convencionales a Figueroa (largo pasaje de su égloga "Tirsi, pastor del más famoso rio») y también, con cierta circunspección, a la novela pastoril de Montemayor - con extractos del libro III de La Diana y poesías insertas como la canción "Pastora, cuya ventura», el soneto "En este claro Sol que resplandece» y la canción "Alcé los ojos por véros»— y a la continuación, apreciada por Cervantes, de Gil Polo — con fragmentos del libro III, la canción de Nerea («En el campo venturoso») y rimas provenzales ("Quando con mil colores devisado») — remitiendo al juicio más riguroso de Florian (Essai sur la pastorale), aun reconociendo el mérito de su estilo. 
y la III) y dos sonetos - el I, cercano a la estética castellana de los cancioneros ( $i \mathrm{O}$ dulces prendas por mi mal halladas»), y el II, plenamente renacentista-, y por las obras originales de fray Luis de León («le second poète classique de l'Espagne»), entre las más bellas de la literatura española — de las que inserta la canción de la vida solitaria «La profecía del Tajo» y la oda sacra "A nuestra Señora" - así como destaca su talento traductor en sus versiones de la égloga I de Virgilio, la oda I de Horacio, una imitación de Petrarca («Mi trabajoso día») y el capítulo final de los Proverbios, «El sabio Salomón aquí pusiera». No obstante, estos elogios palidecen ante los dedicados a Herrera como el más perfecto modelo de lo sublime en la poesía lírica ("Jamais la poésie ne produisit d'images plus riches; jamais elle n'exhala d'accents plus doux et à-la-fois plus majestueux; jamais elle ne trouva de mouvements plus rapides; nulle part enfin elle ne déploya plus de magnificence», p. 177) y culmen de la promoción iniciada por Estala, con una amplia representación de sus canciones, dos elegías, una égloga venatoria, un idilio, un soneto propio y otro en su homenaje. ${ }^{892}$ Asimismo, también reciben su caluroso beneplácito la historia de Juan de Mariana («livre vraiment classique» por su estilo y exactitud), que aún considera la mejor escrita y más estimada - de la que toma varios fragmentos sobre los orígenes (libro I, cap. XII), la muerte de don Rodrigo (libro VI, cap. XXIII) y de Fernando el Católico (libro XXX, cap. XXVII) - y el poema didáctico de Céspedes sobre la pintura, del que incluye pasajes del primer y segundo libro.

Las variaciones estéticas del XVII español ${ }^{893}$ respecto a las normas aristotélicas propician la promoción de autores asumida por las historias

892 Incluye pasajes de sus canciones A Don Juan de Austria, A la batalla de Lepanto y A la pérdida del rey Don Sebastián, trozos de sus elegías "Estoy pensando en medio de mi engaño" y «En esta soledad me satisface»; su soneto "¿Dó vas? ¿dó vas, cruel? ¿¿dó vas? refrena»; pasajes de una égloga venatoria, un idilio ( $\mathrm{El}$ sol del alto cerco descendia») y un soneto compuesto por Baltasar de Escobar en elogio de Herrera.

893 El XVII acoge una variada representación de Lope de Vega, sobre el que no hace valoración crítica alguna, más que confirmar la belleza de su estilo y su fecundidad e imaginación pasmosas, predominantes en sus versos — así, conforme a la fama vigente en el XIX, se destacan sus poesías ("Oda a la barquilla», la canción "O libertad preciosa", el himno "Amor poderoso en el cielo y tierra", y el soneto "Daba sustento a un pajarillo un dia»), seguidas de un fragmento de su poema épico-burlesco La gatomaquia, y otro de la comedia El acero de Madrid (acto II, escena II)—; la condena que Góngora comparte con su tiempo por la corrupción del buen gusto no incumbe a toda su producción - de la que elogia en particular sus sonetos - ni a su talento, la riqueza de sus imáge- 
literarias en virtud de su adecuación a los ideales clásicos así como a las nuevas teorías literarias del XIX. De este modo, Piferrer ratifica la consagración cervantina labrada en el XVIII como novelista moderno — con pasajes de "Los siglos dorados» y de la carta de Sancho Panza a su mujer en la segunda parte del Quijote- y como crítico con un trozo del capítulo IV del Viaje del Parnaso - a notable distancia de los breves pasajes de su Galatea —; estima mucho la conocida historia de Solís — de quien, ya rebajada su fama de dramaturgo con El amor al uso, toma cinco brevísimos pasajes de los libros I (cap. III y XVIII), II (cap. XVII), III (cap. III) y VI (fin del cap. XIV)—; reafirma aún en el canon a los muy respetados Argensola - por su talento, moralidad y fluidez de sus odas y sátiras a pesar de cierta dispersión y dureza-, que descuellan incomparablemente en las poesías ligeras y los sonetos; ${ }^{894}$ canta las alabanzas de la canción "A las ruinas de Itálica» de Rioja, y de los melodiosos versos de Villegas, exponente de las posibilidades de la lengua, reivindicándolo como modelo digno de ser difundido e imitado, con su oda al céfiro y tres anacreónticas ("Como rosa que nace», "Del pajarillo» y "Amor entre las rosas»); recomienda la lectura de algunas églogas de Balbuena, insertas en su mediocre novela pastoril Siglo de Oro en las selvas de Erifile (l'Âge d'or), dignas de las más bellas de la poesía española; y elogia la excelencia de la

nes, la fuerza de su estilo y la originalidad de sus composiciones menores — como la canción "Vuelas, o tortolilla», el romance "Levantando blanca espuma», "Compitiendo con los cielos», la letrilla «Aprended flores de mi» y dos sonetos "Raya, dorado sol, orna y colora» y "Ayer naciste y morirás mañana»—; las máximas morales, las admirables descripciones y hermosos detalles del poema de Ercilla, del que toma un trozo del canto II, no compensan, sin embargo, los grandes defectos de conjunto; la inclusión de Vélez de Guevara se justifica por su muy estimable novela, de la que saca un fragmento del capítulo "La casa de locos», y su pieza teatral Reinar después de morir, de la que inserta dos escenas (IX y X); asimismo, tanto Esquilache, nombrado primer poeta épico español por su Nápoles recuperada por el rey don Alonso, cuyas églogas y romances alaba y de los que entresaca "Las cuatro estaciones» («Pasaban por diciembre») y "A Silvia» («Truécanse los tiempos»), como los historiadores Moncada — de estilo digno de César con el proemio de su Expedición de los Catalanes y un pasaje del cap. XVII- y el siempre valorado Melo - con el prefacio de su Historia de la Guerra de Cataluña y un trozo del libro I- reciben el aprecio de su colector.

894 Piferrer inserta trozos de la canción «De los campos y mares se apodera», de la epístola "¿Qué es nuestra vida más de un breve día», y el soneto "Dime, padre común, pues eres justo» de Bartolomé; una canción ("Alivia sus fatigas») y un soneto ("Lleva tras sí los pámpanos octubre») de Lupercio. 
traducción — superior a veces a su original— de la Aminta de Tasso por Jáuregui, de quien inserta además unas estrofas de su canción «En la muerte de la reina Margarita».

La valoración ambivalente de Quevedo oscila entre la admiración por su lúcida y persuasiva brillantez intelectual, por su ingenio y maestría elocutiva, y el reproche a la oscuridad conceptista y la inclinación escatológica que lastrarían su obra en prosa. Si destaca sus escritos didácticos y ascéticos, acordes con la pureza y la austeridad de la moral cristiana ${ }^{895}$ — pero sin el encanto de los de fray Luis de Granada o Santa Teresa-, su concisión y energía en el género histórico, e incluso la finura y dominio de la lengua en sus obras burlescas, como el pasaje escogido ( Visita de los Chistes») de sus Obras jocosas, su originalidad expresiva y la singularidad del estilo quevediano llevan a Piferrer a proclamarlo «un modèle à étudier, car il est expressif, beau, énergique, et d'un génie supérieur", con todo inimitable («mais vouloir l'imiter serait la plus infructueuse tentative», p. 320). En cambio, su poesía ocupa el último lugar, representada por un soneto ("Quitar codicia, no añadir dinero»), dos romances ("Tiempo, que todo lo mudas» $\mathrm{y}$ «A la sombra de un risco»), una letrilla lírica («Rosal, menos presunción»), otra satírica ("Yo he hecho lo que he podido») y el salmo IX. Por el contrario, aun con alguna resistencia clasicista, Calderón es encumbrado al fin a la cúspide dramática. Después de mencionar, más por extenso que en Lope, el habitual repertorio de diverso género - incluidos sus elogiados autos sacramentales («ses magnifiques drames religieux et allégoriques») — cuya falta de unidad compensan la elegancia y claridad del estilo, su fecunda imaginación y dominio del desenlace dramático y otras bellezas sublimes, Piferrer prefiere a la elección de Mérimée otras dos obras que rivalizan con Shakespeare en energía, caracteres y argumento como Le Médecin de son honneur y La vie est un songe. ${ }^{896}$

895 Como el capítulo II «Propiedades, y excelencias de la devoción» de la Introducción a la vida devota o el pasaje sobre la "Inmortalidad del alma» de Providencia de Dios.

896 De esta última, conocida en Francia desde principios del XIX a través de su refundición por el tamiz italiano (Tragicomédie italienne, tirée de l'espagnol, par Gueullette, París, Briasson, 1717), escoge un pasaje de la jornada primera centrado no tanto en el monólogo del protagonista, reducido a cinco versos, sino en la respuesta de Rosaura; y otro de la jornada segunda que revela en el diálogo con Clotaldo el despertar simbólico del príncipe y la aceptación cristiana de su papel como soberano dueño de sus pasiones y cumplidor de su deber. 
El elenco del siglo XVIII, ${ }^{897}$ si bien no tan copioso, recibe una notable estima por su buen gusto, equilibrada entre el fervor demostrado a otros autores de la centuria precedente y el desdén que comienza a generalizarse en los compendios y antologías. Los ejemplos en prosa seleccionados comprenden extractos muy breves de los aún prestigiosos Mayans, alabado por sus trabajos de erudición como su Vida de Cervantes, considerada aún su obra maestra, y del que selecciona un pasaje de sus Cartas morales; Feijoo, adalid de la razón y debelador de prejuicios y supersticiones con su ambicioso plan divulgativo ("monument scientifique») y su estilo nunca decepcionante; Luzán, muy ensalzado por su poética y su ejemplo en poesías armoniosas, aunque muestran restos visibles del trabajo de lima — como su canción "Ya vuelve el triste invierno»—; los estudios filológicos de Capmany con un fragmento laudatorio del padre Mariana en su estimado Teatro crítico de la elocuencia española; la historia de Conde, elogiado aún por su imparcialidad, su talento expositivo, incluso cierta vivacidad oriental en su estilo, y del que saca un fragmento del capítulo XIII; la alabada novela del padre Isla, de la que toma el habitual fragmento del retrato del protagonista a la vez que otro pasaje de su traducción del Gil Blas; las célebres fábulas literarias de Iriarte, traductor, poeta y dramaturgo, de las que selecciona «La abeja y el cuclillo», «El té y la salvia» o la vivaz "La ardilla y el caballo»; o la admirada lírica de Meléndez — con tres muestras de pasajes de la letrilla VI "La flor del Zurguén», y dos sonetos, el III «El pensamiento»y el XVIII «El remordimiento»—. Junto a esta selección de los nombres más frecuentados del XVIII, a juzgar por el espacio otorgado y la variedad de la temática escogida — desde sus citas al Informe sobre

897 De Feijoo, muy elogiado pero escasamente representado, se escoge un fragmento («El monte de la virtud») de su Teatro crítico universal; de un secundario Nicolás Fernández de Moratín, decepcionante en elegancia e invención, toma la anacreóntica "El arroyo» ("Vagaba por los montes»), la cantilena "El sueño», y varios fragmentos de su canto épico generalmente más apreciado, Las naves de Cortés destruidas; de Cadalso, apreciado por su justa reputación literaria fundada no en su tragedia, sino en sus Cartas marruecas, reproduce un fragmento de estas y dos poesías — su "Elegía a la fortuna» ("¿Dónde hallarás quien resistirse pueda») y una letrilla («De este modo ponderaba»)—; de Samaniego, cuyas fábulas elegantes son dignas de contender con Florian pero no de aspirar a Lafontaine, toma dos de ellas ("El asno y las ranas», "Los navegantes» y una incompleta, «La mona»); de Moratín hijo, respetado sin arrebatos - y de quien se enumeran sus piezas teatrales definidas por la pureza del gusto, sus relatos de viaje, sátiras, poemas y estudios eruditos-, se incluye el diálogo entre doña Irene y don Diego de la escena IV de El sí de las niñas. 
la ley agraria, un pasaje de su Elogio de Carlos III, dos idilios filosóficos «Al sol» y "A la luna», y una muestra de su drama sentimental El delincuente honrado (la decisión de Torcuato de acudir en ayuda de su amigo desoyendo las súplicas de su esposa: acto II, esc. VII); y su alegato contra la tortura: esc. XIV—, la presencia de Jovellanos conserva aún en este colector el renombre de que gozaba ampliamente a principios del XIX.

Al abordar su siglo, Piferrer amplía los límites cronológicos de las historias literarias precedentes con autores representativos que no enjuicia por no mediar el tiempo suficiente para su justa valoración. Menos exhaustivo que Ochoa, este compilador admite principalmente estudios históricos, como la muy estimada del liberal moderado conde de Toreno; obras polemistas como las Cartas del Pobrecito Holgazán de Miñano - piadosamente recordado por su hijo E. de Ochoa, pero no tanto en las historias francesas de la literatura española-; traducciones de fuentes clásicas o de historiadores modernos prestigiosos, trabajos teóricos, poéticas - como un fragmento oratorio del Arte de hablar en prosa y verso (art. III, tomo II, art. III) del neoclásico Hermosilla, y trozos de las anotaciones (X, canto I; XVI, canto II) de la Poética española de Martínez de la Rosa-; poesías — de Arriaza con "La despedida de Silvia», del también dramaturgo Escosura con "El Caminante», o de la novelista Vicenta Maturana con su poema en prosa Himno a la luna, la letrilla «La indiferencia por todo» y el soneto «El ruego»-; páginas costumbristas de Campo Alange como un pasaje de su «Recuerdo de Sevilla», presente asimismo en Ochoa; la comedia contemporánea con la escena VIII (Camila, Rita, don Marcelo) de Ella es él de Bretón de los Herreros, conocido por sus obras teatrales, sátiras, poesías ligeras, y sus buenas traducciones francesas; y el drama con un fragmento de la escena V (don Pedro, Isabel) y la VII (don Martín) de Los amantes de Teruel de Hartzenbusch. De entre los escritores bien representados en distintos géneros destacan Quintana no solo con extractos de sus biografías históricas («Triunfos navales de Roger de Lauria»), sino también por su poesía filosófica como en Maury y Ochoa («A la expedición española para propagar la vacuna en América bajo la dirección de don Francisco de Balmis»); Lista, mentor de varias generaciones españolas, con la introducción a su traducción de la Historia moderna de Segur, su suplemento a la historia de Mariana, un fragmento revelador de sus Lecciones de literatura española, sobre los valores de los conceptos clásico y romántico, y su poema «La vida humana» («¿No ves, Fileno, en la florida espalda»); el 
ilustrado reformador Javier de Burgos, apreciado entonces por sus Anales del reinado de Isabel II, autor de trabajos para la Biographie universelle de Michaud y traductor de Homero, está representado con dos fragmentos oratorios - de su Exposición dirigida a S. M. el señor Don Fernando VII (1820) y de su Discurso leido en la Real Academia Española (19-VII1827) — y su oda "La constancia»; y el ineludible Martínez de la Rosa reaparece con el poema "La Espigadera», y un fragmento de su tragedia clásica Edipo (acto IV, esc. II). En suma, a la altura de 1845 Piferrer no presenta al alumnado francés pasaje alguno de los autores costumbristas más divulgados en la prensa cultural; omite toda referencia a autores ya difundidos entre los franceses como Larra, Mesonero, el duque de Rivas o Espronceda, y no recoge ejemplos del género novelístico contemporáneo, al que prefiere la historia, las traducciones de prestigiosas fuentes clásicas o modernas, el ensayo, la poesía y una representación exigua del teatro.

La voluntariosa aportación en 1849 de Antony Rénal, pseudónimo del lionés Claudius Billiet, ${ }^{898}$ quien ya había hecho sus armas en traducciones del romancero cidiano, está vinculada, por su parte, a los discursos académicos de las sociedades literarias de provincias como la de su ciudad natal, a varios de cuyos miembros dedica algunas de las semblanzas de los autores españoles seleccionados. En su empeño por divulgar un muestrario de las riquezas de la cultura española entre el público francés, edita como colección sus Illustrations littéraires de l'Espagne, esquisses biographiques, ${ }^{899}$ espigadas sin orden cronológico de entre los escritores consagrados

898 Véase Quérard, ob. cit., supplément III, p. 391. Novelista, crítico literario, libretista musical, poeta y autor de folletines, estudios sobre la literatura del sur de Francia, compendios de cantos e himnos revolucionarios, este polígrafo francés perteneció a diversas academias de provincias como la Société Littéraire de Lyon, la Académie de Rouen, o el Institut historique de París, entre otras. Aficionado a la literatura española, había dado ya a la imprenta una de sus obras más conocidas, su traducción del Romancero du Cid (Traduction nouvelle, avec le texte en regard, París, Baudry/Hippolyte Souverain, éditeur commercial, y Lyon, Imprimerie Typographique et Lithographie de Louis Perrin, 1842), sometida también, como esta colección, al escrutinio de sus colegas lioneses. Por ejemplo, el discurso dedicado a M. Bostain en la serie que comentamos a continuación versa con detalle sobre las fuentes consultadas sobre el personaje histórico para su versión del romancero cidiano (Sandoval, Risco, Masdeu y la biografía y documentación de Quintana, principalmente).

899 París, Hippolyte Souverain, éditeur libraire, Lyon, 1849, tomo I, de cuya continuación no tenemos constancia. 
por las historias literarias, a la que añade un abigarrado apéndice alfabético con mínimas notas biográficas en todas las ramas del saber y de las artes, desde los hispanorromanos hasta José Marchena. ${ }^{900}$ El carácter diletante de esta serie literaria — más novedosa por su mayor énfasis y detalle en las noticias biográficas que las compilaciones al uso- se observa en diversas confusiones, ${ }^{901}$ en la no infrecuente imprecisión u omisión de algunas de sus fuentes, ${ }^{902} \mathrm{y}$ en la repetición de enjuiciamientos sancionados por las historias literarias, antologías y colecciones de las dos primeras décadas del XIX. En particular, los no siempre confesos pero sí elogiados Bouterwek y Marchena — por su defensa común de los dramaturgos barrocos de las acusaciones de ignorancia de las reglas del arte y su contextualización en las costumbres de su época-, el compendio de Maury — atribuido erróneamente a Bourgoing, y cuya selección y comentarios se tienen en cuenta- o el prólogo de Moratín a sus obras completas de 1825, a propósito de la decadencia del teatro español y las circunstancias de su reforma en el XVIII. De esta manera, las discriminaciones del historiador alemán — de cuyos dictámenes el autor no

900 Cierta familiaridad de Rénal con la historia de la literatura española se evidencia en las menciones sumarias desperdigadas en desorden en sus artículos a las Coplas de Mingo Revulgo, el romancero general, Rodrigo Cota, Simón de Abril, Pérez de Oliva, Boscán, Pérez de Hita, Villalobos, Rojas de Montalbán, Balbuena, Moreto, Montiano, Nicolás Fernández de Moratín o Jovellanos entre otros. En las páginas finales elabora una suerte de nomenclátor que abarca sabios y poetas de la España hispanorromana, musulmana, judía y cristiana medieval, cuyo censo se incrementa notablemente en el XVI con unos cuarenta nombres entre artistas, cronistas de Indias, teólogos, poetas o historiadores; el XVII, en el que elogia grandemente a Velázquez, y el XVIII, con una veintena cada uno, hasta los tres representantes del XIX, entre los que se cuenta el más conocido José Marchena.

901 Si es disculpable el crédito concedido, como otros estudiosos de entonces, a la superchería de Adolfo de Castro, El Buscapié (1847) atribuido a Cervantes, que Rénal llega a alabar como la mejor crítica salida de la pluma del novelista, también incurre por su parte en yerros y confusiones sobre autores consultados.

902 Además de la limitada enumeración de fuentes que deja en suspenso al final de la obra - diccionarios biográficos como el de Chaudon y Delandine, de Roland (Dictionnaire des Hommes Célèbres), Barré (La Nouvelle Biographie Classique), Le Dictionnaire Biographique Universel, o la Galerie des Contemporains célèbres, par un homme de rien; además de las Lecciones de Marchena (Burdeos, P. Beaume, 1820) o L'Espagne poétique-, en sus discursos acude a memorias académicas, prólogos de ediciones y biografías que no siempre detalla pero de las que extracta información, aunque también hace referencias puntuales en torno al autor presentado (por ejemplo, a propósito de Iriarte, recurre al ensayo de Sempere así como a la valoración del anónimo Essai sur la Littérature espagnole de 1810). 
suele apartarse llegando a veces a injertar sin advertencia pasajes literales- y de algunos de los españoles exiliados en la Francia de la década de los veinte proporcionan sustancialmente, en el año de las ediciones inglesa y americana de Ticknor, las pautas fundamentales de periodización, admisión de sistemas poéticos nacionales y enjuiciamientos, dispersas en el texto de Rénal. ${ }^{903}$

La selección ofrece una galería de retratos literarios de diversos autores españoles, aderezados a menudo con pasajes, la mayor parte de las veces imitados en prosa de sus obras más apreciadas, desde las bellas letras del XVI hasta el aún elogiado Martínez de la Rosa, beneficiario de la buena reputación que se granjeó en Francia en torno a los años treinta. Si bien los plácemes no ocultan los defectos comúnmente registrados por la crítica, entre los buenos autores del siglo XVI se incluye a los hermanos Argensola — con extracto de las mismas sátiras escogidas por Viardot en 1835-; el inmarcesible Garcilaso de la Vega («s'il n’est pas

903 Por otra parte, Rénal suele asumir una postura benevolente respecto a la cultura española. Como apuntara Florán en su reclamación de la década precedente, el colector refuta la especificidad española de la barbarie de sus costumbres, comparándolas con las de pueblos vecinos en otros períodos supuestamente más civilizados como, por ejemplo, durante la Revolución francesa. Si explica la sociedad española del XVII —ejemplo del carácter nacional genuino lleno de contrastes extremos- por el peso de las instituciones políticas, del fanatismo y de las costumbres ancestrales, también propone una superación comprensiva de las categóricas condenas ideológicas de Sismondi. Respetuoso de las leyes del arte, la verdad, la belleza y la moral, Rénal observa las piezas calderonianas como una brillante transición desde los orígenes del teatro hasta la reforma acometida en el XVIII para devolver el buen gusto y las reglas del arte al género dramático. Es más, frente a Sismondi o Puibusque, adjudica el reconocimiento de este hito a la sensibilidad de su público («Le peuple espagnol, malgré ses penchants pour le merveilleux, malgré son attachement prononcé pour les Autos sacramentales, semblait deviner, dans ces beautés étranges, dans ces hardiesses sublimes du poète Calderon, comme une transition habilement ménagée entre les vieilles friperies dramatiques des siècles précédents, et une régénération plus complète, plus radicale du théâtre espagnol, régénération dont l'honneur devait appartenir au poète Iriarte», p. 270). A esas alturas del siglo, frente a la tónica habitual de los críticos de la época respecto al siglo XVIII — con la salvedad aún de la aceptación más moderada de Moratín-, Rénal, quizá en virtud también de sus fuentes, muestra cierto aprecio por esa centuria junto con las aserciones ya habituales a mediados de siglo: las revisiones meritorias de Luzán y Mayans, la aplaudida supresión de los autos sacramentales, y tras los ensayos dramáticos de Nicolás Moratín, Cadalso, Ayala o Huerta, los logros de Iriarte junto a la reivindicación castiza de Ramón de la Cruz ("qui semble, lui seul, avoir compris le caractère de la véritable comédie, malgré les négligences, les hardiesses de mauvais goût que renferment quelques-unes de ses œuvres»). 
le plus grand poète castillan, Garcilaso de la Vega est au moins le plus classique») con una parte de su celebérrima égloga primera y cuatro sonetos - tres plenamente renacentistas (el XXIII, el XXIV y el XXIX) - y uno, el XXVII, con remembranzas de las canciones castellanas; el docto Herrera, al que se le reconoce un lenguaje poético propio, un tanto enfático pero comparable en pompa y riqueza al de los maestros antiguos, ejemplificado en extractos de sus odas; historiadores como Mariana, al que se le reprocha habitualmente su parcialidad histórica y contrastes estilísticos como la cercanía de profusas imágenes y tonos coloquiales, y Ambrosio Morales, celebrado como restaurador de las letras en su tiempo; el pródigo Lope de Vega, cuya novelesca biografía fabula con cierta fruición, y para cuyo juicio Rénal invoca la autoridad de Marchena en pasajes que elogian sus obras, ${ }^{904}$ de entre las cuales el colector francés selecciona el magistral diálogo entre Marfisa y Dorotea («un petit tableau de genre habilement peint et étincelant de vérité, une charmante pochade digne de figurer dans l'immense galerie des œuvres du peintre-poète, et qu'on pourrait malicieusement intituler, il nous semble: Amitiés féminines», p. 225); finalmente, tal vez por aceptar la decisión de Maury, inserta a Góngora — portaestandarte del estilo culto definido habitualmente como ampuloso, descoyuntado y oscuro, de hipérboles y metáforas extremadas-, del que se limita a constatar su reconocido talento y de quien traduce un romance morisco que llama anacreóntica («Premières amours d'une jeune mauresque»).

A la centuria siguiente, el «Grand Siècle» europeo - junto a Corneille, Racine, Molière, Lafontaine, Boileau, Lope de Vega, Shakespeare y Milton-, adscribe a Cervantes, quien inaugura la galería de nombres ilus-

904 Así, la pureza y flexibilidad del estilo, el buen gusto y la originalidad en el tratamiento de los personajes de su poema épico burlesco La gatomaquia, digna de competir con Boileau; la independencia respecto de las antiguas tragedias griegas de sus dramas, caracterizados por la fluidez, naturalidad, gracia y abundancia del verso, la adecuación entre el tema y la expresión, la feliz combinación de situaciones interesantes, generalmente verosímiles y bien resueltas, así como su conocimiento del corazón humano en caracteres bien trazados como los de varias piezas dramáticas como la melindrosa en Los melindres de Belisa; la buscona en El anzuelo de Fenisa; el marido libertino en La bella malmaridada; el protagonista de El condenado por desconfiado; los de la que llama La Zelosa sin amor (Los amantes sin amor), y sobre todo El perro del hortelano. 
tres abandonados por la patria ingrata. ${ }^{905}$ Con cierta ambición por contribuir con su noticia a una biografía completa del autor español aún por hacer, Rénal le rinde homenaje como sufrido héroe moderno, a la vez que perpetúa su reputación de autor de estilo modélico y de excelente crítico. Aun valorando como Bouterwek toda su producción literaria, de la que no silencia los proyectos prometidos en el Quijote, es este su obra cumbre, que a la altura de 1849 sigue calificando de «fine, ingénieuse et éloquente satire» y con la que paga tributo al pintoresquismo decimonónico antes que a la difuminada percepción cervantina del paisaje («il a immortalisé à jamais la fameuse province de la Manche, dont il décrit les montagnes, les vallées profondes et les moindres sites avec l'exactitude et la richesse de pinceaux du plus habile paysagiste», pp. 26-27). Rénal también da cabida en este siglo a Francisco de Rioja; Villegas con dos poesías suyas muy conocidas (la cantilena "De un pajarillo" y "L'amour blessé»); Solís, poeta, dramaturgo y ante todo famoso historiador, de quien toma - pese al reproche habitual de haber exaltado a su héroe a expensas de los hechos históricosfragmentos de su retrato de Cortés; Quevedo, a sus ojos el poeta más elegante del XVII y el favorito de las lectoras, del que, rechazando el apelativo de cáustico Voltaire de España, ofrece una imagen —tamizada por la deformación poética romántica de galanterías y marquesas andaluzasdistante de la acostumbrada; aun así, no olvida sus sátiras, sus conocidas Visiones y su Enfer réformé - séptima visión traducida en el XVIII por La Geneste- antes de traducir el soneto que titula «Du peu de durée de la beauté». Una de las semblanzas más extensas es la dedicada al Calderón consagrado por la crítica alemana, triunfante aun contra la verdad y las leyes del gusto, a juicio de Rénal, y a cuya admiración cede el crítico sin por ello adelantarlo a Shakespeare a pesar de la brillantez imaginativa, originalidad y poesía de sus dramas históricos. Sucesor de Lope, maestro en los diversos géneros dramáticos populares y cortesanos cuya clasificación temática y ejemplos el colector toma de Bouterwek, el Calderón de los

905 Como recuerda más adelante al destinatario de su exposición al referirse a los avatares dramáticos de la historia española: «vous avez dû remarquer, cher ami, qu'il y avait depuis Cervantes jusqu'au poète Melendez qui va nous occuper, depuis Herrera jusqu'à Martinez de la Rosa, le plus grand écrivain de l'Espagne moderne, comme une longue et douloureuse chaîne de confraternité, comme un lien funèbre de funeste solidarité entre tous ces élus du ciel, le plus souvent proscrits ou outragés sur la terre» (p. 293). 
dramas religiosos suscita también una revaloración alejada del cargo de poeta de la Inquisición pronunciado por Sismondi y aceptado aún por numerosos críticos franceses a lo largo del siglo. A partir de las severas apostillas de Marchena para la descripción y ejemplificación de los denostados autos sacramentales, Rénal retoma los juicios más benévolos del historiador alemán y de Chasles que vindican su hondura religiosa, la singular superioridad poética y conmovedora de las tragedias sacras calderonianas y de sus autos sobre los populares e informes espectáculos del Corpus de su tiempo. Y sin embargo, el primero de los más grandes escritores españoles («le plus poète de l'Espagne») no sugiere al colector francés de entre el listado que ofrece de su producción ${ }^{906}$ más aplaudida en su tiempo - ampliando el presentado medio siglo antes por Bouterwek - más que breves pasajes narrativos traducidos de tres comedias incluidas por el historiador alemán — los que titula «Définition d'une armée», del primer acto de Para vencer a amor; "Extravagance des modes», sacado del segundo acto de Eco y Narciso, y "Description des montagnes d'Alpujarras» de El Tuzani de la Alpujarra-. Si bien pretenden hacer resaltar su excelencia reconocida como poeta descriptivo y la insistencia en la relación entre la comedia barroca y la novela apuntada en el XVIII y recordada por Bouterwek, conforme a la curiosidad decimonónica estos extractos reflejan fundamentalmente el interés por el pintoresquismo y el costumbrismo historicista de tiempos pasados, como los detalles sobre el modo de vida de los moriscos, las modas cortesanas o la vida castrense de los soldados del Imperio.

906 Bien Venga el mal si Viene solo, ou Vienne le mal sil vient tout seul; Los Empeños de un Acaso, ou Les obligations du hasard; La Dama duende, ou La dame esprit follet; Finezas contra finezas, ou Générosité pour générosité; Amor el mayor encanto, ou L'amour le plus grand des enchanteurs, "pièce lyrique»; Echo et Narcisse, "pièce pastorale»; El Garrote más bien dado, que considera una de sus mejores comedias; La Flor y la Banda, La fleur et l'écharpe; Auristela y Lisidante; Las Manos blancas no ofenden, ou Des mains blanches n'offensent pas; La Vida es un sueño, ou La vie n'est qu'un songe; Don Fernando o el príncipe constante, "tragédie religieuse très-estimée»; Las Tres Justicias en una, Les trois justices en une seule; las comedias Dar Tiempo al tiempo, ou Laissez venir le temps, $\grave{A}$ Secreto agravio secreta venganza, ou $\grave{A}$ secret outrage, vengeance secrète, Mañanas de abril y mayo, ou les matinées d'avril et de mai, Para vencer a amor querer vencerle, Pour vaincre l'amour il faut vouloir le vaincre, Cual es su mayor perfeccion, ou Quelle est la meilleure des perfections, No Hay Burlas con el amor, ou Il n'y a pas à plaisanter avec l'amour; Amar después de la Muerte, ou Aimer jusques après la mort; El Postrer duelo de España, ou le dernier deuil de l'Espagne, etc. 
El siglo más nutrido en representantes dentro de esta colección de la década de los cincuenta, el XVIII reformista, filosófico y poético, acoge a autores ya reseñados por Maury, varios de cuyos datos y ejemplos retoma tácitamente Rénal: el benedictino Feijoo - a partir sustancialmente del Nouveau Dictionnaire Historique (Lyon, 1804) de Delandine y Chaudon-, debelador de prejuicios y corrupciones y precursor del 89 como difusor de la filosofía moderna de Bacon, Newton o Descartes, por su Teatro crítico, de pasajes aún interesantes a su entender, «malgré l'enflure, l'exagération et parfois la négligence extrême du style»; el José Iglesias de epigramas, anacreónticas y letrillas de humor rabelesiano tomadas de Maury; o el Cadalso crítico de las Lettres de Deux Marocains (Cartas marruecas) -que también supedita a la supremacía inimitable de Montesquieu y a las que reprocha tal vez demasiada mordacidad en su censura de los defectos de su tiempo, más universales que locales a juicio del crítico-, de la irónica y vivaz Les Érudits à la Fleur d'oranger, y, en último término, de rientes anacreónticas como "L'Incrédule» y «L'Homme bien content». Como muestra de su prosa concisa, clara y enérgica y de su reflexión filosófica traduce pasajes sin orden de varias de sus Cartas (XII, XIII, XIV y XVII). No obstante, mayores elogios dirige Rénal a Tomás Iriarte, a Meléndez Valdés y a Moratín. Del primero sobrevive ante todo la reputación de innovador original del género didáctico con sus difundidas y traducidas Fábulas literarias — de las que selecciona "La oruga y la zorra»—y, guiado por el buen gusto y las sanas doctrinas literarias, de primer regenerador del teatro español y antecesor de Moratín. Del segundo, celebrado por el P. Andrés, Bouterwek y Sismondi, y tratado con notable pormenor por Maury, tras destacar la influencia moral y rectora de todo verdadero poeta sobre la sociedad, alaba sus excelentes odas y églogas y su estilo majestuoso y sensible, presente ya en su primera colección poética de 1785 . De todas sus composiciones escoge dos odas anacreónticas, representativas, a su juicio, de su tono melancólico y soñador: la oda I «De mis cantares», la XLI «El amor fugitivo» y el famoso romance «Rosana en los fuegos», tenido por su composición más lograda tras su famosa oda filosófica XVI «A las Estrellas» y tras ellas, como en Maury, el romance "Cuando el claro sol se pone». De toda la producción teatral original y adaptada de Moratín, exaltado como el indiscutible y verdadero restaurador del teatro español («le plus original et le plus fécond de l'Espagne moderne») a la vez que feliz imitador de Molière e historiador de los orígenes dramáticos nacionales, Rénal elogia especialmente el diálogo entre don Roque, de El viejo y la 
niña, con su criado Muñoz, emparentado este con los tipos cómicos de la escena clásica francesa, y en el que también había reparado el joven Mérimée en 1824. En el siglo presente, evaluado favorablemente por su «rétablissement du bon goût», el crítico solo da cabida ${ }^{907}$ a Martínez de la Rosa ("cette grande et pure gloire de l'Espagne moderne»), publicitado en artículos periodísticos primero - hasta su ingreso en las antologías, manuales e historias - desde su estreno parisino del Aben Humeya en los días de la revolución de 1830. Superados los límites temporales de Maury, Rénal acude como fuente principal a la Galerie des Contemporains illustres par un Homme de Rien, detallada pero severa con su trayectoria política que el colector orilla — a pesar de su simpatía por el biografiado («double et glorieuse personnification de la poésie et de la haute éloquence moderne en Espagne»), al que asimila a Villemain y Chateaubriand- para centrarse en su andadura literaria. Así, elogia en particular su Viuda de PadiIla, representada en el Cádiz sitiado por los franceses, su Arte poética y su traducción de la Epistola a los Pisones — terminadas en cautividad y afirmadas en la autoridad de Horacio y Boileau-, sus tragedias Edipo y Moraima —incluidas en sus Obras literarias de 1829—, así como El espiritu del siglo («œuvre philosophique d'une haute portée»). Invocado como guía de la moderna literatura española por los críticos franceses frente a un respetado Quintana — tan estimado por Maury, por viajeros ingleses como Blaquière y en los sectores de la emigración londinense-, su fama perdura hasta Bougeault, quien considera su obra maestra la comedia luego traducida La mère au bal et la fille à la maison (La niña en casa y la madre en la máscara). Este arraigado aprecio en los compendios franceses desde su amigo Viardot, Rendu o Puibusque confirma así tanto la pervivencia de los lugares comunes de un manual a otro como el afianzamiento de las glorias cimentadas en París, centro cultural y cosmopolita, haciendo válida la queja de Larra que reproducía Ochoa en un artículo parisino de $1840 . .^{908}$

907 Rénal enumera entre los numerosos autores contemporáneos dignos de reseña nombres como los elogiados Toreno y en especial Balmes por su obra varias veces traducida Influence morale et civilisatrice du Christianisme, Cienfuegos y el Quintana historiador, además de otras personalidades como Bravo, Agustín Príncipe, Mata, Federico Muntadas, Iturrondo o Navarro.

908 «Publier aujourd'hui un livre en espagnol [...] autant vaut prendre des notes sur son portefeuille!», antes de reivindicar el mérito de la literatura contemporánea («La littérature espagnole au XIX ${ }^{\mathrm{e}}$ siècle», Revue de Paris, t. XX, 1840, p. 36). 
En razón de su planteamiento no solo expositivo, sino también evaluativo, la mayor parte de las historias de la literatura española elaboradas en el extranjero ofrecen numerosos pasajes de los autores comentados formando una suerte de antología en el interior del discurso. Un ejemplo acusado de esta dependencia es la decisión de Baret de editar separadamente el compendio de pasajes originales ${ }^{909}$ que había traducido en su historia. Reducido a un catálogo sin introducción ni notas, que remitía exclusivamente a las páginas del manual en que su autor insertó sus traducciones veinte años atrás, este repertorio se somete a una rigurosa ordenación cronológica en tres períodos: el primero comprende los siglos medievales desde el XIII al XV con una nómina conocida, ${ }^{910}$ desde el cantar de gesta, los hitos de rigor y las crónicas más reiteradas hasta el Cuatrocientos de Santillana, Mena, Jorge Manrique, Pérez de Guzmán y Hernando del Pulgar; el segundo, más holgado, aunque abarca los siglos XVI y XVII, va cercando igualmente en las divisiones genéricas acostumbradas el censo de autores a los irrenunciables: ${ }^{911}$ la poesía lírica ostenta los nombres de Gar-

909 Anthologie espagnole. Complément de l'Histoire de la littérature espagnole, París, Librairie Charles Delagrave, 1884.

910 Del Poema del Cid se seleccionan cinco extractos, tres pasajes del Duelo de la Virgen de Berceo, uno del Libro de Alexandre; un extracto de la Crónica general de España, referente a la Jura de Santa Gadea. En la sección del siglo XIV, se incluye un trozo del exemplo XVI del Libro de Patronio; dos extractos del Libro de cantares del arcipreste de Hita, un pasaje del Rimado de palacio de López de Ayala y otro de la Crónica del rey don Pedro. Del siglo XV, la canción "Quien de vos merçet espera» de las Cançiones y deçires del marqués de Santillana; tres fragmentos del Laberinto de Mena como la invocación a Calíope (copla III; la CLII, donde recomienda la guerra contra los moros, y una tercera "Mientra morian y mientra mataban»); numerosos pasajes de las Coplas de Jorge Manrique; dos fragmentos de las Generaciones y semblanzas de Pérez de Guzmán dedicados a Pero López de Ayala y Álvaro de Luna; y uno de los Claros varones de Castilla de Hernando del Pulgar sobre el marqués de Santillana.

911 Garcilaso de la Vega está presente con distintos pasajes de la égloga primera; fray Luis de León, con "La Noche serena» y "En la Ascensión»; Fernando de Herrera, con extractos de su "Canción por la victoria de Lepanto", junto a un breve fragmento de la dedicada a "La pérdida del rey don Sebastián»; Francisco de Rioja, con la silva "A la rosa». De Lupercio de Argensola se toma el soneto "Al Sueño» y de Santa Teresa el celebérrimo "Al Cristo crucificado». Finalmente, sacados de la colección de Romances caballerescos, los romances «En los campos de Alventosa» y "En San Pedro de Cardeña» del Romancero del Cid; "Para se le dar a Jaén», "Por la plaza de San Lucar», "Paseábase el rey moro» y "Pendiente el letrero trae» de los Romances moriscos, así como "Ah! mis señores poetas», de Romances moriscos satíricos, y "Ya se trata el casamiento" del Romance de los siete infantes de Lara. 
cilaso de la Vega, el único de los tres primeros clásicos — relegados Boscán y Mendoza - de la reforma italiana, asimismo, un exaltado Fray Luis, el Herrera de las grandes odas, Rioja, el mayor de los Argensola, Santa Teresa, y varios romances viejos y nuevos incluidos en la época de sus ediciones impresas; la poesía dramática escogida, ${ }^{912}$ tras el testimonio histórico tomado de la Partida I (tít. VI, ley 34), se caracteriza tanto por la llamativa ausencia de Calderón como por la incorporación de dramaturgos revalorizados en España a fines del XVIII y divulgados en Francia en el curso del XIX como Tirso, Rojas, Moreto o Alarcón, de entre los que se privilegian obras suyas referenciales con mejor o peor fortuna para el teatro francés del XVII; la prosa ${ }^{913}$ aparece representada por Antonio Pérez y Santa Teresa, el elocuente fray Luis de Granada, junto a un infrecuente extracto político de Quevedo, así como por un extenso muestrario de las obras históricas más renombradas y tres ejemplos canónicos del cultivo novelesco - la fundadora del género picaresco, el Lazarillo, el siempre ensalzado Amadis, y dos extractos de las novelas ejemplares cervantinas tan bien conocidas en los artículos y ediciones francesas como Rinconete y Cortadillo y la estimada Gitanilla, en la que Baret había advertido una de las inspiraciones de la Esmeralda de Victor Hugo-. Finalmente, el tercer período, el más parco de todos, clausura la colección en el XVIII con los pasajes más recurrentes de Iriarte, Feijoo y el

912 Se incluyen tres pasajes de la primera parte de Las mocedades del Cid con el desafío del Cid al ofensor de su padre, el monólogo de Diego Laínez y el diálogo con su hijo tras haberlo vengado; uno de El bastardo Mudarra y otro de La fuerza lastimosa de Lope; dos de El burlador de Sevilla atribuido a Tirso, con el monólogo de Tisbea y un largo extracto que comprende el diálogo de don Juan y Catalinón en el cementerio ante el sepulcro y la estatua, y la condenación infernal; extensos trozos de El desdén con el desdén de Moreto; tres largos pasajes de Del rey abajo ninguno de Rojas Zorrilla, bien conocida de los románticos, pero en orden inverso al desarrollo de la acción; y otro del diálogo entre Doña Inés y Beltrán, de Ruiz de Alarcón.

913 Un extracto de las Relaciones de Antonio Pérez y otro de sus Cartas (titulado por el compilador "Cartas a un Señor grande»), además de un pasaje tomado del estudio de Bermúdez de Castro (ob. cit., pp. 284-286); un trozo de la Vida de Marco Bruto de Quevedo; cinco breves de Las moradas, otro del Libro de su vida y tres más de Camino de perfección de Santa Teresa; uno de Introducción al símbolo de la fe de fray Luis de Granada; otro corto fragmento de la Historia general de España de Mariana; uno extenso de la Guerra de Granada de Hurtado de Mendoza; otro de la Guerra de Cataluña de Melo; y uno más de la Historia de la conquista de México de Solís; un trozo del Amadís de Gaula de Montalvo; un corto pasaje del capítulo del escudero del Lazarillo de Tormes; y finalmente tres breves pasajes cervatinos, uno de Rinconete y Cortadillo y otros dos de La Gitanilla. 
padre Isla. ${ }^{914}$ Así pues, frente a la variedad de nombres propuesta en anteriores colecciones, este complemento muestra cierta inclinación a insistir en los más conocidos del imaginario francés, reafirmando así a grandes rasgos las expectativas del lectorado común. Si su repertorio, restringido por fuerza, mantiene autores inderrocables del canon español menos conocidos del público medio, son los más frecuentados de los Siglos de Oro los que mantienen algún nexo con la tradición francesa desde el XVII como la huella del mito cidiano, recordada en el extracto de la crónica alfonsina y en el drama de Guillén, hasta la consagración caballeresca de Corneille, las novelas de costumbres editadas con mayor pujanza desde el XVII como el Lazarillo o las cervantinas que satisfacen las necesidades de pintoresquismo costumbrista, así como la novela de caballerías, las en su tiempo célebres cartas de Antonio Pérez, o los poemas religiosos de Santa Teresa.

Filtros y escrutinios de larga vigencia desde las listas ejemplares alejandrinas o las relaciones medievales, las antologías expresan y transmiten la memoria cultural común. Bajo diversos títulos — tableaux o cuadros panorámicos, lecciones, parnasos o illustrations, entre otros- que revelan una intención didáctica o divulgativa y siempre ejemplificadora, y, para cierta crítica, de indirecta conformación y cohesión social, los colectores anteriores - hombres de letras españoles, traductores, abogados, polígrafos o profesores franceses - reproducen repertorios heredados y en ocasiones promocionan otros modelos y revisiones aplicando las nuevas interpretaciones de las teorías en vigor. Desde el muestrario de Maury, que, junto a las primeras historias literarias, difunde directamente entre el lectorado francés el censo español acordado a fines del XVIII — además de sus propios gustos incorporando a sus admirados mentores y amigos-, hasta los repertorios escolares destinados en nombre de la moral y el buen gusto a la enseñanza instrumental de la lengua y el conocimiento de su literatura, se asientan determinados nombres consagrados por la tradición, se admiten variantes y se ensancha el censo de autores modernos. Las selecciones emanadas de las colecciones españolas de la Península o en el exilio, a través de historias, manuales, analectas o compilaciones, caminan en Francia al paso de variaciones que demuestran la tensión

914 La exigua muestra seleccionada del XVIII ofrece la fábula XXXV de Iriarte ( $«$ La oruga y la zorra»), un pasaje del recurrente discurso primero del Teatro crítico de Feijoo ("La voz del pueblo») y otro de las Cartas críticas (n. $\left.{ }^{\circ} 15\right)$; y, por último, dos extractos habituales de la novela del padre Isla. 
entre la labilidad inherente al canon y la estabilidad preconizada por las instituciones académicas. En el repertorio oficial de la literatura española las antologías francesas atienden mayormente hasta finales de siglo a un censo medieval conservador - beneficiario de ingresos de tanta fortuna como el romancero o un cantar de gesta de calidad artística aún en entredicho-aunque las historias reflejen los descubrimientos eruditos de la recopilación positivista. A su vez, la evolución de los criterios de valoración de la nacionalidad se proyecta asimismo en la presentación de etapas históricas tales como una reafirmada edad gloriosa con el distanciamiento de la égloga pastoril, la consagración de la poesía de raigambre popular, el respeto de la de inspiración clásica con el enaltecimiento de grandes renacentistas - como Fray Luis a la luz de las diversas teorías clasicistas o románticas- y paulatinamente de la lírica mística, la preeminencia de la novela o, por citar un caso emblemático, la aceptación, limitada por ciertas restricciones críticas, de los dramaturgos barrocos por su originalidad irrefutable; así como el declive paulatino del XVIII y el ascenso pausado de la actualidad del XIX. Respetuosos de las sanciones de las historias literarias en uso y receptivos a las antologías y ediciones españolas —-más celosas de su patrimonio en sus vindicaciones pormenorizadas de la primera mitad del siglo-, estos florilegios, generalizados con el afianzamiento de la disciplina en la que cumplen una función pedagógica, ${ }^{915}$ conviven también con la pervivencia de las obras más arraigadas en el imaginario francés en torno a la querencia por la novela de caballerías, la lírica religiosa, el drama barroco o la novela picaresca.

915 Este escrutinio sancionador se perpetuará a lo largo del siglo dando cabida paulatinamente a los autores más aceptados en el canon del XIX. Cuando se asienta al fin el estudio de la literatura española como disciplina impartida con autonomía en la universidad francesa, se hace hueco a los autores españoles en los programas de estudio de esta lengua («Brevet supérieur») con mayor rigor. Así lo demuestran, por ejemplo, los diversos tomitos de extractos escolares de enseñanza secundaria anotados con su correspondiente traducción al francés y una serie de cuestionarios, de la colección Classiques espagnols, promovida por profesores de Burdeos y Toulouse, a fines del XIX y principios del XX: entre ellos, los dedicados a Mesonero Romanos y sus artículos costumbristas (Escenas matritenses), a los Cuentos populares de Trueba, al Quijote cervantino, o a Ruiz de Alarcón, dramaturgo del Siglo de Oro recuperado en el XIX, y su Verdad sospechosa. Otros autores decimonónicos que también suelen ser comentados para el alumnado de secundaria son Moratín con comedias como El barón, junto a contemporáneos como Núñez de Arce con diversas composiciones poéticas ("Velut umbra», "A mi musa») o Emilia Pardo Bazán (Arco iris, en la edición también de París, C. Delagrave, 1909, con notas biográficas y comentarios sucintos de F.-J. Juge). 


\section{CONCLUSIONES}

Desde el propósito acariciado por L'Espagne littéraire de Bricaire de La Dixmerie de esbozar un curso de literatura española a partir de los artículos documentados de sus colaboradores, hasta L'Espagne littéraire de Tannenberg en el umbral del siglo XX, a la largo de la centuria decimonónica el lectorado francés ya puede acceder al conocimiento de la literatura española no solo a través de traducciones, relatos de viajes o ediciones aisladas, sino también gracias a antologías, lecciones públicas, estudios en volumen o en prensa que confluyen en las consolidadas historias literarias. Este último tipo de discurso perpetúa las famas canónicas del repertorio censado por los ilustrados y eruditos españoles del XVIII, sus aportaciones documentales y su periodización, renovándola con el ensanchamiento de las generaciones de autores contemporáneos. El asentamiento de este género está también en deuda con el relevo de conceptos irradiados desde el nuevo centro cultural alemán — cuyos métodos filológicos serán asumidos en Francia a partir de la segunda mitad del siglo- como las influyentes teorías románticas de Schlegel, extendidas también entre la crítica española contemporánea. Partícipes de la corriente general de las ciencias humanas que integra la materia literaria en la historia de la cultura, los estudiosos franceses invocan a su vez la impronta staëliana — portavoz de las inquietudes de su tiempo-, que difunde la interconexión entre las diversas ramas del saber, las bellas artes y la literatura bajo el influjo de las instituciones políticas y sociales; recoge tradiciones inveteradas como la influencia del clima; valoriza la herencia del XVIII y actualiza la división consumada entre Norte y Sur, de gran fortuna en la parcelación del espacio cultural propio y ajeno.

La tensión entre dos movimientos divergentes, la irremisible descentralización del canon en nombre de la nacionalidad literaria —idea matriz 
exportada por la intelectualidad alemana - y el aferramiento a la universalidad de las premisas rectoras de una historia de las literaturas europeas - organizada en torno a una equilibrada clasicidad francesa cuya hegemonía estética declina - caracteriza la conformación y el análisis de la cultura extranjera en las colecciones editadas a lo largo del siglo y con especial vigor en la Tercera República. Erigida desde mediados del XVIII en centro neurálgico europeo, Francia sigue proclamando infatigablemente su papel de mediadora equidistante de los extremos literarios y geográficos. La construcción de su nacionalidad literaria, afirmada sobre un lozano comparatismo, se cumple primero en la vindicación de sus modelos sociales y estéticos — como la sociabilidad francesa, forjada en el Grand Siècle y consagrada en el XVIII, o la confirmación paulatina del panteón francés comenzada asimismo durante la Ilustración-. Si progresivamente se suma, al igual que el resto de países, al rastreo de los orígenes en busca de los rasgos distintivos de un patrimonio tradicional rescatando estilos y movimientos disidentes, autores y obras anteriores al XVII, las instancias académicas continuarán manteniendo la vigencia irrenunciable del buen gusto o - como propuesta generalmente aceptada - reclamando la originalidad de grandes nombres como Corneille $y$, sobre todo, Molière - sancionados por su renovada acogida entre las sucesivas generaciones francesas, clásicos en suma-, a través del procedimiento culto de la imitatio creadora a partir de una pluralidad de tradiciones.

A lo largo del siglo, los estudiosos no solo aceptan la singularidad española, sustentada desde sus orígenes medievales en la fusión — proclamada en el XVIII e idealizada en el XIX- entre la cultura musulmana, la hispanorromana y la germánica cristianizadas, que conforman un sustrato popular en cuya vitalidad reparan siempre los viajeros del Ochocientos; sino que paulatinamente la alientan al referirse a los esfuerzos contemporáneos de regeneración para entroncar con los modelos de su tradición nacional. Sin embargo, el cotejo entre ambas literaturas, francesa y española — rehabilitada esta en Europa por su originalidad popular-, suele conceder indirectamente la primacía a la primera, consagrada como nación literaria desde el apoyo institucional del XVII, en virtud de su capacidad de adaptación y perfeccionamiento de las fuentes asimiladas: así, la abigarrada materia dramática española — una de las deudas más candentes-, o la revisión de la picaresca de Lesage — por citar ejemplos representativos vigentes a fines de siglo-, con excepciones generalmente indis- 
cutidas como Cervantes, árbitro crítico y novelista no solo consagrado como eximio representante de su literatura nacional, sino también reclamado como patrimonio universal. Los cargos de parvedad e inferioridad cualitativa lanzados contra la literatura española en su conjunto, a pesar de las reclamaciones de Bouterwek, los voluminosos estudios de los ilustrados españoles, los resúmenes en prensa y la boga de las traducciones, se extiende aún hasta la década de los treinta, en que comienza la institucionalización de su estudio y se generaliza la moda de lo español. Esta resistencia general de principios de siglo a las reivindicaciones alemanas y españolas irá cediendo relativamente en el curso de la centuria apoyándose en la asimilación de las teorías alemanas y las aportaciones del positivismo. No obstante, los discursos diacrónicos más difundidos aun a finales de la centuria siguen observando una arraigada tendencia a destacar principalmente los grandes representantes de cada literatura, preconizando así la observación de la calidad artística y de la originalidad, sobre una abundancia pretendidamente indiscriminada, tal como le reprochaba Mérimée a la minuciosa historia de Ticknor.

Desde la traducción de Bouterwek, las lecciones de Schlegel y el curso de Sismondi, el Volksgeist recorre la literatura española encarnándose en géneros y obras como el romancero, las crónicas, el cantar de gesta, paulatinamente la lírica profana y mística, y particularmente el teatro barroco, de tal modo que a partir de la tercera década sus calidades, a juicio de los primeros catedráticos de literatura extranjera, dependen más de su respeto al acervo tradicional y distintivo que de su naturalización de los modelos clásicos antiguos, románicos o septentrionales. Investida de los valores propugnados por la reinterpretación romántica, esta literatura meridional reflejará de este modo el carácter atemporal del alma española, fundamentalmente pasional y católica por carácter y tradición, en la que el hálito del espíritu caballeresco, reivindicado también por los progresistas, se mantiene más longevamente que en ninguna otra región de Europa. Concebida asimismo como expresión del estadio cultural de la sociedad que la genera, esta condición simbólica o esencialista será sometida a interpretaciones de diverso signo ideológico. Los críticos e historiadores franceses aplican su revisión mayoritariamente liberal al examen organicista de la evolución y progreso de la literatura española, a las causas de su estancamiento y a las rémoras de su civilización. Ese fondo nacional, documentado y presentado a la luz del nacionalismo desde un punto de vista moral, 
será también estudiado desde una perspectiva política fomentada fructuosamente por la interpretación sociológica de Sismondi, culminante en el último cuarto del siglo en el ejemplo republicano de Hubbard, antes de retornar al conservadurismo dominante con el que converge, sin embargo, en contenidos y periodizaciones.

Estudios, cursos magistrales, historias, antologías o manuales, esta pluralidad de textos está en deuda a su vez con las contribuciones a la conformación y asentamiento de un canon nacional reconstruido y consensuado en la España del XVIII finisecular, al tiempo que heredan sus conflictivos silencios e incomodidades ante su pasado cultural. La tensión no resuelta entre estética e ideología al valorar el llamado Siglo de Oro, sus márgenes difusos y sus propuestas dispares se difunde en Francia, a la vez que sus traducciones — cuidadosamente completadas con notas documentales por los españoles - propagan hasta aproximadamente el meridiano del siglo las premisas de los principales estudios del extranjero, en especial de Alemania, en las obras críticas del sur de los Pirineos. Desde el primer ensayo de 1810, las aportaciones francesas a los progresos del género en este ámbito - las traducciones de las obras fundacionales, cursos públicos, disertaciones académicas, estudios y manuales revisados-, de carácter fundamentalmente difusor en razón de sus propias circunstancias ya expuestas, no alcanzan la envergadura de las historias de Bouterwek - referente principal que enmarca y apuntala sus discursos históricos-, de Ticknor o del olvidado Juan Andrés, ni un eco comparable al conocido Amador de los Ríos ni al magisterio en España de Menéndez Pelayo, coetáneo de los primeros hispanistas franceses de fines de siglo con los que mantiene contacto y cuyas historias comienzan a publicarse en la frontera del siglo XX. Las narraciones francesas examinadas del devenir literario español se incardinan principalmente en los enfoques sociológicos de Sismondi, el comparatismo de Villemain, la erudición académica de raigambre clásica pese a la pausada aceptación de las teorías alemanas y su incursión en la historia de la cultura, o el análisis declaradamente ideológico de Hubbard sobre la cultura española contemporánea. En cambio, las memorias académicas, la correspondencia entre estudiosos, prólogos, monografías o, en particular, las reseñas y artículos de la prensa cultural —más cercanos a los vaivenes editoriales, la actualidad teatral o la experiencia directa con los círculos culturales españoles-, de lo que no nos ocupamos aquí en detalle, presentan un mayor dinamismo. Sin salirse de esos cauces, 
incorporan las novedades críticas y valorativas y se convierten a su vez en referencias de consulta de diccionarios, repertorios bibliográficos, historias y manuales franceses, fijadores oficiales y didácticos del canon en la segunda mitad de siglo.

La aplicación de las teorías románticas schlegelianas a la literatura española se refleja en las valoraciones de su periodización. En líneas generales, menos discutido que el de los siglos posteriores, el canon medieval conoce una relativa aceptación amparada en la ingenuidad raigal atribuida a esa época, así como en la recreación pintoresca de las costumbres del pasado y en el acopio erudito de nuevas fuentes; más dificultoso para los críticos franceses resulta el asentamiento de ciertos valores asignados al Siglo de Oro, así como se evidencia un paulatino retroceso del siglo XVIII en la estima general y, en compensación, una pausada apertura hacia los autores contemporáneos. El auge desde finales del XVIII del primitivismo medieval se alía con la nacionalidad asignada a los tiempos remotos de la antigua primera edad velazqueña, más ensalzada que las obras de los siglos inmediatos. Dada su cercanía al controvertido período culminante, el siglo $\mathrm{XV}$ —estimado por Velázquez y Malmontais, apreciado parcialmente por Bouterwek y, pese al denigramiento de Sismondi, paulatinamente integrado en la riqueza cultural del incipiente Renacimiento conforme al concepto historiográfico difundido por Michelet y Burckhardt- es concebido fundamentalmente como un ambiguo período de transición, penetrado aún de la savia nacional, tomado luego por la artificiosidad imitativa, y umbral del esplendor siguiente. Más fluctuante por la colisión entre la interpretación ideológica del régimen de los Habsburgo y la ejemplaridad de los modelos literarios inspirados en la reforma italiana y en los clásicos grecolatinos, la conflictiva etapa posterior - margen acotado entre el siglo XVI y la mayor parte del XVII-, llamada en ocasiones, entre otras etiquetas, "Siglo de Oro», o "Siglos de Oro» como incluye Hubbard, suscita mayores discrepancias. La reforma literaria del XVI, consagrada desde el XVIII como el renacimiento de las letras y el buen gusto, aureola a sus poetas por su mimesis de los modernos italianos y sobre todo de los clásicos, y los eleva a modelos dignos de ser imitados. Si a finales de esa centuria Bouterwek no censura la naturalización de la influencia extranjera, pronto se les reprocha, como en Quintana o Sismondi, su búsqueda de modelos foráneos en lugar de atender a la tradición nacional, que aprecian, sin embargo, en los principales géneros cultivados por los autores barrocos. La 
tensión que los historiadores proyectan entre la excelencia lograda por la lírica italianizante a partir de modelos extranjeros y su consumación durante la imposición del despotismo político y religioso repercute en un rebajamiento de ciertos géneros como, por ejemplo, el pastoril —decaído ante las nuevas expectativas literarias del XIX-y en el ensalzamiento de las colecciones de romanceros, el costumbrismo de la novela picaresca o de las piezas teatrales triunfantes en un aún discutido siglo XVII, plenamente nacional pero en el que se cumplen los indicios de decadencia larvados en los períodos anteriores. De este modo, aunque se van aceptando autores más excéntricos como Lope, Calderón y sus discípulos por su representatividad nacional atemporal, por una parte, sus parcialmente reconocidas excelencias literarias no suelen sobrepasar los modelos franceses como tampoco en la mayor parte de los casos a su contemporáneo Shakespeare, con quien miden sus cualidades; y, por otra, su valor como reflejo sociológico de la sociedad de su tiempo provoca cierta ambigüedad ideológica entre sus críticos. Si su inspiración para los autores españoles suscita en la prensa cultural moderada el consejo de readaptarlos al moderno estadio socio-cultural, los críticos más progresistas, aun apreciando sus méritos, abominan de su significación histórica, disuadiendo en algunos casos, como Hubbard, de su imitación. Las fronteras de la cuarta edad original, sujetas a las nuevas variaciones estético-ideológicas, van desplazándose en busca de la reanudación — nunca plenamente satisfecha- con los buenos modelos de los reinados de Carlos V y Felipe II, extendidos después a ciertos autores del reinado de los tres Felipes, en oposición retrospectiva principalmente con la propuesta estética barroca y posteriormente con la imitación galicista. El relevo potencial de la contemporaneidad del XVIII — proclamado desde Velázquez y Malmontais - y luego de sus últimas décadas, valoradas hasta el ecuador del siglo siguiente en tanto fusión entre tradición y modernidad foránea, se irá delegando anchurosamente en los autores de las diversas promociones del XIX hasta mermar su presencia en las colecciones francesas finiseculares. La aplicación de la preeminencia de la nacionalidad a las complejas corrientes del XVIII, desnivelando el mencionado equilibrio entre sus grandes opciones ideológico-estéticas, arrincona los esfuerzos de esa centuria desde la reforma bajo Fernando VI con Luzán o Mayans a la cabeza, que culminan bajo el prestigioso reinado de Carlos III y el tercio final del siglo. Hasta los años cuarenta destaca de este último período un Meléndez Valdés al que sobreviven en la estima de los 
estudiosos franceses los sainetes de Ramón de la Cruz o, por ejemplo, un oscilante Moratín, aún respetado por el clasicismo de la academia o por reinterpretaciones ideológicas del tercer cuarto de siglo. A partir de los años setenta las historias francesas dan cabida esporádicamente a la efervescente contemporaneidad española, mayoritariamente considerada la sucesora de la tradición nacional conformada a las perspectivas de la sociedad moderna. Sin embargo, estos estudios - como la historia de Hubbard o las monografías de Tannenberg- ya asumen el Romanticismo con su valor específico de movimiento cultural decimonónico — con representantes genuinos afines a los aspectos más contestatarios como Espronceda o Larra-, a la vez que le reprochan sus excesos literarios y las consiguientes reacciones, rezagadas pero similares a la situación francesa.

La paulatina difusión del patrimonio cultural español entre los estudiosos franceses - primero entre los más cercanos a sus grupos políticos y literarios- y el reconocimiento general de su progresiva modernización a lo largo del siglo XIX tras el impulso del hispanismo alemán ratifican el triunfo de los ímprobos esfuerzos desde los ilustrados del XVIII por reintegrarse a la modernidad europea — sometiéndose al canon dominante y luego reivindicando sus aportaciones particulares a lo largo de su historia, cuando no su adelantamiento a sus coetáneos como en la Edad Media-. En la segmentada república de las letras, pese a los cambios en la concepción de la mimesis, y las interpretaciones ideológicas ante el conflicto entre el ser nacional y lo foráneo, la variación relativa de las jerarquías literarias tomadas de los eruditos españoles respeta algunos autores inmarcesibles: por ejemplo, entre los más recurrentes, Garcilaso — consagrado en el XVI por el Brocense y Herrera- o fray Luis de León —editado por Quevedo en el XVII-, y redescubiertos por la Ilustración valenciana, junto a otras promociones dieciochescas como nombres medievales, entre ellos un siempre gustado Jorge Manrique; poetas de la edad dorada como Herrera, más discutido en el contexto de las disputas estético-ideológicas de sus canonizadores, un ineludible Quevedo pese a los reparos estéticos, los titanes del teatro barroco, Lope y Calderón, de revalorización fluctuante, la rehabilitación de los dramaturgos de sus escuelas, o el prestigio de Cervantes como creador y crítico - cuya guía invocan otros estudiosos franceses para realzar la autoridad de autores recurrentes del XIX hasta mediados de siglo como Martínez de la Rosa-, además de una nómina creciente de autores contemporáneos de mérito. Sin embargo, la relativa con- 
formación de la literatura española a los cánones en vigor, ya sea el clasicista reivindicado en el ensayo de 1810, o fundamentalmente el romántico tras Schlegel y Bouterwek, convive en el curso del siglo con cierta reticencia de los críticos y generalistas franceses, formados en las directrices academicistas, y con la indiferencia del lectorado general hacia esta literatura a partir de la segunda mitad del siglo. Aquella singularidad — tan invocada al tratar de sus autores contemporáneos- que sucedió a la segregación inicial del canon dominante relegará de nuevo a los márgenes a sus principales producciones, en particular las del XIX. El desinterés coetáneo hacia su particularismo, ahora excluyente desde otra perspectiva, se achacará, a juicio de varios críticos como Tannenberg desde la atalaya del fin de siglo, a su excesiva tendencia al localismo, exacerbado por el color local y el costumbrismo de los románticos. No obstante, aceptada la participación española en los fenómenos culturales paneuropeos pese a las restricciones de algunos críticos, tras la labor de los hispanisants en historias y fundamentalmente en artículos, monografías, disertaciones, traducciones, ensayos o memorias, llega la hora de los hispanistas franceses, que acotan al fin su terreno académico en la universidad. Especialistas de más vasta y afinada formación en los métodos científicos de tradición alemana con el desarrollo más depurado del análisis textual sobre la polémica de las nacionalidades, y respaldados por sus nacientes mecanismos de influencia y difusión, ahondan en el estudio de las particularidades de esta literatura y sus relaciones europeas dentro de proyectos globales integradores - como, por ejemplo, los de Morel-Fatio-, traducen, dictan cursos, publican estudios, organizan reuniones y editan nuevas historias de la literatura que se internan más allá de 1900 . 


\section{BIBLIOGRAFÍA PRINCIPAL}

Abbadie-Maumejean, Charles, y Esperanza Cobos Castro, «Les relations franco-espagnoles au XIX ${ }^{\mathrm{e}}$ siècle», Estudios de Investigación Franco-Española, n. ${ }^{\circ}$ 9, 1993, pp. 41-55.

ADAMS, Nicholson B., «Siglo de Oro plays in Madrid, 1820-1850», Hispanic Review, n. ${ }^{\circ}$ 4, 1936, pp. 342-357.

Aguiar e Silva, Vítor Manuel, Teoría de la literatura, Madrid, Gredos, 1986.

AlborG, Juan Luis, Historia de la Literatura Española. IV. El Romanticismo, Madrid, Gredos, 1980.

- Historia de la literatura española. V. Realismo y Naturalismo. La novela. Parte Primera. Introducción. Fernán Caballero. Alarcón. Pereda, Madrid, Gredos, 1996.

ÁlVAREZ BARRIENTOS, Joaquín, «Sobre la institucionalización de la literatura: Cervantes y la novela en las historias literarias del siglo XVIII", Anales Cervantinos, t. XXV-XXVI, 1987-88, pp. 47-63.

- La novela del siglo XVIII, en R. de la Fuente (dir.), Historia de la literatura española, Gijón, Júcar, 1991.

- y Antonio Mestre, "Orígenes de la Historia de la literatura española», en G. Carnero (coord.), Historia de la literatura española. Siglo XVIII (1), Madrid, Espasa-Calpe, 1995, pp. 108-136.

Álvarez de Miranda, Pedro, Palabras e ideas: el léxico de la Ilustración temprana en España (1680-1760), Madrid, Real Academia Española, 1992.

Álvarez Rubio, M. ${ }^{a}$ Rosario, "Xavier Durrieu. Apuntes en torno a un hispanista olvidado", Cuadernos de Filología Francesa, n. ${ }^{\circ} 11,1999$, pp. 165-182.

- La literatura española en la prensa cultural francesa del siglo XIX: la Revue des Deux Mondes et la Revue de Paris, tesis doctoral inédita, Universidad de Oviedo, 2004.

- «Reescrituras del teatro clásico español representadas en la Francia del siglo XIX: Le Collier du Roi de Hippolyte Lucas», en XIII Congreso Internacional de la Asociación de Profesores de Francés de la Universidad Española (APFUE), Oviedo, Servicio de Publicaciones de la Universidad de Oviedo (en prensa). 
Амat, Roman d' (dir.), Dictionnaire de biographie française, París, Librairie Letouzey et Ané, 1970.

ANDIOC, René, Teatro y sociedad en el Madrid del siglo XVIII, Madrid, Castalia, 1987.

- Del siglo XVIII al XIX. Estudios histórico-literarios, Zaragoza, Prensas Universitarias de Zaragoza, 2005.

ANDRÉs, Juan, Origen, progresos y estado actual de toda la literatura, ed. moderna dir. por Pedro Aullón de Haro y ed. por Jesús García Gabaldón, Santiago Navarro Pastor y Carmen Valcárcel, Madrid, Verbum; Valencia, Biblioteca Valenciana, 1997-2001, 6 vols.

ARADRA SÁNCHEZ, Rosa M.a , De la retórica a la teoría de la literatura (siglos XVIII y XIX), Murcia, Universidad de Murcia, 1997.

Arellano, Ignacio, Convención y recepción. Estudios sobre el teatro del Siglo de Oro, Madrid, Gredos, 1999.

- Calderón y su escuela dramática, Madrid, Ediciones del Laberinto, 2001.

Aullón De Haro, Pedro, «Reflexiones sobre el Concepto Histórico de la Literatura y el Arte», en Teoría/Crítica. I. Teoría de la Historia de la Literatura y el Arte, Madrid, Verbum, 1994.

BAASNER, Frank, "Una época clásica controvertida. La polémica sobre el siglo de Oro en la historiografía literaria española de los siglos XVIII y XIX», Revista de Literatura, IX, 119, 1998, pp. 57-78.

BARET, Eugène, Histoire de la littérature espagnole depuis ses origines reculées jusqu’à nos jours, París, Dezobry, Tandou et Cie, 1863.

- Observations sur l'Histoire de la littérature espagnole de M. Amador de los Ríos, París, Pedone-Lauriel, 1875.

- Anthologie espagnole. Complément de l'Histoire de la littérature espagnole, París, Librairie Charles Delagrave, 1884.

BAtaillon, Marcel, «L'Espagne de Mérimée d'après sa correspondance», Revue de littérature comparée, t. XXII, 1948, pp. 35-66.

BeAuforT-D'HautPoul, Comtesse Joséphine, Cours de littérature ancienne et moderne à l'usage des jeunes demoiselles, seconde édition, revue et augmentée d'un volume sur la littérature étrangère, París, Bossange père et fils, 1821, 2 vol. [1. a ed., París, Bossange et Masson; Londres, Bossange et Masson et Leblanc, 1815].

BECQ, Annie, Genèse de l'esthétique française moderne. De la Raison classique à l'Imagination créatrice. 1680-1814, París, Albin Michel, 1994.

BÉNICHOU, Paul, «Romancero español y romanticismo francés», en Hispanic Studies in honor of Joseph H. Silverman, Newark, Juan de la Cuesta, 1988, pp. 77-108.

- Le temps des prophètes. Doctrines de l'âge romantique, París, Gallimard, 1977.

- L'école du désenchantement, París, Gallimard, 1996. 
BerChtold, Alfred, Cinq portraits: Euler, Dufour, Bräker, Pestalozzi, Sismondi et le Groupe de Coppet, Lausana, L'Age d'Homme, 1997.

BERTHIER, Patrick, La presse littéraire et dramatique au début de la Monarchie de Juillet (1830-1836), Villeneuve-d'Ascq, Presses Universitaires du Septentrion, 1997, 4 vols.

Bertrand, Jean-Jacques Achille, «Figures d'hispanologues: Dieze, Bouterwek», Bulletin Hispanique, n. ${ }^{\circ}$ 24, 1922, pp. 343-360.

Blanloeil, Abate, Histoire de la littérature italienne et de la littérature espagnole, París, s.d. [finales del siglo XIX]. El ejemplar consultado es una donación de 1908.

BLAQUIÈRE, Edward, Examen historique de la révolution espagnole, suivi d'Observations sur l'esprit public, la religion, les mours et la littérature d'Espagne; trad. de l'anglais par J.-C. P. [traducción atribuida a Pagès], París, Rosa, 1823.

BleCUA, Alberto, «El concepto de Siglo de Oro», en Leonardo Romero Tobar (ed.), Historia literarialHistoria de la literatura, Zaragoza, Prensas Universitarias de Zaragoza, 2004, pp. 115-160.

Bonstetten, Charles-Victor de, L'Homme du Midi et l'homme du Nord, ou l'influence du climat, Ginebra/París, Paschoud, 1824.

BOTREL, Jean-François, Libros, prensa y lectura en la España del XIX, Madrid, Fundación Germán Sánchez Ruipérez, 1993.

Bougeault, Alfred, Histoire des littératures étrangères. Tome III. Littérature italienne, littérature espagnole, littérature portugaise, littérature grecque modernes, París, Plon, 1876. pp. 263-443.

BOUTERWEK, Friedrich, Histoire de la littérature espagnole traduite de l'allemand [...] par le traducteur des lettres de Jean de Muller (Mme de Streck, avec une préface par M. de Stapfer, d'après Barbier), París, chez Renard, Pauline, frères Michaud, 1812, 2 vols.

- Historia de la literatura española. Desde el siglo XII hasta principios del XVI (t. I), traducida y adicionada por José Gómez de la Cortina y Nicolás Hugalde y Mollinedo; ed. de Carmen Valcárcel Rivera y Santiago Navarro Pastor, Madrid, Verbum, 2002.

BRAGT, Katrin Van, Bibliographie des traductions françaises (1810-1840). Répertoires par disciplines. Avec la collaboration de Lieen D'hulst et de José Lambert, Lovaina, Presses Universitaires de Louvain, 1995.

BRENNER, Clarence Dietz, A biographical list of plays in the French language (17001789), Berkeley, California, AMS Press, 1979 [1. a edición, 1947].

BRICAIRE De LA DixMerie, Nicolas, Lettres sur l'Espagne, ou Essai sur les moeurs, les usages et la littérature de ce royaume, par feu La Dixmerie. Précédé d'un Éloge de l'auteur et suivi d'un Précis sur les formes judiciaires de l'Inquisition, par $C$. P. [Michel de Cubières-Palmézeaux]. Augmenté d'une anecdote espagnole [les Époux amans] et de pièces fugitives, par Mme Fanny de Beauharnais..., París, Librairie économique, 1810, 2 vols. 
BRUnETIÈRE, Ferdinand de, «Revue littéraire. L'influence de l'Espagne dans la littérature française», Revue des Deux Mondes, t. CIV, 1-III-1891, pp. 215-226.

CALDERA, Ermanno, «De la tragedia neoclásica al drama histórico: por qué y cómo", Entresiglos (Roma), n. ${ }^{\circ}$ 2, 1993, pp. 67-74.

Calvo Serraller, Francisco, «La imagen romántica de España», Cuadernos Hispanoamericanos, n. ${ }^{\circ}$ 332-5, 1978, pp. 240-260.

CARNERO, Guillermo, Los orígenes del Romanticismo reaccionario español. El matrimonio Böhl de Faber, Valencia, Universidad de Valencia, 1978.

- (coord.), Historia de la literatura española. Siglo XVIII (II), Madrid, EspasaCalpe, 1995.

- (coord.), Historia de la literatura española. Siglo XIX (I), Madrid, EspasaCalpe, 1996.

Caro Baroja, Julio, Ensayo sobre la literatura de cordel, Madrid, Istmo, 1990.

CARON, Jean-Claude, Générations romantiques: les étudiants de Paris et le Quartier Latin, París, Armand Colin, 1991.

Cebrián, José, «La Historia literaria de España de los Mohedano: Concepto, finalidad y primeros reparos", Cuadernos de Estudios del Siglo XVIII, n. o 2, 1992, pp. 57-71.

Charle, Christophe, Les Professeurs de la faculté des lettres de Paris, vol. I (18091908), París, CNRS, 1985.

CHASLES, Philarète, Études sur l'Espagne et sur les influences de la littérature espagnole en France et en Italie, Ginebra, Slatkine, 1973. Reimpresión de la primera edición de París, Amyot, 1847.

Checa Beltrán, José, Razones del buen gusto. (Poética española del Neoclasicismo), Madrid, CSIC, 1998.

— «En busca del canon perdido: el siglo XVIII», Studi Ispanici, Pisa-Roma, Istituti Editoriali e Poligrafici Internazionali, 2002, pp. 95-115.

— «El libro: La Colección de poetas castellanos (1786-1798)», en Joaquín Álvarez Barrientos (ed.), Espacios de la comunicación literaria, Madrid, CSIC/Instituto de la Lengua Española, 2002, pp. 109-128.

Cioranescu, Alexandre, Le masque et le visage. Du baroque espagnol au classicisme français, Ginebra, Droz, 1983.

Cirujano Marín, Paloma, Teresa Elorriaga Panes y Juan Sisinio Pérez GarZÓN, Historiografía y nacionalismo español, 1834-1868, Madrid, Centro de Estudios Históricos, 1985.

Clavero, Dolores, Romances viejos de temas épicos nacionales. Relaciones con gestas y crónicas, Madrid, Ediciones del Orto, 1994.

Close, Anthony, La concepción romántica del Quijote, Barcelona, Crítica, 2005.

CoE, Ada M., Catálogo bibliográfico y crítico de las comedias anunciadas en los periódicos de Madrid de 1661 hasta 1819, Baltimore, The Johns Hopkins Press, 1935. 
Damas-Hinard, Jean Joseph Stanislas Albert, Romancero Général, ou Recueil des Chants Populaires de l'Espagne, París, Charpentier, 1844, 2 vols.

- Une leçon au Collège de France. Discours sur l'histoire et l'esprit du théatre espagnol, París, B. Duprat, 1847.

DEACON, Philip, «La historia interna de los Orígenes de la poesía castellana de Luis Joseph Velázquez», Boletín del Centro de Estudios del Siglo XVIII, n. 6, 1978, pp. 65-82.

DÉDÉYAn, Charles, Le cosmopolitisme européen sous la Révolution et l'Empire, París, Société d'Édition d'Enseignement Supérieur, 1976.

Défourneaux, Marcelin, Pablo de Olavide. El afrancesado, Sevilla, Padilla, 1990 [ed. orig. fr., París, Presses Universitaires de France, 1959].

DelisLe, Jean, y Judith WOODSWORTH (eds. y dirs.), Translators through History, Ámsterdam-Filadelfia, John Benjamins, 1995.

Dellepierre de Neuve-ÉGlise [ed.], Bibliographie Parisienne, ou Catalogue d'ouvrages, de Sciences, de Littérature, et de tout ce qui concerne les Beaux-Arts, tels que la Musique, la Gravure, etc., imprimés ou vendus à Paris, avec les Jugements qui en ont été portés dans les Écrits périodiques, ensemble l'énoncé des Édits, Arrêts et Déclarations du Roi, etc. Par une Société de Gens de Lettres, París, chez Desnos, Libraire, Ingénieur-Géographe du Roi de Dannemark, 1770.

DemogeOt, Jacques, Histoire des littératures étrangères dans leurs rapports avec le développement de la littérature française. Littératures méridionales, París, Hachette et Cie, 1914, 6. ${ }^{\mathrm{a}}$ ed. [1. ${ }^{\mathrm{a}}$ ed., 1880].

Denis, Ferdinand, Chroniques chevaleresques de l'Espagne et du Portugal, suivies du Tisserand de Ségovie, París, Ledoyen,1839 [1.a ed., ¿1833?].

DÉrOZIER, Albert, Manuel Josef Quintana et la naissance du libéralisme en Espagne, París, Les Belles Lettres, 1970.

DíAZ-PlajA, Guillermo, "Esquema historiográfico de la literatura española», en Guillermo Díaz-Plaja (dir.), Historia general de las literaturas hispánicas, Barcelona, Vergara, 1956, vol. I.

- (dir.), Historia general de las literaturas hispánicas, Barcelona, Vergara, 19561968, t. IV, V y VI.

Díez Borque, José M. a (coord.), Historia de las literaturas hispánicas no castellanas, Madrid, Taurus, 1980.

- Historia del teatro en España. Siglo XVIII. Siglo XIX, Madrid, Taurus, 1988.

DOUAY, Georges, Répertoire général de toutes les pièces représentées sur les théatres de Paris [hasta el año 1911]. Ms. Bibliothèque de l'Arsenal.

DubuIs, Michel, "La "gravité espagnole" et le "sérieux". Recherches sur le vocabulaire de Cadalso et de ses contemporains", Bulletin Hispanique, t. LXXVI, n. ${ }^{\circ} 1-2,1974$, pp. 5-91. 
Dufour, Gérard, «La rivalité entre l'histoire et la littérature et la création du mythe inquisitorial en Espagne au début du XIXe siècle», en Les mythes et leur expression au XIXe siècle dans le monde hispanique et ibéroaméricain, Lille, Presses Universitaires de Lille III, 1984, pp. 11-25.

Dumas, Claude (ed.), Nationalisme et littérature en Espagne et en Amérique Latine au XIXe siècle, Lille, Université de Lille III (Travaux et Recherches. Diffusion PUL), 1982.

Durán, Manuel, y Roberto GonZÁlez Echevarría, Calderón y la crítica: Historia y antología, Madrid, Gredos, 1976, 2 vols.

EISENBERG, Daniel, «Don Quijote, el Romanticismo y el Renacimiento de lo caballeresco", Insula, n. ${ }^{\circ}$ 538, octubre de 1991, pp. 16-17.

ENGLAND, S. L., "Bibliographie des pièces de théatre parues en France de 1815 à 1848 avec indication des pièces ayant un caractère social ou une tendance sociale», Revue d'histoire littéraire, 1934-35.

ESCARPIT, Roger, "La definición del término literatura», en Hacia una sociología del hecho literario, Madrid, Edicusa, 1974, pp. 257-272.

- «Histoire de l'histoire de la Littérature», en Histoire des littératures, t. III, Encyclopédie de la Pléiade, 1962.

Escobar, José, «El teatro del Siglo de Oro en la controversia ideológica entre españoles castizos y críticos: Larra frente a Durán", Cuadernos de Teatro Clásico, n. ${ }^{\circ}$ 5, 1990, pp. 155-170.

Escobar, Juan de, Historia y Romancero del Cid (Lisboa, 1605), ed., estudio bibliográfico e índices por Antonio Rodríguez-Moñino; introducción por Arthur Lee-Francis Askins, Madrid, Castalia, 1973.

Espagne, Michel, Le paradigme de l'étranger. Les chaires de littérature étrangère au XIX $X^{e}$ siècle, París, Les Éditions du Cerf, 1993.

ÉtIenvre, Jean-Pierre, y José Ramón URQuijo Goitia (eds.), España, Francia y la Comunidad Europea, Madrid, Casa de Velázquez/CSIC, 1989.

Ferguson, Wallace K., La Renaissance dans la pensée historique, París, Payot, 1950.

FERNÁNDEZ HeRR, Elena, Les origines de l'Espagne romantique. Les récits de voyage 1755-1823, París, Didier, 1973.

FERnÁNDEZ MONTESINOS, José, Introducción a una historia de la novela en España en el siglo XIX seguida del esbozo de una bibliografía española de traducciones de novelas. 1800-1850, Madrid, Castalia, 1982.

- Costumbrismo y novela. Ensayo sobre el descubrimiento de la realidad española. (Estudios sobre la novela española del siglo XIX), Madrid, Castalia, 1983.

Fitzmaurice-Kelly, James, Bibliographie de l'histoire de la littérature espagnole, París, A. Colin, 1913.

FLITTER, Derek, Teoría y crítica del romanticismo español, Cambridge, Cambridge University Press, 1995 [ed. orig. ingl., 1992]. 
FloecK, Wilfried, «L'article "Espagne" de Masson de Morvilliers dans "L'Encyclopédie Méthodique" et sa version espagnole par Julián de Velasco», Estudios de Investigación Franco-Española, n. ${ }^{\circ} 3$, 1990, pp. 103-124.

Florán, Juan, «État actuel de la littérature espagnole», L'Europe Littéraire, ocho artículos del 17 de mayo al 5 de diciembre de 1833: 17-V, 10-V, 1-IX, 15IX, 6-X, 13-X, 10-XI, 5-XII.

Foulché-Delbosc, Raymond, Bibliographie des voyages en Espagne et en Portugal, Madrid, Julio Ollero Editor, 1991.

Fox, E. Inman, La invención de España. Nacionalismo liberal e identidad nacional, Madrid, Cátedra, 1997.

Fradejas Lebrero, José, Calderón en Europa, Madrid, Aula de Cultura (Ciclo de conferencias: «Madrid, Capital Europea de la Cultura»), 1991.

Fuente, Ricardo de la (ed.), La historia de la literatura y la crítica, Salamanca, Colegio de España, 1999.

FuENTES, Juan Francisco, José Marchena. Biografía politica e intelectual, Barcelona, Grijalbo, 1989.

Fumaroli, Marc, Trois institutions littéraires, París, Gallimard, 1994.

García Castañeda, Salvador, Las ideas literarias en España entre 1840 y 1850, Berkeley-Los Ángeles-Londres, University of California Press, 1971.

García Garrosa, M. a Jesús, La retórica de las lágrimas. La Comedia Sentimental Española, 1751-1802, Valladolid, Universidad de Valladolid, Secretariado de Publicaciones, Caja Salamanca, 1990.

García SANTO-TOMÁs, Enrique, La creación del "Fénix». Recepción crítica y formación canónica del teatro de Lope de Vega, Madrid, Gredos, 2000.

Garrido Gallardo, Miguel Ángel (comp.), Teoría de los géneros literarios, Madrid, Arco Libros, 1988.

Garrido Palazón, Manuel, La filosofía de las Bellas Letras y la Historia literaria en España (1777-1844), Almería, Instituto de Estudios Almerienses, 1992.

- «La Evolución de la Historiografía Literaria Románica», en Teoría/Crítica. 1. Teoría de la Historia de la Literatura y el Arte, Madrid, Verbum, 1994, pp. 85-119.

GERBOD, Pierre, La condition universitaire en France au XIXe siècle, París, PUF, 1965.

- «La scène parisienne et sa représentation de l'histoire nationale dans la première moitié du XIX ${ }^{\mathrm{e}}$ siècle», Revue historique, t. 266, n. ${ }^{\circ}$ 1, 1981, pp. 3-30.

GIEs, David T., Agustin Durán. A Biography and Literary Appreciation, Londres, Tamesis Book, 1975.

- Theatre and politics in nineteenth-century Spain. Juan de Grimaldi as impresario and government agent, Cambridge, Cambridge University Press, 1988.

- El teatro en la España del siglo XIX, Cambridge, Cambridge University Press, 1996 [ed. orig. ingl., 1994]. 
Gies, David T., (ed.), El Romanticismo, Madrid, Taurus, 1989.

Girault DE SAINT-FARGEAU, Eusèbe, Revue des romans. Recueil d'analyses raisonnées des productions remarquables des plus célèbres romanciers français et étrangers, Ginebra, Slatkine, 1968 [reimpr. de la ed. de París, Firmin Didot, 1839, 2 vols.].

GNiscI, Armando (al cuidado de), Introducción a la literatura comparada, Barcelona, Crítica, 2002.

Goblot, Jean-Jacques, Documents pour servir à l'histoire de la presse littéraire. Le Globe, 1824-1830, París, Honoré Champion, 1993.

GuILlÉN, Claudio, Entre lo uno y lo diverso. Introducción a la literatura comparada, Barcelona, Crítica, 1985.

- Teorías de la historia literaria, Madrid, Espasa-Calpe, 1989.

- Múltiples moradas. Ensayo de Literatura Comparada, Barcelona, Tusquets, 1998.

GuINARD, Paul, Dauzats et Blanchard, peintres de l'Espagne romantique, Burdeos, Féret \& fils, Casa de Velázquez/Université de Bordeaux, 1967.

GUISE, René, «La fortune de Lazarille de Tormès en France, au XIX siècle», Revue de Littérature Comparée, t. XXXIX, 1965, pp. 337-357.

GutiérRez, Jesús, "Martín Sarmiento y sus Memorias para la historia de la poesía», Dieciocho, 11, n. ${ }^{\circ}$ 2, 1988, pp. 87-203.

Herking, Marie-L., Charles-Victor de Bonstetten (1745-1832). Sa vie, ses oeuvres, Lausana, La Concorde, 1921.

Histoire du livre et de l'édition dans les pays ibériques, Burdeos, Université de Bordeaux/PUF, 1986.

Hoffmann, Léon-François, Romantique Espagne. L'image de l'Espagne en France entre 1800 et 1850, París, Universités de Princeton/Presses Universitaires de France, 1961.

Holland, Lord Henry, Some account of the lives and writings of Lope de Vega Carpio and Guillen de Castro, Londres, 1806.

Horn-Monval, Madeleine, Répertoire bibliographie des traductions et adaptations française du théâtre étranger du XVe siècle à nos jours, París, CNRS, t. IV, 1961.

HubBARD, Gustave-Nicolas, Histoire de la littérature contemporaine en Espagne, París, Charpentier, 1876.

La imagen de Andalucia en los viajeros románticos, y Homenaje a Gerald Brenan, Málaga, Diputación Provincial de Málaga, 1987.

Imagen romántica de España, Madrid, Ministerio de Cultura. Dirección General de Bellas Artes, Archivos y Bibliotecas, 1981.

ÍNSULA, «Un viaje de ida y vuelta. El canon», n. ${ }^{\circ}$ 600, diciembre de 1996.

— «Calderón en el 2000», n. ${ }^{\circ}$ 644-645, agosto-septiembre de 2000.

JARRY DE MANCY, Adrien, Atlas historique et chronologique des littératures anciennes et modernes, des sciences et des beaux-arts, d'après la méthode et sur le plan 
de l'Atlas de A. Lesage (comte de Las Cases), et propre à former le complément de cet ouvrage, par ..., París, chez Jules Renouard, 1831.

JimÉnEZ, Marc, Qu'est-ce que l'esthétique?, París, Gallimard, 1997.

JOANNidÈs, Alexandre, La Comédie Française de 1680 à 1900. Dictionnaire Général des pièces et des auteurs, avec une préface de Jules Claretie, Nueva York, Burt Franklin, 1901; París, Plon/Nourrit, 1921.

Jones, Michèle-H., Le Théatre National en France de 1800 à 1830, París, Klincksieck, 1975.

JourDA, Pierre, L'Exotisme dans la littérature française, Ginebra, Slatkine, 1970, 2 vols. [reimpr. de las eds. de 1938 y 1956].

JuRETSCHKe, Hans, España ante Francia, Madrid, Fe, 1940.

- Vida, obra y pensamiento de Alberto Lista, Madrid, CSIC, 1951.

- Origen doctrinal y génesis del romanticismo español, Madrid, Ateneo, 1954.

- España y Europa. Estudios de Crítica Cultural, ed. de Miguel Ángel Vega Cernuda, Madrid, Editorial Complutense, 2001.

Kosove, Joan Lynne Pataky, The "Comedia lacrimosa" and Spanish Romantic Drama (1773-1865), Londres, Tamesis Book, 1977.

KRAKOVITCH, Odile, «Le théâtre sous la Restauration et la monarchie de Juillet: lecture et spectacle», en Alain Vaillant (dir.), Mesure(s) du livre, París, Bibliothèque Nationale, 1992, pp. 147-164.

LA HARPE, Jean-François, Lycée ou Cours de littérature ancienne et moderne, París, Didier, 1834.

Lafarga, Francisco, Voltaire en España (1734-1835), Barcelona, Edicions de la Universitat de Barcelona, 1982.

- Las traducciones españolas del teatro francés (1700-1835). I. Bibliografía de Impresos, Barcelona, Universidad de Barcelona, 1983.

- (ed.), Imágenes de Francia en las letras hispánicas, Barcelona, PPU, 1989.

- (ed.), Bibliografía anotada de estudios sobre recepción de la cultura francesa en España (siglos XVI-XX), Barcelona, PPU, 1998.

- y Luis Pegenaute (eds.), Historia de la traducción en España, Salamanca, Ambos Mundos, 2004.

LAMBERT, J., «La traduction en France à l'époque romantique, à propos d'un article récent (de J. A. Béreaud)», Revue d'histoire littéraire de la France, 1975, pp. 396-412.

LAMBERT, Monique, "L'image de l'Espagne en France à la fin du XVI siècle et au $\mathrm{XVII}^{\mathrm{e}}$ siècle à travers les éditions françaises du Lazarille de Tormès», Bulletin de la Bibliothèque Nationale, n. ${ }^{\circ} 2$, junio de 1980 , p. 70-79; n. ${ }^{\circ}$, septiembre de 1980, pp. 134-136.

Lanson, Gustave, «Émile Deschamps et le Romancero. Étude sur l'invention de la couleur locale dans la presse romantique», Revue d'Histoire Littéraire de la France, t. VI, 1899, pp. 1-20. 
LAROUSSE, Pierre, Grand Dictionnaire Universel du XIX siècle Français, historique, géographique, mythologique, bibliographique, littéraire, artistique, scientifique, etc., París, 1869-79 [reimpr., Ginebra-París, Slatkine, 1982].

Latour, Antoine de, "Correspondance d'Espagne. A M. le directeur de la Revue Britannique. Don José Amador de los Ríos. (Histoire critique de la littérature espagnole)», Revue Britannique, agosto de 1862, pp. 451-468.

Lázaro Carreter, Fernando, Clásicos españoles. De Garcilaso a los niños pícaros, Madrid, Alianza Editorial, 2003.

LEATHERS, Victor-L., L'Espagne et les Espagnols dans l'œuvre d'Honoré de Balzac, París, Honoré Champion, 1931.

LEFEVERE, André, Traducción, reescritura y la manipulación del canon literario, Salamanca, Colegio de España, 1997.

- (ed.), Traducción, reescritura y la manipulación del canon literario, Salamanca, Colegio de España, 1997.

LEFRANC, Émile, Histoire élémentaire et critique de la littérature, renfermant, outre des détails biographiques et des considérations générales sur les auteurs, l'examen analytique de leurs principaux ouvrages, París, Périsse, 1838-44; t. VI, Littératures du Midi: Italie, Espagne et Portugal, París-Lyon, pp. 305-466.

Liaño, Álvaro Agustín de, Répertoire portatif de l'histoire et de la littérature des nations espagnole et portugaise, Berlín, Nauck, 2 tomos [h. 1818].

LIPSCHUTZ, Ilse Hempel, La pintura española y los románticos franceses, Madrid, Taurus, 1988.

Lissorgues, Yvan (ed.), Realismo y Naturalismo en España en la segunda mitad del siglo XIX, Barcelona, Anthropos, 1988.

LLORENS, Vicente, Liberales y románticos. Una emigración española en Inglaterra (1823-1834), Madrid, Castalia, 1979.

- El Romanticismo español, Madrid, Fundación Juan March/Castalia, 1979.

LOPEZ, François, "Comment l'Espagne inventa le Siècle d'Or», en Hommage des Hispanistes Français à Noël Salomon, Barcelona, Laia, 1979, pp. 517-576.

LORENZ, Otto, Catalogue général de la Librairie Française pendant 25 ans (18401865), París, chez O. Lorenz, 1867; Estrasburgo, Imprimerie de Veuve Berger-Levrault.

LOUANDRE, Charles, y Félix BOURQUELOT, La Littérature française contemporaine (1827-1844) Dictionnaire bibliographique par ..., París, Félix Daguin, 1848 [continuación de La France Littéraire. Dictionnaire bibliographique... de Quérard].

Magnabal, Joseph-Germain, Aperçu sur l'étude classique des lettres espagnoles en France, Madrid, Imprenta de Aribau y Cía., 1881.

MAINER, José-Carlos, «De historiografía literaria española: el fundamento liberal», en Santiago Castillo, Carlos Forcadell, M. ${ }^{a}$ Carmen García-Nieto, Juan Sisinio Pérez Garzón (coords.), Estudios sobre Historia de España. Homenaje a 
Manuel Tuñón de Lara, Madrid, Universidad Internacional Menéndez Pelayo, vol. II, 1981, pp. 439-472.

MAINER, José-Carlos, "La invención de la literatura española», en José María Enguita y José-Carlos Mainer (eds.), Literaturas regionales en España, Zaragoza, Institución «Fernando el Católico», 1994, pp. 23-45.

Malmontais, De [o Malmontet], Essai sur la littérature espagnole. Publié par J.-B. Lecouteulx de Canteleu, París, C. Barrois, 1810.

MARC, Alfred, Dictionnaire des romans anciens et modernes, París, 1819.

MARCO, Joaquín, Literatura popular en España en los siglos XVIII y XIX, Madrid, Taurus, 1977.

Marichal, Juan, El secreto de España. Ensayos de historia intelectual y política, Madrid, Taurus, 1995.

MARRAST, Robert, «Imprimés castillans et catalans en France: bilan provisoire et perspectives", en Histoire du livre et de l'édition dans les pays ibériques. La dépendance, Burdeos, Presses Universitaires de Bordeaux/PUF, 1986, pp. 53-60.

- José de Espronceda y su tiempo, Barcelona, Crítica, 1989.

MARTín, Ana M.a «" Ensayo bibliográfico sobre las ediciones, traducciones y estudios de Calderón de la Barca en Francia», Bulletin Hispanique, t. XVII, n. ${ }^{\circ} 32-$ 33, pp. 53-100.

MARTIN-Fugier, Anne, «La formation des élites: les "conférences" sous la Restauration et la monarchie de Juillet", Revue d'histoire moderne et contemporaine, abril-junio de 1989, pp. 211-244.

MarTínez MarTín, Jesús Antonio, Lecturas y lectores en la España isabelina (1833-1868), Madrid, Ediciones Universidad Complutense, 1986, 2 vols.

MarTínez Torrón, Diego, Los liberales románticos españoles ante la descolonización americana (1808-1834), Madrid, Fundación Mapfre, 1992.

- Ideología y literatura en Alberto Lista, Sevilla, Alfar, 1993.

- Manuel José Quintana y el espiritu de la España liberal (con textos desconocidos), Sevilla, Alfar, 1995.

MaurY, Juan M.a, Espagne poétique. Choix de poésies castillanes depuis CharlesQuint jusqu'à nos jours, mises en vers français avec une dissertation comparée sur la langue et la versification espagnoles, une introduction en vers, et des articles biographiques, historiques et littéraires, París, P. Mongie, 1826-27, 2 vols.

MaYberry, Robert, y Nancy MayberRY, Francisco Martínez de la Rosa, Boston, Twayne, 1988.

Mélanges à la mémoire de Jean Sarrailh, París, CRIEH, 1966.

Menarini, Piero, «El problema de las traducciones en el teatro romántico español», en Actas del VII Congreso Internacional de Hispanistas, Roma, Bulzoni, 1982, t. II, pp. 751-759. 
Menarini, Piero, et ál., El teatro romántico español (1830-1875). Autores, obras, bibliografía, Bolonia, Atesa, 1982.

Meregalli, Franco, "George Ticknor y España», en Adolfo Sotelo Vázquez (coord.) y Marta Cristina Carbonell (ed.), Homenaje al profesor Antonio Vilanova, Barcelona, Universidad de Barcelona, 1989, vol. II, pp. 413-426.

MérImée, Prosper, "L'Art dramatique en Espagne», Le Globe, n. 29 (13-XI), n. ${ }^{\circ}$ 30 (16-XI), n.o 33 (23-XI), n.o 34 (25-XI-1824).

- Mélanges historiques et littéraires, París, Michel Lévy, 1855.

Mestre, Antonio, Historia, fueros y actitudes politicas. Mayans y la historiografía del XVIII, Valencia, Publicaciones del Ayuntamiento de Oliva, 1970.

Metayer, Louis, "L'Espagne et les Espagnols dans les mélodrames parisiens (1830-1848)», Recherches et études comparatives ibérofrançaises, n. ${ }^{\circ}$ 5, 1983, pp. 46-62.

MiARD, Louis, «Images d'Espagne en France (1820-1880). (Flâneries bibliographiques)», Interférences, n. ${ }^{\circ}$ 6, enero-junio de 1977, pp. 9-145.

MoldieR, Jean-Yves (dir.), Le commerce de la librairie en France au XIXe siècle. 1789-1914, París, Institut Mémoires de l'édition contemporaine (IMEC), Maison des Sciences de l'Homme, 1997.

Moreau, Pierre, "Brunetière, professeur de "littérature comparée" ", Revue de littérature comparée, enero-marzo de 1956, n. ${ }^{\circ}$ 1, pp. 64-85.

Morel-Fatio, Alfred, «L'Hispanisme dans Victor Hugo», en Homenaje ofrecido a Menéndez Pidal, Madrid, Hernando, 1925, vol. I, pp. 161-212.

Moreno Alonso, Manuel, La generación española de 1808, Madrid, Alianza Editorial, 1989.

MORTIER, Roland, "Les Archives littéraires de l'Europe» (1804-1808) et le cosmopolitisme littéraire sous le premier Empire, Bruselas, Palais des Académies, 1957.

- L'Originalité, Ginebra, Droz, 1982.

Mounin, Georges, Les belles infidèles, París, Cahiers du Sud, 1955.

Munsters, Wil, La poétique du pittoresque en France de 1700 à 1830, Ginebra, Droz, 1991.

NAVAS RuIZ, Ricardo, El romanticismo español, Madrid, Cátedra, 1982.

Niño, Antonio, Cultura y diplomacia. Los hispanistas franceses y España 1875-1931, Madrid, CSIC/Casa de Velázquez/Société des Hispanistes Français, 1988.

NOËL, François-Joseph-Michel, y François de LA PLACE, Leçons françaises de littérature et de morale. Vingt-et-unième édition, augmentée d'une liste biographique des auteurs cités, et d'un tableau des vicissitudes de la littérature française, par le Baron de Reiffenberg, Bruselas, J. P. Meline, Libraire-Éditeur, 1836.

Nordmann, Jean-Thomas, La Critique littéraire française au XIX siècle (18001914), París, Librairie Générale Française, 2001.

Nougué, André, "Le théâtre de Tirso dans la première moitié du XIX siècle espagnol», Bulletin Hispanique, t. LXXXI, 1969, pp. 585-590. 
NúÑEZ DE ARENAS, Manuel, «La suerte de Goya en Francia. Manojo de noticias», Bulletin Hispanique, t. LII, 1950, pp. 229-273.

- «Impresos españoles publicados en Burdeos hasta 1850», en L'Espagne des Lumières au Romantisme, París, Centre de recherches de l'Institut d'études hispaniques, 1963, pp. 309-351.

OchOA, Eugenio de, Apuntes para una biblioteca de autores españoles en prosa y verso, París, Baudry, 1840, 2 vols.

- "La littérature espagnole au XIX siècle», Revue de Paris, t. XX, 1840, pp. 3557.

Ojeda Escudero, Pedro, El justo medio. Neoclasicismo y Romanticismo en la obra dramática de Martínez de la Rosa, Burgos, Universidad de Burgos, Servicio de Publicaciones, 1997.

ORTAS DurAND, Esther, Viajeros ante el paisaje aragonés (1759-1850), Zaragoza, Institución «Fernando el Católico», 1999.

PAGEARD, Robert, "Une curieuse figure d'hispanisant français: Coste d'Arnobat, 1731-1808", Revue de littérature comparée, n. ${ }^{\circ} 32$, 1958, pp. 556-562.

- "L'Espagne dans Le Journal Étranger (1754-1762) et La Gazette Littéraire de l'Europe (1764-1766)", Revue de Littérature Comparée, julio-septiembre de 1959, pp. 376-400.

- «Gabriel Hugelmann et sa Revue espagnole et portugaise devenue Revue des races latines (1857-1864). Une présentation de l'Espagne en France sous le Second Empire», Iris, CERLIAM, Université Paul Valéry-Montpellier, 1986-2, pp. 107-148.

Pageaux, Daniel-Henri, L'Espagne devant la conscience française au XVIII siècle, 1979.

- «Une constante culturelle: l'exotisme hispanique en France», en R. Antonioli (ed.), Exotisme et création, Lyon, Hermes, 1985, pp. 107-119.

- «Recherches sur l'espagnolade en France (1870-1914). Éléments d'une bibliographie», Récifs, n. ${ }^{\circ}$ 8, 1986, pp. 123-137.

- "Un aspect des relations culturelles entre la France et la Péninsule Ibérique», en F. Lafarga (ed.), Imágenes de Francia en las letras hispánicas, Barcelona, PPU, 1989.

- Littérature générale et comparée, París, A. Colin, 1994.

- Le bûcher d'Hercule. Histoire critique et théories littéraires, París, Champion, 1996.

PALfREY, Théodore, «L'Europe littéraire» (1833-1834). Un essai de périodique cosmopolite, París, Champion, 1927.

PARIS, Gaston, "La "Romance mauresque" des Orientales», Revue d'Histoire Littéraire de la France, t. VI, 1899, pp. 333-342.

PARKER, Alexander A., Los picaros en la literatura. La novela picaresca en España y Europa (1599-1753), Madrid, Gredos, 1971. 
PARKER, Alexander A., La imaginación y el arte de Calderón. Ensayos sobre las comedias, Madrid, Cátedra, 1991.

Pedraza Jiménez, Felipe B., y Milagros Rodríguez Cáceres, Las épocas de la literatura española, Barcelona, Ariel, 1997.

- «La formación del canon dramático de Lope», Ínsula, n. ${ }^{\circ}$ 658, octubre de 2001, pp. 29-31.

Peers, E. Allyson, Historia del movimiento romántico español, Madrid, Gredos, 1973, 2 vols.

Pellegrini, Carlo, Il Sismondi e la storia delle letterature dell'Europe meridionale, Ginebra, 1926.

Perdices Blas, Luis, Pablo de Olavide (1725-1803). El ilustrado, Madrid, Editorial Complutense, 1993.

Pérez-Bustamante Mourier, Ana-Sofía, y Alberto Romero Ferrer (eds.), Casticismo y literatura en España, Cádiz, Servicio de Publicaciones de la Universidad de Cádiz (Cuadernos Draco, 1), 1992.

PÉReZ Magallón, Jesús, "Gregorio Mayans en la historiografía literaria española», NRFH, t. XXXVIII, n. ${ }^{\circ} 1,1990$, pp. 247-263.

PICARD, Roger, El romanticismo social, México, FCE, 1987.

Pichois, Claude, Philarète Chasles et la vie littéraire au temps du Romantisme, París, Librairie José Corti, 1965, 2 vols.

Piferrer, Francisco, Tableau de la littérature espagnole depuis le $12^{e}$ siècle jusqu’à nos jours, précédé d'une introduction sur l'origine de la langue espagnole. París, Baudry; Toulouse, Delsol, 1845.

Pigoreau, Alexandre, Petite bibliographie biographico-romancière, ou dictionnaire des romanciers, tant anciens que modernes tant nationaux qu'étrangers, avec un mot sur chacun d'eux, et la notice des romans qu'ils ont donnés, soit comme auteurs soit comme traducteurs. Précédé d'un catalogue des meilleurs romans publiés depuis plusieurs années (Suppléments 1-10, 12-17), Ginebra, Slatkine, 1968 [reimpr. de las eds. de París, 1821-28].

PoIrIER, Roger, La Bibliothèque Universelle des Romans, Ginebra, Droz, 1977.

PONT, Jaume, y Josep M. SAlA-VAlldaura (eds.), Cànon literari: ordre i subversió, Lérida, Institut d'Estudis Ilerdencs y Fundació Pública de la Diputació de Lleida, 1998.

Pozuelo Yvancos, José M.a, "Popular/culto, genuino/foráneo. Canon y teatro nacional español», en Jesús G. Maestro (ed.), Theatralia III. Tragedia, Comedia y Canon, Vigo, Universidad de Vigo, 2000, pp. 235-260.

- y Rosa M.a Aradra SÁnchez, Teoría del canon y literatura española, Madrid, Cátedra, 2000.

Prost, Antoine, L'enseignement en France, 1800-1967, París, Librairie Armand Colin, 1968. 
Puibusque, Adolphe de, Histoire comparée des littératures Espagnole et Française, París, G. A. Dentu, 1843, 2 vols.

QueneAu, Raymond, «Préface» a Histoire de littératures, t. II, en Encyclopédie de la Pléiade, París, Gallimard, 1962.

QUÉRARD, Joseph-Marie, La France littéraire, ou Dictionnaire bibliographique des savants, historiens et gens de lettres de la France, ainsi que des littérateurs étrangers qui ont écrit en français, plus particulièrement pendant les XVIII et $X I X^{e}$ siécles. Ouvrage dans lequel on a inséré, afin d'en former une bibliographie nationale complète, l'indication: $1^{0}$ des réimpressions des ouvrages français de tous les ages; $2^{\circ}$ des diverses traductions en notre langue de tous les auteurs étrangers, anciens et modernes; $3^{\circ}$ celle des réimpressions faites en France des ouvrages originaux de ces mêmes auteurs étrangers, pendant cette époque. Par ... París, F. Didot père et fils (Firmin Didot frères), 10 vols. en 8. ${ }^{\circ}, 1827-1939$.

- La Littérature française contemporaine. XIX siècle. Renfermant: $1^{\circ}$ Par ordre alphabétique de noms d'auteurs, l'indication chronologique des publications originales des écrivains français, régnicoles et étrangers, et celle des éditions et traductions françaises des ouvrages des auteurs étrangers, vivants, imprimés en France pour la première fois depuis le commencement de ce siècle; $2^{\circ}$ Une table des livres anonymes et polyonymes, qui, par leurs publications, appartiennent à cette époque; $3^{\circ}$ Une table des sujets. Le tout accompagné de Notes Biographiques et Littéraires. Par ..., auteur de la France Littéraire, París, G.-P. Maisonneuve et Larose, 1965 [facsímil de la ed. orig., 1840].

QUINET, Edgard, Mes vacances en Espagne, París, Éds. d'Aujourd'hui, 1986.

Quintana, Manuel José, Tesoro del Parnaso Español, poesias selectas castellana desde el tiempo de Juan de Mena hasta nuestros días, recogidas y ordenadas por Don Manuel Josef Quintana. Nueva edición aumentada y corregida, París, Librería Europea de Baudry, 1838.

Ramos Corrada, Miguel, La formación del concepto de Historia de la literatura nacional española. Las aportaciones de P. J. Pidal y Antonio Gil de Zárate, Oviedo, Departamento de Filología Española, 1998.

Ramos OrTEGA, Francisco, "La fortuna del Cid en el Romanticismo francés», Revista de Literatura, n. ${ }^{\circ} 43,1981$, pp. 31-58.

Randolph, Donald Allen, Eugenio de Ochoa y el Romanticismo español, BerkeleyLos Ángeles, University of California, 1966.

RaYNOUARD, François-Juste-Marie, «Vie de Lope de Vega par Lord Holland», Journal des Savants, 1817, pp. 643-657.

- «Notice sur la vie et les œuvres de G. de Castro», Journal des Savants, 1817, pp. 725-735.

- «Dissertation sur le genre de la poésie dramatique espagnole», Journal des Savants, 1819, pp. 434-441. 
ReEs, Margaret, French Authors on Spain. 1800-1850. A checklist, Londres, Grant and Cutler, 1977.

Regalado, Antonio, Calderón. Los origenes de la modernidad en la España del Siglo de Oro, Barcelona, Destino, 1995, 2 vols.

RÉNAL, Antony [seudónimo de Claudius Billiet], Illustrations littéraires de l'Espagne, esquisses biographiques, París/Lyon, Hippolyte Souverain, éditeur libraire; 1849 , t. I.

RENDU, Victor, Leçons espagnoles de littérature et de morale, París, Firmin-Didot frères, 1830.

Rivas HeRnándeZ, Ascensión, Lecturas del Quijote (Siglos XVII-XIX), Salamanca, Colegio de España, 1998.

RodrígueZ SÁnCHEZ DE LEÓn, M.a José, «El teatro español del Siglo de Oro y la preceptiva poética del siglo XIX», Cuadernos de Teatro Clásico, n. ${ }^{\circ}$ 5, 1990, pp. 77-98.

- La crítica dramática en España (1789-1833), Madrid, Instituto de la Lengua Española, 1999.

- (ed.), La crítica ante el teatro barroco español (siglos XVII-XIX), Salamanca, Almar/Colegio de España, 2000.

Romantisme, Réalisme, Naturalisme en Espagne et en Amérique Latine, Lille, Centre d'Études Ibériques et Ibéro-Américaines du XIXe Siècle, 1978.

Romero, Mario Germán (ed.), Epistolario de Rufino José Cuervo con Alfred MorelFatio, Gaston Paris y otros hispanistas de lengua francesa, Bogotá, Instituto Caro y Cuervo (Archivo Epistolar Colombiano, XIX), 1987.

ROMERO TOBAR, Leonardo, La teoría dramática española: 1800-1870, Madrid, 1974.

- "Calderón y la literatura española del siglo XIX», Letras de Deusto, n. ${ }^{\circ} 11$, 1981, pp. 101-124.

- «El Cervantes del XIX», Anthropos, n. ${ }^{\circ}$ 98-99, 1989, pp. 116-119.

- Panorama crítico del romanticismo español, Madrid, Castalia, 1994.

- "Algunas consideraciones del canon literario durante el siglo XIX», Insula, n. ${ }^{\circ}$ 600, diciembre de 1996, pp. 14-16.

- «La Historia de la Literatura española en el XIX (materiales para su estudio)», El Gnomo, n. ${ }^{\circ}$ 5, 1996, pp. 151-183.

- «Las Historias de la literatura y la fabricación del canon», en Jaume Pont i Josep M. Sala-Valldaura (eds.), Cànon literari: ordre i subversió, Institut d'Estudis Ilerdencs y Fundació Pública de la Diputació de Lleida, 1998, pp. 47-64.

- La literatura en su historia, Madrid, Arco Libros, 2006.

- (coord.), Historia de la literatura española. Siglo XIX (2), Madrid, Espasa, 1998

- (ed.), Historia literaria/Historia de la literatura, Zaragoza, Prensas Universitarias de Zaragoza, 2004. 
RoZAS, Juan Manuel, «Siglo de Oro: historia de un concepto, la acuñación del término", en Estudios sobre el Siglo de Oro. Homenaje al profesor Francisco Ynduráin, Madrid, Editora Nacional, 1984, pp. 413-428.

Ruiz Doménech, José Enrique, «Interpretaciones de la caballería medieval», Insula, n. ${ }^{0}$ 584-585, agosto-septiembre de 1995, pp. 3-5.

Rumeau, Aristide, «Les éditions romantiques et Hurtado de Mendoza (18101842)", en Mélanges à la mémoire de Jean Sarrailh, París, CRIEH, 1966, pp. 301-311.

Saint-René De TAILlandier, "La littérature espagnole et ses historiens modernes», Revue des Deux Mondes, t. VIII, 15-X-1854, pp. 218-317.

Sainz Rodríguez, Pedro, Historia de la crítica literaria en España, Madrid, Taurus, 1989.

SALIS, Jean-Rodolphe de, Sismondi (1773-1842). La vie et l'ceuvre d'un cosmopolite philosophe, París, Champion, 1932.

SÁNCHEZ, Tomás Antonio, Colección de poesías castellanas anteriores al siglo XV publicadas por ..., Madrid, Sancha, 1779-1790, 4 vols. Nueva edición, hecha bajo la dirección de D. Eugenio de Ochoa. Con notas al pie de las páginas, una introducción y un vocabulario de voces anticuadas, y aumentada con un suplemento que contiene tres poemas nuevamente descubiertos, París, Baudry, Librería Europea, 1842.

SCHLEGel, August Wilhelm, Cours de littérature dramatique. Traduction par Mme Necker de Saussure, París, Lacroix, Verboeckhoven et Cie Éditeurs, Librairie Internationale, 1865, 2 vols. [revisión de la ed. de París de 1814].

Sebold, Russell P., El rapto de la mente. Poética y poesía dieciochesca, Madrid, Prensa Española, 1970.

- Trayectoria del romanticismo español, Barcelona, Crítica, 1983.

SENABRE, Ricardo, «La creación de un mito cultural: el teatro nacional español», en Túa Blesa (ed.), Mitos. Actas del VII Congreso Internacional de la Asociación Española de Semiótica, Universidad de Zaragoza, 1998, vol. I.

SILVER, Philip W., Ruina y restitución: reinterpretación del romanticismo español, Madrid, Cátedra, 1996.

Sismondi, Jean Claude Léonard Simonde de, La littérature du Midi de l'Europe, París-Estrasburgo, Treuttel et Würtz, 1813, tomos III y IV.

Sismondi européen. Actes du Colloque International [1973], Ginebra, Slatkine; París, Honoré Champion, 1976.

STAËL, Mme de, De la littérature considérée dans ses rapports avec les institutions sociales, París, Maradan, 1800, 2 vols.

Sullá, Enric (ed.), El canon literario, Madrid, Arco Libros, 1998.

SulLIVAN, Henry, "Calderón's reception in Spain during the Romantic era 18001850", Ottawa Hispanica, n. ${ }^{4}$ 4, 1982, pp. 27-54.

TACCA, Oscar, La historia literaria, Madrid, Gredos, 1968. 
Tannenberg, Boris de, La poésie castillane contemporaine, París, Librairie Académique Didier, Perrin et Cie, libraires-éditeurs, 1889.

- L'Espagne littéraire, París, A. Picard et fils, 1903.

Tatarkiewicz, Wladislaw, Historia de seis ideas. Arte, belleza, forma, creatividad, mímesis, experiencia estética, presentación de Bohdan Dziemidok; traducción de Francisco Rodríguez Martín, Madrid, Alianza Editorial/Tecnos, 2002.

TICKNOR, George, Historia de la literatura española por ..., traducida al castellano, con adiciones y notas criticas por Pascual de Gayangos y Enrique de Vedia, Madrid, Imprenta y Estereotipia de M. Rivadeneyra, 1851-56.

TiEghem, Philippe van, L'Année Littéraire (1754-1790) comme intermédiaire en France des littératures étrangères, París, F. Rieder \& Cie, Éditeurs, 1917.

Toumson, Rogers, «L'exotisme. Problématiques de la représentation de l'autre et de l'ailleurs», en Mélanges Simon Jeune, Burdeos, Société des Bibliophiles de Guyenne, 1990, pp. 433-450.

TRÉNARD, L., "Images mythiques d'Espagne sous la Restauration», Revue des Sciences Humaines, n. ${ }^{\circ}$ 107, julio-septiembre de 1962, pp. 367-422.

URZAINQUI, Inmaculada, De nuevo sobre Calderón en la crítica española del siglo XVIII, Oviedo, Universidad de Oviedo-Cátedra Feijoo (Anejos del BOCES.XVIII, 2), 1984.

- «El concepto de Historia literaria en el siglo XVIII», en Homenaje a Álvaro Galmés de Fuentes, Madrid, Gredos; Oviedo, Universidad de Oviedo, vol. III, 1987, pp. 565-589.

- «Hacia una teoría de la historia literaria en el siglo XVIII: competencias del historiador», en Leonardo Romero Tobar (ed.), Historia literaria/Historia de la literatura, Prensas Universitarias de Zaragoza, 2004.

VALCÁRCEL, Carmen, «Juan Andrés y la literatura española: la tesis árabe y la polémica sobre el Barroco», en Pedro Aullón de Haro, Jesús García Gabaldón y Santiago Navarro Pastor (eds.), Juan Andrés y la teoría comparatista, Valencia, Biblioteca Valenciana, 2002, pp. 245-265.

Vauchelle-Haquet, Aline, Les ouvrages en langue espagnole publiés en France entre 1814 et 1833 (présentation et catalogue), préface de Gérard Dufour, Aixen-Provence, Publications de l'Universite de Provence, 1985.

- Les ouvrages en langue espagnole publiés en France: au temps de la première guerre carliste. 1834-1840 (présentation et catalogue), Aix-en-Provence, Publications de l'Université de Provence, 2003.

VelázQuez, Luis José de, Orígenes de la poesía castellana por D. Luis Joseph Velázquez, Caballero del Orden de Santiago, de la Academia Real de la Historia, y de la de las Inscripciones, Medallas, y Bellas Letras de París, Málaga, Oficina de Francisco Martínez de Aguilar, 1754.

VIARDOT, Louis, Études sur l'histoire des institutions, de la littérature, du théatre et des beaux-arts en Espagne, París, Paulin, 1835. 
WeIch, H., «Narración polifónica: el Quijote y sus seguidores franceses (siglos XVII y XVIII)", Anthropos, n. ${ }^{\circ} 98-99,1989$, pp. 107-111.

WelleK, René, Historia de la critica moderna (1750-1950), Madrid, Gredos, 1973.

WeRnER, Michael, «À propos de l'évolution historique des philologies modernes. L'exemple de la philologie romane en Allemagne et en France», en M. Espagne y M. Werner (eds.), Philologies. I. Contribution à l'histoire des disciplines littéraires en France et en Allemagne au XIX siècle, París, Éditions de la Maison des Sciences de l'homme, 1990, pp. 159-186.

Wicks, Charles B., The Parisian Stage: Alphabetical Indexes of Plays and Authors (1800-1815), (1816-1830), (1830-1850), University of Alabama Press, t. 1, 1950 ; t. 2, 1953; t. 3, 1961.

WolfzetTer, F., «Valoración del pasado y crítica del presente. Apuntes sobre el paradigma dialéctico del viaje romántico a España», Estudios de Investigación Franco-Española, n. ${ }^{\circ} 11,1995$, pp. 159-174. 



\section{ÍNDICE}

PRÓLOGO ............................................................................

PRELIMINARES ............................................................... 11

1. LA LITERATURA ESPAÑOLA EN FRANCIA: ENTRE LA REHABILITACIÓN Y EL PREJUICIO .............................. 19

1.1. Apertura del canon occidental ..................................... 27

1.2. Redescubrimientos de la literatura española ..................... 31

1.3. Las traducciones en la revalorización de la literatura española .................................................................... 37

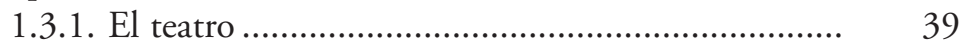

1.3.2. La novela............................................................. 49

1.3.3. El romancero...................................................... 55

2. CONTRIBUCIONES A LA HISTORIA DE LA LITERATURA ESPAÑOLA EN FRANCIA: ESTUDIOS, HISTORIAS, CURSOS MAGISTRALES, ARTÍCULOS, MANUALES, ANTOLOGÍAS

2.1. Primeras décadas del siglo XIX ........................................ 97

2.1.1. Un precursor de entresiglos ................................ 99

2.1.2. La tríada difusora ............................................. 122

2.1.2.1. F. Bouterwek ........................................ 122

2.1.2.2. A. W. Schlegel ......................................... 160

2.1.2.3. Simonde de Sismondi............................ 169 
2.2. Las décadas de los años treinta y cuarenta: impulsos y recapitulaciones

2.2.1. Desde la tribuna de la prensa: Prosper Merimée y Juan Florán........................................................ 188

2.2.2. Louis Viardot .................................................. 200

2.2.3. Cursos magistrales y manuales de transición......... 221

2.2.4. Literaturas paralelas: Adolphe de Puibusque......... 231

2.3. En el meridiano del siglo: recepciones de Ticknor en Francia.....

252

2.4. Segunda mitad del siglo XIX: positivismo, militancia ideológica, continuidades

2.4.1. La primera historia francesa de la literatura española: Eugène Baret ..........................................

2.4.2. Una historia comprometida: el caso republicano de Gustave Hubbard ............................................

2.4.3. Colecciones finiseculares de historias literarias europeas: de Alfred Bougeault a Jacques Demogeot .... 298

2.5. Antologías contemporáneas: algunos ejemplos (1826-1884) 319 
Este libro se terminó de imprimir en los talleres gráficos de Linea 2015, S. L., de Zaragoza, en noviembre de 2007 Wo 
ste libro ofrece una aproximación al panorama que presentan los estudios sobre la historia de la literatura española editados en Francia en el curso del siglo xIx. A través del análisis fundamentalmente descriptivo y diacrónico de un conjunto acotado de textos representativos a la luz de las nuevas teorías estéticas y criticas, la boga de las traducciones y el comparatismo naciente, el respeto hacia su panteón clásico en proceso de canonización y la consagración de la nacionalidad literaria, propone un recorrido por la percepción francesa de esta literatura fronteriza en su devenir y de la difusión de un canon de obras, géneros y autores durante la paulatina institucionalización de esta disciplina en Francia. 